\title{
Kompetencje przyszłości
}

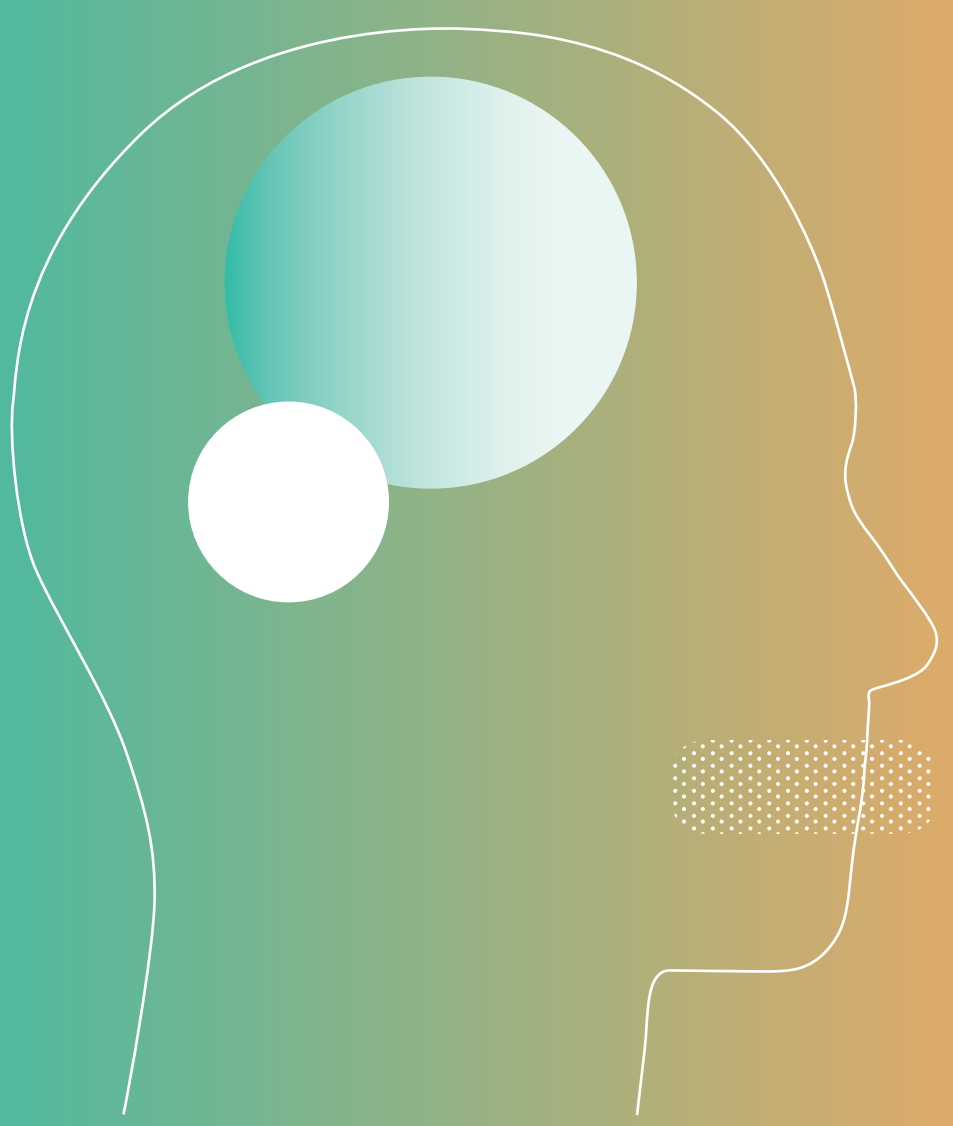


Kompetencje przyszłości 



\section{Kompetencje przyszłości}

Obszary:

Porozmawiajmy o kompetencjach

Wyzwania współczesnej edukacji

Kompetencje cyfrowe

Kompetencje społeczne nauczycieli

redakcja naukowa

Stefan M. Kwiatkowski

\begin{tabular}{l|l} 
fR & Wydawnictwo \\
Se) & FRSE
\end{tabular}

Warszawa 2018 
SERIA NAUKOWA, TOM 3

Kompetencje przyszłości

Obszary:

Porozmawiajmy o kompetencjach

Wyzwania współczesnej edukacji

Kompetencje cyfrowe

Kompetencje społeczne nauczycieli

Redaktor naukowy: $\quad$ prof. dr hab. Stefan M. Kwiatkowski

Recenzent: $\quad$ prof. dr hab. Joanna Madalińska-Michalak

Redaktor prowadzący: $\quad$ Radosław Krąpiec

Korekta: Jadwiga Marculewicz-Olaś

Projekt okładki: Mariusz Skarbek

Projekt graficzny: Diana Makulska/Podpunkt

Skład: $\quad$ Artur Ładno

Druk: $\quad$ Multigraf Drukarnia Sp. z o.o. Bydgoszcz

Wydawca: $\quad$ Fundacja Rozwoju Systemu Edukacji

Narodowa Agencja Programu Erasmus+

Al. Jerozolimskie 142a, 02-305 Warszawa

www.frse.org.pl | kontakt@frse.org.pl

(C) Fundacja Rozwoju Systemu Edukacji, Warszawa 2018

ISBN: 978-83-65591-52-4

Publikacja została wydana przy wsparciu finansowym Komisji Europejskiej w ramach programu Erasmus+. Publikacja odzwierciedla jedynie stanowisko jej autorów i Komisja Europejska nie ponosi odpowiedzialności za zamieszczoną w niej zawartość merytoryczną.

Publikacja bezpłatna

\section{ĐCSE E Erasmus+}

Cytowanie:

Kompetencje przyszłości, red. nauk. Stefan M. Kwiatkowski, Fundacja Rozwoju Systemu Edukacji, Seria Naukowa, t. 3, Warszawa 2018

Dotychczas w ramach Serii Naukowej ukazały się:

Tom 1: Teacher Education Policy and Practice - International Perspectives and Inspiration

Tom 2: Przywództwo nauczycieli

Publikacje dostępne są na stronie czytelnia.frse.org.pl 


\section{Spis treści}

9

Wstęp

Porozmawiajmy o kompetencjach

14

Kompetencje przyszłości

Stefan M. Kwiatkowski

30

Przyszłość należy do świadomych i aktywnych obywateli.

Jakie kompetencje są im niezbędne? Jak skutecznie

je kształtować? (Perspektywa aksjologiczna)

Krystyna Chatas

68

Przedsiębiorczość jako kompetencja przyszłości

Monika Borowiec-Gabryś, Wioletta Kilar, Tomasz Rachwat

90

Kompetencje kluczowe uczniów w międzynarodowych raportach i badaniach

Magdalena Górowska-Fells, Beata Płatos, Agnieszka Rybińska

132

Mobilność edukacyjna sposobem na rozwijanie kompetencji potrzebnych na rynku pracy

Joanna Dąbrowska-Resiak, Mateusz Jeżowski, Michat Pachocki 
Międzynarodowe projekty edukacyjne drogą do rozwoju kompetencji kluczowych

Edward Torończak

\section{Wyzwania współczesnej edukacji}

190

Nowoczesne doradztwo w szkołach: predyspozycje uczniów a ich przyszłość zawodowa

Stefan M. Kwiatkowski

206

Efektywna edukacja.

W poszukiwaniu balansu między technologią, kulturą i naturą Anna Krzyżanowska

228

Kreatywność a standaryzacja: pedagogika twórczości i jej postulaty pod adresem współczesnej szkoły

Krzysztof J. Szmidt

248

Wspieranie rozwoju kreatywności wśród uczniów Jan Fazlagić

270

Racjonalne dostosowania i modyfikacje w edukacji uczniów mających specjalne potrzeby edukacyjne

Ewa Domagała-Zyśk

286

Edukacja międzykulturowa w szkołach i jej znaczenie.

Wyzwania współczesnej edukacji w ramach inicjatyw UE

Magdalena Bartoszak 
Projekt eTwinning jako sposobność do rozwijania inteligencji wielorakich uczniów

Jolanta Okuniewska

\section{Kompetencje cyfrowe}

320

Język programowania jako kompetencja XXI w.

Monika Mojsiejonek, Małgorzata Knap

336

Nowoczesne technologie w nauczaniu przedmiotów ścisłych

Stawomir Wronka

348

Jak zetrzeć kurz nieaktualności z dawnych tekstów kultury?

Dziedzictwo kulturowe w dobie nowoczesnych mediów na przykładzie Mendla Gdańskiego Marii Konopnickiej

Rafat Mazur

362

Cyberbezpieczeństwo w szkołach: skuteczne strategie działania Aneta Wilk, Adam Stępiński

376

Wyzwania i zagrożenia przestrzeni cyfrowej dla edukacji i aktywności zawodowej

Anna Andrzejewska 
398

Od psychologii do edukacji: zasady podnoszenia skuteczności nauczania i wychowania

Przemystaw Bąbel

416

Znaczenie inteligencji emocjonalnej w funkcjonowaniu ucznia i nauczyciela

Katarzyna A. Knopp

430

Coaching w edukacji. Innowacje na rzecz rozwoju

Lilianna Kupaj

448

Prestiż zawodu a kompetencje nauczycieli

Dominika Walczak

468

Kompetentny nauczyciel - przyszłość czy rzeczywistość

Liliana Budkowska, Pawet Poszytek 


\section{Wstęp}

Funkcjonowanie systemu edukacji, kształtowanie kompetencji jego uczestników oraz przyszłości nauczania i uczenia się, szczególnie w kontekście koncepcji uczenia się przez całe życie - to najbardziej aktualne dziś tematy poruszane podczas konferencji naukowych dotyczących systemu szkolnictwa, m.in. Kongresu Rozwoju Systemu Edukacji.

Kompetencjom poświęcamy również niniejszy tom Serii Naukowej Wydawnictwa FRSE. Zagadnienie to jest jednym z najważniejszych obszarów współpracy europejskiej - zdefiniowanie kompetencji kluczowych jako niezbędnych na każdym krajowym i europejskim rynku pracy to priorytet przekrojowy łączący różne programy i inicjatywy Unii Europejskiej. Publikacja Kompetencje przyszłości daje nam podstawę do dyskusji i wymiany doświadczeń dotyczących przyszłości nauczanych umiejętności oraz w samym kontekście rozwoju edukacji.

Temat kompetencji omawiamy na różne sposoby - od artykułu o kompetencjach przyszłości, po tekst pokazujący wyniki - prowadzonych przez Fundację - badań dotyczących tego, jak mobilność edukacyjna w programie Erasmus + staje się sposobem na rozwijanie umiejętności potrzebnych na rynku pracy. Zainteresowanych tematyką wartości zapraszam do lektury artykułu Przyszłość należy do świadomych i aktywnych obywateli, a osoby szukające inspiracji w dziedzinie wspierania rozwoju kreatywności wśród uczniów - do przeczytania tekstu na ten temat. W naszej publikacji nie zabrakło także kwestii ważnych ze względu na postępujący z dnia na dzień rozwój technologiczny, który ma ogromne znaczenie, zarówno stricte w procesie nauczania i uczenia się, jak i w kwestii cyberbezpieczeństwa uczniów i nauczycieli.

Jest sprawą oczywistą, że bez wyposażenia nauczycieli w konieczne i pożądane w tym zawodzie kompetencje społeczne, nie można mówić o rozwoju systemu edukacji oraz kompetencji uczniów i słuchaczy. 
Dlatego nie zapomnieliśmy również o artykułach z zakresu psychologii i coachingu, które m.in. dotyczą znaczenia oraz prestiżu w zawodzie nauczyciela, mówią o wpływie różnych rodzajów inteligencji na funkcjonowanie ucznia i nauczyciela oraz podnoszeniu skuteczności nauczania i wychowania poprzez coaching i mentoring edukacyjny.

Mam nadzieję, że lektura naszej publikacji stanowić będzie dla Państwa źródło wiedzy oraz inspiracje do owocnych i ważnych naukowych dyskusji.

prof. dr hab. Stefan M. Kwiatkowski redaktor naukowy 



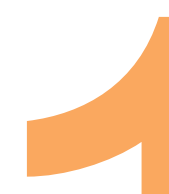


Porozmawiajmy o kompetencjach 


\section{Kompetencje przyszłości}

Stefan M. Kwiatkowski

Tekst dotyczy problematyki kompetencji, ze szczególnym uwzględnieniem kompetencji, które już w najbliższych latach będą niezbędne w życiu społecznym i gospodarczym - kompetencji przyszłości. Zostały one scharakteryzowane na tle kompetencji ogólnych i zawodowych.

\section{Słowa kluczowe:}




\title{
The competences of the future
}

\author{
Stefan M. Kwiatkowski
}

The text concerns the issue of competences, with particular emphasis on competences that will be necessary in social and economic life in the coming years - the competences of the future. They were characterized on the background of general and professional competences.

\section{Keywords:}

general and professional competences

competences of the future 


\section{Wprowadzenie}

Proces edukacji jest współcześnie rozpatrywany w kontekście idei uczenia się przez całe życie. Zakłada ona potrzebę, a nawet konieczność uczenia się zarówno w instytucjach szkolnych i akademickich (edukacja formalna), jak i na różnego typu i poziomu kursach, szkoleniach, warsztatach (edukacja pozaformalna) oraz podczas pracy zawodowej i relacji z innymi ludźmi (edukacja nieformalna). Idea, o której mowa, znana jest od setek lat, ale nabrała nowego znaczenia w dzisiejszych czasach, charakteryzujących się niespotykanym dotąd przyspieszeniem cywilizacyjnym, obejmującym wszystkie sfery życia współczesnego człowieka. Nawet najlepsze wykształcenie zdobyte w ramach edukacji formalnej już po kilku latach wymaga rekonstrukcji polegającej nie tylko na aktualizacji skończonego kierunku kształcenia, lecz także na integracji z wykształceniem przypisywanym dotychczas innym, nie zawsze pokrewnym kierunkom, a w przypadku kształcenia na poziomie wyższym - dyscyplinom naukowym. Stopień złożoności problemów społecznych i zawodowych jest bowiem obecnie tak wysoki, że wymaga łączenia wykształcenia $z$ wielu dziedzin. Wykształcenie medyczne nie wystarcza już do efektywnego zarządzania placówkami służby zdrowia, wykształcenie techniczne wspomagane jest często programami z pogranicza psychologii i socjologii, a $w$ badaniach $w$ dziedzinie nauk społecznych nie można nie uwzględnić podejścia metodologicznego specyficznego dla psychologii, socjologii, pedagogiki, a także nauk o pracy.

Jesteśmy więc obserwatorami, a czasami uczestnikami procesu integracji edukacji formalnej (pierwsze - podstawowe wykształcenie) ze wspierającą ją edukacją pozaformalną i nieformalną (Kwiatkowski, 2014, s. 25). Efektami uczenia się we wszystkich wyróżnionych wyżej formach są interesujące nas kompetencje, w których skład wchodzą następujące:

$\rightarrow$ wiedza, a więc zbiór faktów, praw, teorii, zasad i doświadczeń przyswojonych lub samodzielnie skonstruowanych,

$\rightarrow$ umiejętności, a więc zdolność/gotowość do wykorzystania wiedzy podczas realizacji różnego rodzaju zadań,

$\rightarrow$ kompetencje społeczne, a więc zdolność do projektowania i kształtowania własnego rozwoju oraz autonomicznego i odpowiedzialnego udziału w życiu społecznym i zawodowym [por. Sławiński (red.), 2013, s. 50, 52, 54]. 
Warto zauważyć, że kompetencje wykształcone podczas edukacji formalnej stają się automatycznie (oczywiście po zdaniu odpowiednich egzaminów) kwalifikacjami. Natomiast aby kompetencje, które można zdobyć podczas edukacji pozaformalnej i nieformalnej, mogły być nazywane kwalifikacjami, muszą być poddane procedurom walidacyjnym. Można zatem, i tak często zdarza się w praktyce, mieć kompetencje, a nie mieć kwalifikacji. Sytuacja odwrotna, czyli posiadanie nadanych przez szkoły i uczelnie wyższe kwalifikacji niepopartych kompetencjami, jest naganna i świadczy o niskiej jakości pracy instytucji edukacji formalnej.

Zwróćmy też uwagę na to, że jeszcze do niedawna pojęcie kompetencji było definiowane jako nadany, na podstawie faktycznych kwalifikacji, zakres pełnomocnictw i uprawnień (Nowacki, 2004, s. 100). Takie ujęcie, a więc swoista nadrzędność kompetencji nad kwalifikacjami, wciąż obowiązuje w niektórych profesjach. Na przykład w zawodach prawniczych kwalifikacje będące efektem uczenia się formalnego (akademickiego) nie uprawniają automatycznie do pełnienia funkcji adwokata czy notariusza - trzeba przejść określone procedury, dzięki którym nadawane są uprawnienia do wykonywania tych zawodów.

\section{Kompetencje ogólne i zawodowe}

Kompetencje ogólne zalicza się do podstawowych efektów uczenia się w ramach kształcenia ogólnego, które realizowane jest głównie w szkołach podstawowych i liceach ogólnokształcących. W szkolnictwie zawodowym - w technikach i szkołach branżowych - większą wagę przywiązuje się do kompetencji zawodowych, chociaż w szkołach tego typu kształtowane są również kompetencje ogólne. Nie należą one jednak do pierwszoplanowych celów kształcenia. Ze zrozumiałych względów są nimi kompetencje zawodowe. Kompetencje ogólne, analizowane w kontekście celów kształcenia, wiążą się przede wszystkim z rozwojem intelektualnym uczniów, z szeroko rozumianym wprowadzeniem ich w świat nauk humanistycznych i społecznych, a w rezultacie z przygotowaniem do podjęcia studiów na wyższych uczelniach (Okoń, 2001, s. 104-195).

Kompetencje zawodowe są kształtowane w celach bardziej pragmatycznych, związanych z przyszłą pracą zawodową (Nowacki, 2004, s. 111; Okoń, 2001, s. 197-198). Jak już wspomniano, kompetencje zawodowe uzyskane podczas edukacji formalnej przyjmują postać 
kwalifikacji, a więc stanowią, w odróżnieniu od większości kompetencji ogólnych, określoną wartość rynkową.

W praktyce, w procesie pracy zawodowej, kompetencje ogólne są fundamentem kompetencji zawodowych. Pozwalają na ciągłe uczenie się w obszarze zawodu, specjalności i stanowiska pracy. Można więc powiedzieć, że kompetencje ogólne warunkują rzeczywisty rozwój kompetencji zawodowych i mimo że nie są związane bezpośrednio z wymaganiami współczesnego rynku pracy, w sposób pośredni decydują o jakości kompetencji zawodowych, nawet tych najbardziej ukierunkowanych na potrzeby rynku.

Patrząc z innej perspektywy, można dojść do wniosku, że kompetencje ogólne mają charakter ponadzawodowy - dotyczą wszystkich zawodów występujących w różnorodnych klasyfikacjach, a przede wszystkim w realnym świecie pracy. Można więc przyjąć, że podstawowymi komponentami kompetencji ogólnych są:

$\rightarrow$ umiejętność analizy czynników wpływających na zmienność naszego otoczenia - w sferze kultury, nauki i edukacji (orientacja w świecie) - oraz zdolność do projektowania i podejmowania odpowiednich działań,

$\rightarrow$ znajomość nurtów światopoglądowych i-będących ich pochodną - systemów wartości oraz postępowanie zgodne z własnym systemem wartości,

Wynikają z nich kompetencje bardziej szczegółowe, ale też natury ogólnej, takie jak:

$\rightarrow$ językowe,

$\rightarrow$ społeczno-obywatelskie,

$\rightarrow$ przyrodnicze

oraz dotyczące:

$\rightarrow$ samopoznania i samokształcenia,

$\rightarrow$ komunikacji interpersonalnej.

Wśród kompetencji ogólnych szczególnie istotnych z punktu widzenia kształcenia zawodowego możemy wyróżnić te, które związane są z etosem pracy, a więc z przedsiębiorczością, samodzielnością, odpowiedzialnością, poczuciem własnej wartości, innowacyjnością i decyzyjnością (Bogaj, 1998, s. 102-107).

Z punktu widzenia rozwoju gospodarczego duże znaczenie ma identyfikacja kompetencji ogólnych, które określa się jako przedsiębiorcze. 
Dzieli się je na trzy kategorie obejmujące: działanie, zasoby oraz idee i możliwości ich realizacji.

Działanie wymaga kompetencji polegających na:

$\rightarrow$ przejmowaniu inicjatywy,

$\rightarrow$ planowaniu i zarządzaniu,

$\rightarrow$ radzeniu sobie $z$ niejednoznacznością, niepewnością,

$\rightarrow$ pracy z innymi (współdziałaniu w zespole),

$\rightarrow$ ciągłym uczeniu się z wykorzystaniem doświadczenia.

W kategorii zasoby wyróżniamy następujące kompetencje:

$\rightarrow$ konsolidacja (zasobów),

$\rightarrow$ samoświadomość i poczucie własnej skuteczności,

$\rightarrow$ motywacja i wytrwałość,

$\rightarrow$ mobilizowanie współpracowników,

$\rightarrow$ prowadzenie analiz finansowych i ekonomicznych.

Natomiast z ideami i możliwościami ich realizacji łączą się następujące kompetencje:

$\rightarrow$ dostrzeganie możliwości,

$\rightarrow$ wyzwalanie kreatywności,

$\rightarrow$ tworzenie wizji,

$\rightarrow$ analiza i ocena pomysłów,

$\rightarrow$ etyka i komplementarne myślenie (Carlebach, 2016, s. 8).

W szerszym ujęciu kompetencje ogólne pracowników oraz kadry zarządzającej w małych i średnich przedsiębiorstwach (MŚP) grupuje się w pięciu kategoriach:

$\rightarrow$ kompetencje biznesowe (np. znajomość branży, diagnozowanie potrzeb klientów),

$\rightarrow$ kompetencje firmowe (np. współpraca z przełożonymi, współpraca w gronie pracowników, identyfikacja z firmą, współpraca z instytucjami zewnętrznymi),

$\rightarrow$ kompetencje osobiste (np. wytrwałość i konsekwencja, radzenie sobie ze stresem),

$\rightarrow$ kompetencje społeczne (np. komunikacja interpersonalna, zachowania zgodne z obowiązującymi normami),

$\rightarrow$ kompetencje menedżerskie kadry zarządzającej np. wyznaczanie celów, tworzenie zespołów, organizowanie, motywowanie, przewodzenie, odwaga, decyzyjność (Badania i ewaluacje PARP, 2015). 
Kompetencje zawodowe formułowane na podstawie tak zarysowanych kompetencji ogólnych należy odnosić do określonych grup zawodów, specjalności i stanowisk pracy. W przypadku grupy zawodów technicznych (najliczniejszej) kompetencje tego typu sprowadzają się do:

$\rightarrow$ analizy fizycznych podstaw zjawisk i procesów,

$\rightarrow$ zastosowania praw techniki w projektowaniu technologii produkcji i usług,

$\rightarrow$ projektowania maszyn, urządzeń i obiektów oraz działań (procedur) prowadzących do ich realizacji,

$\rightarrow$ analizy (rzadziej: sporządzania) dokumentacji technicznej/technologicznej,

$\rightarrow$ diagnostyki technicznej (w tym dokonywania pomiarów i interpretacji ich wyników),

$\rightarrow$ obsługi, montażu, demontażu i konserwacji różnego rodzaju instalacji,

$\rightarrow$ efektywnego wykorzystywania metod i środków informatycznych,

$\rightarrow$ organizowania pracy z uwzględnieniem zasad ekonomii i ergonomii.

Jak łatwo się zorientować, przytoczone przykładowe kompetencje zawodowe odnoszące się do grupy zawodów technicznych można i należy poddawać uszczegółowieniu oraz niezbędnej modyfikacji - w zależności od konkretnych zawodów i charakterystycznych dla nich zadań zawodowych.

W praktyce gospodarczej, w rzeczywistych warunkach pracy, kompetencje ogólne i zawodowe wzajemnie się przenikają i warunkują. Dodatkowo, wraz z rozwojem techniki i technologii, kompetencje, które jeszcze do niedawna były uznawane za zawodowe, a nawet wysoce specjalistyczne, stopniowo zaczynają mieć charakter ogólny. Z taką sytuacją mamy do czynienia np. w przypadku kompetencji informatycznych lub - szerzej rzecz ujmując - informacyjnych. Z grupy tych zastrzeżonych dla wąskiego grona wtajemniczonych przeszły do pojemnej grupy kompetencji ogólnych. Dzisiaj trudno znaleźć zawód, w którym byłyby zbędne. Podobnie dzieje się z kompetencjami językowymi przydatnymi, a nawet wręcz niezbędnymi w realizacji coraz bardziej skomplikowanych zadań zawodowych (analiza literatury, dokumentacji, współpraca w zespołach wielokulturowych, udział w międzynarodowych sympozjach, konferencjach i szkoleniach). 
Biorąc pod uwagę postępującą integrację kompetencji ogólnych i zawodowych, można podjąć próbę ich wspólnego (łącznego) określenia. Wspólny rdzeń obu tych rodzajów kompetencji mógłby obejmować:

$\rightarrow$ przygotowanie do życia i twórczej pracy $\mathrm{w}$ demokratycznym państwie (zaufanie, tolerancja, adaptacja, wspólnotowość, autonomia, aktywność, kreatywność, mobilność, odpowiedzialność),

$\rightarrow$ ukształtowanie elastycznie rozumianych umiejętności ogólnozawodowych (wspólnych dla grup zawodów) ułatwiających zmianę pracy,

$\rightarrow$ zdobywanie i przekształcanie umiejętności specjalistycznych (zgodnie ze zmianami technologicznymi),

$\rightarrow$ wykorzystywanie umiejętności interpersonalnych w procesie komunikowania się,

$\rightarrow$ wyszukiwanie, gromadzenie, przetwarzanie i ochrona danych,

$\rightarrow$ wspieranie postaw sprzyjających ciągłemu uczeniu się (Kwiatkowski, 2012, s. 41).

Z perspektywy podziału kompetencji na wiedzę, umiejętności i kompetencje społeczne (utożsamiane często z postawami) można stwierdzić, że:

1. w odniesieniu do wiedzy:

a) wiedza ma istotny komponent ogólny, który umożliwia tworzenie i nieustanną rekonstrukcję wiedzy zawodowej,

b) od poziomu wiedzy ogólnej zależy w dużej mierze zakres i głębia zrozumienia faktów, praw, teorii oraz istoty doświadczeń zawodowych,

c) wiedza, zarówno ogólna, jak i zawodowa, ma charakter obszarowy (dziedzinowy),

d) integracja, o której była mowa wyżej, dotyczy konkretnych obszarów wiedzy ogólnej i zawodowej,

e) wiedza ogólna, będąca efektem edukacji formalnej, jest względnie stała,

f) wiedza zawodowa jest układem dynamicznym, tworzonym na podstawie edukacji formalnej, w procesie edukacji pozaformalnej i nieformalnej;

2. w odniesieniu do umiejętności:

a) umiejętność wyraża się poprzez skuteczne wykorzystanie wiedzy w sytuacji zadaniowej, 
b) umiejętność ogólna jest wynikiem wykorzystania wiedzy ogólnej, a zawodowa - wiedzy ogólnej i zawodowej,

c) umiejętność ukształtowana w oderwaniu od wiedzy jest rodzajem "działania według wzorca", ogranicza możliwość transformowania umiejętności w zależności od zmian warunków realizacji zadania,

d) umiejętność, w sposób bardziej oczywisty (obserwowalny) niż wiedza, jest stopniowalna (można jej przypisać poziomy - stopnie wtajemniczenia),

e) systematycznie wykorzystywana umiejętność przechodzi w nawyk i niesie to ze sobą ryzyko bezrefleksyjnego wykonywania ciągu czynności (złożonych i elementarnych),

f) umiejętności zawodowe można teoretycznie podzielić na intelektualne (koncepcje rozwiązań, plany działania) i motoryczne (wykonawstwo - realizacja planów działania),

g) w praktyce występują ścisłe zależności między umiejętnościami intelektualnymi a motorycznymi (umiejętności motoryczne są zależne od poziomu umiejętności intelektualnych);

3. w odniesieniu do kompetencji społecznych:

a) kompetencje społeczne są egzemplifikacją postaw, wyznawanego systemu wartości,

b) kompetencje społeczne naturalnie integrują sferę ogólną i zawodową (dotyczą ucznia, studenta, a następnie pracownika - bez względu na typ szkoły/uczelni i przedsiębiorstwa),

c) kompetencje społeczne dzielą się na wiele kompetencji cząstkowych, ale wszystkie mają wspólną podstawę, którą tworzą: energia do działania, optymizm, otwartość i zdolność do kooperacji.

Wszystkie wyróżnione kompetencje można poddawać jeszcze bardziej szczegółowym podziałom. Można także poszukiwać związków między ich konstytutywnymi elementami: wiedzą, umiejętnościami i kompetencjami społecznymi. Ma to niezwykle istotne znaczenie z edukacyjnego punktu widzenia. Identyfikacja poszczególnych kompetencji i ich opis umożliwiają bowiem podjęcie próby kształtowania podstawowych kompetencji, które dotyczą teraźniejszości społecznej i gospodarczej. Od opisu tych kompetencji, traktowanych jako zbiór celów kształcenia ogólnego lub/i zawodowego, można już przejść, zgodnie 
z prawidłowościami procesu dydaktycznego, do doboru treści, form i metod kształcenia, a także do sposobów oceny efektów uczenia się.

Bardziej złożony problem stanowią identyfikacja i opis kompetencji, które będą niezbędne $w$ dającej się określić przyszłości. W przypadku edukacji przyszłość ta wyznacza okres między podjęciem nauki w szkole podstawowej a rozpoczęciem pracy zawodowej - minimum 12-13 lat dla absolwentów szkół średnich i 15-18 lat dla absolwentów szkół wyższych.

\section{W poszukiwaniu kompetencji przyszłości}

Pojęcie kompetencje przyszłości jest naturalnie kojarzone z dającymi się przewidzieć kierunkami zmian cywilizacyjnych. Zmiany te będą dotyczyły wszystkich sfer życia. Można je prognozować na podstawie analiz dynamiki rozwoju wybranych kierunków techniki i technologii, obserwowanych np. w ostatnim dziesięcioleciu. To właśnie technologia i wynikające z niej przewartościowania w dziedzinie produkcji i usług skłaniają do rozważań na temat niezbędnych kompetencji pracowników - rozpatrywanych w perspektywie kilkunastu lat (prognozowanie w dłuższym okresie jest zadaniem dla autorów powieści futurystycznych).

Wpływ technologii nie ogranicza się jedynie do obszaru pracy zawodowej. Odgrywa ona istotną rolę również w modyfikacji codziennego funkcjonowania człowieka zarówno w życiu osobistym, jak i społecznym.

Badania nad kompetencjami przyszłości mają, jak już wspomniano, cechy badań prognostycznych, zakładających, że na podstawie doświadczenia z przeszłości i teraźniejszości uprawnione jest formułowanie tez dotyczących przyszłości. Jest to założenie obarczone ryzykiem, gdyż opiera się na przypuszczeniu liniowego rozwoju społeczno-gospodarczego, nie uwzględnia zaś ewentualnego rozwoju skokowego ani zmian, których nie jesteśmy w stanie przewidzieć (Karpiński, 2001, s. 17). Mimo tych zastrzeżeń i wynikających z nich ograniczeń myślenie o kompetencjach przyszłości ma głęboki sens edukacyjny - pozwala odpowiednio projektować proces kształcenia, ale też uzmysławia uczniom potrzebę ciągłego uczenia się, autonomicznego i odpowiedzialnego reagowania na dynamicznie zmieniającą się sytuację.

W ogólnym planie można wyróżnić trzy główne cele studiów nad kompetencjami przyszłości i ich analizy. Zalicza się do nich: 
$\rightarrow$ uświadomienie znaczenia rozważań na temat tego, co - z dużym prawdopodobieństwem - może być kluczowe w kontekście przewidywanego rozwoju cywilizacyjnego (ogólne wsparcie dla idei prognozowania przyszłości),

$\rightarrow$ identyfikacja obszarów (rodzajów problemów), które będą miały decydujący wpływ na przyszłość,

$\rightarrow$ dostarczenie narzędzi niezbędnych do opracowywania założeń (tez) dotyczących przyszłości (Coates, 2002, s. 10).

Biorąc pod uwagę powyższe cele, a także oczywiste ryzyko popełnienia błędu, już dzisiaj można wskazać obszary edukacji, które najsilniej będą wpływały na kształtowanie szeroko rozumianych kompetencji przyszłości. Należy do nich w pierwszej kolejności edukacja formalna - szkolna i akademicka. To ona jest bowiem fundamentem wiedzy, umiejętności i kompetencji społecznych, od których zależy efektywność edukacji pozaformalnej i nieformalnej. Wysoki poziom tego typu edukacji, skorelowany z odpowiednią motywacją i ze zdolnością do wyznaczania sobie celów edukacyjnych oraz projektowania dróg prowadzących do ich osiągnięcia, jest gwarantem płynnego przechodzenia od kompetencji potrzebnych tu i teraz do nieokreślonych jeszcze w pełni kompetencji przyszłości.

Wskazanie na rosnące znaczenie edukacji formalnej to tylko pierwszy krok, wstępna teza przybliżająca nas do bardzo ogólnego nakreślenia wizji kompetencji przyszłości. Rozważania o nich wymagają równolegle prowadzonych analiz zawodów przyszłości. Zawodowi, traktowanemu jako zbiór zadań do wykonania, odpowiadają bowiem określone kompetencje. Wprawdzie zawodom przyszłości, ze względu na ich mało precyzyjne opisy, nie jesteśmy w stanie przyporządkować konkretnych kompetencji, ale możemy pokusić się o sformułowanie prognoz $w$ tej dziedzinie.

Podstawą prognoz, o których mowa, mogą być dostępne dane o:

$\rightarrow$ kierunkach rozwoju gospodarki światowej wynikających z czwartej rewolucji przemysłowej (za jej początek przyjmuje się umownie rok 2010),

$\rightarrow$ zmianach demograficznych (starzejące się społeczeństwa),

$\rightarrow$ zmianach struktury społecznej związanych z poziomem wykształcenia i nasilającym się rozwarstwieniem natury ekonomicznej, 
$\rightarrow$ koncepcji polityki imigracyjnej,

$\rightarrow$ podnoszącej się jakości życia (zdrowa żywność, dbałość o zdrowie i wizerunek, sport i rekreacja).

Analiza kierunków rozwoju gospodarczego wskazuje, że pojawią się nowe zawody związane z:

$\rightarrow$ poszukiwaniem i eksploatacją alternatywnych źródeł energii,

$\rightarrow$ wykorzystaniem metod i technik informatycznych (sztuczna inteligencja - automatyzacja i robotyzacja produkcji oraz usług).

Zmiany demograficzne, wynikające przede wszystkim z wydłużania się życia, stwarzają popyt na zawody opiekuńcze:

$\rightarrow$ kompleksowa opieka domowa nad osobami starszymi,

$\rightarrow$ opieka domowa i w specjalistycznych ośrodkach nad osobami z różnego rodzaju niepełnosprawnościami,

$\rightarrow$ rehabilitacja osób starszych i osób z niepełnosprawnościami.

Wzrost poziomu wykształcenia społeczeństw w dobie rewolucji technologicznej spowoduje zwiększone zainteresowanie pracownikami wykonujących zawody wymagające najwyższych kompetencji specjalistycznych. $Z$ reguły będą poszukiwane kompetencje zintegrowane, czyli na przykład: informatyczne i techniczne, medyczne, biologiczne czy finansowe.

Od polityki imigracyjnej zależy przyszłość zawodów, w których zadania dotyczą:

$\rightarrow$ asymilacji obcokrajowców i umożliwiania im rozwoju zawodowego (kursy językowe, szkolenia zawodowe),

$\rightarrow$ wspierania rodzin obcokrajowców w ich codziennej egzystencji (edukacja dzieci, zajęcia edukacyjne i zawodowe dla współmałżonków, oferta integracyjna).

Obserwowany wzrost jakości życia już dziś owocuje powstawaniem zawodów operujących w sferze:

$\rightarrow$ dietetyki,

$\rightarrow$ kosmetologii,

$\rightarrow$ medycyny estetycznej,

$\rightarrow$ różnego rodzaju doradztwa,

$\rightarrow$ organizacji czasu wolnego. 
Z dużą dozą prawdopodobieństwa można założyć, że zawody tego rodzaju będą się w najbliższej przyszłości niezwykle dynamicznie rozwijać. Trzeba dodać, że są to tylko wybrane przykłady zawodów, a raczej obszarów zawodowych, z których będą się wyodrębniały zawody przyszłości.

Opierając się na prognozach dotyczących obszarów zawodowych, można niezwykle ostrożnie formułować prognozy opisujące kompetencje przyszłości. Ze zrozumiałych względów najtrudniej jest odnosić się do elementów kompetencji wynikających z wiedzy i umiejętności. Nieco łatwiej jest przewidywać zapotrzebowanie na kompetencje społeczne, które nie są bezpośrednio zależne od rozwoju techniki ani technologii. Przy tych ograniczeniach, patrząc z dzisiejszej perspektywy, do kompetencji przyszłości zaliczyć możemy:

$\rightarrow$ kompetencje ogólne zdobywane w okresie edukacji formalnej (możliwie najwyższy poziom kompetencji językowych, matematycznych, informatycznych oraz społecznych i obywatelskich),

$\rightarrow$ kompetencje ogólnozawodowe (specyficzne dla edukacji formalnej), wspólne dla grup zawodów (projektowanie, opracowywanie procedur realizacji projektów, szerokie wykorzystanie narzędzi informatycznych, praca w zespole, tworzenie zespołów i kierowanie ich pracą),

$\rightarrow$ kompetencje zawodowe wynikające z potrzeby realizacji zadań zawodowych (początkowo domena edukacji formalnej, a w późniejszym okresie edukacji pozaformalnej i nieformalnej), mające charakter obszarowy (branżowy),

$\rightarrow$ specyficzne kompetencje zawodowe związane z:

- możliwością transformacji umiejętności zawodowych (wraz ze zmianami technologicznymi),

- integracją wiedzy i umiejętności zawodowych z różnych obszarów (branż) - mechanika i elektronika, informatyka i medycyna, informatyka i ochrona środowiska, chemia i medycyna, biologia oraz nauki techniczne itd.,

$\rightarrow$ ogólne kompetencje społeczne nabywane w toku interakcji z innymi uczestnikami życia społecznego i zawodowego (komunikowanie - formułowanie, przekazywanie/odbiór komunikatów werbalnych i niewerbalnych, autoprezentacja, rozwiązywanie konfliktów, wywieranie wpływu społecznego, negocjowanie, 
współpraca w grupie, również wielokulturowej, organizacja pracy

własnej, odgrywanie różnych ról społecznych),

$\rightarrow$ specyficzne kompetencje społeczne (osobiste), takie jak:

- empatia,

- rozwiązywanie problemów,

- kreatywność,

- elastyczność myślenia,

- inteligencja emocjonalna,

- dojrzałość moralna, etyczność,

- odwaga,

- otwartość na zmiany,

- zarządzanie czasem,

- umiejętność uczenia się,

- przewodzenie (Mayer i Salovey, 1999, s. 34-45).

Zaproponowany układ: kompetencje ogólne, ogólnozawodowe, zawodowe (w tym specyficzne) i społeczne (ogólne i specyficzne) można oczywiście uszczegóławiać, tworzyć nowe kategorie i rozbudowywać ich strukturę. Można również dokonywać racjonalnych syntez. W przedstawionej postaci jest to rodzaj propozycji do dyskusji.

\section{Zakończenie}

Jeżeli przyjmiemy, że znakiem firmowym przyszłości jest zmiana, to podstawową - perspektywiczną kompetencją jest niewątpliwie zdolność do efektywnego reagowania na pojawiające się nowe elementy rzeczywistości. Wymaga to rozwoju swojego rodzaju kompetencji nadrzędnych, które charakteryzuje nie tylko gotowość na zmiany, lecz także aktywny udział $w$ ich kreowaniu, a następnie w rozwiązywaniu problemów (napięć) pojawiających się nieuchronnie na styku starego i nowego porządku społecznego oraz gospodarczego. 


\section{Bibliografia}

$\rightarrow$ Bogaj, A. (1998), Kształcenie ogólne w szkołach zawodowych [w:] S.M. Kwiatkowski (red.), Nowe uwarunkowania edukacji szkolnej, Warszawa: Wydawnictwo Instytutu Badań Edukacyjnych, s. 94-111.

$\rightarrow$ Carlebach, E. (2016), Teach us to be the authors of our own lives [w:] "Live \& Learn", issue $37,7-9$.

$\rightarrow$ Coates, J.F. (2002), O studiach nad przyszłościq̨ na świecie i w Polsce [w:] „Polska 2000 Plus", nr 1 (5), s. 9-22.

$\rightarrow$ Karpiński, A. (2001), Studia nad przyszłością na świecie i w Polsce - doświadczenia i wnioski [w:] „Polska 2000 Plus”, nr 2 (4), s. 9-23.

$\rightarrow$ Kwiatkowski, S.M. (2012), Współczesne cele kształcenia zawodowego [w:] U. Jeruszka (red.), Unowocześnianie metod i form kształcenia zawodowego w Polsce, Warszawa: Wydawnictwo Instytutu Pracy i Spraw Socjalnych, s. 37-44.

$\rightarrow \quad$ Kwiatkowski, S.M. (2014), Od kompetencji do zintegrowanego systemu kwalifikacji [w:] „Ruch Pedagogiczny”, nr 4, s. 25-33.

$\rightarrow$ Mayer, J.D., Salovey, P. (1999), Czym jest inteligencja emocjonalna? [w:] P. Salovey, D.J. Sluyter (red.), Rozwój emocjonalny a inteligencja emocjonalna. Problemy edukacyjne, Poznań: Dom Wydawniczy Rebis, s. 23-69.

$\rightarrow$ Nowacki, T. (2004), Leksykon pedagogiczny, Radom: Wydawnictwo Instytutu Technologii Eksploatacji.

$\rightarrow$ Sławiński, S. (red.) (2013), Słownik podstawowych terminów dotyczących krajowego systemu kwalifikacji, Warszawa: Wydawnictwo Instytutu Badań Edukacyjnych.

$\rightarrow$ Okoń, W. (2001), Nowy słownik pedagogiczny, Warszawa: Wydawnictwo Akademickie "Żak". 


\section{Netografia}

$\rightarrow$ Badania i ewaluacja PARP. Kompetencje przyszłości [online] [dostęp 27.10.2015].

Dostępny w Internecie: badania.parp.gov.pl/kompetencje-przyszlosci. 


\section{Przyszłość należy do świadomych i aktywnych obywateli.}

Jakie kompetencje są im niezbędne? Jak skutecznie je kształtować? (Perspektywa aksjologiczna)

Krystyna Chałas

Obserwując dynamicznie zmieniającą się rzeczywistość (społeczną, kulturową, gospodarczą, polityczną etc., i to zarówno w wymiarze lokalnym, regionalnym, państwowym, jak i europejskim oraz światowym) oraz doświadczając jej nieustannie, nasuwa się nam zasadnicze pytanie o punkty stałe, ponadczasowe, do których będzie można się odwołać mimo dynamiki zmian. Tymi punktami constans są: wartość osoby ludzkiej, jej integralny rozwój i wartości warunkujące go, kompetencje aksjologiczne będące rdzeniem kompetencji społecznych i obywatelskich.

Droga do kształtowania powyższej triady wiedzie poprzez edukację dla obywatelstwa. Z dydaktycznego punktu widzenia na uwagę zasługują:

$\rightarrow$ edukacja aksjologiczna i wychowanie ku wartościom,

$\rightarrow$ nauczanie przez projekty,

$\rightarrow$ tworzenie grup i wspólnot zorientowanych na realizację celów i programów edukacji dla obywatelstwa,

$\rightarrow$ budowanie programów działalności społecznej i obywatelskiej,

$\rightarrow$ pedagogia towarzyszenia.

\section{__ Słowa kluczowe: \\ wartości \\ kompetencje aksjologiczne \\ kompetencje społeczne \\ kompetencje obywatelskie \\ edukacja dla obywatelstwa}




\section{The future belongs to the}

\section{conscious and active citizens.}

\section{What competences are permanent and active for citizens? How to shape them efifectively? (Axiological perspective)}

Krystyna Chałas

In the face of the future, which is hard to predict, observing and experiencing dynamically changing reality (social, cultural, economic, political, etc. and this both in the local, regional, national, European and global dimensions), a fundamental question arises about permanent and timeless points that can be referred to, despite the dynamics of change.

These constants are: the value of the human person, his integral development and values conditioning him, axiological competences being the "core" of social and civic competences.

The path to forming the above triad leads through education for citizenship. From the didactic point of view, the following should be noted:

$\rightarrow$ axiological education and upbringing to values,

$\rightarrow$ teaching through projects,

$\rightarrow$ creation of groups and communities related to social education,

$\rightarrow$ building programs for social and environmental activities,

$\rightarrow$ pedagogy of the association.

Keywords:

values

axiological competence

social competence

civic competence

education for citizenship 


\section{Wprowadzenie}

Przyszłość to wielka niewiadoma, jeśli chodzi o fakty, zjawiska, procesy społeczno-kulturowe, gospodarcze, naukowe i religijne. Żyjemy w rzeczywistości dynamicznie się zmieniającej, targani różnymi konfliktami i wojnami na tle rasowym, gospodarczym, religijnym.

Pogłębiają się przeciwieństwa:

$\rightarrow$ dobrobyt i nędza,

$\rightarrow$ szanse rozwojowe i degradacja człowieczeństwa,

$\rightarrow$ rozpad społeczeństw i integracja grupowa, powstawanie wspólnot,

$\rightarrow$ bezgraniczna szansa komunikacji globalnej i zamknięcie się do relacji z małą liczbą osób, wręcz izolacja.

Niepokojącymi zjawiskami w aspekcie aksjologicznym są: brak wrażliwości na wartości, brak wiedzy o ich istocie i funkcjach, jakie pełnią w życiu jednostkowym i społecznym, odwrót od wartości, ich deprecjonowanie, brak urzeczywistniania własnej, lecz właściwej hierarchii wartości budowanej na podstawie obiektywnego ich porządku.

Powyższe odniesienie do wartości skutkuje zagubieniem człowieka, zwłaszcza młodego, w świecie wartości. W kontekście tematu przedstawionego opracowania jest to zjawisko bardzo niebezpieczne, ponieważ często wiedzie do wykluczenia społecznego (Skorowski, 2016). W tej sytuacji trudno o zaangażowaną aktywność obywatelską. Wykluczenie społeczne implikuje pozbawienie/ograniczenie możliwości korzystania z bogactwa życia społecznego w postaci należnych praw, a co się z tym wiąże - pozbawienie/ograniczenie możliwości zaangażowania w aktywne, twórcze budowanie życia społecznego, przekładającego się na różne obszary funkcjonowania człowieka: edukacyjny, kulturowy/kulturalny, religijny, gospodarczy, ekonomiczny (tamże).

Zagubienie aksjologiczne i wykluczenie społeczne skutkują utratą poczucia rzeczywistej wartości oraz tożsamości. Stanowi to niebezpieczeństwo dla życia społecznego i aktywności obywatelskiej. Człowiek "powinien mieć poczucie swojej wartości - wtedy jest on wartością dla życia społecznego, tzn. ma poczucie tożsamości, jest zintegrowany ze środowiskiem społecznym, w którym żyje; aktywnie partycypuje w życiu społecznym" (Skorowski, 2016, s. 10).

Zagubienie aksjologiczne uwarunkowane jest też czynnikami, które konstytuują społeczeństwo ponowoczesne. 
Cechami społeczeństwa ponowoczesnego są:

$\rightarrow$ kluczowe znaczenie informacji,

$\rightarrow$ uprzywilejowana pozycja technologii intelektualnych,

$\rightarrow$ rozwój technik komputerowych i technologii komunikacyjnych,

$\rightarrow$ informatyzacja życia społecznego,

$\rightarrow$ dynamiczny rozwój czwartego (finanse i ubezpieczenia) i piątego (edukacja) sektora gospodarki,

$\rightarrow$ równoległe istnienie świata rzeczywistego i wirtualnego (Wyleżałek, 2010).

Młody człowiek coraz bardziej funkcjonuje w społeczeństwie sieci. Tworzy ona "nowy model funkcjonowania społecznego, gdzie grupy odniesienia stają się grupami uczestnictwa poprzez sieć komputerową. Sytuacja taka, zupełnie nowa w życiu społecznym, a związana z szybkim przepływem informacji i możliwością szybkiego przemieszczania się w przestrzeni, ma zarówno swoje pozytywne, jak i negatywne konsekwencje" (tamże, s. 71).

Joanna Wyleżałek zwraca uwagę na bardzo ważny aspekt negatywnego skutku społeczeństwa ponowoczesnego, którym jest społeczna podatność na wpływy. Dlatego "coraz bardziej istotnym w społeczeństwie ponowoczesnym, które codziennie się staje, a którego codziennie jesteśmy twórcami i uczestnikami, jest poczucie odpowiedzialności za własne postawy i zachowania". [...] „Człowiek współczesny powinien stanowić wzór godny naśladowania, ponieważ może stać się punktem odniesienia do oceny własnych zachowań przez coraz szerszą grupę społeczną. Tak rozumiane poczucie odpowiedzialności za siebie i przyszły los społeczeństwa powinno spoczywać przede wszystkim na osobach sprawujących funkcje publiczne" (tamże, s. 74).

Jaka będzie przyszłość? Do kogo będzie należeć? Od kogo będzie zależeć? Na powyższe pytania można odpowiedzieć najogólniej: przyszłość będzie zależeć od świadomych, mądrych, aktywnych, odpowiedzialnych obywateli, posiadających kompetencje aksjologiczne, społeczne, obywatelskie.

W powyższym kontekście pierwszy krąg naszych myśli skierowany jest na przedmiot świadomości. Jest nim:

$\rightarrow$ świadomość siebie, swojej tożsamości oraz świadomość drugiego człowieka,

$\rightarrow$ świadomość kultury, 
$\rightarrow$ świadomość funkcji i zadań, jakie stoją przed człowiekiem w perspektywie przyszłości, w tym funkcji i zadań obywatelskich.

Drugi krąg myśli skierowany jest na sylwetkę osobową prawdziwego obywatela - demokraty, jego kompetencje aksjologiczne stanowiące rdzeń życia społecznego/obywatelskiego oraz kompetencje społeczne i obywatelskie.

Przedmiotem trzeciego obszaru myślowych analiz są sposoby kształtowania kompetencji aktywnych obywateli w perspektywie aksjologicznej.

\section{Świadomość siebie i kultury punktem wyjścia do aktywności obywatelskiej}

Świadomość siebie prowadzi do postawienia sobie podstawowych pytań: „Kim jestem?", „Kim mogę się stać?”, „Kim powinienem się stać?”, "Jakim powinienem się stać?", "Jaka powinna być aksjosfera życia i działania w sferze prywatnej, życia osobistego i w sferze społeczno-publicznej?".

W świetle personalizmu odpowiedź na te pytania brzmi: jestem osobą, a więc bytem cielesno-duchowym/jednością cielesno-duchową. Osoba ma przymioty, które stanowią trajektorię jej aktywności zanurzonej w dobro osobiste i dobro wspólne. Tymi przymiotami są: godność osobowa i osobowościowa, rozumność - mądrość, wolność, odpowiedzialność, zdolność do twórczości, miłości, transcendencji.

Każda z tych cech osoby warunkuje - na swój sposób - aktywność człowieka, nadaje jej osobowy charakter. Przymioty osoby decydują o przyszłości z "ludzką twarzą". Godność osobowa dana człowiekowi określa jego najwyższą wartość i zobowiązuje do życia na miarę tego, kim się jest, zobowiązuje do poszanowania siebie i drugiego człowieka, do kształtowania swoich kompetencji.

W obliczu narastających zjawisk i procesów integracyjnych, a także różnic, dyskusji, a nawet sporów toczących się w zjednoczonej Europie, potrzeba nam obywateli świadomych dziedzictwa kulturowego Polski, które wpisuje się w dziedzictwo Europy. Jest ono tworzone na podstawie:

$\rightarrow$ kultury greckiej, która wprowadziła wartości moralne, prymat myśli naukowej, racjonalnej, a także dała początek ustrojowi demokratycznemu, 
$\rightarrow$ kultury Rzymu, która wprowadziła idee obywatelskie, cnoty społeczne, fundamenty prawa,

$\rightarrow$ kultury chrześcijańskiej, która dała początek wartościom i prawdom ewangelicznym, wprowadziła wzory osobowe męczenników za wiarę, wartości zawarte w Dekalogu,

$\rightarrow$ myśli patronów Europy - wnoszą do kultury prawdę o Bogu i człowieku, o jego wielkiej godności.

Dziś potrzeba nam obywateli świadomych tego, że Europa jest zróżnicowana, że stanowi różne rzeczywistości przyrodnicze, ekonomiczne, społeczne, religijne, naukowe, polityczne, ideowe i kulturowe. Ta różnorodność stanowi wspólne dziedzictwo. To wspólne dziedzictwo staje się zadaniem, które trzeba chronić, ale też budować na mocnych podstawach, stanowiących fundament europejskiego domu. Żeby podjąć to zadanie, trzeba wyposażać młodych ludzi w wiedzę, stwarzać szanse na spotkania synergiczne, budowanie tożsamości postkonwencjonalnej, która będzie tworzyć nowe wartości i warunki do integralnego rozwoju, do osiągania pełni człowieczeństwa. Idea poszanowania różnorodności jest priorytetem w procesie wychowania młodych ludzi.

Drugim ważnym celem jest budowanie Europy jako wspólnoty ducha. Na ten wspólny kanon wartości mimo różnorodności zwracał uwagę Jan Paweł II. Do wspólnych wartości chrześcijańskich i ludzkich papież zaliczył: godność osoby ludzkiej, głębokie przywiązanie do sprawiedliwości i wolności, pracowitość, ducha inicjatywy, miłość rodzinną, szacunek dla życia, tolerancję, pragnienie współpracy i pokoju, szacunek dla innych religii, szacunek dla prawdziwych swobód1.

Ważnym zadaniem w budowaniu świadomości oraz aktywności społecznej i obywatelskiej jest urzeczywistnianie ideału europejskiego, którym jest szacunek dla osoby. Implikuje on stworzenie bezpiecznego życia osobie oraz ładu społecznego i moralnego budowanego na sprawiedliwości społecznej, na urzeczywistnianiu wartości moralnych. W świadomość oraz aktywność społeczną i obywatelską wpisuje się wartość pracy, jej godność, poszanowanie pracy oraz jej efektów, zarówno materialnych, jak i osobowych. Idea pracy powinna łączyć narody Europy. 
W to dziedzictwo wpisuje się kultura Polski, ze swoją specyfiką kulturową i z tradycją chrześcijańską, architekturą, dziełami sztuki i literatury, ich pięknem, z myślą naukową i społeczną oraz kulturą ludową. Świadomość dziedzictwa kultury polskiej, jej tożsamości stanowi istotny czynnik kształtowania aktywności obywatelskiej, bo w tej kulturze tkwi zakres treści działania obywatelskiego. W ten sposób, poprzez kulturę, kształtowana jest aktywność obywatelska. I - zwrotnie - aktywność obywatelska kształtuje kulturę, urzeczywistniając wartości kulturowe, które są transcendentne, mają charakter ponadindywidualny, ponadczasowy, a także cechę powszechności, moc zobowiązującą do postępowania zgodnego z tymi wartościami, które pomagają dokonywać wyborów, ukierunkowują i wskazują cele oraz środki działania (zob. Dyczewski, 2016).

\section{Osoba - integralny rozwój - pełnia człowieczeństwa - aktywność społeczna i obywatelska}

Podstawowe założenie znajdujące się u podstaw - przedstawionych w tym rozdziale - analiz brzmi: w centrum aktywności obywatelskiej znajduje się człowiek jako osoba. Osoba, określana jako jedność cielesno-duchowa, jest wielostronnie zanurzona w aktywność społeczno-obywatelską. " Człowiek-osoba przerasta całą otaczającą go rzeczywistość. Jako osoba charakteryzuje się on bowiem posiadaniem siebie, przynależnością do samego siebie, dysponowaniem sobą, nieprzekazywalną odpowiedzialnością za samego siebie, co w praktyce oznacza, że nie może on być zawłaszczany przez żadną instytucję, lecz należy do siebie; nie może być przez żadną osobę wykorzystywany, ponieważ sam dla siebie jest celem zasadniczym; nie może być przez nikogo reprezentowany, lecz odpowiada sam za siebie. Biorąc to pod uwagę, należy w odniesieniu do człowieka mówić o jego niepowtarzalnej wartości" (Skorowski, 2014, s. 331). Ta niepowtarzalna wartość osoby określana jest mianem godności osoby - godności osobowej.

Janusz Mariański, syntetyzując dotychczasowe rozważania wielu autorów na temat godności osobowej, określa ją jako "właściwość człowieka jako osoby pozostającej $w$ relacjach interpersonalnych, ostatecznie uzasadniających i nadających sens życiu ludzkiemu. [...] Godność osobowa przysługuje każdej osobie ludzkiej. Konstytuuje ludzki byt osobowy w powiązaniu z bytem absolutnym. Każdemu człowiekowi przysługuje ta naturalna i podstawowa, niezbywalna i zobowiązują- 
ca godność, pełniąca funkcję obiektywnej normy moralności. Idzie tu o wartość, jaką reprezentuje każda osoba przez to, że jest kimś, a nie czymś po prostu. Jest to wartość powszechna i nieutracana" (Mariański, 2016, s. 43-44).

W kontekście tematu opracowania na uwagę zasługuje definicja znajdująca się w „Encyklopedii katolickiej”: „Godność (łac. dignitas), szczególna wartość człowieka jako osoby pozostającej w relacjach interpersonalnych (ostatecznie do osoby Boga), uzasadniających i nadających sens życiu osobowemu, a także pozytywnie wartościująca relację do własnej osoby i grupy (np. zawodowej, klasowej, narodowej), z którymi jednostka się identyfikuje. Konstytuującym komponentem tego ustosunkowania się jest samoocena polegająca na przeżywaniu swojej wartości, pozytywnego obrazu samego siebie, która motywuje do moralnie wartościowych zachowań, uodparnia na wszelkie formy manipulacji i zniewalania oraz wpływa na radzenie sobie w sytuacjach trudnych; godność zakłada poczucie wewnętrznej wolności, autodeterminacji (podmiotowości) i odpowiedzialności" (Chlewiński, Zaleski, 1989, s. 1231-1232).

Godność osobowa jest wartością fundamentalną, wrodzoną, naturalną, daną $w$ akcie stworzenia przez Boga, jest wartością powszechną, trwałą, niezbywalną, nieutracaną, zobowiązującą, pełniącą funkcję obiektywnej normy moralnej, jest najwyższą wartością, określa bowiem wartość człowieka, jego wyjątkowość (Mariański, 2017). Stanowi ona podstawę godności osobowościowej określanej jako doskonałość, która zrodziła się w działaniach moralnie wartościowych i utrwaliła się w osobowości człowieka (Mazurek, 2001).

W kontekście godności osobowej można mówić o podstawowych kompetencjach godnościowych. Wyrażać się one będą w wiedzy o fenomenie tej kategorii godności, poszanowaniu własnej godności jako wielkiej wartości oraz poszanowaniu godności drugiego człowieka, budowaniu pozytywnego obrazu siebie, tworzeniu przestrzeni własnej wolności i wolności drugiego człowieka, podejmowaniu działań o charakterze podmiotowym, twórczym, przejawianiu postawy odpowiedzialności, umiejętności rozwiązywania problemów, budowaniu pozytywnych relacji interpersonalnych, poszanowaniu praw człowieka i odważnym stawaniu w ich obronie. Tak rozumiana godność osobowa jest czynnikiem integrującym społecznie bez względu na pochodzenie, wykształcenie, odgrywaną rolę i pełnioną funkcję, wykonywany zawód. 
Aktywność obywateli zorientowana na budowanie demokracji musi mieć swoje odniesienie do godności. „Fundamentalną bowiem ideą demokracji jest godność człowieka jako jednostki i wspólnoty osób. Takie ujęcie demokracji oznacza, że z samej jej istoty człowiek musi być uszanowany w swej godności. Jeśli bowiem najgłębszą podstawą demokracji jest godność człowieka, to cała rzeczywistość musi być stworzona na miarę tej godności. W konkretnej rzeczywistości uszanowanie to dokonuje się przez zagwarantowanie osobie jej praw - naturalnych i niezbywalnych" (Skorowski, 2014, s. 332).

Aktywność społeczna i obywatelska powinna więc stanowić przestrzeń rozszerzającego się horyzontu poszanowania godności człowieka. Odnosząc godność do konkretnej rzeczywistości społecznej, jej poszanowanie warunkuje urzeczywistnianie dwóch wartości: wolności i sprawiedliwości (tamże).

Aktywność obywateli integralnie związana jest z wolnością. Wolność warunkuje aktywność obywateli. „Bez wolności żaden czyn, żadne pragnienie, żadne spełnianie funkcji nie będzie własnym czynem człowieka. Człowiek powinien być sobą w swych czynach. Gdzie brak wolności, tam człowiek nie jest sobą - nawet gdy robi, co od niego wymagają" (Tischner, 1981, s. 49).

Aktywność poszerza pole wolności. Należy przy tym podkreślić, że chodzi tu o właściwie rozumianą wolność, a więc wolność do wyboru dobra i wolność od wyboru zła, od tego wszystkiego, co niszczy godność człowieka, co stanowi barierę jego rozwoju.

Gwarancją wolności są podstawowe prawa człowieka. Głównie prawa wolnościowe.

Ten fakt podkreśla Henryk Skorowski: „[...] prawa wolnościowe, których przedmiotem są szczegółowe wolności, i to zarówno »od «, jak i »do «, w sferze wewnętrznych przekonań i zewnętrznego działania, w tym sensie stoją w służbie wolności, że niejako prawnie i wprost określają, zabezpieczają i gwarantują człowiekowi, jako istocie bytowo wolnej, możliwość korzystania z wolności w różnych płaszczyznach. W tym sensie stanowią one jak gdyby próg autentycznej możliwości urzeczywistniania przez osobę jej istotowej wolności, a tym samym możliwość urzeczywistniania siebie w swej podmiotowości. Tylko bowiem mając zapewnioną możliwość korzystania z wolności w szeroko rozumianym życiu społecznym, człowiek może realizować siebie" (Skorowski, 2014, s. 334). A to oznacza, że może służyć drugiemu człowiekowi, dawać 
siebie, budować wspólnotę i podejmować działania na rzecz budowania nowej i lepszej rzeczywistości społecznej, politycznej, kulturowej, gospodarczej etc.

Aktywny obywatel musi więc nabyć kompetencje urzeczywistniania wolności oraz kompetencje respektowania i przestrzegania praw wolnościowych. Wiąże się to ze zdobywaniem wiedzy o właściwie rozumianej wolności, z budowaniem w sobie wolności wewnętrznej poprzez pracę nad sobą. A także wolności zewnętrznej wyrażającej się w wyborze i urzeczywistnianiu różnego rodzaju dobra jednostkowego i dobra wspólnego oraz odrzucaniem tego wszystkiego, co degraduje człowieczeństwo, ogranicza integralny rozwój, niszczy integrację społeczną, funkcjonowanie grup i wspólnot społecznych. Ważnymi predyspozycjami są odwaga i umiejętność zachęcania innych do budowania wolności, stawania się ludźmi wolnymi.

Kolejnym ważnym zagadnieniem jest znajomość swoich obowiązków, rzetelne ich wykonywanie oraz poznawanie, respektowanie i przestrzeganie praw wolnościowych, stawanie się prawym człowiekiem.

Jak już zostało podkreślone, drugą ważną wartością zapewniającą poszanowanie godności człowieka jest sprawiedliwość. Jej gwarancją są prawa społeczne, których przedmiotem są sprawy społeczne, gospodarcze, kulturowe (tamże, s. 335).

Prawa społeczne obejmują szczegółowe uprawnienia przysługujące osobie i obejmują „prawo do pracy, sprawiedliwej płacy, posiadania własności, mieszkania, wyżywienia, korzystania z dóbr kultury, dostępu do nauki itp."(tamże). Chodzi o "społeczne prawa do tych wartości i dóbr, które w jakikolwiek sposób warunkują w pełni ludzką egzystencję" (tamże).

Odnosząc powyżej wskazane zagadnienia sprawiedliwości i praw człowieka do aktywności obywateli, należy podkreślić, że ta aktywność powinna być "zanurzona" w problematyce praw społecznych i w ten sposób stać na straży sprawiedliwości społecznej. Wiąże się to ze zdobywaniem wiedzy o tych prawach, z rozeznaniem w sytuacji życiowej najbliższego i dalszego środowiska, oceną sytuacji w aspekcie zabezpieczenia praw społecznych, korzystaniem z nich, przestrzeganiem tych praw oraz podejmowaniem działań w celu gwarancji zapewnienia praw do wartości i dóbr warunkujących w pełni ludzką egzystencję, integralnym rozwojem człowieka. Zadaniem staje się przejawianie postawy sprawiedliwości wyrażającej się „w powinności bezwzględnego 
szanowania uprawnień drugiego człowieka do określonych dóbr i wartości, które są mu należne na mocy jego człowieczeństwa" (tamże, s. 337). Jej szczegółowym przedmiotem musi być odniesienie do przymiotów osoby: godności, samodzielności myślenia, wolności-swobody wyrażania poglądów i przekonań; swobodnego angażowania się na rzecz drugiego człowieka; szacunku dla życia i zdrowia innej osoby, warunków materialno-bytowych/ekonomicznych; odniesienie człowieka do człowieka wyrażające się w poszanowaniu, uznaniu uprawnień, przestrzeganiu normy personalistycznej; odniesienie społeczności do jednostki wyrażające się w poszanowaniu ze strony społeczności uprawnień jednostkowego człowieka; bezwzględne szanowanie przez jednostkę uprawnień wspólnoty, zaangażowanie w jej konstytuowanie, budowanie ${ }^{2}$.

W powyższym kontekście wyrasta podstawowa kompetencja aktywnego obywatela, którą można określić mianem kompetencji budowania rzeczywistości polityczno-społeczno-gospodarczej na miarę wielkości i godności człowieka - osoby. To kompetencja godnościowa.

Jak zostało to już podkreślone, godność osobowa jest podstawą godności osobowościowej, która ma charakter relatywny, zależy od zachowań i postaw jednostki, a także od społeczności mniejszych i większych, w których człowiek funkcjonuje - żyje i pracuje. Może być przez człowieka w różnym stopniu budowana, pomniejszana, utracona. Można ją utracić poprzez własne zachowania i postawy niemoralne, aspołeczne, a więc czynniki wewnętrzne. Źródłem jej budowania lub utraty jest sam podmiot działania poprzez jakość swojego życia, wyrażającą się w stopniu urzeczywistniania właściwych struktur hierarchicznych, w których swoje znaczące miejsce zajmują wartości uniwersalne, moralne, duchowe (zob. Chałas, 2006).

Źródłem godności osobowościowej jest aktywność człowieka. Józef Kozielecki godność osobowościową w aspekcie aktywności ujmuje trójwymiarowo, wyróżniając jej trzy źródła: wierność wobec siebie, podejmowanie celów pozaosobistych, działalność twórcza (zob. Kozielecki, 1977).

Płaszczyzną, na której konstytuuje się i rozwija godność osobowościowa, jest czyn człowieka, a więc działanie moralnie wartościowe ${ }^{3}$.

2. Zob. tamże. Zob. także K. Wojtyła (1982), Elementarz etyczny, Wrocław: Wydawnictwo Wrocławskiej Księgarni Archidiecezjalnej, s. 117-118.

3. Zob. Jan Paweł II... 
Czyn człowieka wprowadza go w świat wartości i konstytuowany jest przez wartości. Wychodzi od człowieka i wraca do osoby, wyrażając jej wielkie człowieczeństwo. Początek człowieka i podstawa tkwią w osobie - urzeczywistnianiu jej przymiotów, następnie w realizacji nadrzędnego celu, jakim jest integralny rozwój, który warunkuje jakość i zakres działań moralnie wartościowych, podejmowanych w różnych sferach życia i funkcjonowania człowieka. Czyn człowieka wymaga urzeczywistniania właściwych struktur wartości i posiadania kompetencji aksjologicznych.

Przez kompetencje aksjologiczne rozumieć należy wiedzę o wartościach, zintegrowaną z budowaniem i odpowiedzialnym urzeczywistnianiem własnej, lecz właściwej hierarchii wartości prowadzącej do integralnego rozwoju, do pełni człowieczeństwa, oraz aksjologiczną animację społeczności, w których człowiek żyje i funkcjonuje. Kompetencje aksjologiczne mają więc wymiar jednostkowy i społeczny.

Za kompetentną aksjologicznie należy uznać osobę, która ma rzetelną wiedzę o wartościach, potrafi rzetelnie i odpowiedzialnie urzeczywistniać własną, lecz właściwą hierarchię wartości i animować innych do jej urzeczywistniania we własnym życiu, życiu społecznym, obywatelskim.

Kompetencje aksjologiczne stanowią rdzeń kompetencji społecznych i obywatelskich. Wpisują się one w świadomość i aktywność obywateli, nadając jej osobowy wymiar.

Na uwagę zasługuje postawa odpowiedzialności za i odpowiedzialności przed. Bez tej postawy każda kompetencja, w tym aksjologiczna, społeczna, obywatelska, może obrócić się przeciwko człowiekowi, tym bardziej kompetencja społeczna, określana jako „możliwości gwarantujące wywiązywanie się z zakresu działań odpowiadających przypisywanej kwalifikacji; uprawnienia przysługujące osobie lub instytucji" (Zemło, 2016, s. 491).

Bez odpowiedzialności kompetencje aksjologiczne, społeczne, obywatelskie mogą stanowić niszczycielską siłę człowieka, grup i wspólnot. Podstawą, filarem i pierwszym warunkiem ich nabywania jest urzeczywistnianie przymiotów osoby ludzkiej: godności, rozumności - mądrości, wolności, odpowiedzialności, zdolności do miłości, twórczości, transcendencji. Wyrażać się ono będzie w nabywaniu takich ustosunkowań do przymiotów osoby ludzkiej, że stawać się będą cechami osobowości człowieka. Będziemy mogli wówczas powiedzieć: człowiek 
szanujący własną godność i godność drugiego człowieka, potrafiący ją afirmować i stanąć w jej obronie; człowiek racjonalny, mądry, wolny do wyboru dobra i wolny od wyboru zła; odpowiedzialny; kochający; podejmujący działania twórcze - człowiek twórczy, przekraczający swoje ograniczenia; człowiek rozwijający swoją duchowość 4 .

Urzeczywistnianie przymiotów osoby stanowi warunek pogłębiania świadomości, budowania poczucia wartości, tożsamości osobowej, aktywności społecznej i obywatelskiej zanurzonej w obiektywne dobro.

Nadrzędnym celem życia i funkcjonowania człowieka jest zdążanie do integralnego rozwoju i osiąganie pełni człowieczeństwa. Droga do tego celu wiedzie między innymi przez aktywność społeczną i obywatelską. Co więcej, zaangażowanie obywateli w budowanie nowej i lepszej jakościowo rzeczywistości uwarunkowane jest integralnym rozwojem człowieka, jego dążeniem do osiągania pełni człowieczeństwa.

Przez integralny rozwój rozumieć będziemy całościowy, holistyczny rozwój człowieka obejmujący wszystkie jego warstwy życia i funkcjonowania: warstwę biologiczną, psychiczną, społeczną, kulturową i światopoglądową (zob. Kunowski, 2004).

Czynnikiem integralnego rozwoju jest integralne wychowanie, które wyraża się we wspomaganiu osoby wychowanka w drodze do pełni człowieczeństwa - w harmonijnym rozwoju swoich potencjalności tkwiących w warstwie fizycznej, psychicznej, społecznej, kulturowej i światopoglądowej oraz ich integrowaniu ze sobą 5 . Jak podkreśla Alina Rynio, „integralny charakter wychowania wyraża się w tym, że obejmuje ono całego człowieka z jego niepowtarzalnym życiem fizycznym, psychicznym, duchowym, religijnym, i chroni go przed różnego rodzaju modnymi dziś z zarazem zgubnymi »redukcjonizmami « mającymi zakorzenienie w błędnym rozumieniu osoby ludzkiej" (Rynio, 2014, s. 13).

Istotnym czynnikiem integralnego rozwoju człowieka jest urzeczywistnianie wartości. Chodzi tu o wartości, które naturalnie związane są z poszczególnymi warstwami życia i funkcjonowania. Ich strukturę przedstawia tab. 1.

4. Por. K. Ostrowska (1994), W poszukiwaniu wartości, Gdańsk: Rubikon, s. 14.

5. Zob. K. Chałas (2007), Wychowanie ku wartościom wiejskim jako szansa integralnego rozwoju wychowanka, Lublin: Wydawnictwo KUL, s. 9-25. Zob. też K. Chałas (2012), Optymalizacja szans edukacyjnych młodzieży gimnazjalnej-perspektywa aksjologiczna, Warszawa: Oficyna Drukarska Jacek Chmielewski, s. 29-34 i wiele innych opracowań autorki. 
Tab. 1. Warstwy życia i funkcjonowania człowieka - struktura wartości

\begin{tabular}{|c|c|c|}
\hline LP. & RODZAJ WARSTWY & RODZAJ WARTOŚCI \\
\hline 1. & $\begin{array}{l}\text { Warstwa światopo- } \\
\text { glądowa }\end{array}$ & $\begin{array}{l}\text { szczęście człowieka, wartości religijne: wiara w Boga, } \\
\text { religia, nadzieja, miłość, modlitwa, świętość }\end{array}$ \\
\hline 2. & $\begin{array}{l}\text { Warstwa kulturolo- } \\
\text { giczna (kulturotwór- } \\
\text { cza) }\end{array}$ & $\begin{array}{l}\text { wartości zawarte w sztuce, poezji, muzyce, plastyce, war- } \\
\text { tości określające kulturę narodu, bytujące w tradycjach } \\
\text { narodowych, pamięci historycznej, kulturze ludowej }\end{array}$ \\
\hline 3. & $\begin{array}{l}\text { Warstwa socjolo- } \\
\text { giczna }\end{array}$ & $\begin{array}{l}\text { wartości moralne - prawość, wierność, poczucie odpowie- } \\
\text { dzialności, poszanowanie prawdy, dobroć; } \\
\text { wartości społeczne - godność, ojczyzna, naród, Kościół, } \\
\text { patriotyzm, niepodległość, praworządność, tradycja, } \\
\text { wolność, pokój, tolerancja, sprawiedliwość, równość spo- } \\
\text { łeczna demokracja, solidarność; } \\
\text { wartości życia codziennego - rodzina, sumienność, } \\
\text { uczciwość, honor, dom, wspólnota, odpowiedzialność, } \\
\text { posłuszeństwo, opanowanie, cierpliwość, odwaga, ko- } \\
\text { leżeństwo, czystość, samodzielność, umiejętność bycia } \\
\text { sobą, lojalność, wytrwałość, prawdomówność, praca, pra- } \\
\text { cowitość, łagodność, ufność, uprzejmość, punktualność, } \\
\text { systematyczność, dyskrecja, szczerość, stałość przekonan,, } \\
\text { szacunek, poszanowanie życia, pokora, przebaczenie, } \\
\text { wyrzeczenie, jałmużna, dobre obyczaje. }\end{array}$ \\
\hline 4. & Warstwa psychiczna & wiedza, nauka, mądrość, odkrywczość, twórczość \\
\hline 5. & Warstwa biologiczna & $\begin{array}{l}\text { wartości hedonistyczne - wolność, seks, zabawa; wartości } \\
\text { witalne - zdrowie, pokarm, powietrze, ruch, wypoczynek, } \\
\text { wartości geograficzno-przyrodnicze; } \\
\text { wartości materialne - wszystkie dobra materialne ułatwia- } \\
\text { jące życie, zapewniające egzystencję, pieniądze, mieszka- } \\
\text { nie, środki lokomocji, sprzęt techniczny. }\end{array}$ \\
\hline
\end{tabular}

Powyżej wskazana struktura wartości stanowi płaszczyznę kształtowania kompetencji aksjologicznych, społecznych, obywatelskich podejmowania działań moralnie wartościowych we wszystkich sferach życia i funkcjonowania człowieka.

W kontekście tematu przedstawionego opracowania na szczególną uwagę zasługują działania społeczne i obywatelskie, których podstawą aksjologiczną są wartości opisujące osobę ludzką (przymioty osoby), wartości moralno-społeczne, życia codziennego oraz wartości kulturowe.

Integralny rozwój człowieka jest podstawowym warunkiem zdążania do pełni człowieczeństwa. Droga do niego wiedzie poprzez harmonijne 
i hierarchiczne zaspokajanie potrzeb: biologicznych, psychicznych, społecznych, duchowych oraz przejawianie postaw i urzeczywistnianie wartości.

Według Krystyny Ostrowskiej model postaw i wartości pomagający w osiągnięciu pełni człowieczeństwa przedstawia się następująco:

$\rightarrow$ godność, doskonałość,

$\rightarrow$ wolność,

$\rightarrow$ odpowiedzialność,

$\rightarrow$ samoakceptacja,

$\rightarrow$ samodyscyplina,

$\rightarrow$ pasja,

$\rightarrow$ ambicja, wytrwałość,

$\rightarrow$ aktywność, troska o siebie i innych,

$\rightarrow$ otwartość na rzeczywistość pozaludzką,

$\rightarrow$ otwartość na innych,

$\rightarrow$ otwartość w stosunku do siebie,

$\rightarrow$ wytyczanie zadań i celów,

$\rightarrow$ refleksyjność w stosunku do siebie,

$\rightarrow$ poszukiwanie stałości w zmienności,

$\rightarrow$ życie jako zadanie,

$\rightarrow$ uznanie własnej niewystarczalności,

$\rightarrow$ współdziałanie z innymi,

$\rightarrow$ akceptacja potrzeby przekraczania siebie,

$\rightarrow$ akceptacja rozwoju,

$\rightarrow$ postawa akceptacji własnej egzystencji.

W kontekście tematu opracowania jednym $\mathrm{z}$ istotnych zadań stojących przed obywatelami jest tworzenie struktur międzyludzkich: grup, wspólnot, instytucji. Żeby one trwały, muszą być budowane na mocnej podstawie aksjologicznej.

Struktura postaw i wartości warunkujących współdziałanie z innymi, tworzenie struktur międzyludzkich według Ostrowskiej:

$\rightarrow$ miłość,

$\rightarrow$ odpowiedzialność,

$\rightarrow$ wolność,

$\rightarrow$ partnerstwo,

$\rightarrow$ koleżeństwo,

$\rightarrow$ przyjaźń, 
$\rightarrow$ uznanie wolności innych,

$\rightarrow$ altruizm,

$\rightarrow$ zaufanie do innych,

$\rightarrow$ szacunek dla innych,

$\rightarrow$ wyrozumiałość,

$\rightarrow$ dobroć,

$\rightarrow$ uznanie prawdy jako podstawy życia społeczeństwa,

$\rightarrow$ uznanie rozwoju innych,

$\rightarrow$ uznanie życia innych, uznanie potrzeby terytorium,

$\rightarrow$ uznanie indywidualności i różnorodności,

$\rightarrow$ uznanie wspólnoty 6 .

Aktywny i mądry obywatel musi być świadomy zadań w stosunku do "kosmosu". Ta świadomość "kosmosu" pozwala wzbogacać jego walory, by zachować dziedzictwo natury i kultury, poprzez jego ochronę, a także rozwój. Ostrowska zwraca na to uwagę i nakreśla strukturę postaw oraz wartości wobec "kosmosu” celem utrzymania i pomnażania jego walorów. Do nich zalicza:

$\rightarrow$ więź z otaczającym światem,

$\rightarrow$ uznanie potrzeby podporządkowania się,

$\rightarrow$ odpowiedzialność,

$\rightarrow$ tworzenie nowej jakości,

$\rightarrow$ współdziałanie z otoczeniem,

$\rightarrow$ przekształcanie otoczenia,

$\rightarrow$ uznanie potrzeby włączenia się w "kosmos",

$\rightarrow$ uznanie własnej małości,

$\rightarrow$ utrzymywanie kontaktu z otoczeniem,

$\rightarrow$ poznanie praw otoczenia,

$\rightarrow$ uznanie, że otaczająca rzeczywistość służy zaspokajaniu potrzeb z wszystkich wyróżnionych dziedzin,

$\rightarrow$ uznanie różnorodności w otaczającym świecie,

$\rightarrow$ uznanie, że ma się jakieś zadania wobec otoczenia,

$\rightarrow$ opanowanie tendencji eksploatatorskich, uznanie praw otoczenia do trwania i rozwoju?

6. Zob. tamże.

7. Zob. tamże. 
Wskazane powyżej struktury wartości i postaw pozwalają określić tożsamość człowieka oraz nadają kierunek jego aktywności w przestrzeni osobistej, społecznej, obywatelskiej. Gruntują świadomość siebie jako osoby zaangażowanej we własny rozwój oraz w rozwój otoczenia: przyrodniczego, społecznego, kulturowego, ekonomiczno-gospodarczego, wpisują się w kompetencje aksjologiczne, społeczne, obywatelskie.

W kontekście tym rysuje się sylwetka obywatela demokraty. Nakreślając ją, mamy na myśli osobę zaangażowaną w przestrzeni społecznej i obywatelskiej, mądrze, odpowiedzialnie rozwiązującą problemy w perspektywie rozwoju osobistego integralnie związanego z rozwojem dobra wspólnego. Pozostaje pytanie, jakie cechy powinien mieć prawdziwy obywatel demokrata. Według Marii Osowskiej spektrum tych cech obejmuje:

$\rightarrow$ perfekcjonizm,

$\rightarrow$ otwartość umysłu,

$\rightarrow$ dyscyplinę wewnętrzną,

$\rightarrow$ tolerancję,

$\rightarrow$ aktywność,

$\rightarrow$ odwagę cywilną,

$\rightarrow$ uczciwość intelektualną,

$\rightarrow$ krytycyzm,

$\rightarrow$ odpowiedzialność za słowo,

$\rightarrow$ uspołecznienie - szeroko i humanistycznie rozumiane,

$\rightarrow$ rycerskość,

$\rightarrow$ wrażliwość estetyczną,

$\rightarrow$ poczucie humoru ${ }^{8}$.

Świadomy, aktywny, odpowiedzialny obywatel integralnie łączy się z przejawianiem postawy patriotycznej. Patriotyzm najogólniej definiowany jest jako miłość ojczyzny.

Tak więc pierwszym celem edukacyjnym jest poznanie elementów składowych pojęcia „ojczyzna”. Patriotyzm to integracja uczucia miłości ojczyzny i zaangażowania w wypełnianie wobec niej obowiązków. Człowiek, szczególnie młody, powinien zrozumieć, że postawa patrio-

8. Za: P. Gliński (2008), Demokracja bez partycypacji. O konieczności zaangażowania obywatelskiego uczniów [w:] Wychowanie. Pojęcia. Procesy. Konteksty, M. Dudzikowa, M. Czerepaniak-Walczak (red.), Gdańsk: GWP, s. 200. 
tyczna wymaga poszanowania ojczyzny, ale również zobowiązuje do poszanowania innych narodów i ich ojczyzn.

Rdzeniem wiedzy o ojczyźnie jest prawda, że ojczyzna to integracja dobra osobistego każdego człowieka z dobrem wspólnym. To zespół wartości warunkujących rozwój człowieczeństwa. Na ten zespół wartości składają się dobra wyniesione $z$ domu rodzinnego, a więc wartości przekazane przez rodzinę, obecne $w$ środowisku lokalnym i utworzone przez to środowisko oraz dobra otrzymane od środowiska ponadlokalnego. Powinnością młodego człowieka staje się zachowanie otrzymanych wartości oraz podejmowanie twórczych działań zmierzających do pomnażania dobra. Podstawowym warunkiem rozwoju dobra wspólnego jest nie tylko samodoskonalenie, lecz także rozwój swoich możliwości, by pełniej uczestniczyć w budowaniu ojczyzny.

Postawa prorozwojowa wobec samego siebie staje się elementem postawy patriotycznej. Ta zależność postawy patriotycznej do samorozwoju i samodoskonalenia implikuje wiele zadań. Należą do nich: poszanowanie własnej godności i drugiego człowieka, odkrywanie mocnych stron osobowości i ich rozwijanie poprzez zgłębianie wiedzy, poszukiwanie obszarów samorealizacji, stawianie sobie ambitnych zadań na miarę swoich możliwości i odpowiedzialna ich realizacja, budowanie dobrych relacji interpersonalnych ${ }^{9}$.

Postawa patriotyczna wyraża się w zaangażowaniu we wszystkie sprawy narodu, ojczyzny i państwa, w podejmowaniu działań dla jego dobra $w$ różnorodnych sytuacjach życia codziennego. Elementami konstytutywnymi są: służba ojczyźnie, aktywność obywatelska, rzetelna i efektywna praca, troska o wspólne dobro, gotowość obrony słusznych interesów ojczyzny. Coraz ważniejsze jest więc zadanie zaszczepienia w wychowankach potrzeby zaangażowania się w działania czy rozwijania własnej twórczej wizji przyszłych działań10.

Do cech obywatela demokraty $w$ aspekcie aksjologicznym należy zaliczyć: otwartość na wartości i zdolność ich urzeczywistniania, wrażliwość aksjologiczną, zaangażowanie we własny integralny rozwój

9. Szerzej na temat kształtowania postawy patriotycznej: K. Chałas (2006), Teoretyczne podstawy wychowania ku wartościom narodowo-patriotycznym [w:] K. Chałas, S. Kowalczyk, Wychowanie ku wartościom narodowo-patriotycznym. Naród, ojczyzna, patriotyzm, państwo, pokój, Lublin-Kielce: Wydawnictwo „Jedność", s. 157-168 (wykorzystano fragmenty).

10.

Zob. tamże. 
i w urzeczywistnianie własnej, lecz właściwej hierarchii wartości prowadzącej do pełni człowieczeństwa, animację aksjologiczną w perspektywie społecznej (środowisk mniejszych i większych), zaangażowanie w integrację społeczną z uwzględnieniem zróżnicowania kulturowego, społecznego, religijnego, a także mądrość wyrażającą się w wiedzy, rozeznaniu w dobru i złu, podejmowaniu decyzji realizacji dobra obiektywnego $\mathrm{i}$ jego urzeczywistnianiu.

Jak już zostało podkreślone, warunkiem nabywania cech aktywnego i mądrego obywatela demokraty są kompetencje: aksjologiczne, społeczne, obywatelskie. Należy przy tym podkreślić, że kompetencje aksjologiczne, społeczne i obywatelskie to nie rzeczywistość gotowa, ale są one zadane, a to oznacza, że muszą być permanentnie rozwijane, kształtowane, kreowane.

W kompetencjach tych upatruje się czynnik warunkujący przygotowanie młodych ludzi do skutecznego i konstruktywnego uczestniczenia w życiu osobistym, społecznym, politycznym i zawodowym. W kontekście sylwetki obywatela demokraty, jego kompetencji aksjologicznych, społecznych i obywatelskich, wyrasta zadanie edukacji obywatelskiej. Biorąc pod uwagę doświadczenia różnych krajów, propozycje Unii Europejskiej, wypracowane doświadczenia polskie oraz perspektywę przyszłości zorientowanej aksjologicznie, edukacja obywatelska powinna obejmować:

1. Rozwój świadomości jednostkowej, społecznej, obywatelskiej, politycznej:

$\rightarrow$ zdobycie wiedzy antropologiczno-filozoficznej, odpowiedź na pytania: „Kim jest człowiek?", „Dokąd zmierza?”, „Kim może się stać?", „Kim powinien się stać?",

$\rightarrow$ zdobycie wiedzy o obowiązkach i prawach człowieka,

$\rightarrow$ zdobycie wiedzy o instytucjach społecznych, państwowych, pozarządowych,

$\rightarrow$ analiza warunków sprzyjających integralnemu rozwojowi człowieka, zrównoważonemu rozwojowi,

$\rightarrow$ zdobycie wiedzy o konstytucji i innych kluczowych aktach prawnych o randze państwowej,

$\rightarrow$ promowanie wartości dziedzictwa kulturowego i historycznego o zasięgu lokalnym, regionalnym, krajowym, europejskim,

$\rightarrow$ promowanie szacunku dla innych kultur narodowych, etnicznych. 
2. Rozwijanie myślenia krytycznego, kształtowanie postaw, urzeczywistnianie wartości:

$\rightarrow$ kształtowanie umiejętności potrzebnych do aktywnego uczestnictwa w życiu społecznym:

a) otwartość na drugiego człowieka i traktowanie go jako celu, a nie środka,

b) umiejętność i sprawność komunikowania się,

c) umiejętność współpracy z drugim człowiekiem, ze wspólnotą,

d) odpowiedzialność za siebie i drugiego człowieka, grupę, wspólnotę,

e) umiejętność radzenia sobie w sytuacjach problemowych i stresowych,

f) gotowość do działalności dobrowolnej w różnego rodzaju organizacjach,

g) zaangażowanie w podejmowane zadania,

h) przejawianie postawy innowacyjnej,

$\rightarrow$ kształtowanie szacunku dla siebie i innych / szanowanie godności własnej i drugiego człowieka w celu wzajemnego zrozumienia;

$\rightarrow$ urzeczywistnianie odpowiedzialności indywidualnej, społecznej i moralnej;

$\rightarrow$ wzmacnianie ducha solidarności, by budować więzi społeczne/ wspólnotowe/grupowe;

$\rightarrow$ wychowanie ku wartościom osobowym, społecznym, moralnym, kulturowym z uwzględnieniem różnych perspektyw społecznych w świetle obiektywizmu aksjologicznego i odniesienia personalnego (podmiotowego);

$\rightarrow$ kształtowanie postawy przyjaźni, pozytywnego nastawienia do drugiego człowieka;

$\rightarrow$ kształtowanie umiejętności pokojowego rozwiązywania konfliktów;

$\rightarrow$ kształtowanie postawy proekologicznej, wyrażającej się troską o środowisko na rzecz zrównoważonego rozwoju;

$\rightarrow$ kształtowanie bardziej aktywnych strategii zwalczania rasizmu i ksenofobii.

\section{Promowanie aktywnej partycypacji uczniów:}

$\rightarrow$ stwarzanie szans na aktywność poprzez włączanie się w działania społeczności szkolnej, lokalnej, narodowej i międzynarodowej, 
$\rightarrow$ stwarzanie szans zdobywania doświadczeń demokratycznych w szkole,

$\rightarrow$ tworzenie grup i wspólnot uczniowskich ${ }^{11}$.

W tak ujętą edukację obywatelską wpisują się edukacja aksjologiczna i wychowanie ku wartościom. Podstawę aksjologiczną tworzą cztery kręgi wartości:

$\rightarrow$ wartości opisujące osobę ludzką,

$\rightarrow$ wartości warunkujące integralny rozwój człowieka,

$\rightarrow$ wartości środowiska, w którym człowiek żyje i funkcjonuje,

$\rightarrow$ wartości stanowiące europejską wspólnotę ducha.

\section{Jak ksztalcić kompetencje potrzebne aktywnym obywatelom?}

Odpowiadając na powyższe pytanie, należy przyjąć dwa założenia: pierwsze dotyczy perspektywy aksjologiczno-etycznej, drugie obywatelstwa.

Pierwsze zakłada, że kształcenie kompetencji potrzebnych przyszłemu obywatelowi musi uwzględniać perspektywę działania etycznego, która najogólniej zorientowana jest na urzeczywistnianie zasady robienia dobra i unikania zła oraz perspektywę działania w aksjosferze i na rzecz budowania aksjosfery dla integralnego rozwoju osoby, dobra osobistego zintegrowanego $z$ dobrem wspólnym, zrównoważonego rozwoju.

Priorytetowym zadaniem stają się więc edukacja aksjologiczna i wychowanie ku wartościom. Edukacja aksjologiczna określana jest przez Katarzynę Olbrycht jako "nauczanie o sposobach traktowania wartości, wartościowania, o sposobach ich uzasadniania, a także o uwarunkowaniach i konsekwencjach różnych postaw wobec wartości" (Olbrycht, 2000 , s. 89). Wychowanie ku wartościom określane jest jako wspomaganie dzieci i młodzieży w urzeczywistnianiu w swoim życiu własnej, lecz właściwej hierarchii wartości prowadzącej do integralnego rozwoju, do pełni człowieczeństwa, oraz animacja innych do urzeczywistniania właściwych struktur aksjologicznych (zob. Chałas, 2006). 
Rodzi się pytanie, jak prowadzić edukację i wychowanie ku wartościom. Ogólnie można wskazać pewne drogi:

$\rightarrow$ zdobywanie wiedzy o fenomenie poszczególnych wartości i ich funkcji w życiu człowieka. Źródłem tej wiedzy są literatura, spotkanie z drugim człowiekiem - jego biografia, zreflektowane własne doświadczenia,

$\rightarrow$ stwarzanie sytuacji, szans wyboru spośród alternatyw i szczegółowa analiza skutków wyborów w aspekcie dobra i zła, szans i zagrożeń,

$\rightarrow$ wspomaganie przez nauczyciela $w$ dokonywaniu właściwych wyborów, z własnym przekonaniem co do słuszności, z akceptacją wyborów,

$\rightarrow$ wspomaganie $\mathrm{w}$ urzeczywistnianiu wartości i doświadczania wartości w swoim życiu,

$\rightarrow$ wspomaganie uczniów $w$ animacji innych do działań aksjologicznych - urzeczywistniania wartości (zob. tamże).

Priorytetowym zadaniem nauczyciela jest towarzyszenie uczniom w drodze aksjologicznej. Istotnym czynnikiem edukacji i wychowania w tym kierunku jest inspirowanie uczniów do zgłębiania tajników wiedzy aksjologicznej poprzez czytanie literatury, organizowanie konferencji popularnonaukowych i debat aksjologicznych, poszanowanie i promowanie wzorów godnych naśladowania.

Jak już zostało wskazane $w$ tym artykule, drugie założenie dotyczące sposobów kształtowania kompetencji przyszłych obywateli dotyczy obywatelstwa. Aby mówić o aktywności obywatelskiej, należy najpierw rozważyć zagadnienie obywatelstwa. W wąskim ujęciu obywatelstwo (w minimalnej interpretacji) promuje interesy elitarne i wyłączające, wybranym grupom społecznym. Edukacja obywatelska sprowadza się do zdobycia wiedzy o społeczeństwie.

W szerokim zaś ujęciu celem edukacji obywatelskiej jest nie tylko zdobycie przez uczniów wiedzy o społeczeństwie, lecz także zrozumienie rzeczywistości społecznej oraz rozwijanie/zwiększanie zdolności 
do uczestnictwa w życiu społecznym. Centrum jej stanowią więc: wiadomości, umiejętności, wyznawane wartości i postawy ${ }^{12}$.

Eugenia Potulicka, na podstawie angielskiej literatury, wskazuje trzy kategorie edukacji obywatelskiej:

$\rightarrow$ edukacja o obywatelstwie - przekazanie odpowiedniej wiedzy, rozumienie historii narodowej, znajomość struktur władzy, procesów rządzenia i życia politycznego,

$\rightarrow$ edukacja poprzez obywatelstwo - nabywanie doświadczeń, uczenie się poprzez działanie, aktywne uczestnictwo w społeczności szkolnej, lokalnej, ponadlokalnej,

$\rightarrow$ edukacja dla obywatelstwa - wyposażenie uczniów w zestaw narzędzi (wiedzę, rozumienie, umiejętności, postawy, wartości) umożliwiających im aktywne i sensowne odgrywanie ról i branie na siebie odpowiedzialności, których wymaga dorosłe życie ${ }^{13}$.

Założenie dotyczące obywatelstwa brzmi: powyższa edukacyjna triada powinna znaleźć swe miejsce w procesie wychowawczo-dydaktycznym. W kontekście tematu przedstawionego opracowania na szczególną uwagę zasługuje edukacja dla obywatelstwa. Łączy ona nierozerwalnie wartości i wiedzę oraz umiejętności, wśród których znaczące miejsce zajmują te służące odgrywaniu aktywnej roli w społeczeństwie na poziomie lokalnym, ponadlokalnym, narodowym, międzynarodowym. Łączą się one z umiejętnościami społecznymi. Wśród nich na szczególną uwagę zasługują umiejętności: słuchania, ujmowania zagadnień w sposób strukturalny, rozpoznawania i formułowania problemów, rozpoznawania wartości i budowania aksjosfery poprzez ich urzeczywistnianie, dyskutowanie, debatowanie, animowanie społeczności do działań społeczno-obywatelskich, organizowanie działań, wartościowanie efektów i na ich podstawie budowanie kolejnych programów działalności obywatelskiej ${ }^{14}$.

Tak rozumiana edukacja obywatelska integralnie łączy:

$\rightarrow$ "odpowiedzialność społeczną i moralną,

12. Zob. E. Potulicka (2008), Wychowanie obywatelskie-nowy przedmiot nauczania w Anglii [w:] Wychowanie. Pojęcia. Procesy. Konteksty, t. IV, M. Dudzikowa, M. Czerepaniak-Walczak (red.), Gdańsk: GWP, s. 40.

13. Zob. tamże, s. 40 .

14. Por. tamże, s. 43. 
$\rightarrow$ zaangażowanie w działalność wspólnotową,

$\rightarrow$ świadomość polityczną"15.

Należy przy tym podkreślić, że tak ujęta edukacja obywatelska wprowadza uczniów w przestrzeń wartości społecznych, moralnych, kulturowych - ich doświadczanie i urzeczywistnianie.

W kształceniu aktywnych obywateli istotną funkcję pełnią wartości. Jak podkreśla Potulicka: „To, jak poszczególne kraje wyrażają swoje wartości, ma duży wpływ na definiowanie edukacji obywatelskiej i podejście do niej" ${ }^{16}$. Autorka na podstawie badań w 16 krajach świata wyróżniła trzy kategorie:

$\rightarrow$ państwa odwołujące się w minimalnym zakresie do wartości w legislacji dotyczącej szkół-Kanada, Holandia, Stany Zjednoczone,

$\rightarrow$ państwa, w których wartości narodowe wyrażane są w terminach ogólnych na poziomie kraju, a szczegółowo przez władze edukacyjne - Australia, Nowa Zelandia, Włochy, Hiszpania,

$\rightarrow$ państwa, w których wartości narodowe wyrażane są szczegółowo - Japonia, Korea, Singapur, Szwecja ${ }^{17}$.

W kontekście aksjologicznym Potulicka stawia pytania: „Czy wychowanie obywatelskie powinno mieć jasno określone wartości i promować te z nich, które są częścią szerszego, uzgodnionego w państwie systemu norm i przekonań, czy powinno być neutralne z punktu widzenia aksjologii, zajmować bezstronne stanowisko w kwestiach kontrowersyjnych, pozostawiając decyzje jednostkom?"18.

W świecie dynamicznie narastających zmian, pojawiających się przeciwieństw, konfliktów, niepewnej przyszłości wiele państw dąży do wyraźnego określenia wartości, ich struktur oraz ich urzeczywistniania w systemach szkolnych, zobowiązując nauczycieli do wychowania ku wartościom ${ }^{19}$. Rządzący stoją na stanowisku, że "bez przygotowania jednostek i organizacji do uczestniczenia w życiu publicznym i brania za

\footnotetext{
15. Tamże.

16. Tamże, s. 38.

17. Zob. tamże.

18. Tamże.

19. Zob. tamże, s. 39.
} 
nie odpowiedzialności oraz bez zainteresowania sprawami publicznymi obywatelstwo nie jest możliwe" 20.

Edukacja aksjologiczna i wychowanie ku wartościom stanowią podstawę kształtowania kompetencji społecznych i obywatelskich. Jak już wcześniej podkreślono, tę strukturę aksjologiczną stanowią przymioty osoby ludzkiej, wartości warunkujące integralny rozwój człowieka oraz wartości środowiska, w którym człowiek żyje.

Podsumowując wyżej wskazane zagadnienia obywatelstwa, należy podkreślić, że obywatelskość obejmuje wymiar osobowy. Budowana jest na wartościach i postuluje ich urzeczywistnianie.

A więc najpierw przedmiotem uwagi musi być wychowanie człowieka jako osoby, prowadzenie go do dojrzałej osobowości. Następnie dobrego obywatela, świadomego swych obowiązków oraz praw i zaangażowanego w odpowiedzialne ich wypełnianie i przestrzeganie. Wreszcie patrioty - człowieka kochającego ojczyznę, dającego świadectwo tej miłości swoim życiem poprzez urzeczywistnianie własnej i właściwej hierarchii wartości. Trajektorię kształcenia świadomych i aktywnych obywateli stanowi triada: człowiek - osoba-obywatel - patriota (zob. Chałas, 2006).

Nauczanie skutkujące zdobywaniem przez uczniów wiedzy z dziedziny wychowania obywatelskiego nie wyczerpuje nabywania kompetencji obywatelskich. Jak zauważa Marian Nowak, do prawdziwego wychowania obywatela "potrzebna jest jeszcze praktyka właściwych postaw, odpowiedniego sposobu życia i funkcjonowania w społeczności. W tym sensie wymaga się budowania w szkole takich relacji, które będą służyły wzajemnej akceptacji i tolerancji oraz poszanowaniu stanowiska innych, nawet przeciwnego. Istotny jest współudział organizacji życia społecznego przez wskazywanie na konkretne problemy dzielnicy, miasta czy regionu" (Nowak, 2008, s. 419).

Ten sam autor, wskazując prace Romano Guardiniego, podkreśla, że w kształtowaniu kompetencji obywatelskich istotną funkcję pełni praca nad sobą, autoformacja, w której znaczącą rolę, według Guardiniego, odgrywają język i komunikacja werbalna.

Autor wyróżnia trzy problemy:

$\rightarrow$ obietnica (das Versprechen), 
$\rightarrow$ osądzanie (das Urteil),

$\rightarrow$ opinia publiczna (die öffentliche Heinung) (zob. tamże, s. 427).

Obietnica wyraża się w samozobowiązaniu. W aspekcie kompetencji obywatelskich na uwagę zasługuje rozpoznawanie obietnicy danej przez drugiego człowieka, grupy, wspólnoty, organizacje rządowe i pozarządowe oraz dawanie obietnicy wyrażającej się w samozobowiązaniach do działania w określony sposób na rzecz innych. Dotrzymywanie obietnicy buduje kompetencje obywatelskie, natomiast deprecjonowanie danego słowa degraduje godność osobowościową - ważny filar kompetencji obywatelskich.

Kolejnym elementem jest osądzanie, związane z siłą słowa. Opiniowanie może mieć różne zakresy i przedmioty. Może ono dotyczyć grup mniejszych i większych, państwa. Przedmiotem opiniowania mogą być cele, sposoby działania, zakresy działania, środki, efekty. W opiniowaniu zawierającym szczegółową ocenę należy uwzględnić strukturę: przedstawienie sytuacji, ocenę możliwości, dokonanie pomiaru skali trudności, konsekwentne działania (zob. tamże, s. 427-428).

Kształcenie umiejętności budowania opinii publicznej i uwzględnianie opinii publicznej to trzeci ważny element autoformacji. Wyraża się on w przyjęciu punktu widzenia odnośnie do jakiegoś argumentu.

Działalność mikrostruktur społecznych oraz państwa będzie prowadzona konstruktywniej, jeśli z powagą i odpowiedzialnością będzie odzwierciedlać stanowisko opinii publicznej. Jak podkreśla Nowak: „Każdy obywatel jest podmiotem opinii publicznej i uczestniczy w jej tworzeniu. Opowiadając o rzeczach nieprawdziwych, wypowiadając sądy niesprawdzone, rozpowszechniając bezpodstawne podejrzenia i nieufność, uczestniczy w niszczeniu opinii publicznej" (zob. tamże).

Stąd ważnym zadaniem w kształtowaniu u uczniów kompetencji obywatelskich staje się wychowanie do prawdy, u którego podstaw znajdzie się wspomaganie młodych ludzi w urzeczywistnianiu tej wartości. Nowak nakreśla proces formowania dobrego obywatela według Guardiniego. Na proces ten składają się:

$\rightarrow$ nabywanie i utrwalanie postawy politycznej - obejmuje wiedzę o stanie państwa, analizę rzeczywistości politycznej, rozumienie istoty państwa, przyjmowanie postawy propaństwowej, zainteresowanie parlamentem, autorytetami, instytucjami państwowymi, 
życiem każdego obywatela, wyrażenie dyspozycyjności w kwestii polityki, przejawianie postawy niezależności;

$\rightarrow$ bycie "człowiekiem polityki", który działa w imieniu państwa - skupienie aktywności na suwerenności państwa i jego prawie, którego celem jest ochranianie wolności, życia i własności. Ta perspektywa nakreśla zadania dla obywatela. Powinien on: mieć głęboko zakorzenione pojęcie państwa, pragnąć jego suwerenności, umieć rozpoznawać, że podstawę życia stanowi wszystko to, co pożyteczne, ekonomia, uporządkowana praca, a także przyjąć to, co zaskakuje prawo, umieć podjąć konstruktywną krytykę;

$\rightarrow$ zachowanie się jak człowiek polityki - dostrzeganie własnej relacji ze środowiskiem, z przeszłością historyczną i aktualną rzeczywistością, przeżywanymi jako pewna żywotna jedność. W państwie jest nią naród.

Ważną kwestią jest budowanie państwa według zasady: państwo w nas - państwo przybiera formę w szkole, rodzinie, grupach, urzędach (zob. Nowak, 2008). Istotne jest dokonywanie wyborów według kryterium dobra osobistego zintegrowanego $z$ dobrem wspólnym.

W tym kontekście na uwagę zasługuje partycypacja obywatelska, określana przez Piotra Glińskiego jako „zbiorowe i indywidualne działania odnoszące się przede wszystkim do sfery dobra wspólnego, łączące w sobie zaangażowanie, niezależność, zaufanie i solidarność społeczną oraz odpowiedzialność za wspólnotę, w której żyjemy" (Gliński, 2008, s. 178).

Gliński na podstawie analizy badań nad aktywnością obywatelską stwierdza, że „zakres uczestnictwa obywatelskiego jest bardzo ograniczony, jego jakość nie zawsze najwyższej próby, a blokady partycypacyjne różnorodne i poważne" (tamże, s. 191).

Ten sam autor wskazuje drogi rozwiązania problemu. Pierwszoplanowym zadaniem jest "wielki proces wychowawczy, edukacyjny i samoedukacyjny prowadzący do zasadniczej, proobywatelskiej zmiany społecznej i kulturowej. Proces ten powinien być nakierowany na wszystkie grupy społeczne (przede wszystkim młodzież, ale również przedstawicieli elit, osoby $w$ różnym wieku i o różnym statusie społecznym, a także ludzi starszych - na przykład dzięki uniwersytetom trzeciego wieku), powinien angażować w sposób skoordynowany i systemowy najróżniejsze instytucje państwowe, samorządowe, medialne 
i pozarządowe oraz obejmować zróżnicowany wachlarz metod edukacyjno-wychowawczych" (tamże, s. 192).

Wskazane zadanie natury ogólnej implikuje szczegółowe cele i zadania:

$\rightarrow$ jednym z celów szkoły jest wychowanie światłego, kompetentnego i sprawnego obywatela,

$\rightarrow$ u podstaw edukacji obywatelskiej powinny znaleźć się wartości zaakceptowane przez zdecydowaną część społeczeństwa,

$\rightarrow$ zmiana stylu funkcjonowania państwa, w którego centrum znajdują się wiarygodność poczynań władzy, przekaz wartości (zob. tamże, s. 193).

Szkoła jest ważnym podmiotem edukacji obywatelskiej. Jej działalność w tym zakresie, zdaniem Glińskiego, powinna koncentrować się głównie na "zdobywaniu przez jej podmioty (uczniów, nauczycieli, rodziców) wiedzy i umiejętności obywatelskich poprzez doświadczenia i praktykowanie działań obywatelskich, rozwiązywanie konkretnych problemów społecznych i lokalnych czy wręcz uczestniczenie w instytucjach partycypacji obywatelskiej (choć zacząć należy po prostu od reaktywowania autentycznego samorządu uczniowskiego i szkolnego oraz urealnienia pracy rad rodziców, co nie dokona się bez przyznania wszystkim tym instytucjom odpowiednich kompetencji)" (tamże, s. 198).

Drugim ważnym zadaniem jest współpraca szkoły ze środowiskiem społeczno-kulturowym (samorząd lokalny, organizacja społeczna, media). Sprowadzać się ona powinna do włączenia młodzieży w realizację programów instytucjonalnych oraz opracowywania przez szkołę projektów działalności społeczno-obywatelskiej i włączania w ich realizację instytucji lokalnych i pozalokalnych (zob. tamże).

W powyższym kontekście na uwagę zasługują programy:

$\rightarrow$ szkoła w środowisku - aktywnie włączająca się w realizację programów,

$\rightarrow$ szkoła dla środowiska - oferująca projekty edukacji obywatelskiej.

Trzecim zadaniem, które wskazuje Gliński, są staże aktywizacyjne dla młodzieży - w lokalnych mediach, organizacjach pozarządowych, instytucjach samorządowych (zob. tamże). Ta forma edukacji obywatelskiej nawiązuje do praktyk uczniowskich prowadzonych już dawniej w polskiej oświacie. Ważne w tym względzie są: oddolna inicjatywa, 
zaufanie, troska, solidarność, odpowiedzialność, twórcze podejście do problemów.

Zdaniem Glińskiego „edukacja obywatelska powinna [...] polegać na przekazywaniu pewnego zakresu wiedzy teoretycznej, wiedzy »stosowanej « i doświadczeń praktycznych oraz tego, co określić można jako proces wychowania do wartości (formacja). Teoria musi być przekazywana w sposób w miarę syntetyczny i prosty (odchudzanie programów), ale powinna obejmować także nowoczesne podstawy wiedzy na temat sektora pozarzą dowego (na przykładzie roli tego sektora w demokracji, idei ekonomii społecznej czy zasady pomocniczości). Edukacja stosowana powinna kształcić rozmaite obywatelskie umiejętności praktyczne uczniów, uczyć przez doświadczenie sprawnego dialogu, mediacji, poruszania się w świecie instytucji demokratycznych czy rozwiązywania różnorodnych zadań obywatelskich" (tamże, s. 199-200).

W przyszłości, obojętnie, jaka ona będzie w aspekcie obywatelskości (przypuszczalnie będzie zróżnicowana tożsamościowo), wpisane jest spotkanie. Zdaniem Krystyny Najder-Stefaniak „może ono wydarzyć się tylko w kontekście różnorodności. By zrozumieć spotkanie, potrzebujemy dwóch pojęć: różnica i tożsamość" (Najder-Stefaniak, 2010, s. 218).

Zarówno tożsamość, jak i różnica są pojęciami ważnymi w dyskursie o zasięgu nie tylko krajowym, lecz także europejskim i światowym. Człowiek i jego relacje z drugą osobą są bowiem ponadczasowymi zagadnieniami, zagadnieniami globalnymi.

Dialogowe spotkanie jest trajektorią, na której budowany jest proces zmierzania do prawdy, budowania edukacji obywatelskiej. Najder-Stefaniak podkreśla: „W zależności od praktykowanego przez nas sposobu myślenia o różnicy będziemy skłonni i zdolni realizować różne typy spotkań. Wyróżniamy myślenie antagonizujące, myślenie dialektyczne, myślenie komplementarne i myślenie synergiczne" (tamże, s. 221). Każdy rodzaj myślenia warunkuje inny typ spotkania.

„Myślenie dostrzegające i akcentujące antagonizujące właściwości różnicy jest myśleniem w schemacie "albo-albo «" (tamże). Autorka podkreśla, że „pozostając $w$ tym schemacie, przyjmujemy, że różnica dyskwalifikuje jeden z członów tego, co różne. W efekcie albo odrzucamy to, co inne, broniąc tego, co własne, albo zafascynowani innością akceptujemy ją kosztem własnej inności" (tamże).

W myśleniu dialektycznym różnica pełni funkcję antytezy, która umożliwia osiągnięcie syntezy (zob. tamże). 
„Myślenie komplementarne sumuje różnice, zakładając, że są one efektem różnych perspektyw postrzegania lub realizowania tego samego" (tamże).

Różnice są czynnikiem inspirującym myślenie synergiczne do pogłębiania rozumienia (zob. tamże).

Każdy z tych rodzajów myślenia implikuje inny rodzaj spotkania:

$\rightarrow$ wynikiem myślenia antagonizującego jest spotkanie typu „konkurencja lub wrogość",

$\rightarrow$ myślenie dialektyczne implikuje spotkanie typu „wspólne poczucie braku",

$\rightarrow$ wynikiem myślenia komplementarnego jest spotkanie typu „dopełnienie",

$\rightarrow$ myślenie synergiczne implikuje spotkanie typu "poczucie godności" - spotkanie synergiczne (zob. tamże, s. 221).

Na szczególną uwagę w kontekście tematu opracowania zasługuje spotkanie synergiczne. W tym typie spotkania "różnica nie antagonizuje, nie inspiruje do obrony tożsamości, nie dopełnia ani też nie usprawiedliwia braku perspektywy uniwersalizmu, lecz wzbogaca rozumienie i doświadczanie świata" (tamże).

Pełni ono według Najder-Stefaniak określone funkcje:

$\rightarrow$ "może pomóc otworzyć się na ten rodzaj transcendentnej prawdy, która pomaga zdystansować się do porządkujących myślenie i bycie paradygmatów i zrozumieć ich implikacje,

$\rightarrow$ sprawić, że różnica będzie nas inspirować do poszukiwania zrozumienia uniwersalnych prawd i wartości,

$\rightarrow$ sprawić, że nie rezygnując $z$ własnej tożsamości, będziemy mogli przekraczać jej granice" (tamże, s. 221-222).

W spotkaniu synergicznym następuje ubogacenie własnej tożsamości, inności bez uniformizacji i konfliktu.

Zjawiskiem, które coraz dynamiczniej się rozwija i wciąż powstaje w różnych obszarach życia i funkcjonowania człowieka na globie, jest konflikt. Najder-Stefaniak określa go jako "spotkanie "niegościnnych “, zamkniętych na siebie racji, interesów, poglądów lub postaw" (zob. tamże, s. 222). W jego centrum znajduje się różnica, z którą podmioty nie potrafią sobie poradzić. 
Drogami rozwiązania konfliktów są:

$\rightarrow$ kompromis - występuje rezygnacja z podmiotowości bądź jej ograniczenie, redukcja stanowisk, postaw, dóbr do tego, co stanowi „wspólny mianownik”, zawieszenie własnych racji i rezygnacja z własnych praw,

$\rightarrow$ podporządkowanie jednej ze stron drugiej - z jednej strony występuje redukcja własnej indywidualności i rezygnacja z podmiotowości,

$\rightarrow$ twórcze podejście do rozwiązania problemu - występuje prezentacja sposobów myślenia o problemie, wartościowanie w perspektywie podejmowania działań, zrozumienia uwarunkowań skutków myślenia i działania, promocja różnorodności.

Różnorodność stanowi czynnik twórczego przekraczania swoich potencjalności, inspiruje do aktywności, dialogu, zmiany utartych schematów myślenia i działania (zob. tamże, s. 222-223).

W tym kontekście przed nauczycielami stoją zadania, które sprowadzają się do stwarzania szans realizowania spotkań, których efektem jest synergia. Są to spotkania generujące realizację "eksperymentów" przyrodniczych, gospodarczych, kulturowych; spotkania generujące metanoję; spotkania otwarte, których "rdzeniem" jest "gościnność" otwierająca na zrozumienie odmienności innego, ale niepozwalająca na wchłonięcie siebie. Takie spotkania pozwalają pozostać sobą, a jednocześnie czerpać z inności tego, co spotkamy. W ten sposób możemy bardziej świadomie poznawać i rozumieć siebie, otaczającą rzeczywistość, świat; odkrywać prawdę, która tkwi w spotkaniu, podejmować razem zadania zorientowane na dobro wspólne (zob. tamże, s. 225).

Biorąc pod uwagę aspekt dydaktyczny kształcenia kompetencji potrzebnych zaangażowanemu, mądremu obywatelowi, można sformułować określone zadania wychowawczo-dydaktyczne, metody i formy.

Pierwszym zadaniem jest majeutyka osoby - wzbudzenie osoby w osobie. Sprowadza się ona do wspomagania dzieci i młodzieży w urzeczywistnianiu wartości opisujących osobę, a więc godności, rozumności-mądrości, wolności, odpowiedzialności, zdolności do twórczości, miłości i transcendencji.

Drugim zadaniem jest wspomaganie uczniów w integralnym rozwoju poprzez integralne wychowanie, czyli pomoc w urzeczywistnianiu 
wartości związanych z poszczególnymi warstwami rozwojowymi: biologiczną, psychiczną, społeczną, kulturową i światopoglądową.

Urzeczywistnianie struktur wartości związanych z poszczególnymi warstwami staje się źródłem budowania różnego rodzaju wspólnot uczniowskich (kultury fizycznej, kultury zdrowotnej, naukowych, kulturotwórczych, służby drugiemu człowiekowi, religijnych), które to wspólnoty warunkują aktywność społeczną i obywatelską, są przestrzenią kształtowania kompetencji aksjologicznych, społecznych, obywatelskich.

Należy podkreślić, za Lucyną Dziaczkowską, że wspólnota stanowi przestrzeń, w której jej członkowie poznają swoją wartość, uczą się odpowiedzialności za realizację celów wspólnoty i za nią samą, a także współdziałania z innymi osobami. Wspólnota jest celem wychowania i środowiskiem wychowawczym oraz czynnikiem wychowania (zob. Dziaczkowska, 2016, s. 1347).

W odniesieniu do wspólnoty wiodącym zadaniem jest ukazanie istoty wspólnoty, jej celów, działalności, zasobów i strategii jej budowania. Wspólnota stanowi cel, ma wpływ na swoich członków i zewnętrzne środowisko, uczy dochowywania wierności, życzliwości, rzetelnego wypełniania zadań i obowiązków, przestrzegania prawa i jego poszanowania, sztuki otwartości i szacunku dla przekonań innych. Źródłem wiedzy o wartości wspólnoty są prowadzone przez uczniów badania historyczne nad wspólnotą rodzinną i lokalną - jej tożsamością, działaniami, osiągnięciami.

Ważnym zadaniem staje się nauczanie przez projekty. Poczynając od pracy nad sobą (indywidualne programy wychowawcze), a kończąc na projektach dydaktycznych (przyrodniczych, społecznych, historycznych o charakterze badawczym). Wśród nich znaczące miejsce zajmują projekty animacji społecznej w środowisku lokalnym, których celem jest budzenie świadomości i aktywności obywatelskiej.

Czwarte zadanie sprowadza się do inspirowania uczniów do aktywnej działalności w organizacjach szkolnych oraz tworzenia nowych organizacji i wspólnot uczniowskich. To organizacje szkolne winny być mikroszkołą kształcenia kompetencji aksjologicznych, społecznych i obywatelskich.

Ważnym zadaniem jest działalność edukacyjna szkoły poprzez organizowanie wewnątrzszkolnych oraz adresowanych do środowiska: konferencji, sesji popularnonaukowych, seminariów o tematyce 
aksjologicznej, społecznej, obywatelskiej, patriotycznej, połączonych z programami działania prospołecznego, obywatelskiego.

Ta forma pracy wychowawczo-dydaktycznej stwarza szansę aktywizacji podmiotów szkoły, integracji społecznej, budowania projektów działań prorozwojowych w aspekcie indywidualnym i społecznym. $\mathrm{Na}$ uwagę $w$ tym względzie zasługuje urzeczywistnianie wartości środowiska lokalnego. Stanowi to trajektorię przygotowania młodych ludzi do budowania integracji społecznej na rzecz tworzenia różnych grup działania, służby, "małej ojczyzny”, a przez to do nabywania doświadczenia w służbie ojczyźnie.

Podsumowując, w kształceniu kompetencji przyszłego obywatela należy:

1. Kształtować w uczniach personalistyczną postawę.

2. Wprowadzać uczniów w świat wartości i wspomagać ich w urzeczywistnianiu właściwych struktur poprzez edukację aksjologiczną i wychowanie ku wartościom.

3. Wspomagać uczniów w urzeczywistnianiu roztropności i mądrości.

4. Rozwijać umiejętność formułowania celów, zwłaszcza celów prorozwojowych $w$ aspekcie integralnego i zrównoważonego rozwoju.

5. Kształtować umiejętności podejmowania i realizacji decyzji.

6. Kształtować umiejętności rozpoznawania zinstytucjonalizowanych potrzeb i interesów różnych grup społecznych.

7. Rozwijać podmiotowość poprzez odwagę podejmowania oddolnej aktywności (projektowanie i wdrażanie programów działalności społecznej i obywatelskiej).

8. Wspomagać w podejmowaniu zadań i towarzyszyć uczniom $w$ ich realizacji.

9. Inicjować powstawanie wspólnot, organizacji, grup społecznych i inspirować uczniów do podmiotowego ich współtworzenia.

10. Stosować nauczanie przez projekty.

Wskazane cele powinny znaleźć swe odzwierciedlenie w postawie patriotyzmu, wyrażającej się w gruntownym zdobywaniu wiedzy, rzetelnym wykonywaniu obowiązków, braniu odpowiedzialności za własny rozwój, za dobro wspólne, za losy państwa; urzeczywistnianiu wartości tkwiących w dziedzictwie kulturowym rodziny, społeczności lokalnej, ojczyźnie. 


\section{Podsumowanie}

Kształcenie kompetencji potrzebnych świadomym, aktywnym i mądrym obywatelom musi w centrum postawić osobę ucznia, z jej przymiotami i nadrzędnym celem, jakim jest integralny rozwój.

Rdzeniem kompetencji społecznych i obywatelskich są kompetencje aksjologiczne. Droga do nich wiedzie przez edukację aksjologiczną i wychowanie ku wartościom.

Edukacja dla obywatelstwa $\mathrm{z}$ jednej strony stanowi podstawę nabywania kompetencji stanowiących triadę: kompetencje aksjologiczne - kompetencje społeczne - kompetencje obywatelskie, z drugiej zaś powyżej wskazane kompetencje warunkują kształt tej edukacji.

W aspekcie dydaktycznym na drogę nabywania kompetencji potrzebnych aktywnym obywatelom składają się:

$\rightarrow$ pedagogia spotkania,

$\rightarrow$ nauczanie przez projekty,

$\rightarrow$ projektowanie i realizowanie programów działalności społecznej i obywatelskiej,

$\rightarrow$ tworzenie grup i wspólnot, których cele i programy działania koncentrują się na edukacji dla obywatelstwa,

$\rightarrow$ stosowanie pedagogii towarzyszenia. 


\section{Bibliografia}

$\rightarrow$ Bieńkowski, L. (1989), Encyklopedia katolicka, t. V, Lublin: Towarzystwo Naukowe KUL.

$\rightarrow$ Chałas, K., Maj, A. (2016), Encyklopedia aksjologii pedagogicznej, Radom: Polskie Towarzystwo Encyklopedyczne Powlen.

$\rightarrow$ Chałas, K. (2012), Optymalizacja szans edukacyjnych młodzieży gimnazjalnej - perspektywa aksjologiczna, Warszawa: Oficyna Drukarska Jacek Chmielewski.

$\rightarrow$ Chałas, K., Teoretyczne podstawy wychowania ku wartościom narodowo-patriotycznym [w:] K. Chałas, S. Kowalczyk (2006), Wychowanie ku wartościom narodowo-patriotycznym. Naród, ojczyzna, patriotyzm, państwo, pokój, Lublin-Kielce: Wydawnictwo „Jedność".

$\rightarrow$ Chałas, K. (2007), Wychowanie ku wartościom wiejskim jako szansa integralnego rozwoju wychowanka, Lublin: Wydawnictwo KUL.

$\rightarrow$ Chałas, K. (2006), Wychowanie ku wartościom, t. l, Godność, wolność, odpowiedzialność, tolerancja, Lublin-Kielce: Wydawnictwo "Jedność".

$\rightarrow$ Chlewiński, S., Zaleski, Z. (1989), Godność [w:] Encyklopedia katolicka, t. V, L. Bieńkowski (red.), Lublin: Towarzystwo Naukowe KUL.

$\rightarrow$ Dudzikowa, M., Czerepaniak-Walczak, M. (red.) (2008), Wychowanie. Pojęcia. Procesy. Konteksty, Gdańsk: GWP.

$\rightarrow$ Dyczewski, L. (2016), Wartości kulturowe [w:] Encyklopedia aksjologii pedagogicznej, K. Chałas, A. Maj (red.), Radom: Polskie Wydawnictwo Encyklopedyczne Powlen.

$\rightarrow$ Dziaczkowska, L. (2016), Wspólnota [w:] Encyklopedia aksjologii pedagogicznej, K. Chałas, A. Maj (red.), Radom: Polskie Wydawnictwo Encyklopedyczne Powlen.

$\rightarrow$ Fel, S., Wódka, M. (2014), Godność osoby ludzkiej w społeczeństwie i gospodarce, Lublin: Wydawnictwo KUL.

$\rightarrow$ Gliński, P. (2008), Demokracja bez partycypacji. O konieczności zaangażowania obywatelskiego uczniów [w:] Wychowanie. Pojęcia. Procesy. Konteksty, M. Dudzikowa, M. Czerepaniak-Walczak (red.), Gdańsk: GWP. 
$\rightarrow$ Jan Paweł II, Akt europejski w Santiago de Compostela, 9 listopada 1982.

$\rightarrow$ Kobylińska, Z., Melnyk, M., Skorowski, H. (2016), Aksjologia społeczno-polityczna, Warszawa-Olsztyn: Międzynarodowe Centrum Dialogu Międzykulturowego i Międzyreligijnego, UKSW.

$\rightarrow$ Kozielecki, J. (1977), O godności człowieka, Warszawa: Czytelnik.

$\rightarrow$ Kunowski, S. (2004), Podstawy współczesnej pedagogiki, Warszawa: Wydawnictwo Salezjańskie.

$\rightarrow$ Mariański, J. (2017), Godność ludzka - wartość ocalona. Studium socjopedagogiczne, Płock: Płocki Instytut Wydawniczy.

$\rightarrow$ Mariański, J. (2016), Godność ludzka jako wartość społeczno-moralna: mit czy rzeczywistość, Toruń: Wydawnictwo Adam Marszałek.

$\rightarrow$ Mazurek, F.J. (2001), Godność osoby podstawq praw człowieka, Lublin: Wydawnictwo KUL.

$\rightarrow$ Najder-Stefaniak, K., Plyska, Y. (2010), Człowiek w przestrzeni spotkań [w:] Człowiek w przestrzeni spotkań, K. Najder-Stefaniak, Y. Plyska (red.), Warszawa: Zakład Filozofii WNH SGGW.

$\rightarrow$ Najder -Stefaniak, K. (2010), Wartość spotkania, Warszawa: Zakład Filozofii WNH SGGW.

$\rightarrow$ Nowak, M. (2008), Teorie i koncepcje wychowania, Warszawa: WAiP.

$\rightarrow$ Olbrycht, K. (2000), Prawda, dobro i piękno w wychowaniu człowieka jako osoby, Katowice: Wydawnictwo Uniwersytetu Śląskiego.

$\rightarrow$ Ostrowska, K. (1994), W poszukiwaniu wartości, Gdańsk: Rubikon.

$\rightarrow$ Potulicka, E. (2008), Wychowanie obywatelskie - nowy przedmiot nauczania w Anglii [w:] Wychowanie. Pojęcia. Procesy. Konteksty, M. Dudzikowa, M. Czerepaniak-Walczak (red.), Gdańsk: GWP.

$\rightarrow$ Rynio, A. (2014), Integralne wychowanie w myśli Jana Pawła II, Lublin: Wydawnictwo KUL.

$\rightarrow$ Skorowski, H. (2014), Demokracja przestrzeniq uszanowania człowieka [w:] Godność osoby ludzkiej w społeczeństwie i gospodarce, S. Fel, M. Wódka (red.), Lublin: Wydawnictwo KUL.

$\rightarrow$ Skorowski, H. (2016), Zagubienie współczesnego człowieka w świecie wartości [w:] Aksjologia społeczno-polityczna, Z. Kobylińska, M. Melnyk, H. Skorowski (red.), Warszawa-Olsztyn: Międzynarodowe Centrum Dialogu Międzykulturowego i Międzyreligijnego, UKSW.

$\rightarrow$ Tischner, J. (1981), Etyka solidarności, Kraków: Znak.

$\rightarrow$ Wojtyła, K. (1982), Elementarz etyczny, Wrocław: Wydawnictwo Wrocławskiej Księgarni Archidiecezjalnej. 
$\rightarrow$ Wyleżałek, J. (2010), Zmiany społeczne a kryzys tożsamości współczesnego człowieka [w:] Człowiek w przestrzeni spotkań, K. Najder-Stefaniak, Y. Plyska (red.), Warszawa: Zakład Filozofii WNH SGGW.

$\rightarrow$ Zemło, J. (2016), Kompetencje społeczne [w:] Encyklopedia aksjologii pedagogicznej, K. Chałas, A. Maj (red.), Radom: Polskie Wydawnictwo Encyklopedyczne Powlen. 



\section{Przedsiębiorczość jako \\ kompetencja przyszłości}

Monika Borowiec-Gabryś, Wioletta Kilar, Tomasz Rachwał

W artykule podjęto problematykę wyzwań przyszłości w zakresie kształtowania kluczowych kompetencji oraz wskazano na współczesne procesy społeczno-gospodarcze i kulturowe, które w największym stopniu warunkują zapotrzebowanie na nowe kompetencje pracowników. Zależność między przedsiębiorczością a rozwojem społeczno-gospodarczym dowodzi, że w procesie tym ważną rolę odgrywa przedsiębiorczy człowiek, a wiele istotnych na współczesnym rynku pracy kompetencji ma ścisły związek z szeroko rozumianą przedsiębiorczością. Na tym tle przedstawiono miejsce przedsiębiorczości w polskim systemie edukacji w świetle nowej podstawy programowej i wskazano na jej zwiększającą się rolę w przyszłości.

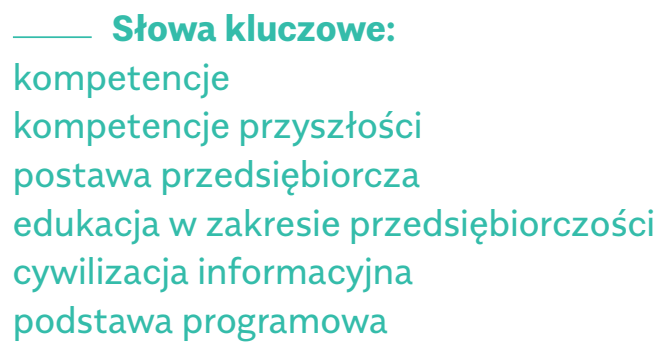




\section{Entrepreneurship as the competence of the future}

Monika Borowiec-Gabryś, Wioletta Kilar, Tomasz Rachwał

The text deals with the challenges for the future in the area of developing key competences and points to contemporary socioeconomic and cultural processes that determine to the greatest extent the need for new competences of employees. The relations between entrepreneurship and socio-economic development prove that an entrepreneurial person plays an important role in this process, and many of the competencies important in the contemporary labour market are closely related to broadly understood entrepreneurship. Against this background, the place of entrepreneurship in the Polish education system is presented in the light of the new core curriculum and its increasing role in the future is indicated.

\section{_ Keywords: \\ competences \\ competences for the future \\ entrepreneurial attitude \\ entrepreneurship education \\ information civilization \\ core curriculum}




\section{Wprowadzenie}

Era informacyjna jest okresem bardzo dynamicznych przemian, co oznacza konieczność szybkiego reagowania na nowe uwarunkowania. Szczególnie powinni o tym pamiętać decydenci i osoby zarządzające przedsiębiorstwami, instytucjami i różnej skali układami przestrzennymi. Zmiany przebiegu wielu procesów wymagają wizji i gotowości do zaakceptowania niepewności, co - pomimo zmniejszenia przejściowo możliwości działania w takiej sytuacji - w konsekwencji może przyczyniać się do zwiększenia kreatywności (Schratz, 2014). Podstawowym czynnikiem rozwoju cywilizacji informacyjnej są zasoby kapitału ludzkiego, którego jakość jest kształtowana w procesie edukacyjnym (Borowiec, 2009). „Społeczeństwo informacyjne będzie na tyle konkurencyjne, na ile jego gospodarka zostanie oparta na wiedzy. Kluczem do wiedzy jest edukacja. Dlatego wykształcenie społeczeństwa nie może być traktowane wyłącznie jako indywidualna sprawa uczącego się, tylko jako strategiczne zadanie dla państwa" (Abramowicz, Gogołka, Stokłosa, Sysło, 2002, s. 121). W procesie tym zmienia się zapotrzebowanie w zakresie zarówno kwalifikacji, jak i kompetencji pracowników na rynku pracy. Warto zauważyć, że szerokie analizy definicyjne pojęcia kwalifikacje zawodowe oraz zależność między kwalifikacjami a kompetencjami zawodowymi zostały przeprowadzone przez Stefana Michała Kwiatkowskiego i Krzysztofa Symelę (2001). Uważają oni, że kompetencje są pochodną kwalifikacji zawodowych i składają się na nie zarówno wiedza, doświadczenie, zdolności oraz umiejętności, jak i cechy psychologiczne wrodzone i nabyte, powierzchowność i kultura osobista. Przyjmują oni, że kompetencja jest to "taka dyspozycja człowieka, uświadamiana przez niego samego oraz dostrzegana przez innych, którzy mogą orzekać, że według nich dana osoba jest kompetentna w wybranej dziedzinie" (Kwiatkowski, Symela, 2001, s. 19). Symela traktuje kompetencje jako "zdolność wykonywania określonych zadań zawodowych, uprawnienia do działania, decydowania, wypowiadania sądów i ocen potrzebnych pracownikom do wypełniania ich funkcji i ról zawodowych zgodnie z przyjętymi kryteriami lub standardami wykonania (produktu, usługi lub podjęcia istotnej decyzji)" (Symela, 1995, s. 109). Kompetencje zawodowe oznaczają nieformalną jakość człowieka, która wynika z umiejętności praktycznego wykorzystania wiedzy i doświadczenia do właściwego realizowania zadań zawodowych w zmieniających się uwarunkowaniach, wymagających twórczego rozwiązywania problemów 
(Kwiatkowski, Woźniak, 2002). Kompetencje od kwalifikacji odróżniają zatem: niepowtarzalność, jednostkowość, niemierzalność. Współczesne rozumienie kompetencji podkreśla znaczenie uczenia się przez całe życie, edukacji nieformalnej i predyspozycji człowieka.

\section{Uwarunkowania i wyzwania przyszłości} w zakresie ksztaltowania kompetencji

Kształtując kompetencje przyszłości, warto uwzględnić przewidywania Światowego Forum Ekonomicznego, które wskazują, że aż 30 proc. umiejętności, które będą pożądane w 2020 r. na rynku pracy, dziś nie zalicza się do kluczowych ${ }^{1}$. Według globalnego raportu konkurencyjności 2016-2017 wśród barier rozwoju Polski kwalifikacje pracowników niestety zajmują wysokie szóste miejsce. Dodatkowo OECD wskazuje, że aż 65 proc. dzieci rozpoczynających edukację będzie pracować w zawodach, które jeszcze nie istnieją. Uwarunkowania te stawiają ogromne wyzwania przed systemem edukacji.

Rodzi się pytanie, jakie współczesne procesy społeczno-gospodarcze i kulturowe w największym stopniu warunkują zapotrzebowanie na nowe kompetencje pracowników. Publikacja Trends Shaping Education 2016², wydawana cyklicznie średnio co dwa lata i sporządzana na podstawie baz danych OECD, Banku Światowego oraz Organizacji Narodów Zjednoczonych, prezentuje najważniejsze pod względem gospodarczym, społecznym, demograficznym i technologicznym współczesne trendy oraz potencjalny wpływ, jaki wywierają one na edukację. Autorzy pracy wskazują na następujące kluczowe ogólnoświatowe procesy wpływające na edukację: globalizacja, procesy urbanizacyjne, zmiany klimatyczne, zmiana modelu rodziny oraz nowe technologie ${ }^{3}$. Przemiany te stają się wyzwaniem dla edukacji, która poprzez kształtowanie odpowiednich kompetencji przygotowuje młodych ludzi do wejścia na szybko zmieniający się rynek pracy. Przedstawione w publikacji odniesienia do rozwiązań zastosowanych w różnych państwach mogą stać się

1.

2. read.oecd-ilibrary.org/education/trends-shaping-education-2016_trends_edu-2016en\#page21, OECD (2016), Trends Shaping Education 2016, OECD Publishing, Paris.

3. www.paryzoecd.msz.gov.pl/pl/c/MOBILE/aktualnosci/trendy_w_edukacji_kompetencje_ przyszlosci, dostęp 23.04.2018. 
źródłem inspiracji oraz uzupełnić wskaźniki, według których mierzony jest postęp dokonujący się w sektorze edukacji i systemie kształcenia.

Także zespół naukowców z Institute for the Future Uniwersytetu w Phoenix (IFTF) wraz z pracownikami m.in. IBM i studia Walta Disneya przygotowali raport, w którym wskazują na sześć uwarunkowań wpływających na rynek pracy i stwarzających konieczność kształtowania nowych kompetencji pracowników potrzebnych w 2020 r. ${ }^{4}$ Należą do nich:

$\rightarrow$ procesy przemian demograficznych, głównie starzenie się społeczeństw i wydłużający się czas życia człowieka,

$\rightarrow$ wejście na rynek inteligentnych systemów i maszyn,

$\rightarrow$ rozwój mediów społecznościowych,

$\rightarrow$ ogromne przyśpieszenie w zakresie informatyzacji świata,

$\rightarrow$ ekspansja globalnych korporacji,

$\rightarrow$ nasilenie sieci powiązań społecznych, ekonomicznych i politycznych.

Wymienione w opracowaniu kompetencje są w dużym stopniu aktualnie na rynku pracy, ale pojawiają się także nowe i bardziej przyszłościowe:

$\rightarrow$ nadawanie sensu (sense-making) - umiejętność odkrywania i nadawania głębszego sensu temu, co chcemy wyrazić,

$\rightarrow$ inteligencja społeczna (social intelligence) - umiejętność sprawnego komunikowania się i wchodzenia w relacje międzyludzkie,

$\rightarrow$ nowatorskie i adaptacyjne myślenie (novel and adaptive thinking) - sprawność w rozwiązywaniu problemów, wymyślaniu rozwiązań wykraczających poza schematy czy reguły,

$\rightarrow$ kompetencje wielokulturowe (cross-cultural competency) - umiejętność funkcjonowania w zróżnicowanym środowisku kulturowym,

$\rightarrow$ myślenie obliczeniowe (computational thinking) - umiejętność przetwarzania dużej ilości informacji i właściwego interpretowania danych,

4. Www.iftf.org/uploads/media/SR-1382A_UPRI_future_work_skills_sm.pdf, Future Work Skills 2020, 2011, Institute for the Future for the University of Phoenix Research Institute University Avenue. 
$\rightarrow$ znajomość nowych mediów (new-media literacy) - umiejętność korzystania z nowych mediów i opracowania treści, krytycznej oceny informacji publikowanych w nowych mediach, a także wykorzystania ich w skutecznej komunikacji,

$\rightarrow$ interdyscyplinarność (transdisciplinarity) - umiejętność czytania i rozumienia pojęć z wielu dziedzin,

$\rightarrow$ myślenie projektowe (design mindset) - umiejętność prezentowania i rozwijania sposobów pracy dla osiągnięcia pożądanych rezultatów,

$\rightarrow$ zarządzanie ładunkiem (szumem informacyjnym) poznawczym (cognitive load management) - umiejętność filtrowania informacji pod kątem ważności oraz zdolność do zmaksymalizowania funkcjonowania poznawczego i przyswajania wielu bodźców przy użyciu różnych narzędzi i technik,

$\rightarrow$ współpraca wirtualna (virtual collaboration) - umiejętność wydajnej i zaangażowanej pracy jako członek wirtualnego zespołu.

W literaturze przedmiotu pojawiają się też nieco inne ujęcia tych kompetencji lub wymieniane są dodatkowo inne kompetencje: krytyczne myślenie, współpraca, efektywna komunikacja, techniki kreatywnego rozwiązywania problemów, elastyczność, otwartość na zmiany i gotowość do ciągłego doskonalenia się, a także kompetencje przywódcze i strategiczno-biznesowe, które wraz z technicznymi składają się na trzy obszary kompetencji menedżera projektu (Project Managera) ${ }^{5}$. Poza tym Komisja Europejska wśród kluczowych kompetencji przyszłości wymienia programowanie ${ }^{6}$.

W raporcie Dwa światy. Kompetencje przyszłości $2014^{7}$ autorzy wskazują aż 18 kompetencji: inteligencja emocjonalna, przetwarzanie dużej ilości informacji, doprowadzanie zadań do końca, koncentracja i selekcja informacji, adaptowanie się do nowych warunków, kreatywność, innowacyjność, samodzielność, wielozadaniowość, świadomość swoich mocnych i słabych stron, radzenie sobie w zaskakujących i trudnych sytuacjach, radzenie sobie ze stresem, doświadczenie zawodowe

5. www.outsourcingportal.eu/pl/kompetencje-przyszlosci.

6. biznes.newseria.pl/news/programowanie-kluczowa,p611046578.

7. kariera.kozminski.edu.pl/fileadmin/kariera.kozminski.edu.pl/Raporty/RAPORT_KOMPETENCJE_ PRZYSZLOSCI_-_pracodawca.pdf. 
w branży, proaktywność, budowanie dobrych relacji, praca zespołowa, systematyczność, przekuwanie pomysłów na działanie oraz otwartość na pomysły i wiedzę innych. Wiele z tych wymienianych przez różnych autorów i ekspertów kluczowych instytucji kompetencji zawiera się w szeroko rozumianej przedsiębiorczości jako kompetencji kluczowej, często określanej jako zbiór kompetencji, lub wykazuje ścisłe związki z nią.

\section{Przedsiębiorczość jako kompetencja kluczowa przyszłości}

Przedsiębiorczość jest często traktowana jako pojęcie polisemiczne i niejednoznaczne zarówno w języku potocznym, jak i naukowym. Najczęściej ujmowana jest jako:

$\rightarrow$ cecha osobowości człowieka i związane z nią umiejętności,

$\rightarrow$ podejmowanie własnej działalności gospodarczej,

$\rightarrow$ zdolność do wykorzystywania szans obecnych w otoczeniu i podejmowania kreatywnych (innowacyjnych) działań lub projektów.

Jest to zjawisko ze swej istotny trudno poddające się kwantyfikacji, dlatego częściej problematyka ta na gruncie nauk ekonomicznych podejmowana jest w naukach o zarządzaniu niż w ekonomii. W naukach ekonomicznych dominują analizy tego zjawiska oparte na uproszczonych modelach, opierające się na samozatrudnieniu (liczba nowo powstałych firm osób fizycznych, tj. jednoosobowej działalności gospodarczej) lub liczbie przedsiębiorstw sektora małych i średnich przedsiębiorstw (MŚP) na liczbę mieszkańców i ich udziału w ogóle przedsiębiorstw. Co więcej, literatura ekonomiczna głównego nurtu w zasadzie pomija przedsiębiorczość jako jedną ze zmiennych w swoich modelach, nie wspominając o roli przedsiębiorczości we wzroście gospodarczym lub w rozwoju społeczno-gospodarczym. Warto zwrócić uwagę na podstawowe wymiary przedsiębiorczości, jakie opisywane są w literaturze ekonomicznej. Traktowana jest więc ona jako: funkcja osobowości, czynności menedżerskich, indywidualnego przedsiębiorcy i rynku. Przedsiębiorczości przypisuje się także trzy pochodne funkcje w modelach na etapie ich operacjonalizacji: samozatrudnienie, sektor małych i średnich przedsiębiorstw (MŚP) oraz czwarty czynnik produkcji (Wach, 2015). Nader częste upraszczanie problematyki przedsiębiorczości do samozatrudnienia czy sektora MŚP z punktu widzenia teorii przedsiębiorczości jest nieuzasadnione 
i wypacza fenomen przedsiębiorczości (Wach, 2015; zob. także Wach, 2013, 2014).

Przedsiębiorczość, szczególnie na potrzeby edukacji na różnych szczeblach, powinna być zatem rozumiana zdecydowanie szerzej i w większym stopniu odnosić się do pierwszego z wymienionych ujęć, tj. jako funkcji osobowości. Zawężanie kształtowania kompetencji przedsiębiorczości w systemie edukacji do zdolności założenia i prowadzenia własnej firmy jest niewłaściwe. Trudno przecież założyć, że każdy absolwent szkoły podstawowej czy średniej, a nawet studiów wyższych, będzie prowadził własną działalność gospodarczą. Dlatego wydaje się, że konieczne jest nieco szersze spojrzenie na przedsiębiorczość, jako na zespół cech osobowości, takich jak inicjatywność, kreatywność, energia i zapał do pracy, wytrwałość w działaniu, a także ciekawość świata, pewność siebie i wiara we własne siły, samodyscyplina, skłonność do podejmowania wyważonego ryzyka i branie odpowiedzialności za siebie i innych. Cechy te pozwalają nie tylko na dobre prowadzenie przedsiębiorstwa, czyli bycie przedsiębiorcą, lecz także umożliwiają aktywne uczestniczenie w życiu społeczno-gospodarczym ( $w$ tym w udanym życiu rodzinnym), dając dużo satysfakcji i zadowolenia, niezależnie od charakteru wykonywanej pracy i zajmowanego stanowiska.

Człowiek przedsiębiorczy nie boi się trudności, podejmowania nowych, nieznanych zadań, nie załamuje się niepowodzeniami, jest chętny do zdobywania wiedzy i nowych umiejętności, potrafi cieszyć się z sukcesów, jest otwarty na otoczenie, ma zdolność empatii, potrafi dobrze ułożyć sobie stosunki z innymi ludźmi, panować nad swoimi emocjami oraz postępować zgodnie z wartościami etycznymi (Rachwał, 2004, 2005). Do kompetencji przedsiębiorczości zalicza się także zestaw określonych umiejętności, takich jak wyszukiwanie i wykorzystywanie szans, które stwarza rynek, zdobywanie, selekcja i przetwarzanie informacji, interpretowanie procesów gospodarczych, a także te z zakresu autoprezentacji, komunikacji interpersonalnej oraz umiejętności organizacyjne (Borowiec, Rachwał, 2011). Kształtowanie inteligencji emocjonalnej i finansowej, cech równie ważnych, traktowane bywa jako, w pewnym sensie, zapomniany i brakujący element kształtowania przedsiębiorczości w przestrzeni edukacyjnej (Kopczyński, 2017). Znaczenie inteligencji emocjonalnej już wiele lat wcześniej podkreślali niektórzy autorzy (Rachwał, 2005; Borowiec, Rachwał, 2011). Problemem jest więc raczej brak zrozumienia przez nauczycieli jej roli jako 
komponentu postawy przedsiębiorczej lub nieco błędne przeświadczenie, że nie daje się jej skutecznie w toku edukacji szkolnej rozwijać. Od lat podejmowanych jest też wiele inicjatyw na rzecz rozwoju inteligencji finansowej jako nieodłącznego elementu przedsiębiorczości przez m.in.: Narodowy Bank Polski, Komisję Nadzoru Finansowego, Ministerstwo Finansów, Zakład Ubezpieczeń Społecznych, Giełdę Papierów Wartościowych w Warszawie, Fundację Warszawski Instytut Bankowości (program Bankowcy dla Edukacji) $\mathrm{i}$ inne instytucje ${ }^{8}$.

Taki punkt widzenia postawy przedsiębiorczej jest więc powszechnie przyjmowany przez wielu autorów, zarówno badaczy, jak i autorów podręczników szkolnych (zob. Rachwał, Makieła, 2002, 2012; Borowiec i in., 2014; Kalita, 2015). Opiera się on na założeniu, że przedsiębiorczym może i powinien być każdy człowiek, nie tylko pracodawca (właściciel firmy), lecz także jego pracownik. Każda osoba niezależnie od rodzaju pracy, jaką wykonuje, i roli, jaką odgrywa w społeczeństwie. Wykształcenie absolwenta szkoły ponadgimnazjalnej o tak ukształtowanej postawie przedsiębiorczej, na którą składa się wiele cech i związanych z nią umiejętności, wydaje się bardzo trudne, jednak zaproponowane rozumienie postawy przedsiębiorczości należy traktować jako cel, do którego powinno się dążyć w procesie edukacji.

Takie podejście jest zgodne z definicją przedsiębiorczości jako kompetencji kluczowej w europejskich systemach edukacji. W świetle definicji przyjętej przez Komisję Europejską kompetencje określone jako inicjatywność i przedsiębiorczość oznaczają zdolność osoby do wcielania pomysłów w czyn. Obejmują one kreatywność, innowacyjność i podejmowanie ryzyka, a także zdolność do planowania przedsięwzięć i prowadzenia ich dla osiągnięcia zamierzonych celów. Stanowią one wsparcie dla indywidualnych osób nie tylko w ich codziennym życiu prywatnym i społecznym, lecz także w ich miejscu pracy, pomagając im uzyskać świadomość kontekstu ich pracy i zdolność wykorzystywania szans. Są podstawą bardziej konkretnych umiejętności potrzebnych tym, którzy podejmują przedsięwzięcia o charakterze społecznym lub handlowym bądź w nich uczestniczą. Powinny one obejmować świadomość wartości etycznych i promować dobre zarządzanie (Kompetencje...,

8. Warto jednak zauważyć, za Renatą Raszką (2017), że za edukację finansową młodego pokolenia odpowiadają przede wszystkim rodzice wraz z opiekunami. To bowiem w domu rodzinnym kształtowane są pierwsze postawy i nawyki związane z pieniądzem. 
2007). I choć, generalnie rzecz ujmując, takie rozumienie tej kompetencji dla celów edukacyjnych jest powszechnie przyjmowane, niestety nie wszyscy autorzy podręczników definiują pojęcie przedsiębiorczości zgodnie z zaleceniami zawartymi w Europejskich ramach odniesienia (Kalita, 2015). Część autorów nie wspomina o konieczności powiązania wiedzy z umiejętnościami i postawą, tymczasem już na początku zajęć z przedsiębiorczości uczniowie potrzebują jasnego przekazu na temat tego, jakie warunki muszą spełniać, aby nabyć kompetencję przedsiębiorczości. Wskazane jest zatem, aby uczniowie poznali wszystkie trzy aspekty tego pojęcia, a więc dowiedzieli się, że istotna jest zarówno wiedza, jak i umiejętność jej praktycznego wykorzystania oraz odpowiednia postawa (Kalita, 2015) ${ }^{9}$. Analizując podręczniki przedsiębiorczości, nie wszyscy autorzy zauważają jednak ten problem (Kocurek, 2017). Pozostaje mieć nadzieję, że większość nauczycieli jest jednak świadoma potrzeby holistycznego podejścia do przedsiębiorczości.

\section{Przedsiębiorczość jako wartość w edukacji współcześnie i w przyszłości}

Uznanie przedsiębiorczości za jedną z ośmiu kompetencji kluczowych stanowi ważny sygnał o jej dużym znaczeniu w edukacji. Samo w sobie nie wskazuje to jeszcze na jej wartość w kształceniu. Konieczne jest uświadomienie sobie ważnych funkcji, jakie pełni przedsiębiorczość nie tylko w życiu każdego człowieka, lecz także rozwoju przedsiębiorstw, instytucji i układów przestrzennych różnej skali, od lokalnych przez regionalne do krajowych, a nawet europejskich i światowych. $Z$ zarysowanych wyżej podejść do definiowania przedsiębiorczości wynika jednoznacznie jej ogromna rola w funkcjonowaniu każdego człowieka zarówno w jego miejscu pracy, jak i na innych polach aktywności oraz w życiu rodzinnym. Dlatego często przyjmuje się, że być przedsiębiorczym to wiedzieć, jak żyć we współczesnym świecie. Znaczącą rolę przedsiębiorczość odgrywa także w rozwoju firm. Bez przedsiębiorczych pracowników trudno mówić o innowacyjności jakiegokolwiek biznesu, o stałym podnoszeniu konkurencyjności na rynku.

To cechy przedsiębiorcze każdego pracownika składają się na przedsiębiorczość firm i instytucji. Jest to szczególnie ważne w budowie

9. W odpowiedzi na tego typu obserwacje w nowej podstawie programowej jasno zdefiniowano cele ogólne właśnie w podziale na te trzy kategorie, o czym mowa w dalszej części tekstu. 
gospodarki opartej na wiedzy (GOW) i fazie informacyjnej rozwoju cywilizacyjnego. GOW cechuje się m.in.: zwiększeniem znaczenia wiedzy w procesach przemian gospodarczych, w tym wiedzy aplikacyjnej tworzonej w podmiotach gospodarczych, w konsekwencji zwiększaniem zatrudnienia w sektorze wiedzy, wzrostem znaczenia kapitału intelektualnego $w$ procesie szybkich zmian technologicznych, a także zwiększaniem roli technologii informacyjnych i telekomunikacyjnych w procesach innowacyjnych (Borowiec, 2008). Występuje tu rodzaj sprzężenia zwrotnego. Rosnąca w szybkim tempie ilość informacji, ciągłość zmian, nowe techniki komunikacyjne, rosnąca mobilność ludzi zwiększają zapotrzebowanie na wiedzę. Nowe techniki informacyjne przyczyniają się także do zmian w systemie edukacji. Pojawiają się nowe metody dostępu uczniów i nauczycieli do informacji, a rozwój technik informacyjnych znacząco zmienia możliwości przekazu. Konieczne jest więc przygotowanie przyszłych pracowników do wykorzystywania oprzyrządowania informatycznego (Borowiec, 2009). W tej skomplikowanej, szybko zmieniającej się rzeczywistości wyzwaniom związanym z rozwojem GOW i społeczeństwa informacyjnego może sprostać tylko przedsiębiorczy człowiek, który nie boi się trudności ani zmian otoczenia, a zmieniające się uwarunkowania społeczno-gospodarcze traktuje jako szansę na rozwój i osiągnięcie sukcesu, a nie zagrożenie. W tym procesie podstawową rolę odgrywają przedsiębiorcze postawy dobrze wyedukowanego społeczeństwa (Zioło, 2009). Proces ten będzie się nasilać w najbliższych dziesięcioleciach, stąd tym bardziej przedsiębiorczość, do której podstawowych składowych należą kreatywność i zdolność do wykorzystywania szans w otoczeniu, trzeba traktować jako kluczową kompetencję przyszłości.

„Podstawową rolę w zakresie kształtowania gospodarki opartej na wiedzy odgrywają uwarunkowania pozwalające na zintensyfikowanie procesu rozwoju zasobów intelektualnych społeczeństwa. Ludzkie zasoby o odpowiednim poziomie aspiracji i wykształcenia, wyposażone w odpowiednie umiejętności, są bowiem najważniejszym kapitałem w fazie budowania społeczeństwa informacyjnego, którego podstawową cechą jest gospodarka oparta na wiedzy. Oznacza to, że w procesie kształtowania człowieka znajdującego swoje miejsce w nowej fazie rozwoju społeczno-gospodarczego szczególnie ważnym zadaniem jest pobudzanie jego ciekawości, rozwijanie aspiracji i pomoc w kształtowaniu racjonalnych planów życiowych i zdobywaniu odpowiednich 
zasobów wiedzy. Rewolucję przemysłową spowodowało wynalezienie silnika parowego, elektryfikacja wprowadziła drugą rewolucję, a mikroelektronika wywołuje kolejną rewolucję i kształtuje społeczeństwo informacyjne. Mogło się to dokonać tylko dzięki kreatywności jednostek i społeczeństwa, które potrafiło podjąć nowe wyzwania cywilizacyjne" (Zioło, 2008, s. 13).

Warto zwrócić także uwagę na rzadziej podejmowaną kwestię roli przedsiębiorczości w rozwoju układów terytorialnych: gmin, miast, regionów, krajów czy nawet organizacji państw, takich jak Unia Europejska. To rosnące jej znaczenie wynika z coraz większej roli przedsiębiorcy, podejmującego określone decyzje dotyczące lokalizacji i kierunków rozwoju przedsiębiorstwa, które poprzez swoje relacje w układach przestrzennych wpływa na ich rozwój bądź recesję. Procesy przemian społeczno-gospodarczych i kulturowych w różnego typu układach przestrzennych wynikają z podejmowania określonych decyzji, u których podstaw leży przedsiębiorczość konkretnych osób czy zespołów, w tym przedsiębiorców i różnego typu decydentów, przedstawicieli władz centralnych i samorządowych. Tym samym przedsiębiorczość można traktować jako jeden z podstawowych czynników przemian, przyczyniający się do podnoszenia pozycji konkurencyjnej tych układów (Rachwał, Zioło, 2012; por. Zioło, 2015; Wach, 2015). Mamy więc ścisłą zależność między przedsiębiorczością a tempem wzrostu gospodarki, które wpływają na przyspieszanie rozwoju społecznego, można więc przyjąć tezę, że szczególną rolę odgrywa tu odpowiednio przygotowany, przedsiębiorczy człowiek, który uczestniczy w procesie wzrostu produkcji i rozwoju gospodarczym, a rozumiejąc mechanizmy tych procesów, przyczynia się do racjonalnego rozwoju społeczeństwa (Zioło, 2006).

\section{Miejsce przedsiębiorczości w szkole}

Zmiany polityczno-społeczne zachodzące w Polsce po 1989 r. wymuszały przekształcenia na wielu płaszczyznach, w tym zmiany polityczne, społeczno-gospodarcze, a także w systemie edukacji, który musiał odpowiadać na zmieniające się uwarunkowania i wyzwania cywilizacyjne. Wydaje się, że szczególnie predestynowanym przedmiotem do kształtowania kompetencji przyszłości w szkole są podstawy przedsiębiorczości, choć należy podkreślić, że powinny one być kształtowane w toku całej edukacji szkolnej, także na innych przedmiotach (Borowiec, Rachwał, 2011). 
Przedsiębiorczość jako obowiązkowy przedmiot została wprowadzona do szkół ponadgimnazjalnych w roku szkolnym 2002/2003, jako odpowiedź na potrzeby młodych ludzi wynikające przede wszystkim z konieczności odnalezienia się w szybko zmieniającym się otoczeniu. W zreformowanej w 1999 r. szkole nauczanie przedmiotu podstawy przedsiębiorczości w ramach kształcenia ogólnego odbywało się podczas dwóch godzin tygodniowo. W zależności od decyzji kierownictwa szkoły przedmiot ten mógł być nauczany w jednej klasie (przez jeden rok) w wymiarze dwóch godzin lub przez dwa lata w wymiarze jednej godziny tygodniowo. Podczas kolejnej reformy z 2008 r. podtrzymano założenia, że podstawy przedsiębiorczości, jako obowiązkowy przedmiot szkolny, realizowane były w cyklu 60 godzin (jedna klasa, dwie godziny tygodniowo). Jednocześnie na III etapie edukacyjnym, czyli w gimnazjum, część treści z zakresu podstaw przedsiębiorczości została wpisana również do podstawy programowej wiedzy o społeczeństwie. Równolegle wprowadzono fakultatywny przedmiot szkolny ekonomia w praktyce, który według założeń był ściśle związany z podstawami przedsiębiorczości. Trzecia reforma podtrzymuje liczbę godzin w całym cyklu kształcenia, natomiast przedmiot ten będzie realizowany w II i III klasie szkoły ponadpodstawowej. W założeniach nowej podstawy programowej podstaw przedsiębiorczości dla szkół ponadpodstawowych (zgodnie z harmonogramem wdrażania reformy będzie ona obowiązywać od roku szkolnego 2019/2020) przyjęto, że jednym z głównych celów dydaktycznych przedmiotu jest przygotowanie uczniów do planowania swojej przyszłości oraz do aktywności zawodowej w roli pracowników najemnych lub osób prowadzących własną działalność gospodarczą. Ma to sprzyjać przygotowaniu uczniów do aktywności społecznej i gospodarczej, a także do życia rodzinnego w znaczeniu ekonomicznym, dając podstawowe umiejętności konkurencyjnych zachowań na rynku, w tym ponoszenia konsekwencji swoich decyzji.

Należy podkreślić, że mimo wielu prób podejmowanych przez różne środowiska przez cały czas realizacji podstaw przedsiębiorczości w szkole przedmiot ten wprowadzono jedynie w zakresie podstawowym. Dotychczas nie udało się również podnieść jego rangi poprzez wprowadzenie go do grupy przedmiotów kończących się egzaminem dojrzałości, choć było to i jest dyskutowane (Bartoń, 2005; Tracz, Rachwał, 2007; Rachwał, 2017a). 


\section{Treści realizowane w szkole na podstawach przedsiębiorczości w kontekście reformy systemu edukacji}

Podstawy programowe są dokumentami, które w polskim prawie oświatowym wskazują obowiązkowy na danym etapie edukacyjnym zestaw treści nauczania oraz umiejętności. Muszą one być uwzględnione w programach nauczania i podręcznikach. Podstawy umożliwiają również ustalenie kryteriów ocen szkolnych i wymagań egzaminacyjnych. Podstawa programowa, która była wynikiem reformy z 1999 r., została uchwalona w Rozporzq̨dzeniu Ministra Edukacji Narodowej i Sportu 26 lutego 2002 r. w sprawie podstawy programowej wychowania przedszkolnego oraz kształcenia ogólnego w poszczególnych typach szkół.

Zapisy podstawy podzielono na cztery części:

$\rightarrow$ Cele edukacyjne - zawarto w nich osiem ogólnych sformułowań, w których uwzględniono, w jakich ramach powinno się zawierać kształcenie w zakresie podstaw przedsiębiorczości.

$\rightarrow$ Zadania szkoły - w pięciu hasłach zawarto zobowiązania szkoły wobec realizacji podstawy programowej w szkole.

$\rightarrow$ Treści nauczania - w 22 krótkich sformułowaniach określono, czego powinno dotyczyć kształcenie podczas podstaw przedsiębiorczości.

$\rightarrow$ Osiągnięcia - w 13 punktach wskazano, jakie umiejętności powinien nabyć uczeń.

Podstawy programowe z lat 2008 oraz 2018 są zbudowane podobnie - wyróżniono w nich wymagania ogólne i szczegółowe. W 2008 r. wymagania ogólne ograniczyły się jedynie do czterech zagadnień: komunikacja i podejmowanie decyzji, gospodarka i przedsiębiorstwo, planowanie i kariera zawodowa oraz zasady etyczne, w których wpisano najważniejsze efekty kształcenia. Natomiast treści kształcenia ujęto w sześć rozbudowanych zagadnień.

W podstawie programowej z $2018 \mathrm{r}$. cele kształcenia podzielono na trzy grupy: wiedza, umiejętności i stosowanie wiedzy w praktyce oraz kształtowanie postaw, a w każdej z nich uwzględniono najważniejsze wymagania ogólne.

Należy zauważyć, że cele edukacyjne, nazywane też w podstawach programowych celami kształcenia, od pierwszej omawianej podstawy były coraz bardziej rozbudowywane, choć wskazują na zbliżone wymagania. 
We wszystkich dokumentach zwraca się uwagę przede wszystkim na konieczność:

$\rightarrow$ kształtowania właściwej postawy wobec otoczenia, w tym pracodawców, oraz umiejętności aktywnego uczestniczenia w rynku pracy,

$\rightarrow$ umiejętności świadomego uczestniczenia w życiu gospodarczym,

$\rightarrow$ poznania mechanizmów funkcjonowania gospodarki rynkowej oraz roli państwa w tej gospodarce,

$\rightarrow$ rozwijania zarówno wiedzy, jak i umiejętności w zakresie podejmowania własnej działalności gospodarczej.

W dotychczasowych podstawach programowych wskazywano również na potrzebę rozwijania umiejętności pracy w zespole, co w ramach podstaw przedsiębiorczości dotychczas było obecne. Jednak w ostatniej podstawie, ze względu na liczne powtórzenia realizowanych treści w dotychczasowych podstawach $w$ ramach różnych przedmiotów szkolnych, zrezygnowano z tego zagadnienia, gdyż zaplanowano, że będzie ono poruszane $w$ ramach wymagań szczegółowych w wiedzy o społeczeństwie. Jednocześnie zauważa się liczne korelacje międzyprzedmiotowe treści kształcenia z podstaw przedsiębiorczości przede wszystkim z: geografią, matematyką, informatyką, historią oraz ze wspomnianą wiedzą o społeczeństwie, dlatego przygotowania ostatniej podstawy programowej obejmowały również uzgodnienia między zespołami przedmiotowymi co do zapisów i realizacji konkretnych treści, które pozostawały na styku tych przedmiotów szkolnych.

Odnosząc się do treści nauczania, które uwzględnione są w omawianych trzech podstawach programowych z zakresu podstaw przedsiębiorczości, zauważalne jest przede wszystkim to, że w dokumencie z 2002 r. (pierwsza dla podstaw przedsiębiorczości podstawa programowa) dokonano ogólnych zapisów, często $w$ formie równoważników zdań. Podobnie napisano także część nazwaną Osiagnnięcia. Niestety, wydaje się, że takie zapisy pozostawiają twórcom programów nauczania, podręczników $\mathrm{i}$ innych elementów obudowy podstawy programowej zbyt dużą dowolność. W efekcie okazuje się na przykład, że w zapisach nie jest sprecyzowane, jakie treści kryją się pod hasłami rynek pracy, ani nie jest wskazane, że należy nauczyć uczniów przygotowywania aplikacji do pracy, która - jak się wydaje w kontekście tego tematu - powinna być najważniejszym efektem kształcenia. 
W kolejnych dwóch podstawach programowych (z lat 2008 i 2018) zapisano już wymagania szczegółowe w postaci efektów kształcenia, dlatego mają one bardziej jednoznaczny i precyzyjny charakter. W podstawie programowej z 2008 r. podzielono treści nauczania na sześć części głównych:

$\rightarrow$ człowiek przedsiębiorczy,

$\rightarrow$ rynek - cechy i funkcje,

$\rightarrow$ instytucje rynkowe,

$\rightarrow$ państwo, gospodarka,

$\rightarrow$ przedsiębiorstwo,

$\rightarrow$ rynek pracy.

W ostatniej zaś podstawie wyróżniono cztery grupy tematyczne, które dotyczą problematyki:

$\rightarrow$ gospodarki rynkowej,

$\rightarrow$ rynku finansowego,

$\rightarrow$ rynku pracy,

$\rightarrow$ przedsiębiorstwa.

Szczegółowo analizując zapisy w objętych badaniami podstawach programowych, zauważa się, że wszystkie trzy dokumenty rozpoczynają się od cech, jakimi wyróżnia się osoba przedsiębiorcza, oraz od zdefiniowania, czym jest postawa przedsiębiorcza. W grupie powtarzających się treści znajdują się także zagadnienia związane przede wszystkim z:

$\rightarrow$ rozróżnianiem cech gospodarki centralnie planowanej i rynkowej oraz ze zmianami w Polsce w tym zakresie po 1989 r.,

$\rightarrow$ funkcjonowaniem i ze zróżnicowaniem rynków oraz z procesami na nich zachodzącymi,

$\rightarrow$ budżetem państwa,

$\rightarrow$ ochroną konsumenta,

$\rightarrow$ pieniądzem i jego obiegiem w gospodarce,

$\rightarrow$ instytucjami rynku finansowego,

$\rightarrow$ pozyskiwaniem i inwestowaniem kapitału,

$\rightarrow$ szeroko rozumianym rynkiem pracy i przygotowaniem do uczestnictwa w nim,

$\rightarrow$ przedsiębiorstwem i umiejętnością przygotowania projektu własnej firmy,

$\rightarrow$ istotą etyki w postępowaniu człowieka. 
Ponadto w ostatniej podstawie programowej zapisano nowe, nieznajdujące się we wcześniejszych podstawach programowych treści, które są odzwierciedleniem zmian współczesnego świata. Należą do nich: dostrzeganie potrzeby rozwijania kreatywności i innowacyjności w życiu osobistym oraz rozwoju społeczno-gospodarczym w różnych skalach, zagadnienia związane z innowacyjnymi modelami biznesu (w tym start-upami) oraz nowoczesnymi formami finansowania działalności gospodarczej. Wyodrębniono także treści, które dotychczas włączone były w bardziej ogólne zapisy, czyli konieczność systematycznego oszczędzania, poznawanie metod przeciwdziałania zjawiskom kryzysowym w gospodarce krajowej i światowej, krytyczną analizę umów kredytowych, znajdowanie i analizę informacji o rodzimych przedsiębiorcach i ich sukcesach. Takie przedstawienie niniejszych treści podkreśliło ich ważną rolę we współczesnym funkcjonowaniu w otaczającej nas rzeczywistości oraz potrzebę ich dostrzegania.

Wydaje się, że choć treści zapisów w podstawach programowych są do siebie podobne, to różnią się efektami kształcenia. Dzięki takiemu ujęciu wskazano jednoznacznie, co uczniowie powinni wiedzieć i umieć po zakończeniu edukacji w szkole średniej, aby być w pełni odpowiedzialnymi i by umieli ponosić konsekwencje podejmowanych decyzji.

\section{Podsumowanie i wnioski}

Wydaje się, że rola przedsiębiorczości jako kompetencji kluczowej będzie w przyszłości coraz większa. Tym bardziej pilna staje się potrzeba jej szerokiego kształtowania na wszystkich szczeblach edukacji, od przedszkolnej do szkolnictwa wyższego i kształcenia ustawicznego. $\mathrm{Na}$ kwestię tę zwraca uwagę wielu autorów. Proces ten powinien być wspierany przez różnorodne podmioty gospodarcze i instytucje funkcjonujące w otoczeniu społeczno-gospodarczym i kulturowym każdego człowieka (Zioło, 2012). Podejmowane w ostatnich latach działania na rzecz wzmocnienia rozwoju kompetencji przedsiębiorczości przynoszą generalnie pozytywne skutki. Coraz większy nacisk położony jest także na rozwój umiejętności i kompetencji społecznych, a nie wyposażenie uczniów w wiedzę ekonomiczną, co dominowało we wcześniejszych podejściach do edukacji w tym zakresie w polskiej szkole (por. Rachwał i in., 2016). Coraz większego znaczenia nabiera też realizowanie celów wychowawczych, w efekcie czego lepiej powinny być kształtowane 
postawy etyczne uczniów i zrozumienie zasad solidarności społecznej oraz odpowiedzialnego biznesu. Na szczególną uwagę zasługuje wiele inicjatyw podejmowanych przez instytucje pozaszkolne. Można więc mówić o szerokim włączeniu się zarówno podmiotów rządowych oraz samorządowych, jak i organizacji pozarządowych w rozwój tej kompetencji. W jednostkach naukowych podejmowane są też liczne projekty badawcze i edukacyjne mające na celu rozwijanie postaw przedsiębiorczych oraz organizowane cykliczne konferencje będące stałym forum wymiany myśli między naukowcami, praktykami życia gospodarczego a środowiskiem szkolnym w zakresie tej problematyki (por. Rachwał, 2017b). Wydaje się, że powinno się to przyczynić do jeszcze lepszego rozwoju tej kompetencji u młodego pokolenia. 


\section{Bibliografia}

$\rightarrow$ Abramowicz, W., Gogołka, W., Stokłosa, J., Sysło, M.M. (2002), Obywatele globalnego społeczeństwa informacyjnego, rozdział: Edukacja [w:] W. Cellary (red.), Polska w drodze do globalnego społeczeństwa informacyjnego. Raport o rozwoju społecznym, Raport przygotowany przez Program Narodów Zjednoczonych ds. Rozwoju (UNDP).

$\rightarrow$ Bartoń, M. (2005), Przedsiębiorczość jako przedmiot matury 2008, „Przedsiębiorczość - Edukacja", 1, s. 255-258.

$\rightarrow$ Bezzina, Ch., Madalińska-Michalak, J. (2014), Przywództwo służebne: spojrzenie w przyszłość [w:] S.M. Kwiatkowski, J. Madalińska-Michalak (red.), Przywództwo edukacyjne, współczesne wyzwania, Warszawa: Wolters Kluwer SA.

$\rightarrow$ Kalita, B. (2014), Przedsiębiorczość jako kompetencja kluczowa w procesie uczenia się przez całe życie, „Zeszyty Naukowe Politechniki Śląskiej”, seria: "Organizacja i Zarządzanie", z. 72, s. 51-64.

$\rightarrow$ Borowiec, M. (2008), Rola szkolnictwa wyższego w procesie kształtowania gospodarki opartej na wiedzy, „Przedsiębiorczość - Edukacja”, 4, s. 24-36.

$\rightarrow$ Borowiec, M. (2009), Rola edukacji w kształtowaniu społeczeństwa informacyjnego, „Przedsiębiorczość - Edukacja”, 5, s. 37-47.

$\rightarrow$ Borowiec, M., Rachwał, T. (2011), Kształtowanie postaw przedsiębiorczych na lekcjach geografii wyzwaniem edukacyjnym w procesach globalizacji, „Przedsiębiorczość - Edukacja", 7, s. 321-332.

$\rightarrow$ Borowiec, M., Dorocki, S., Kilar, W., Płaziak, M., Szymańska, A.l., Świętek, A., Wilczyński, P.L. (2014), Przedsiębiorczość w praktyce. Podręcznik dla szkół ponadgimnazjalnych do podstaw przedsiębiorczości i ekonomii w praktyce (zakres podstawowy), e-podręcznik, Poznań: Fundacja Wrota Edukacji-EduGate.

$\rightarrow$ Kocurek, D. (2017), Kształtowanie postawy przedsiębiorczości ucznia szkoły średniej [w:] Przedsiębiorczość jako wartość w edukacji, A. Murzyn, U. Szuścik (red.), Katowice: Wydawnictwo Uniwersytetu Śląskiego, s. 94-102. 
$\rightarrow$ Kompetencje kluczowe w uczeniu się przez całe życie. Europejskie ramy odniesienia (2007), Luksemburg: Urząd Oficjalnych Publikacji Wspólnot Europejskich.

$\rightarrow$ Kopczyński, T. (2017), Brakujq̨ce elementy kształtowania przedsiębiorczości w przestrzeni edukacyjnej [w:] A. Murzyn, U. Szuścik (red.), Przedsiębiorczość jako wartość w edukacji, Katowice: Wydawnictwo Uniwersytetu Śląskiego, s. 83-93.

$\rightarrow$ Kwiatkowski, S.M., Symela, K. (red.) (2001), Standardy kwalifikacji zawodowych. Teoria. Metodologia. Projekty. Warszawa: Instytut Badań Edukacyjnych.

$\rightarrow$ Kwiatkowski, S.M., Woźniak, I. (red.) (2002), Standardy kwalifikacji zawodowych i standardy edukacyjne. Relacje. Modele. Aplikacje, Warszawa: Instytut Badań Edukacyjnych.

$\rightarrow$ Makieła, Z., Rachwał, T. (2002), Podstawy przedsiębiorczości, Warszawa: Nowa Era.

$\rightarrow$ Makieła, Z., Rachwał, T. (2012), Krok w przedsiębiorczość, Warszawa: Nowa Era.

$\rightarrow$ Mazurkiewicz, G. (2014), Przywództwo edukacyjne - ambitny projekt zmiany [w:] S.M. Kwiatkowski, J. Madalińska-Michalak (red.), Przywództwo edukacyjne, współczesne wyzwania, Warszawa: Wolters Kluwer SA.

$\rightarrow$ Rachwał, T. (2004), Podstawy przedsiębiorczości. Słownik dla liceum ogólnokształcącego, liceum profilowanego i technikum, Warszawa: Wydawnictwo Nowa Era.

$\rightarrow$ Rachwał, T. (2005), Kształtowanie postaw uczniów na lekcjach podstaw przedsiębiorczości, „Przedsiębiorczość - Edukacja”, 1, s. 137-144.

$\rightarrow$ Rachwał, T. (2006), Kształtowanie postaw przedsiębiorczych edukacji szkolnej [w:] B. Muchacka (red.), Szkoła w nauce i praktyce edukacyjnej, t. II, Kraków: Oficyna Wydawnicza "Impuls", Akademia Pedagogiczna w Krakowie, s. 427-434.

$\rightarrow$ Rachwał, T. (2017a), Entrepreneurship in School in the Conditions of the Education System Reform in Poland - a Voice in the Discussion on the Directions of Change, "Przedsiębiorczość - Edukacja”, 13, s. 330-339.

$\rightarrow$ Rachwał, T. (2017b), Działalność na rzecz edukacji w zakresie przedsiębiorczości Zakładu Przedsiębiorczości i Gospodarki Przestrzennej Instytutu Geografii Uniwersytetu Pedagogicznego w Krakowie, „Przedsiębiorczość-Edukacja”, 13, s. 468-490.

$\rightarrow$ Rachwał, T., Kurek, S., Boguś, M. (2016), Entrepreneurship Education at Secondary Level in Transition Economies: A Case of Poland, "Entrepreneurial Business and Economics Review", 4(1), s. 61-81.

$\rightarrow$ Raszka, R. (2017), Edukacja finansowa dzieci [w:] Przedsiębiorczość jako wartość w edukacji, A. Murzyn, U. Szuścik (red.), Katowice: Wydawnictwo Uniwersytetu Śląskiego, s. 140-153. 
$\rightarrow$ Rozporządzenie Ministra Edukacji Narodowej i Sportu z dnia 26 lutego 2002 r. w sprawie podstawy programowej wychowania przedszkolnego oraz kształcenia ogólnego w poszczególnych typach szkół, Dz.U. 2002 nr 51 poz. 458.

$\rightarrow$ Rozporządzenie Ministra Edukacji Narodowej z dnia 23 grudnia 2008 r. w sprawie podstawy programowej wychowania przedszkolnego oraz kształcenia ogólnego w poszczególnych typach szkół, Dz.U. 2009 nr 4 poz. 17.

$\rightarrow$ Rozporzqqdzenie Ministra Edukacji Narodowej z dnia 30 stycznia 2018 r. w sprawie podstawy programowej kształcenia ogólnego dla liceum ogólnokształcacego, technikum oraz branżowej szkoły Il stopnia, Dz.U. 2018 poz. 467.

$\rightarrow$ Schratz, M. (2014), Tworzenie zmiany od wewnq̨trz. Przywództwo jako uczenie się z wyłaniajqcej się przyszłości [w:] S.M. Kwiatkowski, J. Madalińska-Michalak (red.), Przywództwo edukacyjne, współczesne wyzwania, Warszawa: Wolters Kluwer SA.

$\rightarrow$ Symela, K. (1995), Standardy programowania treści kształcenia zawodowego [w:] M. Butkiewicz (red.), Model polskich standardów kwalifikacji, Warszawa-Radom: EP, ITeE.

$\rightarrow$ Tracz, M., Rachwał, T. (2007), Przedmiot podstawy przedsiębiorczości-założenia realizacji a przygotowanie nauczycieli, „Przedsiębiorczość - Edukacja”, 3, s. 286-296.

$\rightarrow$ Wach, K. (2013), Edukacja na rzecz przedsiębiorczości wobec współczesnych wyzwań cywilizacyjno-gospodarczych, „Przedsiębiorczość - Edukacja”, 9, s. 246-257.

$\rightarrow$ Wach, K. (2014), Edukacja dla przedsiębiorczości: pomiędzy przedsiębiorczq pedagogikq a edukacjq ekonomicznq i biznesowq, "Horyzonty Wychowania", 13(28), s. 11-32.

$\rightarrow$ Wach, K. (2015), Przedsiębiorczość jako czynnik rozwoju społeczno-gospodarczego: przegląd literatury, „Przedsiębiorczość - Edukacja”, 11, s. 24-36.

$\rightarrow$ Zioło, Z. (2006), Rola przedsiębiorczości w podnoszeniu konkurencyjności społeczeństwa i gospodarki, „Przedsiębiorczość - Edukacja”, 2, s. 10-17.

$\rightarrow$ Zioło, Z. (2008), Ekonomiczne i społeczne uwarunkowania rozwoju gospodarki opartej na wiedzy, „Przedsiębiorczość - Edukacja”, 4, s. 12-23.

$\rightarrow$ Zioło, Z. (2009), Rola przedsiębiorczości w kształtowaniu społeczeństwa informacyjnego. „Przedsiębiorczość - Edukacja”, 5, s. 10-18.

$\rightarrow$ Zioło, Z. (2012), Miejsce przedsiębiorczości w edukacji, „Przedsiębiorczość - Edukacja", 8, s. 10-23. 


\section{Netografia}

$\rightarrow$ Kompetencje przyszłości [online] [dostęp 21.08.2018]. Artykuł dostępny w Internecie: www.outsourcingportal.eu/pl/kompetencje-przyszlosci.

$\rightarrow$ Trends Shaping Education 2016. OECD Publishing, Paris [online] [dostęp 21.08.2018]. Dostępny w Internecie: read.oecd-ilibrary.org/education/trends -shaping-education-2016_trends_edu-2016-en\#page21.

$\rightarrow$ Trendy w edukacji. Kompetencje przyszłości [online] [dostęp 23.04.2018]. Dostępny w Internecie: www.paryzoecd.msz.gov.pl/pl/c/MOBILE/aktualnosci/ trendy_w_edukacji_kompetencje_przyszlosci.

$\rightarrow$ Future Work Skills 2020, 2011, Institute for the Future for the University of Phoenix Research Institute University Avenue [online] [dostęp 21.08.2018]. Dostępny w Internecie: www.iftf.org/uploads/media/SR-1382A_UPRI_future_work_skills_sm.pdf.

$\rightarrow$ Programowanie kluczowq kompetencją przyszłości. Jego podstaw powinny się uczyć już najmłodsze dzieci [online] [dostęp 21.08.2018]. Dostępny w Internecie: biznes.newseria.pl/news/programowanie-kluczowa,p611046578.

$\rightarrow$ Raport: Dwa światy. Kompetencje przyszłości 2014 [online] [dostęp 21.08.2018]. Dostępny w Internecie: kariera.kozminski.edu.pl/fileadmin/kariera.kozminski. edu.pl/Raporty/RAPORT_KOMPETENCJE_PRZYSZLOSCI_-_pracodawca.pdf. 


\section{Kompetencje kluczowe \\ uczniów w międzynarodowych \\ raportach i badaniach}

Magdalena Górowska-Fells, Beata Płatos, Agnieszka Rybińska

Tekst poświęcony jest koncepcji rozwoju kompetencji kluczowych $w$ ujęciu historycznym, traktuje o sposobach realizacji tej koncepcji w szkołach, sposobach mierzenia stopnia rozwoju kompetencji kluczowych uczniów, a także najnowszych propozycjach zmian w koncepcji kompetencji kluczowych sformułowanych na forum Unii Europejskiej.

\section{Słowa kluczowe:}

definicje kompetencji kluczowych

kompetencje kluczowe uczniów

międzynarodowe badania edukacyjne 


\section{Students' key competences in international reports and research}

Magdalena Górowska-Fells, Beata Płatos, Agnieszka Rybińska

The article examines the concept of key competences and its development over time, and looks at ways it has been implemented in European schools. The text focuses on ways to measure students' key competences and presents results of the most relevant international research in this area.

\footnotetext{
Keywords:

key competence definition

student key competences

international educational research
} 


\section{Definicja kompetencji kluczowych}

Termin kompetencje od dłuższego czasu funkcjonuje w języku zarówno naukowym, jak i potocznym, również w terminologii edukacyjnej. Samo pojęcie kompetencji jest definiowane na różne sposoby, w zależności od kontekstu oraz dyscypliny naukowej, w której funkcjonuje osoba nim się posługująca. Pierwotnie termin francuski compétence określał pewne zdolności do wykonywania zadania i był używany w kształceniu zawodowym. Jednak w latach 90. XX w. coraz częściej stosowano szersze rozumienie tego terminu, odnoszące się do wiedzy i umiejętności jej zastosowania w różnych kontekstach. W 1996 r. Rada Europy zaproponowała następującą definicję: „Pojęcie kompetencji interpretuje się jako mniej lub bardziej wyspecjalizowany system zdolności, umiejętności czy sprawności niezbędnych lub wystarczających do osiągnięcia określonego celu". Jest to więc termin ogólny, uniwersalny i nadający się do stosowania $w$ różnych kontekstach oraz dyscyplinach naukowych (Eurydice, 2002).

Obecnie kompetencje są na ogół rozumiane jako zasoby kulturowe jednostki, jej strategie indywidualnego i społecznego działania, stosunek do wartości, umiejętność ciągłego uczenia się, które determinują jej szanse i aktywne postawy w grze społecznej (Bałachowicz, 2015).

W ramach współpracy europejskiej tematyka podstawowych, czy najważniejszych, kompetencji pojawiła się $\mathrm{w}$ roku $2000 \mathrm{w}$ związku $z$ uruchomieniem procesu wyznaczania wspólnych celów europejskich w dziedzinie edukacji, tzw. benchmarków. To właśnie wtedy Rada Europejska na posiedzeniu w Lizbonie wyznaczyła sobie zadanie uczynienia gospodarki europejskiej najbardziej konkurencyjną i dynamiczną gospodarką świata, opartą na wiedzy, zdolną do trwałego wzrostu. Oznaczało to przyjęcie konkretnych celów: trzech strategicznych i 13 szczegółowych, odnoszących się do systemów edukacji państw członkowskich Unii. Realizacja celów edukacyjnych, szczególnie tych odnoszących się do uczenia się przez całe życie, realizowanych nie tylko w ramach edukacji szkolnej, wymagała stworzenia nowego zestawu pojęć określających podstawowe oczekiwania wobec mającego edukować się społeczeństwa. Terminologia pedagogiczna okazała się niewystarczająca, gdyż koncentrowała się raczej na wiedzy, a nie na umiejętnościach i kompetencjach.

Rada Europejska wezwała państwa członkowskie, Radę UE i Komisję Europejską (KE) do stworzenia nowych definicji umiejętności podsta- 
wowych zdobywanych w procesie edukacji przez całe życie, a także umiejętności w zakresie technologii informacyjnych, znajomości języków obcych, kultury technicznej, przedsiębiorczości i umiejętności społecznych.

Komisja Europejska powołała grupy robocze ekspertów wyznaczonych przez kraje członkowskie do pracy w trzech obszarach priorytetowych (umiejętności podstawowych, technologii informacyjnych i komunikacyjnych oraz matematyki, nauk ścisłych i techniki). Grupa zajmująca się tematyką umiejętności podstawowych zaproponowała w 2002 r. listę ośmiu podstawowych kompetencji kluczowych (Eurydice 2002, 2012):

$\rightarrow$ porozumiewanie się w języku ojczystym,

$\rightarrow$ porozumiewanie się w językach obcych,

$\rightarrow$ kompetencje matematyczne i podstawowe kompetencje naukowo-techniczne,

$\rightarrow$ kompetencje informatyczne,

$\rightarrow$ umiejętność uczenia się,

$\rightarrow$ kompetencje społeczne i obywatelskie,

$\rightarrow$ inicjatywność i przedsiębiorczość,

$\rightarrow$ świadomość i ekspresja kulturalna.

W zaleceniu Parlamentu Europejskiego i Rady z 18 grudnia 2006 r. opublikowano listę ośmiu kluczowych kompetencji, niezbędnych człowiekowi przez całe życie. „Zakłada się, że kompetencje kluczowe, na które składają się: wiedza, umiejętności i postawy, sprzyjają samorealizacji jednostki, uruchamiają jej aktywną postawę obywatelską, pomagają w procesie integracji społecznej i ułatwiają odnalezienie się na rynku pracy. Wszystkie kluczowe kompetencje są wzajemnie zależne, ponieważ ich cechami wspólnymi są: krytyczne myślenie, kreatywność, inicjatywa, umiejętność rozwiązywania problemów, zdolność do oceny ryzyka, podejmowania trafnych decyzji, konstruktywnego kierowania emocjami" (Uszyńska-Jarmoc, Bilewicz, 2015).

Ponieważ Rada Europejska i KE wielokrotnie wzywały do kontynuacji działań w dziedzinie umiejętności podstawowych, nawiązując albo do koncepcji ośmiu kompetencji kluczowych, albo do poszczególnych umiejętności, kompetencje kluczowe zostały na stałe włączone zarówno do europejskiej współpracy w dziedzinie edukacji, jak i wspólnotowej polityki w dziedzinie zatrudnienia. W białej księdze o edukacji 
i szkoleniach z roku 1996 zaproponowano wprowadzenie europejskiego systemu porównywalności i promocji umiejętności kluczowych oraz opracowanie metod ich kształtowania, oceniania i certyfikacji. Zamiast ogólnie przyjętej praktyki poświadczania kwalifikacji na zakończenie kształcenia formalnego (świadectwa ukończenia szkoły) zaproponowano wprowadzenie systemu certyfikacji poszczególnych umiejętności, nawet tych cząstkowych. Memorandum KE z 2002 r. w sprawie kształcenia ustawicznego (obecnie raczej stosuje się termin uczenie się przez całe życie) przyniosło postulat zdefiniowania nowych umiejętności podstawowych dla wszystkich. Nowe umiejętności nawiązywały przede wszystkim do konieczności przygotowania obywateli do aktywnego uczestnictwa w społeczeństwie i gospodarce opartych na wiedzy. Podkreślano również wagę tradycyjnych podstawowych umiejętności czytania ze zrozumieniem i myślenia matematycznego. Solidne wykształcenie podstawowe uzupełnione o umiejętność samodzielnego uczenia się zostało wskazane jako fundament uczestnictwa w społeczeństwie opartym na wiedzy (Eurydice, 2002).

Odrębnie nawiązywano do poszczególnych kompetencji kluczowych, np. w zakresie technologii informacyjnych i komunikacyjnych (np. eEurope 2002, 2005), wzywano nie tylko do podnoszenia kompetencji cyfrowych obywateli UE, lecz także do upowszechniania usług edukacyjnych oferowanych online.

Oprócz instytucji europejskich znaczący wpływ na definicję i ocenę kompetencji kluczowych miały dwie organizacje: Międzynarodowe Stowarzyszenie ds. Oceny Osiągnięć Szkolnych (IEA) i Organizacja Współpracy Gospodarczej i Rozwoju (OECD). Jeśli edukacja jest uważana za jeden z motorów rozwoju gospodarczego w społeczeństwie opartym na wiedzy, to zapewnianie wysokiej jakości nauczania staje się priorytetem politycznym, a badania edukacyjne prowadzone w celu znalezienia najlepszych rozwiązań stają się ważnym elementem współpracy. Właśnie IEA i OECD zaangażowały się na początku XXI w. w wiele badań mających na celu międzynarodowe porównania osiągnięć uczniów w zakresie podstawowych przedmiotów nauczania i kluczowych kompetencji (Eurydice, 2002).

Efektem tej inicjatywy było m.in. uruchomienie cyklicznych międzynarodowych badań umiejętności uczniów PISA (OECD). Sprawdzano przede wszystkim umiejętności w zakresie nauk ścisłych i języka ojczystego jako łatwiejsze do porównań międzynarodowych, ale w 2000 r. 
PISA objęła również takie kompetencje przedmiotowe jak motywacja do nauki, umiejętność obsługi komputera czy samodzielnego uczenia się. W ramach kolejnych badań PISA kontynuowano kierunek sprawdzania różnych umiejętności, w tym rozwiązywania problemów i korzystania z technologii informacyjno-komunikacyjnych.

\section{Wpływ międzynarodowych badań edukacyjnych na definicję kompetencji kluczowych}

Międzynarodowe badania umiejętności uczniów rozpoczęto już w latach 60. XX w. (Sawiński, 2017). Zainteresowanie wynikami pierwszych badań skutkowało powstaniem IEA oraz uruchomieniem Programu Międzynarodowej Oceny Umiejętności Uczniów (PISA), prowadzonego przez OECD. Obecnie IEA co cztery lata bada umiejętności matematyczne oraz kompetencje w naukach przyrodniczych w ramach Trends in International Mathematics and Science Study (TIMSS). Z kolei umiejętność czytania sprawdzana jest co pięć lat w projekcie Progress in International Reading Literacy Study (PIRLS). Powtarzane jest także badanie wiedzy obywatelskiej: International Civic and Citizenship Education Study (ICCS). Oprócz badań cyklicznych IEA organizuje badania ad hoc, w zależności od tego, jakie problemy zostaną uznane za istotne dla edukacji oraz potrzeb krajów partnerskich. Przykładem jest to z $2013 \mathrm{r}$. dotyczące kompetencji komputerowych i informacyjnych (ICILS). IEA zrzesza przedstawicieli około 70 krajów, ale tylko część z nich regularnie bierze udział w badaniach. Polska współpracowała z IEA już na początku lat 80. w ramach badania dotyczącego umiejętności przyrodniczych. Nasz kraj wziął też udział w analizie wiedzy obywatelskiej w 1999 r., od roku 2006 uczestniczy zaś w większości badań (tamże).

\section{Program PISA}

Z wymienionych powodów OECD rozpoczęła własne badanie - Program Międzynarodowej Oceny Umiejętności Uczniów. Od 2000 r. co trzy lata sprawdza się umiejętności 15-letnich uczniów w zakresie matematyki, czytania ze zrozumieniem oraz kompetencji przyrodniczych. W badaniu biorą udział kraje OECD, ale zaprasza się również kraje spoza tej organizacji, o ile spełnią rygorystyczne wymogi procedury badawczej. W 2012 r. w projekcie wzięło udział 65 krajów, dzięki czemu PISA stała się największym badaniem edukacyjnym na świecie. 
W programie tym uwzględniono szeroki zakres czynników, które mogą wpływać na efektywność edukacji. Bierze się pod uwagę organizację systemu szkolnego i wiek rozdzielenia młodzieży do szkół różnego typu, bada się wyposażenie szkół, liczebność klas oraz kwalifikacje nauczycieli. Uczniów pyta się o aspiracje, postawy wobec szkoły i o to, jak według nich wykształcenie wpływa na sukces w życiu. Oddzielnie uwagę poświęca się poziomowi życia w poszczególnych krajach czy wielkości publicznych środków przeznaczanych na oświatę (tamże).

\section{Wskaźniki i poziomy odniesienia}

Dla instytucji europejskich planujących monitorowanie umiejętności obywateli UE jasne było wykorzystanie istniejących już zasobów dostarczanych przez wyżej wymienione badania edukacyjne. Unia wniosła jednak do koncepcji monitorowania rozwoju kompetencji kluczowych swój własny wkład - to zastosowanie koncepcji tzw. poziomów odniesienia.

Tworzenie poziomów odniesienia dopiero niedawno stało się narzędziem służącym do doskonalenia jakości kształcenia. Zjawisko to powstało w świecie biznesu, gdy przedsiębiorstwa zaczęły badać metody pracy stosowane przez konkurencyjne zakłady, by odkryć źródła ich sukcesów (Eurydice, 2002). W European Benchmarking Code of Conduct podano następującą definicję tworzenia poziomów odniesienia: „Proces identyfikacji przykładów dobrej praktyki w innych organizacjach i uczenia się na tych przykładach". Oryginalnie więc benchmarking oznaczał poszukiwanie rozwiązań stosowanych przez innych i przenoszenie ich na własny grunt, by poprawić własne wyniki.

Dopiero połączenie dwóch koncepcji, czyli wykorzystania wyników międzynarodowych badań edukacyjnych oraz wyznaczania wspólnych poziomów odniesienia, znalazło swoje odzwierciedlenie w sformułowaniu wspólnych europejskich celów edukacyjnych obejmujących także poprawę umiejętności uczniów.

Wspólne cele europejskie (benchmarki) w dziedzinie edukacji są zdefiniowane w dwóch kluczowych dokumentach UE: strategii Europa 2020 oraz strategii Education and Training 2020.

Strategia Europa 2020 określa nadrzędny cel rozwoju do roku 2020, u którego podstaw znajdują się dwa mierzalne cele dotyczące edukacji i szkoleń:

$\rightarrow$ obniżenie odsetka osób wcześnie kończących naukę z 14 proc. w 2010 r. do co najwyżej 10 proc., 
$\rightarrow$ zwiększenie udziału osób z wykształceniem wyższym lub równoważnym w populacji w wieku 30-34 lat z 33,5 proc. $w 2010 \mathrm{r}$. do co najmniej 40 proc.

Drugą podstawę współpracy państw członkowskich UE w obszarze edukacji stanowi dokument Strategiczne ramy europejskiej współpracy w zakresie edukacji i szkolenia - ET 2020, przyjęty przez Radę UE ds. Edukacji, Młodzieży i Kultury w maju 2009 r.

Konkluzje Rady zawierają główne cele oraz wyzwania przyszłej europejskiej współpracy w dziedzinie kształcenia i szkolenia do 2020 r. Są to:

1. uczenie się przez całe życie i mobilność w celach edukacyjnych,

2. poprawa jakości i wyników kształcenia oraz skuteczności oferty edukacyjnej,

3. promowanie sprawiedliwości i aktywnej postawy obywatelskiej,

4. zwiększanie innowacji i kreatywności na wszystkich poziomach kształcenia.

Jednocześnie, w ramach realizacji ww. celów strategicznych, Komisja Europejska zaproponowała realizację pięciu europejskich poziomów odniesienia (benchmarków) dotyczących: zwiększania udziału dorosłych w uczeniu się przez całe życie, zmniejszania odsetka uczniów z niskimi kompetencjami w czytaniu ze zrozumieniem oraz zbyt wcześnie kończących naukę, zwiększania udziału dzieci w edukacji przedszkolnej oraz nowego benchmarku zmierzającego do zwiększenia odsetka młodych osób mających wyższe wykształcenie. Jednocześnie KE zapewniła, że będzie kontynuować prace w zakresie mobilności, rynku pracy oraz uczenia się języków obcych, by ewentualnie opracować kolejne benchmarki.

W związku z nowymi ramami europejskiej współpracy do $2020 \mathrm{r}$. założono następujące cele do osiągnięcia $w$ ramach benchmarków:

$\rightarrow$ Udział dorosłych w uczeniu się przez całe życie: do 2020 r. min. 15 proc. dorosłych powinno uczestniczyć w uczeniu się przez całe życie.

$\rightarrow$ Uczniowie z niskimi kompetencjami w czytaniu ze zrozumieniem: do 2020 r. udział 15-latków ze słabymi umiejętnościami w czytaniu ze zrozumieniem, matematyce i naukach przyrodniczych powinien być mniejszy niż 15 proc. 
$\rightarrow$ Zdobycie wyższego wykształcenia: do 2020 r. udział osób w wieku od 30 do 34 lat $z$ wykształceniem wyższym powinien wynosić co najmniej 40 proc.

$\rightarrow$ Zbyt wcześnie kończący naukę: do 2020 r. udział osób zbyt wcześnie kończących naukę powinien być mniejszy niż 10 proc.

$\rightarrow$ Udział w edukacji przedszkolnej: do 2020 r. min. 95 proc. dzieci w wieku od czterech lat do rozpoczęcia obowiązkowej nauki powinno uczestniczyć w edukacji przedszkolnej.

\section{Realizacja koncepcji kompetencji kluczowych w szkołach w Europie - na podstawie raportów Eurydice}

W 2012 r. Eurydice podjęła inicjatywę zebrania danych o realizacji koncepcji kompetencji kluczowych we wszystkich krajach europejskich. Nawiązywała w ten sposób do podobnej inicjatywy z 2002 r., kiedy analiza taka została przeprowadzona dla ówczesnych członków UE. Raport z 2002 r. prezentował szczegóły wprowadzania koncepcji kompetencji kluczowych do programów i praktyki szkolnej w ujęciu porównawczym. Odnosił się do szeroko rozumianej koncepcji kompetencji kluczowych zwanych w różnych krajach kompetencjami podstawowymi lub bazowymi. Pojęcia kompetencje i umiejętności były stosowane jako synonimy. Ze względów metodologicznych w raporcie nie uwzględniono kluczowych kompetencji uczenia się ani świadomości i ekspresji kulturalnej.

Najważniejsze wnioski z raportu pokazują, że mimo różnych podejść stosowanych przez różne kraje niemal wszystkie z nich w swoich strategicznych dokumentach uwzględniły rozwój kompetencji informatycznych oraz kompetencji w zakresie przedsiębiorczości. Najpowszechniejsze okazały się inicjatywy dotyczące nauczania języka ojczystego oraz nauk przyrodniczych i ścisłych. Najpopularniejsze działania podejmowane na szczeblu krajowym to reformy programów nauczania poszczególnych przedmiotów, kształcenia i doskonalenia zawodowego nauczycieli oraz wprowadzenie różnych form wsparcia dla uczniów ze słabymi wynikami. Kompetencje przekrojowe (interdyscyplinarne), czyli m.in. umiejętność posługiwania się technologiami informacyjno-komunikacyjnymi, przedsiębiorczość i kompetencje obywatelskie, były w dużym stopniu w 2012 r. włączone do programów nauczania w szkołach podstawowych i średnich. Kompetencje przekrojowe były nauczane jako oddzielny przedmiot, w ramach szerszego programu 
nauczania, a także realizowane jako ogólne cele wyznaczone dla szkoły, gdzie odpowiedzialność za ich realizację ponoszą nauczyciele wszystkich przedmiotów (Eurydice, 2012). Jednak integracja kompetencji kluczowych ze szkolnymi programami nauczania nie oznaczała, że były one w pełni realizowane. Na przykład badania międzynarodowe cytowane przez Eurydice pokazują bardzo niski poziom zintegrowania kompetencji informatycznych w zakresie nauczania matematyki, nauk ścisłych i przyrodniczych oraz języków, a dotyczyło to nawet krajów z dobrym dostępem do sprzętu komputerowego.

Kilka krajów - w ramach wprowadzania koncepcji kompetencji kluczowych - by wzmocnić spójność procesu uczenia się, podjęło inicjatywy związane ze zmianą sposobu oceniania. W całej Europie standaryzowane testy ogólnokrajowe koncentrowały się na umiejętnościach podstawowych, przede wszystkim na nauczaniu języka ojczystego i matematyki, oraz w mniejszym stopniu na naukach przyrodniczych i ścisłych oraz językach obcych. Spośród kompetencji przekrojowych tylko kompetencje obywatelskie i społeczne były sprawdzane na szczeblu krajowym, a liczba krajów, które stosowały takie egzaminy, wciąż rosła.

\section{Strategie rozwoju kompetencji kluczowych w poszczególnych krajach}

Większość krajów Unii Europejskiej opracowała strategie krajowe dla co najmniej trzech kompetencji kluczowych. Strategie dotyczące języka ojczystego miały na celu poprawę poziomu umiejętności czytania i pisania oraz promowanie dobrych nawyków czytelniczych. Z kolei strategie dotyczące nauk przyrodniczych i ścisłych koncentrowały się na rozbudzeniu zainteresowania kształceniem $w$ tych dziedzinach, by doprowadzić do zwiększenia liczby kandydatów (i absolwentów) na studia w dziedzinach STEM (ang. Science, Technology, Engineering and Mathematics, czyli nauki ścisłe, technologia, inżynieria i matematyka), dążeniu do większej równowagi płci na studiach i w zawodach związanych z tym dziedzinami oraz zapewnieniu pracodawcom pracowników mających niezbędne umiejętności. W strategiach kompetencji informatycznych najczęściej wymienianymi celami edukacyjnymi były: zwiększenie integracji wiedzy z zakresu technologii informacyjno-komunikacyjnych w procesie nauczania i uczenia się, wyposażenie uczniów w niezbędne umiejętności z tego zakresu, zapewnienie nauczycielom szkoleń oraz poprawa infrastruktury w szkołach (Eurydice, 2012). 
Inaczej było z językami obcymi - tylko mniej niż połowa krajów europejskich miała ogólną strategię wspierania rozwoju umiejętności w tym zakresie. Również mniej niż połowa krajów opracowała całościowe strategie kompetencji społecznych i obywatelskich, natomiast strategie poświęcone rozwijaniu kompetencji inicjatywności i przedsiębiorczości były znacznie bardziej powszechne. Z kolei niemal wszystkie kraje europejskie miały strategie krajowe dotyczące kompetencji informatycznych - ogólne lub poświęcone wyłącznie TIK (technologie informacyjno-komunikacyjne).

Kraje, które nie opracowały szeroko zakrojonych strategii, w większości uruchomiły inicjatywy zakładające zwiększenie zainteresowania określonym obszarem tematycznym poprzez ogólnokrajowe kampanie, duże projekty, tworzenie nowych ośrodków naukowych czy współpracę ze światem gospodarczym (szczególnie w przypadku rozwijania inicjatywności i przedsiębiorczości).

W publikacji z 2012 r. Eurydice informowała, że ostatnie reformy programów nauczania w krajach sieci polegały właśnie na włączeniu koncepcji kompetencji kluczowych i efektów kształcenia (tego, co uczeń powinien wiedzieć, rozumieć i umieć zrobić po skończeniu określonego poziomu kształcenia), a niektóre kraje wprowadziły nawet skale osiągnięć. W wielu krajach koncepcja nauczania oparta na przedmiotach została przebudowana i zastąpiona nową, bardziej złożoną strukturą włączającą umiejętności praktyczne i uwzględniającą podejście interdyscyplinarne. Jest to szczególnie widoczne w przypadku kompetencji przekrojowych, np. przedsiębiorczości, technologii informacyjno-komunikacyjnych i wychowania obywatelskiego.

Umiejętności podstawowe były nadal nauczane w ramach tzw. przedmiotów tradycyjnych, natomiast kompetencje przekrojowe w ramach odrębnych przedmiotów, a także włączano je do istniejących już przedmiotów nauczania (np. umiejętności obywatelskie mogą być włączane do kursu nauczania historii) oraz zyskały status interdyscyplinarny, czyli były definiowane jako cel ogólny pracy szkoły i wszyscy nauczyciele byli zobowiązani je wprowadzać. Wymaga to od pedagogów ścisłej współpracy i umiejętności wykraczania poza tradycyjne ramy przedmiotów szkolnych. Oznacza to również, że nauczyciele muszą prowadzić zajęcia tak, aby pozwolić uczniom rozwijać w tym samym czasie więcej niż jedną kompetencję, np. technologie informacyjno-komunikacyjne mogą być wykorzystywane jako narzędzie do nauki in- 
nych przedmiotów. Mimo że kompetencje kluczowe zostały w zasadzie wprowadzone do podstawy nauczania we wszystkich krajach, nadal widoczne były różnice w nacisku na umiejętności podstawowe z pewnym niedoborem w przypadku umiejętności przekrojowych - głównie ze względu na to, że większość systemów szkolnych była (i nadal jest) zorganizowana na podstawie nauczania przedmiotowego (Eurydice, 2012).

\section{Umiejscowienie poszczególnych kompetencji kluczowych w programach szkolnych}

Po roku 2012 Eurydice skoncentrowała się na opracowaniu odrębnych raportów dotyczących poszczególnych kompetencji kluczowych. W krótkich odstępach czasu zredagowano trzy raporty na temat: przedsiębiorczości (2014), edukacji obywatelskiej (2017) i nauczania języków obcych w szkołach w Europie (2017). Trwają prace nad kolejnym raportem poświęconym edukacji cyfrowej.

$Z$ danych o nauczaniu języków obcych wynika, że uczą się ich w Europie coraz młodsze dzieci (w porównaniu z sytuacją sprzed 10 lat), coraz więcej uczniów szkół średnich pierwszego stopnia uczy się dwóch języków obcych, a język angielski jest najbardziej rozpowszechnionym językiem obcym nauczanym w szkołach europejskich. W szkołach europejskich uczy się przede wszystkim: angielskiego, niemieckiego, hiszpańskiego i francuskiego, inne języki niemal się nie pojawiają, przy czym nauka drugiego języka obcego często nie jest obowiązkowa. Uczniowie szkół zawodowych mają mniej godzin nauki i uczą się mniejszej liczby języków obcych niż ich koledzy w szkołach ogólnokształcących.

$Z$ kolei raporty na temat kompetencji przekrojowych dowodzą, że przedsiębiorczość i edukacja obywatelska nie mają charakteru typowych przedmiotów szkolnych. Ich włączanie do programów nauczania w wielu krajach wynikało wprost $z$ wciągnięcia ich na listę kompetencji kluczowych. Podobnie jak przed 2012 r. poszczególne kraje przyjęły więc różne strategie włączania treści składających się na te kompetencje - od tworzenia odrębnych przedmiotów takich jak przedsiębiorczość i edukacja obywatelska przez włączanie ich do programów tradycyjnych przedmiotów, takich jak historia i nauki społeczne, do realizowania ich w trybie interdyscyplinarnym, jako cele ogólne dla całej szkoły realizowane przez wszystkich nauczycieli (projekty, konkursy, współpraca ze środowiskiem lokalnym). 
W dziedzinie edukacji obywatelskiej okazało się, że ma ona na celu wykształcenie następujących umiejętności uczniów: działania w sposób demokratyczny i społecznie odpowiedzialny, wchodzenia w efektywne i konstruktywne relacje z innymi oraz myślenia krytycznego. Wyposażenie młodych ludzi w tego typu umiejętności wymaga czegoś więcej niż tylko efektywne nauczanie przedmiotu. Umiejętność współdziałania w grupie i szacunek dla innych to cechy, które kształtują się raczej poza tradycyjnymi lekcjami. Szkoły wprowadzają więc różne formy demokratycznego uczestnictwa w postaci działań samorządów uczniowskich, realizują projekty zachęcające do uczestnictwa w życiu społecznym. Nauczanie zachowań obywatelskich ma też swój komponent międzynarodowy obejmujący wiedzę o działaniu instytucji międzynarodowych oraz prawach człowieka i obywatela.

W kolejnym raporcie Eurydice (2016) informuje, że w dziedzinie przedsiębiorczości w większości krajów jako cel edukacji w tym zakresie przyjmuje się ułatwienie młodzieży zdobycia zatrudnienia. Nauczanie przedsiębiorczości przyjmuje różne formy: od włączania treści interdyscyplinarnych do kształcenia w szkole podstawowej do odrębnego przedmiotu i bardziej złożonych działań w projektach w szkołach średnich. Niestety, kształcenie to ma charakter w dużej mierze teoretyczny, a szkolenia o charakterze praktycznym (miniprzedsiębiorstwa uczniowskie, projekty) rzadko są obowiązkowe i realizowane podczas zajęć, częściej zaś w ramach dodatkowych działań fakultatywnych. Najbardziej rozpowszechniony efekt kształcenia w tej dziedzinie to znajomość zagadnień finansowych (być może ze względu na łatwą ich mierzalność).

\section{Ocenianie uczniów w zakresie kompetencji kluczowych}

Prowadzenie porównywalnego oceniania wyników uczniów w zakresie kompetencji kluczowych jest możliwe na dwa sposoby. Są to: międzynarodowe badania edukacyjne badające umiejętności uczniów (opisane szczegółowo w odrębnym podrozdziale) oraz, na poziomie krajowym, prowadzenie egzaminów ogólnokrajowych.

Ogólnokrajowe egzaminowanie uczniów zostało w Eurydice zdefiniowane jako prowadzenie w skali kraju standaryzowanych testów i centralnie opracowywanych egzaminów (Eurydice, 2012).

Z raportów z lat 2012 i 2017 wynika, że większość krajów europejskich przeprowadza egzaminy ogólnokrajowe. Ich wyniki są wykorzy- 
stywane dwutorowo - do przyznawania świadectw i/lub do kontrolowania i ewaluacji pracy szkół i/lub całych systemów edukacji. Niektóre egzaminy krajowe kładą nacisk na sprawdzanie kompetencji uczniów, co świadczy o konsekwentnej zmianie podejścia z promowania wiedzy przedmiotowej uczniów na podejście promujące ich umiejętności. W większości krajów europejskich standaryzowane egzaminy i testy zewnętrzne koncentrują się na podstawowych umiejętnościach, przede wszystkim w zakresie języka ojczystego i matematyki, a w mniejszym stopniu w zakresie nauk ścisłych i przyrodniczych, języków obcych oraz kompetencji społecznych i obywatelskich. Z trzech kompetencji przekrojowych jedynie kompetencje społeczne i obywatelskie były sprawdzane w 2010 r. za pomocą standaryzowanych testów, i to tylko w około jednej trzeciej krajów. Kompetencje informatyczne i przedsiębiorczość w 2012 r. znajdowały się w zasadzie poza systemem egzaminów krajowych w szkolnictwie obowiązkowym. Oznacza to, że tendencja dostosowywania się lub ograniczenia do tych aspektów, które podlegają testowaniu, była i jest w Europie bardzo rozpowszechniona. Tę sytuację obserwowano zwłaszcza tam, gdzie egzaminy miały duże znaczenie dla uczniów, nauczycieli lub samych szkół (Eurydice, 2012).

W 2017 r. Eurydice opublikowała raport poświęcony osiągnięciom w zakresie podstawowych umiejętności uczniów w Europie, uwzględniając $w$ analizie wykorzystanie ogólnokrajowych egzaminów i testów z języka ojczystego, matematyki oraz nauk ścisłych i przyrodniczych. Raport ten potwierdził obserwację sprzed pięciu lat, że obecnie większość krajów europejskich przeprowadza egzaminy ogólnokrajowe (nie przeprowadzają ich tylko Niemieckojęzyczna Wspólnota w Belgii, Grecja, Chorwacja ani Bośnia i Hercegowina). Również dane z 2017 r. potwierdzają wnioski z 2012 r., zgodnie z którymi podstawowe umiejętności w zakresie języka ojczystego i matematyki są testowane we wszystkich krajach, natomiast w zakresie nauk ścisłych i przyrodniczych - w większości (dwie trzecie). W niektórych krajach sprawdza się umiejętności uczniów na zasadzie zmieniania co roku testowanego przedmiotu (tzw. rotating subject). Służy to ograniczeniu obciążeń związanych z organizacją egzaminów, a jednocześnie dostarcza porównywalnych danych o umiejętnościach uczniów. Rozwiązanie to stosowane jest w Finlandii, Austrii, Niemczech, Belgii (Wspólnota Flamandzka) i Szkocji.

Większość krajów prowadzi jednak regularne egzaminy, wciąż dodając nowe testy (w ostatnich latach były to: Hiszpania, Litwa, Łotwa, 
Szwecja, Anglia i Szkocja). Tylko Chorwacja zrezygnowała całkowicie z prowadzenia egzaminów krajowych. Warto podkreślić, że rezygnacja z testowania umiejętności nie oznacza rezygnacji z ich wprowadzania do programów nauczania (np. Chorwacja reformuje podstawę programową szkolnictwa podstawowego i średniego). Nadrzędnym celem reformy jest kształtowanie kompetencji kluczowych jako podstawy realizacji koncepcji uczenia się przez całe życie i rozwoju potencjału osobistego wszystkich uczących się, tzw. National Education Systems (Eurydice, 2017).

Kolejne źródło wiedzy o osiągnięciach uczniów to prowadzone regularnie krajowe badania edukacyjne. Większość krajów europejskich publikuje wyniki badań dotyczących osiągnięć uczniów w każdej z trzech dziedzin umiejętności podstawowych. Raporty krajowe są uzupełnianie o dane z badań międzynarodowych PISA (ang. Programme for International Student Assessment), TIMSS (Trends in International Mathematics and Science Study) i PIRLS (Progress in International Reading Literacy Study). Jedna trzecia krajów opiera się tylko na wynikach badań międzynarodowych, a zupełny brak danych obserwuje się wyłącznie w Bośni i Hercegowinie. Na poziomie krajowym badane są najczęściej umiejętności posługiwania się językiem ojczystym i matematyką, w mniejszym zaś stopniu te związane z naukami ścisłymi i przyrodniczymi - tylko jedna trzecia krajów prowadziła takie badania (Eurydice, 2016).

\section{Działania na rzecz poprawy słabych wyników uczniów}

W świetle uzgodnionych w ramach współpracy europejskiej benchmarków słabe wyniki uczniów to problem, który niepokoi władze edukacyjne wielu krajów. Chodzi tu o benchmark (wspólny cel) przyjęty w 2008 r. przez Radę Europejską w ramach strategii ET 2020 mówiący, że do 2020 r. należy zmniejszyć odsetek 15-latków, którzy osiągają zbyt niskie wyniki w zakresie czytania, matematyki oraz nauk ścisłych i przyrodniczych, do poziomu poniżej 15 proc. Poziom odniesienia tego benchmarku to wyniki badania PISA ogłaszane co trzy lata - z ostatnich badań z 2012 r. wynika, że 22,1 proc. europejskich uczniów osiąga słabe wyniki w matematyce, 17,8 proc. - w czytaniu oraz 16,6 proc. - w naukach ścisłych i przyrodniczych (Eurydice, 2016). Można więc uznać, że wszelkie działania krajowe zmierzające do poprawienia słabych wyników uczniów bezpośrednio wpływają na poprawę poziomu 
ich kompetencji kluczowych. Warto dodać, że słabe wyniki często dotyczą wszystkich kompetencji podstawowych i problemy z czytaniem w języku ojczystym oraz z liczeniem przekładają się na ogólnie słabsze wyniki w nauce matematyki, przedmiotów ścisłych i przyrodniczych (Eurydice, 2016). W większości szkół europejskich oferuje się pomoc uczniom mającym trudności z opanowaniem podstawowych umiejętności, takich jak czytanie i liczenie. Pomoc w nauce języków obcych, przedmiotów ścisłych i przyrodniczych jest oferowana znacznie rzadziej. Najczęściej stosowane środki wsparcia to: wczesne rozpoznanie i interwencja, zróżnicowanie sposobów oceniania, a szczególnie oceny formatywnej, działania na rzecz zwiększania motywacji do nauki oraz zindywidualizowana pomoc.

Kraje deklarują, że wykorzystują wyniki badań międzynarodowych, takich jak PISA, do monitorowania wyników i identyfikowania przyczyn słabszych wyników. Często analizy te są uzupełnianie o wyniki ogólnokrajowych egzaminów i raportów z inspekcji szkolnych (Eurydice, 2012).

\section{Przegląd wybranych międzynarodowych badań dotyczących kompetencji kluczowych}

Od lat zwraca się uwagę na to, że szkoła ma nie tylko przekazywać wiedzę, lecz także rozwijać kompetencje uczniów w różnych obszarach. Niektórzy przyjmują, że wyróżniamy cztery podstawowe grupy kompetencji, w jakie wyposażani są uczniowie:

$\rightarrow$ podstawowe kompetencje szkolne z zakresu matematyki, humanistyki, nauk przyrodniczych wraz z umiejętnością ich praktycznego wykorzystania,

$\rightarrow$ umiejętności związane z wykorzystaniem TIK pozwalające na uczestnictwo w życiu społeczeństwa informacyjnego,

$\rightarrow$ zdolność posługiwania się językiem obcym,

$\rightarrow$ tzw. twarde kompetencje, niezbędne w pracy zawodowej (Boni, 2011).

Piąta grupa, do której zaliczane są tzw. kompetencje miękkie (społeczne, emocjonalne), nie jest objęta programami kształcenia i nie ma danych, które pozwoliłyby je zmierzyć.

Idąc tym tropem, można zadać pytania: „Na ile sprawdzalny jest rozwój tych kompetencji u uczniów?" i „Na ile jest to zasługa samego systemu edukacji?". Odpowiedź na nie nie jest łatwa, biorąc pod uwagę 
wpływ, jaki ma na człowieka środowisko, w którym funkcjonuje ${ }^{1}$ (Zasac$k a, 2014$, s. 58). Mimo to $w$ środowiskach międzynarodowych wiele razy podejmowano próby zbadania i porównania stopnia rozwoju kompetencji kluczowych dzieci i młodzieży w poszczególnych krajach. Dotyczą one umiejętności czytania, liczenia, kompetencji cyfrowych, rozumowania naukowego, posługiwania się językiem obcym, a także dotykają do pewnego stopnia umiejętności argumentacji i myślenia krytycznego.

\section{Umiejętność czytania}

Jednym z badań jest wspomniany już PIRLS, stanowiący międzynarodowy pomiar osiągnięć szkolnych w czytaniu, przeznaczony dla 10-letnich uczniów w czwartym roku nauki², dokonywany na podstawie testu opracowanego przez międzynarodową grupę ekspertów (Konarzewski, 2017). Test pozwala zdobyć wiedzę o zmianach poziomu osiągnięć w każdym kraju uczestniczącym w badaniu więcej niż raz. Jest tak skonstruowany, że część zamieszczonych w nim tekstów i pytań powtarza się, tzn. została zaczerpnięta z testów przeprowadzanych w poprzednich edycjach badania, co daje możliwość porównywania wyników. I tak na przykład pomiar dla 2016 r. przeprowadzony był na podstawie odpowiedzi na pytania do sześciu tekstów literackich i sześciu tekstów użytkowych (łącznie 179 pytań, z czego 103 mierzy poziom umiejętności wyszukiwania informacji i prostego wnioskowania, a reszta sprawdza umiejętności interpretacji i oceniania tekstu), przy czym każdy uczeń dostawał zeszyt zawierający po jednym tekście literackim i użytkowym wraz z odnoszącymi się do nich pytaniami, w większości otwartymi. Edycją 2016 objęto łącznie ponad 287 tys. uczniów z ponad 10 tys. szkół (50 krajów), w tym ponad 4 tys. uczniów ze 148 szkół w Polsce.

Badanie prowadzone jest od 2001 r., Polska dołączyła do niego w roku 2006. Poniżej przytoczono rezultaty porównań międzynarodowych, pokazujące zmianę osiągnięć w czytaniu na przestrzeni lat.

1. Badanie czytelnictwa dzieci i młodzieży w Polsce wskazuje, że na nawyki czytelnicze w dużym stopniu wpływa rodzina - dzieci z rodzin o wyższym kapitale kulturowym chętniej sięgają samodzielnie po książki.

2. Badanie, prowadzone co pięć lat od 2001 r., koordynuje Międzynarodowe Stowarzyszenie ds. Oceny Osiągnięć Szkolnych (IEA), konsorcjum krajowych organizacji badawczych i agencji rządowych z prawie 70 krajów. 
Tabela 1. Zmiany osiągnięć w czytaniu (średnie wraz z błędem standardowym i różnice) w ramach kolejnych edycji badania PIRLS (wybrane kraje)

\begin{tabular}{|c|c|c|c|c|c|}
\hline KRAJ & $\begin{array}{c}\text { EDYCJA } \\
\text { BADANIA }\end{array}$ & ŚREDNIA & 2006 & 2011 & 2016 \\
\hline Anglia & $\begin{array}{l}2001 \\
2006 \\
2011 \\
2016\end{array}$ & $\begin{array}{l}553(3,5) \\
539(2,5) \\
552(2,6) \\
559(1,9)\end{array}$ & -13 & $\begin{array}{l}-1 \\
12\end{array}$ & $\begin{array}{l}6 \\
19 \\
7\end{array}$ \\
\hline Austria & $\begin{array}{l}2006 \\
2011 \\
2016\end{array}$ & $\begin{array}{l}538(2,2) \\
529(1,9) \\
541(2,4)\end{array}$ & & -9 & $\begin{array}{l}2 \\
12\end{array}$ \\
\hline Belgia (francuska) & $\begin{array}{l}2006 \\
2011 \\
2016\end{array}$ & $\begin{array}{l}500(2,6) \\
506(2,9) \\
497(2,6)\end{array}$ & & 6 & $\begin{array}{l}-2 \\
-9\end{array}$ \\
\hline Bułgaria & $\begin{array}{l}2001 \\
2006 \\
2011 \\
2016\end{array}$ & $\begin{array}{l}550(3,8) \\
547(4,4) \\
532(4,1) \\
552(4,2)\end{array}$ & -3 & $\begin{array}{l}-19 \\
-15\end{array}$ & $\begin{array}{l}1 \\
5 \\
20\end{array}$ \\
\hline Czechy & $\begin{array}{l}2001 \\
2011 \\
2016\end{array}$ & $\begin{array}{l}537(2,3) \\
545(2,2) \\
543(2,1)\end{array}$ & & 9 & $\begin{array}{c}6 \\
-2\end{array}$ \\
\hline Dania & $\begin{array}{l}2006 \\
2011 \\
2016\end{array}$ & $\begin{array}{l}546(2,2) \\
554(1,7) \\
547(2,1)\end{array}$ & & 8 & $\begin{array}{c}1 \\
-7\end{array}$ \\
\hline Federacja Rosyjska & $\begin{array}{l}2001 \\
2006 \\
2011 \\
2016\end{array}$ & $\begin{array}{l}528(4,3) \\
565(3,4) \\
568(2,7) \\
581(2,2)\end{array}$ & 37 & $\begin{array}{l}40 \\
4\end{array}$ & $\begin{array}{l}53 \\
16 \\
12\end{array}$ \\
\hline Francja & $\begin{array}{l}2001 \\
2006 \\
2011 \\
2016\end{array}$ & $\begin{array}{l}525(2,4) \\
522(2,0) \\
520(2,7) \\
511(2,2)\end{array}$ & -4 & $\begin{array}{l}-5 \\
-2\end{array}$ & $\begin{array}{l}-14 \\
-10 \\
-9\end{array}$ \\
\hline Gruzja & $\begin{array}{l}2006 \\
2011 \\
2016\end{array}$ & $\begin{array}{l}471(3,2) \\
488(3,1) \\
488(2,8)\end{array}$ & & 17 & $\begin{array}{l}17 \\
1\end{array}$ \\
\hline Hiszpania & $\begin{array}{l}2006 \\
2011 \\
2016\end{array}$ & $\begin{array}{l}513(2,6) \\
513(2,3) \\
528(1,7)\end{array}$ & & 1 & $\begin{array}{l}15 \\
15\end{array}$ \\
\hline Holandia & $\begin{array}{l}2001 \\
2006 \\
2011 \\
2016\end{array}$ & $\begin{array}{l}554(2,4) \\
547(1,5) \\
546(2,0) \\
545(1,7)\end{array}$ & -7 & $\begin{array}{l}-8 \\
-1\end{array}$ & $\begin{array}{l}-9 \\
-2 \\
-1\end{array}$ \\
\hline Hongkong & $\begin{array}{l}2001 \\
2006 \\
2011 \\
2016\end{array}$ & $\begin{array}{l}528(3,1) \\
564(2,4) \\
571(2,3) \\
569(2,7)\end{array}$ & 36 & $\begin{array}{l}43 \\
7\end{array}$ & $\begin{array}{l}41 \\
5 \\
-2\end{array}$ \\
\hline
\end{tabular}




\begin{tabular}{|c|c|c|c|c|c|}
\hline Iran & $\begin{array}{l}2001 \\
2006 \\
2011 \\
2016\end{array}$ & $\begin{array}{l}414(4,3) \\
421(3,2) \\
457(2,9) \\
428(4,0)\end{array}$ & 7 & $\begin{array}{l}44 \\
36\end{array}$ & $\begin{array}{l}14 \\
7 \\
-29\end{array}$ \\
\hline Litwa & $\begin{array}{l}2001 \\
2006 \\
2011 \\
2016\end{array}$ & $\begin{array}{l}543(2,6) \\
537(1,7) \\
528(2,0) \\
550(2,8)\end{array}$ & -6 & $\begin{array}{l}-15 \\
-9\end{array}$ & $\begin{array}{l}6 \\
13 \\
22\end{array}$ \\
\hline Łotwa & $\begin{array}{l}2001 \\
2006 \\
2016\end{array}$ & $\begin{array}{l}545(2,3) \\
541(2,3) \\
558(1,7)\end{array}$ & -4 & & $\begin{array}{l}13 \\
17\end{array}$ \\
\hline Niemcy & $\begin{array}{l}2001 \\
2006 \\
2011 \\
2016\end{array}$ & $\begin{array}{l}539(1,9) \\
548(2,2) \\
541(2,3) \\
537(3,2)\end{array}$ & 9 & $\begin{array}{r}2 \\
-7\end{array}$ & $\begin{array}{l}-2 \\
-10 \\
-4\end{array}$ \\
\hline Norwegia & $\begin{array}{l}2001 \\
2006 \\
2011 \\
2016\end{array}$ & $\begin{array}{l}499(2,9) \\
498(2,6) \\
507(2,0) \\
517(2,0)\end{array}$ & -1 & $\begin{array}{l}8 \\
9\end{array}$ & $\begin{array}{l}18 \\
19 \\
10\end{array}$ \\
\hline Nowa Zelandia & $\begin{array}{l}2001 \\
2006 \\
2011 \\
2016\end{array}$ & $\begin{array}{l}529(3,7) \\
532(2,1) \\
531(1,9) \\
523(2,2)\end{array}$ & 3 & $\begin{array}{r}2 \\
-1\end{array}$ & $\begin{array}{l}-6 \\
-9 \\
-8\end{array}$ \\
\hline Rumunia & $\begin{array}{l}2001 \\
2006 \\
2011\end{array}$ & $\begin{array}{l}512(4,6) \\
489(5,0) \\
502(4,3)\end{array}$ & -22 & $\begin{array}{c}-12 \\
13\end{array}$ & \\
\hline Singapur & $\begin{array}{l}2001 \\
2006 \\
2011 \\
2016\end{array}$ & $\begin{array}{l}528(5,2) \\
558(2,9) \\
567(3,3) \\
576(3,2)\end{array}$ & 30 & $\begin{array}{l}39 \\
9\end{array}$ & $\begin{array}{l}48 \\
18 \\
9\end{array}$ \\
\hline Słowacja & $\begin{array}{l}2001 \\
2006 \\
2011 \\
2016\end{array}$ & $\begin{array}{l}518(2,8) \\
531(2,8) \\
535(2,7) \\
535(3,1)\end{array}$ & 13 & $\begin{array}{l}17 \\
4\end{array}$ & $\begin{array}{l}17 \\
4 \\
0\end{array}$ \\
\hline Słowenia & $\begin{array}{l}2001 \\
2006 \\
2011 \\
2016\end{array}$ & $\begin{array}{l}502(1,9) \\
522(2,1) \\
530(2,0) \\
542(2,0)\end{array}$ & 20 & $\begin{array}{l}29 \\
9\end{array}$ & $\begin{array}{l}41 \\
21 \\
12\end{array}$ \\
\hline Stany Zjednoczone & $\begin{array}{l}2001 \\
2006 \\
2011 \\
2016\end{array}$ & $\begin{array}{l}542(3,8) \\
540(3,4) \\
556(1,6) \\
549(3,1)\end{array}$ & -2 & $\begin{array}{l}14 \\
16\end{array}$ & $\begin{array}{l}7 \\
10 \\
-7\end{array}$ \\
\hline Szwecja & $\begin{array}{l}2001 \\
2006 \\
2011 \\
2016\end{array}$ & $\begin{array}{l}561(2,2) \\
549(2,3) \\
542(2,1) \\
555(2,4)\end{array}$ & -12 & $\begin{array}{l}-19 \\
-8\end{array}$ & $\begin{array}{c}-6 \\
6 \\
13\end{array}$ \\
\hline Tajwan & $\begin{array}{l}2006 \\
2011 \\
2016\end{array}$ & $\begin{array}{l}535(2,0) \\
553(1,8) \\
559(2,0)\end{array}$ & & 18 & $\begin{array}{l}24 \\
6\end{array}$ \\
\hline
\end{tabular}




\begin{tabular}{l|l|l|l|l|l}
\hline Trynidad i Tobago & 2006 & $436(4,8)$ & & 35 & 44 \\
& 2011 & $471(3,8)$ & & & 9 \\
& 2016 & $479(3,3)$ & & & \\
\hline Węgry & 2001 & $543(2,2)$ & 8 & -4 & 11 \\
& 2006 & $551(2,9)$ & & -12 & 3 \\
& 2011 & $539(2,8)$ & & & 15 \\
\hline Włochy & 2016 & $554(2,9)$ & & & 7 \\
& 2001 & $541(2,4)$ & 11 & 1 & -3 \\
& 2006 & $551(2,9)$ & & -10 & 7 \\
& 2011 & $541(2,2)$ & & &
\end{tabular}

Źródło: Opracowanie na podstawie PIRLS 2016. Wyniki międzynarodowego badania osiągnięć czwartoklasistów w czytaniu, K. Konarzewski, K. Bulkowski (red.), IEA, Warszawa: IBE, 2017, s. 38.

Tabela nr 1 pokazuje wyniki testowania w badanym kraju, oszacowane jako średnia ważona osiągnięć w odniesieniu do przyjętej średniej wzorcowej 500 i odchyleniu standardowym 100. Zmiany zaznaczone kolorem szarym (zmiana na niekorzyść) i zielonym (zmiana na korzyść) pokazują różnice, które są statystycznie istotne. Z tabeli wyłączono kraje (w tym Polskę), dla których pomiaru dokonano tylko w dwóch latach. Biorąc to pod uwagę, można zaobserwować poprawę wyników w czytaniu uczniów w przypadku prawie połowy krajów, wyraźny spadek wyników w odniesieniu do Francji i Holandii oraz wahania wyników w 13 krajach biorących udział w badaniu. Polska w edycji 2006 uzyskała średni wynik 519, w edycji 2011 - 526, a w 2016 r. - 565, przy czym w roku tym poddano badaniu dzieci starsze (zmiany w legislacji dotyczące wieku obowiązku szkolnego), więc nie można było dokonać porównania wyników między edycjami (Konarzewski, 2017).

Poziom umiejętności czytania jest przedmiotem analiz w ramach największego międzynarodowego badania umiejętności uczniów na świecie - Programu Międzynarodowej Oceny Umiejętności Uczniów (ang. Programme for International Student Assessment), wdrażanego przez międzynarodowe konsorcjum koordynowane przez OECD co trzy lata od 2000 r. we wszystkich krajach OECD, a także w kilkudziesięciu krajach partnerskich (Federowicz, 2017). Obejmuje ono grupę 15-latków (uczniowie, którzy w roku poprzedzającym badanie skończyli 15 lat). W badaniu umiejętność czytania idzie w parze z interpretacją, co oznacza zarówno rozumienie tekstu (zrozumienie zawartej w nim 
treści), jak i działania intelektualne, które pozwalają na jego objaśnienie. Innymi słowy, zastosowane w badaniu zadania sprawdzają i proste umiejętności, i umiejętności bardziej złożone, pokazujące, na ile szkoła odchodzi od rutyny i pracuje z uczniami metodami pozwalającymi im na większą aktywność umysłową oraz samodzielność. W latach, w których czytanie i interpretacja stanowiły główną dziedzinę międzynarodowego pomiaru, użyto większej liczby zadań (140 w 2000 r., 99 w 2009 r.), w pozostałych zdecydowanie mniej. W edycjach z lat: $2000,2003,2006$, 2009 oraz 2012 zadania rozwiązywano w tradycyjnej papierowej formie, podczas gdy w 2015 r. w większości krajów (w tym w Polsce) wykorzystano wyłącznie komputery.

Kilkunastoletni okres, w którym prowadzone jest badanie, daje możliwość przyjrzenia się trendom występującym na świecie $w$ rozwijaniu umiejętności czytania uczniów, a także zmianom dokonywanym na przestrzeni lat $w$ odniesieniu do jednego kraju lub do grupy krajów. Każdy uczestniczący w badaniu kraj może odnaleźć swoją pozycję w międzynarodowym porównaniu, gdzie o miejscu na liście decyduje wynik mierzony odległością od średniego wyniku dla krajów OECD w nim uczestniczących. Białe tło w tab. nr 2 oznacza państwa, których wynik nie był istotnie różny od przeciętnego w krajach OECD, szare tło to kraje, w których uzyskano lepsze wyniki, a zielone - kraje, w których wyniki były gorsze od średniego (Federowicz, 2017). 
Tabela 2. Średnie wyniki uczniów z pomiaru umiejętności czytania i interpretacji w kolejnych edycjach badania PISA. Polska i kraje Unii Europejskiej biorące udział w badaniu

\begin{tabular}{|c|c|}
\hline \multicolumn{2}{|c|}{ PISA 2000 } \\
\hline Kraj & $\begin{array}{c}\text { Średni } \\
\text { wynik }\end{array}$ \\
\hline Finlandia & 546 \\
\hline Irlandia & 527 \\
\hline Szwecja & 516 \\
\hline Austria & 507 \\
\hline Belgia & 507 \\
\hline Francja & 505 \\
\hline Dania & 497 \\
\hline Hiszpania & 493 \\
\hline Czechy & 492 \\
\hline Włochy & 487 \\
\hline Niemcy & 484 \\
\hline Węgry & 480 \\
\hline Polska & 479 \\
\hline Grecja & 474 \\
\hline Portugalia & 470 \\
\hline Łotwa & 458 \\
\hline Bułgaria & 430 \\
\hline Rumunia & 428 \\
\hline
\end{tabular}

\begin{tabular}{|c|c|}
\hline \multicolumn{2}{|c|}{ PISA 2003 } \\
\hline Kraj & $\begin{array}{c}\text { Średni } \\
\text { wynik }\end{array}$ \\
\hline Finlandia & 543 \\
\hline Irlandia & 515 \\
\hline Szwecja & 514 \\
\hline Holandia & 513 \\
\hline Belgia & 507 \\
\hline Polska & 497 \\
\hline Francja & 496 \\
\hline Dania & 492 \\
\hline Niemcy & 491 \\
\hline Austria & 491 \\
\hline Łotwa & 491 \\
\hline Czechy & 489 \\
\hline Węgry & 482 \\
\hline Hiszpania & 481 \\
\hline Luksemburg & 479 \\
\hline Portugalia & 478 \\
\hline Włochy & 476 \\
\hline Grecja & 472 \\
\hline Słowenia & 469 \\
\hline
\end{tabular}

\begin{tabular}{|c|c|}
\hline \multicolumn{2}{|c|}{ PISA 2006 } \\
\hline Kraj & $\begin{array}{c}\text { Średni } \\
\text { wynik }\end{array}$ \\
\hline Finlandia & 547 \\
\hline Irlandia & 517 \\
\hline Polska & $\mathbf{5 0 8}$ \\
\hline Holandia & 507 \\
\hline Szwecja & 507 \\
\hline Estonia & 501 \\
\hline Belgia & 501 \\
\hline Niemcy & 495 \\
\hline Wielka Brytania & 495 \\
\hline Dania & 494 \\
\hline Słowenia & 494 \\
\hline Austria & 490 \\
\hline Francja & 488 \\
\hline Czechy & 483 \\
\hline Węgry & 482 \\
\hline Łotwa & 479 \\
\hline Luksemburg & 479 \\
\hline Chorwacja & 477 \\
\hline Portugalia & 472 \\
\hline Litwa & 470 \\
\hline Włochy & 469 \\
\hline Słowacja & 466 \\
\hline Hiszpania & 461 \\
\hline Grecja & 460 \\
\hline Bułgaria & 402 \\
\hline Rumunia & 396 \\
\hline
\end{tabular}




\begin{tabular}{|c|c|}
\hline \multicolumn{2}{|c|}{ PISA 2009 } \\
\hline Kraj & $\begin{array}{c}\text { Średni } \\
\text { wynik }\end{array}$ \\
\hline Finlandia & 536 \\
\hline Holandia & 508 \\
\hline Belgia & 506 \\
\hline Estonia & 501 \\
\hline Polska & 500 \\
\hline Szwecja & 497 \\
\hline Niemcy & 497 \\
\hline Irlandia & 496 \\
\hline Francja & 496 \\
\hline Dania & 495 \\
\hline Wielka Brytania & 494 \\
\hline Węgry & 494 \\
\hline Portugalia & 489 \\
\hline Włochy & 486 \\
\hline Łotwa & 484 \\
\hline Słowenia & 483 \\
\hline Grecja & 483 \\
\hline Hiszpania & 481 \\
\hline Czechy & 478 \\
\hline Słowacja & 477 \\
\hline Chorwacja & 476 \\
\hline Luksemburg & 472 \\
\hline Litwa & 468 \\
\hline Bułgaria & 429 \\
\hline Rumunia & 424 \\
\hline
\end{tabular}

\begin{tabular}{|c|c|}
\hline \multicolumn{2}{|c|}{ PISA 2012 } \\
\hline Kraj & $\begin{array}{c}\text { Średni } \\
\text { wynik }\end{array}$ \\
\hline Finlandia & 524 \\
\hline Irlandia & 523 \\
\hline Polska & $\mathbf{5 1 8}$ \\
\hline Estonia & 516 \\
\hline Holandia & 11 \\
\hline Belgia & 509 \\
\hline Niemcy & 508 \\
\hline Francja & 505 \\
\hline Wielka Brytania & 499 \\
\hline Dania & 496 \\
\hline Czechy & 493 \\
\hline Włochy & 490 \\
\hline Austria & 490 \\
\hline Łotwa & 489 \\
\hline Węgry & 488 \\
\hline Hiszpania & 488 \\
\hline Luksemburg & 488 \\
\hline Portugalia & 488 \\
\hline Chorwacja & 485 \\
\hline Szwecja & 483 \\
\hline Słowenia & 481 \\
\hline Litwa & 477 \\
\hline Grecja & 477 \\
\hline Słowacja & 463 \\
\hline Rumunia & 438 \\
\hline Bułgaria & 436 \\
\hline
\end{tabular}

\begin{tabular}{|c|c|}
\hline \multicolumn{2}{|c|}{ PISA 2015 } \\
\hline Kraj & $\begin{array}{c}\text { Sredni } \\
\text { wynik }\end{array}$ \\
\hline Finlandia & 526 \\
\hline Irlandia & 521 \\
\hline Estonia & 519 \\
\hline Niemcy & 509 \\
\hline Polska & 506 \\
\hline Słowenia & 505 \\
\hline Holandia & 503 \\
\hline Szwecja & 500 \\
\hline Dania & 500 \\
\hline Francja & 499 \\
\hline Belgia & 499 \\
\hline Portugalia & 498 \\
\hline Wielka Brytania & 498 \\
\hline Hiszpania & 496 \\
\hline Łotwa & 488 \\
\hline Czechy & 487 \\
\hline Chorwacja & 487 \\
\hline Austria & 485 \\
\hline Włochy & 485 \\
\hline Luksemburg & 481 \\
\hline Litwa & 472 \\
\hline Węgry & 470 \\
\hline Grecja & 467 \\
\hline Słowacja & 453 \\
\hline Malta & 447 \\
\hline Cypr & 443 \\
\hline Rumunia & 434 \\
\hline Bułgaria & 432 \\
\hline
\end{tabular}

Źródło: Program Międzynarodowej Oceny Umiejętności Uczniów. Wyniki badania PISA 2015 w Polsce, M. Federowicz, M. Sitek (red.), Warszawa: Instytut Badań Edukacyjnych, 2017, s. 61. 


\section{Umiejętność liczenia}

Badaniem poziomu wiedzy i rozumowania w zakresie matematyki na skalę międzynarodową zajmuje się konsorcjum agencji badawczych i rządowych, koordynowane przez Międzynarodowe Stowarzyszenie ds. Oceny Osiągnięć Szkolnych (IEA). TIMSS (ang. Trends in International Mathematics and Science Study) to jedno z najdłużej prowadzonych międzynarodowych badań porównawczych, przeprowadzane co cztery lata od 1995 r. ${ }^{3}$ (Konarzewski, 2016). Polska została nim objęta w latach 2011 i 2015. Badanie obejmuje zwykle uczniów IV klas szkół podstawowych, a także klas VIII (Polska nie uczestniczyła dotychczas w badaniu na tym poziomie). Podobnie jak w przypadku PIRLS do pomiaru umiejętności włącza się programy nauczania, a test osiągnięć matematycznych jest obszerny i składa się z dużej liczby pytań (169 w 2015 r.), jest również dzielony na indywidualne zeszyty dla każdego badanego ucznia. Część zadań powielana jest w kolejnych latach, by móc porównać wyniki.

Tabela 3. Osiągnięcia matematyczne w kolejnych edycjach badania TIMSS (wybrane kraje)*

\begin{tabular}{l|l|l|l|l|l}
\multicolumn{1}{c|}{ KRAJ } & \multicolumn{1}{c|}{$\mathbf{1 9 9 5}$} & \multicolumn{1}{c}{$\mathbf{2 0 0 3}$} & \multicolumn{1}{c}{$\mathbf{2 0 0 7}$} & \multicolumn{1}{c}{$\mathbf{2 0 1 1}$} & \multicolumn{1}{c}{$\mathbf{2 0 1 5}$} \\
\hline Anglia & $484(3,3) \mathrm{c}$ & $531(3,7)$ & $541(2,9)$ & $542(3,5)$ & $546(2,9)$ \\
\hline Australia & $495(3,4) \mathrm{b}$ & $499(3,9) \mathrm{b}$ & $516(3,5) \mathrm{a}$ & $516(2,9) \mathrm{a}$ & $517(3,1) \mathrm{a}$ \\
\hline Austria & $531(2,9) \mathrm{b}$ & & $505(2,0) \mathrm{a}$ & $508(2,6) \mathrm{a}$ & \\
\hline $\begin{array}{l}\text { Belgia } \\
\text { (flamandzka) }\end{array}$ & & $551(1,8) \mathrm{a}$ & & $549(1,9) \mathrm{a}$ & $546(2,1) \mathrm{a}$ \\
\hline Cypr & $475(3,2) \mathrm{c}$ & $510(2,4) \mathrm{b}$ & & & $523(2,7) \mathrm{a}$ \\
\hline Czechy & $541(3,1) \mathrm{d}$ & & $486(2,8) \mathrm{c}$ & $511(2,4) \mathrm{b}$ & $528(2,2) \mathrm{a}$ \\
\hline Dania & & & $523(2,4) \mathrm{b}$ & $537(2,6) \mathrm{a}$ & $539(2,9) \mathrm{a}$ \\
\hline $\begin{array}{l}\text { Federacja } \\
\text { Rosyjska }\end{array}$ & & $532(4,7) \mathrm{b}$ & $544(4,9) \mathrm{b}$ & $542(3,7) \mathrm{b}$ & $564(3,4) \mathrm{a}$ \\
\hline Gruzja & & & & & \\
\hline Holandia & $549(3,0) \mathrm{c}$ & $540(2,1) \mathrm{b}$ & $535(2,1) \mathrm{ba}$ & $540(1,7) \mathrm{b}$ & $530(1,7) \mathrm{a}$ \\
\hline Hongkong & $557(4,0) \mathrm{e}$ & $575(3,2) \mathrm{d}$ & $607(3,6) \mathrm{cab}$ & $602(3,4) \mathrm{b}$ & $614(2,9) \mathrm{a}$ \\
\hline Iran & $387(5,0) \mathrm{c}$ & $389(4,2) \mathrm{c}$ & $402(4,1) \mathrm{b}$ & $431(3,5) \mathrm{a}$ & $432(3,2) \mathrm{a}$ \\
\hline Irlandia & $523(3,5) \mathrm{b}$ & & & $527(2,6) \mathrm{b}$ & $548(2,2) \mathrm{a}$ \\
\hline Japonia & $567(1,9) \mathrm{c}$ & $565(1,6) \mathrm{c}$ & $568(2,1) \mathrm{c}$ & $585(1,7) \mathrm{b}$ & $593(1,9) \mathrm{a}$ \\
\hline Korea Płd. & $581(1,8) \mathrm{b}$ & & & $605(1,9) \mathrm{a}$ & $608(2,2) \mathrm{a}$ \\
\hline
\end{tabular}

3. Przeprowadzone w latach: 1995, 1999, 2003, 2007, 2011 i 2015 (w 1995 r. dla 41 krajów, w 2007 r. dla 48, w 2011 dla 63, w 2015 dla 49). 


\begin{tabular}{l|l|l|l|l|l}
\hline Litwa & & $534(2,8) \mathrm{a}$ & $530(2,4) \mathrm{a}$ & $534(2,4) \mathrm{a}$ & $536(2,7) \mathrm{a}$ \\
\hline Niemcy & & & $525(2,1) \mathrm{b}$ & $528(2,2) \mathrm{b}$ & $522(2,0) \mathrm{a}$ \\
\hline Norwegia & $476(3,0) \mathrm{c}$ & $451(2,3) \mathrm{c}$ & $473(2,5) \mathrm{b}$ & $495(2,8) \mathrm{a}$ & $493(2,3) \mathrm{a}$ \\
\hline $\begin{array}{l}\text { Nowa Zelan- } \\
\text { dia }\end{array}$ & $469(4,4) \mathrm{c}$ & $493(2,2) \mathrm{b}$ & $492(2,3) \mathrm{ba}$ & $486(2,6) \mathrm{a}$ & $491(2,3) \mathrm{ba}$ \\
\hline Portugalia & $442(3,9) \mathrm{c}$ & & & $532(3,4) \mathrm{b}$ & $541(2,2) \mathrm{a}$ \\
\hline Singapur & $590(4,5) \mathrm{c}$ & $594(5,6) \mathrm{cb}$ & $599(3,7) \mathrm{cb}$ & $606(3,2) \mathrm{b}$ & $618(3,8) \mathrm{a}$ \\
\hline Słowacja & & & $496(4,5) \mathrm{a}$ & $507(3,8) \mathrm{a}$ & $498(2,5) \mathrm{a}$ \\
\hline Słowenia & $462(3,1) \mathrm{e}$ & $479(2,6) \mathrm{d}$ & $502(1,8) \mathrm{c}$ & $513(2,2) \mathrm{b}$ & $520(1,9) \mathrm{a}$ \\
\hline $\begin{array}{l}\text { Stany Zjedno- } \\
\text { czone }\end{array}$ & $518(2,9) \mathrm{d}$ & $518(2,4) \mathrm{dc}$ & $529(2,4) \mathrm{b}$ & $541(1,8) \mathrm{a}$ & $539(2,3) \mathrm{a}$ \\
\hline $\begin{array}{l}\text { Szwecja } \\
\text { Tajwan }\end{array}$ & & & $503(2,5) \mathrm{b}$ & $504(2,0) \mathrm{b}$ & $519(2,8) \mathrm{a}$ \\
\hline Tunezja & & $339(4,7) \mathrm{b}$ & $327(4,5) \mathrm{b}$ & $359(3,9) \mathrm{a}$ & \\
\hline Węgry & $521(3,6) \mathrm{a}$ & $529(3,1) \mathrm{a}$ & $510(3,5) \mathrm{cb}$ & $515(3,4) \mathrm{b}$ & $529(3,2) \mathrm{a}$ \\
\hline Włochy & & $503(3,7) \mathrm{a}$ & $507(3,1) \mathrm{a}$ & $508(2,6) \mathrm{a}$ & $507(2,6) \mathrm{a}$
\end{tabular}

* Istotność statystyczna różnic między średnimi pomiaru pokazywana jest za pomocą liter a-e. Różnica jest istotna, jeśli średnie nie mają wspólnych liter. W nawiasach błędy standardowe.

Źródło: Wybrane kraje na podstawie TIMSS 2015. Wyniki międzynarodowego badania osiągnięć czwartoklasistów w matematyce i przyrodzie, K. Konarzewski, K. Bulkowski (red.), IEA, Warszawa: IBE, 2016, s. 39.

Tabela nr 3 pokazuje różnice między średnimi późniejszego i wcześniejszego pomiaru. Uwzględniono w niej kraje, dla których pomiaru dokonano w więcej niż w dwóch latach. Wyniki pokazują stopniowy wzrost osiągnięć uczniów w większości krajów oraz spadek w Holandii i Austrii. Czechy, Węgry i Norwegia odnotowały z kolei duże wahania wyników. Cztery kraje: Włochy, Słowacja, Litwa i Belgia charakteryzowały się stosunkową stabilnością wyników na przestrzeni lat. Ponadto spadek zróżnicowania wyników wystąpił w ośmiu krajach: w Australii, Anglii, na Cyprze, w Hongkongu, Irlandii, Portugalii, Singapurze i Słowenii, wzrost zróżnicowania w pięciu krajach: w Danii, Iranie, Korei Płd., Szwecji i na Tajwanie (Konarzewski, 2017). 
Badanie PISA pozwala zarówno na skomentowanie trendu zmian poziomu umiejętności matematycznych obserwowanych od 2003 r. ${ }^{4}$, jak i na odniesienie uzyskiwanych poziomów danego kraju do średnich wyników w krajach objętych badaniem (Federowicz, 2017). Pomiar prowadzony jest na grupie 15-latków i bada, w jakim stopniu są oni w stanie rozwiązać zadania praktyczne, wykorzystując wiedzę i umiejętności matematyczne. Najlepsze wyniki mogli uzyskać ci uczniowie, którzy potrafią wykorzystywać pojęcia matematyczne i narzędzia do analizy zjawisk, co wykracza poza standardowe odtworzenie wyuczonych schematów. W edycji 2015 zastosowano 70 zróżnicowanych zadań, z czego w przypadku 44 należało pokazać samodzielnie opracowane rozwiązanie, bez wskazywania odpowiedzi z podanej listy. Wyniki badania w ramach edycji 2015 wskazują na systematyczne obniżanie się średniego wyniku pomiaru umiejętności matematycznych w krajach OECD na przestrzeni lat. Na tym tle polscy uczniowie wypadają lepiej, poprawiając swoje osiągnięcia w każdej kolejnej edycji badania (tamże). Jest to szczególnie widoczne w zadaniach wymagających rozumowania matematycznego, począwszy od edycji 2012 badania, w której po raz pierwszy polscy uczniowie uzyskali wynik w tej grupie zadań podobny do średniej OECD lub lepszy od niej (opracowana na potrzeby badania skala sześciu poziomów trudności zadań z odpowiadającymi im umiejętnościami uczniów pozwalała zbadać, jak uczniowie radzą sobie z zadaniami wysoko na skali, mierzącymi umiejętności złożone).

Wykres 1. Wyniki uczniów w Polsce i w krajach OECD w badaniu PISA 2015 w zadaniach wymagających rozumowania matematycznego (w proc.)

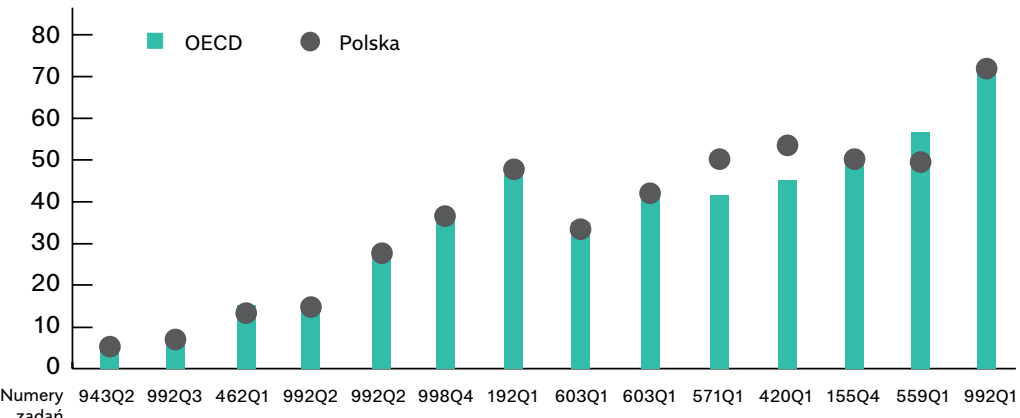
zadań

Źródło: Program Międzynarodowej Oceny Umiejętności Uczniów. Wyniki badania PISA 2015 w Polsce, M. Federowicz, M. Sitek (red.), Warszawa: Instytut Badań Edukacyjnych, 2017, s. 78.

4. Matematyka była główną dziedziną badania PISA w edycjach 2003 i 2012. 


\section{Rozumowanie naukowe}

Jedna z kompetencji kluczowych wymienionych powyżej to rozumowanie naukowe. Przytoczymy dwa międzynarodowe badania mierzące osiągnięcia uczniów w tym obszarze. Pierwsze z nich to badanie TIMSS, drugie - PISA.

Podobnie jak w przypadku matematyki test osiągnięć przyrodniczych TIMSS składa się corocznie z wielu pytań (np. $168 \mathrm{w}$ edycji 2015), uwzględniając programy nauczania przedmiotów przyrodniczych w różnych krajach (Konarzewski, 2016). Test jest dzielony na podzbiory i w formie zeszytów przydzielany do wypełnienia uczniom klas IV szkół podstawowych (zadania dotyczą biologii, geografii i fizyki). W edycji 2015 średni wynik dla Polski wyniósł 547 pkt i był wyższy od międzynarodowej średniej (dziewiąte miejsce wśród 47 krajów). Polscy uczniowie lepiej radzili sobie z wykorzystywaniem wiadomości, gorzej z zadaniami wymagającymi rozwiązywania problemów. Biorąc pod uwagę pomiar osiągnięć w czasie, w przypadku niektórych krajów (w tym Polski) nie można było pokusić się o wnioski. Pomimo że $w$ badaniu bierze udział kilkadziesiąt krajów (45 państw uczestniczyło w przynajmniej dwóch edycjach badania w latach 1995-2015), w tabeli nr 4 uwzględniono wyłącznie te, które dysponują przynajmniej trzema pomiarami - jest ich łącznie 29. Znaczne wahania wyników na przestrzeni lat odnotowano w trzech krajach: Czechach, Norwegii i we Włoszech. Stopniowy wzrost następował w połowie krajów, a spadek w dwóch (Belgia i Holandia). Względna stabilizacja w poziomach osiągnięć uczniów w zakresie nauk przyrodniczych dotyczyła: Australii, Niemiec, Słowacji, Stanów Zjednoczonych i Tajwanu (Konarzewski, 2016).

Tabela 4. Osiągnięcia przyrodnicze w kolejnych edycjach badania TIMSS (wybrane kraje)

\begin{tabular}{l|l|c|c|c|c}
\multicolumn{1}{c|}{ KRAJ } & \multicolumn{1}{c|}{$\mathbf{1 9 9 5}$} & $\mathbf{2 0 0 3}$ & $\mathbf{2 0 0 7}$ & $\mathbf{2 0 1 1}$ & \multicolumn{1}{c}{$\mathbf{2 0 1 5}$} \\
\hline Anglia & $528(3,2) \mathrm{b}$ & $540(3,5) \mathrm{a}$ & $542(2,8) \mathrm{a}$ & $529(3,0) \mathrm{a}$ & $536(2,4) \mathrm{a}$ \\
\hline Australia & $521(3,7) \mathrm{ba}$ & $521(4,3) \mathrm{ba}$ & $527(3,3) \mathrm{b}$ & $516(2,9) \mathrm{a}$ & $524(2,9) \mathrm{ba}$ \\
\hline Austria & $538(3,6) \mathrm{b}$ & & $526(2,5) \mathrm{a}$ & $532(2,8) \mathrm{a}$ & \\
\hline $\begin{array}{l}\text { Belgia } \\
\text { (flamandzka) }\end{array}$ & & $518(1,9) \mathrm{b}$ & & $509(2,0) \mathrm{a}$ & $511(2,3) \mathrm{a}$ \\
\hline Cypr & $450(3,4) \mathrm{b}$ & $480(2,4) \mathrm{a}$ & & & \\
\hline Czechy & $532(3,1) \mathrm{a}$ & & $515(3,0) \mathrm{b}$ & $511(2,4) \mathrm{a}$ & $528(2,2) \mathrm{a}$ \\
\hline Dania & & & $517(2,9) \mathrm{b}$ & $528(2,8) \mathrm{a}$ & $527(2,1) \mathrm{a}$ \\
\hline
\end{tabular}




\begin{tabular}{|c|c|c|c|c|c|}
\hline $\begin{array}{l}\text { Federacja } \\
\text { Rosyjska }\end{array}$ & & $526(5,3)$ & $546(5,0)$ & $552(3,4)$ & $567(3,2)$ \\
\hline Gruzja & & & $418(4,6)$ & $455(3,9)$ & $451(3,7)$ \\
\hline Holandia & $530(3,2)$ & $525(2,0)$ & $523(2,6)$ & $531(2,2)$ & $517(2,7)$ \\
\hline Hongkong & $508(3,4)$ & $542(3,0)$ & $554(3,5)$ & $535(3,7)$ & $556(2,9)$ \\
\hline Iran & $380(4,6)$ & $414(4,2)$ & $436(4,4)$ & $453(3,8)$ & $421(4,0)$ \\
\hline Irlandia & $553(1,7)$ & $543(1,5)$ & $548(2,1)$ & $559(1,9)$ & $569(1,8)$ \\
\hline \multicolumn{6}{|l|}{ Japonia } \\
\hline Korea Płd. & $576(2,1) b$ & & & $587(2,1) a$ & $589(2,0) a$ \\
\hline Litwa & & $512(2,6) b$ & $514(2,4) b$ & $515(2,4) b$ & $530(2,7) a$ \\
\hline Niemcy & & & $528(2,4) a$ & $528(2,9) \mathrm{a}$ & $528(2,4) a$ \\
\hline Norwegia & $504(3,7) d$ & $466(2,6) c$ & $477(3,5) b$ & $494(2,5) a$ & $493(2,2) a$ \\
\hline $\begin{array}{l}\text { Nowa Zelan- } \\
\text { dia }\end{array}$ & $505(5,4) a b$ & $520(2,4) b c$ & $504(2,7) a$ & $497(2,4) b$ & $505(2,7) a$ \\
\hline Portugalia & $452(4,1) c$ & & & $522(3,8) b$ & $508(2,2) a$ \\
\hline Singapur & $523(4,8) c$ & $565(5,5) b$ & $587(4,1) a$ & $583(3,4) a$ & $590(3,7) a$ \\
\hline Słowacja & & & $\begin{array}{l}526(4,8) \\
a b\end{array}$ & $532(3,7) b$ & $520(2,6) a$ \\
\hline Słowenia & $464(3,1) \mathrm{e}$ & $490(2,6) d$ & $518(1,9) b c$ & $520(2,6) b$ & $542(2,4) a$ \\
\hline $\begin{array}{l}\text { Stany Zjedno- } \\
\text { czone }\end{array}$ & $542(3,4) a b$ & $536(2,5) b$ & $539(2,7) b$ & $544(2,1) a$ & $546(2,2) a$ \\
\hline Szwecja & & & $525(2,9) b$ & $533(2,8) a$ & $540(3,6) a$ \\
\hline Tajwan & & $551(1,8) b$ & $557(2,0) a$ & $552(2,2) a b$ & $555(1,8) a b$ \\
\hline Tunezja & & $314(5,7) b$ & $318(5,9) b$ & $346(5,3) a$ & \\
\hline Węgry & $508(3,4) c$ & $530(2,8) b$ & $\begin{array}{l}536(3,4) \\
a b\end{array}$ & $\begin{array}{l}534(3,7) \\
\mathrm{ab}\end{array}$ & $542(3,3) a$ \\
\hline Włochy & & $516(3,8) a$ & $535(3,2) c$ & $524(2,7) b$ & $516(2,6) a$ \\
\hline
\end{tabular}

* Istotność statystyczna różnic między średnimi pomiaru pokazywana jest za pomocą liter a-e. Różnica jest istotna, jeśli średnie nie mają wspólnych liter. W nawiasach błędy standardowe.

Źródło: Wybrane kraje na podstawie TIMSS 2015. Wyniki międzynarodowego badania osiągnięć czwartoklasistów w matematyce i przyrodzie, K. Konarzewski, K. Bulkowski (red.), IEA, Warszawa: IBE, 2016, s. 50.

Badanie PISA służy z kolei weryfikacji, w jakim stopniu uczniowie potrafią zastosować wiedzę z zakresu nauk przyrodniczych do rozwiązywania zadanych problemów (Federowicz, 2017). Badane rozumowanie naukowe obejmuje znajomość faktów, standardowej metodyki pozyskiwania danych i reguł wnioskowania. Rozumowanie 
w naukach przyrodniczych było główną dziedziną pomiaru w dwóch edycjach badania: 2006 i 2015. W edycji 2015 zwrócono uwagę na trzy aspekty: wiedzę, umiejętności i postawy, przy czym umiejętności objęły wyjaśnianie zjawisk w sposób naukowy, poprawność zastosowanych procedur badawczych oraz interpretację danych. Do pomiaru zastosowano 184 zadania, z czego 85 było wykorzystywanych we wcześniejszych pomiarach, co pozwoliło na dokonanie porównań. Nowością było obligatoryjne wykorzystanie komputera jako narzędzia badawczego.

Wykres 2. Zmiany wyników pomiaru rozumowania w naukach przyrodniczych uczniów w Polsce i średnio w krajach OECD w latach 2000-2015

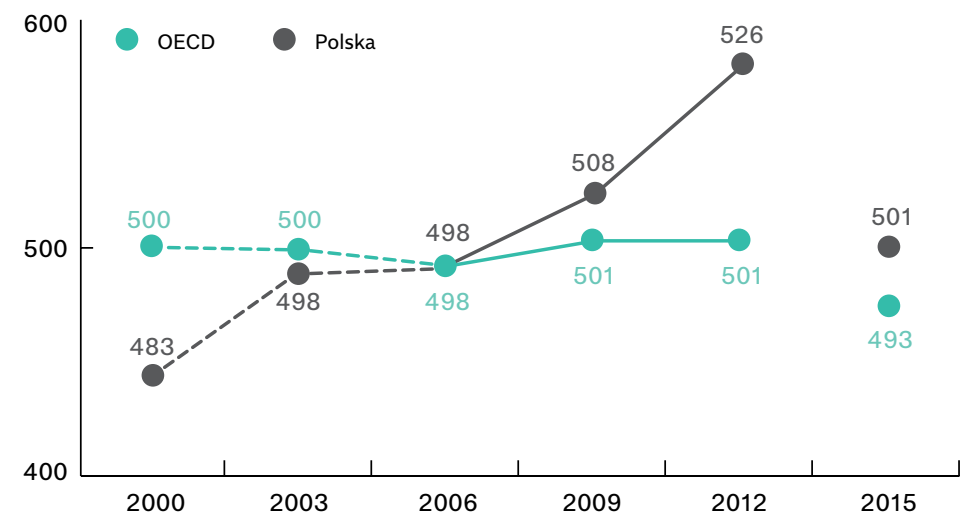

Źródło: Program Międzynarodowej Oceny Umiejętności Uczniów. Wyniki badania PISA 2015 w Polsce, M. Federowicz, M. Sitek (red.), Warszawa: Instytut Badań Edukacyjnych, 2017, s. 41.

Linią przerywaną zaznaczono wyniki, które nie są porównywalne (pełnego skalowania do pomiaru dokonano w 2006 r.). Zmiana narzędzia pomiaru (z papierowego na komputerowy) między edycjami 2012 i 2015 również uniemożliwiła porównanie wyników, co zaznaczono z kolei brakiem linii łączącej. W związku z tym średni wynik dla krajów OECD uczestniczących w pomiarze (57 krajów) to 498 pkt w 2006 r. i 493 pkt (dla 72 krajów) w 2015 r. Porównując dane, można zauważyć, że średni wynik dla krajów OECD nie ulega dużej zmianie, z wyjątkiem ostatniej edycji badania, w której jest on niższy, na co mogła mieć wpływ zmiana sposobu pomiaru z papierowego na komputerowy 
(Federowicz, 2017, s. 41). Wyniki dla Polski systematycznie rosły, ze średniego poziomu w $2006 \mathrm{r}$. do znacznie wyższego od średniej OECD w roku 2015. Co istotne, osiągnięcia polskich uczniów (pomimo spadku w latach 2012-2015) w okresie 2006-2015 charakteryzują się dodatnim trendem wzrostowym.

\section{Kompetencje komputerowe i informacyjne}

Jednym z badań dokonujących międzynarodowego pomiaru poziomu posługiwania się technologiami informacyjno-komunikacyjnymi jest Badanie Kompetencji Komputerowych i Informacyjnych (ang. ICILS, International Computer and Information Literacy Study). Przeprowadzone było po raz pierwszy w 2013 r. przez konsorcjum krajów koordynowanych przez IEA (Fraillon i in., 2014). Nasz kraj wziął w nim udział w pierwszej edycji (2870 uczniów ze 157 szkół) jako jedno z 21 badanych państw i/lub systemów edukacyjnych. Łącznie w badaniu udział wzięło ponad 60 tys. uczniów z ponad 3,3 tys. szkół. Zgodnie z definicją zawartą $w$ raporcie krajowym $z$ badania kompetencje komputerowe i informacyjne zdefiniowane zostały jako „zdolność jednostki do korzystania z komputera $w$ dociekaniu, tworzeniu i komunikowaniu informacji w celu skutecznego udziału w kontekście rodziny, szkoły, miejsca pracy i szeroko rozumianego społeczeństwa", a samo badanie sprawdzało, jak uczniowie Il klasy gimnazjum potrafią ocenić, przekształcić informację i podzielić się nią przy użyciu komputera (Sijko, 2014).

Polscy uczniowie osiągnęli wyniki należące do najwyższych w badaniu (Fraillon i in., 2014). Jednocześnie porównanie międzynarodowe pokazuje, że w przypadku krajów o najwyższych wynikach różnice między nimi nie przekraczały 10 pkt, jeśli zaś chodzi o kraje mające najsłabsze wyniki, wówczas różnice były wyraźnie większe, np. między Chile a Turcją to aż 126 pkt.

Tabela 5. Średnie wyniki dla pomiaru kompetencji komputerowych i informacyjnych (w nawiasie błąd standardowy), rok nauki i średnia wieku badanych uczniów, według krajów

\begin{tabular}{l|l|l|l}
\multicolumn{1}{c|}{ KRAJ } & \multicolumn{1}{c|}{ ROK NAUKI } & \multicolumn{1}{c}{ ŚREDNIA WIEKU } & \multicolumn{1}{c}{ ŚREDNI WYNIK } \\
\hline Czechy & 8. & 14,3 & $553(2,1)$ \\
\hline Australia & 8. & 14,0 & $542(2,3)$ \\
\hline Polska & 8. & 14,8 & $537(2,4)$ \\
\hline Norwegia & 9. & 14,8 & $537(2,4)$ \\
\hline
\end{tabular}




\begin{tabular}{l|l|l|l}
\hline Korea Płd. & 8. & 14,2 & $536(2,7)$ \\
\hline Niemcy & 8. & 14,5 & $523(2,4)$ \\
\hline Słowacja & 8. & 14,3 & $517(4,6)$ \\
\hline Federacja Rosyjska & 8. & 15,2 & $516(2,8)$ \\
\hline Chorwacja & 8. & 14,6 & $512(2,9)$ \\
\hline Słowenia & 8. & 13,8 & $511(2,2)$ \\
\hline Litwa & 8. & 14,7 & $494(3,6)$ \\
\hline Chile & 8. & 14,2 & $487(3,1)$ \\
\hline Tajlandia & 8. & 13,9 & $373(4,7)$ \\
\hline Turcja & 8. & 14,1 & $361(5,0)$ \\
\hline Krajeniespełnajace & &
\end{tabular}

Kraje niespełniające wymagań odnośnie do wielkości próby

\begin{tabular}{l|l|l|l}
\hline Dania & 8. & 15,1 & $542(3,5)$ \\
\hline Hongkong & 8. & 14,1 & $509(7,4)$ \\
\hline Holandia & 8. & 14,3 & $535(4,7)$ \\
\hline Szwajcaria & 8. & 14,7 & $526(4,6)$ \\
\hline \multicolumn{5}{l}{ Systemy edukacyjne włączone do benchmarku } \\
\begin{tabular}{l|l|l|l} 
Nowa Fundlandia \\
i Labrador, Kanada
\end{tabular} & 8. & 13,8 & $528(2,8)$ \\
\hline Ontario, Kanada & 8. & 13,8 & $547(3,2)$ \\
\hline
\end{tabular}

Systemy edukacyjne włączone do benchmarku, niespełniające wymagań odnośnie do wielkości próby

\begin{tabular}{l|l|l|l}
\hline $\begin{array}{l}\text { Miasto Buenos Aires, } \\
\text { Argentyna }\end{array}$ & 8. & 14,2 & $450(8,6)$
\end{tabular}

Źródło: Opracowanie na podstawie Fraillon, J., Ainley, J., Schulz, W., Friedman, T., Gebhardt, E., Preparing for Life in a Digital Age. The IEA International Computer and Information Literacy Study International Report, 2014, s. 96.

Zastosowanie w badaniu mapy ze zdefiniowanymi czterema przedziałami pozwoliło z kolei na weryfikację poziomu umiejętności uczniów w odniesieniu do określonego poziomu kompetencji, gdzie poziom 1 odpowiada podstawowej wiedzy o komputerze pozwalającej na wykonanie prostych zadań, natomiast poziom 4 odpowiada umiejętności selekcjonowania najbardziej odpowiednich dla komunikacji informacji. W dalszej części tekstu przytoczono wyniki dla poziomu od 3 wzwyż (poziom 3 to taki, na którym uczniowie potrafią samodzielnie pozyskać informacje z dostępnych źródeł, aby odpowiedzieć na zadawane im pytania). 
Wykres 3. Proporcja uczniów przypadająca na poszczególne poziomy wykonania testu CIL (Computer and Information Literacy) - kraje posortowane malejąco względem proporcji uczniów na poziomie 3 lub wyżej

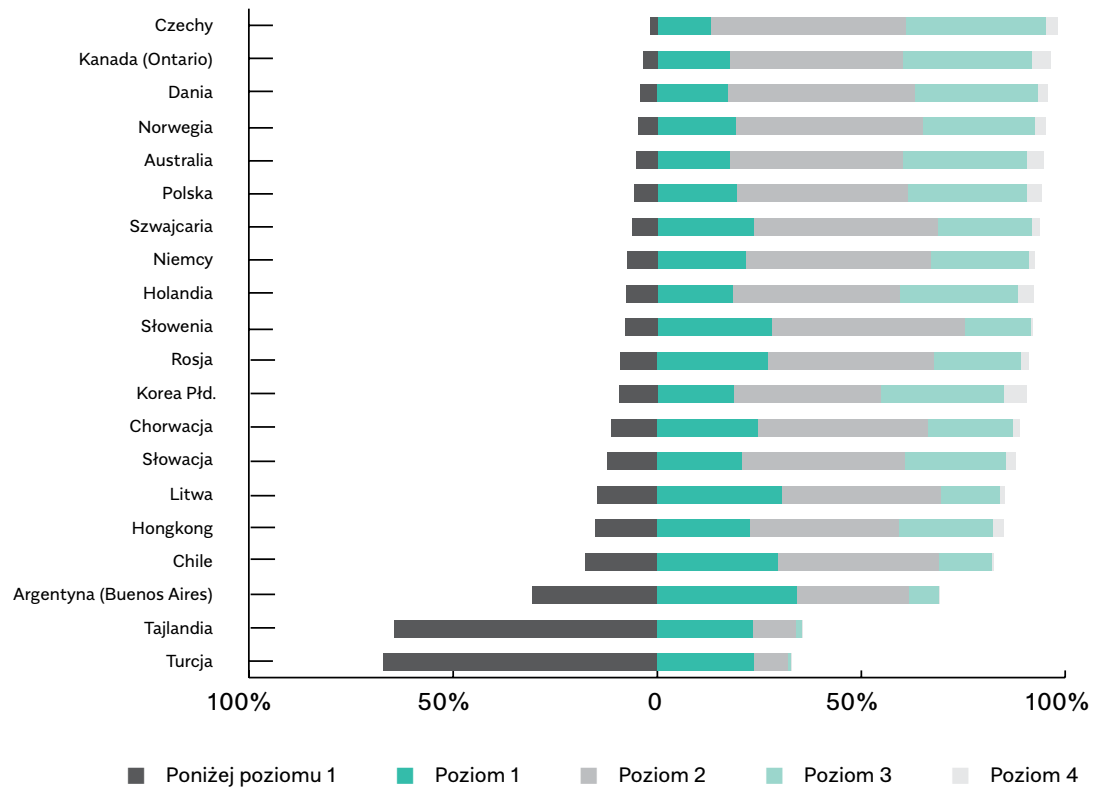

Źródło: Kompetencje komputerowe i informacyjne młodzieży w Polsce. Raport

z międzynarodowego badania kompetencji komputerowych i informacyjnych ICILS 2013,

K. Sijko (red.), Warszawa: IBE, 2014, s. 44.

Jak widać na wykresie nr 3, prawie we wszystkich krajach największy odsetek uczniów plasuje się na poziomie 2. Zdecydowana większość badanych uczniów osiągnęła wyniki lokujące ich na poziomach 1-3. Wśród krajów mających najwyższe wyniki (Czechy, Dania, Australia, Polska, Norwegia) i w mieście Ontario odsetek uczniów powyżej poziomu 2 jest zdecydowanie wyższy niż dla poziomu 1 i niżej. Z kolei dla większości pozostałych krajów, które mają najwyższy odsetek uczniów na poziomie 2, odsetek uczniów poniżej tego poziomu jest wyższy od tego powyżej tego poziomu. W przypadku Tajlandii i Turcji dominował odsetek uczniów osiągający maksymalnie poziom 1 na mapie kompetencji. Polska wypada podobnie jak inne kraje rozwinięte. Jak zauważają autorzy krajowego raportu, ważne jest jednak postawienie pytania, czy wysokie 
wyniki świadczą o tym, że poziom wiedzy i umiejętności uczniów jest "wystarczająco dobry", gdyż badanie ma charakter porównawczy i nie daje podstaw do odpowiedzi na nie (Sijko, 2014).

Poziom znajomości technik komputerowo-informacyjnych lub stopień dostępu do sprzętu z oprogramowaniem były przedmiotem również kilku innych badań (Sijko, 2014). Należą do nich badanie COMPED (realizowane w 1989 r. i koordynowane również przez IEA, koncentrujące się na zasobności polskich szkół w komputery i oprogramowanie), sondaż Survey of Schools przeprowadzony przez organizację European Schoolnet na zlecenie Komisji Europejskiej w 2013 r. (zarówno oceniający dostęp do sprzętu komputerowego, Internetu, jak i m.in. porównujący deklaracje nauczycieli dotyczące częstotliwości korzystania z narzędzi TIK na zajęciach) oraz - przytaczane już wcześniej - badanie PISA (wykorzystanie komputera jako obowiązkowego narzędzia badawczego w rozwiązywaniu zadań testowych począwszy od edycji 2015). W innym wymienionym już badaniu - TIMSS - można znaleźć informacje o wykorzystaniu komputerów na zajęciach podczas wykonywania zadanych przez nauczyciela ćwiczeń, jednakże nie były one przedmiotem większych analiz.

\section{Umiejętność posługiwania się językiem obcym}

Umiejętność posługiwania się językiem obcym determinuje stopień otwarcia się młodego człowieka na świat i poruszania się w nim. Z tego względu w większości państw Europy uczy się w szkołach dwóch języków obcych obowiązkowo lub - jak jest to w niektórych krajach - nauka drugiego języka jest opcjonalna. Systemy szkolne, które oferują szeroki wachlarz języków obcych, mają tendencję do osiągania lepszych wyników w ich nauczaniu (Costa i in., 2015). Mimo że na rynku pracy nie wszystkie z nich się liczą w równym stopniu, różnorodność językowa jest niezwykle ważna dla osobistego rozwoju człowieka.

Egzaminy zewnętrzne, o których była wcześniej mowa, są podstawą mierzenia jakości nauczania języka obcego w szkole. $Z$ kolei najbardziej znane badanie międzynarodowe w obszarze pomiaru osiągnięć uczniów w rozwijaniu kompetencji posługiwania się językiem obcym to Europejskie Badanie Kompetencji Językowych (ang. ESLC - European Survey on Language Competences). Zrealizowano je w 2011 r. z inicjatywy Komisji Europejskiej i nie miało ono dotychczas kolejnej edycji. Wzięło w nim udział około 54 tys. uczniów z 14 krajów Europy (w tym ponad 3 tys. gimnazjalistów III klas z Polski) i dotyczyło weryfikacji poziomu znajomości dwóch najczęściej nauczanych języków obcych - angielskiego i niemiec- 
kiego w przypadku Polski (Szpotowicz, 2013). Test pisemny sprawdzał dwie z trzech sprawności językowych, jakimi są rozumienie tekstu pisanego, samodzielne tworzenie tekstu oraz rozumienie ze słuchu, i był jednym z trzech testów dostosowanych odpowiednio do poziomu zaawansowania ucznia (zadania na poziomie A1 i A2 według ESOKJ5 - najniższy stopień trudności, A2 i B1 - średni, B1 i B2 - najwyższy).

Wykres 4. Odsetek uczniów zakwalifikowanych na poszczególne poziomy ESOKJ w pierwszym badanym języku dla poszczególnych krajów uczestniczących w badaniu

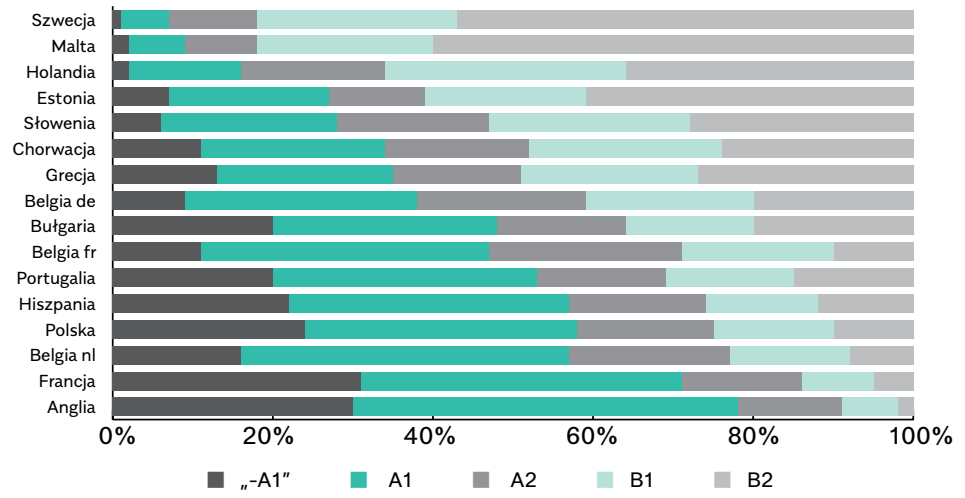

Wykres 5. Odsetek uczniów zakwalifikowanych na poszczególne poziomy ESOKJ w drugim badanym języku dla poszczególnych krajów uczestniczących w badaniu

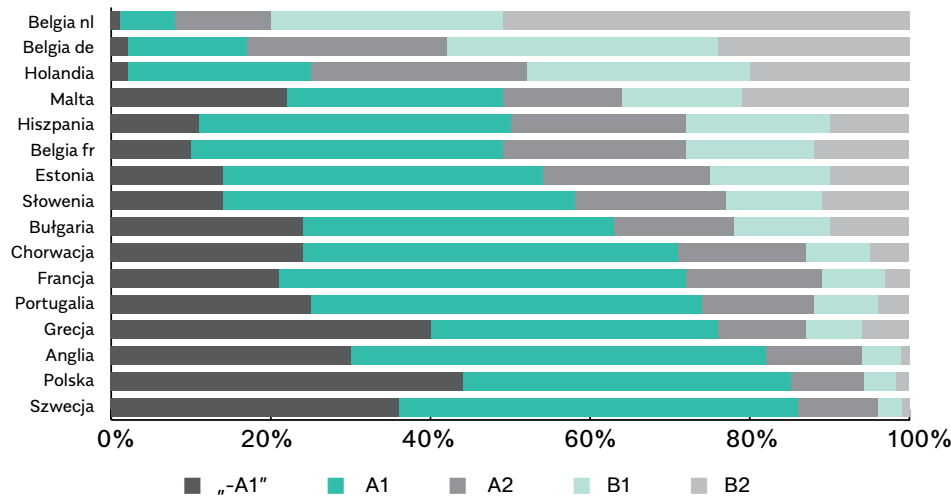

Źródło: Raport tematyczny. Europejskie Badanie Kompetencji Językowych ELSC, Raport krajowy 2011, M. Szpotowicz (red.), Warszawa: IBE, 2013, s. 26.

5. Europejski System Opisu Kształcenia Językowego. 
Wyniki przedstawione na wykresie nr 3 pokazały znaczne różnice w umiejętności posługiwania się językiem obcym wśród uczniów różnych krajów. Jednocześnie pokazały dwa czynniki najmocniej na to wpływające: rozpowszechnienie danego języka obcego w danym państwie i na świecie (liczba osób posługujących się nim, obecność języka w mediach, źródłach informacji) oraz status języka jako pierwszego (lub drugiego) najczęściej nauczanego w danym kraju (Szpotowicz, 2013, s. 25). Stąd wśród wszystkich języków obcych to właśnie dla angielskiego odsetek uczniów znających go na poziomie B1 i B2 jest najwyższy. W zależności od badanej umiejętności - np. pisania samodzielnie tekstów - jest on również dwa razy większy niż odsetek uczniów osiągających najwyższe wyniki (poziom B2) w przypadku drugiego języka obcego. W przypadku zarówno pierwszego, jak i drugiego języka rozumienie tekstów pisanych oraz rozumienie ze słuchu mają podobne rozkłady. Co ciekawe, prawie 16 proc. uczniów uczących się języka obcego pierwszego i 20 proc. uczniów uczących się języka obcego drugiego nie osiąga poziomu początkującego A1 (wyniki na wykresach określone jako poziom $\left.{ }_{\text {}}-\mathrm{A} 1 "\right)$.

\section{Kompetencje społeczne i obywatelskie}

Badanie dotyczące edukacji obywatelskiej International Civic and $\mathrm{Ci}$ tizenship Education Study (ICCS) dostarcza informacji o tym, jak młodzi ludzie są przygotowywani do odgrywania roli obywateli w świecie (Schulz i in., 2018). Jest realizowane od 2009 r., przy czym zagadnienia te badane były przez IEA czterokrotnie (w ramach badania CIVED 1999 i Six Subject Survey przeprowadzonego w 1971 r., w latach 2009 i 2016 jako ICCS). Grupą docelową są uczniowie VIII lub XIX klasy (w krajach, w których średnia wieku uczniów w VIII klasie jest niższa niż 13,5 roku). Należy podkreślić, że 17 z $24^{6}$ uczestniczących krajów lub systemów edukacyjnych wprowadziło elementy wiedzy o społeczeństwie i edukacji obywatelskiej do wszystkich przedmiotów nauczanych w szkole. W badaniu ocenia się poziom wiedzy uczniów, stopień zrozumienia zagadnień, postawy, a także ich zaangażowanie obywatelskie, wyko-

6. Kraje biorące udział w badaniu: Belgia (flamandzka), Bułgaria, Chile, Chiny (Tajwan), Chorwacja, Kolumbia, Dania, Republika Dominikany, Estonia, Finlandia, Niemcy (Nadrenia Północna-Westfalia), Hongkong, Włochy, Łotwa, Litwa, Malta, Meksyk, Holandia, Norwegia, Peru, Korea Płd., Federacja Rosyjska, Słowenia, Szwecja. 
rzystując różne zadania i testy kognitywne. Ponadto zostało ono wzbogacone o trzy moduły regionalne - dla Azji, Europy i Ameryki Łacińskiej - co miało na celu uwzględnienie regionalnych kontekstów kulturowych.

Badanie pokazało, że średnio 35 proc. studentów uzyskało wyniki testów wiedzy na poziomie $A, 32$ proc. - na poziomie $B, 21$ proc. - na poziomie $C, 10$ proc. - na poziomie $D$, a jedynie 3 proc. uczniów wykazało bardzo niski poziom wiedzy obywatelskiej sklasyfikowanej jako poniżej poziomu D (Schulz i in., 2018, s. 201). Porównując z rokiem 2009, w edycji 2016 średnie wyniki wzrosły dla 11 krajów. Nie zaobserwowano także statystycznie istotnych spadków w wykazanej wiedzy w żadnym państwie z uczestniczących w obu edycjach badania. Kraje, które osiągały najsłabsze wyniki w badaniu (Kolumbia, Meksyk, Republika Dominikany), odnotowały w 2016 r. nieco wyższe odsetki uczniów z wiedzą obywatelską na poziomie B lub wyżej w porównaniu z edycją 2009. Analizowano także stopień zaangażowania uczniów w różne sfery życia społecznego, identyfikując czynniki sprzyjające temu zjawisku lub je utrudniające. Najważniejsze z nich to telewizja i rozmowy z rodzicami o sprawach społecznych i politycznych, przy czym zaobserwowano spadek liczby wskazań na telewizję jako źródło informacji. Wpływ gazet okazał się wraz z upływem czasu mniejszy w niemal wszystkich krajach biorących udział w obu edycjach badania. Wykorzystanie nowych mediów społecznościowych do zaangażowania obywatelskiego jest nadal ograniczone, choć zróżnicowane w zależności od kraju.

\section{Propozycje zmian w definicjach kompetencji kluczowych}

Zalecenie Rady Unii Europejskiej z 22 maja 2018 r. w sprawie kompetencji kluczowych w procesie uczenia się przez całe życie wprowadza nowe, zaktualizowane definicje kompetencji kluczowych przyjętych w zaleceniu z 2006 r. Zmiany są wynikiem konsultacji rozpoczętych w 2016 r., które wskazały na potrzebę zmian, ale nie znaczną redefinicję pojęć. W efekcie postawiono nieco inne akcenty. Nowa lista kompetencji uwzględnia:

\section{Kompetencje w zakresie pisania i czytania (ang. Literacy competence); $w$ oficjalnym tłumaczeniu UE przyjęto polski termin: Kompetencje $w$ zakresie rozumienia i tworzenia informacji}

Umiejętność czytania i pisania jest rozumiana jako zdolność identyfikowania, rozumienia, wyrażania, tworzenia i interpretowania pojęć, uczuć, faktów i opinii w mowie oraz piśmie, przy wykorzystaniu obrazu, 
dźwięku i technologii cyfrowych we wszystkich dziedzinach oraz kontekstach. Zakłada ona przede wszystkim zdolność do efektywnego komunikowania się z innymi osobami. Rozwój tej kompetencji stanowi podstawę procesu dalszego uczenia się.

W porównaniu z dotychczasową definicją pierwszej kompetencji kluczowej, która w zaleceniu z 2006 r. była nazwana „porozumiewanie się w języku ojczystym" (ang. Communication in the mother tongue), nowe rozumienie kompetencji w zakresie czytania i pisania nie zawęża ich do języka ojczystego, ale zakłada, że mogą być rozwijane w języku nauczania lub języku urzędowym kraju lub regionu.

\section{Kompetencje w zakresie wielojęzyczności}

\section{(ang. Languages competence)}

Kompetencje te określają zdolność właściwego i skutecznego korzystania z różnych języków w celu porozumiewania się (w 2006 r. nazwane „porozumiewanie się w języku obcym”, ang. Communication in foreign languages). Nowa definicja obejmuje również utrzymywanie i dalszy rozwój kompetencji porozumiewania się w języku ojczystym.

\section{Kompetencje matematyczne oraz kompetencje} w zakresie nauk przyrodniczych, technologii i inżynierii (ang. Mathematical competence and competence in science, technology and engineering)

Kompetencje matematyczne to najogólniej umiejętność rozwijania i wykorzystywania myślenia matematycznego w rozwiązywaniu problemów życia codziennego. Kompetencje naukowe odnoszą się do zdolności i chęci wykorzystywania istniejącej wiedzy i metodologii do wyjaśniania świata przyrody, w celu formułowania pytań i wyciągania wniosków opartych na wynikach badań. Nowy w stosunku do definicji z 2006 r. (kompetencje matematyczne, naukowe i techniczne, ang. Mathematical competence and basic competences in science and technology) komponent definicji obejmujący kompetencje techniczne i inżynierskie jest rozumiany jako stosowanie tej wiedzy i metod w odpowiedzi na postrzegane ludzkie potrzeby lub pragnienia.

\section{Kompetencje cyfrowe (ang. Digital competence)}

Kompetencje cyfrowe obejmują krytyczne i odpowiedzialne korzystanie z technologii cyfrowych i wykorzystywanie ich do różnych celów, 
w tym: uczenia się, pracy i udziału w życiu społecznym. Oprócz akcentowanej w poprzednim zaleceniu (2006) obsługi programów i urządzeń (komputera), z oczywistym uwzględnieniem postępu technologicznego, w zaktualizowanym rozumieniu zakłada się też umiejętność korzystania z informacji i danych, porozumiewania się i współpracy, a także tworzenia treści cyfrowych (w tym programowania), kompetencje związane z bezpieczeństwem cybernetycznym i rozwiązywanie problemów.

\section{Kompetencje osobiste, społeczne i w zakresie uczenia się (ang. Personal, social and learning competence)}

Termin umiejętność uczenia się (ang. Learning to learn) z 2006 r. zastąpiły "kompetencje osobiste, społeczne i w zakresie uczenia się". Są one definiowane jako zdolność autorefleksji, skutecznego zarządzania czasem i informacjami, konstruktywnej pracy z innymi osobami, zarządzania własnym uczeniem się i karierą zawodową. Obejmują ponadto m.in.: zdolność radzenia sobie w trudnych sytuacjach, naukę uczenia się, wspieranie swojego dobrostanu fizycznego i emocjonalnego, empatię i zarządzanie konfliktem.

\section{Kompetencje obywatelskie (ang. Civic competence)}

Kompetencje obywatelskie, które zastąpiły kompetencje społeczne i obywatelskie (ang. Social and civic competence) z 2006 r. są rozumiane jako zdolność do podejmowania przez jednostkę odpowiedzialnego działania wynikającego z bycia obywatelem oraz pełnego uczestnictwa w życiu społecznym. Zakładają rozumienie struktur społecznych, gospodarczych i politycznych, a także znajomość wydarzeń i trendów globalnych oraz świadomość ciągłości w rozwoju społeczeństw.

\section{Kompetencje w zakresie przedsiębiorczości}

\section{(ang. Entrepreneurship competence)}

W projekcie wprowadzającym zaktualizowane kluczowe kompetencje szczególny nacisk położono na propagowanie przedsiębiorczości i rozwijanie innowacyjnego sposobu myślenia, które umożliwia uwolnienie osobistego potencjału osób uczących się. Kompetencje w zakresie przedsiębiorczości odnoszą się do zdolności wykorzystywania szans i pomysłów oraz przekształcania ich. Przedsiębiorczość opiera się na kreatywności, myśleniu krytycznym, rozwiązywaniu problemów, podejmowaniu inicjatywy, a także na wytrwałości i zdolności do wspól- 
nego działania, planowaniu i zarządzaniu projektami mającymi wartość kulturalną, społeczną lub komercyjną.

\section{Kompetencje w zakresie świadomości i ekspresji kulturalnej (ang. Cultural awareness and expression competence)}

Tak sformułowana nazwa ósmej kompetencji nie zmieniła się. Kompetencje w zakresie świadomości i ekspresji kulturalnej obejmują rozumienie sposobów kreatywnego wyrażania i wymiany pomysłów oraz znaczeń w różnych kulturach za pomocą różnych rodzajów sztuki i form kulturalnych oraz poszanowanie tego procesu. Obejmują również angażowanie się w rozwój i wyrażanie, na różne sposoby i w wielu kontekstach, własnych pomysłów oraz poczucie własnego miejsca i roli w społeczeństwie.

Zaproponowane kluczowe kompetencje uwzględniają zmiany edukacyjne i społeczne. Wymagania dotyczące kompetencji uległy zmianie m.in. w związku z rosnącą liczbą miejsc pracy poddanych automatyzacji oraz coraz istotniejszą rolą technologii we wszystkich dziedzinach pracy i życia. Rośnie także znaczenie kompetencji społecznych, obywatelskich i w zakresie przedsiębiorczości, które stanowią fundament zdolności dostosowywania się do zmian i właściwego funkcjonowania w zmieniającym się świecie.

W zaleceniu podkreśla się, że „inwestowanie w umiejętności i kompetencje oraz we wspólne, zaktualizowane rozumienie kompetencji kluczowych jest pierwszym krokiem ku wspieraniu poziomu kształcenia, szkolenia i uczenia się pozaformalnego w Europie". Wyniki omawianych międzynarodowych badań i wnioski z raportów Eurydice potwierdzają, że wciąż jest miejsce na szukanie skutecznych sposobów na poprawę umiejętności uczniów. 


\section{Bibliografia}

$\rightarrow$ Costa, P., Albergaria-Almeida, P., The European Survey on Language Competences: measuring foreign language student proficiency, "Procedia-Social and Behavioral Sciences", 191 (2015) 2369-2373.

$\rightarrow$ Bałachowicz, J. (2015), Edukacja dziecka w okresie przemian kulturowych [w:] J. Uszyńska-Jarmoc, M. Bilewicz (red.), Kompetencje kluczowe dzieci i młodzieży. Teoria i badania, Warszawa: Wydawnictwo Akademickie „Żak".

$\rightarrow$ Boni, M. (red.) (2011), Młodzi 2011, Warszawa: Kancelaria Prezesa Rady Ministrów.

$\rightarrow$ Eurydice (2017), Eurydice Brief. Citizenship Education at School in Europe 2017, Bruksela: Eurydice EACEA.

$\rightarrow$ Eurydice (2002), Key Competencies. A developing concept in general compulsory education/Kompetencje kluczowe. Realizacja koncepcji na poziomie szkolnictwa obowiq̨zkowego, Bruksela/Warszawa: Europejskie Biuro Eurydice/ Fundacja Rozwoju Systemu Edukacji.

$\rightarrow$ Federowicz, M., Sitek, M. (red.) (2017), Program Międzynarodowej Oceny Umiejętności Uczniów. Wyniki badania PISA 2015 w Polsce, Warszawa: Instytut Badań Edukacyjnych.

$\rightarrow$ Fraillon, J., Ainley, J., Schulz, W., Friedman, T., Gebhardt, E. (2014), Preparing for Life in a Digital Age. The IEA International Computer and Information Literacy Study International Report, Springer.

$\rightarrow$ Komisja Europejska/EACEA/Eurydice (2012), Developing Key Competences at School in Europe: Challenges and Opportunities for Policy/Rozwijanie kompetencji kluczowych w szkołach w Europie: wyzwania i szanse dla polityki edukacyjnej, Luksemburg Raport Eurydice, Urząd Publikacji Unii Europejskiej.

$\rightarrow$ Komisja Europejska/EACEA/Eurydice (2016), Entrepreneurship Education at School in Europe/Nauczanie przedsiębiorczości w szkołach w Europie, Raport Eurydice, Luksemburg: Urząd Publikacji Unii Europejskiej.

$\rightarrow$ Konarzewski, K., Bulkowski, K. (red.) (2017), PIRLS 2016. Wyniki międzynarodowego badania osiągnięć czwartoklasistów w czytaniu, Warszawa: IEA, IBE. 
$\rightarrow$ Konarzewski, K., Bulkowski, K. (red.) (2016), TIMSS 2015, Wyniki międzynarodowego badania osiągnięć czwartoklasistów w matematyce i przyrodzie, Warszawa: IEA, IBE.

$\rightarrow$ Uszyńska-Jarmoc, J., Bilewicz, M. (2015), Wprowadzenie [w:] J. Uszyńska-Jarmoc, M. Bilewicz (red.), Kompetencje kluczowe dzieci i młodzieży. Teoria i badania, Warszawa: Wydawnictwo Akademickie "Żak".

$\rightarrow$ Sawiński, Z. (2017), Propozycja globalnego spojrzenia na badania w edukacji [w:] Zrozumieć edukację w Europie. 20 lat Eurydice w Polsce, Warszawa: Fundacja Rozwoju Systemu Edukacji.

$\rightarrow$ Sijko, K. (red.) (2014), Kompetencje komputerowe $i$ informacyjne młodzieży w Polsce. Raport z międzynarodowego badania kompetencji komputerowych i informacyjnych ICILS 2013, Warszawa: IBE.

$\rightarrow$ Schulz, W., Ainley, J., Fraillon, J., Losito, B., Agrusti, G., Friedman, T. (2018), ICCS 2016 International Report. Becoming Citizens in a Changing World, Springer.

$\rightarrow$ Szpotowicz, M. (red.) (2013), Raport tematyczny. Europejskie Badanie Kompetencji Językowych ELSC, Raport krajowy 2011, Warszawa: IBE.

$\rightarrow$ Zasacka, Z. (2014), Czytelnictwo dzieci i młodzieży, Warszawa: Instytut Badań Edukacyjnych. 



\section{Mobilność edukacyjna sposobem na rozwijanie kompetencji \\ potrzebnych na rynku pracy}

Joanna Dąbrowska-Resiak, Mateusz Jeżowski, Michał Pachocki

W artykule skoncentrowano się na najważniejszych efektach zagranicznych mobilności edukacyjnych finansowanych ze środków programu Erasmus+ dla trzech kategorii uczestników: uczniów i absolwentów polskich szkół zawodowych, studentów uczelni wyższych oraz młodych osób w wieku od 18 do 30 lat realizujących długoterminowy zagraniczny projekt wolontariatu. Autorzy zestawiają kompetencje zdobywane w trakcie tych trzech typów zagranicznej mobilności z wymaganiami kompetencyjnymi pracodawców, aby odpowiedzieć na pytanie, czy i w jakim stopniu umiejętności zdobyte podczas zagranicznych wyjazdów edukacyjnych przydatne są na współczesnym rynku pracy.

\section{_ Słowa kluczowe: \\ mobilność edukacyjna \\ kompetencje \\ Erasmus+ \\ edukacja formalna \\ edukacja pozaformalna \\ rynek pracy}




\section{Learning mobility as a tool for developing competences required on the labour market}

Joanna Dąbrowska-Resiak, Mateusz Jeżowski, Michał Pachocki

The article focuses on the most important effects of learning mobility financed through Erasmus + programme for three groups of participants: Polish vocational schools pupils and graduates, higher education students and young people aged 18-30 who participate in a long-term volunteering activity. The authors compare the competences acquired through these three types of learning mobility with competence requirements declared by the employers in order to verify whether and to what extent they are valued on the labour market.

\section{Keywords: \\ learning mobility \\ competences \\ Erasmus+ \\ formal education \\ non-formal education \\ labour market}




\section{Wstęp}

Zagraniczna mobilność edukacyjna to wyjazd do innego kraju, by zdobywać nową wiedzę, umiejętności, uczyć się języka obcego oraz rozwijać szeroko pojęte kompetencje międzykulturowe. Zgodnie z zasadami europejskich programów edukacyjnych taki wyjazd może zostać zorganizowany na różnych etapach kształcenia, również przez instytucje działające poza obszarem edukacji formalnej. Od 2007 r., kiedy Komisja Europejska rozpoczęła realizację programów "Uczenie się przez całe życie" oraz "Młodzież w działaniu", ze środków unijnych sfinansowano ponad 500 tys. wyjazdów, w których udział mogła wziąć również polska młodzież. W ramach realizowanych projektów polskie instytucje edukacyjne organizowały m.in. wymiany studenckie, programy studiów i nauki zawodu za granicą, staże i praktyki, wymiany młodzieży oraz projekty o charakterze wolontariackim. Program Erasmus+ przewidziany na lata 2014-2020, opierając się na osiągnięciach z ponad 25 lat funkcjonowania europejskich programów edukacyjnych, kontynuuje te działania. Jego sztandarową inicjatywą jest właśnie międzynarodowa mobilność edukacyjna w dziedzinie kształcenia, szkolenia i młodzieży, która ma na celu:

$\rightarrow$ podniesienie poziomu kluczowych kompetencji i umiejętności, w szczególności w zakresie ich przydatności dla rynku pracy i ich wkładu w spójność społeczeństwa, zwłaszcza dzięki zwiększonym możliwościom dotyczącym mobilności edukacyjnej oraz dzięki zacieśnionej współpracy między środowiskiem kształcenia i szkolenia a środowiskiem pracy,

$\rightarrow$ poprawę jakości innowacyjnej i umiędzynarodowienia instytucji edukacyjnych oraz szkoleniowych, w szczególności dzięki zacieśnionej współpracy transnarodowej między organizatorami kształcenia i szkolenia a innymi zainteresowanymi stronami,

$\rightarrow$ wspieranie tworzenia europejskiego obszaru uczenia się przez całe życie, który ma służyć dopełnieniu krajowych reform politycznych oraz wspieraniu modernizacji systemów kształcenia i szkolenia, w szczególności dzięki zacieśnionej współpracy politycznej, lepszemu zastosowaniu unijnych narzędzi przejrzystości i uznawalności oraz dzięki upowszechnianiu dobrych praktyk, a także zwiększaniu świadomości tego obszaru, 
$\rightarrow$ poszerzanie międzynarodowego wymiaru kształcenia i szkolenia, w szczególności poprzez współpracę między instytucjami krajów programu a krajów partnerskich w dziedzinie kształcenia i szkolenia zawodowego oraz szkolnictwa wyższego, dzięki zwiększeniu atrakcyjności europejskich instytucji szkolnictwa wyższego oraz wspieraniu działań zewnętrznych Unii, w tym jej celów rozwoju, poprzez promowanie mobilności i współpracy między instytucjami szkolnictwa wyższego z krajów programu i krajów partnerskich oraz poprzez ukierunkowane budowanie potencjału w krajach partnerskich,

$\rightarrow$ poprawę nauczania i uczenia się języków oraz promowanie szerokiej różnorodności językowej Unii i świadomości międzykulturowej (Komisja Europejska, 2018).

\section{Kompetencje niezbędne na rynku pracy}

Rynek pracy początku XXI w. stoi przed istotnymi wyzwaniami, spowodowanymi przemianami demograficznymi i postępem technologicznym, zmianami modeli ścieżek zawodowych, ewoluującą rolą pracodawców i środowiska pracy, ograniczonymi możliwościami efektywnego wykorzystania kapitału ludzkiego oraz istnieniem biernych grup edukacyjnych (Górniak, 2015). Szybkie starzenie się społeczeństwa ${ }^{1}$ powoduje, że wydłużenie okresu aktywności zawodowej stanie się faktem, a co za tym idzie - wzrośnie potrzeba aktualizacji kompetencji i kwalifikacji, powodowana także szybkim postępem technologicznym. Naturalną konsekwencją tych procesów jest destandaryzacja i dynamizacja ścieżek zawodowych oraz przejście do otwartego modelu kariery zawodowej, charakteryzującego się kilkakrotnym przekwalifikowaniem się, częstymi zmianami zawodu, pracodawcy czy miejsca zamieszkania (tamże). W tym kontekście szczególnego znaczenia nabiera koncepcja uczenia się przez całe życie, badania już dziś bowiem wskazują, że oprócz kompetencji zawodowych i doświadczenia na znaczeniu zyskują kompetencje miękkie oraz znajomość języków obcych (Kocór, Strzebońska, Dawid-Sawicka, 2015). 
Wykres 1. Ogólne wymagania wobec poszukiwanych pracowników w latach 2010-2014

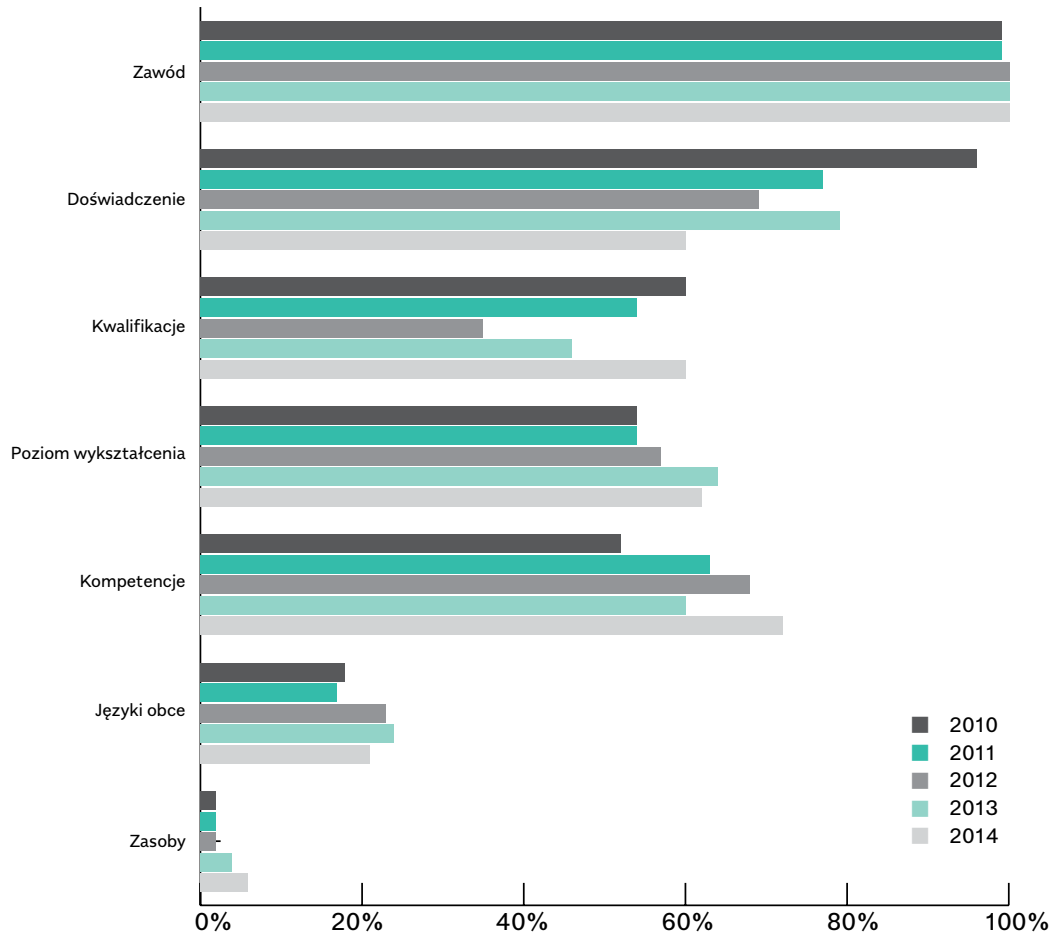

Źródło: BKL - Badanie ofert pracy 2010-2014.

Znajduje to odzwierciedlenie w deklarowanym przez pracodawców zapotrzebowaniu na kompetencje. W 2014 r. pierwsze miejsce pod względem częstości wskazań w treści ogłoszeń o pracę zajmowały bowiem oczekiwania w zakresie kompetencji, czyli wiedzy i umiejętności formalnie niepotwierdzonych (Kocór, Strzebońska, Dawid-Sawicka, 2015). Oprócz posiadania kompetencji związanych z wykonywaniem danego zawodu pracodawcy najczęściej oczekiwali od kandydatów kompetencji interpersonalnych, samoorganizacyjnych, kierowniczych i komputerowych. 
Tabela 1. Wymagania dotyczące kompetencji kandydatów do pracy w różnych zawodach, 2014

\begin{tabular}{|c|c|c|c|c|c|c|c|c|}
\hline Stanowisko & $\begin{array}{c}\text { Kie- } \\
\text { rowni- } \\
\text { cy }\end{array}$ & $\begin{array}{c}\text { Spe- } \\
\text { cjali- } \\
\text { ści }\end{array}$ & $\begin{array}{r}\text { Śred- } \\
\text { ni } \\
\text { per- } \\
\text { sonel }\end{array}$ & $\begin{array}{c}\text { Pra- } \\
\text { cow- } \\
\text { nicy } \\
\text { biuro- } \\
\text { wi }\end{array}$ & $\begin{array}{r}\text { Pra- } \\
\text { cow- } \\
\text { nicy } \\
\text { usług } \\
\text { i sprze- } \\
\text { dawcy }\end{array}$ & $\begin{array}{r}\text { Robot- } \\
\text { nicy } \\
\text { prze- } \\
\text { mysłowi } \\
\text { i rze- } \\
\text { mieślni- } \\
\text { cy }\end{array}$ & $\begin{array}{c}\text { Opera- } \\
\text { torzy } \\
\text { i mon- } \\
\text { terzy } \\
\text { maszyn } \\
\text { i urzą- } \\
\text { dzeń }\end{array}$ & $\begin{array}{r}\text { Pra- } \\
\text { cownicy } \\
\text { przy } \\
\text { pracach } \\
\text { pro- } \\
\text { stych }\end{array}$ \\
\hline kognitywne & 24 & 22 & 16 & 12 & 13 & 3 & 2 & 2 \\
\hline samoorganizacyjne & 54 & 57 & 63 & 44 & 48 & 15 & 12 & 16 \\
\hline artystyczne & 6 & 13 & 13 & 14 & 14 & 3 & 3 & 2 \\
\hline fizyczne & 2 & 4 & 9 & 7 & 7 & 4 & 6 & 8 \\
\hline interpersonalne & 43 & 54 & 64 & 38 & 48 & 5 & 5 & 5 \\
\hline kierownicze & 54 & 26 & 24 & 14 & 24 & 2 & 1 & 1 \\
\hline dyspozycyjne & 22 & 17 & 20 & 18 & 18 & 9 & 8 & 8 \\
\hline biurowe & 3 & 3 & 2 & 7 & 2 & 0 & 0 & 0 \\
\hline techniczne & 3 & 5 & 3 & 3 & 6 & 14 & 7 & 2 \\
\hline komputerowe & 31 & 46 & 28 & 42 & 21 & 5 & 15 & 3 \\
\hline matematyczne & 0 & 0 & 0 & 0 & 0 & 0 & 0 & 0 \\
\hline zawodowe & 48 & 40 & 27 & 15 & 24 & 22 & 14 & 9 \\
\hline
\end{tabular}

Źródło: BKL - Badanie ofert pracy 2014.

\section{Edukacja formalna i edukacja pozaformalna}

Opisywane w tym artykule efekty uczenia się dotyczą osób, które brały udział w projektach w ramach dwóch typów edukacji: formalnej (uczniowie i absolwenci polskich szkół zawodowych biorący udział w mobilnościach w ramach programu Erasmus+ i studenci realizujący mobilności w ramach programu Erasmus i Erasmus+) i pozaformalnej (osoby w wieku od 18 do 30 lat realizujące długoterminowy zagraniczny projekt Wolontariatu Europejskiego).

Jak wiadomo, uczestnictwo w edukacji formalnej jest do pewnego wieku obowiązkowe i wynika zazwyczaj z motywacji zewnętrznej, edukacja pozaformalna oparta jest zaś na dobrowolnym uczestnictwie i zależy najczęściej od wewnętrznej motywacji uczącego się. Cel nauki w edukacji formalnej jest określony odgórnie i zależy od programu nauczania, natomiast w edukacji pozaformalnej jest on określony przez osobę uczącą się. Ponadto, stosunki między uczącymi się a prowadzącymi 
zajęcia oparte są na odmiennych zasadach: o ile w edukacji formalnej nauczyciel realizuje program i kieruje się zasadą uczeń-mistrz, o tyle w edukacji pozaformalnej prowadzący zajęcia (facylitator) jest moderatorem procesu i podąża za tokiem uczenia się uczniów, a podstawą relacji z nimi są zasady partnerskie, które zakładają zmienność ról: uczestnicy mogą przekazywać wiedzę facylitatorowi oraz innym uczestnikom procesu uczenia się (Szlęk, Bratek, Miłoń, 2014).

Proces uczenia się w edukacji pozaformalnej został opisany i zobrazowany przez Davida Kolba i Rogera Frye'a już w latach 70. XX w. Opracowany przez nich model podkreśla role subiektywnego doświadczenia podczas uczenia się, a edukacja pozaformalna jest definiowana jako „proces, w którym wiedza jest tworzona przez transformację doświadczenia" (Kolb, 1984, s. 31). Model ten (rys. 1) zakłada istnienie czterech następujących po sobie etapów procesu uczenia się przez doświadczenie: doświadczenia, refleksji, abstrakcyjnej konceptualizacji i aktywnego eksperymentowania (tamże).

Rysunek 1. Cykl uczenia się według Kolba

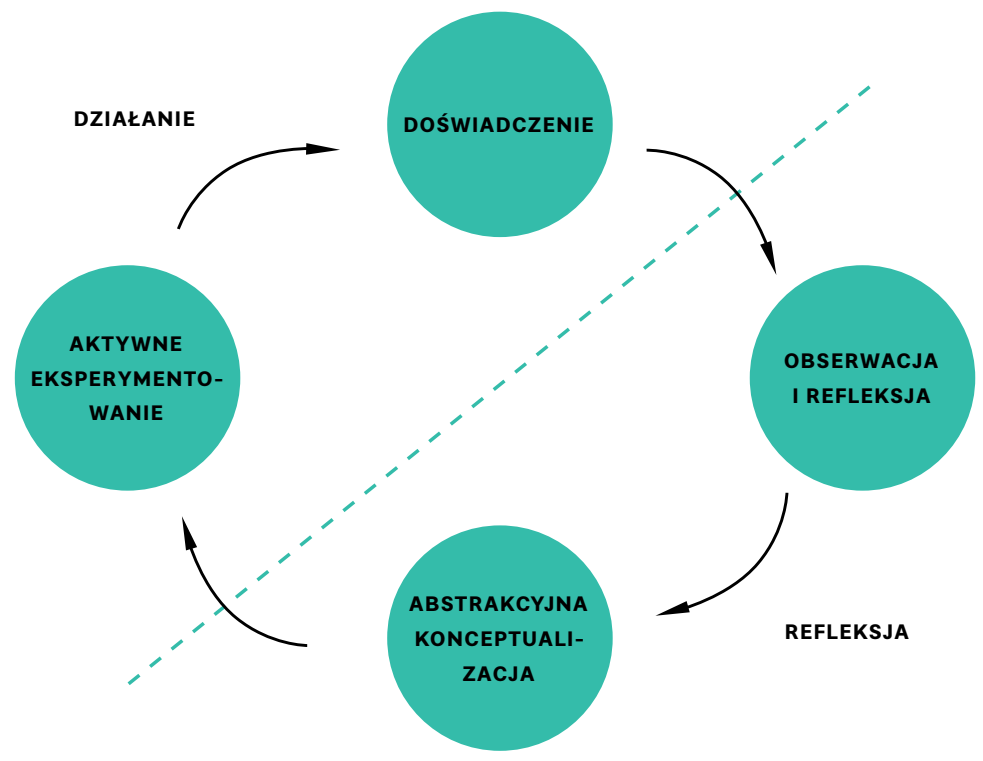

Źródło: Experiential learning: experience as the source of learning and development. 
Doświadczenie to pierwszy etap procesu uczenia się opisanego przez Kolba. Odnosi się on do sytuacji przeżywanej przez ucznia. Kolejnym etapem jest refleksja, czyli obserwacja i zastanowienie się nad przeżywaną sytuacją, która naturalnie przechodzi w trzeci etap, zwany abstrakcyjną konceptualizacją, czyli wyciąganiem wniosków z przeżytej sytuacji. Ostatnim etapem jest zaś aktywne eksperymentowanie, które pozwala, na podstawie przeżytego doświadczenia i refleksji nad nim, zmienić swoje zachowanie i stosować nową wiedzę oraz umiejętności w praktyce, testując ich użyteczność.

Podczas uczenia się w edukacji pozaformalnej bardzo ważną rolę odgrywa facylitator. Zgodnie z założeniami programu Erasmus+ Młodzież jego rola polega na "asystowaniu młodym ludziom w przemyślanym i kreatywnym procesie, który inspiruje do odkrywania ich potencjału" ${ }^{2}$. Facylitator powinien zatem aktywnie słuchać i obserwować uczestników oraz dostosowywać swoje podejście, aby zaspokajać potrzeby młodzieży, z którą pracuje. Niezwykle istotne jest jego wsparcie podczas każdego etapu uczenia się. Stwarza on warunki do bezpiecznego doświadczania, wspomaga oraz ukierunkowuje proces refleksji i abstrakcyjnej konceptualizacji, a także przygotowuje uczniów do transferu zdobytej wiedzy i umiejętności do nowych sytuacji i problemów. Relację facylitatora z osobami uczącymi się w edukacji formalnej i pozaformalnej obrazuje rysunek nr 2 .

Rys. 2. Role uczących się i przekazujących wiedzę w edukacji formalnej i pozaformalnej
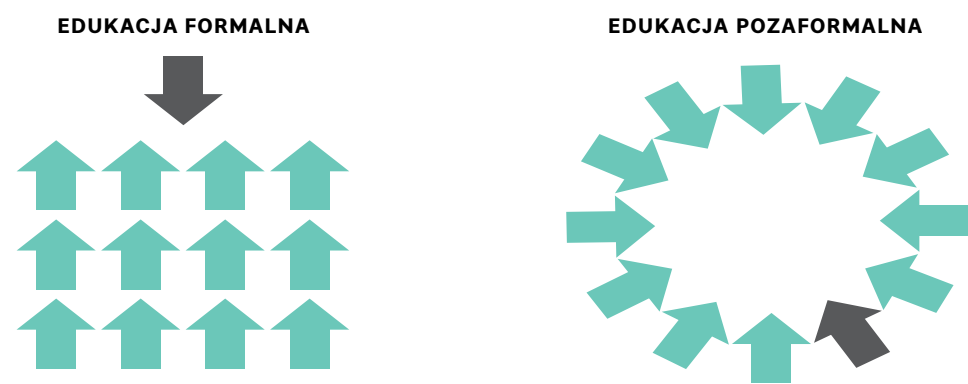

Źródło: Uczyć się inaczej. Kompendium wiedzy o edukacji pozaformalnej na podstawie doświadczeń uczestników i uczestniczek programu „Młodzież w działaniu” (2007-2013).

2. Na podstawie materiałów Fundacji Rozwoju Systemu Edukacji oraz Przewodnika po programie Erasmus+ wersja 2 (2018): 15.12.2017. 


\section{Wpływ zagranicznych mobilności edukacyjnych na rozwijanie kompetencji}

\section{Badanie wpływu zagranicznych staży i praktyk na kompetencje uczniów oraz absolwentów polskich szkół zawodowych}

Badanie wpływu zagranicznych staży i praktyk na kompetencje uczniów oraz absolwentów polskich szkół zawodowych zostało przeprowadzone z wykorzystaniem technik ilościowych i jakościowych. Uzyskane wyniki zostały również wzbogacone o dane pozyskane w ramach analizy desk research (głównie informacji kontekstowych oraz statystycznego podsumowania realizacji badanych programów). Kwestionariusz przesłano na wszystkie dostępne adresy uczestników zakończonych staży i praktyk zrealizowanych w latach 2007-2016, a link do ankiety udostępniony został również szkołom, z prośbą o przekazanie byłym uczniom i absolwentom placówek uczestniczących w programie. Ostatecznie Narodowa Agencja Programu Erasmus+ otrzymała ponad 2,6 tys. anonimowych wypełnień udostępnionego kwestionariusza. Respondentami 20 indywidualnych wywiadów pogłębionych (IDI) byli absolwenci szkół z doświadczeniem udziału w zagranicznych stażach i praktykach w ramach badanych programów. Wybrana losowo próba była zróżnicowana zarówno pod względem wyuczonych zawodów, płci, miejsca obecnego zamieszkania, jak i krajów docelowych zrealizowanych mobilności. Spotkania zorganizowano w miejscach zamieszkania, pracy lub nauki byłych stażystów. W ramach badania zrealizowano również pięć zogniskowanych wywiadów grupowych (FGI) w szkołach aktywnie realizujących projekty, które zostały wybrane w taki sposób, by móc stworzyć grupy kształcące się w różnych zawodach i branżach. W wywiadach wzięli udział uczniowie uczestniczący w wyjazdach oraz absolwenci, którzy zakończyli naukę w roku szkolnym poprzedzającym badanie. W wywiadach wzięło udział łącznie 65 osób.

\section{Kompetencje miękkie}

Uczestnicy wyjazdów edukacyjnych o charakterze zawodowym zauważyli, że wyjazdy na zagraniczne staże i praktyki pozwalają rozwijać nie tylko umiejętności związane bezpośrednio z nauką zawodu, lecz także wiele kompetencji miękkich, takich jak umiejętność pracy zespołowej, zdolność do samodzielnego rozwiązywania problemów oraz umiejętność radzenia sobie $w$ trudnych warunkach. Ponad połowa respon- 
dentów badania kwestionariuszowego przyznała również, że wyjazd zdecydowanie pomógł im lepiej radzić sobie ze stresem i łatwiej znajdować rozwiązania w nietypowych sytuacjach. Zdecydowana większość respondentów zauważyła też, że udział w stażu za granicą pozwolił im lepiej planować i prowadzić samodzielnie proces nauki (ponad 51 proc. badanych potwierdziło, że wpływ ten był bardzo zauważalny) oraz lepiej zarządzać czasem (ponad połowa respondentów). Dla sporej części badanych wyjazd na staż był również pierwszym samodzielnym wyjazdem za granicę. Respondenci badania kwestionariuszowego zauważyli, że zagraniczne wyjazdy miały duży wpływ na naukę samodzielności, a staż w dużym stopniu wpłynął na sposób organizacji pracy stażystów i praktykantów. Ponad 57 proc. ankietowanych uznało, że efektem mobilności były zdecydowanie lepsze planowanie i organizacja zadań.

Wykres 2. Wpływ stażu na kompetencje miękkie. Zestawienie odpowiedzi na pytanie: Proszę określić, w jakim stopniu zgadza się Pan(-i) z poniższymi twierdzeniami (wyniki badania kwestionariuszowego, $N=2592$ )

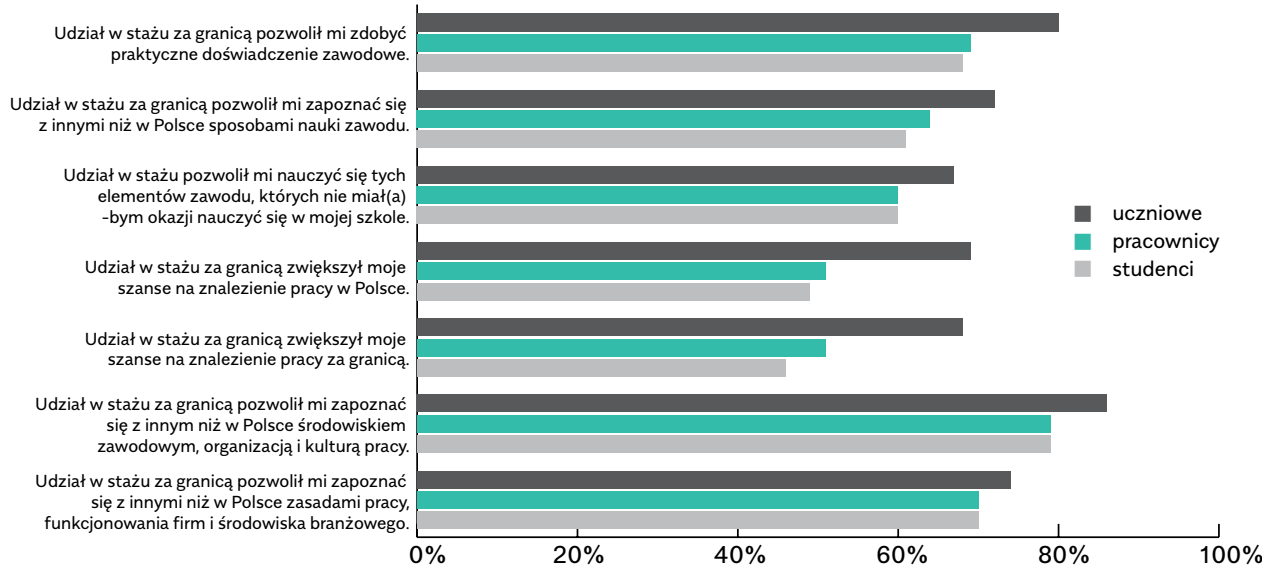

Źródło: Opracowanie własne.

Respondenci badania szczególnie docenili również wpływ stażu na rozwój umiejętności interpersonalnych, umiejętność pracy zespołowej oraz pracy w międzynarodowym i międzykulturowym środowisku. Ponad 69 proc. absolwentów staży przyznało, że doświadczenie pracy za granicą pozwoliło im na łatwiejsze nawiązywanie kontaktów z innymi osobami. Większość respondentów przyznała również, że dzięki 
doświadczeniom zdobytym podczas stażu mogą łatwiej realizować zadania w zespołach (ponad 77 proc.) oraz wykonywać pracę w międzynarodowym środowisku (ponad 74 proc.). Osoby, z którymi przeprowadzono wywiad, szczególnie podkreślały, że udział w projekcie wpłynął na zmianę ich poglądów i pozwolił poznać inne kultury.

\section{Kompetencje językowe}

Międzynarodowy charakter mobilności sprawił, że zwiększenie kompetencji językowych uczestników było jednym z najbardziej widocznych efektów zagranicznych szkoleń o charakterze zawodowym. Ponad 97 proc. uczestników badania kwestionariuszowego potwierdziło, że udział w wyjazdach miał pozytywny wpływ na ich kompetencje językowe, przy czym ponad dwie trzecie respondentów uznało, że zagraniczne wyjazdy w wysokim stopniu poprawiły ich zdolność do porozumiewania się językiem obcym w środowisku pracy. Deklaracje dotyczące poprawy znajomości języka obcego pojawiały się również w wypowiedziach respondentów wywiadów w kontekstach związanych z rozwijaniem kompetencji społecznych, które nierzadko wymieniano jako jedną z najistotniejszych korzyści wynikających z udziału w projektach. Poruszając temat kompetencji językowych, często wskazywano na możliwości przełamania barier w komunikacji z cudzoziemcami. Co ważne, często wynikało ono nie tyle z konieczności wykonywania zleconych zadań, ile po prostu z konieczności porozumiewania się z innymi osobami, co wymagało pokonania nieśmiałości i bariery językowej. Dla zwiększenia umiejętności posługiwania się językiem obcym istotny okazał się również rzetelnie zaplanowany okres przygotowania do wyjazdu, chociaż należy dodać, że poziom zadowolenia z zajęć $w$ dużej mierze zależał od stopnia dostosowania zakresu realizowanego materiału do potrzeb wyjeżdżającej grupy oraz charakteru i tematyki danego projektu.

\section{Kompetencje zawodowe}

Jednym z najważniejszych celów zagranicznych staży i praktyk zawodowych jest zwiększenie wiedzy uczestników wyjazdów oraz zdobywanie przez nich nowych kompetencji, przydatnych na dalszych etapach rozwoju edukacyjno-zawodowego. $Z$ danych zebranych podczas badania losów absolwentów mobilności wynika jednoznacznie, że praktyczne kształcenie za granicą bardzo wzbogaciło doświadczenie zawodowe 
uczestników, a zdecydowana większość badanych stażystów uznała, że taka forma kształcenia wykracza poza ramy formalnej edukacji, pozwalając (często pierwszy raz w życiu) doświadczyć realiów pracy na danym stanowisku (ponad dwie trzecie respondentów zadeklarowało, że poleciłoby praktyczną naukę zawodu za granicą innym osobom wchodzącym na rynek pracy).

Wykres 3. Wyniki badania kwestionariuszowego: poziom wskaźnika

NPS. Zestawienie odpowiedzi na pytanie: W skali od 0 do 10 na ile prawdopodobne jest, że poleciłby(-aby) Pan(-i) wyjazd na zagraniczny staż/ praktykę osobom, które dopiero wchodzą na rynek pracy? $(\mathrm{N}=\mathbf{2 5 9 2})$

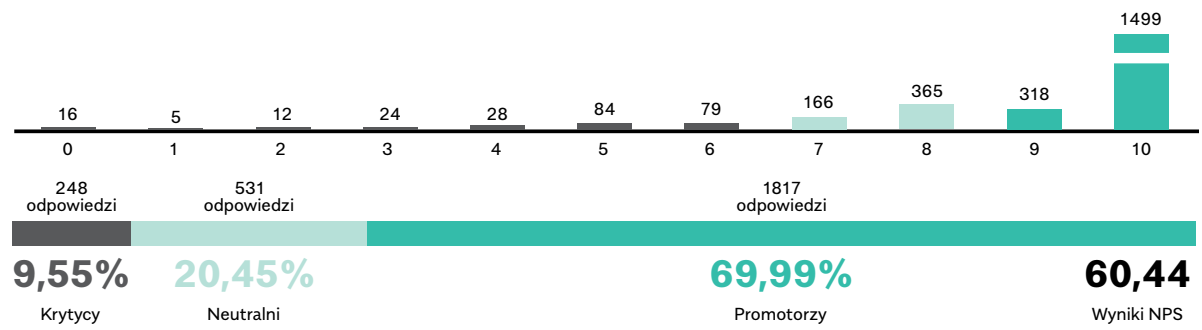

Źródło: Opracowanie własne.

W opinii byłych stażystów i praktykantów już samo poznanie kontekstu pracy zawodowej przyniosło istotne korzyści dla ich rozwoju zawodowego. Ponad 92 proc. badanych potwierdziło, że wyjazd pomógł im poznać specyfikę zadań wykonywanych na danym stanowisku pracy. Często okazywało się, że już samo otrzymywanie od pracodawców codziennych zadań, pozwalających na ciekawe i różnorodne zajęcie, miało istotny wpływ na poznanie specyfiki pracy w danym zawodzie. 
Wykres 4. Korzyści płynące z realizacji mobilności w kontekście oferty praktyk zawodowych w Polsce. Na wykresie przedstawiono dane dotyczące respondentów, którzy zgodzili się z danym stwierdzeniem (wyniki badania kwestionariuszowego, $\mathbf{N}=\mathbf{2 5 9 2}$ )

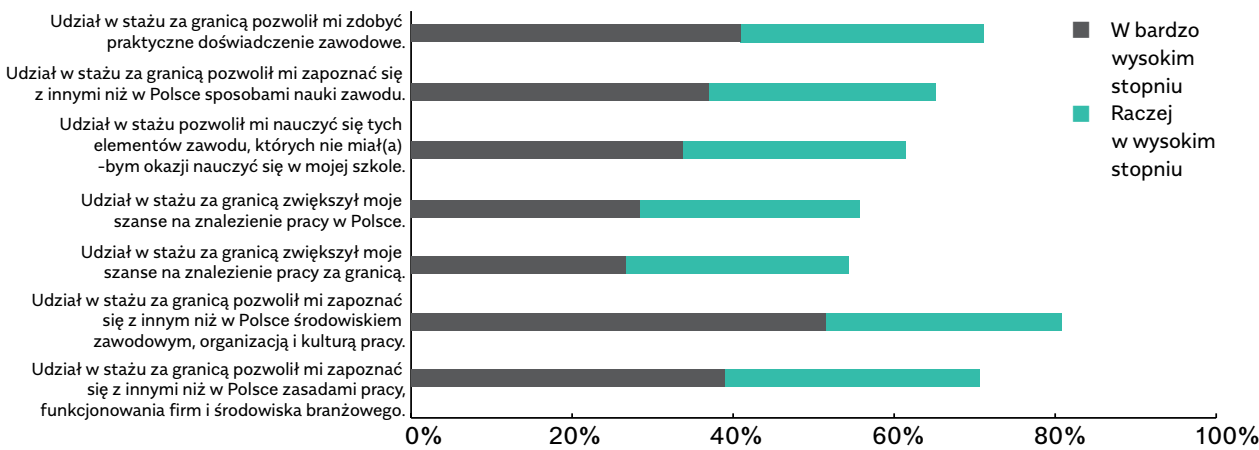

Źródło: Opracowanie własne.

Praktyczne szkolenie za granicą to również szansa na lepsze poznanie zasad i mechanizmów funkcjonowania przedsiębiorstw z danej branży. W opinii badanych absolwentów istotnym czynnikiem jakościowym stażu był nie tylko właściwy dobór instytucji, lecz także wybór odpowiednich mentorów, których autorytet niejednokrotnie wpływał na zmiany postaw stażystów. Należy jednak zaznaczyć, że było to uzależnione przede wszystkim od stopnia porozumienia, jakie udało się nawiązać stażyście z jego opiekunem, oraz od zaangażowania przedstawicieli instytucji przyjmujących na staż. W opinii badanych było to zdecydowanie łatwiejsze, kiedy swoje zadania stażyści realizowali w mniejszych grupach.

Pytani o zakres czynności wykonywanych na stanowisku pracy respondenci wymieniali wiele zadań, od bardzo prostych czynności fizycznych, które nie wymagały specjalistycznej wiedzy ani doświadczenia, do bardziej skomplikowanych zadań, bezpośrednio związanych ze ścieżką kształcenia, a czasem wymagających specjalistycznej wiedzy i umiejętności. Większość badanych zauważyła znaczące różnice między nauką zawodu w Polsce i za granicą, chwaląc zagraniczną infrastrukturę, dostępność sprzętu, opiekę mentorską, a przede wszystkim możliwość wykonywania ciekawszych zadań.

Wyniki badania pokazują różny poziom deklaracji respondentów w odniesieniu do poszczególnych kompetencji zawodowych, których 
rozwój był związany z udziałem w zagranicznych stażach i praktykach. Chociaż niemal wszyscy badani stażyści potwierdzili, że doświadczenie pracy za granicą miało wpływ na zdobycie większości wymienionych kompetencji, to nie wszyscy zgodzili się, że staż w tak samo istotny sposób przyczynił się do rozwoju każdej z nich. Deklarowane rozbieżności dotyczyły głównie takich kompetencji jak opracowywanie dokumentów, znajomość nowych technologii i oprogramowania oraz umiejętności interpersonalne związane z obsługą klienta, prowadzeniem negocjacji lub wykorzystaniem technik sprzedażowych. Mniej niż połowa ankietowanych uznała, że staż przyczynił się do zwiększenia wymienionych umiejętności w raczej wysokim lub bardzo wysokim stopniu.

Wykres 5. Wpływ mobilności na kompetencje zawodowe. Zestawienie odpowiedzi na pytanie: Proszę ocenić, w jakim stopniu wyjazd na zagraniczny staż/praktykę pozwolił Panu(-i) na nabycie lub zwiększenie poniższych kompetencji (wyniki badania kwestionariuszowego, $N=2592$ )

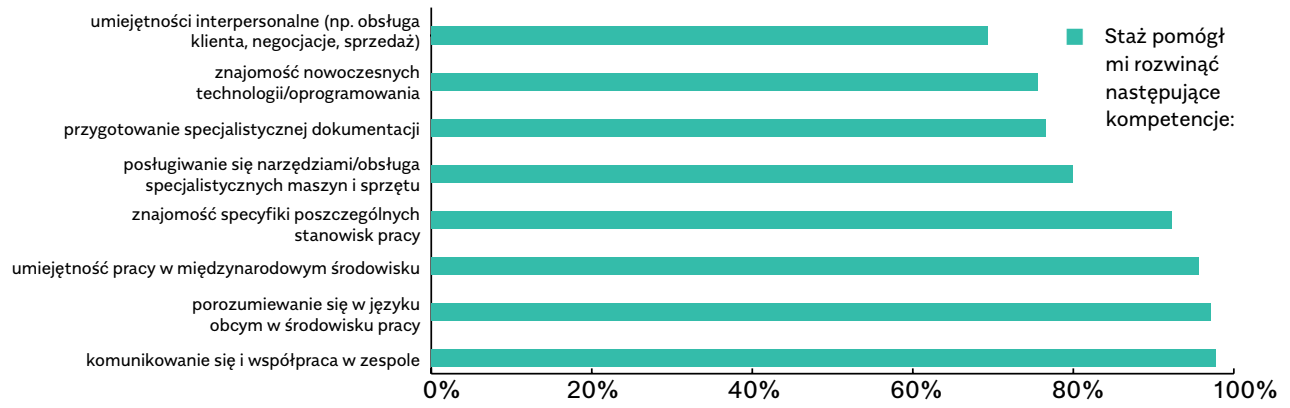

Źródło: Opracowanie własne.

Różnice w postrzeganiu przez byłych stażystów wpływu mobilności na zdobywanie i rozwój poszczególnych kompetencji zawodowych pokazuje również zestawienie wyników w podziale na branże, w jakich realizowano wyjazdy. Podczas gdy ponad trzy czwarte uczestników staży w branży mechanicznej zauważyło, że wyjazdy w wysokim stopniu pomogły w lepszej obsłudze narzędzi i specjalistycznego sprzętu, wzrost kompetencji w tym obszarze zadeklarował jedynie co trzeci absolwent mobilności w branży administracyjno-biurowej. Istotne różnice w postrzeganiu korzyści płynących z udziału w zagranicznych szkoleniach dotyczyły również wpływu wyjazdów na zwiększenie 
znajomości nowoczesnych technologii i oprogramowania, które okazały się zdecydowanie ważniejsze dla absolwentów kierunków związanych z branżą mechaniczną (ponad 60 proc.), elektryczno-elektroniczną (ponad 55 proc.) i budowlaną (ponad 50 proc.) niż dla osób realizujących staże $w$ administracji i usługach (ponad 37 proc.) czy turystyce (ponad 32 proc.).

Możliwość poznania nowych technologii szczególnie doceniali absolwenci klas informatycznych, którzy zwracali uwagę na możliwość poznania bardziej zaawansowanego sprzętu i oprogramowania niż te, na jakich pracowali w kraju. Zdaniem respondentów najczęściej wynikało to z zupełnie innych możliwości finansowych zagranicznych instytucji. Również absolwenci staży i praktyk w branży budowlanej podkreślali różnice w zaawansowaniu technologicznym polskich i zagranicznych instytucji partnerskich. Byli stażyści często podkreślali, że instytucje przyjmujące, pomimo bogatego zaplecza, były również w stanie zapewnić dodatkowe narzędzia i specjalistyczny sprzęt, jeżeli tylko był on niezbędny do wykonywania pracy. 


\section{Wykres 6. Wpływ stażu na kompetencje zawodowe. Zestawienie odpowiedzi}

na pytanie: Proszę ocenić, w jakim stopniu wyjazd na zagraniczny staż/praktykę

pozwolił Panu(-i) na nabycie lub zwiększenie poniższych kompetencji

(dane dotyczą respondentów, którzy uznali, że nabyli wskazane kompetencje

w wysokim stopniu; wyniki badania kwestionariuszowego, $N=2592$ )

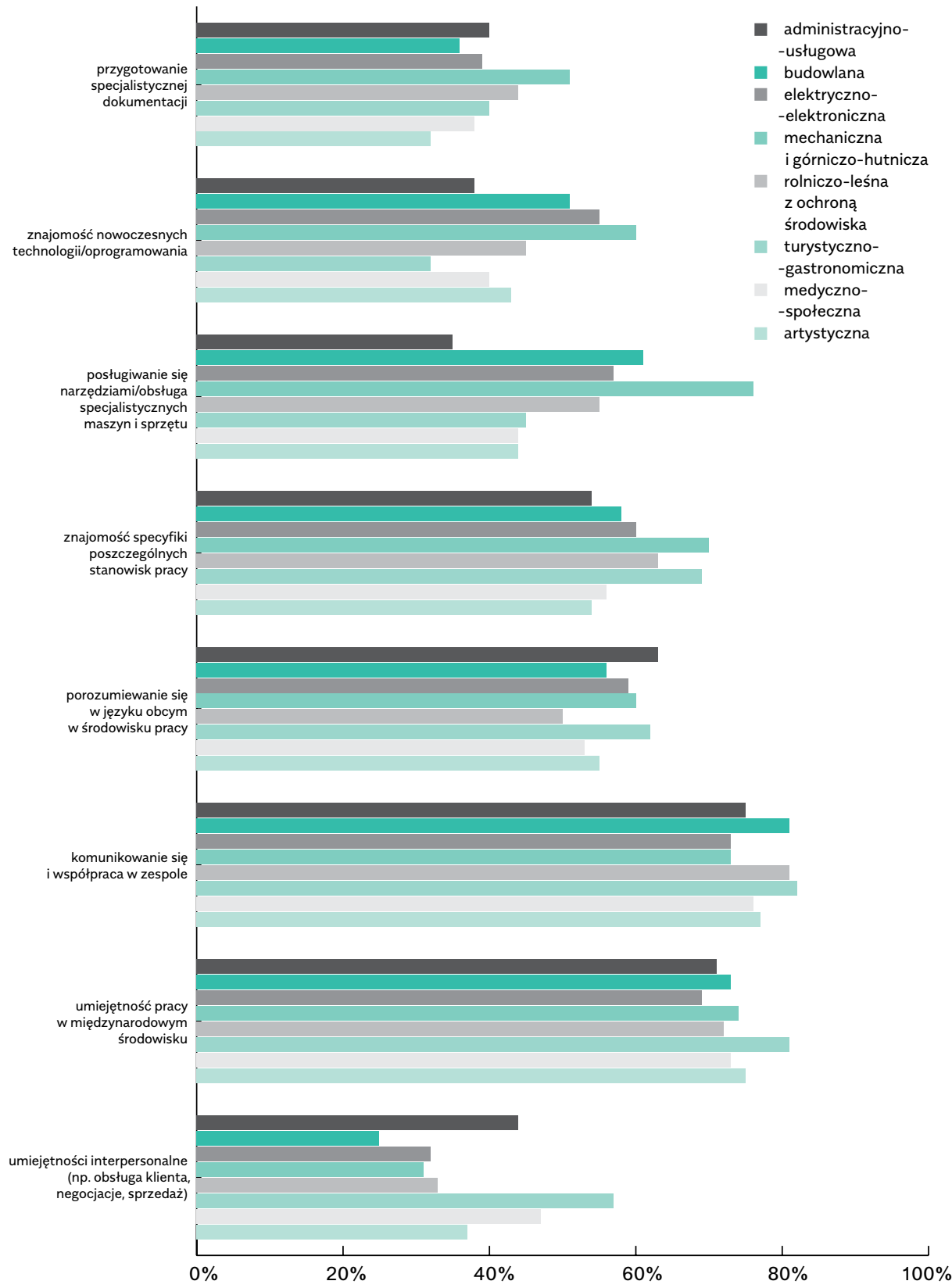

Źródło: Opracowanie własne. 
Ponad dwie trzecie osób aktywnych zawodowo potwierdziło, że zagraniczne staże i praktyki w istotny sposób ułatwiają młodym ludziom znalezienie pracy. Dla wielu uczestników badania istotna okazała się również możliwość formalnego potwierdzenia udziału w mobilnościach. Ponad dwie trzecie respondentów uznało, że otrzymane od zagranicznych pracodawców dyplomy i certyfikaty okazały się przydatne podczas poszukiwania zatrudnienia. Doświadczenie zagranicznych staży i praktyk ma często znaczący wpływ na utwierdzenie uczniów w przekonaniu o słuszności ich wyborów ścieżek edukacyjno-zawodowych. Dotyczyło to szczególnie tych osób, które wcześniej nie uczestniczyły w praktycznych szkoleniach, oraz przypadków, kiedy realizowane wcześniej praktyki krajowe nie spełniły oczekiwań w kwestii lepszego poznania branży kształcenia lub kontekstu przyszłej pracy zawodowej. Wyniki badania absolwentów szkół zawodowych, którzy brali udział w zagranicznych stażach i praktykach podczas nauki w szkole, pokazują, że ponad dwie trzecie absolwentów aktywnych na rynku pracy potwierdziło związek między obecnie wykonywanym zawodem a branżą, w której realizowano mobilność. Jednocześnie ponad połowa badanych studentów zauważyła związek między tematyką stażu a wybranym kierunkiem studiów.

Wykres 7. Ocena korzyści zawodowych z perspektywy potrzeb rynku pracy.

Zestawienie wypowiedzi uczniów, studentów oraz osób pracujących, dotyczące opinii osób, które zgodziły się z danym twierdzeniem w raczej wysokim lub bardzo wysokim stopniu (wyniki badania kwestionariuszowego, $N=2012$ )

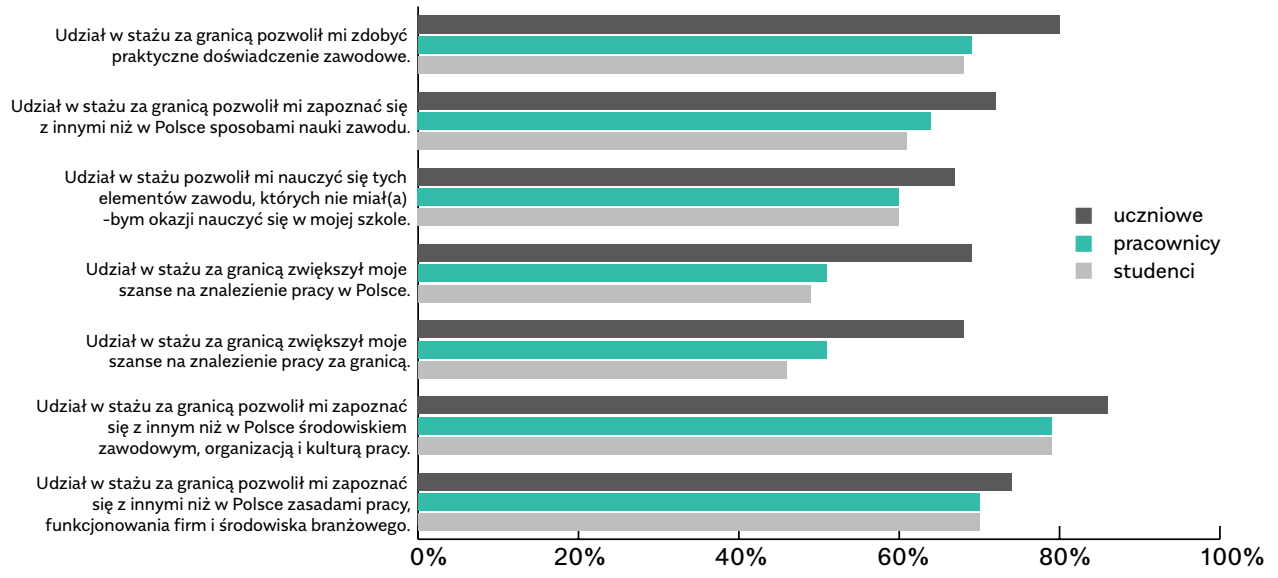

Źródło: Opracowanie własne. 
Badanie pokazało również, że postrzeganie korzyści płynących ze stażu różni się w zależności od doświadczeń respondentów związanych z poznaniem rynku pracy. Uczestnicy badania, którzy nie skończyli jeszcze szkoły, okazali się zdecydowanie mniej krytyczni w ocenach przydatności stażu z perspektywy oczekiwań rynku pracy. Ponad 80 proc. badanych uczniów uznało, że staż w wysokim stopniu pozwolił im zdobyć praktyczne doświadczenie zawodowe. Podobne deklaracje dotyczyły jednak niespełna 70 proc. studentów i ponad 68 proc. osób aktywnych zawodowo. Różnice w deklaracjach widać również w ocenach dotyczących zwiększenia potencjalnych szans byłych stażystów na znalezienie zatrudnienia. Podczas gdy ponad dwie trzecie uczniów uznało, że doświadczenie mobilności zwiększyło ich szanse na znalezienie pracy zarówno w Polsce (ponad 69 proc.), jak i za granicą (ponad 68 proc.), podobne deklaracje dotyczyły nieco ponad 51 proc. studentów i niespełna połowy pracowników.

\section{Badanie losów studentów uczestniczących w mobilnościach w programie Erasmus i Erasmus+}

Badanie losów studentów uczestniczących w mobilnościach w programie Erasmus i Erasmus + ma charakter badania ilościowego. Zakłada połączenie dwóch schematów badawczych: schematu trackingowego, który jest rodzajem badania przekrojowego, oraz schematu panelowego, czyli jednej z metod badań podłużnych. Badanie zaplanowano jako panelowe, czyli takie, które polega na kilkakrotnym powtórzeniu pomiaru z użyciem tych samych lub podobnych narzędzi pomiarowych wśród tej samej grupy respondentów $w$ regularnych odstępach czasowych. Jednocześnie wykorzystanie metody badania trackingowego pozwala na objęcie badaniem co roku kolejnych grup absolwentów. W 2017 r. badanie zostało zainicjowane, przeprowadzono także pilotaż narzędzia oraz zrealizowano pierwszą fazę o charakterze badania trackingowego.

Głównym celem przedsięwzięcia jest prześledzenie dalszych losów edukacyjnych i zawodowych tych osób, które podczas studiów zostały stypendystami programu Erasmus lub Erasmus+ i dzięki temu wyjechały na zagraniczne studia lub praktyki zawodowe. Główne obszary tematyczne badania obejmują karierę zawodową absolwentów studiów wyższych (w tym: zadowolenie z sytuacji zawodowej i oczekiwania wobec pracy), dalszą edukację (kontynuowanie nauki na poziomie studiów magisterskich, a także rozpoczęcie kariery naukowej) oraz mobilność 
(wpływ wyjazdów zagranicznych na sytuację zawodową i edukacyjną uczestnika wyjazdu). Badaniem objęto wszystkich studentów, którzy uczestniczyli w projektach mobilnościowych w ramach programu Erasmus i Erasmus+ w latach 2007-2015. Do próby włączono zarówno osoby odbywające praktyki, jak i te studiujące na uczelni zagranicznej w ramach programu. W badaniu uczestniczyli absolwenci wszystkich stopni studiów, od licencjackiego do doktoranckiego. Wykluczono natomiast osoby, które wciąż studiują, a w latach wcześniejszych jeszcze nie ukończyły żadnego stopnia studiów. W tym artykule zostaną omówione wyniki badania przeprowadzonego w grupie osób, które uczestniczyły w praktykach zawodowych w ramach programu Erasmus.

Program Erasmus (a także jego następca, Erasmus+) kojarzony jest przede wszystkim z wyjazdami na zagraniczne uczelnie, gdzie studenci realizują część programu studiów. Jednak nie jest to cała oferta - począwszy od 2007 r., wraz z rozpoczęciem programu „Uczenie się przez całe życie", studenci zyskali możliwość wyjazdu na zagraniczne praktyki i staże. Pierwsi polscy studenci wyjechali na zagraniczne praktyki w roku akademickim 2007/2008. W pierwszym roku za granicę wyruszyło łącznie niespełna 900 osób. W kolejnych latach zainteresowanie praktykami znacznie wzrosło, a, co ciekawe, liczba studentów wyjeżdżających na praktyki rosła bardziej dynamicznie niż liczba studentów wyjeżdżających na studia. Od roku 2011 średnio 3,5 tys. polskich studentów wyjeżdża w każdym roku akademickim na praktyki w ramach stypendium z programu Erasmus. W 2007 r. stypendyści wyjeżdżający na praktyki stanowili niecałe 10 proc. wszystkich mobilności w programie Erasmus - ponad 90 proc. mobilności dotyczyło wyjazdów na studia. Popularność praktyk wzrosła na tyle, że w latach 2014 i 2015 wyjazdy na praktyki stanowiły już ponad 30 proc. mobilności w każdym roku.

\section{Kompetencje i umiejętności}

Badanie przeprowadzone wśród stypendystów programu Erasmus i Erasmus+ nie dotyczyło bezpośrednio rozwoju kompetencji dzięki wyjazdom zagranicznym, ale kwestia ta została w nim ujęta jako jeden z wątków. Przede wszystkim należy tu podkreślić, że wyjazdy na praktyki miały duże znaczenie dla rozwoju respondentów - już po kilku latach stypendyści Erasmusa zauważyli, że wyjazd miał największy wpływ właśnie na rozwój ich kompetencji i umiejętności (stwierdziło tak 83 proc. ankietowanych). Drugim w kolejności obszarem, na który 
największy wpływ miały praktyki, jest rozwój zawodowy respondentów (79 proc. stypendystów).

Wykres 8. Wpływ wyjazdu na zagraniczne praktyki studenckie w opinii stypendystów programu Erasmus $(\mathrm{N}=1352)$

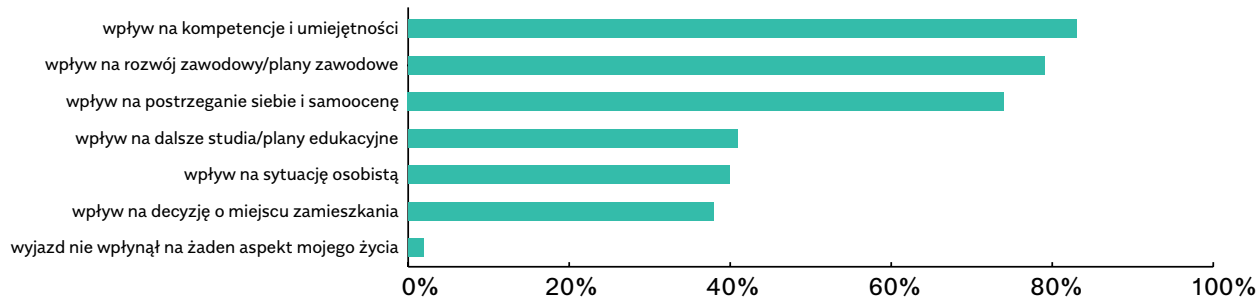

Źródło: Opracowanie własne.

Uczestnicy badania, już teraz absolwenci studiów, bardzo wysoko oceniają sam wyjazd. Wskaźnik NPS (Net Promoter Score), opisujący stosunek respondentów do określonego zjawiska, w przypadku praktyk w programie Erasmus jest bardzo wysoki - wynosi 88,31. Oznacza to, że ponad 90 proc. respondentów to promotorzy programu: oceniają oni swoje praktyki na 9 lub 10 w skali 0-10. Odsetek osób krytycznie nastawionych do swojego wyjazdu jest bardzo niski - jedynie niespełna 2 proc. respondentów oceniło go w przedziale 0-6.

Wykres 9. Poziom wskaźnika NPS dla uczestników zagranicznych praktyk studenckich w programie Erasmus. Zestawienie odpowiedzi na pytanie: W skali od 0 do 10, na ile prawdopodobne jest, że poleci Pan(-i) wyjazd na zagraniczne praktyki innym studentom? $(N=1352)$

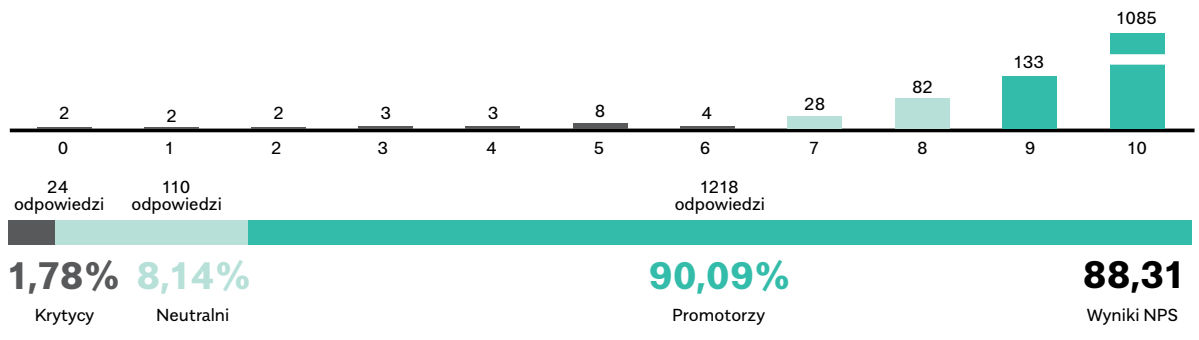

Źródło: Opracowanie własne. 
Zdecydowana większość respondentów chętnie powtórzyłaby wyjazd na praktyki z programu Erasmus. Co szczególnie ważne z punktu widzenia programu, 94 proc. badanych chciałoby wrócić do tego samego kraju, a 85 proc. wróciłoby do tej samej instytucji, w której odbyło praktyki w trakcie studiów.

Wykres 10. Odsetek stypendystów, którzy zdecydowaliby się na ponowny wyjazd na praktyki w programie Erasmus do tego samego kraju $(\mathrm{N}=1352)$

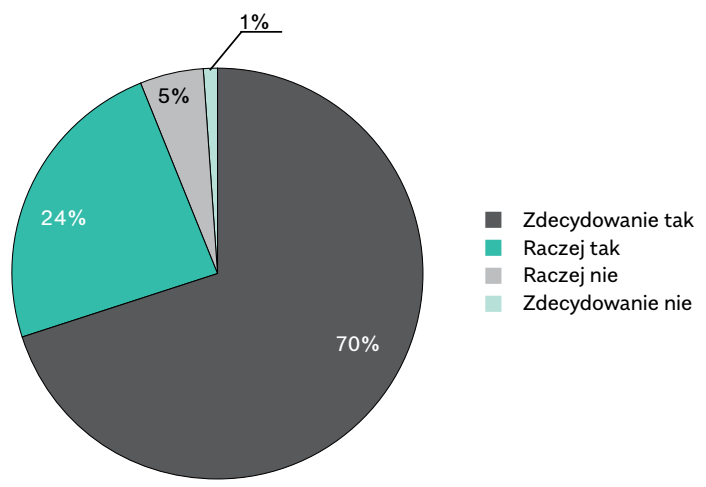

Źródło: Opracowanie własne.

Wykres 11. Odsetek stypendystów, którzy zdecydowaliby się na ponowny wyjazd na praktyki w programie Erasmus do tej samej instytucji $(N=1352)$

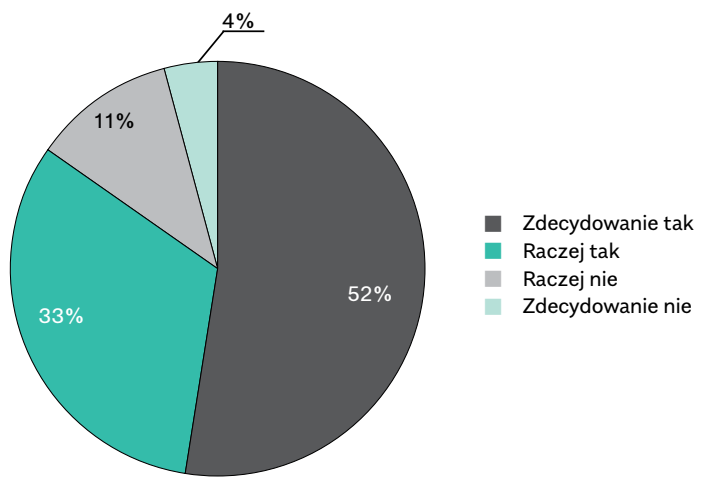

Źródło: Opracowanie własne. 


\section{Kompetencje językowe i rozwój osobisty}

W ramach badania respondenci zostali także poproszeni o wskazanie najważniejszych korzyści, jakie odnieśli dzięki wyjazdowi na zagraniczne praktyki. Ankietowany mógł wskazać do trzech najważniejszych korzyści. Niemal dwie trzecie respondentów uznało, że najważniejszy dla nich był rozwój kompetencji językowych - 64 proc. było zdania, że to poprawa znajomości języków obcych stanowi największą korzyść, jaką odnieśli z wyjazdu. Wielu stypendystów uznało także, że duże znaczenie mają dla nich te aspekty wyjazdu, które związane są z ich rozwojem osobistym - kompetencjami międzykulturowymi (doświadczenie życia w innym kraju i innej kulturze) oraz poznaniem nowych osób. Warto także zwrócić uwagę na te korzyści, które związane są bezpośrednio z karierą zawodową, takie jak ułatwienie startu na rynku pracy (28 proc. ankietowanych), zwiększenie szans na zatrudnienie w Polsce (16 proc. respondentów) oraz za granicą ( 25 proc. badanych osób). Są to aspekty szczególnie cenne, ponieważ respondenci wypełniający ankietę $w$ większości mieli już za sobą pierwsze doświadczenia na rynku pracy, a tym samym oceniali wyjazd na praktyki już z perspektywy osoby zatrudnionej.

Wykres 12. Najważniejsze korzyści płynące z praktyk w programie

Erasmus+ $\mathrm{w}$ ocenie stypendystów $(\mathrm{N}=1352)$

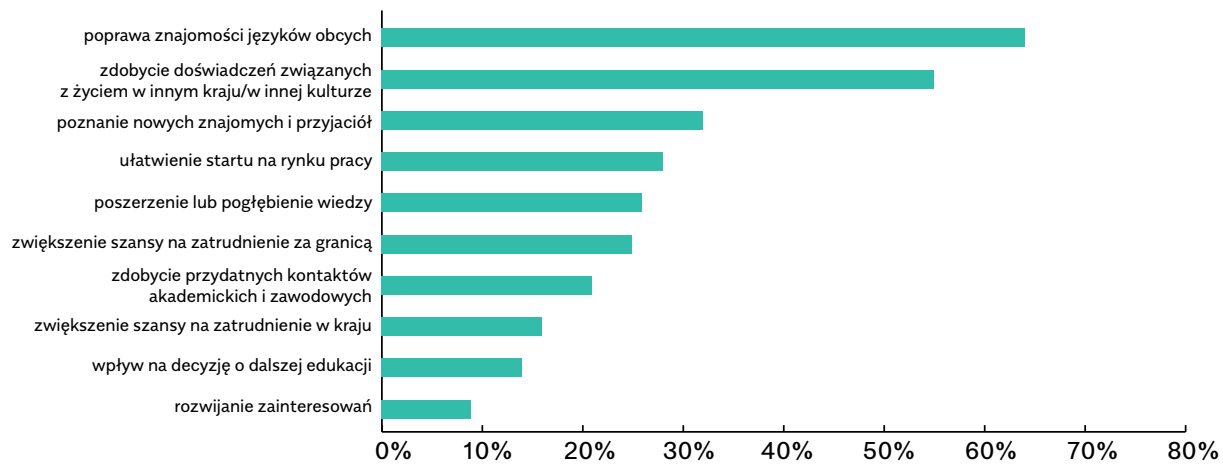

Źródło: Opracowanie własne. 
Wykres 13. Kontakty z osobami poznanymi podczas praktyk $(\mathrm{N}=1352)$

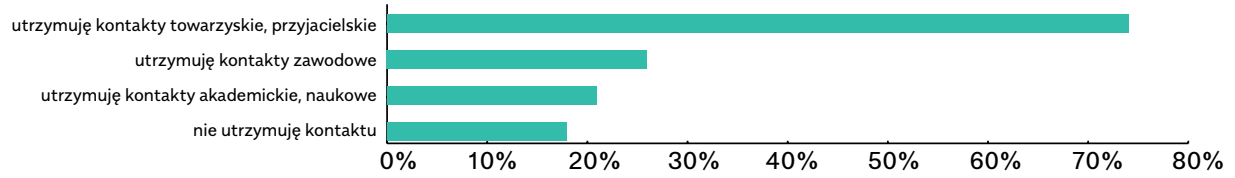

Źródło: Opracowanie własne.

Wykres 14. Wpływ wyjazdu na praktyki w programie Erasmus na otrzymanie stałej pracy. Zestawienie odpowiedzi na pytanie: Czy Pana(-i) zdaniem wyjazd z programu

Erasmus pomógł Panu (-i) w otrzymaniu pierwszej stałej pracy? $(\mathrm{N}=\mathbf{7 2 1})$

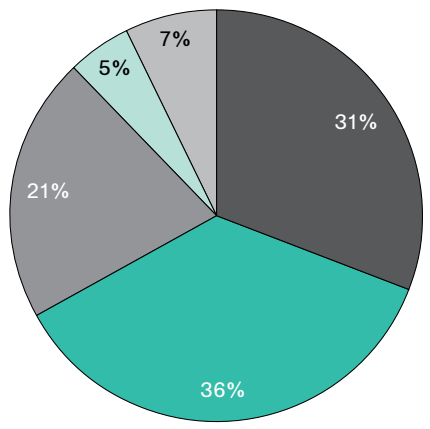

- Zdecydowanie tak

- Raczej tak

Raczej nie

Zdecydowanie nie

Nie dotyczy,

nie musiałem(-am)

brać udziału

w procesie

rekrutacji

Źródło: Opracowanie własne.

\section{Poszukiwanie pracy}

Niektórzy respondenci w czasie brania udziału w badaniu pracowali już zawodowo. Zostali oni zapytani, czy według nich wyjazd na zagraniczne praktyki wpłynął na otrzymanie przez nich stałej pracy - często było to pierwsze zatrudnienie $w$ życiu, rozpoczęte jeszcze $w$ trakcie studiów lub zaraz po otrzymaniu dyplomu. Blisko dwie trzecie respondentów uznało, że wyjazd na zagraniczne stypendium z programu Erasmus był istotnym walorem i przyczynił się do otrzymania przez nich oferty pracy. Ponad trzy czwarte ankietowanych (77,12 proc.) przyznało się też, że podczas poszukiwania pracy podkreślało fakt wyjazdu na zagraniczne stypendium. Niemal wszyscy uczestnicy praktyk odnotowali to w swoim CV (94 proc.). Blisko dwie trzecie podczas rozmowy kwalifikacyjnej poruszyło kwestię swojego doświadczenia uzyskanego dzięki zagra- 
nicznym praktykom (64 proc.), a prawie co trzeci ankietowany powołał się na takie doświadczenie także w liście motywacyjnym (30 proc.).

Respondenci zostali także poproszeni o uszeregowanie w kolejności od najważniejszych do najmniej ważnych czynników, które przyczyniły się do dostania przez nich pracy. Pierwsza trójka rankingu związana jest z kompetencjami zawodowymi - za najważniejszy czynnik uznano skończenie odpowiedniego kierunku studiów, a za drugi-umiejętności związane z konkretnym zawodem albo branżą. Podium zamyka znajomość języków obcych. Sam fakt wyjazdu na zagraniczne stypendium ma mniejsze znaczenie - respondenci uznali, że udział w praktykach to szósty (z ośmiu) pod względem ważności czynnik, jednak już kompetencje, które rozwijane są podczas takiego wyjazdu, mają znaczenie niebagatelne. Samo dalsze uczenie się języka obcego dzięki takim wyjazdom pozwala na zwiększenie szans absolwenta studiów na rynku pracy, podobnie jak zdobycie $w$ trakcie praktyki nowych umiejętności zawodowych.

Na uwagę zasługuje też to, że udział w stażach i praktykach zawodowych (niezależnie od tego, czy w ramach programu Erasmus, czy nie) został umieszczony już na miejscu czwartym, więc respondenci uznali go za istotny. Takie uszeregowanie czynników pozwala przypuszczać, że choć fakt wyjazdu na zagraniczne praktyki sam w sobie nie stanowi o wyraźnej przewadze jednego kandydata do pracy nad drugim, to już umiejętności i kompetencje rozwinięte dzięki wyjazdom (np. nabycie nowych kompetencji zawodowych lub lepsze posługiwanie się językiem obcym) mogą mieć dużo większe znaczenie. Warto również zauważyć, że zdaniem samych respondentów kompetencje miękkie nie mają dużego znaczenia podczas procesu rekrutacji do pracy. 
Rysunek 3. Ranking czynników wpływających na otrzymanie pierwszej

stałej pracy (w kolejności od najbardziej do najmniej ważnych)

- w ocenie uczestników praktyk w programie Erasmus $(\mathbf{N}=724)$

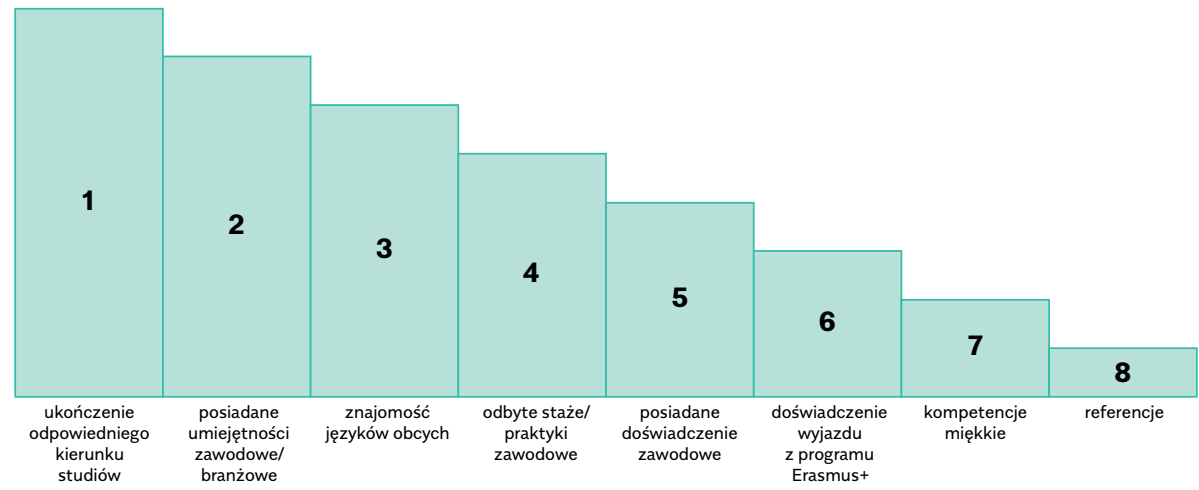

Źródło: Opracowanie własne.

Oprócz oceny wpływu mobilności na dalszą sytuację zawodową respondenci z grupy studentów wyjeżdżających na zagraniczne praktyki, którzy podjęli już stałą pracę zawodową, w ramach badania losów zostali poproszeni o ocenę swoich kompetencji. Miała ona formę deklaratywną - respondenci sami oceniali, w jakim stopniu opanowali daną umiejętność. Ogólna ocena w całej grupie jest bardzo wysoka: badani uznali, że opanowali wszystkie kompetencje w wysokim i bardzo wysokim stopniu. Dotyczy to zarówno kompetencji o charakterze przekrojowym, jak i wiedzy o swojej dziedzinie specjalizacji oraz kompetencji międzykulturowych. 
Wykres 15. Deklaratywna ocena kompetencji wśród uczestników praktyk $(\mathbf{N}=1352)$

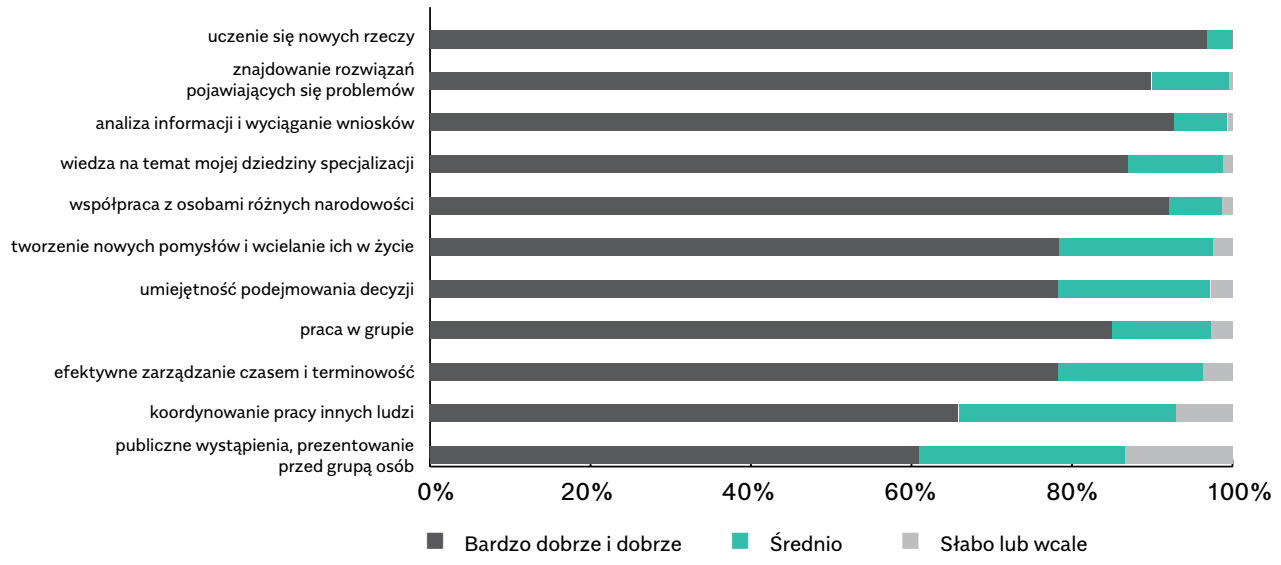

Źródło: Opracowanie własne.

Najsłabiej w samoocenie ankietowanych wypadła umiejętność wystąpień publicznych: ponad 13 proc. osób uznało, że nie ma tej umiejętności wcale lub posiada ją jedynie w niewielkim stopniu, a dalsze 25 proc. oceniło, że opanowało ją średnio. Jednocześnie jednak warto podkreślić, że ponad 60 proc. respondentów uważa, że posiada kompetencję związaną z wystąpieniami publicznymi na wysokim lub bardzo wysokim poziomie. Drugą najgorzej opanowaną przez badanych umiejętnością jest koordynowanie pracy innych osób - niespełna dwie trzecie ankietowanych oceniło, że opanowało tę umiejętność na wysokim poziomie, średnio kompetencję tę opanowało 27 proc. respondentów, a wcale lub słabo - kolejne 7 proc. W przypadku pozostałych kompetencji w zasadzie trudno jest wskazać te, które ankietowani (w swojej samoocenie) opanowali słabo. Warto natomiast wyróżnić te, które w wysokim stopniu opanowali niemal wszyscy respondenci. Ponad 99 proc. osób oceniło, że co najmniej w stopniu średnim posiadają kompetencje kluczowe: uczenie się $(96,74$ proc. w stopniu wysokim i bardzo wysokim) i powiązaną z nim kompetencję analizy informacji i wnioskowania (92,67 proc. w stopniu wysokim i bardzo wysokim) oraz rozwiązywania problemów $(99,49$ proc. w stopniu wysokim i bardzo wysokim). Niemal wszyscy ankietowani ocenili także bardzo wysoko swoje kompetencje międzykulturowe - współpraca z osobami innych narodowości nie stwarza trudności 92,09 proc. respondentów. Takie 
wyniki nie powinny dziwić ze względu na doświadczenie wyjazdu na zagraniczne stypendium i pracy w środowisku międzykulturowym już w okresie studiów.

\section{Badanie efektów uczenia się w projektach Wolontariatu Europejskiego}

Efekty uczenia się w projektach Wolontariatu Europejskiego są jednym z przedmiotów międzynarodowego badania Exploring Erasmus+: Youth in Action (RAY), prowadzonego w Europie od 2009 r. Badanie RAY stawia następujące pytania badawcze:

$\rightarrow$ Jak projekty programu Erasmus+ Młodzież wpływają na uczestniczących w nich młodych ludzi i osoby pracujące z młodzieżą oraz na organizacje i środowiska lokalne, w których są realizowane?

$\rightarrow$ W jakich warunkach realizowane są projekty programu Erasmus+ Młodzież? Jaki jest profil ich uczestników oraz organizacji je realizujących?

$\rightarrow$ W jaki sposób wyniki badania RAY mogą przyczynić się do upowszechniania przykładów dobrych praktyk projektów programu Erasmus+ Młodzież i zapewnić istotny wkład w opracowywanie kolejnych edycji unijnych programów skierowanych do młodzieży?

Żeby znaleźć odpowiedzi na te pytania, badanie prowadzone jest za pomocą kwestionariusza online dostępnego dla ankietowanych trzy miesiące po zakończeniu projektu finansowanego ze środków programu Erasmus+ Młodzież, co w założeniu miało umożliwić im bardziej wyważoną i obiektywną ocenę projektu oraz jego efektów. Jego najnowsza edycja (całkowita próba badawcza: 19421 osób, z czego 797 stanowili uczestnicy projektów Wolontariatu Europejskiego) jasno pokazuje, że dzięki długoterminowym projektom Wolontariatu Europejskiego ich uczestnicy mają szansę na rozwinięcie cennych kompetencji i umiejętności przydatnych na rynku pracy (Bammer, Fennes, Karsten, 2017).

\section{Wolontariat Europejski}

Jednym z komponentów programu Erasmus+ jest Wolontariat Europejski (European Voluntary Service - EVS). Stwarza on osobom w wieku od 17 do 30 lat możliwość zaangażowania się w nieodpłatny i prowadzony w innym kraju Unii Europejskiej lub spoza niej w pełnym wymiarze czasu pracy wolontariat trwający maksymalnie rok. Projekt Wolonta- 
riatu Europejskiego może koncentrować się na różnych zagadnieniach i obszarach tematycznych, np. kulturze, problematyce i działalności młodzieżowej, sporcie, opiece społecznej, dziedzictwie kulturowym, sztukach pięknych, obronie cywilnej, środowisku czy tzw. współpracy na rzecz rozwoju. Wolontariusze goszczą w innym kraju i pracują dla społeczności lokalnej. Jest to praca niezarobkowa i wykonywana w pełnym wymiarze godzin. Projekt Wolontariatu Europejskiego może angażować od 1 do 30 wolontariuszy, którzy pracują indywidualnie bądź w grupie. W przypadku grupy wolontariuszy pracują oni w tych samych ramach czasowych, a ich zadania łączy wspólna tematyka.

Wolontariat Europejski w dużej mierze opiera się na zasadach edukacji pozaformalnej, czyli nauce poprzez praktykę i doświadczenie, która nie opiera się na tradycyjnej relacji uczeń - nauczyciel. W edukacji pozaformalnej osoba ucząca (facylitator) i nauczana (uczestnik) pozostają w relacji partnerskiej. Osoba ucząca (w przypadku Wolontariatu Europejskiego są to zazwyczaj pracownicy organizacji goszczącej wolontariuszy) może wspomagać i wpływać na procesy uczenia się, ale nie narzuca uczestnikom prawd ani wiadomości. Uczestnik znajduje się w centrum procesu uczenia się, a zadaniem facylitatora jest wspieranie go w tym.

\section{Rozwój kompetencji i umiejętności}

Długoterminowe projekty Wolontariatu Europejskiego są bardzo skutecznym i bezpiecznym środowiskiem do sprawdzenia w praktyce wiedzy zdobytej podczas kształcenia formalnego. Wolontariusze pracują w doświadczonych i akredytowanych przez Narodową Agencję Erasmus+ organizacjach, których przedstawiciele, zgodnie z zasadami edukacji pozaformalnej, dbają o ich proces uczenia się i zdobywania kompetencji. Aż 67,1 proc. badanych uczestników twierdzi, że dzięki udziałowi w tego typu projekcie ma jaśniej sprecyzowane cele zawodowe, a 80 proc. planuje dalszą naukę. Ponadto ponad 70 proc. ankietowanych uważa, że dzięki udziałowi w projekcie wolontariatu ich szanse na rynku pracy wzrosły. Wolontariat Europejski daje także możliwość zweryfikowania, czy wybór ścieżki kształcenia lub przyszłego zawodu był słuszny. Znajduje to odzwierciedlenie w wynikach innego badania przeprowadzonego przez FRSE - Kompetencje zdobywane w ramach Wolontariatu Europejskiego w kontekście wymogów rynku pracy. Wynika z niego, że niektórzy wolontariusze po zakończeniu projektu zmienili 
kierunek kształcenia, często na taki, który związany jest z tematyką ich projektu wolontariatu (Jeżowski, 2018).

Uczestnicy projektów Wolontariatu Europejskiego deklarują rozwinięcie wielu kompetencji kluczowych ${ }^{3}$. Aż 97,4 proc. ankietowanych wolontariuszy twierdzi, że lepiej porozumiewa się w języku obcym, 81,8 proc. częściej podejmuje inicjatywę i stało się bardziej przedsiębiorczymi, a 78,6 proc. rozwinęło umiejętność uczenia się. Co czwarty ankietowany zaś utrzymuje, że po udziale w projekcie bardziej interesuje się życiem politycznym i społecznym swojego kraju, można zatem przyjąć, że rozwinął tym samym swe kompetencje społeczne i obywatelskie. Uczestnicy projektu deklarują również zdobycie i rozwinięcie wielu tzw. kompetencji miękkich, które mogą być szczególnie przydatne na rynku pracy. Mowa tu przede wszystkim o umiejętności pracy w grupie (90 proc. ankietowanych wolontariuszy), argumentacji i bronienia swojego zdania (82,4 proc.), umiejętnościach negocjacyjnych (83,9 proc.) oraz komunikacji w wielokulturowym i wielojęzycznym środowisku (95,5 proc.).

3. W badaniu posłużono się następującymi definicjami kompetencji kluczowych, zgodnie z Europejskimi ramami odniesienia: porozumiewanie się w języku obcym [opiera się w znacznej mierze na tych samych wymiarach umiejętności co porozumiewanie się w języku ojczystym - na zdolności do rozumienia, wyrażania i interpretowania pojęć, myśli, uczuć, faktów i opinii w mowie oraz piśmie (rozumienie ze słuchu, mówienie, czytanie i pisanie) w odpowiednim zakresie kontekstów społecznych i kulturalnych (w edukacji i szkoleniu, pracy, domu i czasie wolnym) w zależności od chęci lub potrzeb danej osoby]; kompetencje matematyczne (umiejętność rozwijania i wykorzystywania myślenia matematycznego w celu rozwiązywania problemów wynikających z codziennych sytuacji); kompetencje naukowe (odnoszą się do zdolności i chęci wykorzystywania istniejącego zasobu wiedzy i metodologii do wyjaśniania świata przyrody, w celu formułowania pytań i wyciągania wniosków opartych na dowodach); kompetencje cyfrowe [obejmują umiejętne i krytyczne wykorzystywanie technologii społeczeństwa informacyjnego (TSI) w pracy, rozrywce i porozumiewaniu się]; umiejętność uczenia się (zdolność konsekwentnego i wytrwałego uczenia się, organizowania własnego procesu uczenia się, w tym poprzez efektywne zarządzanie czasem i informacjami, zarówno indywidualnie, jak i w grupach); kompetencje społeczne (kompetencje osobowe, interpersonalne i międzykulturowe obejmujące pełny zakres zachowań przygotowujących osoby do skutecznego i konstruktywnego uczestnictwa w życiu społecznym i zawodowym, szczególnie w społeczeństwach charakteryzujących się coraz większą różnorodnością, a także rozwiązywania konfliktów w razie potrzeby); kompetencje międzykulturowe (umiejętność odnalezienia się w zmieniających się i wielokulturowych społecznościach); kompetencje obywatelskie (umiejętność pełnego i świadomego uczestnictwa w życiu publicznym); świadomość kulturalna (docenianie znaczenia twórczego wyrażania idei, doświadczeń i uczuć za pośrednictwem wielu środków wyrazu, w tym muzyki, sztuk teatralnych, literatury i sztuk wizualnych). 
Przydatność wyżej wymienionych kompetencji i umiejętności potwierdzają byli wolontariusze europejscy, którzy po zakończonym projekcie weszli na rynek pracy. Wyniki badania Kompetencje zdobywane w ramach Wolontariatu Europejskiego w kontekście wymogów rynku pracy dowodzą wręcz, że są one wyżej cenione przez byłych wolontariuszy niż umiejętności zdobyte $w$ trakcie edukacji formalnej.

Wykres 16. Przydatność w życiu zawodowym wiedzy i umiejętności zdobytych w trakcie edukacji formalnej $(\mathrm{N}=544)$

- Czy uważasz, że wiedza i umiejętności zdobyte podczas edukacji formalnej są przydatne w Twoim życiu zawodowym?

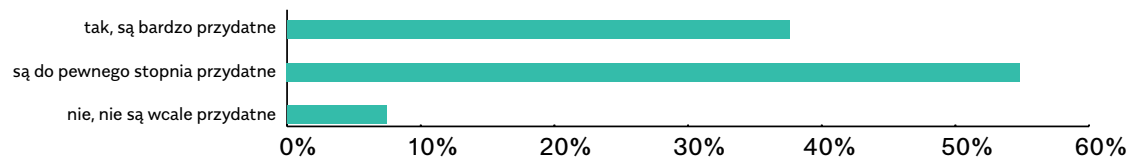

Źródło: Opracowanie własne.

Wykres 17. Przydatność w życiu zawodowym wiedzy i umiejętności zdobytych w trakcie edukacji pozaformalnej $(\mathrm{N}=544)$

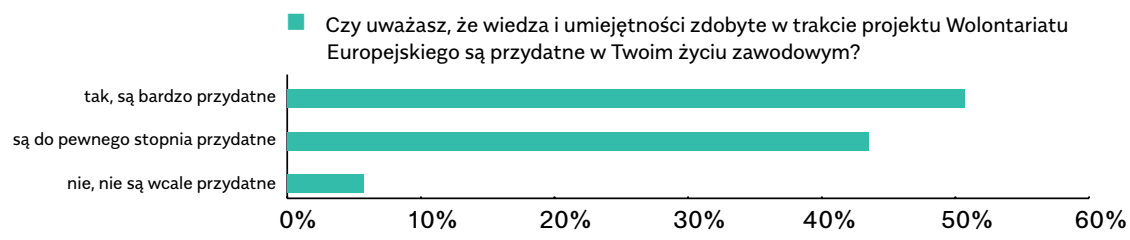

Źródło: Opracowanie własne. 
Wykres 18. Kompetencje rozwinięte podczas uczestnictwa w projekcie Wolontariatu Europejskiego ( $N=544)$

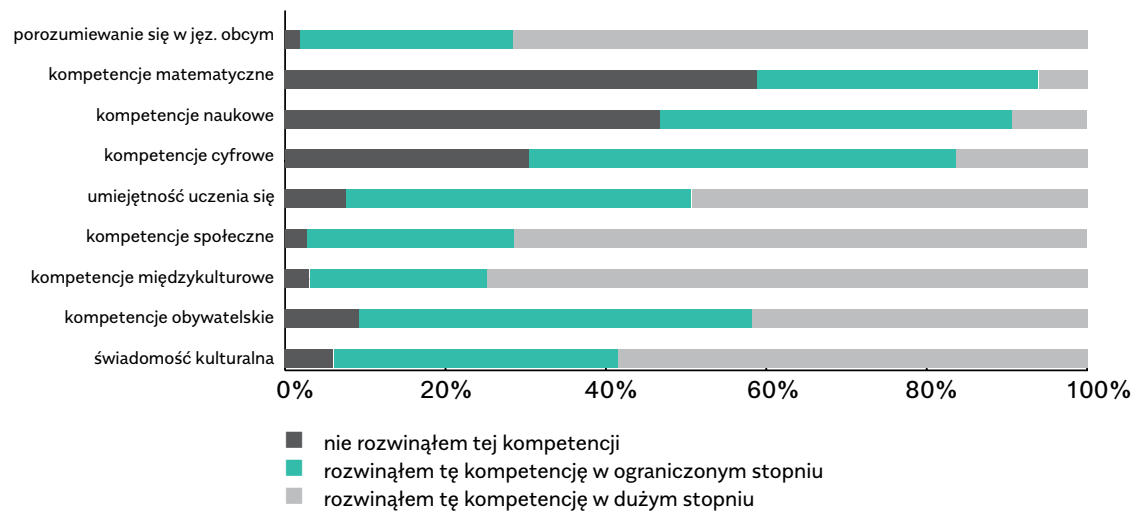

Źródło: Opracowanie własne.

Zestawiając wymagania pracodawców wobec pracowników oraz zestaw kompetencji nabywanych dzięki uczestnictwu w projekcie Wolontariatu Europejskiego, widać, że część najbardziej pożądanych na rynku pracy kompetencji - znajomość języków obcych, umiejętność pracy w zespole, kompetencje społeczne czy interpersonalne - doskonale można rozwinąć właśnie poprzez długoterminowy projekt Wolontariatu Europejskiego. Stwarza on wolontariuszom możliwość poznania podstaw zarządzania projektami, budżetem, a wszystko to w obcym kręgu kulturowym i przy użyciu języka innego niż ojczysty. Wolontariat Europejski jest zatem niezwykle cennym uzupełnieniem i rozwinięciem wiedzy zdobytej podczas edukacji formalnej. To nie tylko niezwykle cenne doświadczenie, zarówno zawodowe, jak i życiowe. W czasach spowolnienia gospodarczego, gdy młodzi ludzie są szczególnie dotknięci problemem bezrobocia, stał się on także ciekawą alternatywą dla pierwszych doświadczeń zawodowych, dającą dodatkowo możliwość nabycia kompetencji językowych, społecznych i międzykulturowych. Nie daje on co prawda możliwości zarobku, lecz może stanowić istotne narzędzie $w$ walce $z$ bezczynnością bezrobotnych młodych ludzi. 


\section{Wnioski}

Przedstawione wyniki badań dowodzą, że zagraniczne wyjazdy edukacyjne w programie Erasmus+ służą rozwijaniu szerokiego wachlarza kompetencji: zawodowych, interpersonalnych i społecznych, a także językowych. Ponadto zagraniczna mobilność edukacyjna przyczynia się do wzrostu pewności siebie, skonkretyzowania swoich planów zawodowych i budowania sieci kontaktów przydatnych w późniejszej karierze. Biorąc pod uwagę wymagania kompetencyjne pracodawców oraz ich oczekiwania wobec poszukiwanych pracowników, można stwierdzić, że uczestnictwo w mobilności edukacyjnej w ramach programu Erasmus+ sprzyja nabywaniu i rozwijaniu kompetencji oraz umiejętności cenionych na rynku pracy w Polsce. Co więcej, większość ankietowanych, niezależnie od rodzaju realizowanego projektu, stwierdziła, że doświadczenie mobilności edukacyjnej pomogło im w znalezieniu zatrudnienia. Uczestnictwo w zagranicznej mobilności jest także często określane przez jej uczestników jako cenne doświadczenie życiowe, a zdecydowana większość ankietowanych w ramach opisanych wyżej badań poleciłaby innym osobom wzięcie udziału w mobilności edukacyjnej. 


\section{Bibliografia}

$\rightarrow$ Bammer, D., Fennes, H., Karsten, A., (2017) Exploring Erasmust: Youth in Action. Effects and outcomes of the Erasmus+: Youth in Action Programme from the perspective of project participants and project leaders. Transnational analysis 2015/2016, Innsbruck: University of Innsbruck.

$\rightarrow$ Erasmus+ Przewodnik po programie, wersja 2 (2018), Komisja Europejska.

$\rightarrow$ Fennes, H., Gadinger, S., Hagleitner, W., Chisholm, L., Transnational Analysis. Results from the surveys with project participants and project leaders in November 2010 and May 2011, Innsbruck, 2012, dostęp: 2014.

$\rightarrow$ Górniak, J. (red.) (2015), Polski rynek pracy - wyzwania i kierunki działań, Warszawa-Kraków: PARP.

$\rightarrow$ Jeżowski, M. (2018), Kompetencje zdobywane w ramach Wolontariatu Europejskiego w kontekście wymogów rynku pracy, Warszawa: Fundacja Rozwoju Systemu Edukacji.

$\rightarrow$ Kocór, M., Strzebońska, A., Dawid-Sawicka, M. (2015), Rynek pracy widziany oczami pracodawców, Warszawa: PARP.

$\rightarrow$ Kolb, D.A. (1984), Experiential learning: experience as the source of learning and development, New Jersey: Prentice-Hall.

$\rightarrow$ Szlęk, A., Bratek, T., Miłoń, E. (2014), Uczyć się inaczej. Kompendium wiedzy o edukacji pozaformalnej na podstawie doświadczeń uczestników i uczestniczek programu "Młodzież w działaniu" (2007-2013), Warszawa: Fundacja Rozwoju Systemu Edukacji. 



\section{Międzynarodowe projekty \\ edukacyjne drogą do rozwoju \\ kompetencji kluczowych}

Edward Torończak

Ogólnopolska Konferencja Naukowa

Ogólnopolska Konferencja Naukowa
SZKOŁA W ŚWIECIE ZMIAN

I NOWYCH TECHNOLOGII

Uczestnictwo w międzynarodowych projektach edukacyjnych stwarza sprzyjające warunki do kształtowania postaw przedsiębiorczych, prospołecznych, obywatelskich i demokratycznych oraz rozwijania kompetencji interpersonalnych. Pozwalają one lepiej zarządzać sobą, skuteczniej radzić sobie na rynku pracy oraz pełniej uczestniczyć w życiu społeczeństwa. Międzynarodowe projekty odgrywają ważną rolę w jakościowym funkcjonowaniu szkoły w wymiarze zarówno pedagogicznym, pogłębiając wiedzę i podnosząc umiejętności nauczycieli oraz młodzieży, jak i społecznym, promując postawę społecznej odpowiedzialności.

\section{Słowa kluczowe:}

kompetencje kluczowe

umiejętności

projekty

edukacja

rozwój 


\section{International educational projects as a way to develop \\ key competences}

Edward Torończak

Participation in international educational projects creates favourable conditions for the development of entrepreneurial, socially-oriented, civic and democratic attitudes as well as interpersonal competences. They enable more efficient self-management, better performance on the labour market and fuller engagement in society. International educational projects play an important role in quality functioning of a school in pedagogical dimension, developing knowledge and skills of teachers and pupils. Regarding social dimension, they promote social responsibility attitude.

\section{Keywords:}

key competences

skills

projects

education

development 


\section{Wprowadzenie}

Heraklitowe panta rhei (z gr. wszystko płynie) jest jedną z charakterystycznych cech współczesnego świata. Zachodzące zmiany dotyczą wszystkich dziedzin życia, również edukacji. Decydenci edukacyjni uświadomili sobie, że przystosowanie się do nowych przemian cywilizacyjnych jest możliwe tylko wtedy, gdy przeorientuje się edukację z dość jednostronnego procesu przekazywania treści nauczania na efekty uczenia się. Określają one to, co uczący się wie, rozumie i potrafi wykonać po ukończeniu procesu uczenia się. W gospodarce opartej na wiedzy nie wystarczy już zapamiętywanie faktów i procedur, ale ważne jest nabywanie konkretnych umiejętności.

Kompetencje kluczowe to jedno z ważniejszych pojęć we współczesnej literaturze naukowej i popularnonaukowej. Choć ma ono już pewną historię, to nadal toczą się o nie spory i dyskusje na jego temat (Smoczyńska, 2005). W prowadzonych rozważaniach będą odniesienia do definicji kompetencji kluczowych zawartych w zaleceniu Rady z 22 maja 2018 r. w sprawie kompetencji kluczowych w procesie uczenia się przez całe życie. Rada definiuje kompetencje kluczowe jako połączenie wiedzy, umiejętności i postaw. Zrozumienie każdego z elementów jest ważne dla zarysowania ram omawianego zagadnienia. Podczas gdy wiedza typu know-what jest wiedzą o faktach - informacją, wiedza typu know-how obejmuje umiejętności lub zdolności wykonywania określonych zadań i rozwiązywania złożonych problemów. Z kolei postawa jest skłonnością i gotowością do działania lub reagowania na idee, osoby lub sytuacje. W kompetencjach kluczowych należy zatem poszukiwać systemu wiedzy teoretyczno-praktycznej, utrwalonej w konkretnych umiejętnościach i odpowiedzialnych postawach (Torończak, 2011b). Uważa się je za jednakowo ważne, ponieważ każda z nich przyczynia się do udanego życia w społeczeństwie. W zaleceniu Rady ustanowiono osiem kompetencji kluczowych (Zalecenie Rady, 2018):

$\rightarrow$ w zakresie rozumienia i tworzenia informacji,

$\rightarrow$ w zakresie wielojęzyczności,

$\rightarrow$ matematyczne oraz $\mathrm{w}$ zakresie nauk przyrodniczych, technologii i inżynierii,

$\rightarrow$ cyfrowe,

$\rightarrow$ osobiste, społeczne i w zakresie umiejętności uczenia się,

$\rightarrow$ obywatelskie, 
$\rightarrow$ w zakresie przedsiębiorczości,

$\rightarrow$ w zakresie świadomości i ekspresji kulturalnej.

Kompetencje kluczowe można nabywać w różny sposób i w różnych kontekstach. Wydaje się, że realizacja międzynarodowych projektów edukacyjnych stwarza sprzyjające warunki do nabywania i rozwijania kompetencji kluczowych. W realizacji międzynarodowych przedsięwzięć można mówić o pewnej dynamice już i jeszcze nie. Uczestnicy projektów mają już pewne umiejętności, ale jeszcze nie posiadają ich w stopniu doskonałym. Dlatego można je ciągle rozwijać i doskonalić. W artykule zostaną zaprezentowane projekty z sektora edukacji szkolnej, które były realizowane zarówno w programie Erasmus+, jak i dawniej realizowanym programie "Uczenie się przez całe życie”. Jednak zanim zostaną zeprezentowane możliwości rozwijania kompetencji kluczowych w projektach, warto odpowiedzieć sobie na pytanie: „Czym właściwie jest projekt?". Jest wiele definicji odnoszących się do pojęcia projekt. Powszechnie definiuje się go jako „złożone przedsięwzięcie, podejmowane $w$ różnych dziedzinach z zamiarem osiągnięcia założonego celu w oznaczonym czasie i przy określonym budżecie" (Roszkowski, Wiatrak, 2005, s. 9). Jeśli projekt jest złożonym przedsięwzięciem, które obejmuje wiele etapów jego realizacji, to stwarza on przestrzeń do nabywania i rozwijania nowych umiejętności i kompetencji. W tym kontekście należy spróbować odpowiedzieć sobie na kilka dość ważnych pytań. Czym w ogóle są kompetencje kluczowe? W jaki sposób można je rozwijać w projektach? Jak realizacja międzynarodowych projektów wpływa na rozwój kompetencji kluczowych jego uczestników? Na ile projekty inspirują procesy edukacyjne w szkole w zakresie kompetencji kluczowych?

\section{Międzynarodowe projekty edukacyjne a kompetencje w zakresie rozwijania i tworzenia informacji}

Wydaje się, że tłumaczenie wyrażenia Literacy competence na język polski jako "kompetencje w zakresie rozumienia i tworzenia informacji" nie do końca jest precyzyjne, bo nie wskazuje bezpośrednio na podstawowe umiejętności czytania i pisania, które stanowią fundament dalszego procesu uczenia się i nabywania innych kompetencji. W zaleceniu Rady stwierdzono: „Umiejętność rozumienia i tworzenia informacji to zdolność identyfikowania, rozumienia, wyrażania, tworzenia 
i interpretowania pojęć, uczuć, faktów i opinii w mowie i piśmie, przy wykorzystaniu obrazów, dźwięków i materiałów cyfrowych we wszystkich dziedzinach i kontekstach. Zakłada ona zdolność skutecznego komunikowania się i porozumiewania się z innymi osobami, we właściwy i kreatywny sposób" (Zalecenie Rady, 2018, s. 8). Prezentowana definicja wskazuje na całą grupę umiejętności podstawowych, które z powodzeniem są rozwijane podczas przygotowania i realizacji międzynarodowego projektu edukacyjnego.

Już na etapie przygotowywania projektu konieczne jest zbadanie potrzeb instytucji, a następnie precyzyjne określenie jego celów. Odpowiednie ich sformułowanie umożliwia właściwe określenie rezultatów projektu (outputs) oraz jego efektów (results). Wyznaczanie celów wymaga zaawansowanego procesu rozumowania i pogłębionej analizy tego, co ma zostać osiągnięte w projekcie. Formułując cele projektu i jego rezultaty, należy precyzyjnie określić wskaźniki, aby móc później zweryfikować sukces projektu. Przygotowanie koncepcji projektu wymaga opracowania struktury podziału zadań, oszacowania zasobów ludzkich, przygotowania harmonogramu, określenia budżetu, zaplanowania monitoringu i ewaluacji oraz stworzenia strategii promowania i upowszechniania rezultatów projektu. Tego rodzaju działania wymagają od zespołu namysłu, pogłębionej refleksji, zdolności identyfikowania problemów, a także skutecznej komunikacji i porozumiewania się ze wszystkimi członkami grupy projektowej (Torończak, 2011).

$Z$ kolei etap realizacji projektu inspiruje proces uczenia się w sposób wielostronny, stawiając nie tyle na wiedzę i opanowanie technik, ile na rozumienie procesów, konstruowanie hipotez, definiowanie problemów praktycznych i kształtowanie strategii działania. Nauczyciele i uczniowie, przystępując do realizacji projektów, muszą stale porównywać rzeczywisty postęp prac, identyfikować niezbędne działania prewencyjne lub korekcyjne, czuwać nad stanem ryzyka projektu, dostarczać informacje o rezultatach i stanie ich przygotowań, a także szacować aktualny budżet i koszty związane z realizacją działań projektowych (Torończak, 2011). Wszystkie te działania zakładają posiadanie umiejętności w zakresie rozwijania i tworzenia informacji, a także przyczyniają się do „wykorzystywania źródeł różnego rodzaju, poszukiwania, gromadzenia i przetwarzania informacji, wykorzystywania odpowiednich pomocy oraz formułowania i wyrażania swoich argumentów w mowie i piśmie w przekonujący sposób, odpowiednio do kontekstu" (Zalecenie Rady, 
2018 , s. 8). Niewątpliwie przygotowanie i realizacja międzynarodowego projektu stwarza przestrzeń do rozwijania kompetencji w zakresie rozwijania i tworzenia informacji.

\section{Międzynarodowe projekty edukacyjne a kompetencje w zakresie wielojęzyczności}

W zaleceniu Rady stwierdzono, że kompetencje w zakresie wielojęzyczności „określają zdolność do prawidłowego i skutecznego korzystania z różnych języków w celu porozumiewania się. Jeśli chodzi o zakres umiejętności, pokrywa się on zasadniczo z umiejętnością rozumienia i tworzenia informacji" (Zalecenie Rady, 2018, s. 8). Definicja ta wskazuje na ścisły związek między kompetencjami w zakresie „rozwijania i tworzenia informacji" a wielojęzycznością. Jeśli język ojczysty jest pierwszym i podstawowym narzędziem komunikacji człowieka ze światem i determinuje w zasadniczy sposób jego myślenie, wyrażanie emocji i uczuć, przekonania i wartości oraz kształtowanie tożsamości, to doświadczenie języka ojczystego jest podstawą, na której budowane są słowa i struktury każdego języka obcego (Gajek, 2009; Sokol, 2012). Być może dlatego niektórzy autorzy określają wielojęzyczność jako „kod genetyczny" Unii Europejskiej, który stanowi jej naturalne dziedzictwo.

W realizacji międzynarodowych projektów edukacyjnych języki obce stanowią podstawowe narzędzie komunikacji, porozumiewania się i budowania wzajemnych relacji. Jego uczestnicy rozwijają kompetencje językowe w mowie i piśmie, ponieważ w komunikacji z partnerami zagranicznymi „ma miejsce autentyczne negocjowanie znaczeń językowych i kulturowych" (Gajek 2009, s. 40). Przykładem możliwości rozwijania kompetencji językowych są projekty "Mobilności kadry edukacji szkolnej" (Akcja 1), realizowane w programie Erasmus+. Mają one na celu poprawę jakości pracy placówek oświatowych poprzez udział ich pracowników w trzech typach wyjazdów zagranicznych:

$\rightarrow$ w kursach i szkoleniach,

$\rightarrow$ w obserwacjach pracy zagranicznej szkoły partnerskiej lub innej organizacji związanej z edukacją szkolną (job shadowing),

$\rightarrow$ w prowadzeniu zajęć dydaktycznych w szkole partnerskiej za granicą (teaching assignment).

Jak pokazują badania, ten rodzaj mobilności przynosi wiele korzyści kadrze edukacyjnej. W opinii beneficjentów tego typu wyjazdy stwarzają 
"wiele możliwości doskonalenia kompetencji związanych z nauczaniem języka obcego" ("Mobilni nauczyciele”, 2016, s. 15). Kontakt z osobami z innych krajów, uczestnictwo w kursach i szkoleniach, prowadzenie zajęć w języku obcym sprawiają, że "umiejętności językowe zdobyte podczas zagranicznych mobilności pozwalają na bezproblemowe porozumiewanie się, pomimo błędów i ograniczonego słownictwa" („Mobilni nauczyciele", 2016, s. 15). Wartością dodaną tego typu mobilności jest używanie języka obcego również w codziennych sytuacjach podczas pobytu za granicą. " Umiejętności językowe, w tym znajomość języków specjalistycznych, stają się zatem nieodłącznym warunkiem powodzenia projektów mobilnościowych, a skokowy przyrost kompetencji językowych obserwujemy we wszystkich grupach docelowych, które brały udział w dotychczasowych programach" (Komorowska, Zając, 2012, s. 16).

Inną możliwością rozwijania kompetencji językowych jest realizacja projektów w ramach partnerstw strategicznych i współpracy szkół (Akcja 2), których celem jest międzynarodowa współpraca różnych instytucji edukacyjnych w Europie. Ten rodzaj projektów zakłada dwa rodzaje mobilności zagranicznych: międzynarodowe spotkania projektowe (TPM) oraz działania służące uczeniu się, nauczaniu i szkoleniom dla kadry i uczniów (LTT). To właśnie w ramach tych działań rozwijana jest świadomość językowa oraz doskonalone są umiejętności językowe. Ciekawym przykładem przedsięwzięcia poświęconego doskonaleniu metod nauczania języka angielskiego jest projekt pt. DysTEFL2 - Dyslexia for Teachers of English as a Foreign Language, zrealizowany przez Uniwersytet Łódzki. Celem tego projektu było ulepszenie metod nauczania języka angielskiego uczniów z dysleksją. W ramach przedsięwzięcia przygotowano szkolenia i kursy internetowe (interaktywny kurs na platformie Moodle, kurs MOOC - Massive Open Online Learning Course) oraz materiały do samokształcenia. Rezultaty projektu mają duży wpływ na zmniejszenie luki w szkoleniu nauczycieli pracujących z dyslektykami (Adamski i in., 2017). W tym kontekście warto dodać, że projekty edukacyjne nie tylko stanowią doskonałą formę realizacji wymagań językowych podstawy programowej, lecz także stwarzają okazję do rozwijania umiejętności niejęzykowych wspomagających uczenie się. Przykładem jest korzystanie z różnych źródeł informacji, rozwijanie świadomości językowej i strategii komunikacyjnych oraz współdziałanie w grupie (Szpotowicz, 2011). 


\section{Międzynarodowe projekty edukacyjne}

\section{a kompetencje w zakresie nauk matematycznych,}

\section{przyrodniczych, technologii i inżynierii}

Zalety matematyki w życiu codziennym odkryto już w starożytności, przez wieki jej znaczenie ciągle rosło. Współcześnie matematyka należy do nauk elementarnych umożliwiających funkcjonowanie każdego człowieka w życiu osobistym, zawodowym i społecznym. Wydaje się, że kompetencje matematyczne przydatne są jedynie w sytuacjach wymagających konkretnych umiejętności „liczenia, znajomości miar i struktur", ale w dokumencie dotyczącym kompetencji kluczowych stwierdza się, że przyczyniają się one również do "rozwiązywania problemów w codziennych sytuacjach" (Zalecenie Rady 2018, s. 9). W przypadku omawianego zagadnienia będą to sytuacje związane z realizacją projektu, w którym myślenie matematyczne odgrywa istotną rolę.

Kompetencje matematyczne rozwijane są nie tylko podczas zbierania i opracowywania różnego rodzaju danych w projekcie (określania wskaźników ilościowych, szacowania budżetu, określania kosztów). Praktycznie wszystkie etapy realizacji projektu wykorzystują matematyczne sposoby myślenia oraz prezentacji. Projektowanie ewaluacji jest jednym z przykładów wykorzystywania umiejętności matematycznych w projekcie. Dobrze zaprojektowana ewaluacja podporządkowana jest metodologicznemu procesowi zbierania informacji. Opiera się on na następujących krokach: zebranie informacji o osiągniętych lub przewidywanych wynikach, ich analiza, ocena, wyciągnięcie wniosków oraz podjęcie decyzji dotyczących poprawy jakości działań w projekcie. Przystępując do ewaluacji projektu, należy opracować własny zestaw wskaźników ilościowych rezultatu. Są to miary statystyczne mierzące poziom rezultatów w następujący sposób (Stronkowski, 2010, s. 54-57):

$\rightarrow$ liczba (np. liczba podręczników, uczniów, nauczycieli),

$\rightarrow$ odsetek (np. odsetek uczestników projektów, którzy zdali egzamin),

$\rightarrow$ współczynnik, czyli stosunek dwóch liczb do siebie (np. wzrost/spadek liczby uczniów z danej szkoły biorących udział w olimpiadach przedmiotowych w stosunku do liczby takich uczniów w poprzednim roku.

Nie tylko podczas zarządzania projektem rozwijane są umiejętności matematyczne, lecz także podczas realizacji projektów poświęconych 
kompetencjom matematycznym. Dobrym przykładem jest projekt The world with Mathematics. In search of new teaching methods of Mathematics and related subjects, zrealizowany przez gminę Tarnobrzeg. Jego zasadniczym celem było wdrożenie nowego podejścia do nauczania matematyki i innych przedmiotów ścisłych. Nowy model nauczania matematyki przyczynił się do pobudzenia twórczego działania nauczycieli oraz sprawił, że w nauczaniu matematyki stosuje się podejście interdyscyplinarne. Widocznym efektem projektu była zmiana nastawienia uczniów do matematyki, co przełożyło się na wyższe wyniki egzaminów zewnętrznych. $Z$ kolei nauczyciele zaczęli szerzej stosować podejście interdyscyplinarne nie tylko w matematyce, lecz także w innych przedmiotach ścisłych (Adamski i in., 2017).

Postulat interdyscyplinarności nauk ścisłych zakłada zalecenie Rady dotyczące kompetencji kluczowych, w którym kompetencje matematyczne, nauk przyrodniczych, technologii i inżynierii zestawione są w jednej grupie. Ciekawym przykładem interdyscyplinarności nauk ścisłych jest projekt Pollution! Find a STEM sollution, zrealizowany przez Zespół Szkół nr $7 \mathrm{w}$ Kaliszu. Jego celem było podniesienie kompetencji uczniów w zakresie fizyki, chemii, inżynierii i informaty$\mathrm{ki}$, a także matematyki. Uczestnicy projektu zdobyli między innymi umiejętności związane z programowaniem przy wykorzystaniu LEGO Mindstorm. Z kolei młodzież nauczyła się budować panele słoneczne, minielektrownie wiatrowe, urządzenia do pomiaru jakości powietrza (tamże). Zrealizowany projekt jest żywym przykładem tego, w jaki sposób można rozwijać podejście interdyscyplinarne w kompetencjach odnoszących się do nauk ścisłych.

\section{Międzynarodowe projekty edukacyjne a kompetencje cyfrowe}

We współczesnym świecie kompetencje cyfrowe stanowią podstawowe narzędzie komunikacji (communication), współpracy (cooperation) i współdziałania (collaboration), ponieważ cechuje je wygoda, niezależność od czasu i miejsca, a także możliwość zwiększonej interakcji poza tradycyjnymi formami komunikacji. Niewątpliwie kompetencje cyfrowe uczą krytycznego myślenia, wspierają wyższe operacje umysłowe, rozwijają procesy uspołecznienia, a także stanowią ważne narzędzie rozwiązywania wielu problemów. Dlatego w zaleceniu Rady stwierdza się: „Kompetencje cyfrowe obejmują pewne, krytyczne i od- 
powiedzialne korzystanie $z$ technologii cyfrowych $\mathrm{i}$ interesowanie się nimi do celów uczenia się, pracy i udziału w społeczeństwie. Obejmują one umiejętność korzystania z informacji i danych, komunikowanie się i współpracę" (Zalecenie Rady, 2018, s. 9). Warto w tym miejscu dodać, że podstawowymi założeniami wykorzystywania technologii informacyjno-komunikacyjnych (ICT) są nie tylko cele techniczne, lecz także poznawcze, pedagogiczne, językowe oraz interkulturowe (Krajka, 2009).

Przykładem intensywnego wykorzystywania narzędzi ICT w międzynarodowym przedsięwzięciu jest projekt Uczę się, więc wiem! Z TIK-iem na szczyt, zrealizowany przez Zespół Szkolno-Przedszkolny $\mathrm{nr} 8 \mathrm{w}$ Żorach. Jego celem było zwiększenie efektywnego korzystania $z$ technologii informacyjno-komunikacyjnych podczas nieinformatycznych zajęć dydaktycznych. Udział w projekcie zachęcił nauczycieli do podwyższania swoich kompetencji oraz pozwolił nabyć umiejętność przekładania zajęć teoretyczno-warsztatowych na środowisko szkoły, a także środowisko lokalne. Nauczyciele zdobyli praktyczne umiejętności tworzenia animowanych pokazów, slajdów, pobierania i edytowania filmów oraz projektów, tworzenia blogów, projektowania stron internetowych, tworzenia quizów i krzyżówek w programie Hot Potatoes oraz przetwarzania dźwięku w Audacity. Projekt miał bezpośredni wpływ na uczniów, którzy częściej i efektywniej korzystali z zasobów internetowych zarówno na zajęciach lekcyjnych, jak i poza nimi (Łyszkowski i in., 2016).

Narzędzia cyfrowe wykorzystuje się nie tylko w projektach poświęconych stricte tematyce kompetencji cyfrowych, lecz także w większym lub mniejszym stopniu wykorzystywane są one w każdym projekcie. Przykładem są tutaj działania typu blended learning. W edukacji szkolnej w ramach partnerstw strategicznych organizowane są "mobilności uczniów łączone z mobilnością wirtualną". Są to działania, na które składa się jeden lub kilka krótkich okresów mobilności fizycznej i mobilność wirtualna, polegająca na intensywnym wykorzystywaniu narzędzi ICT, np. prowadzenie transmisji na żywo, prowadzenie wideokonferencji, czy wykorzystywanie mediów społecznościowych (Przewodnik po programie, 2018). Uczestnicy tego rodzaju działań poznają nowe narzędzia cyfrowe i nabywają nowych umiejętności posługiwania się nimi, poza tym zwiększa się także ich zaangażowanie w proces uczenia się. 


\section{Międzynarodowe projekty edukacyjne}

\section{a kompetencje osobiste, społeczne i uczenia się}

We współczesnym świecie potrzebni są ludzie, którzy będą umieli aktywnie i z zaangażowaniem współkształtować rzeczywistość społeczną. Jeśli mówi się dzisiaj o realnym podziale na społeczeństwa bogate w kompetencje i ubogie, wówczas oznacza to, że ich brak rodzi realne podziały. Konieczny jest zatem rozwój kompetencji osobistych i społecznych, ponieważ mają one realny wpływ na budowanie większej równowagi społecznej. W zaleceniu Rady stwierdza się: „Kompetencje osobiste, społeczne i w zakresie umiejętności uczenia się to zdolność do autorefleksji, skutecznego zarządzania czasem i informacjami, konstruktywnej pracy z innymi osobami, zachowania odporności oraz zarządzania własnym uczeniem się i karierą zawodową" (Zalecenie Rady, 2018, s. 10). W zaprezentowanej definicji zawarta jest duża grupa cząstkowych kompetencji, które w sposób istotny wpływają nie tylko na rozwój osobisty i zawodowy poszczególnych osób, lecz także na budowanie więzi społecznych.

Jak już wspomniano, projekt jest „złożonym przedsięwzięciem", które jest realizowane w określonym środowisku. Jest to bez wątpienia środowisko kreatogenne. Już sama praca oparta na metodzie projektu wymaga kreatywności, czyli podejmowania wielu działań niekonwencjonalnych, a także konstruktywnej pracy z innymi osobami. Przygotowanie międzynarodowego projektu pociąga za sobą tworzenie nowych skojarzeń, idei, pomysłów, wymaga pogłębionej refleksji, krytycznego myślenia, tworzenia koncepcji i biegłości w twórczym rozwiązywaniu problemów. $Z$ kolei realizacja projektu sprzyja wzajemnemu uczeniu się (peer learning), wymianie doświadczeń, doskonaleniu komunikacji i współpracy partnerskiej, która łączy wspólnotę celów i działań opartych na zasadach wzajemnej odpowiedzialności i wsparcia. Wszystkie te działania wymagają pewnych umiejętności, ale rozwijają również wiele nowych zdolności, które są niezbędne do budowania trwałego i udanego partnerstwa.

Zdaniem niektórych autorów partnerstwo to "rodzaj stosunków pomiędzy jednostkami lub grupami polegający na wspólnocie celów i działań, oparty na zasadach równości, lojalności, wzajemnej odpo- 
wiedzialności i pomocy" (Okoń, 2004). Tworzenie trwałych i udanych partnerstw w projektach nie jest rzeczą łatwą, ponieważ tworzą je osoby pochodzące z różnych krajów oraz różnych środowisk kulturowych i społecznych, które mają odmienne potrzeby i oczekiwania. W niektórych okolicznościach ten rodzaj współpracy w projektach rodzi różnego rodzaju trudności. W takich sytuacjach uczestnicy projektów muszą mieć nie tylko odpowiednią wiedzę, lecz także wysoki poziom interpersonalnych kompetencji, które pomogą im rozwiązać różnego rodzaju kwestie sporne w projektach (Torończak, 2011).

Należy wyraźnie podkreślić, że realizacja międzynarodowych projektów umożliwia współpracę między różnymi strukturami kształcenia, szkolenia i nauczania. Uruchamia ona również proces wzajemnego uczenia się, co w sposób istotny stymuluje rozwijanie innowacyjnego podejścia do nauczania i uczenia się. W tym kontekście warto również podkreślić, że umiejętność uczenia się odgrywa szczególną rolę wśród innych umiejętności, ponieważ to dzięki niej można mówić o możliwości ciągłego przyswajania wiedzy, a także zdobywania nowych kompetencji.

\section{Międzynarodowe projekty edukacyjne}

\section{a kompetencje obywatelskie}

Współczesna szkoła powinna stwarzać przestrzeń do rozwijania kompetencji obywatelskich młodych ludzi poprzez inspirowanie i zachęcanie ich do współuczestniczenia w podejmowaniu i realizowaniu decyzji ważnych dla społeczności szkolnej. Wydaje się jednak, że w polskim systemie edukacji dominuje raczej zdobywanie wiedzy w zakresie kompetencji społecznych i obywatelskich, a nie nabywanie konkretnych umiejętności i kształtowanie postaw. Być może wynika to z tego, że $w$ wielu szkołach nadal króluje model edukacyjny oparty na jednostronnym "przekazywaniu wiedzy" uczniom. W takim modelu młodzież ma przede wszystkim posiąść wiedzę w zakresie kompetencji obywatelskich, często wiedzę historyczną. Nie przywiązuje się zaś wagi do nabywania konkretnych umiejętności i postaw związanych z demokratycznymi procesami życia samej szkoły. W wielu sytuacjach projekty edukacyjne przychodzą w sukurs szkołom w praktycznym nabywaniu umiejętności i kształtowaniu postaw w zakresie kompetencji obywatelskich. Takim przykładem jest projekt One vote, one thought, zrealizowany przez Gimnazjum nr 5 w Lesznie. Dzięki niemu uczniowie 
mieli szansę poznać zasady demokracji, porównując ich zastosowanie w krajach partnerskich. W każdej szkole zorganizowano wybory do szkolnego parlamentu. Reprezentanci szkolnego parlamentu i wybrani nauczyciele wzięli udział w zaplanowanych spotkaniach w krajach partnerskich, aby pokazać, że demokracja jest dla nich wszystkich wspólną wartością (Raport końcowy, 2012).

Z pewnością ważnym zadaniem szkoły jest kształtowanie młodych ludzi w zgodzie z takimi wartościami jak równość, solidarność, aktywność społeczna i tolerancja. Wartości te są podstawą demokratycznego, obywatelskiego społeczeństwa. Dlatego podejmowanie różnych przedsięwzięć przyczyniających się do nabywania kompetencji obywatelskich jest ważne w rozwoju demokracji obywatelskiej (partycypacyjnej). W zaleceniu Rady stwierdza się, że „kompetencje obywatelskie to zdolność działania jako odpowiedzialni obywatele oraz pełnego uczestnictwa w życiu obywatelskim i społecznym, w oparciu o rozumienie pojęć i struktur społecznych, gospodarczych, prawnych i politycznych, a także wydarzeń globalnych i zrównoważonego rozwoju" (Zalecenie Rady, 2018, s. 10). Tego rodzaju działania były i są podejmowane w wielu międzynarodowych projektach edukacyjnych.

Rozwijanie kompetencji obywatelskich opiera się na jednoczesnym zdobywaniu wiedzy, doskonaleniu praktycznych umiejętności oraz kształtowaniu odpowiednich postaw. Przykładem takiego podejścia jest projekt Citizenship, Globally and Locally, zrealizowany przez Zespół Szkół Społecznych SPLOT w Nowym Sączu. Nauczyciele w ramach tego przedsięwzięcia poruszali zagadnienia dotyczące obywatelstwa, zaangażowania i umiejętności społecznych, demokracji oraz budowania wspólnoty w wymiarze międzynarodowym i wielokulturowym. Realizacja projektu przyczyniła się do wspierania szkół z krajów partnerskich w procesie kształtowania postaw obywatelskich młodych ludzi. Jednocześnie projekt pokazał, że szkoła może inspirować i zachęcać uczniów do współuczestniczenia w podejmowaniu i realizowaniu decyzji ważnych dla społeczności szkolnej, lokalnej czy międzynarodowej (Raport końcowy, 2012).

Świadomość praw, umiejętność dyskusji, współdziałania i rozwiązywania konfliktów, a także równość w sferze praw obywatelskich są dzisiaj bardzo potrzebne. Te zagadnienia były z powodzeniem podejmowane w projekcie Women as Spiritus Movens towards equality in the European citizenship, zrealizowanym przez IX Liceum Ogólnokształcą- 
ce im. C.K. Norwida w Częstochowie. Międzynarodowe przedsięwzięcie pokazało, jak świadomie zapobiegać różnym formom dyskryminacji i przemocy, a jednocześnie wzmocnić wzajemne zrozumienie między mężczyznami i kobietami. Wszystkie szkoły uczestniczące w projekcie doceniły wagę działań w kierunku równości w sferze praw obywatelskich (Raport końcowy, 2014).

\section{Międzynarodowe projekty edukacyjne}

\section{a kompetencje w zakresie przedsiębiorczości}

Rozwój kompetencji w zakresie przedsiębiorczości ma pomóc ludziom, szczególnie młodym, przygotować się do życia w społeczeństwie informacyjnym, w którym wiodącą rolę odgrywają sektor przemysłów wysokiej technologii (high-tech) oraz usługi intensywnie wykorzystujące wiedzę. Wydaje się zatem, że posiadanie wiedzy, umiejętności oraz postaw w zakresie przedsiębiorczości będzie decydowało o przyszłości zawodowej oraz przyszłym dobrostanie ludzi (Torończak, 2011). Dlatego „złożoność problemów, jakie stają przed nami zarówno w pracy zawodowej, jak i w życiu prywatnym sprawia, że poszukujemy przywódców - osób mających cechy osobowości i potrafiących skutecznie realizować plany współpracy z innymi" (Kwiatkowski, 2010, s. 13). W świecie dynamicznie dokonujących się zmian cywilizacyjnych jednym z kluczowych pojęć jest przywództwo, rozpatrywane w kategoriach procesu przechodzenia od celów do wyników.

Realizacja międzynarodowych projektów edukacyjnych wymaga uczestnictwa koordynatora, czyli osoby, która odgrywa kluczową rolę w zarządzaniu zespołem i projektem. Ustanowienie koordynatora (kierownika projektu) w 93 proc. wpływa na sukces projektu; jego kompetencje $\mathbf{w} 88$ proc. decydują o sukcesie projektu, a jego wysoki autorytet -w 85 proc. Inne przyczyny powodzenia projektu odnoszą się do jasno zdefiniowanego celu (90 proc.), ustanowienia zespołu projektowego (86 proc.) i poparcia zarządu firmy dla projektu (84 proc.) (Spałek, 2004). Dane te pokazują, że od koordynatora projektu w dużym stopniu zależy sukces lub porażka całego przedsięwzięcia.

W projektach partnerstw strategicznych i współpracy szkół koordynator wybierany jest spośród instytucji biorących udział w międzynarodowym przedsięwzięciu. Wymaga się od niego nie tylko wiedzy merytorycznej, lecz także wielu cech przedsiębiorczych: zmysłu inicjatywy, proaktywności, decyzyjności, wytrwałości w dążeniu do celu, 
umiejętności nawiązywania kontaktów, empatii, a także samodyscypliny związanej z realizacją celów projektu. Mowa głównie o samodyscyplinie emocjonalnej, ponieważ pozwala ona łagodzić konflikty w projekcie. W wielu przypadkach wymaga się od koordynatora umiejętności negocjacyjnych, opartych na zasadzie „zwycięzca-zwycięzca” (win-win), które zapewniają efektywną współpracę i skuteczne zarządzanie całym projektem. Pełnienie funkcji koordynatora nie organiczna się tylko do kwestii formalnych, ale w wielu przypadkach staje się on rzeczywistym liderem projektu.

Nie tylko koordynatorzy projektów mają możliwość rozwijania cech przedsiębiorczych. Dotyczy to praktycznie wszystkich uczestników projektu, jeśli jest on poświęcony tematyce przedsiębiorczości. W tym kontekście warto zaprezentować projekt Entrepreneurship in secondary schools, realizowany przez VIII Liceum Ogólnokształcące w Zespole Szkół Medycznych i Ogólnokształcących im. H. Chrzanowskiej w Bielsku-Białej. Jego głównym celem było sprzyjanie zatrudnieniu uczniów poprzez kształcenie w nich ducha przedsiębiorczości oraz uczenie ich postaw przedsiębiorczych. Realizacja tego projektu przynosi uczestnikom wiele korzyści, wśród których wymienia się:

$\rightarrow$ zwiększenie umiejętności kreatywnego poruszania się po rynku pracy,

$\rightarrow$ wzrost postaw przedsiębiorczych, innowacyjnych i organizacyjnych,

$\rightarrow$ poznanie zasad funkcjonowania rynków pracy w krajach partnerskich,

$\rightarrow$ wzrost poczucia pewności siebie i własnej wartości,

$\rightarrow$ rozwinięcie zdolności przywódczych i liderskich,

$\rightarrow$ wzrost umiejętności nawiązywania kontaktów i pracy zespołowej,

$\rightarrow$ wzrost zaangażowania i motywacji do skutecznego działania,

$\rightarrow$ zwiększenie odporności na stres i umiejętności radzenia sobie w trudnych sytuacjach,

$\rightarrow$ wzrost umiejętności twórczego rozwiązywania problemów,

$\rightarrow$ poznanie metod przeprowadzania badań rynkowych oraz tworzenia biznesplanu,

$\rightarrow$ wzrost umiejętności podejmowania decyzji w sytuacjach podwyższonego ryzyka,

$\rightarrow$ poznanie zasad promocji poszukiwania partnerów biznesowych,

$\rightarrow$ zdobycie wiedzy o procedurach rozpoczynania działalności gospodarczej (Raport przejściowy, 2017). 
W tym kontekście można powiedzieć, że międzynarodowy projekt edukacyjny jest doskonałym poligonem doświadczalnym, na którym jego uczestnicy borykają się z realnymi problemami, niejednokrotnie trudnymi, które przyczyniają się do rozwijania wielu cech przedsiębiorczych.

\section{Międzynarodowe projekty edukacyjne a kompetencje w zakresie świadomości i ekspresji kulturowej}

We współczesnym świecie dokonuje się wiele procesów związanych z przemianami społecznymi. Z jednej strony kontynuowany jest proces integracji europejskiej, który prowadzi do współdziałania i współpracy w ramach różnego rodzaju partnerstw. Z drugiej strony postępuje proces globalizacji, który sprawia, że coraz częściej dochodzi do kontaktu z przedstawicielami różnych kultur. W tle tych zjawisk zachodzą procesy migracyjne i zmiany kulturowe w różnych krajach. Wszystko to jest dużym wyzwaniem dla edukacji, która powinna przygotować ludzi do życia w świecie zróżnicowanym narodowościowo, religijnie i kulturowo. Dlatego w zaleceniu Rady stwierdza się: „Kluczowe znaczenie ma otwartość wobec różnorodności ekspresji kulturalnej i jej poszanowanie, wraz z etycznym i odpowiedzialnym podejściem do własności intelektualnej i kulturowej. Pozytywna postawa obejmuje również ciekawość świata, otwartość na wyobrażanie sobie nowych możliwości oraz gotowość do uczestniczenia w doświadczeniach kulturalnych" (Zalecenie Rady, 2018, s. 12). Definicja ta wyraźnie wskazuje, że jednym z kluczowych zadań edukacji międzykulturowej jest kształtowanie otwartości na odmienności religijne i kulturowe oraz przygotowanie ludzi do życia w pluralizmie etnicznym i kulturowym.

Międzynarodowe projekty stanowią naturalny kontekst poznawania innych kultur i tradycji, co bezpośrednio wiąże się z rozwojem kompetencji międzykulturowych. W ramach projektów nauczyciele i uczniowie wyjeżdżają za granicę, aby spotykać się i współpracować z osobami z różnych krajów. Tego rodzaju wyjazdy polegają nie tylko na fizycznym przekraczaniu granic, lecz także na psychologicznym przekraczaniu granic. Ten drugi proces zachodzi w sytuacjach bezpośredniego zetknięcia się nauczycieli i uczniów z nową kulturą w kraju partnerskim. Znalezienie się w nowej sytuacji kulturowej inspiruje beneficjentów do samodzielnego interpretowania różnych zjawisk kulturowych i społecznych. W konsekwencji prowadzi to do zmiany perspektywy patrzenia na własne dziedzictwo kulturowe, a także jest przyczynkiem do 
podjęcia głębszej refleksji nad różnymi aspektami własnej tożsamości kulturowej. Jak stwierdza Bauman, we współczesnej rzeczywistości, którą określa "płynną" (liquid life), nie można przyjąć swojej tożsamości a priori, ale należy ją świadomie skonstruować (Bauman, 2006). Słusznie zatem pisze Bogucka, że "rozwijanie wrażliwości interkulturowej polega na tworzeniu spójnej całości, kształtowaniu poczucia tożsamości z kulturą ojczystą i otwartości na bogactwa innych kultur" (Bogucka, 2011, s. 98).

Jeśli nawet główna tematyka projektu dotyczy na przykład kompetencji społecznych i obywatelskich, to realizacja danego przedsięwzięcia często powiązana jest z rozwijaniem innych kompetencji (np. w zakresie świadomości i ekspresji kulturowej, przedsiębiorczości czy kompetencji cyfrowych). Innymi słowy, nabywanie jednych kompetencji jest niejednokrotnie powiązane z rozwojem innych. W tym kontekście wart uwagi jest, już wcześniej zaprezentowany, projekt Women as Spiritus Movens towards equality in the European citizenship. Realizacja tego przedsięwzięcia przyczyniła się do zdobycia przez beneficjentów wielu umiejętności jednocześnie, co zostało przedstawione w raporcie końcowym:

$\rightarrow 98$ proc. uczniów zaangażowanych w projekt uważa, że ich umiejętności językowe znacząco się rozwinęły,

$\rightarrow 96$ proc. uważa, że wzrosła ich świadomość kulturowa,

$\rightarrow 88$ proc. sądzi, że zwiększyły się ich kompetencje obywatelskie i społeczne,

$\rightarrow 79$ proc. uczniów jest przekonanych, że rozwinęła się ich wiedza o zagadnieniach biznesowych,

$\rightarrow 71$ proc. uczniów stwierdza, że poprawiły się ich umiejętności uczenia się,

$\rightarrow 56$ proc. uczniów po ukończeniu zadań w Polsce zauważyło zwiększenie umiejętności wykorzystania IT (Raport końcowy, 2014).

Zaprezentowany projekt nie tylko przyczynił się do rozwoju wielu umiejętności kluczowych, lecz także wskazał na zasadniczą rolę edukacji międzykulturowej w polskich szkołach, które nie są wystarczająco przygotowane do pracy z młodzieżą z innych kręgów kulturowych. Należy podkreślić, że wiele międzynarodowych projektów realizowanych w programie Erasmus+ przyczynia się do traktowania różnorodności kulturowej jako integralnej części procesu edukacyjnego w szkole. 


\section{Zakończenie}

W kontekście przeprowadzonych rozważań można powiedzieć, że tylko szkoła realizująca model semper reformanda (łac. stale reformująca się) umożliwi przygotowanie młodych ludzi do życia w świecie, w którym dokonują się dynamiczne zmiany cywilizacyjne. Szczególną rolę w przystosowaniu się do nowych przemian cywilizacyjnych odgrywają projekty unijne. Uczestnictwo w międzynarodowych przedsięwzięciach edukacyjnych zapewnia warunki do zdobycia niezbędnego doświadczenia i praktycznego wykorzystania wiedzy przedmiotowej. Projekty stwarzają możliwość kształtowania postaw przedsiębiorczych, prospołecznych, obywatelskich i demokratycznych. Rozwijają również umiejętności w zakresie kompetencji interpersonalnych, które odgrywają zasadniczą rolę nie tylko w zarządzaniu sobą, lecz także w funkcjonowaniu na rynku pracy i w środowisku społecznym.

Realizacja międzynarodowych projektów odgrywa również ważną rolę w jakościowym rozwoju szkoły. Przejawia się to zarówno w wymiarze pedagogicznym (pogłębianie wiedzy i podnoszenie umiejętności uczniów), jak i społecznym (promowanie różnorodnych postaw i wartości w szkole). Wiedza, umiejętności i kompetencje nabywane oraz rozwijane przez nauczycieli w projektach są "transferowane" na grunt macierzystych placówek edukacyjnych, podnosząc jakość ich funkcjonowania.

Wydaje się więc, że słowa Seneki Młodszego: „Uczymy się nie dla szkoły, lecz dla życia" (łac. Non scholae, sed vitae discimus) są ciągle aktualne. Międzynarodowe projekty edukacyjne są doskonałą formą nabywania i rozwijania kluczowych kompetencji, które pozwalają nauczycielom i uczniom w pełni uczestniczyć w życiu społeczeństwa i skutecznie radzić sobie ze zmianami na rynku pracy. 


\section{Bibliografia}

$\rightarrow$ Adamski, M. i in. (red.) (2017), EDUinspiracje. Konkurs 2017, Warszawa: Fundacja Rozwoju Systemu Edukacji.

$\rightarrow$ Bauman, Z. (2006), Liquid modernity, Cambridge: Polity Press.

$\rightarrow$ Bogucka, M. (2011), Świadomość i ekspresja kulturowa istotą pracy projektów uczniów w szkole podstawowej [w:] M. Szpotowicz (red.), Europejski wymiar edukacji-program Comenius w Polsce, Warszawa: Fundacja Rozwoju Systemu Edukacji, s. 87-101.

$\rightarrow$ Gajek, E. (2009), Kompetencje kluczowe w projektach międzynarodowych programu eTwinning [w:] E. Gajek, P. Poszytek (red.), eTwinning droga do edukacji przyszłości, Warszawa: Fundacja Rozwoju Systemu Edukacji, s. 31-71.

$\rightarrow$ Gajek, E. (2011), Technologie informacyjne i komunikacyjne w językowych projektach edukacyjnych [w:] M. Szpotowicz (red.), Europejski wymiar edukacji - program Comenius w Polsce, Warszawa: Fundacja Rozwoju Systemu Edukacji, s. 133-147. i ich zastosowanie przy korzystaniu ze środków Unii Europejskiej. Warszawa:

$\rightarrow$ Komorowska, H., Zając, J. (2012), Wstęp [w:] H. Komorowska, J. Zając (red.), Kompetencje językowe podstawq sukcesu zawodowego i społecznego w Europie, Warszawa: Fundacja Rozwoju Systemu Edukacji, s. 19-20.

$\rightarrow$ Krajka, J. (2009), Technologie informacyjno-komunikacyjne w projektach współpracy na odległość - od eTwinningu 1.0 do eTwinningu 2.0 [w:] E. Gajek, P. Poszytek (red.), eTwinning drogą do edukacji przyszłości, Warszawa: Fundacja Rozwoju Systemu Edukacji, s. 72-89.

$\rightarrow$ Kwiatkowski, S.M. (2010), Miejsce i rola przywództwa w edukacji [w:] S.M. Kwiatkowski, J.M. Michalak (red.), Przywództwo edukacyjne w teorii i praktyce, Warszawa: Fundacja Rozwoju Systemu Edukacji, s. 13-23.

$\rightarrow$ Łyszkowski, J. i in. (red.) (2016), EDUinspiracje 2016. Przykłady dobrych praktyk, Warszawa: Fundacja Rozwoju Systemu Edukacji. 
$\rightarrow$ Okoń, W. (2004), Nowy słownik pedagogiczny, Warszawa: Wydawnictwo Akademickie "Żak".

$\rightarrow$ Pachocki, M. (red.) (2016), Mobilni nauczyciele zmieniajq swoje szkoły, Warszawa: Fundacja Rozwoju Systemu Edukacji.

$\rightarrow$ Program Erasmus+ w Polsce. Raport 2016 (2017), Warszawa: Fundacja Rozwoju Systemu Edukacji.

$\rightarrow$ Roszkowski, H., Wiatrak, A.P. (2005), Zarządzanie projektem. Istota, procedury i ich zastosowanie przy korzystaniu ze środków Unii Europejskiej, Warszawa: Wydawnictwo SGGW.

$\rightarrow$ Smoczyńska, A. (red.) (2005), Kompetencje kluczowe. Realizacja kompetencji na poziomie szkolnictwa obowiq̨zkowego, Warszawa: Fundacja Rozwoju Systemu Edukacji.

$\rightarrow$ Sokol, J. (2012), Europejska wielojęzyczność i jej konsekwencje polityczne [w:] H. Komorowska, J. Zając (red.), Kompetencje językowe podstawq sukcesu zawodowego i społecznego w Europie, Warszawa: Fundacja Rozwoju Systemu Edukacji, s. 23-30.

$\rightarrow$ Stronkowski, P. (2010), ABC wskaźników w projektach edukacyjnych. Poradnik dla piszących i oceniających wnioski, Warszawa: Ministerstwo Edukacji Narodowej Departament Funduszy Strukturalnych, Szkoła Główna Gospodarstwa Wiejskiego.

$\rightarrow$ Szpotowicz, M. (2011), Integracja przedmiotowo-językowa w międzynarodowym projekcie edukacyjnym [w:] M. Szpotowicz (red.), Europejski wymiar edukacji-program Comenius w Polsce, Warszawa: Fundacja Rozwoju Systemu Edukacji, s. 31-50.

$\rightarrow$ Torończak, E. (2011) Metoda projektu edukacyjnego w procesie kształcenia [w:] M. Szpotowicz (red.), Europejski wymiar edukacji-program Comenius w Polsce, Warszawa: Fundacja Rozwoju Systemu Edukacji, s. 11-29.

$\rightarrow$ Torończak, E. (2011a), W drodze do pedagogiki kompetencji kluczowych, „Kwartalnik Pedagogiczny", 4(222), s. 65-82.

$\rightarrow$ Torończak, E. (2011b), Znaczenie kompetencji kluczowych dla budowania partnerstwa w Europie, "Kwartalnik Edukacyjny”, 1(64), s. 3-17.

$\rightarrow$ Zając, J. (2011), Rozwijanie świadomości wielokulturowej w międzynarodowym projekcie edukacyjnym [w:] M. Szpotowicz (red.), Europejski wymiar edukacji - program Comenius w Polsce, Warszawa: Fundacja Rozwoju Systemu Edukacji, s. $102-116$. 


\section{Netografia:}

$\rightarrow$ Erasmus+. Przewodnik po programie, Wersja 2 (2018): 15/12/2017 [online], <ec. europa.eu/programmes/erasmus-plus/programme-guide/introduction/how-to -read-programme-guide_pl>, dostęp 4.06.2018.

$\rightarrow$ Zalecenie Rady z dnia 22 maja 2018 r. w sprawie kompetencji kluczowych w procesie uczenia się przez całe życie [online], <eur-lex.europa.eu/legal-content/

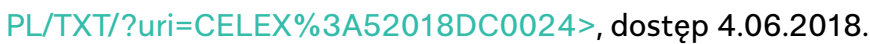

$\rightarrow$ Zalecenie Parlamentu Europejskiego i Rady z dnia 18 grudnia 2006 r. w sprawie kompetencji kluczowych w procesie uczenia się przez całe życie [online] <eur -lex.europa.eu/legal-content/pl/TXT/PDF/?uri=CELEX:32006H0962>, dostęp 4.06.2018. 



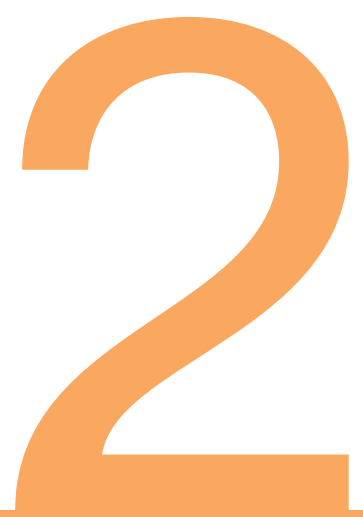




\section{Wyzwania wspólczesnej edukacji}




\section{Nowoczesne doradztwo \\ w szkołach: predyspozycje uczniów \\ a ich przyszłość zawodowa}

Stefan M. Kwiatkowski

W tekście przedstawiono teorie socjologiczne i psychologiczne będące podstawą pracy doradcy edukacyjno-zawodowego. Dokonano także przeglądu typologii doradców. Na tym tle omówiono standard kompetencji/kwalifikacji zawodowych doradcy oraz scharakteryzowano metody, techniki i narzędzia stosowane w jego pracy z uczniami.

\section{__ Słowa kluczowe:}

teorie socjologiczne i psychologiczne

typologie doradców

standard kompetencji/kwalifikacji zawodowych doradcy

metody, techniki i narzędzia pracy doradców zawodowych 


\section{Modern counseling in schools: predispositions of students and their professional future}

Stefan M. Kwiatkowski

The text presents the sociological and psychological theories underlying the work of educational and vocational counselors. A typology of counselors was also reviewed. On this background, the standard of vocational competencies/qualifications of the counselor was discussed and the methods, techniques and tools of the counselors' work with students were characterized.

\section{Keywords:}

sociological and psychological theories

typologies of counselors

standard of competencies/qualifications of counselors

methods, techniques and tools of work of vocational counselors 


\section{Wprowadzenie}

Obserwowana współcześnie, niespotykana w historii cywilizacji skala przeobrażeń zachodzących w życiu społecznym i gospodarczym oraz ich tempo powodują wzrost niepewności i zagubienia wśród uczniów stojących przed wyborem szkoły oraz uczelni, a następnie miejsca i rodzaju pracy zawodowej.

Rozwój techniki i towarzyszące mu zmiany technologii produkcji oraz usług sprawiają, że z tradycyjnych profesji wyodrębniają się nowe specjalności, a także powstają nieznane dotąd zawody i stanowiska pracy. Wraz z wprowadzaniem kolejnych generacji technologii zanikają zawody związane z poprzednimi procedurami działania. Tworzy się dynamiczne środowisko pracy wymagające od pracowników ciągłego uczenia się - modyfikowania i uzupełniania wiedzy, rekonstrukcji umiejętności i ukierunkowanego rozwoju kompetencji społecznych.

Charakterystyczny dla współczesnych czasów brak stabilności zwiększa znaczenie wszelkiego rodzaju doradców - przewodników znających bardzo dobrze teraźniejszość, a zarazem potrafiących wskazać główne nurty wytyczające przyszłość (Bauman, 2006, s. 249-253). Zmieniają się zatem zadania zawodowe doradców. Doradcy, będący przedmiotem naszych rozważań, z doradców edukacyjnych (ułatwiających uczniom wybór szkoły i uczelni) stają się coraz częściej doradcami edukacyjno-zawodowymi, pomagającymi zarówno uczniom i studentom, jak i osobom już pracującym konstruować indywidualne drogi prowadzące do odpowiedniej edukacji (wynikającej z predyspozycji) i satysfakcjonującej pracy, a także wspierającymi ich w tych działaniach.

W syntetycznym ujęciu doradztwo edukacyjno-zawodowe polega na interakcji między uczniem, studentem, pracownikiem a doradcą, w której wyniku następuje świadomy i autonomiczny wybór szkoły ponadpodstawowej, uczelni i kierunku kształcenia, zatrudnienia (rodzaj przedsiębiorstwa, typ zadań zawodowych, stanowisko pracy), a także sposobu dokształcania i doskonalenia zawodowego. Świadomego i autonomicznego wyboru dokonuje uczeń, student, pracownik przy diagnostycznym (diagnoza predyspozycji) i informacyjnym (informacje o możliwościach kształcenia ogólnego i zawodowego w szkołach ponadpodstawowych, o kierunkach studiów oraz o sytuacji na rynku pracy) wsparciu doradcy.

Integralną częścią tak rozumianego doradztwa edukacyjno-zawodowego jest orientacja zawodowa, która poprzedza proces wyboru 
konkretnej drogi edukacyjnej i konkretnego zawodu. Polega ona na realizacji przez rodziców, szkoły i szeroko rozumiane środowisko lokalne (grupy osób i instytucji) ciągu działań mających na celu przygotowanie młodzieży do perspektywicznego myślenia o przyszłości edukacyjnej i zawodowej oraz do podejmowania decyzji (samodzielnie lub przy współudziale doradców) w tym zakresie. Ten etap w pedagogice pracy jest nazywany edukacją przedzawodową, czyli wprowadzeniem do odgrywania ról społecznych, i rozpoczyna się przed podjęciem nauki w szkole podstawowej (Kwiatkowski, 2006, s. 246).

\section{Podstawy teoretyczne pracy doradcy edukacyjno-zawodowego}

W grupie teorii możliwych do wykorzystania w pracy doradcy edukacyjno-zawodowego szczególnie istotne są teorie natury socjologicznej i psychologicznej.

Teorie socjologiczne, uwzględniające znaczenie wyboru szkoły, uczelni i pracy, odnoszą się do ról zawodowych i pozycji zawodowych pracowników rozpatrywanych w kontekście struktury społecznej. Przyjęcie takiej perspektywy umożliwia szersze spojrzenie na społeczne uwarunkowania podejmowanych decyzji edukacyjnych i zawodowych.

Wśród teorii socjologicznych duże znaczenie dla zrozumienia procesów leżących u podstaw wyborów edukacyjnych i zawodowych mają: teoria osiągnięć edukacyjnych i teoria (koncepcja) nierówności edukacyjnych. Są one komplementarne, dlatego można je rozpatrywać łącznie. W obu tych teoriach zwraca się uwagę na znaczenie środowiska społecznego ucznia w jego drodze edukacyjnej i zawodowej. Szczególną rolę przypisuje się w nich statusowi społecznemu rodziny (wykształcenie rodziców, poziom dochodów, warunki do nauki, miejsce zamieszkania: miasto czy wieś) i wynikającemu z niego kapitałowi kulturowemu przekazywanemu dzieciom przez rodziców.

Z edukacyjnego punktu widzenia podstawową funkcję pełni socjologiczna konstatacja mówiąca, że status społeczny rodziny odgrywa pierwszoplanową rolę przy wyborze szkoły ponadpodstawowej. Dalsze wybory uczniów zależą już od oddziaływania środowiska rodzinnego w sferze motywowania dzieci do samodzielnego uczenia się, a w efekcie do przechodzenia na coraz wyższe poziomy edukacyjne. Łatwa do zauważenia jest zależność między wykształceniem rodziców, szczególnie zaś matek, a sukcesami edukacyjnymi ich dzieci. Jednakże wraz ze wzrostem 
poziomu edukacyjnego decydującą rolę zaczynają odgrywać predyspozycje i zdolności dzieci (uczniów/studentów), a także środowisko szkolne/akademickie, maleje zaś znaczenie statusu społecznego rodziny.

Warto zauważyć, że wspomniany już kapitał kulturowy, będący pochodną statusu społecznego rodziny, wpływa na dzieci już od wczesnych lat ich życia. W rodzinie bowiem przekazywane są zasady, wartości i normy, które jeszcze przed rozpoczęciem nauki w szkole podstawowej stanowią rodzaj kapitału początkowego (wejściowego), determinującego późniejsze aspiracje edukacyjne oraz będące ich wynikiem wybory edukacyjne i zawodowe. $Z$ reguły od statusu społecznego rodziny zależy poziom jej świadomości edukacyjnej. $Z$ wysokiego statusu wynika wysoka ranga, jaką rodzina przypisuje edukacji. Edukacja zajmująca centralne miejsce w systemie wartości rodziców staje się znaczącym elementem tożsamości ich dzieci. Wzrastają one w specyficznym kulcie wiedzy i wykształcenia. Nie wyobrażają sobie życia bez ciągłego podnoszenia swoich kompetencji i kwalifikacji. Chcą osiągnąć, nierzadko przy wsparciu całej rodziny, status społeczny przewyższający pozycję, jaką mają ich rodzice. Oczywiście niski status społeczny rodziny nie uniemożliwia dzieciom osiągnięcia sukcesów edukacyjnych ani zawodowych. Należy jednak wówczas przezwyciężyć bariery wynikające z niskiego poziomu kapitału kulturowego rodziców oraz skoncentrować się na rozwoju i wykorzystaniu własnych predyspozycji oraz zdolności (por. Lelińska, 2004, s. 116-117).

Przytoczone teorie socjologiczne, dzięki swojemu uniwersalnemu charakterowi, pozwalają na przejście do bardziej szczegółowych i operacyjnych teorii psychologicznych. Psychologia, a ściślej rzecz ujmując - psychologia pracy, wyborowi drogi edukacyjnej i zawodowej przypisuje niezwykle ważną rolę. Już na początku XX w. zwracał na to uwagę prekursor doradztwa zawodowego Frank Parsons, formułując założenia swojej teorii cechy i czynnika. Jej główne przesłanie dotyczy dopasowania: człowiek - środowisko. Współcześnie można ją interpretować jako zależność między trzema czynnikami:

$\rightarrow$ samopoznaniem (samoświadomość, czyli postrzeganie siebie jako podmiotu w świecie zewnętrznym, oraz samowiedza - wiedza o swoich cechach, zainteresowaniach, zdolnościach, potrzebach, systemie wartości),

$\rightarrow$ informacjami o wymaganiach edukacyjnych w poszczególnych typach szkół i uczelni oraz sytuacji na rynku pracy, 
$\rightarrow$ umiejętnością konfrontacji (porównania) wyników samopoznania z możliwościami podjęcia nauki i pracy (Parsons, 1909, s. 5).

Samopoznanie jest rozumiane jako rodzaj autodiagnozy, która może być przeprowadzona autonomicznie lub przy wsparciu doradcy (w różnych zakresach). W jej efekcie identyfikuje się mocne i słabe strony ucznia, studenta, pracownika. Drugi czynnik wymaga swobodnego operowania zbiorami dostępnych informacji natury edukacyjnej i rynkowej - jest to z reguły domena doradców edukacyjno-zawodowych. Porównanie efektów samopoznania z paletą ofert edukacyjnych i zawodowych jest najtrudniejszym czynnikiem omawianej teorii. Stawia on przed doradcą zadanie, do którego realizacji, obok rozległej wiedzy o instytucjach edukacyjnych i przedsiębiorstwach funkcjonujących na lokalnym i globalnym rynku pracy, niezbędne są także praktyczne umiejętności psychologiczne (szczególnie interpersonalne).

Teoria cechy i czynnika była inspiracją do opracowania i wdrożenia do praktyki teorii osobowości zawodowej (Holland, 1985). Zakłada ona, że każdą osobę można przyporządkować jednemu typowi osobowości zawodowej lub ewentualnie kilku:

$\rightarrow$ realistycznemu,

$\rightarrow$ badawczemu,

$\rightarrow$ artystycznemu,

$\rightarrow$ społecznemu,

$\rightarrow$ przedsiębiorczemu,

$\rightarrow$ konwencjonalnemu.

Zgodnie $\mathrm{z}$ tą teorią równolegle $\mathrm{z}$ wymienionymi typami osobowości występują analogiczne typy środowiska pracy, czyli: realistyczne, badawcze, artystyczne, społeczne, przedsiębiorcze i konwencjonalne.

Samopoznanie, o którym była wcześniej mowa, pozwala na zidentyfikowanie dominującego typu osobowości zawodowej, a następnie wskazanie odpowiadającego mu typu środowiska pracy. W tym miejscu pojawia się pojęcie dopasowania, którego najwyższy stopień jest związany z jednorodnością typów: osobowości zawodowej i środowiska pracy (np. typ realistyczny - środowisko realistyczne), a najniższy z przeciwieństwem obu typów (np. typ realistyczny - środowisko społeczne). Wynika to $z$ analizy tzw. modelu heksagonalnego obrazującego „odległości" między omawianymi typami (Paszkowska-Rogacz, 2003, s. 40). 
Teoria osobowości zawodowej, z pewnymi modyfikacjami wynikającymi z analiz rynku pracy, jest wciąż stosowana przez doradców edukacyjno-zawodowych. Wprawdzie w swojej nazwie akcentuje pojęcie zawodu, ale biorąc pod uwagę to, że do konkretnego zawodu lub grup zawodów prowadzą równie konkretne drogi edukacyjne, można ją traktować szerzej - jako teorię odnoszącą się do doradztwa edukacyjno-zawodowego (Kwiatkowski, S.T., 2013, s. 106-107).

\section{Typologia doradców edukacyjno-zawodowych}

Praca doradcy edukacyjno-zawodowego przybiera postać ciągłych (cyklicznych) relacji z osobami poszukującymi profesjonalnego wsparcia w czasie dokonywania wyboru szkoły, uczelni czy miejsca pracy. Charakter tych relacji wymaga integracji dwóch konstytutywnych cech zawodu doradcy: wiedzy zawodowej i cech osobowości, wyrażających się poprzez umiejętności interpersonalne.

Biorąc pod uwagę cechy osobowości, przy założeniu wysokiego poziomu wiedzy zawodowej, możemy wśród doradców edukacyjno-zawodowych spotkać:

$\rightarrow$ ekspertów skupionych na problemie, traktujących osobę, której doradzają, w sposób przedmiotowy (doradztwo dyrektywne),

$\rightarrow$ informatorów gromadzących i przetwarzających informacje pochodzące z różnych źródeł z myślą o osobie poszukującej pomocy w swoich wyborach edukacyjno-zawodowych (doradztwo dyrektywne),

$\rightarrow$ konsultantów uwrażliwionych na oczekiwania i potrzeby swoich partnerów, dążących do ich możliwie pełnego poznania oraz zaangażowania w proces doradczy (doradztwo dialogowe),

$\rightarrow$ opiekunów koncentrujących się przede wszystkim na osobie, której doradzają, na stwarzaniu warunków sprzyjających samodzielnemu podejmowaniu decyzji (doradztwo liberalne).

Przytoczona typologia za kryterium podziału doradców przyjmuje rodzaj i poziom ich współpracy z osobami, którym udzielane jest wsparcie - od braku partnerstwa we wzajemnych relacjach do pełnego partnerstwa. W rzeczywistości można raczej mówić o dominującym typie doradcy lub o doradcy, który w zależności od sytuacji, w tym od oczekiwań i cech osobowości osoby, której doradza, zmienia typ pracy lub łączy typy w celu osiągnięcia pożądanego rezultatu (por. Wołk, 2006, s. 195-197). 


\section{Metody, techniki i narzędzia stosowane w pracy doradcy edukacyjno-zawodowego}

Podstawową metodą wykorzystywaną w pracy doradcy edukacyjno-zawodowego jest diagnoza (metoda diagnostyczna). Umożliwia ona otrzymanie odpowiedzi na pytania o aktualny stan wiedzy, umiejętności i kompetencje społeczne osoby zgłaszającej się po pomoc i wsparcie. Przypomnijmy $w$ tym miejscu, że do diagnozy prowadzi znane już z teorii cechy i czynnika samopoznanie. Pozwala ono na podjęcie dialogu $z$ doradcą edukacyjno-zawodowym, mającego na celu przygotowanie w pierwszej kolejności diagnozy klasyfikacyjnej, a następnie diagnozy genetycznej, celowościowej i wreszcie diagnozy fazy. Na podstawie tych cząstkowych diagnoz można już przygotować tzw. diagnozę rozwiniętą, będącą punktem wyjścia do opracowania prognozy, czyli określenia realnych możliwości rozwiązania problemu doradczego (Wołk, 2006, s. 217-220).

W metodzie diagnostycznej, która ma cechy znanej w naukach społecznych metody indywidualnego przypadku, stosuje się w praktyce wiele technik i narzędzi. Odwołując się do przywołanej wyżej typologii doradców i doradztwa, możemy wyróżnić techniki specyficzne dla:

$\rightarrow$ doradztwa dyrektywnego,

$\rightarrow$ doradztwa dialogowego,

$\rightarrow$ doradztwa liberalnego.

W doradztwie dyrektywnym przeważają takie techniki jak:

$\rightarrow$ kierowanie (doradca dominuje nad radzącym się, steruje nim),

$\rightarrow$ zadawanie pytań (często trudnych - bez wczuwania się w sytuację osoby oczekującej pomocy),

$\rightarrow$ przekonywanie (do swoich racji-z pozycji eksperta),

$\rightarrow$ perswazja (skłanianie do podjęcia decyzji zgodnych z oczekiwaniami doradcy),

$\rightarrow$ pouczanie (dawanie wskazówek bez głębszego zrozumienia sytuacji, w jakiej znalazła się osoba potrzebująca rady).

Dla doradztwa dialogowego charakterystyczne są poniższe techniki:

$\rightarrow$ stymulowanie narracji (formułowanie pytań pomagających w samopoznaniu),

$\rightarrow$ interpretowanie narracji (wyjaśnianie znaczenia przytaczanych faktów i wygłaszanych opinii), 
$\rightarrow$ partnerstwo w rozwiązywaniu problemów (od nawiązania odpowiednich relacji do przygotowania procedur działania),

$\rightarrow$ konsultacja (dyskusja o problemach i ich uwarunkowaniach),

$\rightarrow$ porada (jako efekt końcowy dialogu).

Z kolei $w$ doradztwie liberalnym mamy do czynienia $z$ technikami polegającymi na:

$\rightarrow$ aktywnym słuchaniu (sprzężenie zwrotne informujące o zainteresowaniu doradcy przedstawianym problemem - narracją),

$\rightarrow$ obserwowaniu (bezpośrednim lub pośrednim - z wykorzystaniem arkusza obserwacji lub dziennika obserwacji),

$\rightarrow$ wspieraniu (akceptacji, tworzeniu warunków do wyrażania uczuć, opinii) (Wojtasik, 2004, s. 91-105).

Uniwersalnymi technikami stosowanymi zarówno przez doradców dyrektywnych, jak i dialogowych oraz liberalnych są ankieta i wywiad. Ankieta jest techniką kojarzoną przede wszystkim z metodą sondażu diagnostycznego. W przypadku codziennej pracy doradcy edukacyjno-zawodowego służy ona do gromadzenia danych pomocnych w procesie przygotowywania diagnozy stanu osoby potrzebującej porady i wsparcia. Właściwie przygotowana ankieta (pytania ankietowe) pozwala na uzyskanie w stosunkowo krótkim czasie obszernego materiału badawczego opisującego badaną osobę lub zjawisko wymagające podjęcia decyzji. Wywiad jest stosowany na ogół w celu pogłębienia danych uzyskanych techniką ankiety. Może przybierać formę swobodnej wypowiedzi na zadane przez doradcę pytanie (przedstawiony problem) lub odpowiedzi na pytania zawarte w kwestionariuszu wywiadu - sformułowane z myślą o wzbogaceniu danych otrzymanych podczas ankietowania.

W przyjętej konwencji terminologicznej narzędziami stosowanymi przez doradcę edukacyjno-zawodowego są kwestionariusze ankiety i wywiadu. Analizując metody pracy doradcy edukacyjno-zawodowego, warto odnotować, że do diagnozy rozwiniętej może prowadzić coraz częściej stosowana metoda bilansu kompetencji. W jej strukturze można wyróżnić kilka podstawowych etapów:

$\rightarrow$ wstępny (poznanie procedury bilansu przez osobę potrzebującą porady),

$\rightarrow$ badawczy (analiza drogi społeczno-zawodowej osoby badanej, identyfikacja poziomu jej wiedzy, umiejętności i kompetencji 
społecznych, porównanie charakterystyki osoby badanej z występującymi w bliższym i dalszym otoczeniu typami działalności zawodowej - przemysł, rolnictwo, usługi - oraz określenie kierunków niezbędnych zmian związanych z osobą badaną i jej środowiskiem społecznym, a także zawodowym),

$\rightarrow$ rekomendacji (przedstawienie możliwości nauki lub/i pracy, wskazanie obszarów wiedzy, umiejętności i kompetencji społecznych wymagających uzupełnień oraz modyfikacji) (por. Trzeciak, 2004, s. 148-152).

Jak widać, jest to w swojej istocie metoda nawiązująca do teorii cechy i czynnika. Przedmiotem porównań są bowiem, zgodnie z tą teorią, kompetencje. Bilans dotyczy zależności między kompetencjami rzeczywistymi danej osoby (osoby badanej metodą bilansu kompetencji) a kompetencjami pożądanymi z punktu widzenia szkoły, uczelni, przedsiębiorstwa.

\section{Standard kompetencji/kwalifikacji doradcy edukacyjno-zawodowego}

Standard kompetencji/kwalifikacji jest minimalnym poziomem wiedzy, umiejętności i kompetencji społecznych, który może być zaakceptowany przez środowisko edukacji lub/i pracy. Badania nad standardami, ich strukturą i treścią, polegają na możliwie precyzyjnej identyfikacji oczekiwań szkół, uczelni, przedsiębiorstw, formułowanych w stosunku do uczniów, studentów, pracowników (Kwiatkowski, S.M., 2012, s. 169-170). W ten sposób powstał również standard kompetencji/kwalifikacji doradcy zawodowego (a właściwie edukacyjno-zawodowego).

Aktualnie stosowany standard kompetencji/kwalifikacji doradcy edukacyjno-zawodowego składa się z następujących elementów:

$\rightarrow$ podstawy prawne wykonywania zawodu (np. ustawa $z$ dnia 20 kwietnia 2004 r. o promocji zatrudnienia i instytucjach rynku pracy - Dz.U. nr 99 z dnia 1 maja 2004 r., poz. 1001),

$\rightarrow$ syntetyczny opis zawodu (istota działalności, zasady pracy),

$\rightarrow$ stanowiska pracy (wykaz stanowisk pracy: doradca zawodowy - stażysta, doradca zawodowy, doradca zawodowy I stopnia, doradca zawodowy II stopnia, starszy doradca zawodowy, kierownik referatu/wydziału poradnictwa zawodowego, dyrektor/kierownik centrum informacji i planowania kariery zawodowej),

$\rightarrow$ zadania zawodowe (podstawowy element standardu): 
- udzielanie bezrobotnym i osobom poszukującym pracy indywidualnych oraz grupowych porad ułatwiających wybór zawodu, zmianę kwalifikacji, podjęcie lub zmianę zatrudnienia,

- udzielanie indywidualnych oraz grupowych informacji o zawodach, rynku pracy, możliwościach kształcenia i szkolenia,

- wykonywanie badań zainteresowań i uzdolnień zawodowych z wykorzystaniem standaryzowanych metod,

- opracowywanie diagnoz przydatności zawodowej na podstawie zebranego materiału badawczego,

- gromadzenie, opracowywanie i aktualizacja informacji o zawodach (stanowiskach pracy), możliwościach uzyskania kwalifikacji zawodowych oraz potrzebach rynku pracy,

- prowadzenie dokumentacji osób zgłaszających się po poradę,

- utrzymywanie stałej współpracy z publicznymi służbami zatrudnienia, innymi instytucjami rynku pracy oraz organizatorami kształcenia i szkolenia zawodowego,

- udzielanie informacji i doradzanie pracodawcom w zakresie doboru kandydatów do pracy na stanowiska wymagające szczególnych predyspozycji psychofizycznych oraz dotyczących restrukturyzacji zatrudnienia,

- badanie jakości i kontrola skuteczności wykonania usług doradczych,

$\rightarrow$ składowe kompetencji/kwalifikacji zawodowych (wyróżnione - zintegrowane kompetencje/kwalifikacje),

$\rightarrow$ korelacje między zadaniami zawodowymi a składowymi kompetencji/kwalifikacji zawodowych,

$\rightarrow$ kwalifikacje ponadzawodowe, ogólnozawodowe, podstawowe i specjalistyczne dla zawodu (układy wiedzy, umiejętności i cech psychofizycznych/kompetencji zawodowych, przyporządkowane obowiązującym poziomom kompetencji/kwalifikacji) (Krajowy standard kwalifikacji zawodowych. Doradca zawodowy, 2007).

Komplementarne w stosunku do zadań doradcy edukacyjno-zawodowego wyróżnionych w standardzie są kompetencje, na które zwraca uwagę International Association for Educational and Vocational Guidance:

$\rightarrow$ etyczność i profesjonalność,

$\rightarrow$ umiejętność pracy w grupie i kierowania pracą grupy (chodzi również o grupy wielokulturowe), 
$\rightarrow$ skuteczne stosowanie teorii doradztwa zawodowego (np. omówionych teorii socjologicznych i psychologicznych) w praktyce doradczej,

$\rightarrow$ świadomość własnych ograniczeń (por. Nawrat-Wyraz, 2017, s. 88-89).

Standardy kompetencji/kwalifikacji zawodowych mogą stanowić punkt wyjścia do opracowywania poszerzonych modeli informacji o zawodach. Takie informacje dla tysiąca zawodów są przygotowywane w ramach realizowanego od 2017 r. projektu Ministerstwa Pracy i Polityki Społecznej „Rozwijanie, uzupełnianie i aktualizacja informacji o zawodach oraz jej upowszechnianie za pomocą nowoczesnych narzędzi komunikacji". W projekcie tym, noszącym roboczą nazwę INFOdoradca+, przyjęto, że pełna informacja o zawodach, w tym o zawodzie doradcy edukacyjno-zawodowego, powinna zawierać:

\section{Dane identyfikacyjne zawodu:}

$\rightarrow$ nazwy i kod zawodu (w Klasyfikacji zawodów i specjalności),

$\rightarrow$ nazwy zwyczajowe zawodu,

$\rightarrow$ usytuowanie zawodu w innych klasyfikacjach (z uwzględnieniem Polskiej ramy kwalifikacji i Sektorowej ramy kwalifikacji).

\section{Opis zawodu:}

$\rightarrow$ synteza zawodu,

$\rightarrow$ opis pracy i sposobu jej wykonania,

$\rightarrow$ środowisko pracy (warunki pracy, maszyny i narzędzia pracy, zagrożenia, organizacja pracy),

$\rightarrow$ wymagania psychofizyczne, zdrowotne,

$\rightarrow$ wykształcenie i uprawnienia niezbędne do podjęcia pracy w zawodzie,

$\rightarrow$ możliwości rozwoju zawodowego, potwierdzania/walidacji kompetencji,

$\rightarrow$ zawody pokrewne.

\section{Zadania zawodowe i wymagane kompetencje:}

$\rightarrow$ zadania zawodowe,

$\rightarrow$ kompetencje (wiedza, umiejętności i kompetencje społeczne) niezbędne do realizacji zadań zawodowych, 
$\rightarrow$ odniesienie kompetencji zawodowych do poziomów kwalifikacji Polskiej ramy kwalifikacji i Sektorowej ramy kwalifikacji,

$\rightarrow$ profil kompetencji kluczowych dla zawodu.

\section{Zawód na rynku pracy-możliwości doskonalenia zawodowego:}

$\rightarrow$ możliwości podjęcia pracy w zawodzie,

$\rightarrow$ instytucje oferujące kształcenie, szkolenie lub/i walidację kompetencji w ramach zawodu,

$\rightarrow$ zarobki osób wykonujących dany zawód (daną grupę zawodów),

$\rightarrow$ możliwości zatrudnienia osób z niepełnosprawnościami.

\section{Odniesienie do Europejskiej klasyfikacji umiejętności, kom- petencji, kwalifikacji i zawodów (ESCO).}

\section{6. Źródła dodatkowych informacji o zawodzie.}

\section{Słownik:}

$\rightarrow$ definicje powiązane z opisem informacji o zawodzie,

$\rightarrow$ definicje dotyczące wykonywania zawodu.

Taka struktura informacji o zawodzie doradcy edukacyjno-zawodowego wypełniona konkretną treścią pozwoli z jednej strony na przygotowanie odpowiednich programów kształcenia, a następnie zaproponowanie elastycznych dróg rozwoju zawodowego dla tej grupy zawodowej, z drugiej zaś, w odniesieniu do innych zawodów, dostarczy doradcom edukacyjno-zawodowym materiałów do ich codziennej pracy doradczej.

\section{Zakończenie}

Doradztwo edukacyjno-zawodowe powinno w sposób naturalny towarzyszyć uczniom, studentom, a w kolejnych etapach życia również osobom poszukującym pracy lub zamierzającym zmienić jej charakter. Szczególną rolę w całożyciowym doradztwie ma do odegrania szkoła. To właśnie w niej można i należy zapoczątkować profesjonalnie prowadzony proces wspomagania identyfikacji uzdolnień i zainteresowań dzieci i młodzieży. Wydaje się, że właśnie w tym kierunku zmierzają ustawowe zapisy wprowadzające zajęcia z doradztwa zawodowego do szkół podstawowych, branżowych szkół I stopnia, liceów i techników (Ustawa z dnia 14 grudnia 2016 r. - Prawo oświatowe). 


\section{Bibliografia}

$\rightarrow$ Bauman, Z. (2006), Płynna nowoczesność, Kraków: Wydawnictwo Literackie.

$\rightarrow$ Holland, J.L. (1985), Making vocational choices. A theory of vocational personalities \& work environments, New Jersey: Prentice-Hall Inc.

$\rightarrow$ Kwiatkowski, S.M. (2006), Pedagogika pracy [w]: B. Śliwerski (red.), Pedagogika, t. III, Gdańsk: Gdańskie Wydawnictwo Pedagogiczne, s. 337-252.

$\rightarrow$ Kwiatkowski, S.M. (2012), Standardy kwalifikacji i kompetencji zawodowych [w:] „Studia Pedagogiczne”, t. LXV, s. 163-173.

$\rightarrow$ Kwiatkowski, S.T. (2013), Stopień dopasowania zawodowego studentów pedagogiki w kontekście psychopedagogicznego paradygmatu przystosowania człowieka do pracy [w:] „Ruch Pedagogiczny”, nr 4, s. 101-118.

$\rightarrow$ Lelińska, K. (2004), Znaczenie socjologicznych teorii wyboru zawodu w pacy doradcy zawodowego [w:] H. Bednarczyk, J. Figurski i M. Żurek (red.), Pedagogika pracy. Doradztwo zawodowe, Radom: Wydawnictwo Instytutu Technologii Eksploatacji, s. 114-127.

$\rightarrow$ Ministerstwo Pracy i Polityki Społecznej (2007), Krajowy standard kwalifikacji zawodowych. Doradca zawodowy, Warszawa.

$\rightarrow$ Nawrat-Wyraz, D. (2017), Zadania i kompetencje doradcy zawodowego w procesie przemian - wybrane konteksty [w:] J. Bluszcz (red.), Doradca zawodowy na drodze do profesjonalizmu - oczekiwania a rzeczywistość, Warszawa: Wydawnictwo Akademii Pedagogiki Specjalnej, s. 83-106.

$\rightarrow$ Parsons, F. (1909), Choosing a vocation, London: Gay \& Hancock Ltd.

$\rightarrow$ Trzeciak, W. (2004), Bilans kompetencji-nowa metoda poradnictwa zawodowego [w:] H. Bednarczyk, J. Figurski i M. Żurek (red.), Pedagogika pracy. Doradztwo zawodowe, Radom: Wydawnictwo Instytutu Technologii Eksploatacji, s. $146-163$.

$\rightarrow$ Wojtasik, B. (2004), Wybrane metody i techniki stosowane przez doradcę zawodowego [w:] H. Bednarczyk, J. Figurski i M. Żurek (red.), Pedagogika pracy. 
Doradztwo zawodowe, Radom: Wydawnictwo Instytutu Technologii Eksploatacji, s. 91-105.

$\rightarrow$ Wołk, Z. (2006), Poradnictwo zawodowe w edukacji młodzieży, Zielona Góra: Oficyna Wydawnicza Uniwersytetu Zielonogórskiego. 



\section{Efektywna edukacja. \\ W poszukiwaniu balansu między \\ technologią, kulturą i naturą}

Anna Krzyżanowska

Planowanie i realizacja procesu dydaktycznego z uczniami na każdym szczeblu edukacyjnym to rodzaj sztuki. Jej kreatorem staje się nauczyciel odpowiedzialny zarówno za realizację podstawy programowej przedmiotu, jak i umożliwianie swoim podopiecznym wszechstronnego rozwoju poznawczego i osobistego. Artykuł jest refleksją nad możliwościami i wyzwaniami, przed jakimi stają nauczyciele poszukujący efektywności w prowadzonym procesie nauczania i uczenia się.

\section{Słowa kluczowe}

balans w edukacji

zmiana

natura

kultura

technologia 


\section{An effective education. \\ Searching for the balance between \\ technology, nature and culture}

Anna Krzyżanowska

Setting up an educational process in any educational level is a piece of art. Curriculum is an obligatory frame. Thinking about knowledge, competences, social skills, creativity and participation as important features for students' development makes teaching an extraordinary demanding and challenging task. In this article I am trying to focus on the possibilities and challenges that teachers meet when thinking about effective teaching and learning.

\section{Keywords}

educational balance

change

nature

culture

technology 


\section{Wprowadzenie}

Trudno zaprzeczyć, że XXI w. przyniósł nauczycielom niewyobrażalne dotąd możliwości, szczególnie w obszarze rozwoju, wyboru i tworzenia. Nigdy wcześniej nauczyciele nie dysponowali tak szerokim wachlarzem koncepcji pedagogicznych, wartościowych inicjatyw i metod nauczania skrojonych na miarę każdego etapu nauki. Zasoby edukacyjne w przestrzeni wirtualnej są dosłownie na wyciągnięcie ręki. Potencjał świata cyfrowego jest tak ogromny, że niejednego pedagoga przyprawia o zawrót głowy.

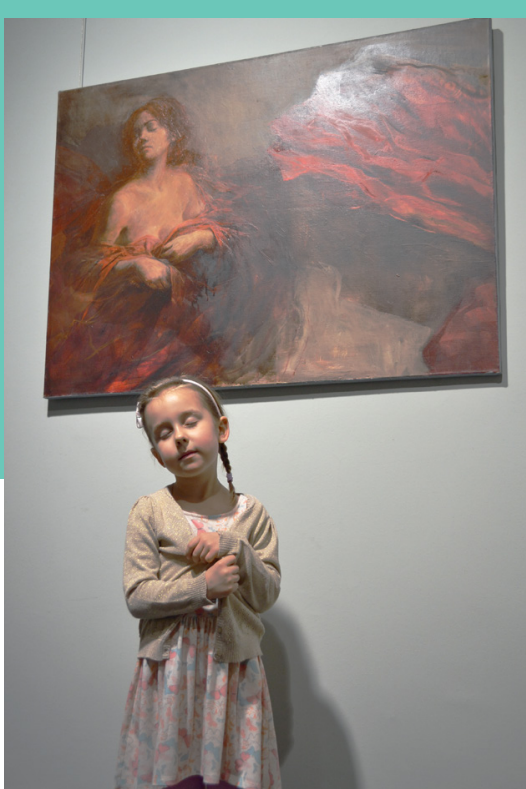

Interpretacja kultury

Nie bez znaczenia jest swobodny dostęp do form doskonalenia zawodowego w trybie stacjonarnym oraz online realizowanych w kraju i za granicą - uwarunkowany nie tyle względami materialnymi, ile chęcią skorzystania z finansowania zewnętrznego, np. z funduszy UE. Jeśli do tej szerokiej perspektywy dodać wiodącą koncepcję pracy szkoły, własne przekonania i doświadczenia pedagogiczne, to można powiedzieć, że refleksyjny nauczyciel znajduje się na prawdziwej huśtawce metodologiczno-filozoficznej (o ile to już nie cywilizacyjny rollercoaster).

W poszukiwaniu optymalnej ścieżki nauczania zdarza się nam rozstrzygać, jak wysoko w hierarchii naszych pedagogicznych priorytetów znajduje się wiedza (osiągana dzięki metodycznym procedurom i trosce o intelektualną dyscyplinę uczniów), a gdzie aktywna postawa ucznia i jego umiejętności (zdobywane poprzez działanie i doświadczanie). Co więcej, w relacji nauczyciel-uczeń wciąż nie jest jasne, kto ma mówić, a kto słuchać. Dylemat dominacji wymiaru ilościowego nad jakościowym w procesie nauczania i ewaluacji efektywności tego procesu jest wciąż aktualny i nierozstrzygnięty.

Świadomość, że dzięki osiągnięciom technologicznym oraz programom, takim jak Erasmus + i eTwinning, przestrzeń klasy czy przedszkolnej sali rozpościera się dosłownie na cały świat, może jednocze- 
śnie zachwycać i przerażać. Jak więc wybrać to, co najważniejsze? Jak zbalansować wszystkie czynniki składające się na sukces pedagogiczny, by nie balansować na krawędzi porażki? Czy dokonany przez nas wybór będzie skutkował efektywnością procesu nauczania i wychowania? A w zasadzie na jakiej efektywności nam zależy? Co właściwie stawiamy sobie za cel, stając codziennie oko w oko z naszymi uczniami?

Ugruntowanie działań pedagogicznych na stabilnych podstawach, określających cel, sposób dążenia do jego osiągnięcia oraz przestrzeń działania, wymaga spojrzenia na edukację z perspektywy zarówno dziecka/ucznia, które doświadcza złożoności otaczającego je świata, jak i nauczyciela, który tę różnorodną rzeczywistość współtworzy. Podejmując się tego zadania, warto sięgnąć do etymologicznego znaczenia słowa edukacja (z łac. educere - wyciągać, wydobywać), rozumianego przez Ryszarda Łukasiewicza jako "wyprowadzanie na jaw tego, co w człowieku ukryte, ale jego własne" (Łukaszewicz, 1995, za: Wollman-Mazurkiewicz, 2000, s. 190). Jest zatem z zasady ukierunkowana na "podmiotowe ujawnianie i rozwijanie ludzkiego potencjału, jego indywidualnych możliwości" (Wollman-Mazurkiewicz, 2000, s. 190). Według prof. Łukasiewicza edukacja ma być narzędziem, dzięki któremu człowiek zachowuje równowagę z otaczającym go światem, pełnym różnorakich związków i współzależności. Poznanie świata polega jednak nie tylko na percepcji otoczenia, jego werbalnym opisie i odtwórczej reakcji na płynące z niego bodźce. Wymaga otwartości na samodzielną interpretację, adekwatną do dziecięcych emocji i wyobrażeń inicjowanych poprzez elementy eksplorowanej natury i kultury (tamże).

Sposobem nauczania uznanym przez prof. Łukasiewicza za efektywny i stymulujący potencjał twórczy ucznia jest projektowanie okazji edukacyjnych rozumiane jako "tworzenie okazji do działania, ale bez zakładania, co i jak dzieci zrobią, co powiedzą, co stworzą" (Dzikie życie, 2010). Stawianie przed uczniami zadań otwartych, w których dopuszcza się różnorodne rozwiązania i sposoby dochodzenia do nich, ma, poza rozwijaniem funkcji poznawczych, stymulować potencjał twórczy dziecka i wpływać na jego poczucie sprawstwa, skutkujące odwagą do podejmowania kolejnych wyzwań edukacyjnych.

Stawianie wyzwań przed dziećmi, adekwatnych do ich możliwości, lecz wymagających wysiłku i zaangażowania, wpływa bezpośrednio na ich gotowość do pokonywania przeszkód, nie tylko edukacyjnych, 
W przyszłości. W myśl sentencji: „Nie zabieraj dziecku kamieni spod nóg, bo gdy dorośnie, potknie się o ziarenko piasku", każde (większe, mniejsze, przyjemne czy przykre) doświadczenie pozwala młodemu człowiekowi stawiać kolejne kroki w rozwoju. Dzięki nim poznaje własne możliwości, sposoby reakcji innych ludzi, odkrywa zjawiska zachodzące w najbliższym środowisku, budując tym samym własną relację ze światem.

Obecnie szkoła nastawiona jest na to, by uczeń skrzętnie zarejestrował obraz świata. Niby zwalczamy encyklopedyzm, ale nasze podręczniki pełne sq faktów, wytłuszczonych informacji, ramek, które wyraźnie wskazują: zapamiętaj. Nauczanie w wykonaniu większości nauczycieli to pas transmisyjny: ja, nauczyciel, mówię ci, co masz zapamiętać, bo tak to jest. Dlatego też jeżeli mamy zastanawiać się nad zmianq podejścia do edukacji i jej praktyki, koniecznym jest wyjście od zmiany, jaka dokonała się w rozumieniu świata $w$ ogóle.

Ryszard Łukasiewicz

(Dzikie życie, 2010)

Jeśli dążymy do rozumienia świata jako środowiska ustawicznego uczenia się, to musimy wziąć pod uwagę poszczególne elementy otaczającej rzeczywistości, w której funkcjonują i dorastają nasi uczniowie. Należą do nich: środowisko rodzinne dziecka, przedszkole/szkoła, świat cyfrowy, świat kultury i natury. Bez względu na to, czy dostrzegamy w tych elementach świata perspektywę interakcji czy swoistej „wojny światów", one istnieją, wzajemnie na siebie oddziałują i mają wpływ na całościowy rozwój nowego pokolenia.

Słusznie więc o szerokim zasięgu nowoczesnej edukacji wypowiada się Stanisław Drzażdżewski, przekonany, że „nie można redukować jej do przestrzeni szkoły” (Drzażdżewski, 2013, s. 2). W jego opinii: „Szkoła i klasa nie są jedynymi miejscami uczenia się. W wysoko rozwiniętym społeczeństwie edukacja jest obecna niemal wszędzie" (tamże). Również w opinii Lidii Wollman-Mazurkiewicz wspomnianego miejsca i czasu edukacji „nie ogranicza przestrzeń klasy czy dzwonek na przerwę. Wiedzę najlepiej zdobywać u źródeł, a więc w parku, lesie, na łące, w tartaku, muzeum czy wiejskiej zagrodzie. Zawsze tam, gdzie istnieje problem do zbadania" (2000, s. 191). Idąc tym tokiem rozumowania, 
traktowanie budynku przedszkola i szkoły jako dominującego środowiska rozwoju zawęża przestrzeń wychowawczą i poznawczą ucznia. Mówiąc dosadniej - rezygnacja z zasobów edukacyjnych dostępnych w kontakcie ze środowiskiem oraz światem cyfrowym zubaża proces nabywania kompetencji niezbędnych do życia w społeczeństwie XXI w.

Uczestnicy warsztatu „Efektywna edukacja: w poszukiwaniu balansu pomiędzy technologią, kulturą i naturą", który został zorganizowany podczas ogólnopolskiej konferencji naukowej „Szkoła w świecie zmian i nowych technologii" w Zakopanem (21-22 maja 2018 r.), wypowiadali się o korzyściach płynących z aktywności uczniów w różnorodnej rzeczywistości poznawczej, próbując odpowiedzieć na pytanie, na ile wychodzą one naprzeciw ich potrzebom. Dzielili się także wątpliwościami co do zagrożeń wynikających z nadmiernej koncentracji nauczycieli na poszczególnych elementach świata. Refleksje nauczycieli nad rzeczywistością szkoły i przedszkola, światem cyfrowym, kulturą i naturą w edukacji są uwzględnione $w$ dalszej części artykułu.

\section{Środowisko rodzinne dziecka}

Mimo często szerokiego zakresu współpracy przedszkola czy szkoły z rodzicami środowisko rodzinne ucznia należy to tych przestrzeni rozwojowych, na które nauczyciele mają najmniejszy wpływ. Dom jest enklawą osobistych przekonań i doświadczeń, z których wynikają stosowane przez rodziców metody wychowawcze. Nawet jeśli wydaje się nam, nauczycielom, że metody te są nieskuteczne lub wręcz ich brak, to przejmowanie przez nauczycieli obowiązku wychowania dzieci i młodzieży nie ma szans na powodzenie. Oczywiście powinno nam zależeć na otwartych relacjach z rodzicami, bo bez nich trudno zbudować przestrzeń do współpracy i uruchomić realny proces interakcji tych dwóch, jakże odmiennych światów, jednak trzeba mieć na uwadze, że istnieje fizyczny i metaforyczny próg domu, którego nauczyciel nie jest w stanie przekroczyć. Tam realne oddziaływanie na dzieci należy już głównie do rodziców.

Wracając jednak do rzeczywistości przedszkolnej i szkolnej, warto zastanowić się nad tym, czy projektując swoją przestrzeń wychowawczą, bierzemy pod uwagę to, na czym realnie najbardziej zależy uczniom lub ich rodzicom. Obserwując w mediach społecznościowych wpisy publikowane bezpośrednio po zakończeniu roku szkolnego, można odnieść wrażenie, że oczekiwania rodziców kończą się na kolekcji 
pozytywnych ocen dziecka na świadectwie, okraszonych biało-czerwonym paskiem. Wszyscy jednak wiemy, że oceny te przekładają się wprost proporcjonalnie na sukces dziecka i jego przyszły samodzielny start w dorosłość. Wystarczy zapytać rodziców, czego pragną dla swoich dzieci, i bardzo szybko wychodzimy ze strefy ocen, a nawet not z zachowania. Rodzice mówią jasno i wprost: chcemy, by dzieci wyrosły na dobrych, mądrych ludzi, by znalazły kogoś, kto będzie je kochał i wspierał. Rodzice chcą, żeby ich dzieci znalazły ciekawe zajęcie w życiu lub - inaczej to ujmując - by miały satysfakcjonującą pracę. Wszystko po to, by nie musiały się martwić o pieniądze, albo raczej po to, by były szczęśliwe.

A my, nauczyciele, na jakich rezultatach koncentrujemy cały swój intelektualny i twórczy potencjał? Czemu poświęcamy czas i zaangażowanie? Wspomniano w tym artykule już o dawaniu uczniom okazji do mówienia, czego oczekują od nauczycieli, czego chcieliby się nauczyć w szkole, a nawet wcześniej - już w przedszkolu. Warto o tym pamiętać, chociażby by uświadomić sobie to, co jest dla nich istotne. Wielowątkowy wywiad $z$ dziećmi w wieku od trzech do sześciu lat, poruszający zagadnienia partycypacyjne, przeprowadzono w 2016 r. wśród dzieci z Przedszkola nr 48 z Oddziałami Specjalnymi i z Oddziałami Integracyjnymi w Zabrzu, w ramach projektu Erasmus + Through democracy to literacy. Jedno z pytań wywiadu odnosiło się do tego, co dzieci chciałyby robić lub czego chciałyby się nauczyć w przedszkolu1. Z odpowiedzi dowiemy się, że poza umiejętnościami czytania i pisania, które są dla dzieci bardzo ważne, chciałyby one także uczyć się mówić po francusku, grać w szachy, obserwować ptaki, ślimaki i motyle, robić bransoletki, puszczać papierowe samoloty, nauczyć się pić wodę z kubka, robić fikołki do tyłu i się huśtać. Czy tego rodzaju dziecięce pragnienia traktujemy poważnie podczas kreowania przestrzeni edukacyjnej i sytuacji poznawczej? Czy stają się one naszym drogowskazem i inspiracją, czy traktujemy je jedynie jako dziecięce fantazjowanie?

\section{Cyfrowa rzeczywistość}

Jakikolwiek mamy pogląd na cyfrową rzeczywistość w edukacji, bez względu na to, czy skupiamy się na jej potencjale czy zagrożeniach, bez 
względu na stopień wyposażenia technologicznego placówki, a w końcu bez względu na etap edukacji, w jakim przychodzi nam funkcjonować, bez wątpienia cyfrowy świat istnieje. Co więcej, jest strefą szerokiego zasięgu

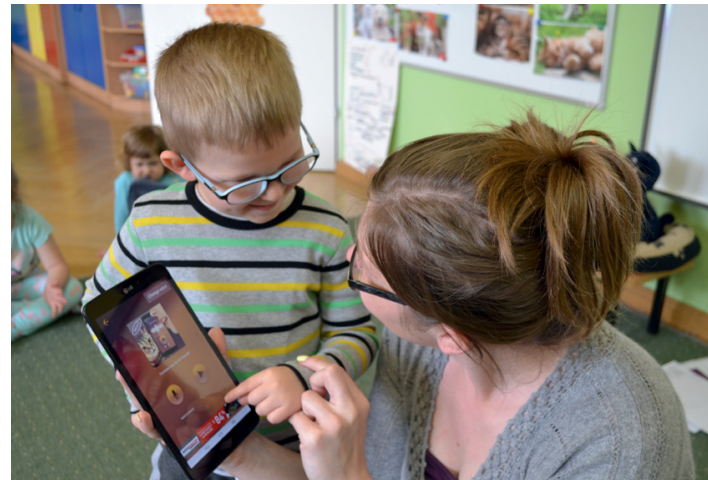

Nowe technologie używane w przedszkolu i możliwości. Nie sposób przechodzić obok niego obojętnie, gdyż będzie nieodłącznym elementem funkcjonowania naszych uczniów w przyszłości, na dodatek w formacie, którego jeszcze nie znamy i może nawet nie potrafimy sobie wyobrazić. Nauczyciele doskonale zdają sobie z tego sprawę. Z jednej strony dostrzegają negatywne zjawiska, jakie niesie dla uczniów wirtualna rzeczywistość, i chodzi tu nie tylko o niepożądane kontakty i treści, hejt czy cyfrowy ekshibicjonizm, lecz także plagiat zasobów sieciowych, pasywność ucznia oraz pozbawione refleksji przyjmowanie niezweryfikowanych informacji. Z drugiej strony nauczyciele doceniają powszechny dostęp do wiedzy oraz możliwość percepcji miejsc i zjawisk, które są na co dzień niedostępne naszym oczom i uszom. Zdają sobie sprawę z potencjału wirtualnej przestrzeni (wykreowanej w postaci stron WWW), służącej wymianie zdań, dzieleniu się wiedzą oraz nawiązywaniu międzyludzkich kontaktów czy podtrzymywaniu przyjaźni.

To niezaprzeczalne perspektywy rozwoju poznawczego i osobistego dla nas samych i naszych uczniów. Wydawałoby się więc, że - jak pisze Lechosław Hojnacki - „wachlarz możliwości mobilnych technologii powinien owocować ich szerokim upowszechnieniem w edukacji", tymczasem, z uwagi na wspomniane obawy nauczycieli, „są one często używane w szkole w stopniu symbolicznym, w żaden sposób nieodzwierciedlającym ich potencjału edukacyjnego ani powszechności poza murami szkoły" (Hojnacki, 2014, s. 66).

Celem propagatorów przestrzeni cyfrowej w edukacji nie jest jednak „zamiana monopolu technologii tradycyjnych na monopol technologii cyfrowych" (Hojnacki, 2014, s. 65). Jak zauważa Hojnacki, „nie pretendują one do zdominowania całego życia, ale są idealnym asystentem 
ucznia i nauczyciela. Nie mają wypełniać całych lekcji, a tylko być pod ręką na żądanie" (tamże). Jednym słowem, jeśli będzie dla nich miejsce w edukacji, to mogą stać się jej naturalnym sprzymierzeńcem. Dobrze, że uczymy się programowania i kodowania, bo tym samym stawiamy technologie na właściwym miejscu - jako poddane ludziom i mające służyć zaspokajaniu ich potrzeb i oczekiwań. Warto pamiętać i przypominać uczniom, że nie potrzebujemy ich do myślenia, kreowania ani budowania wyobrażeń. Do myślenia nie potrzeba bowiem maszyny. Jesteśmy królami swojej głowy. Ona, tak jak komputer, zrobi tyle, na ile jej pozwolimy.

\section{Strefa kultury}

Rudolf Seitz, propagator wielozmysłowej eksploracji świata, zwraca uwagę na silny związek między spostrzeganiem otaczającej dziecko rzeczywistości a odnajdywaniem swojego miejsca w świecie. Dzięki bezpośredniemu kontaktowi z otoczeniem, przedstawiającym się dziecku poprzez przedmioty, barwy, kształty i wszelkie bodźce zmysłowe, w tym dobra szeroko rozumianej kultury, zachodzi twórczy proces rozumienia własnej osoby. Dziecko z początkowego świadka staje się współtwórcą otoczenia, dostrzegając możliwość wprowa-

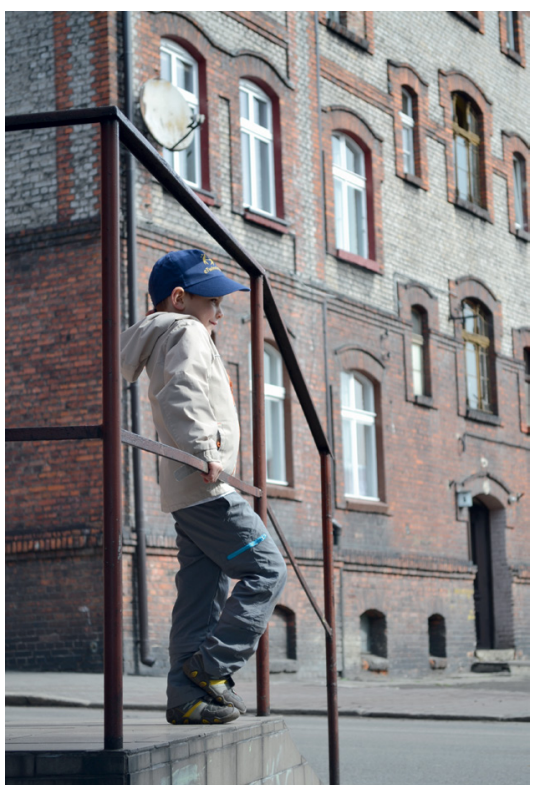

Tożsamość z przestrzenią dzania w nim zmian, aktywnej partycypacji w środowisku, w którym przebywa na co dzień i dorasta. Seitz uważa, że nauczyciele w dzisiejszych czasach znajdują się $w$ łatwiejszej, a zarazem trudniejszej sytuacji niż wychowawcy poprzednich pokoleń. W świecie, w jakim dorastają dzieci i uczniowie, dostarczającym tak wielu bodźców wizualnych, przechodzą oni nieustanny trening w patrzeniu. Jednocześnie, jak pisze autor, „tracą coś innego: umiejętność dokładnego obserwowania przedmiotów, zależności, społecznych warunków i rzeczywistości oraz ich krytycznego 
oceniania" (Seitz, 2001, s. 11). Nie sposób się z tym nie zgodzić. W środowisku zarówno miejskim, jak i wiejskim funkcjonujemy w szeroko pojętej strefie kultury, obejmującej dziedzictwo kulturowe, bezcenne z punktu widzenia historii i tożsamości miejsca czy regionu, ośrodki kultury (muzeum, teatr, kino, filharmonia, galeria sztuki, biblioteka itp.) czy restauracje, sklepy i punkty usługowe, a także stadion, siedziby służb mundurowych czy lokalnych przedsiębiorstw. Ośrodki te można bez wątpienia potraktować również jako nośniki wiedzy z różnych dziedzin życia, a co więcej z wielu obszarów podstawy programowej czy programów nauczania przedmiotowego. Nauczyciele analizujący korzyści płynące $z$ bezpośredniego kontaktu uczniów z zasobami kultury wskazali na jego pozytywne konsekwencje: poszerzanie horyzontów, kształtowanie tożsamości, rozbudzanie zainteresowań, poznawanie i aktywny odbiór różnych form kultury. W ich ocenie równie ważny jest także aspekt prospołeczny (budowanie więzi, kultura wpływająca na integrowanie się grupy) oraz behawioralny (widoczny we wzroście zachowań empatycznych, poznawaniu norm etycznych czy umiejętności kulturalnego zachowania się w miejscach projekcji kultury).

Udział w życiu kulturalnym dostępnym w bliższym lub dalszym otoczeniu może być jednak utrudniony z przyczyn zarówno finansowych, jak i organizacyjnych. Z doświadczeń nauczycieli wynika, że w ocenie innych członków społeczności szkolnej uczestnictwo w wycieczce czy spektaklu o walorach kulturowych może być waloryzowane negatywnie - jako strata czasu wobec dydaktycznej wartości standardowej lekcji lub jako działająca na niekorzyść innej klasy nieobecność nauczyciela skutkująca zastępstwem (przerwaniem ciągłości dydaktycznej przedmiotu). Z pewnością w uprzywilejowanej sytuacji są nauczyciele w przedszkolach i edukacji wczesnoszkolnej, dla których wizyta w pobliskiej bibliotece, teatrze, na stadionie piłkarskim czy w osiedlowych punktach usługowych w naturalny sposób wpisuje się w podstawę programową i jest mile widzianym uzupełnieniem zajęć programowych, a nawet nieodłącznym elementem programu dydaktyczno-wychowawczego. Nauczyciele na kolejnych etapach edukacji, o ile są przekonani o słuszności podejmowanych działań prokulturowych, z pewnością są w stanie skłonić swoich zwierzchników do ułatwień organizacyjnych w szkole, tak aby bilans korzyści i strat miał charakter dodatni. 
Natura ludzkiej egzystencji wymaga, aby człowiek był w nieprzerwanym kontakcie ze światem zewnętrznym. Człowiek jest bowiem częściq świata i czy mu się to podoba, czy nie, istnieje wzajemny wpływ jego osoby i tego, co zewnętrzne. Jednak to człowiek jest aktywnym elementem tego kontaktu. To on w tym kontakcie szuka tego, co dla niego ważne, istotne, niezbędne.

(Michałowski, 2000, s. 101)

Pozostaje więc wierzyć, że wychowanie do kultury pozwoli na zbudowanie wewnętrznej motywacji młodego człowieka do korzystania z jej zasobów i być może pomoże mu w naturalny sposób przeobrazić się z odbiorcy w kreatora sztuki, wpływającego swą twórczością na kolejne generacje. Refleksyjne zetknięcie z kulturą jest niezbędne także do zachowania związku między przeszłością, teraźniejszością i przyszłością, aby uczniowie mieli świadomość, skąd przychodzą, gdzie są, i by kierowali się w stronę, w którą chcą podążać.

\section{Świat natury}

Dzieci i dorośli spędzają dziś ok. 90 proc. czasu w domach, szkołach, instytucjach, sklepach i miejscach pracy. Cztery ściany naszego domu niepostrzeżenie, dzięki dostępowi do Internetu, mogą stać się centrum wszechświata - miej-

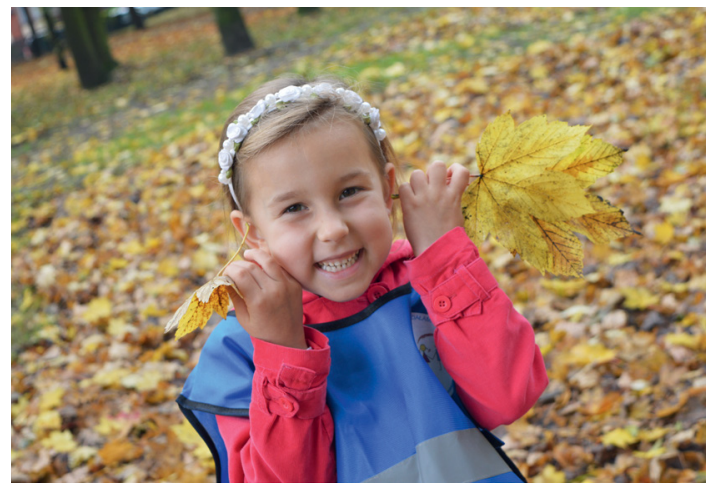

Blisko natury scem, z którego nie trzeba wyjść, by załatwić sprawy urzędowe, zrobić zakupy, zamówić jedzenie, być w kontakcie ze znajomymi lub zapewnić sobie rozrywkę. Egzystencja w przestrzeni "wewnątrz" w tak znacznym zakresie może pozbawiać nas wystarczającej ilości światła słonecznego i świeżego powietrza, co wpływa negatywnie nie tylko na zdrowie i dobre samopoczucie, lecz także na umiejętność uczenia się. Zjawisko zainspirowało badaczy do nadania całemu pokoleniu nieformalnego przydomka Indoor Generation (z ang. generacja wewnątrz). Znaczące wideo obra- 
zujące skalę i konsekwencje tego zjawiska jest dostępne w Internecie i rzeczywiście skłania do zastanowienia się nad perspektywą cywilizacyjnego zamknięcia przestrzeni z własnego wyboru oraz potrzebą zmiany podejścia wobec świata zewnętrznego².

Podobną refleksją dzieli się Bronisława Dymara, która stwierdza, że "przyroda w życiowym pościgu za konsumpcją doskonałą, w jego karierze, staje się coraz bardziej mało znaczącym tłem życia lub co najwyżej źródłem tlenu" (Dymara, 2000, s. 16). Szukając remedium na tę sytuację, autorka postuluje, by w swojej filozofii życia i poszukiwania wiedzy "zastosować motto Festina lente, czyli spiesz się powoli, bo wtedy więcej przeżyjesz, spotkasz, zobaczysz, zrozumiesz" (tamże, s. 15). Ma ono szczególne znaczenie w odniesieniu do budowania więzi z naturą i traktowania jej jako źródła poznania. Powinno być ono brane pod uwagę także przez nauczycieli, kreujących sytuacje edukacyjne w kontakcie z najbliższym otoczeniem przyrodniczym dziecka tak, by „przyroda otaczająca dziecko nigdy nie stała się obojętnym tłem, lecz była zawsze elementem życia, celem poznania, przedmiotem zainteresowań, może nawet pasją" (Dymara, 2000, s. 16).

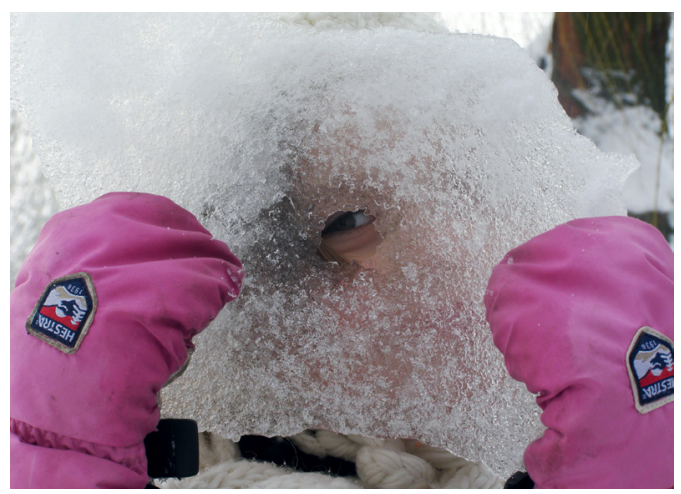

Percepcja świata

Korzyści płynące $z$ samego kontaktu z naturą wydają się oczywiste. Nauczyciele dostrzegają pozytywny wpływ natury na zdrowie i kondycję psychiczną, fizyczną i emocjonalną uczniów. W ich ocenie wprowadza ona większą równowagę dzięki bieżącemu zaspokajaniu potrzeby ruchu dziecka i zapewnieniu mu pozytywnych bodźców wzrokowych. W sposób bezpośredni odrywa dziecko choć na chwilę od świata cyfrowego, co może mieć duże znaczenie w przypadku braku zdroworozsądkowego podejścia do cyfrowych limitów czasowych. Zdaniem nauczycieli debatujących na temat tego zagadnienia podczas 
konferencji naukowej "Szkoła w świecie zmian i nowych technologii” w Zakopanem kontakt z naturą wpływa na kształtowanie instynktu opiekuńczego i wrażliwości na zwierzęta, przynosi poczucie bycia integralną częścią przyrody, co skutkuje rozumieniem konieczności dbania o nią na miarę swoich możliwości.

Ważne też, by pamiętać o traktowaniu przyrody jako uniwersalnego źródła pozyskiwania wiedzy, co więcej-by dostrzegać w naturze i tym, co nas otacza (nawet w samym centrum ruchliwego miasta), potencjał przenoszenia treści nauczania na grunt praktyczny. I nie mówimy tutaj jedynie o nauczaniu przyrody, ale niemalże o wszystkich zagadnieniach, przedmiotach, sferach rozwojowych. Medium dydaktycznym może być dosłownie wszystko dookoła nas. Najbliższe środowisko (np. park, łąka, pola uprawne, ścieżka między blokami) wręcz zalewa nas bogactwem kształtów, barw, relacji przestrzennych, zestawieniami cyfr i liter. W naturalny sposób można przełożyć je na zjawiska matematyczne czy językowe - przeliczanie, klasyfikowanie, mierzenie i ważenie, porównywanie i wnioskowanie, analizę i syntezę czy działania słowotwórcze. Na łonie natury z równym powodzeniem co $w$ sali gimnastycznej można zrealizować tor przeszkód i biegi przełajowe. Motorem edukacji, zwanej w tym kontekście edukacją "na zewnątrz", będzie więc "wszystko, co dostarcza bezpośrednie doświadczenia $z$ autentycznym środowiskiem ucznia, kreatywne działanie z dostępnym w otoczeniu materiałem oraz zapewnia aktywną partycypację uczestników aktywności i współdziałanie (Dahlgren, Szczepanski, 2005, s. 26; tłum. aut.).

Zaprojektowane przez nauczyciela aktywności inspirowane środowiskiem przyrodniczym to nie koniec mocy natury. Dahlgren i Szczepanski znajdują żartobliwe określenie współczesnego człowieka - homo urbaniensis, oznaczające, że poprzez odseparowanie od natury zapomina on, jak dalece można zachwycić się jej bogactwem. „Tymczasem daje nam ona szanse spotkania "nieoczekiwanego « i uczenia się sytuacyjnego. Wówczas prawdziwie poznajemy najbliższe środowisko - drogą zmysłową, poprzez jego najmniejsze elementy, w sposób całościowy i refleksyjny" (Dahlgren, Szczepanski, 2005, s. 48, tłum. aut.). Dahlgren i Szczepanski zwracają przy tym uwagę, że istnieje znacząca różnica między wiedzq o czymś (knowing about something) a poznaniem czegoś (knowing something). Pytanie tylko, na czym nam, nauczycielom, zależy bardziej. 
Warto jeszcze przytoczyć jeden istotny aspekt uczenia się, także w toku edukacji na zewnq̨trz - walor społeczny. Jak zauważa Daniela Braun, podczas eksploracji otaczającej je rzeczywistości „dzieci potrzebują swoich rówieśników, którzy będą dzielili z nimi zachwyt dla odkryć, wynalazków i badań" (Braun, 2002, s. 10). W tym procesie potrzebują jednak również dorosłych partnerów, odgrywających znaczącą rolę w podtrzymywaniu potrzeby eksploracji świata. Ich zadaniem, w opinii autorki, jest "wspieranie ich ciekawości i ducha badawczego, pobudzanie oraz hamowanie, a także stawianie na ich drodze przeszkód" (tamże). Potrzebują nauczycieli, którzy „będą dodawali im odwagi oraz wspierali ich ciekawość świata, żądzę wiedzy i pęd ku dociekaniu istoty wszystkiego wokół siebie" (tamże).

\section{Refleksja nad osobą nauczyciela}

Kiedy rozmawiamy o zmianie systemu edukacji, myślę, że musimy zrozumieć, jaki to rodzaj systemu. To system ludzki. Nie jest mechaniczny ani bezwładny. Tworza go działania, uczucia, zwiqzki i relacje niezliczonej liczby ludzi.

Ken Robinson ${ }^{3}$

Nie sposób mówić o zmianie w edukacji bez refleksji nad osobą nauczyciela i jego rolą w dorastaniu dzieci i młodzieży, przypadającym niemalże w całości na okres przedszkolno-szkolny. Role nauczyciela i ucznia wzajemnie się przeplatają. Działanie

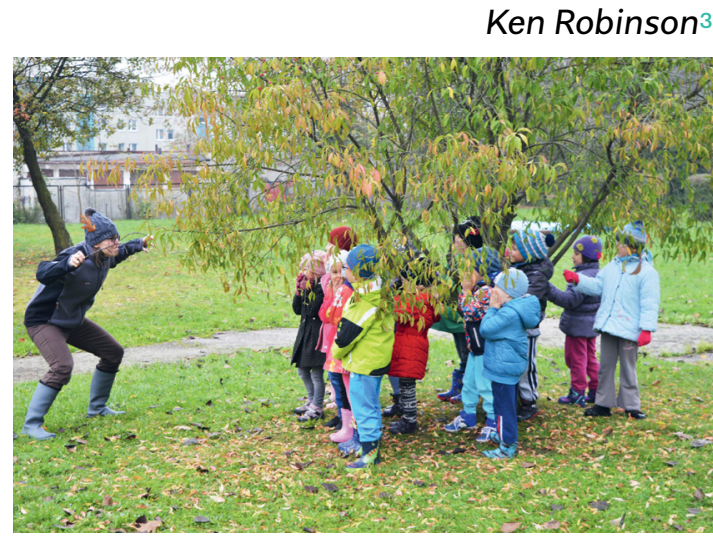
i reakcja ucznia wynika bezpośrednio z postawy nauczyciela. Ta z kolei jest wypadkową jego własnych przekonań, efektem analizy tego, co najistotniejsze $w$ dydaktyce i wychowaniu, oraz obserwacji reakcji na 
sytuacje tu i teraz. Sytuacja jest więc złożona. Czasem na tyle, że aby pozostawać obiektywnym i efektywnym pedagogiem, potrzebny jest ktoś, kto spojrzy na nas z boku, dokona konstruktywnej analizy, która pomoże nam w autorefleksji. Bez względu na to, czy dokonujemy jej na bieżąco, czy sporadycznie, w wyjątkowych sytuacjach, umożliwia nam osobistą odpowiedź na pytanie, jakim człowiekiem jestem i jakim jestem nauczycielem.

Typologie stylów nauczania i klasyfikacje ról nauczycieli dostępne w pedeutologii rzetelnie zestawia w literaturze pedagogicznej Dymara. Proponuje również ciekawy zestaw bibliograficzny zapewniający nauczycielom poznanie różnorodnych poglądów i sposobów postrzegania człowieka w świetle ludzkiej kultury i przyrody. W jej zestawieniu i przytaczanych typologiach osobowościowych można przejrzeć samego siebie na wskroś. I tak przykładowo dzięki klasyfikacji Caselmanna możemy zastanowić się, czy reprezentujemy typ logotropa (który ceni wiedzę, kładzie nacisk na kształcenie, lecz często zaniedbuje wychowanie) czy pajdotropa (który czuje się bardziej wychowawcą, tatwo nawiązuje kontakt z dziećmi). Zgodnie z typologią Auerbach odnajdziemy w sobie aktora (nauczyciela przejętego sobą, czasem zagłuszającego uczniów, któremu brak cierpliwości i ochoty do wysłuchiwania drugiego) lub reżysera (dyskretnie kierującego pracą uczniów, mogącego jednak tracić panowanie nad klasą) (Dymara, 2000).

Autoanalizę i świadomy dobór postaw ułatwia typologia Dörning. Dzięki niej łatwiej nam określić, czy kierują nami uczucia i rozluźniona dyscyplina, czy wykazujemy większą bezwzględność i władczość. Czy kształtujemy uczniów według siebie, czy wczuwamy się w ich indywidualność. Czy jesteśmy wyrozumiali, w relacjach z wychowankami kierując się empatią, czy interesują nas głównie wiedza i sposoby jej przekazania. W końcu czy dążenie do podporządkowania sobie uczniów przeważa nad dbałością o korzyści płynące z umiejętności i wiedzy? Należy zauważyć, że żadna z opisywanych postaw nie jest uniwersalna, nie sprawdza się we wszystkich sytuacjach, jakie napotkamy w relacjach z uczniem. Stąd naturalne, oczekiwane i potrzebne jest lawirowanie między rolami nauczyciela zależnie od bieżącej sytuacji i kontekstu.

Bez względu na etap edukacyjny czy nauczany przedmiot nauczyciel powinien zastanowić się, jak mocno akcentuje systematyczność i rzetelność zadań wykonywanych przez uczniów, względem stawiania im poznawczych wyzwań. Czy poza gromadzeniem wiedzy ceni osiągnięcia 
i badawczą postawę ucznia wobec świata? Na ile jest gotowy oddać coś ze swojej dominującej postawy na rzecz nabywania przez ucznia pewności siebie oraz przejawiania inicjatywy i potrzeby partycypacji w procesie uczenia się.

I jeszcze jedno - mówmy mniej! Doskonale ujął to brytyjski edukator, Tom Rylands, który podczas spotkań z nauczycielami całkiem serio nazywał kubek ich najważniejszym atrybutem. Dlaczego? Kubek, będący zawsze w zasięgu ręki, potrzebny jest po to, by w czasie rozmowy z uczniami sięgać po niego i... zamilknąć na chwilę. Ograniczyć swoją pedagogiczną potrzebę mówienia i dzielenia się wszechwiedzą na rzecz dyskusji i swobodnej wypowiedzi uczniów dochodzących do sedna procesu poznania. Banalne? Tak proste, a jak trudne.

\section{Strefa projektów edukacyjnych}

Słuszne jest stwierdzenie Mazurkiewicz, że znaczna część wiedzy zdobywanej przez uczniów w szkole nie jest poparta przeżyciem ani doświadczeniem: „Nauczyciele często zapominają, że najlepiej i najtrwalej dzieci zdobywają wiedzę dzięki własnej aktywności, poprzez badanie, działanie, stawianie pytań i samodzielne poszukiwanie odpowiedzi" (Mazurkiewicz, 2000, s. 196). Naprzeciw zmianom w tym obszarze funkcjonowania szkoły wychodzą nowe technologie i nauczanie metodą projektów edukacyjnych, które mogą stać się metodologicznym

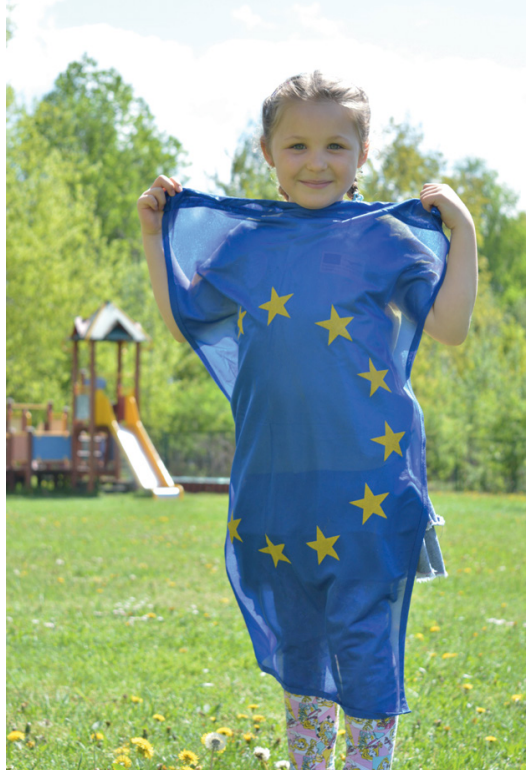

Ubrani w Europę narzędziem ożywiającym założenia podstawy programowej. Poszerzają bowiem kontekst poznawczy, zapewniają przestrzeń do doświadczania i aktywności we współpracy z innymi, a ponadto umożliwiają interakcję między perspektywą edukacji wewnątrz i na zewnątrz (indoor i outdoor).

W 2005 r. (w tym samym, w którym zapoczątkowano w Europie program eTwinning) w publikacji Outdoor education. Literary education and 
sensory experience Dahlgren i Szczepanski odnieśli się do perspektywy edukacji skoncentrowanej na działaniu. Piszą w niej, że „w dzisiejszych czasach, w sposób bezprecedensowy, umożliwia uczniom na całym świecie wykorzystywanie technologii informacyjno-komunikacyjnych do wymiany zdobytych informacji, pomysłów, zapewniając im niezależne od położenia geograficznego możliwości nabywania wiedzy i informacji dla zrównoważonego sposobu życia na naszej planecie" (Dahlgren, Szczepanski, 2005, s. 23, tłum. aut.). Słowa te doskonale oddają ideę współpracy międzynarodowej programów Erasmus+ i eTwinning. Właśnie one, obok różnego rodzaju projektów lokalnych oraz inicjatyw własnych nauczycieli i szkół, zapewniają niekonwencjonalne i pozbawione granic geograficznych doświadczenia poznawcze oraz społeczne, nadające znaczenie procesowi uczenia się. W ocenie nauczycieli mających doświadczenie w pracy metodą projektów edukacyjnych, w tym tych o charakterze międzynarodowym, istnieje jedna, można powiedzieć, negatywna konsekwencja ich realizacji - dodatkowe obciążenie nauczycieli. Mimo tego z zapałem i przekonaniem podejmują się tego wyzwania, widząc wiele korzyści dla uczniów i samych siebie, jakie ono niesie.

Mówiąc o pozytywnych rezultatach projektów, wskazują na:

$\rightarrow$ wymianę doświadczeń,

$\rightarrow$ poznawanie różnych poglądów i koncepcji,

$\rightarrow$ adoptowanie dobrych i ciekawych rozwiązań,

$\rightarrow$ poznawanie i wzbogacanie kultury,

$\rightarrow$ przełamywanie stereotypów i naukę tolerancji,

$\rightarrow$ kształtowanie świadomości bycia obywatelem świata,

$\rightarrow$ podniesienie samooceny,

$\rightarrow$ rozwijanie samodzielności, a jednocześnie umiejętności pracy w zespole,

$\rightarrow$ motywację do zdobywania wiedzy,

$\rightarrow$ wzmocnienie komunikacji językowej i motywacji do nauki języka obcego.

Jak w praktyce, poprzez projekty edukacyjne, realizować założenia podstawy programowej, wykorzystując dostępne technologie, zasoby środowiska przyrodniczego i kulturowego? Poszukując odpowiedzi na to pytanie, warto odwołać się do doświadczenia nauczycieli realizują- 
cych współpracę międzynarodową w Przedszkolu nr 48 z Oddziałami Specjalnymi i Integracyjnymi w Zabrzu.

Przykłady aktywności łączących elementy natury, kultury i wykorzystania technologii:

$\rightarrow$ Tworzenie komiksu prezentującego propozycje wypowiedzi naukowców (Marii Skłodowskiej-Curie i Isaaca Newtona) przedstawionych w sposób sytuacyjny na obrazach malarskich.

Projekt: Exploring the World with Maria and Isaac

Komiks w wersji online: issuu.com/annakrzyzanowska/docs/odgadnij_my_li_naukowc_w

$\rightarrow$ Fotografowanie części ciała zaprezentowanych na zdjęciach rentgenowskich realizowane poprzez współpracę w parach.

Projekt: Exploring the World with Maria and Isaac

Galeria zdjęć: mariaisaac.wordpress.com/2012/03/20/digital-x -rays-in-pairs/

$\rightarrow$ Tworzenie wynalazków naukowych wspólnie z rodzicami i ich prezentacja na forum grupy.

Projekt: Exploring the World with Maria and Isaac

Relacja z prezentacji wynalazku o nazwie "Kaskobidon": www.youtube.com/watch?v=xyiliQSKwlE

$\rightarrow$ Kreowanie nowego gatunku zwierzęcia (Sępocianojada) z trzech ptasich reprezentantów krajów partnerskich (sęp, bocian, ostrygojad) techniką kolażu.

Projekt: Talking pictures

Galeria Sępocianojadów: ourtalkingpictures.wordpress. com/2013/04/25/sepocianojad-our-international-species/

$\rightarrow$ Swobodne tworzenie opowiadania słowno-obrazkowego, zawierającego znaki drogowe wybrane przez dzieci trzech krajów partnerskich.

Projekt: Talking pictures

Opowiadanie w polskiej wersji językowej: ourtalkingpictures.wordpress.com/story-of-signs/polish-version/

$\rightarrow$ Przygotowanie raportów pogodowych, zawierających fotografie tego, co mamy u stóp, nad głową i wokół siebie - zadanie symultaniczne wykonywane w trzech grupach projektowych (eksploracja otoczenia w tym samym czasie).

Projekt: From picture to adventure 
Raporty pogodowe: pictureadventure.wordpress.com/tag/weather-investigation/

$\rightarrow$ Nagranie fragmentu opowiadania będącego tematyką projektu oraz międzynarodowy słownik z nazwami postaci.

Projekt: Read the World

Nagrania: kidsreadtheworld.wordpress.com/listen-aboutgruffalo/ 


\section{Bibliografia}

$\rightarrow$ Braun, D. (2002) Badanie i odkrywanie świata z dziećmi, Kielce: Wydawnictwo "Jedność".

$\rightarrow$ Clouder, C., Heys, B., Matthes, M. (2009), Improving the quality of childhood in the European Union - Current perspectives.

$\rightarrow$ Dahlgren, L.O., Szczepanski, A. (1998), Outdoor education. Literary education and sensory experience. An attempt at defining the identity of outdoor education, Linköping: Linköping University, Kinda Educational Centre.

$\rightarrow$ Drzażdżewski, S. (2013), Przestrzeń nowoczesnej edukacji najmłodszych dzieci i uczniów [w:] „Meritum", nr 1, 2-4.

$\rightarrow$ Dymara, B. (2000), Przyroda w literaturze i życiu dziecka [w:] B. Dymara, S. Michałowski, L. Wollman-Mazurkiewicz (red.), Dziecko w świecie przyrody, Kraków: Oficyna Wydawnicza "Impuls", s. 13-97.

$\rightarrow$ European Commission (2016), Great Start in Life! The Best Possible Education in the Early Years, Brussels.

$\rightarrow$ Gajek, E. (2013), Przestrzeń cyfrowa w edukacji [w:] „Meritum”, nr 1, s. 74-80.

$\rightarrow$ Hojnacki, L. (2014), Mobilność to przyszłość edukacji [w:] „IT w Edukacji”, nr 1, s. 64-67.

$\rightarrow$ Kickbusch, I. (2012), Learning for Well-being. A Policy Priority for Children and Youth in Europe. A process for change, Universal Education Foundation.

$\rightarrow$ Krzyżanowska, A. (2017), Kiedy matematyka wybiera się na spacer [w:] „Dialog Edukacyjny", nr 4/38, s. 11-15.

$\rightarrow$ Michałowski, S.C. (2000), Dziecko. Przyroda. Wartości [w:] B. Dymara, S. Michałowski, L. Wollman-Mazurkiewicz (red.), Dziecko w świecie przyrody. Kraków: Oficyna Wydawnicza "Impuls", s. 101-124.

$\rightarrow$ ÖIAT (2010), Korzystanie z telefonu komórkowego w szkole. Zarządzanie szansami i zagrożeniami. Warszawa: FRSE.

$\rightarrow$ Seitz, R. (2001), Co widzisz wokół siebie? Zabawy rozwijajq̨ce zmysł wzroku, Kielce: Wydawnictwo "Jedność". 


\section{Netografia}

$\rightarrow$ Szkoła to marzenie rzucone rzeczywistości, aby uległa. Rozmowa z prof. Ryszardem M. Łukaszewiczem (2009), „Miesięcznik Dzikie Życie”, nr 9/183 [online] [dostęp 27.06.2018] dzikiezycie.pl/archiwum/2009/wrzesien-2009/szkola-to -marzenie-rzucone-rzeczywistosci-aby-ulegla-rozmowa-z-prof-ryszardem -m-lukaszewiczem.

$\rightarrow$ Tołwińska-Królikowska, E. (2013), Leśna szkoła - przestrzeń edukacyjna poza budynkiem szkolnym [w:] „Meritum”, nr 1, s. 57-61.

$\rightarrow$ Wollman-Mazurkiewicz, L. (2000), Przyroda i edukacja. [w:] B. Dymara, S. Michałowski, L. Wollman-Mazurkiewicz (red.), Dziecko w świecie przyrody. Kraków: Oficyna Wydawnicza "Impuls", s. 189-238.

$\rightarrow$ (2016) Erasmus ewaluacja dziecięca pytanie 9 [plik wideo] [online] [dostęp 20.06.2018] youtu.be/yHAx6YrKmwU.

$\rightarrow$ (2016) Interview with children - Poland [blog] [online] [dostęp 20.06.2018] throughdemocracytoliteracy.wordpress.com/evaluations/2016-interviews-withchildren/interview-with-children-poland/.

$\rightarrow$ (2018) Ken Robinson - czy rzeczywiście wierzysz w rewolucję w edukacji? [plik wideo] [online] [dostęp 26.06.2018] www.facebook.com/wydawnictwoelement/ videos/1739171562836089/.

$\rightarrow$ (2018) The Indoor Generation by VELUX [plik wideo] [online] [dostęp 20.06.2018] www.youtube.com/watch?v=ygHUOmQGuJU. 



\section{Kreatywność a standaryzacja: pedagogika twórczości i jej postulaty pod adresem współczesnej szkoły}

Krzysztof J. Szmidt

W artykule autor omawia główne postulaty pedagogiki twórczości skierowane do szkoły i nauczycieli, odnoszące się do trzech głównych zadań szkoły, która zamierza włączyć do programu nauczania: 1) dostarczanie studentom wiedzy z różnych dziedzin kreatywności; 2) rozwijanie praktycznych umiejętności twórczych;3) tworzenie środowiska sprzyjającego ujawnianiu kreatywności studentów, określanego jako środowisko twórcze lub kreatogenne. Autor precyzuje te postulaty w trzech częściach tekstu, a na koniec konfrontuje je z rosnącym ruchem standaryzacji wszelkich form nauczania w szkołach, określanym jako terror testu. Uzasadnia, że kształcenie dywergencyjne znajduje się w stanie ciągłego konfliktu ze szkołą konwergencyjną, w której przeważają testy i uczenie się "pod test”.

\section{Słowa kluczowe:}

kreatywne nauczanie

kreatywna klasa

testowanie

uczenie się pod test 


\section{Creativity and standardization: \\ pedagogy of creativity and its \\ postulates for contemporary school}

Krzysztof J. Szmidt

In the article, the author discusses the main postulates of pedagogy of creativity addressed to school and teachers, they refer to the three main tasks of the school, which wants to include in the curriculum creative goals: 1) providing students with knowledge in various areas of creativity; 2 ) developing practical creative skills; 3 ) creating an environment conducive to the disclosure of students' creativity, referred to as a creatogenic environment. The author concretes these postulates in three parts of the text. In the end he confronts them with the increasing movement of standardization of teaching in schools, called test terror. He justifies that divergent education is in conflict with a convergent school in which tests and learning "under test" prevail.

\section{Keywords}

teaching creativity

creative classroom

obsession with testing

divergent problems

teaching divergency 


\section{Wprowadzenie}

Postulaty wychowania człowieka kreatywnego formułują politycy i działacze oświatowi na całym świecie, naukowcy badający naturę procesów twórczych, autorzy programów nauczania, rodzice, nauczyciele, przedsiębiorcy. Kreatywność i jej potęgowanie stają się jednym z głównych celów wychowania, są w cenie i w kręgu zainteresowań niemal wszystkich podmiotów troszczących się o przyszłość szkoły. To zainteresowanie często ma charakter pobożnych życzeń i deklaracji programowych, bez należytego urzeczywistnienia w programach nauczania, bez wsparcia finansowego dla autorów programów nauczania twórczości i pedagogów, bez przeznaczenia, tak przecież cennego, czasu lekcyjnego na zajęcia twórcze. Inaczej mówiąc, wielu zwolenników kształcenia do kreatywności, i to nie tylko w Polsce, głosi modne hasła, nie dbając o ich wcielenie w życie. Realizacji programów rozwoju kreatywności w szkole nie tylko nie służy fasadowe ich ujmowanie, bez realizacji w klasach szkolnych, lecz także sprzeczny z postulatami pedagogiki twórczości ruch standaryzacji niemal wszelkich dziedzin aktywności uczniów. Jak zobaczymy, rozwój, a nawet dyktat standaryzacji wyników nauczania i uczenia się hamuje skutecznie realizację celów wychowania do twórczości.

Moim celem jest syntetyczne przedstawienie głównych postulatów pedagogiki twórczości pod adresem szkół i nauczycieli, pragnących uczynić ze szkół środowisko kreatogenne. Środowisko, które w dobie konkurencji talentów i zdolności na całym świecie pomoże uczniom rozpoznawać własne zdolności i umiejętności przydatne w działaniach twórczych, da nauczycielom narzędzia heurystyczne uczące twórczego rozwiązywania problemów i ułatwi stworzenie odpowiedniej kultury, w której ceni się uczniów kreatywnych. Ideą spajającą tego typu działania jest zaktualizowana, a powstała jeszcze przed drugą wojną światową w Polsce koncepcja pomocy uczniom w tworzeniu (Szmidt, 2001). W drugiej części artykułu przedstawię, jak tej owocnej idei szkodzą działania mające charakter terroru testu i realizowanie antytwórczej strategii szkoły konwergencyjnej.

\section{Główne postulaty pedagogiki twórczości pod adresem szkoły}

Źródeł postulatów pod adresem nauczycieli, mówiących o konieczności nauczania i wychowania do twórczości, można szukać zarówno w programach nowego wychowania i koncepcjach głównych przedstawicieli 
tego nurtu w pedagogice, np. Johna Deweya, Ovide'a Decroly'ego, Marii Montessori oraz Henryka Rowida, jak i teoriach oraz praktycznych realizacjach wychowawczych polskich pedagogów społecznych, pedagogów sztuki, techniki i dydaktyków, a także psychologów poznawczych. Helena Radlińska, Kazimierz Korniłowicz, Irena Wojnar, Stefan Szuman, Zbigniew Pietrasiński, Józef Kozielecki, Roman Schulz - by wymienić tylko głównych głosicieli tych postulatów w XX w. - apelowali o to, by szkoła i generalnie wychowanie zerwały $z$ dotychczasową praktyką kształcenia człowieka oświeconego, dobrze przystosowanego do rzeczywistości, a skupiły się na wychowaniu człowieka innowacyjnego, twórczego, zmieniającego tę rzeczywistość w imię ideałów społecznych i zadań czekających w nowym tysiącleciu. Pedagogika twórczości, która wyłoniła się pod koniec XX w. z różnych nurtów pedagogicznych, podchwyciła te postulaty i potraktowała jako główne wyzwanie uprawianej na jej gruncie teorii i dydaktyki twórczości (psychodydaktyki kreatywności). Współcześnie pedagodzy twórczości uzasadniają rację kształcenia do twórczości, odwołując się do dwóch głównych przekonań, ugruntowanych w wynikach badań empirycznych (Starko, 2018):

$\rightarrow$ pedagogicznego poglądu, że twórczość jest wartością esencjalną w zmieniającym się świecie, bez której nie da się już żyć na wysokim poziomie,

$\rightarrow$ wiary, że twórczość może być taką samą wartością esencjalną w życiu szkoły.

Twórczość jest wartością esencjalną w życiu człowieka (Starko, 2005). Bez niej nie byłoby sztuki, nauki, innowacji, żadnego postępu. Twórczość może odgrywać taką samą esencjalną rolę w szkole. Dzięki niej uczniowie uczą się strategii odkrywania problemów, podejmowania decyzji i szukania rozwiązań w środowisku zarówno szkolnym, jak i pozaszkolnym. Klasy, które organizują czas dla tworzenia, stają się miejscami uczenia się oraz głębokich, tak ważnych w dzisiejszych czasach rozmyślań nad sobą i światem. „Nasze dzieci będą musiały myśleć twórczo, aby wypracować rozwiązania dla problemów, z którymi my nie dość, że nigdy się nie zetknęliśmy, to nawet nigdy nie rozważaliśmy ich czysto teoretycznie" (Fuller, 2017, s. 19). Oznacza to, że nauczyciele i rodzice muszą się dogłębnie zastanowić nad tym, w jaki sposób wychować człowieka, który będzie zarówno refleksyjny, jak i zaradny w zmaganiu się z problemami zmieniającego się świata, i to 
takimi, których nie jesteśmy sobie w stanie nawet wyobrazić. Idąc śladem Fullera, możemy rozważyć, jak młodzież poradzi sobie z nieistniejącymi jeszcze 10 lat temu problemami fonoholizmu - uzależnienia od telefonu komórkowego - bądź gwałcenia praw autorskich spotykanymi w Internecie. Do rozwiązania tych i podobnych problemów niezbędne jest podejście twórcze, co oznacza konieczność nauczania heurystyki - metod twórczego rozwiązywania problemów, a wcześniej - sztuki odkrywania i formułowania problemów. Mówię tu więc o dwóch ważnych kompetencjach twórczych, które należy budzić i rozwijać u uczniów w nowym tysiącleciu: myśleniu pytajnym, czyli dociekliwości, ciekawości poznawczej, zdolności odkrywania i definiowania problemów, podawaniu w wątpliwość (Szmidt, 2006a, 2009), oraz biegłości w wykorzystywaniu metod CPS (Creative Problem Solving).

Kiedy analizujemy głoszone przez pedagogów twórczości postulaty pod adresem szkoły przyszłości, można je sprowadzić do trzech głównych zadań (Szmidt, 2005, 2013):

I dostarczanie uczniom wiedzy z różnych dziedzin twórczości,

II rozwijanie praktycznych umiejętności twórczych,

III tworzenie odpowiedniego środowiska, sprzyjającego ujawnianiu się kreatywności uczniów, szkolnego i szerszego, nazywanego, jak już wiemy, środowiskiem kreatogennym.

\section{Wiedza o twórczości i jej aspektach}

Nauczanie twórczości realizowane jest w praktyce szkolnej według jednego $z$ dwóch modeli dydaktycznych (Szmidt, 2003):

1) Twórczość jako nowy przedmiot nauczania - nauczanie poprzez specjalnie do tego celu wyodrębnione jednostki lekcyjne, mające charakter zajęć psychoedukacyjnych, wzbogacających ofertę programową szkoły czy ośrodka wychowawczego. Możemy ten model nazwać specjalistycznym, wyodrębnionym sposobem nauczania twórczości. Szkoła organizuje specjalne wyodrębnione w programie nauczania zajęcia twórcze, mające charakter treningu twórczości, treningu ekspresji twórczej, dramy twórczej, lekcji twórczości czy grup Odysei Umysłu.

2) Twórczość jako treść i metoda kształcenia ogólnego - nauczanie poprzez wzbogacenie oferty programowej istniejących przedmiotów nauczania, np. języka polskiego, techniki, fizyki, chemii, o treści związane z twórczością i umiejętnościami twórczymi, 
przepojenie ich tematyką kreatywności z danej dziedziny wiedzy - ten sposób można określić jako ogólne nauczanie twórczości. Szkoła zatrudnia i wspiera nauczycieli przedmiotowców, którzy albo tworzą w jakiejś nauczanej przez siebie dziedzinie, albo są zainteresowani wzbogacaniem standardowych treści nauczania o zagadnienia związane z naturą procesów twórczych, uwarunkowaniami powstania dzieł $w$ danej dziedzinie, charakterem twórców reprezentujących wykładaną specjalność, np. polonista nie tylko zachęca do analizy Sonetów krymskich Adama Mickiewicza, lecz także wyjaśnia strukturę sonetu i zachęca uczniów do autorskich prób stworzenia tej formy poetyckiej, chemik w liceum opisuje zaś znaczenie przypadków w odkryciach naukowych, np. Roentgena i Fleminga, a później zachęca uczniów do założenia Dziennika odkrywcy, w którym będą notowali wszelkie pytania i pomysły dotyczące natury rzeczy. Dobrym wprowadzeniem do tego rodzaju nauczania są przewodnik Roberta Sternberga i kolegów (Sternberg i in., 2018) oraz praca zbiorowa Ronalda Beghetta i kolegów (Beghetto i in., 2015).

Oba sposoby nauczania twórczości mają swoje zalety i wady, oba jednak polegają na zachęcaniu uczniów do zdobywania wiedzy z zakresu twórczości i jej czterech aspektów: wytworu twórczego, procesów tworzenia, osoby twórcy i czynników stymulujących bądź hamujących aktywność innowacyjną. Mówiąc metaforycznie, pedagogika twórczości zrywa z tradycją wyłącznego nauczania o twórczości na rzecz nauczania twórczości. To zasadnicza różnica, nie tylko definicyjna. Badania empiryczne dowodzą, że uczniowie nie tylko polskich szkół przechodzą wieloletni kurs uczenia się o twórczości wybitnych pisarzy i poetów, odkrywców w dziedzinie chemii czy fizyki, działalności publicznej oraz innowacyjnej wielkich innowatorów społecznych i politycznych, rzadko jednak mają okazję do twórczości własnej (Beghetto, Kaufman, 2017). Rzadko piszą wiersze i opowiadania lub nie robią tego w ogóle, nie prowadzą odkrywczych badań laboratoryjnych, nie wymyślają ani nie wdrażają do praktyki społecznej innowacji ułatwiających funkcjonowanie społeczności lokalnej lub szkolnej. Serwowana im na ogół w nadmiarze, zwłaszcza na poziomie szkoły średniej, wiedza deklaratywna i pewna („Wiem, że...") nie przeradza się w wiedzę proceduralną ani heurystyczną („Wiem, jak..."). Dorota Klus-Stańska, wielki krytyk tradycyjnej dydaktyki 
szkolnej, twierdzi słusznie, że polski uczeń nieźle interpretuje treści tabel i wykresów, natomiast ma ogromne kłopoty z tworzeniem nowych tabel i wykresów (Klus-Stańska, 2008).

Wiedza o twórczości to ugruntowane informacje nie tylko o faktach historycznych dotyczących na ogół wytworów wybitnych twórców, będących bohaterami podręcznika, lecz także o procesach twórczych i ich kulturowych uwarunkowaniach (aspekt procesualny i środowiskowy twórczości), którym poświęca się mało uwagi w planach nauczania. Jak Mickiewicz tworzył Sonety krymskie? Jakie mechanizmy twórcze (poetyckie) wykorzystywał lub wymyślił? Co jest oryginalnego w jego sposobie tworzenia? Co mu pomagało (stymulatory), a co przeszkadzało w procesie twórczym (inhibitory) i w ogóle w życiu? Jaki wpływ na jego twórczość mieli: rodzina, środowisko kolegów, krytycy i pochlebcy, a szerzej - środowisko życia? Kim był jako twórca i jako człowiek? Oto tylko niektóre pytania, mogące wyznaczać treści nauczania.

Ten rodzaj nauczania nie oznacza, że rezygnujemy z uczenia wiedzy deklaratywnej, historycznej, pewnej, która wszak stanowi fundament każdej twórczości - uczeń, który nie zna struktury sonetu, nie napisze oryginalnego dzieła, a uczennica, która nie miała lekcji z geologii, raczej nie odkryje kryształu górskiego w Górach Sowich. Ugruntowana wiedza z danej dziedziny twórczości stanowi budulec i rdzeń przyszłych, niespotykanych pomysłów, mogących być odskocznią do kariery ucznia. Wspomniana już Alane Jordan Starko (2005) twierdzi, że wiedzy o faktach, np. historycznych, powinna towarzyszyć wiedza o tym, jak tworzy się ową wiedzę. Uczniowie, którzy chcą być odkrywcami problemów historycznych (problem finders), muszą znać nie tylko fakty historyczne, koncepcje i uogólnienia, lecz także wiedzieć, w jaki sposób historia jako nauka funkcjonuje i co robią historycy. Co i w jaki sposób decyduje o podjęciu określonych badań historycznych? Jakiego rodzaju problemów historycy szukają i jak je rozwiązują? Jak zbierać potrzebne do rozwiązania problemu informacje? Nauczanie autentycznej metodologii jakiejś dyscypliny naukowej pozwoli uczniom stawać się poszukiwaczami i "rozwiązywaczami" (problem solvers) autentycznych, rzeczywistych problemów (zob. Szmidt, 2006b).

\section{Rozwijanie praktycznych umiejętności twórczych}

Rozwinięta i pogłębiona wiedza proceduralna z zakresu heurystyki twórczej to nic innego, jak tylko biegłość w posługiwaniu się opera- 
cjami twórczego rozwiązywania problemów (Creative Problem Solving - CPS). Postulat, by współczesnych uczniów nauczać heurystyki stosowanej w danej dziedzinie twórczości, nie jest nowy, lecz ciągle nie jest praktycznie realizowany w szkołach (Szmidt, 2017). Nauczanie heurystyki, czyli działań sprzyjających twórczości, nakłada na nauczyciela zadanie posługiwania się - jako stymulatorami - problemami (zadaniami) otwartymi, mającymi wiele oczekiwanych lub pożądanych odpowiedzi czy rozwiązań. Określane są one jako problemy dywergencyjne, w przeciwieństwie do problemów zamkniętych, mających na ogół jedno oczekiwane rozwiązanie, czyli problemów konwergencyjnych. Nauczyciel pytający ucznia o to, w którym roku Adam Mickiewicz wydał Sonety krymskie, posługuje się klasycznym problemem konwergencyjnym, natomiast nauczyciel pytający ucznia, jakie znaczenie ma to dzieło dla poezji polskiej okresu romantyzmu, używa wtedy problemu dywergencyjnego.

W dydaktyce twórczości powstała tradycja polegająca na tym, że jedną z głównych zasad nauczania twórczości jest dywergencyjność stawianych przed uczniem problemów. Polega ona na tym, że chcąc pobudzić procesy twórcze, lepiej jest stosować zadania mające wiele możliwych, poprawnych lub oryginalnych odpowiedzi czy rozwiązań, ponieważ takie zadanie stymuluje ważne czynniki myślenia twórczego, płynność, giętkość, oryginalność oraz elaborację (staranność dopełnienia). Jest zasadnicza różnica między sytuacją, gdy uczeń pisze esej na temat "Uzasadnij słuszność postulatów zwolenników Romantyzmu dla rozwoju poezji polskiej", a tą, gdy stawia się przed nim temat zadania rozwinięcia tematu: "Bohater romantyczny i ja". Problemy zamknięte "są na swój sposób sztuczne, dobrze określone, oderwane od pozaszkolnych doświadczeń dziecka i od tego, co dziecko ceni najbardziej. Chodzi w nich o jedno rozwiązanie, o »dobrą odpowiedź ", co w warunkach szkolnych oznacza potwierdzenie ze strony nauczyciela. Odzwierciedlają one wyizolowany charakter uczenia się. Przydają się, by sprawdzić, co uczniowie umieją, co pamiętają, jak władają daną umiejętnością, nie skłaniają jednak, by głębiej wejść w przedmiot" (Fisher, 1999, s. 108). A problemy spotykane w życiu przez uczniów są zgoła inne: niedookreślone, źle zdefiniowane, otwarte i nie mają charakteru prostej alternatywy „albo-albo". Wymagają one od ucznia namysłu 
i refleksji oraz zdefiniowania lub zredefiniowania sytuacji problemowej, czyli kompetencji określanej jako myślenie pytajne.

Tabela 1. Różnice między myśleniem konwergencyjnym a dywergencyjnym w ujęciu Arthura i Davida Cropleyów

\begin{tabular}{l|l}
\multicolumn{1}{c|}{ MYŚLENIE KONWERGENCYJNE } & \multicolumn{1}{c}{ MYŚLENIE DYWERGENCYJNE } \\
\hline Logiczne rozumowanie & Myślenie niekonwencjonalne \\
\hline Naprowadzanie na najlepszą odpowiedź & Postrzeganie znanego w nowym świetle \\
\hline Rozpoznawanie znanego & $\begin{array}{l}\text { Poszukiwanie nowych perspektyw dla } \\
\text { faktów }\end{array}$ \\
\hline Trzymanie się limitu & Wychodzenie poza limit \\
\hline "Polowanie" na najważniejsze fakty & $\begin{array}{l}\text { Łączenie nieznanych rzeczy i pojęć } \\
\text { Łączenie tego, co już jest związane ze sobą }\end{array}$ \\
\hline Konserwowanie znanych informacji & Wymyślanie nowych technik \\
\hline Gwarantowanie wykonalności & Przekształcanie tego, co znane \\
\hline & Branie ryzyka poznawczego na siebie \\
& Gwarantowanie nowości
\end{tabular}

Źródło: Cropley, D.H., Cropley, A.J. (2015), The Psychology of Innovation in Organizations, New York: Cambridge University Press, s. 47.

Drugi warunek stymulującego nauczania kompetencji twórczych to autentyczność problemów (zadań). Większość pedagogów twórczości podkreśla wartość problemów, które:

$\rightarrow$ nie mają z góry ustalonej odpowiedzi,

$\rightarrow$ mają osobistą wartość dla ucznia,

$\rightarrow$ mogą być badane przy użyciu jednej lub kilku metodologii,

$\rightarrow$ stwarzają szansę, że uczniowie dzięki dostarczanej im odpowiedniej wiedzy i umiejętności rozwiążą je, że będą efektywni.

A zatem nie są to wypreparowane z rzeczywistości, zawarte w podręczniku, sztuczne problemy dydaktyczne, na ogół obce uczniowi, lecz problemy ważne, palące, mające określone znaczenie dla ucznia i jego środowiska. Oto przykład takiego ćwiczenia, które spełnia tego rodzaju kryteria, zaczerpniętego z podręcznika do zajęć stymulujących ideację - zdolność generowania oryginalnych i efektywnych rozwiązań, 
w tym przypadku pobudzające mechanizm bisocjacji - dwójkojarzenia (Szmidt, 2016).

\section{Ćwiczenie katalogi}

Kiedy przeglądam katalogi różnych produktów, zastanawiam się nad wielką pomysłowością ludzi wymyślających tak przeróżne rzeczy jak: rajstopy wyszczuplające, dwustronne podkładki do słoików, preparat do czyszczenia fug, płyn do mycia szyb z antyparą, mazakopędzelki, pałeczki silikonowe dla dzieci, fluid do czyszczenia płyt kompaktowych, długopis ze wskaźnikiem laserowym, zakładki indeksujące w kolorze tęczy, stojak na okulary z drzewa oliwnego w kształcie nosa, urządzenie do domowej mikrodermabrazji, smoczki uspokajające, klips przeciwko chrapaniu, ozonator powietrza z funkcją jonizacji i aromaterapii, słuchawki bezprzewodowe Bluetooth, otwieracz do napojów z licznikiem... Naprawdę, pomysłowość ludzi nie ma granic! Choć czasem, gdy odwiedzam wielkie supermarkety budowlane i z narzędziami technicznymi, wydaje się, że już wszystko wymyślono, wszelkie narzędzia, przyrządy, urządzenia, które służą do przykręcania, odkręcania, malowania, klejenia, przycinania, murowania, strojenia itd. Kiedy spojrzy się na działy hydrauliki czy malowania, rodzaj i liczba wymyślonych przez ludzi wytworów robi ogromne wrażenie. W zasadzie nie ma już chyba czynności wykonywanej przez ludzi, która nie doczekałaby się odpowiedniego narzędzia, mającego mu usprawnić ową czynność. A może jednak nie, może nie wszystko wymyślono.

Sięgnijmy do katalogów handlowych, jakich pełno w naszych skrzynkach pocztowych. Wybierzmy po kilka produktów z trzech różnych działów, a następnie spróbujmy połączyć je w akcie bisocjacji, a w zasadzie trisocjacji, żeby wymyślić całkowicie nowy produkt. Czego jeszcze nie wymyślono ani nie ma na półkach supermarketów spożywczych, kosmetycznych czy technicznych? 


\begin{tabular}{|c|c|c|c|}
\hline $\begin{array}{c}\text { PRODUKT } 1 \\
\text { DZIAt SPOŻYWCZY }\end{array}$ & $\begin{array}{c}\text { PRODUKT } 2 \\
\text { CHEMIA DOMOWA }\end{array}$ & $\begin{array}{c}\text { PRODUKT } 3 \\
\text { ARTYKUŁY SZKOLNE }\end{array}$ & $\begin{array}{l}\text { NOWY PRODUKT JAKO EFEKT } \\
\text { POŁĄCZEN }\end{array}$ \\
\hline lody śmietankowe & $\begin{array}{l}\text { kapsułki żelowe } \\
\text { do prania }\end{array}$ & pióro kulkowe & $\begin{array}{l}\text { kulki z farbą dla awangardo- } \\
\text { wych artystów, którzy mogą } \\
\text { je rozbijać o ściany, tworząc } \\
\text { abstrakcyjne murale; } \\
\text { naboje do piór wiecznych } \\
\text { w miękkich kapsułkach o dużej } \\
\text { pojemności, które można swo- } \\
\text { bodnie chować w obsadce; } \\
\text { przyrząd do ozdabiania tortów } \\
\text { lodowych w kształcie dużego } \\
\text { pióra, z którego - po naci- } \\
\text { śnięciu - wydobywa się masa } \\
\text { ozdabiająca. }\end{array}$ \\
\hline bułka tarta & gąbka do naczyń & $\begin{array}{l}\text { fartuszek } \\
\text { wodoodporny }\end{array}$ & \\
\hline $\begin{array}{l}\text { koncentrat } \\
\text { pomidorowy }\end{array}$ & worki na śmieci & flet szkolny prosty & \\
\hline warzywa na patelnię & ręczniki kuchenne & $\begin{array}{l}\text { podkład szkolny } \\
\text { na biurko }\end{array}$ & \\
\hline kawa ziarnista & $\begin{array}{l}\text { dywanik } \\
\text { łazienkowy }\end{array}$ & $\begin{array}{l}\text { tablica } \\
\text { suchościeralna }\end{array}$ & \\
\hline
\end{tabular}

Nauczanie twórczości za pomocą problemów otwartych i autentycznych polega $w$ istocie na zapoznawaniu uczniów $z$ wybranymi metodami heurystycznymi (w przykładzie powyżej chodziło o wykorzystanie zasady kojarzenia ze sobą odległych obiektów oraz wymyślania oryginalnej syntezy) i konsekwentnym ich stosowaniu w codziennej pracy. W dydaktyce twórczości przepisy (wskazówki) heurystyczne z reguły określa się terminami: zasada, metoda, technika. Różni je stopień ogólności i funkcje, jakie mogą pełnić w procesie rozwiązywania problemów (Dobrołowicz, 1993). Zasady heurystyczne stanowią najbardziej ogólne wskazówki, które mają ułatwić przebieg procesu twórczego, np. zasada etapowości procesu rozwiązywania problemów, zasada odroczonego wartościowania, zasada wykorzystania tego, co już jest znane, zasada łączenia odległych skojarzeń, zasada wykorzystywania myślenia intuicyjnego, zasada wykorzystywania paradoksów, zasada rozwiązania idealnego. Ogólne zasady heurystyczne znajdują uszczegółowienie w metodach i technikach rozwiązywania problemów. Na metodę składają się na ogół czynności umysłowe i praktyczne, odpowiednio dobrane i realizowane w ustalonej kolejności. W każdej metodzie są 
stosowane określone techniki rozumiane jako operacje ułatwiające osiągnięcie celów etapowych w rozwiązywaniu złożonych problemów. Przykładami technik mogą być: kruszenie, superpozycje, identyfikacja z obiektem, redefiniowanie problemu, modyfikacja rozwiązania, techniki typu random word, ideatons, mind mapping itp.

W szkole polskiej nauczyciele deklarują, że najczęściej stosują burzę mózgów i jej odmiany, choć bliższa analiza tego problemu w ostatnich latach świadczy o tym, że nie respektuje się głównych zasad tej metody i ogranicza się ją do formy dyskusji grupowej, mającej charakter brainstormingu. Inne metody heurystyczne, na przykład SCAMPER, analiza wartości, bionika czy listy kontrolne, są niemal nieznane. Istnieje wobec tego konieczność dokształcania nauczycieli z zakresu metod heurystycznych, które realizuje w toku cyklicznych Laboratoriów Treningu Twórczości Polskie Stowarzyszenie Kreatywności.

Postulat, by heurystykę uczynić treścią kształcenia, można sprowadzić do konkretnych działań dydaktycznych (Szmidt, 2017):

1. Warunkiem dobrego nauczania heurystyki jest profesjonalne przygotowanie nauczyciela z zakresu wiedzy o danej metodzie, jej zasadach, przebiegu i ograniczeniach oraz - co jasne - stanie na straży poprawności jej realizowania na zajęciach. A zatem erudycja heurystyczna przede wszystkim!

2. Ważnym warunkiem efektywności dydaktycznej w nauczaniu metod CPS jest dysponowanie przez nauczyciela problemem, będącym osią (treścią) zajęć. Źródłem tego problemu może być omawiany $w$ toku lekcji temat wyspecyfikowany $z$ literatury przedmiotu, dylemat zaobserwowany w życiu codziennym przez prowadzącego lub uczniów, tak zwany problem dyżurny, opisywany w podręcznikach heurystyki (słynne "Co zrobić z pudłem żarówek na bezludnej wyspie?"). Należy pamiętać, by był to problem:

$\rightarrow$ otwarty (dywergencyjny), mający postać dylematu, który można rozwiązać na wiele nowych, alternatywnych i oryginalnych sposobów, a nie problem zamknięty (konwergencyjny), $\rightarrow$ ważny, autentyczny, aktualny - dotyczący ważnych spraw przewidzianych w programie nauczania danego przedmiotu, angażujący większość uczniów, związany z bieżącymi dylematami dyscypliny, 
$\rightarrow$ prospektywny, rozwojowy - dotyczący poszukiwania lepszych rozwiązań na przyszłość, nie zaś zmuszający uczniów do ciągłej analizy tego, co już było i przyczyn szwankowania tego, co już ustalone.

3. Nie wystarczy zaaplikować uczniom wybranej metody heurystycznej raz lub dwa, od przypadku do przypadku. Opanowanie heurystyki wymaga spełnienia takiego samego warunku jak opanowanie innych skomplikowanych umiejętności: wytrwałego powtarzania w różnych sytuacjach problemowych. Nauczanie twórczości wymaga zatem pogłębionych ćwiczeń. Żeby uczynić heurystykę treścią kształcenia w sali ćwiczeniowej, należy metody i techniki twórczego rozwiązywania problemów stosować jak najczęściej, co więcej, tę samą metodę - np. burzę mózgów 635 czy metodę projektowania idealnego - wykorzystywać do różnego typu problemów, ażeby praktycznie ukazać uczniom ich uniwersalne, właściwe heurystyce, zastosowanie.

\section{Tworzenie odpowiedniego środowiska sprzyjającego ujawnianiu się kreatywności uczniów}

To postulat pedagogiki twórczości najbardziej ogólny, w zasadzie warunek, by dwa pierwsze mogły dojść do głosu. W wąskim znaczeniu jednak zbyt wąskim. Apeluje się do dyrektorów szkół i nauczycieli o stworzenie w nich tzw. klimatu twórczego, w szerszym - o kultywowanie kultury szkoły określanej jako środowisko kreatogenne.

Badacz twórczości w szkole i jednocześnie wieloletni dyrektor szkoły oraz mentor nauczycieli Doug Johnson twierdzi, że sprzyjająca kreatywności uczniów i nauczycieli kultura szkoły charakteryzuje się 13 właściwościami. Oto kilka najważniejszych:

1. Klimat szkoły - można go wyczuć już po kilku minutach pobytu w placówce: śmiech uczniów i personelu, rozmowy pełne szacunku, otwarte drzwi sal lekcyjnych, obecność wolontariuszy itp. "Twórczość kwitnie w szkołach, które dbają o swoich uczniów i personel".

2. Praca twórcza uczniów jest doceniana - korytarze szkoły nie tylko są pełne dowodów dawnych triumfów i sukcesów, lecz także prezentują na wystawach aktualne dokonania twórcze uczniów, ich oryginalne dzieła i projekty. To samo dotyczy "korytarzy" na stronach internetowych szkoły. 
3. Szeroka oferta zajęć do wyboru i zajęć pozalekcyjnych - dla każdej grupy wiekowej szkoła ma ofertę aktywności uczących umiejętności społecznych i rozwijających określone zainteresowania. Sztuka, muzyka, technologie, sport i zajęcia z dziedzin społecznych mają uczyć młodzież rozwiązywania problemów, przywództwa, pomagać osiągać rezultaty $w$ dziedzinach nieobjętych przedmiotami szkolnymi.

4. Otwarte klasy - otwartość ma dwojakie znaczenie, pierwsze dotyczy otwartych drzwi szkoły dla rodziców, specjalistów, wolontariuszy i innych gości, drugie oznacza otwartość na nowe idee i formy ekspresji, pytania uczniów i różne rodzaje codziennych dyskusji. Cechami charakterystycznymi tej otwartości są „żywe dyskusje i otwarte, autentyczne pytania" .

5. Uczenie się oparte na metodzie projektów - prezentacja projektów i różnych dokonań praktycznych to jednocześnie okazja do uczenia się trzech głównych czynników twórczości: oryginalności, skuteczności oraz rzemiosła twórczego. „Kiedy twórczość jest autentycznie doceniana za pomocą oceny formatywnej, rośnie kreatywność uczniów".

6. Autentyczne zarządzanie przez uczniów - szkoły będące środowiskiem kreatogennym dają uczniom okazję do rzeczywistego zarządzania wieloma sprawami: uczniowie wybierają i kierują szkolnymi spektaklami, tworzą komitety i zespoły, którymi realnie zarządzają. Uczestniczą w konstruowaniu klasowych kodeksów postępowania i rozwiązują rzeczywiste problemy, którymi dzieli się nauczyciel. Są darzeni autentycznym zaufaniem.

7. Zrozumienie, że zabawa jest niezbędna - badania pokazują, że jeśli chcemy wychować bardziej twórczą i innowacyjną młodzież, powinniśmy jej zapewnić czas na zabawę. W szkołach twórczych łatwo znaleźć nauczycieli, którzy znajdują różnorodne sposoby, aby zapewnić uczniom czas niepoddawany ocenie oraz przestrzeń do konstruktywnych zabaw. W takich szkołach uczniowie są nie tylko bardziej twórczy, lecz także bardziej szczęśliwi (Johnson, 2015).

Szkoły o wysokiej kulturze twórczej to placówki, w których panuje życzliwa atmosfera sprzyjająca zadawaniu pytań i rozwiązywaniu problemów przez uczniów (problem - friendly classroom). Atmosferę tę tworzą następujące działania nauczyciela: 
$\rightarrow$ dostarczanie uczniom doświadczeń związanych z różnymi wyborami,

$\rightarrow$ dostarczanie ważnych informacji zwrotnych zawartych w ocenach nauczyciela,

$\rightarrow$ ośmielanie uczniów do dokonywania samooceny,

$\rightarrow$ ostrożne stosowanie nagród (konkursy twórczości nie są najlepszym sposobem motywowania do aktywności twórczej),

$\rightarrow$ uczenie współpracy i niezależności jednocześnie,

$\rightarrow$ ośmielanie uczniów do podawania w wątpliwość założeń i odważnego eksperymentowania.

W takich klasach pytania uczniów są witane z radością, nawet niecodzienne, a przede wszystkim takie, na które sam nauczyciel nie zna odpowiedzi. O jak wielu klasach możemy tak powiedzieć? To w takich klasach zdarzają się perełki uczniowskiej twórczości, takie jak te poniżej, które są wynikiem systematycznego treningu twórczości literackiej w liceum, prowadzonego przez wiele lat w Radziejowie przez wybitego pedagoga twórczości Janusza Kujawskiego (Czapiewski, Walszczyk, Wielgosz, 1998).

\author{
Ich wiedza \\ ich oceny \\ moje życie. \\ Marta Walaszczyk
}

Zaspana wskazówka gra na czas. Umieram. Mam węża w kieszeni. Moja wolna wola wodzi mnie za nos. Mam to gdzieś. Chyba w domu.
List
Szkoło:
czy ja przypadkiem
nie narzucam się
swoim towarzystwem?
Uczeń
Kuba Czapiewski

\title{
Standaryzacja przeciwko kreatywności
}

$Z$ dużą dozą prawdopodobieństwa można powiedzieć, że trzy opisane powyżej postulaty pedagogiki twórczości nie zostaną zrealizowane 
w praktyce nauczania naszych szkół, jeśli ruch standaryzacji edukacji, określany też jako terror testów, będzie rozwijał się w takim tempie, jak to jest obecnie. Nie miejsce tu na szczegółowy opis tego ruchu $i$ jego krytykę, która potęguje się w świecie, ważne, by zaakcentować jego główne niebezpieczeństwa dla dopiero pączkującego w edukacji nauczania twórczości. Jak pisze Howard Gardner, twórca teorii inteligencji wielorakich i badacz twórców wybitnych: „Podczas nauki we współczesnej szkole [...] większość uczniów przechodzi setki, jeśli nie tysiące, testów. Rozwijają one w wysokim stopniu umiejętność wykonywania ćwiczeń, która stanie się prawie bezużyteczna po skończeniu szkoły" (Gardner, 2002, s. 30). Praktyka określana przez Douga Johnsona jako obsesja testowania zagraża postulatom nauczania kreatywności, gdyż polega na zbyt szerokim i nieadekwatnym do celów pomiaru szkolnego stosowaniu testów dydaktycznych. Wymaga się w nich od ucznia jednej poprawnej odpowiedzi lub dwóch, które przewidział autor testu, i jednocześnie karze uczniów odpowiadających w sposób oryginalny, nieprzewidziany w kluczu testu (Johnson, 2015). Ruch standaryzacji opartej na testach „jest sceptyczny wobec kreatywności, osobistej ekspresji oraz niewerbalnych, niematematycznych sposobów pracy, a także wobec uczenia się przez odkrywanie i twórczą zabawę, nawet w przedszkolu" (Robinson, Aronica, 2015, s. 39). Istnieją bowiem fundamentalne różnice między nauczaniem i uczeniem się opartym na aktywności twórczej a uczeniem się pod test. W ujęciu cytowanego już tu Douga Johnsona wygląda to tak:

Tabela 2. Różnice między nauczaniem opartym na testach a nauczaniem twórczości

\begin{tabular}{l|l}
\multicolumn{1}{c|}{ TESTY } & \multicolumn{1}{c}{ TwóRCzość } \\
\hline Testy są ograniczone czasowo & Twórczość nie jest ograniczona czasowo \\
\hline Testy są (podobno) obiektywne & Twórczość jest zawsze subiektywna \\
\hline $\begin{array}{l}\text { Testy wymuszają posłuszeństwo wobec } \\
\text { tych, którzy testują }\end{array}$ & $\begin{array}{l}\text { Twórczość kwestionuje i przeciwstawia się } \\
\text { autorytetom }\end{array}$
\end{tabular}

Źródło: Opracowanie własne na podstawie D. Johnsona (2015).

„Wtedy, gdy profesjonalna ocena ucznia zależy od tego, czy poprawnie postawi on znaczek w rubryce testu, twórczość staje się wrogiem 
w klasie" (Johnson, 2015, s. 108). Johnson podaje też przykład autentycznego zadania testowego:

$\rightarrow$ Co pada z nieba i zmienia ziemię na biało?

- śnieg,

- deszcz,

- pył.

Nauczanie myślenia twórczego w tym przypadku polegałoby na postawieniu uczniom zadania: podaj odpowiedź, której nie ma na tej liście. Jak piszą czołowi badacze twórczych uczniów, James Kaufman i Ronald Beghetto: "[...] nauczyciele, którzy wspierają twórczy potencjał swoich uczniów, raczej witają i pracują nad ich nieoczekiwanymi interpretacjami i wglądami, niż je pomijają i tłumią" (Kaufman, Beghetto, 2017, s. 75).

Twórczość uczniów i nauczycieli rozwija się w środowisku otwartym na różnice i tolerującym oryginalność myślenia, wyjście poza schematy, a fiksacje poznawcze - w środowisku, które z podejrzliwością traktuje brak sporów oraz różnorodności. Ruch standaryzacji zabija indywidualność i samodzielność myślenia - oto teza, którą trudno podważyć. Uczenie się twórczości i uczenie się pod test to dwa żywioły nie do pogodzenia. Howard Gardner, wielki krytyk dominacji testów jako wyłącznych sprawdzianów osiągnięć szkolnych, pisze z emfazą: „Tam, gdzie używano dawniej w ściśle określonym celu jednego narzędzia, pojawiły się setki standaryzowanych testów typu papier i ołówek, które wykorzystywane są do rozmaitych celów, poczynając od kwalifikowania uczniów do szkół specjalnych, przez egzaminy wstępne na studia, aż po porównania osiągnięć uczniów w różnych krajach. Dawniej testy te były swego rodzaju ozdobnikiem bieżących programów nauczania; teraz mamy szkoły i programy przygotowane specjalnie do polepszenia osiągnięć mierzonych za pomocą tych narzędzi, przy czym niewiele uwagi poświęca się znaczeniu takich lepszych wyników. Nie jest przesadnym stwierdzenie, że dopuściliśmy do tego, iż testy, które miały w zamierzeniu ich twórców pełnić rolę służebną, zaczęły rządzić programami nauczania" (Gardner, 2002, s. 107).

A zatem szkoła przyszłości stoi przed dylematem: czy nauczać lepszych "wypełniaczy testów”, czy odważnie, samodzielnie i oryginalnie myślących ludzi, którzy wychodzą poza test i myślą - jak określają to Anglicy - out of the box? Na kim nam zależy: na konformistach czy innowatorach, adaptatorach czy inicjatorach? 


\section{Bibliografia}

$\rightarrow$ Beghetto, R.A., Kaufman, J.C., Baer, J. (2015), Teaching for Creativity in the Common Core Classroom, New York and London: Teachers College Press.

$\rightarrow$ Beghetto, R.A., Kaufman, J.C. (red.) (2017), Nurturing Creativity in the Classroom. New York: Cambridge University Press.

$\rightarrow$ Cropley, D.H., Cropley, A.J. (2015), The Psychology of Innovation in Organizations. New York: Cambridge University Press.

$\rightarrow$ Czapiewski, K., Walaszczyk, M., Wielgosz, M. (1998), Piqtek. Godzina 16, Toruń.

$\rightarrow$ Dobrołowicz, W. (1993), Psychika i bariery, Warszawa: WSiP.

$\rightarrow$ Fisher, R. (1999), Uczymy, jak myśleć, Warszawa: WSiP.

$\rightarrow$ Fuller, A. (2017), Psychologia geniuszu, Warszawa: Wydawnictwo Mamania.

$\rightarrow$ Gardner, H. (2002), Inteligencje wielorakie. Teoria w praktyce. Poznań: Media Rodzina.

$\rightarrow$ Johnson, D. (2015), Teaching Outside the Lines. Developing Creativity in Every Learner, Thousand Oaks: Corwin.

$\rightarrow$ Kaufman, J.C., Beghetto, R.A. (2017), Creativity in the Classroom Coda: Twenty Key Points and Other Insights [w:] R.A. Beghetto, J.C. Kaufman (red.) Nurturing Creativity in the Classroom, New York: Cambridge University Press.

$\rightarrow$ Klus-Stańska, D. (2008), Twórcze myślenie uczniów - mity, nieporozumienia, możliwości, „Problemy Wczesnej Edukacji”, nr 1(7).

$\rightarrow$ Robinson, K., Aronica, L. (2015), Kreatywne szkoły. Oddolna rewolucja, która zmienia szkoły, Kraków: Wydawnictwo Element.

$\rightarrow$ Starko, A.J. (2005), Creativity in the Schools. Schools of Curious Delight. 3 edition, New York: Lawrence Erlbaum Associates, Publishers.

$\rightarrow$ Starko, A.J. (2018), Creativity in the Schools. Schools of Curious Delight. 6 edition, New York: Routledge.

$\rightarrow$ Sternberg, R.J., Grigorenko, E.L., Jarvin, L. (2018), Mądrość, inteligencja i twórczość w nauczaniu. Jak zapewnić uczniom sukces, Łódź: Wydawnictwo UŁ. 
$\rightarrow$ Szmidt, K.J. (2001), Twórczość i pomoc $w$ tworzeniu w perspektywie pedagogiki społecznej, Łódź: Wydawnictwo UŁ.

$\rightarrow$ Szmidt, K.J. (2003), Współczesne koncepcje wychowania do kreatywności i nauczania twórczości: przegląd stanowisk polskich [w:] K.J. Szmidt (red.), Dydaktyka twórczości. Koncepcje - problemy - rozwiq̨zania, Kraków: Oficyna Wydawnicza "Impuls", s. 19-133.

$\rightarrow$ Szmidt, K.J. (2006a), Teoretyczne i metodyczne podstawy procesu rozwijania zdolności myślenia pytajnego [w:] W. Limont, J. Cieślikowska (red.), Dylematy edukacji artystycznej, tom II, Edukacja artystyczna a potencjał twórczy człowieka, Kraków: Oficyna Wydawnicza „Impuls", s. 21-50.

$\rightarrow$ Szmidt, K.J. (2006b), Szkoła ciekawości i zachwytu - rzecz o koncepcji wychowania do twórczości Alane Jordan Starko [w:] W. Dobrołowicz, K.J. Szmidt, I. Pufal-Struzik, U. Ostrowska, J. Gralewski (red.), Kreatywność - kluczem do sukcesu w edukacji, Warszawa: Wszechnica Polska Szkoła Wyższa TWWP, s. 134-144.

$\rightarrow$ Szmidt, K.J. (2009), Ciekawość - pierwszy stopień do twórczości, „Psychologia w Szkole" nr 1(21), s. 67-77.

$\rightarrow$ Szmidt, K.J. (2013), Pedagogika twórczości, wydanie drugie poszerzone, Sopot: Gdańskie Wydawnictwo Psychologiczne.

$\rightarrow$ Szmidt, K.J. (2016), Sesje twórczej pomysłowości dla pedagogów, psychologów i trenerów grupowych, Gliwice: Wydawnictwo Helion.

$\rightarrow$ Szmidt, K.J. (2017), Edukacyjne uwarunkowania rozwoju kreatywności, Łódź: Wydawnictwo UŁ. 



\section{Wspieranie rozwoju \\ kreatywności wśród uczniów}

Jan Fazlagić

Kreatywność jest stałym elementem naszego życia. Nie jest jedynie zarezerwowana dla elity geniuszy. Model pruskiej szkoły, jaki się wykształcił i rozprzestrzenił na całym świecie, akcentował dyscyplinę i posłuszeństwo. Najlepszym absolwentom pruskiej szkoły pisana była kariera akademicka. W epoce sztucznej inteligencji i innych zjawisk w otoczeniu kreatywność staje się tak cenną kompetencją jak umiejętność pisania w XIX w. Nowoczesna szkoła, aby być skuteczna, powinna zrezygnować z pewnych dogmatów i utartych schematów dotyczących zarządzania procesem kształcenia. Ponadto powinna wykorzystywać najnowsze ustalenia naukowe, nie tylko z zakresu pedagogiki, lecz także ekonomii (slow and fast thinking). Wielu naukowców i praktyków edukacji wyraża zaniepokojenie perspektywami, jakie roztacza przed światem system edukacji nastawiony na testy. Nauczyciele powinni być szkoleni, jeśli chodzi o umiejętność rozwoju kreatywności u dzieci.

\section{Słowa kluczowe:}

\section{kreatywność}




\section{Supporting the development of student creativity}

Jan Fazlagić

Creativity has become a permanent feature of everyday life. It has been long since creativity was attributed only to geniuses and top-elite of intellectuals, The current model of the Prussian school which become literally a world standard put emphasis on discipline and obedience. The top graduates of this school were destined to take up an academic career. In the ear of artificial intelligence and other developments, creativity looms as a precious competence, equal to literacy in the 19th century. To be effective, the modern school has to abandon the mental models and dogma related to the process of teaching. It should also draw upon the latest developments in science, not necessarily only in pedagogy but also in economic (e.g. The concept of slow and fast thinking). Many scholars and practitioners in education are worried by the focus on teaching-to-the-test which is present in most education systems cross the Word. Teachers should be trained in developing creativity and its assessment.

\section{Keywords:}

creativity

model of school

development of creativity 


\section{Wprowadzenie}

Wspieranie kreatywności wśród uczniów to temat, który nie rodzi zbyt wielu kontrowersji ani nie wywołuje ożywionych dyskusji dotyczących polityki oświatowej. Kreatywność budzi chyba wyłącznie pozytywne skojarzenia (abstrahując od wykorzystania tego pojęcia w kontekście pejoratywnym, np. kreatywna księgowość). To, że kreatywność nie budzi kontrowersji, jest zarówno zaletą, jak i wadą. Kreatywność jest wykorzystywana zwykle jako mniej lub bardziej użyteczny dodatek do głównych celów systemu edukacji, które ogniskują się na przekazywaniu wiedzy i wychowaniu.

W ostatnich latach uzmysłowiono sobie, że rozwój gospodarczy oparty wyłącznie na eksploatacji surowców i walce konkurencyjnej przedsiębiorstw oraz wspierających je rządów nie jest wystarczającym gwarantem bogactwa. Żyjemy w czasach, w których bogactwo jest stworzone według innego modelu niż w przeszłości. Akumulacja kapitału jako recepta na wzrost gospodarczy coraz częściej zastępowana jest akumulacją kreatywnych działań.

Mark Zuckerberg stworzył Facebooka nie dlatego, że był mistrzem finansów. Nie miał też dostępu do unikatowych zasobów. Stał się piątym najbogatszym człowiekiem na świecie w ciągu 10 lat, ponieważ wykorzystał kreatywność własną i swoich współpracowników. Rodzi się więc pytanie o rolę kreatywności jako cechy, która jest kształtowana w systemie edukacji. Model pruskiej szkoły powstał z przyczyn bardzo pragmatycznych. Wychowanek XIX-wiecznej szkoły był doskonale dopasowany do realiów ówczesnego świata i mógł z łatwością odnaleźć się w rzeczywistości. Dzisiejszy absolwent ma coraz większe problemy z funkcjonowaniem w swoim otoczeniu. Żeby zilustrować ten problem, można posłużyć się przykładem bohatera filmu, w którym główną rolę grał Jerzy Stuhr. Uciekając przed rzeczywistością pod koniec lat 80. XX w., postanowił on zostać mnichem i odizolować się od świata. Po zmianie systemowej w Polsce powrócił zaś do nowej rzeczywistości, ale nie potrafi się w niej odnaleźć. Podobny szok kulturowy przeżywają często absolwenci szkół, którzy po kilkunastu latach uczenia się definicji i dyscypliny polegającej na bezrefleksyjnym wykonywaniu zadań wyznaczonych przez nauczyciela trafiają do przedsiębiorstw i pracodawców, którzy wymagają od nich samodzielnego myślenia, odnajdywania sensu informacji oraz podejmowania inicjatywy. 


\section{Uzasadnienie nauczania kreatywności}

Wszyscy, którzy choć trochę znają historię i literaturę, znają także obraz XIX-wiecznej Anglii opisywanej przez Charlesa Dickensa. W książce pt. Ciężkie czasy (wyd. 1854 r.) występuje postać dyrektora szkoły Thomasa Gradgrinda, który tak postrzega edukację:

Wszystko, czego oczekuję od was, to fakt. Nie uczcie tych chłopców i dziewczynek niczego więcej niż tylko faktów. Do życia wystarczq fakty. Sadźcie w ich umysłach jedynie fakty i wypleniajcie wszystko inne. Umysły rozumnych zwierząt można kształtować jedynie na podstawie faktów, nic innego się im nie przyda w życiu. Tę zasadę wykorzystuję, wychowując moje własne dzieci, i na tej zasadzie będę wychowywał uczniów. Niech pan się trzyma faktów, Sir!

Tak właśnie kształtował się obraz szkoły, który nadal jest silnie zakorzeniony w strukturach systemów edukacji i mentalności nauczycieli w większości krajów świata, także tych będących obiektem niniejszej analizy (szczególnie bliski tego modelu jest ten z Korei Południowej). Trzeba także zaznaczyć, że w XIX w. opisana wyżej koncepcja była bardzo nowoczesna. Pruski model szkoły, który upowszechnił się na zachodzie Europy, w tym także w wiktoriańskiej Wielkiej Brytanii, był przedmiotem eksperymentu, który objął cały świat. Gdy pod koniec XIX w. zaczęła reformować się Japonia, także zapożyczyła pruski model edukacji. Kraje azjatyckie, takie jak Chiny, Korea Południowa i Singapur, nie tworzyły własnego modelu edukacji, ale importowały go od lokalnego lidera, jakim była Japonia. Analizując zatem systemy edukacji, szczególnie w krajach azjatyckich i w nowym świecie, warto pamiętać o historycznych korzeniach, a także sekwencji transferu rozwiązań instytucjonalnych w systemach edukacji (Prusy - Francja - Japonia - Korea Południowa itd.). W XIX-wiecznym modelu szkoły nie oczekiwano od uczniów korzystania z wyobraźni. W wiktoriańskiej Anglii nie prowadzono badań nad kreatywnością dzieci. Możemy krytykować ówczesny system edukacji z perspektywy XXI w. Kształtowanie się osobowości dziecka nie odbywa się jednak tylko w szkole. Jest to ważna uwaga, ponieważ - jak wiemy - w XIX w. Wielka Brytania była najbardziej innowacyjnym krajem na świecie. Czy wiktoriańskie szkoły zabijały wtedy kreatywność? Z pewnością nie. W grę musiały wchodzić inne czynniki 
odpowiedzialne za innowacyjność. W Wielkiej Brytanii był już wtedy dojrzały system demokratyczny, a względny dobrobyt na tle innych krajów europejskich pozwalał na awans osobom z niższych warstw społecznych. Rozległe imperium dawało szansę na karierę "niepokornym". Silna była wówczas także rola Kościoła jako instytucji kształtującej normy moralne i etyczne. Duże wielopokoleniowe rodziny zapewniały bezpieczeństwo socjalne i emocjonalne. Wszystkie te czynniki uległy jednak radykalnym zmianom w XIX w. poza... modelem szkoły.

Jeśli chcemy projektować szkołę i programy nauczania sprzyjające rozwojowi kreatywności u uczniów, to powinniśmy najpierw zdefiniować to, kim jest kreatywny uczeń, a także przygotować nauczycieli do pracy w nowym systemie priorytetów. Chodzi o to, że istnieją pewne obszary kolizyjne między priorytetami współczesnej szkoły nastawionej na uniformizację i standaryzację a priorytetami modelowej szkoły wspierającej rozwój kreatywności u uczniów. Obszary te zostały w zarysie przedstawione $\mathrm{w}$ tabeli $\mathrm{nr} 1$.

Tabela 1. Obszary kolizyjne dotyczące szkoły sprzyjającej kreatywności

\begin{tabular}{|c|c|c|}
\hline OBSZARY KOLIZYJNE & $\begin{array}{l}\text { ODNIESIENIE DO SZKO } K Y \\
\text { TRADYCYJNEJ }\end{array}$ & $\begin{array}{c}\text { ODNIESIENIE DO SZKOŁY } \\
\text { SPRZYJAJĄCEJ KREATYWNOŚcI }\end{array}$ \\
\hline $\begin{array}{l}\text { Sposób ewaluacji pracy } \\
\text { ucznia }\end{array}$ & Nastawienie na wyniki & $\begin{array}{l}\text { Nastawienie na ocenę procesu } \\
\text { rozwiązywania problemu }\end{array}$ \\
\hline $\begin{array}{l}\text { Metody pracy } \\
\text { z uczniem }\end{array}$ & $\begin{array}{l}\text { Wykład, studium przypadku, } \\
\text { praca projektowa }\end{array}$ & $\begin{array}{l}\text { Praca metodą problemową } \\
\text { (problem-based learning) }\end{array}$ \\
\hline $\begin{array}{l}\text { Mierniki oceny predys- } \\
\text { pozycji ucznia }\end{array}$ & Testy na inteligencję & Testy na kreatywność \\
\hline Rola środowiska pracy & $\begin{array}{l}\text { Drugorzędna, wyniki nie są } \\
\text { uzależnione od kontekstu } \\
\text { sytuacyjnego }\end{array}$ & $\begin{array}{l}\text { Wyniki nie są uzależnione } \\
\text { od kontekstu sytuacyjnego }\end{array}$ \\
\hline $\begin{array}{l}\text { Założenia prezentowa- } \\
\text { ne przez nauczycieli }\end{array}$ & $\begin{array}{l}\text { Akademicka doskonałość } \\
\text { jest dowodem na wysokie } \\
\text { kompetencje ucznia }\end{array}$ & $\begin{array}{l}\text { Multidyscyplinarność i zdol- } \\
\text { ność do myślenia dywergencyj- } \\
\text { nego skutkująca tworzeniem } \\
\text { kreatywnych rozwiązań są } \\
\text { dowodami na kompetencje } \\
\text { ucznia }\end{array}$ \\
\hline Kształcenie nauczycieli & $\begin{array}{l}\text { Nastawienie na dziedzinowe } \\
\text { opanowanie materiału, który } \\
\text { będzie nauczany }\end{array}$ & $\begin{array}{l}\text { Nastawienie na proces, anga- } \\
\text { żowanie ucznia, odkrywanie } \\
\text { talentów }\end{array}$ \\
\hline
\end{tabular}


Jedną z ważnych cech szkoły wspierającej rozwój kreatywności jest uznanie znaczenia środowiska, w jakim wychowuje się i pracuje uczeń, dla oceny jego zdolności kreatywnych. Podobnie jak to jest w przypadku edukacyjnej wartości dodanej (EWD) również w kreatywności niezbędne jest uchwycenie nie tylko rezultatu końcowego, lecz także postępów. Ewaluacja pracy ucznia jest zatem bardziej skomplikowana. Należy jej poddać i uwzględnić przy ocenie końcowej następujące czynniki':

1. Person-osoba,

2. Product - wynik procesu kreatywnego,

3. Process - proces,

4. Press-środowisko,

5. Passion - pasja.

\section{Kreatywność a współczesna szkoła}

Popularność terminu kreatywność jest tak wielka, że coraz częściej używany jest on bezrefleksyjnie, niemal jako synonim wysokiej jakości nauczania. Tymczasem warto najpierw ustalić, czym jest kreatywność w szkole, czy naprawdę jej potrzebujemy, a jeśli tak, to w jakim celu. Najczęstsze skojarzenia związane z kreatywnością odnoszą się do aktywności artystycznej, sposobów ubierania się oraz ogólnego braku konformizmu (Moran, 2010). Generalnie kreatywność oznacza tworzenie oryginalnych rozwiązań, które są adekwatne do problemu lub są odpowiedzią na zapotrzebowanie (patrz np. Amabile, 1996; Sternberg, 1999). Jednak paradoks kreatywności polega na tym, że wybitne dzieła kreatywne nie tyle zaspokajają jakieś zapotrzebowanie, ile po prostu je tworzą. Pod koniec XIX w. nikt nie zgłaszał zapotrzebowania na samochód, a pomimo tego wynalazek ten powstał. Społeczeństwo wówczas raczej oczekiwało lepszej wersji konia. Kreatywność to jedna z tych cech, które odróżniają nas od zwierząt. Haidth zwrócił uwagę na istnienie genu neofilii, który sprawił, że nasz gatunek ewoluował tak, iż jednostki przekazujące ten gen swojemu potomstwu odnosiły większe sukcesy (Haidth, 2013). W dzisiejszych czasach coraz bardziej popularna staje się teza, że o sukcesie człowieka w najbliższej przyszłości będzie decydowała jego zdolność do bycia kreatywnym.

1. Autorem koncepcji „Pięciu P" kreatywności (pierwotnie cztery P) był James Melvin Rhodes (1916-1976). Patrz: M. Rhodes, An analysis of creativity, Phi Delta Kappa 1961, Vol. 42, s. 305-311. 
Z dzisiejszej perspektywy jest ona dość banalna, lecz w zestawieniu $z$ ideologią XIX-wiecznej szkoły jest to twierdzenie bardzo radykalne. Szkoła XIX-wieczna miała przede wszystkim uczyć dyscypliny, przekazywać kody kulturowe zgodne z polityką państwa oraz przygotowywać absolwentów do pracy w przemyśle i wojsku.

Wielu badaczy (m.in. Bellanca, Brandt, 2010; Trilling, Fadel, 2009) uważa, że obecnie szkoły powinny być zorientowane tak, by uwzględniać potrzeby uczniów, a nie nauczycieli. A więc już sama konstrukcja współczesnej szkoły i układ klas są hamulcami dla jej rozwoju (Wagner, 2012).

W czasie dyskursu na temat kreatywności w szkole warto rozróżnić kreatywne nauczanie i nauczanie, którego celem jest rozwój kreatywności (NACCCE, 1999). To pierwsze podejście jest bardzo ważnym elementem metodyki nauczania i wiąże się z postawą nauczyciela, jego pasją, a także umiejętnością zastosowania różnych metod nauczania. Jednak rozróżnienie to może nie oddawać w pełni istoty problemu (Jefrey, Craft, 2010). Nauczyciel stosujący kreatywne metody nauczania w naturalny sposób inspiruje ucznia i pokazuje możliwości wykorzystania kreatywności w życiu. Natomiast warto spojrzeć na te dwie kwestie z perspektywy celów. W pierwszym przypadku mamy do czynienia z dążeniem do zwiększenia efektywności nauczania, a nauczanie kreatywności jest swego rodzaju produktem ubocznym. Jak twierdzą Jefrey i Craft (2010), obu kwestii nie da się jednak rozdzielić. Nauczanie dla kreatywności często pojawia się spontanicznie i wyłania się z kontekstów pojawiających się w procesie nauczania. Dlatego rozdzielenie tych dwóch pojęć wydaje się szkodliwe. Szkoła nauczająca kreatywności powinna łączyć w sobie oba podejścia.

Badania nad kreatywnością rozpoczęły się dzięki pracom Joya Paula Guilforda (1950) oraz Ellisa Paula Torrance'a $(1962,1974)$. Do dziś testy kreatywności Torrance'a są uznawane za najbardziej wiarygodne. Robert Sternberg i Todd Lubart $(1991,1995)$ wprowadzili do teorii kreatywności koncepcję inwestowania zapożyczoną z nauk ekonomicznych. „Kupowanie po niskich cenach" w przypadku osób kreatywnych oznacza zainteresowanie i poświęcenie czasu ideom mało znanym i niepopularnym. Gdy idea staje się popularna z czasem, osoba kreatywna "sprzedaje ją" i upowszechnia, często zyskując uznanie oraz sławę. Z perspektywy edukacji taka teoria oznacza, że współczesna szkoła uczy przede wszystkim „inwestycji mało ryzykownych". Uczniowie nie 
są przyzwyczajani do tego, że efekt pracy (kreatywnej) może być „niesprzedawalny". A zatem współczesna szkoła uczy, że edukacja polega na odnajdywaniu właściwego i istniejącego już rozwiązania.

\section{Jak wspierać kreatywność w szkole?}

W Holandii, podobnie jak w wielu innych krajach na świecie, obserwujemy rosnący poziom frustracji, jeśli chodzi o efektywność szkoły w kształtowaniu kreatywności. W tamtejszym Radboud University w Nijmegen w 2016 r. zainicjowano projekt badawczy pt. Kultywowanie kreatywności w edukacji. Interakcje między nauczaniem a uczeniem się (Radboud Teachers Academy, 2016). Zauważa się, że uczniowie potrzebują zdolności do wykorzystania wiedzy w sposób innowacyjny (Ferrari i in., 2009). Ponadto za zwiększeniem szeroko rozumianej kreatywności szkoły przemawia argument związany z jej pozytywnym wpływem na jakość życia (Deci i Ryan, 2002). Jednocześnie istnieje wiele dowodów na to, że odpowiednio zaprojektowana szkoła może mieć realny wpływ na podniesienie poziomu kreatywności uczniów (Sternberg, 2006). Współczesna szkoła pełni przede wszystkim funkcję kwalifikacyjną (Biesta, 2014), lecz nie jest zbyt skuteczna w pełnieniu funkcji socjalizacyjnej oraz nadawania podmiotowości uczniowi. Kultywowanie kreatywności w szkole połączenia tych trzech ważnych funkcji w procesie edukacji. W projekcie Radboud University zwrócono uwagę na kilka rodzajów interakcji zachodzących w procesie edukacji:

1. Interakcja między nauczaniem a uczeniem się. Po stronie nauczycieli mamy więc kreatywną metodykę nauczania oraz wiedzę profesjonalną, która wchodzi w interakcję z procesem uczenia się po stronie uczniów.

2. Interakcja między nauczycielem a miejscem pracy (rozwój zawodowy i doskonalenie nauczycieli) - szkolenia nauczycieli powinny być zawsze powiązane z kontekstem wykonywania przez nich pracy (Meirink i in., 2010).

3. Tożsamość nauczyciela - położenie nacisku na kultywowanie kreatywności często wiąże się z koniecznością zmian postaw i modeli myślowych po stronie nauczycieli. Nauczyciele muszą rozwiązać dylemat, jaki pojawia się między dyscypliną a swobodą dawaną uczniowi.

4. Ogólna kreatywność czy kreatywność dziedzinowa? Badaczom kreatywności udało się wyszczególnić uniwersalne oraz specy- 
ficzne dla danej dziedziny wiedzy cechy procesu kreatywnego. Wyzwaniem jest więc zaprojektowanie szkoły, w której kształtowany będzie zarówno uniwersalny komponent związany z myśleniem kreatywnym, jak i kreatywność dziedzinowa, nauczana w ramach poszczególnych przedmiotów.

Cheng zaproponował typologię rodzajów myślenia, która może mieć praktyczne zastosowanie w tworzeniu programów nauczania wspierających rozwój kreatywności uczniów, a także programów interdyscyplinarnych (Cheng, 2004a, 2004b). Wyróżnił:

1. Myślenie technologiczne - oparte na technologicznej racjonalności, która wyraża się planowaniem, wykorzystaniem struktur i metodologii naukowych. Zakłada wykorzystanie metody naukowej do rozwiązywania problemów naukowych i założonych celów. Wynikiem tego rodzaju myślenia jest produkt. Jeżeli efekt końcowy różni się od oczekiwanego, wówczas oznacza to, że popełniono jakieś błędy w planowaniu lub procedurze realizacji.

2. Myślenie ekonomiczne - oparte na ekonomicznej racjonalności, tzn. maksymalizacji korzyści poprzez optymalne wykorzystanie zasobów. Efektywność, opłacalność, zarządzanie zasobami oraz ekonomiczna optymalizacja stanowią podstawę tego rodzaju myślenia. Myślenie ekonomiczne polega na organizowaniu zasobów zewnętrznych i wewnętrznych oraz dążeniu do uzyskania korzyści. Jakość wyniku ocenia się na podstawie sposobu wykorzystania zasobów oraz wyników ekonomicznych.

3. Myślenie społeczne - dotyczy wartości oraz czynników społecznych związanych z ludzkim działaniem. Jest oparte na społecznej racjonalności, która podkreśla znaczenie relacji międzyludzkich i podejmowania inicjatywy. Społeczne interakcje i relacje, zaspokajanie ludzkich potrzeb, inicjatywy podejmowane przez ludzi oraz ideologie są podstawą myślenia społecznego. Myślenie społeczne służy organizacji sieci społecznych oraz motywowaniu ludzi do realizacji celów. Wynikiem myślenia społecznego są dobrze funkcjonujące sieci społeczne oraz więzi ludzkie oparte na solidarności i wzajemnym szacunku.

4. Myślenie polityczne - oparte na politycznej racjonalności, która podkreśla znaczenie zróżnicowania interesów i oczekiwań różnych aktorów oraz grup interesów. W takim rodzaju myślenia 
liczą się zdolność do budowania sojuszy, negocjacje, kompromisy, partycypacja społeczna i procesy demokratyczne. W myśleniu politycznym dużą rolę odgrywają walka o władzę, konflikty interesów oraz konfrontacja. Wynikiem myślenia politycznego są uzyskane kompromisy oraz przenikanie się poglądów uczestników zmagań o władzę.

5. Myślenie kulturowe - oparte na kulturowej racjonalności, która zakłada, że efektywność działań organizacyjnych pozostaje pod wpływem wartości, przekonań, etyki oraz tradycji stanowiących dziedzictwo poszczególnych uczestników organizacji. W związku z tym tworzenie organizacji, których członkowie posiadają wspólne wartości, przekonania i normy moralne, stanowi główny cel myślenia kulturowego. Jego efektem są symboliczne produkty lub wytworzone zdarzenia.

6. Myślenie adaptacyjne (learning thinking) - połączone z koniecznością ciągłego uczenia się i adaptowania do zmian. Głównym celem działań związanych z tym rodzajem myślenia jest odkrywanie nowych pomysłów, wiedzy i sposobów rozwiązywania problemów. Efektami tego rodzaju myślenia są odkrycie i zmiana w stanie wiedzy.

Być może właśnie te rodzaje myślenia mogą stanowić podstawę do stworzenia nowej struktury świadectwa ukończenia szkoły. Zamiast nazw przedmiotów odnotowywałoby cząstkowe kompetencje w różnych obszarach myślenia. Takie oceny mogliby wystawiać nauczyciele różnych przedmiotów.

Na podstawie przedstawionych rozważań można zaproponować pewne założenia służące przeprojektowaniu współczesnej szkoły w taki sposób, by lepiej niż obecnie wspierała ona rozwój kreatywności. Pod uwagę należy wziąć następujące zagadnienia:

1. Jakość środowiska pracy w szkole, w tym m.in. projekt pomieszczeń szkolnych, wykorzystywane pomoce naukowe.

2. Kompetencje nauczycieli.

3. Mierniki kreatywności uczniów i sposoby ich pomiaru.

4. Ewaluacja wyników pracy ucznia - jak będziemy oceniać jego postępy i efekty pracy.

5. Czy będziemy oceniać kreatywność ogólnie czy dziedzinowo? Czy będziemy skłonni wystawiać ocenę ogólną z kreatywności 
na świadectwie tak jak obecnie z zachowania, czy zaplanujemy cząstkową ocenę kreatywności ucznia w ramach każdego ocenianego przedmiotu?

Typologia opracowana przez Chenga zawiera zupełnie nowe spojrzenie na kompetencje ucznia. Nie ma w niej mowy o podziale na przedmioty. Być może szkoła przyszłości powinna więc być szkołą, w której celem edukacyjnym nie będzie zdobycie przez ucznia jakiejś konkretnej wiedzy, ale właśnie dążenie do doskonałości w różnych rodzajach myślenia.

\section{Polska podstawa programowa w świetle postulatów związanych ze wspieraniem kreatywności u uczniów}

Zapisy związane z podstawą programową, treściami programowymi oraz metodami nauczania są zawarte $w$ dokumentach MEN. Na przykład Wymaganie nr 3 wskazane w Rozporządzeniu Ministra Edukacji Narodowej z dnia 6 sierpnia 2015 r. w sprawie wymagań wobec szkół i placówek stanowi: „Uczniowie nabywają wiadomości i umiejętności określone w podstawie programowej". Szkoły, nauczyciele podejmują działania, których celem jest spełnienie tego wymagania na poziomie niskim lub wysokim. Ewaluacja zewnętrzna prowadzona przez kuratoria oświaty jako organ nadzoru pedagogicznego ocenia zaś efekt ich pracy. Na podstawie wyników badań ewaluacyjnych przeprowadzonych w szkołach w danym roku powstaje raport. Poniżej przedstawiono wybrane wyniki i wnioski:

$\rightarrow$ "Nauczyciele stawiaja przed uczniami zadania, które w większym stopniu umożliwiajg̨ im [...] wykonywanie powtarzalnych procedur i wykorzystanie wiedzy w sytuacjach typowych, w mniejszym zaś pozwalajg na rozumowanie złożone, dowodzenie, argumentowanie, dostrzeganie zależności i zwiq̨zków".

$\rightarrow$ Nauczyciele kształtują najważniejsze umiejętności wynikające z podstawy programowej, przy czym powszechny charakter ma kształtowanie umiejętności uczenia się, czytania, komunikowania się w języku ojczystym i w języku obcym; w mniejszym zakresie kształtowane są umiejętności pracy zespołowej, myślenia naukowego i matematycznego oraz posługiwania się nowoczesnymi technologiami informacyjno-komunikacyjnymi.

$\rightarrow$ Nauczyciele stawiają przed uczniami zadania, które w większym stopniu umożliwiają im zapamiętywanie faktów, definicji, wyko- 
nywanie powtarzalnych procedur i wykorzystanie wiedzy w sytuacjach typowych, w mniejszym zaś pozwalają na rozumowanie złożone, dowodzenie, argumentowanie, dostrzeganie zależności i związków.

$\rightarrow$ Nauczyciele podczas zajęć spełniają zalecane warunki i stosują sposoby realizacji podstawy programowej, przy czym w codziennej pracy z uczniami realizują główne cele kształcenia przedmiotowego i kluczowe zadania nauczyciela przedmiotu, stosują zalecane metody pracy; najrzadziej spełnianym warunkiem realizacji podstawy programowej jest zapewnienie uczniowi ciągłości i kontynuacji w nabywaniu wiedzy przedmiotowej.

$\rightarrow$ Nauczyciele monitorują i analizują osiągnięcia uczniów, ograniczając się przy tym do stałych tradycyjnych form, takich jak zadawanie pytań, sprawdzanie, w jaki sposób uczniowie wykonują zadania i czy właściwie zrozumieli omawiane kwestie, oraz zachęcanie uczących się do zadawania pytań.

Uważa się, że najlepszym gwarantem kreatywności w nauczaniu jest zaangażowanie kreatywnego nauczyciela (Tanggaard, 2011). Tymczasem wiedza wśród nauczycieli o kreatywności jest bardzo uboga. Nie naucza się ich, jak wspierać kreatywność uczniów na studiach, tematyka ta nie jest także popularna na szkoleniach dla nauczycieli. W polskiej szkole bohaterem pozytywnym jest typ "człowieka oświeceniowego", który właśnie wyzwolił się ze strachu przed siłami przyrody i magii, który naukę i odkrycia traktuje jako odreagowanie poprzedniego okresu, gdy wiedza o świecie była znana tylko nielicznym, a wyjaśnianie zjawisk przyrodniczych było domeną elit2. Polska szkoła preferuje zdolność szybkiego myślenia (fast thinking). Zdolności uczniów, które ujawniają się w procesie XIX w. - lata 70. XX w.), świat zmieniał się na tyle powoli, że wiedza zdobyta w szkole była aktualna przez kilkanaście lat po opuszczeniu murów instytucji przez absolwentów. Na przykład napęd żaglowy na statkach handlowych przestano definitywnie stosować dopiero w latach 60. XX w. Koń był podstawowym rodzajem transportu i zapewniał mobilność zarówno rydwanom rzymskim, jak i niemieckim dywizjom piechoty zajmującym Polskę w 1939 r. Wiek XXI wymaga jednak zmian w podejściu do problemu aktualności wiedzy w szkole, czyli aktualizacji podstawy programowej. I wcale nie dotyczy to wiedzy wyłącznie technicznej: nowe odkrycia archeologiczne z ostatnich 15 lat powinny być uwzględnione w podręcznikach historii Polski, ponieważ rzucają nowe światło na początki państwa polskiego, a zmiany kulturowe i społeczne pozwalają nam inaczej postrzegać sceny polowania zawarte w Panu Tadeuszu itd. 
wolnego myślenia (slow thinking), są rzadko nagradzane i nieoceniane w polskiej szkole.

Należy rozwijać w uczniach umiejętność wykorzystywania wiedzy w praktyce, gdy tylko jest ku temu okazja. Nauczyciele powinni wykształcić nawyk ilustrowania każdej tezy przykładami, a od uczniów wymagać podania przykładów. Zgodnie z postulowaną tu zasadą ocena pozytywna ucznia w szkole powinna odzwierciedlać nie poziom wiedzy, jak obecnie, lecz poziom wykorzystania wiedzy w praktyce według gradacji:

3.0 - "zna" - posiada wiedzę teoretyczną,

4.0 - potrafi podać przykład zastosowania znany z lekcji,

5.0 - potrafi przedstawić własny oryginalny przykład wykorzystania wiedzy.

Umiejętność wykorzystania wiedzy w praktyce jest silnie akcentowana w systemach: japońskim, niemieckim, duńskim i fińskim. Warto też wykorzystać założenia irlandzkie, czyli odwoływanie się do learning retention theory, według której odsetek przyswojonej przez ucznia wiedzy uzależniony jest od zastosowanej metody kształcenia. Wartości wynoszą odpowiednio: 5 proc. dla wykładu, 75 proc. dla pracy eksperymentalnej ucznia, 90 proc. dla sytuacji, w których uczniowie wzajemnie się od siebie uczą (peer tutoring).

Obowiązująca podstawa programowa wyrasta z ideologii transmisji kulturowej, w której od dziecka oczekuje się przede wszystkim podporządkowania intelektualnego (dziedzictwo pruskiego systemu edukacji, który miał kształcić posłusznych rekrutów do armii), a nie niezależności i rozmachu w poznawaniu świata. Nie wskazuje celów najistotniejszych dla podmiotowości wychowanka, takich jak:

$\rightarrow$ niezależność emocjonalna,

$\rightarrow$ wiara we własne siły,

$\rightarrow$ ciekawość poznawcza,

$\rightarrow$ samodzielność,

$\rightarrow$ podejmowanie działań,

$\rightarrow$ kreatywność,

$\rightarrow$ umiejętność współpracy, komunikacji,

$\rightarrow$ potrzeba samodoskonalenia.

Model pruskiej szkoły znacząco odbiega od realiów współczesnej szkoły w Finlandii, gdzie dzieci wychodzą do szkoły niezbyt wcześnie 
i niezbyt późno z niej wracają. Mają krótkie zajęcia, długie wakacje i zadaje się im niewiele pracy domowej. Z perspektywy projektowania podstawy programowej w polskiej szkole można wyróżnić pewne zjawiska, które utrudniają wspieranie kreatywności u uczniów:

$\rightarrow$ Promowanie powierzchownego uczenia się (shallow learning) - około 90 proc. wiedzy nabytej w trakcie uczenia powierzchownego jest utracone. Zaliczanie klasówek i egzaminów przez uczniów dostarcza pozytywnych informacji zwrotnych nauczycielowi, ale wiedza zdobyta w procesie uczenia się powierzchownego (shallow knowledge) nie wzbogaca intelektualnie uczniów. W związku z tym szkoły powinny więcej czasu poświęcać na ćwiczenia umysłowe (wszelakiego rodzaju), bo udział w takich ćwiczeniach ma znacznie większy wpływ na rozwój umysłowy niż traktowanie mózgu jako "gąbki", która powinna "wchłaniać" wiedzę. Uczenie się pod test (teaching to the test) z pewnością może wspierać umiejętność uczenia się powierzchownego.

$\rightarrow$ Posługiwanie się przez nauczycieli programem nauczania - z perspektywy ucznia program nauczania jest pojęciem abstrakcyjnym. Wyjątkiem mogą być m.in. lekcje wychowania fizycznego lub języka obcego. Tam uczeń może łatwiej (i przy mniejszym wysiłku ze strony nauczyciela) zrozumieć istotę tego, czego oczekuje od niego nauczyciel. W przypadku WF-u może to być wykonanie trudnego ćwiczenia fizycznego, uzyskanie wyniku w sporcie itp. W przypadku nauczania języków obcych takim kamieniem milowym może być zdolność do zrozumienia tekstu filmu lub porozumienie się $w$ konkretnej sprawie z obcokrajowcem (np. zabukowanie hotelu przez telefon). W przypadku większości innych przedmiotów uczeń nie ma pełnej świadomości, że cele edukacyjne wyznaczane przez nauczyciela i szkołę są jego celami.

$\rightarrow$ Nauczanie treści programowych, które są zdezaktualizowane - obniża to autorytet szkoły i nauczyciela. Ponadto pozbawia ucznia doświadczania tego, że wiedza ciągle się rozwija, że należy być czujnym ze względu na jej szybką dezaktualizację.

$\rightarrow$ Podział na przedmioty, który jest jednym z kanonów współczesnych systemów edukacji, choć ma wiele zalet, może wpływać negatywnie na rozwój kreatywności. Teresa Amabile w badaniu przeprowadzonym na próbie 9 tys. osób pracujących nad 
projektami wymagającymi kreatywności i innowacji udowodniła, że prawdopodobieństwo powstania innowacji jest większe, jeśli pracownicy pracują nad jednym projektem. I na odwrót: osoby, które miały plan dnia podzielony na wiele różnych aktywności, okazywały się mniej kreatywne (Amabile, 2002). Jeśli więc zaplanowana $w$ ramach podstawy programowej wiedza byłaby przekazywana uczniom w ramach interdyscyplinarnych (międzyprzedmiotowych) projektów, wówczas można by się spodziewać pozytywnego wpływu na kreatywność uczniów. Wymagałoby to jednak radykalnego przeorganizowania pracy szkoły, zmian w kształceniu nauczycieli, którzy mieliby się stać ekspertami w kilku obecnych „przedmiotach". Innym rozwiązaniem mogłaby być praca symultaniczna (kilku nauczycieli pracuje jednocześnie z grupą uczniów) lub - co jest tańszym rozwiązaniem - sekwencyjna w czasie projektu.

$\rightarrow$ Nadmierne faworyzowanie uczniów, którzy łatwo ustępują i się podporządkowują oraz wykazujących się wysokim poziomem dyscypliny - należy, dbając o dyscyplinę, raczej skoncentrować się na karaniu ekstremalnych przypadków naruszania reguł niż na nagradzaniu tych, którzy nigdy żadnych reguł nie przekroczyli. Nie jest to kwestia semantyki. To, kto jest nagradzany w szkole, ma dużą siłę wychowawczą i motywującą. Sposób, w jaki szkoła kreuje bohaterów pozytywnych i negatywnych, ma fundamentalne znaczenie dla kształtowania kompetencji proinnowacyjnych. Sprawa ustalenia profilu (profili) pozytywnych bohaterów kultury organizacyjnej szkoły jest bardzo ważna w procesie zwiększania jej zdolności do kształtowania kompetencji proinnowacyjnych. Należy bezwzględnie dokonać rewizji naszego rozumienia pojęcia dobry uczeń, wzorowy uczeń.

$\rightarrow$ Zabijanie spontaniczności poprzez zakazywanie uczniom prób rozwiązania problemu, zanim się dowiedzą od nauczyciela, jaka jest metoda jego rozwiązania. Powstrzymywanie uczniów od spontanicznych prób w tym względzie jest bardzo szkodliwą, a jednocześnie standardową praktyką w szkole. Tymczasem w życiu codziennym poszukiwanie sposobu rozwiązania problemu jest częścią procesu kreatywnego. W szkole, można powiedzieć, jest on brutalnie "amputowany" $\mathrm{i}$ eliminowany $z$ procesu dydaktycznego. 
$\rightarrow$ Promowanie imitacji - wykorzystywanie różnego rodzaju gotowych zestawów odpowiedzi, zachęcanie, aby reszta klasy postępowała tak jak wzorowy uczeń - tego typu zachowania nauczycieli skłaniają do imitowania, a zniechęcają do samodzielności i odwagi.

$\rightarrow$ Promowanie uproszczonych, sztucznych opisów sytuacji pozbawionych elementu niepewności i nieprzewidywalności.

Należy radykalnie zwiększyć liczbę zajęć prowadzonych w grupach w celu poprawy umiejętności współpracy, a także skuteczności procesu uczenia się (peer tutoring). Metoda ta jest stosowana powszechnie w Niemczech.

Szkoła nastawiona na ocenę wyników testu zupełnie odbiera sens myśleniu kreatywnemu. Zdany egzamin jest tylko biurokratycznym zdarzeniem, a nie osiągnięciem ucznia $w$ takim znaczeniu, jak rozumie to psychologia kreatywności. W celu rozwoju kreatywności polskie szkoły powinny wprowadzić do programów nauczania możliwość tworzenia bardziej trwałych osiągnięć przez uczniów. Na lekcjach plastyki takimi trwałymi efektami działań z pewnością są rysunki tworzone przez uczniów. Tego typu dzieł trudno jednak doszukać się w nauczaniu innych przedmiotów. Wielu naukowców i praktyków edukacji wyraża zaniepokojenie perspektywami, jakie roztacza system edukacji nastawiony na zdawanie testów. Całe pokolenie uczniów na świecie wykształciło się w takim systemie. Co prawda są także argumenty przemawiające za promowaniem rygorystycznych testów, ale niezbędne jest zrównoważenie programów nauczania i zawarcie w nich większej liczby celów nastawionych na kształcenie kompetencji proinnowacyjnych. Na drodze do rozwoju kompetencji proinnowacyjnych stoi brak zdolności do projektowania. W tradycyjnym systemie edukacji pewną wiedzę o projektowaniu zdobywa się dopiero na studiach, natomiast innowacyjne szkoły uczą uczniów projektowania na bardzo wczesnym etapie. Ostatnią barierą dla rozwoju kreatywności w szkole jest ścisłe przestrzeganie rozgraniczenia między nauką a zabawą. Najbardziej kreatywne firmy uzyskują jednak dobre wyniki w tworzeniu innowacji dzięki temu, że pracownicy doskonale się w nich bawią. Co więcej, nauczyciele powinni być szkoleni w umiejętnościach oceny pracy. Każdy powinien znać cztery podstawowe kryteria oceny kreatywności: 
1. Płynność (liczba odpowiedzi).

2. Elastyczność (zróżnicowanie kategorii).

3. Oryginalność (statystyczna rzadkość występowania).

4. Staranność opisu (wysiłek włożony w prezentację dzieła przez autora).

\section{Wnioski końcowe i rekomendacje}

W niniejszym artykule podjęto próbę wyjaśnienia problemów współczesnej szkoły z perspektywy dorobku naukowego i wyników badań dotyczących kreatywności. Główny problem związany z kreatywnością polega na tym, że nie jest ona czymś, co można aplikować uczniom indywidualnie. Kreatywność wydarza się w pewnym środowisku, a więc kształtowanie postaw sprzyjających kreatywności dotyczy także zachowań osób, które same nie są twórcami, lecz mogą mieć pozytywny wpływ na efekty pracy twórczej jednostek wybitnych. Kwestia ta jest zresztą powiązana z kształtowaniem kapitału społecznego.

Reasumując rozważania na temat szkoły wspierającej kreatywność uczniów, można zaproponować następujące rekomendacje:

1) Należy promować kształcenie międzyprzedmiotowe - poza silosami wyznaczonymi przez przedmioty (przykład nowej strategii planowanej w Irlandii Północnej). Od nauczycieli należy wymagać, by na zajęciach ze swojego przedmiotu stosowali wiedzę z innych przedmiotów. Na przykład łączenie matematyki z biologią mogłoby polegać na obliczaniu powierzchni drzewa, liczby gałęzi. Nauczanie historii mogłoby uwzględniać informacje o logistyce i kampaniach toczonych przez polskie wojsko. Podstawowych nazw zjawisk fizycznych można by nauczać także na lekcjach języka angielskiego, np. H-Height (wysokość), V-Velocity (prędkość) lub Voltage (napięcie), wychowanie fizyczne (siła) itd. Dodatkową korzyścią byłoby kształcenie umiejętności wykorzystania wiedzy w praktyce. Takie podejście wymaga zmian w kształceniu nauczycieli.

2) Należy zwiększyć świadomość wszystkich aktorów w polskim systemie edukacji dotyczącą różnicy między inteligencją a kreatywnością. Kreatywność objawia się innymi zachowaniami i produktami pracy intelektualnej niż inteligencja. $Z$ badań prowadzonych nad osobami wybitnymi wynika jednoznacznie, że powyżej pewnego progu korelacja między inteligencją a kreatywnością znacząco 
spada. Osoby osiągające największe sukcesy życiowe charakteryzuje umiarkowanie wysoki poziom inteligencji. W systemie edukacji pokutuje jednak pogląd, że najlepsi uczniowie to tacy, którzy mają zdolność do sprawnego rozwiązywania z góry zdefiniowanych problemów.

3) Należy radykalnie zwiększyć liczbę zajęć prowadzonych w systemie grupowym. Uczniowie powinni być przypisywani do grup, w których spotkają zarówno rówieśników im znanych, jak i osoby im wcześniej nieznane. Dzięki temu kształtowana będzie zdolność do budowania zaufania. Organizacja obowiązkowych zajęć grupowych, w których czasie uczniowie będą rozwiązywać zadania twórcze, problemowe, sytuacyjne. Dokumentację tych zajęć mogą stanowić np. indywidualne lub grupowe portfolio, e-portfolio, dzienniki uczniowskie, sprawozdania itp. Pomysł zajęć prowadzonych zespołowo może być krytykowany za to, że pozwalają one na uchylanie się od pracy ("efekt gapowicza" - free-riding), lecz nie jest to argument silnie przemawiający przeciwko temu rozwiązaniu. Nauka odpowiedzialności, dyscyplinowanie i motywowanie do pracy to także elementy kompetencji związanych z umiejętnością pracy zespołowej.

4) Należy promować sukcesy każdego ucznia w dziedzinie twórczości i kreatywności - np. w postaci dodatkowych punktów przy rekrutacji do szkoły wyższego szczebla. Można w ramach realizacji tego postulatu wprowadzić "Olimpiadę/Konkurs kreatywności/innowacyjności" na wzór obecnie organizowanych olimpiad/konkursów przedmiotowych (np. matematyczne, językowe), których laureaci uzyskują preferencyjne punkty.

5) Należy wprowadzić ocenę opisową w zakresie kompetencji związanych z kreatywnością i różnymi stylami myślenia (rozumowania) na każdym etapie kształcenia.

6) Kwestia wdrażania innowacji w szkołach nie powinna być utożsamiana z kształtowaniem kompetencji proinnowacyjnych. Kompetencje proinnowacyjne można kształtować bez wykorzystania innowacji edukacyjnych, a nie wszystkie innowacje mogą i powinny służyć kształtowaniu kompetencji proinnowacyjnych. W analizowanych systemach edukacji tematyka innowacji edukacyjnych jest w zasadzie mało zauważalna na poziomie deklaratywnym. Innowacje mają powstać po prostu z programów, zmian organizacji 
systemu edukacji itp. Tworzenie innowacji przez nauczycieli nie jest traktowane jako strategiczny wyznacznik jakości systemu edukacji. Nie oznacza to, że w systemach tych innowacje nie powstają, lecz są one niejako immanentną cechą pracy każdego nauczyciela i nie są odgórnie nakazywane przez ministerstwa edukacji.

7) Należy wprowadzić zadania twórcze na egzaminie zewnętrznym oceniane opisowo z wykorzystaniem dostępnych narzędzi. W sytuacji, gdy kluczową rolę odgrywa w systemie edukacji system egzaminów zewnętrznych, należy rozważyć wprowadzenie pewnych elementów związanych z kompetencjami proinnowacyjnymi jako obiekt pomiaru, np. zadanie twórcze do wyboru. Idąc śladem reformy w Irlandii, warto wprowadzić przedmioty multidyscyplinarne, na których uczniowie rozwiązują problemy z wykorzystaniem wiedzy z kilku przedmiotów.

8) Warto, aby nauczyciele częściej stosowali metody i formy pracy ukierunkowane na stymulowanie aktywności uczniów podczas zajęć szkolnych. Taka organizacja pracy może mieć wpływ na zaangażowanie uczniów oraz zwiększenie atrakcyjności lekcji, co w konsekwencji może podnieść efektywność kształcenia.

9) Istnieje potrzeba szerzenia wśród wszystkich uczestników procesu nauczania właściwego znaczenia pojęcia inicjatywa uczniowska, rozumianego nie jako uczestnictwo w działaniach podejmowanych przez szkołę, ale propozycje wychodzące bezpośrednio od uczniów ${ }^{3}$.

3. Raport ORE 2015 - Wnioski i rekomendacje, czyli co warto zmienić w szkole, IBE, Warszawa 2015. 


\section{Bibliografia}

$\rightarrow$ Amabile, T.M. (1996), Creativity in context; 2nd ed, Boulder, CO: Westview Press.

$\rightarrow$ Baer, J. (2010), Is creativity domain specific? [w:] J.C. Kaufman, R.J. Sternberg (eds.), Cambridge Handbook of Creativity (pp. 321-341). Cambridge: Cambridge University Press.

$\rightarrow$ Bellanca, J., Brandt, R. (2010), 21st century skills: rethinking how students learn, Bloomington: Solution Tree Press.

$\rightarrow$ Biesta, G.J. (2014), The beautiful risk of education, Boulder: Paradigm Publishers.

$\rightarrow$ Cheng, Y.C. (2004a), Multiple thinking in organizational learning: new approaches to creativity and effectiveness in education - keynote speech presented at the 5th Thinking Qualities Initiative International Conference with the theme "Thinking and learning in action", Hong Kong, 25-26 June.

$\rightarrow$ Cheng, Y.C. (2004b), Learner-centred approach: enhancing multiple thinking and creativity in organizational learning, keynote speech presented at the 4th International Forum on Education Reform with the theme "Learner-centered approach towards education for sustainable development", organized by the Office of Education Council of Thailand Government, Bangkok, 6-10 September.

$\rightarrow$ Deci, E.L., Ryan, R.M. (2002), Overview of self-determination theory: An organismic dialectical perspective [w:] E.L. Deci, R.M. Ryan (eds.), Handbook of Self-Determination Research (pp. 3-34), Rochester: University of Rochester Press.

$\rightarrow$ Ferrari, A., Cachia, R., Punie, Y. (2009), Innovation and creativity in education and training in the EU member states: Fostering creative learning and supporting innovative teaching. JRC Technical Note, 52374 [w:] Radboud Teachers Academy, 2016, Cultivating Creativity In Education. Interactions Between Teaching And Learning, Radboud University, Nijmegen, Research Programme 2016-2021.

$\rightarrow$ Guilford, J.P. (1950), Creativity. "American Psychologist", 5, s. 444-454. 
$\rightarrow$ Moran, S., Littleton, K., Wood, C., Kleine-Staarman, J. (2010), Creativity in school. International Handbook of Psychology in Education, Bingley: Emerald Group Publishing Ltd., s. 319-359.

$\rightarrow$ Meirink, J.A., Imants, J., Meijer, P.C., Verloop, N. (2010), Teacher learning and collaboration in innovative teams, "Cambridge Journal of Education", 40(2), s. 161-181 [w:] Radboud Teachers Academy, 2016, Cultivating Creativity In Education. Interactions Between Teaching And Learning, Radboud University, Nijmegen, Research Programme 2016-2021 .

$\rightarrow$ NACCCE (1999), All our futures: creativity, culture and education, London: DfEE.

$\rightarrow$ Sternberg, R.J., (1999), Handbook of creativity, New York: Cambridge University Press.

$\rightarrow$ Sternberg, R.J., Lubart, T.I. (1995), Defying the crowd, New York: Free Press.

$\rightarrow$ Sternberg, R.J., Lubart, T.I. (1991), An investment theory of cre-ativity and its development, Miasto: Human Development, 34(1), s. 1-31.

$\rightarrow$ Torrance, E.P. (1974), Torrance tests of creative thinking, Lexington: Personnel Press.

$\rightarrow$ Torrance, E.P. (1962), Guiding creative talent, Englewood Cliffs: Prentice Hall.

$\rightarrow$ Trilling, B., Fadel, C. (2009), 21st century skills: learning for life in our times, San Francisco: Jossey-Bass.

$\rightarrow$ Wagner, T. (2012), Calling all innovators. Educational Leadership, 69: s. 66-69. 



\section{Racjonalne dostosowania i modyfikacje w edukacji uczniów mających specjalne potrzeby edukacyjne}

Ewa Domagała-Zyśk

Obecne zmiany systemu edukacji w Polsce w dużej mierze związane są z inkluzją - modelem edukacji, w którym każde dziecko, bez względu na poziom swoich możliwości i niepełnosprawności, jest w stanie kształcić się wraz z rówieśnikami w znajomym środowisku szkoły najbliższej swojemu miejscu zamieszkania. Dla nauczycieli oznacza to przede wszystkim konieczność doskonalenia swoich kompetencji metodycznych tak, aby móc efektywnie nauczać dzieci i młodzież ze zróżnicowanymi specjalnymi potrzebami edukacyjnymi. Celem tego rozdziału jest przedstawienie modelu projektowania uniwersalnego w uczenia się oraz zasad stosowania racjonalnych adaptacji i modyfikacji w nauczaniu i uczeniu się. Racjonalne adaptacje to termin niejednoznaczny. Najefektywniej można zaś nauczyć się zasad racjonalnego dostosowania poprzez analizę codziennych doświadczeń szkolnych. W tekście przedstawiono i przeanalizowano wiele przykładów racjonalnych i irracjonalnych dostosowań i modyfikacji, które pomogą czytelnikowi rozwinąć własny sposób projektowania i samooceny własnej metodyki nauczania.

\section{Słowa kluczowe:}

\section{specjalne potrzeby edukacyjne}

\section{projektowanie uniwersalne w uczeniu}




\section{Rational adaptations and modifications in education of students with special educational needs}

Ewa Domagała-Zyśk

Ongoing changes of educational system in Poland are to a large extent related to inclusion - a model of education in which every child, regardless of the level of their abilities and disabilities, has the opportunity to educated together with his peers and in a familiar environment of a school nearest to his/her place of living. For teachers, this means first and foremost the necessity of building their own methodological skills in order to be able to effectively teach children and youth with various special educational needs.

The aim of the chapter is to present the model of Universal Learning Design and the principles of applying rational adaptations and modifications in teaching and learning. Rational adaptation is an ambiguous term that can best be learned through the analysis of everyday practice experience. The text presents and analyzes many examples of rational and irrational adjustments and modifications, which will help the reader to develop their own way of designing and evaluating their teaching methodology.

\section{Keywords:}

special educationl needs

universal learning design

reasonable adjustment

reasonable modifications 


\section{Wstęp}

Szkoła - podobnie jak wiele innych instytucji - pracuje dla przyszłości, a jednym z największych marzeń nauczycieli jest dobre przygotowanie dzieci i młodzieży do odpowiedzialnego wykonywania przyszłych zadań zawodowych i społecznych. Uczenie się tabliczki mnożenia czy czytanie Kubusia Puchatka znacznie wykraczają poza relatywną prostotę tych zadań, ponieważ wykonujący te czynności ośmiolatek ma szansę nauczyć się rozwiązywania problemów, radzenia sobie z trudnościami, krytycznego myślenia oraz zdrowej rywalizacji i współpracy z innymi, a kompetencje te wykorzystać także w dorosłym życiu.

Nieustanna zmiana jest stałą cechą edukacji, co należy wiązać przede wszystkim ze stałymi zmianami cywilizacyjnymi, kulturowymi i społecznymi. Pracujący kilkadziesiąt lat nauczyciel ma bowiem szansę wychować kilka pokoleń dzieci i młodzieży różniących się w dużym stopniu od siebie sposobem odbierania świata i rozwiązywania pojawiających się zadań i problemów. Zdolność do elastycznego reagowania na zmieniające się warunki pracy, wysoka motywacja do uczenia się przez całe życie i kreatywne radzenie sobie z nowymi zadaniami to istotne cechy wybitnych nauczycieli, którzy nawet po wielu latach pracy nie zamykają się $w$ twierdzy własnych pomysłów metodycznych, ale otwarcie poszukują nowych sposobów przekazania młodym pokoleniom pasji uczenia się.

Zmiany dotyczące współczesnej szkoły w Polsce w dużej mierze związane są z inkluzją - modelem edukacji, w którym każde dziecko, niezależnie od stopnia sprawności, ma możliwość uczenia się w szkole najbliższej swojego miejsca zamieszkania (rejonowej), razem ze swoimi rówieśnikami i w znanym sobie środowisku. Dla nauczycieli oznacza to przede wszystkim konieczność takiego budowania własnego warsztatu metodycznego, by móc efektywnie uczyć dzieci i młodzież mające różne specjalne potrzeby edukacyjne (SPE). Jest to zadanie niełatwe, ale w wysokim stopniu możliwe do wykonania.

Celem artykułu jest przybliżenie modelu projektowania uniwersalnego w uczeniu się (Universal Learning Design) oraz zasad stosowania racjonalnych dostosowań i modyfikacji w uczeniu się i nauczaniu. „Racjonalne dostosowanie" jest terminem niejednoznacznym, najlepiej można je poznać poprzez analizę doświadczeń codziennej praktyki edukacyjnej. W tekście przedstawiono i przeanalizowano wiele przykładów racjonalnych oraz nieracjonalnych dostosowań i modyfikacji, co pomoże czytelnikowi wypracować własny sposób ich projektowania i ewaluacji. 


\section{Projektowanie uniwersalne w edukacji}

Projektowanie uniwersalne w edukacji (PUE) oznacza takie przygotowywanie usług i produktów edukacyjnych (programów nauczania, scenariuszy zajęć, pomocy dydaktycznych), aby jak największa grupa uczniów (także uczniów mających specjalne potrzeby edukacyjne) mogła z nich korzystać bez konieczności przygotowywania specjalistycznych dostosowań i modyfikacji. Przykładami takich działań może być przygotowanie filmu edukacyjnego z napisami, intuicyjnej i prostej instrukcji do ćwiczenia multimedialnego czy zastosowanie na lekcji metod pracy włączających we wspólne działanie także uczniów ze SPE.

Projektowanie uniwersalne w edukacji opiera się na współczesnej neuropsychologii, wiedzy o mechanizmach uczenia się oraz wykorzystaniu technologii informacyjnej i komunikacyjnej (TIK). Zakłada stosowanie różnorodnych, polimodalnych środków prezentacji materiału dydaktycznego, elastyczność w zakresie formy prezentowania wiedzy i kompetencji przez uczniów ( $w$ formie pisanej, ustnej lub działania praktycznego) oraz stosowanie zróżnicowanych środków motywowania uczniów do pracy. W PUE stosuje się następujące zasady:

1. równość $w$ dostępie,

2. elastyczność,

3. intuicyjność,

4. dostępność informacji,

5. tolerancja błędów,

6. niski poziom wysiłku fizycznego,

7. odpowiednie przestrzeń i miejsce, które są szczegółowo omówione w literaturze (por. Domagała-Zyśk, 2018).

Stosowanie modelu projektowania uniwersalnego zapewnia dostęp do usług edukacyjnych dla większości uczniów. Jeśli jednak nie zaspokaja ich potrzeb, to konieczne jest zastosowanie specjalistycznych dostosowań i modyfikacji.

\section{Racjonalne dostosowania i modyfikacje}

Zastosowanie modelu projektowania uniwersalnego w edukacji pozwala w dużej mierze na przygotowanie takiego środowiska uczenia się, które jest dostępne także dla uczniów mających specjalne potrzeby edukacyjne, np. uczeń z trudnościami motorycznymi bez przeszkód może dotrzeć do budynku szkoły oraz poruszać się po salach i korytarzach, 
uczeń słabosłyszący oglądający razem z klasą film korzysta z napisów, a elektronicznie dostępne podręczniki i karty pracy mogą być przez nauczyciela dostosowywane (np. czcionki o dowolnej wielkości) i drukowane na odpowiednio dobranym papierze.

Zdarzają się jednak sytuacje, kiedy potrzeby ucznia są na tyle specyficzne, że wyczerpują się możliwości uniwersalnego projektowania i potrzebne są dodatkowe modyfikacje i dostosowania. Racjonalne dostosowania i modyfikacje (RDM) to zmiany w środowisku uczenia się, które umożliwiają uczniowi mającemu specjalne potrzeby edukacyjne uczenie się w optymalnych dla niego warunkach, nie powodując jednocześnie nadmiernego czy nieproporcjonalnego obciążenia organizatorów i innych uczestników procesu edukacji. Cele racjonalnych dostosowań i modyfikacji to: wyrównanie szans edukacyjnych uczniów ze SPE, umożliwienie im równego dostępu do edukacji, stworzenie warunków do pełnego i integralnego rozwoju oraz zmniejszenie trudności w funkcjonowaniu psychospołecznym.

Dostosowywania i modyfikacje to dwie różne formy wsparcia. W przypadku dostosowań nie obniżamy wymagań wobec dziecka - są one takie same jak w stosunku do dzieci bez dysfunkcji, inna jest natomiast forma przekazu nauczanych treści. Modyfikacje w edukacji polegają natomiast na zmianach w zakresie treści nauczania, co zazwyczaj polega na ograniczeniu treści fakultatywnych i poszerzających materiał nauczania, zmniejszeniu liczby wykonanych zadań, rezygnacji z zadań trudniejszych lub wymagających umiejętności, których nie mają uczniowie ze SPE. Mogą oni potrzebować modyfikacji o różnym zakresie, jednak w żadnej sytuacji zakres treści nauczania potrzebny do ukończenia danego etapu edukacji nie powinien być mniejszy, niż zakłada to podstawa programowa kształcenia ogólnego. Racjonalne dostosowania i modyfikacje nie oznaczają faworyzowania ucznia lub grupy uczniów, ale likwidowanie barier, które uniemożliwiają danej osobie funkcjonowanie na poziomie podobnym do poziomu funkcjonowania osób sprawnych. Oznaczają także stworzenie takich warunków edukacji, aby umożliwić uczniom równy dostęp do edukacji i innych praw przynależnych osobom w ich wieku.

Jeśli możliwe jest przygotowanie dostosowań i modyfikacji, ale nie jest to realizowane z powodu opieszałości lub niechęci pracowników instytucji edukacyjnej, wówczas świadczy to o dyskryminacji uczniów mających specjalne potrzeby edukacyjne. 


\section{Zakres racjonalności dostosowań i modyfikacji}

Konwencja praw osób niepełnosprawnych oraz inne międzynarodowe i krajowe dokumenty wskazują, że zakres dostosowań i modyfikacji w edukacji uczniów ze SPE powinien być racjonalny. Używane w tym kontekście pojęcie reasonable może być też tłumaczone jako rozsq̨dny, uzasadniony, sensowny, umiarkowany czy godziwy.

Projektowanie uniwersalne zakłada, że dany produkt będzie używany przez wielu różnorodnych odbiorców, natomiast dostosowania i modyfikacje są zawsze przygotowywane dla konkretnego ucznia, po należytym rozważeniu zakresu jego potrzeb i możliwości przygotowania konkretnej zmiany. Dobrą praktyką jest podejmowanie decyzji o zakresie oraz sposobach dostosowań i modyfikacji w zespole. W jego skład wchodzą: uczeń i/lub jego rodzice, wychowawca (który występuje w imieniu nauczycieli pracujących z dzieckiem), specjaliści kompetentni w zakresie oceny potrzeb i możliwości ucznia mającego specjalne potrzeby edukacyjne oraz pracownik administracji odpowiedzialny za finansowanie placówki. Taki zespół w trakcie dyskusji i poszukując koniecznego kompromisu, jest odpowiedzialny za podjęcie decyzji o możliwości przygotowania konkretnych rozwiązań, a następnie monitorowania i ewaluacji efektów zmian. Decyzje powinny być podejmowane z uwzględnieniem następujących kroków i zasad:

1. Uczeń (lub jego rodzice/opiekunowie prawni) zgłasza potrzebę danego dostosowania lub wyraża zgodę na taką propozycję ze strony szkoły.

2. Niezbędnym krokiem jest pozyskanie opinii i rekomendacji specjalistów w kwestii potrzeb i możliwości uczniów z daną dysfunkcją.

3. Następnie oceniana jest praktyczność konkretnego rozwiązania, z uwzględnieniem nakładu pracy i czasu nauczycieli oraz innych osób pracujących z uczniem.

4. Przy przygotowywaniu dostosowań i modyfikacji konieczne jest przestrzeganie zasad BHP - dostosowanie nie może zagrażać życiu ani bezpieczeństwu innych uczniów i pracowników szkoły.

5. Standardy edukacyjne (przede wszystkim w zakresie realizacji podstawy programowej) nie mogą zostać znacząco zmienione.

6. Dostosowania i modyfikacje nie mogą naruszać dobra innych uczniów.

7. Konieczna jest ocena kosztów danych rozwiązań i realnych możliwości zdobycia funduszy na ich wdrożenie. 
W dalszej części teksu zostaną omówione te zasady oraz przeanalizowane przykłady rozwiązań racjonalnych i nieracjonalnych. Analizy te mogą stać się przedmiotem dalszych dyskusji, a także pomóc nauczycielom i specjalistom w zakresie edukacji inkluzyjnej w wypracowaniu stanowiska w kolejnych sytuacjach, z którymi przyjdzie im się zmierzyć w praktyce edukacyjnej.

\section{Uczeń (lub jego rodzice/opiekunowie prawni) zgłasza potrzebę danego dostosowania lub wyraża zgodę na taką propozycję ze strony szkoły}

Jak już wspomniano w tym artykule, dostosowania i modyfikacje przygotowywane są dla konkretnego ucznia, choć mogą także służyć innym osobom. Oznacza to, że kluczowe jest ustalenie, jakie są potrzeby danej osoby oraz jakie są cele procesu przygotowywania dostosowań i modyfikacji w ścisłej współpracy z uczniem lub jego rodzicami (opiekunami).

\section{Sytuacja 1}

Dyrektor szkoły po otrzymaniu informacji, że w kolejnym roku szkolnym w placówce będzie uczył się chłopiec z dysfunkcją słuchu, zorganizował dla wszystkich nauczycieli kurs języka migowego. We wrześniu okazało się jednak, że chłopiec ten nie zna języka migowego, natomiast odnosi dużą korzyść z posługiwania się systemem FM. Niestety, szkoła nie miała już funduszy na zakup tego typu urządzeń. Co prawda kurs języka migowego może okazać się pomocny w pracy z innymi uczniami, którzy w przyszłości mogą trafić do tej szkoły, jednak w tym konkretnym przypadku zabrakło współpracy z zainteresowaną osobą i/lub jej rodzicami.

\section{Sytuacja 2}

Dyrektor, wiedząc, że od września w jego szkole rozpocznie naukę dziecko poruszające się na wózku inwalidzkim, kilka miesięcy przed rozpoczęciem roku szkolnego zaprosił ucznia z rodzicami na spotkanie, by poznać jego potrzeby i możliwości. Szkoła miała podjazd dla wózków oraz windę umożliwiającą uczniowi sprawne przemieszczanie się po budynku. Okazało się jednak, że wysokość wózka uniemożliwia dziecku wygodne korzystanie z ławki szkolnej, dlatego dyrektor zamówił stolik o odpowiedniej wysokości. 


\section{Pozyskanie opinii i rekomendacji specjalistów o potrzebach oraz możliwościach uczniów z daną dysfunkcją}

Potrzebę dostosowań i modyfikacji najczęściej przedstawiają w dokumentach medycznych czy psychopedagogicznych specjaliści zajmujący się rehabilitacją ( $w$ tym rehabilitacją edukacyjną) ucznia. Potrzeby dziecka określają w zaświadczeniu lekarskim, opinii czy orzeczeniu. Jednocześnie rodzice, będący najbliżej dziecka, są najczęściej osobami dobrze poinformowanymi o zasadności i niezbędności konkretnych rozwiązań. Przy ustalaniu ostatecznych wersji dostosowań i modyfikacji rolą profesjonalistów jest szczegółowe przedstawienie rodzicom wad i zalet określonych rozwiązań oraz ich wpływu na dalszą edukację dziecka. To psycholodzy, pedagodzy i nauczyciele są ekspertami od edukacji, nie należy więc oczekiwać od rodziców i opiekunów, by podejmowali kompetentne decyzje o ścieżce edukacyjnej dziecka bez umożliwiania im należytego rozeznania w konsekwencjach bieżących decyzji. Rodzice mogą mieć trudność w ocenie możliwości edukacyjnych i zawodowych swojego dziecka. Mogą też mieć tendencję do nadmiernego odciążania dziecka, zwalniania go z różnych obowiązków i zadań lub przeciwnie - mogą stawiać dziecku zbyt wygórowane wymagania. Rekomendacje specjalistów są w tym zakresie bardzo ważną wskazówką warunkującą zastosowanie lub wykluczenie danej zmiany w edukacji.

\section{Sytuacja 3}

Uczennica słabosłysząca od pierwszych lekcji języka angielskiego została uznana za osobę, która - mimo że dosyć dobrze posługiwała się mową w języku narodowym - nie będzie mówić w obcym języku, ale będzie się go uczyć tylko $w$ formie pisemnej. Zgodziła się na to jej matka, która była przekonana o bardzo niskich możliwościach intelektualnych swojego dziecka. Przez kilka lat nauki w szkole żaden z nauczycieli nie pracował nad wymową angielskiego tej uczennicy - chcąc coś powiedzieć w języku obcym, odczytywała słowa zgodnie z ich zapisem. Jako nastolatka po operacji wszczepienia implantu miała dużo lepsze możliwości słyszenia, w znaczący sposób poprawiła się jej sprawność mówienia w języku polskim. Okazało się również, że uczennica mogłaby też mówić po angielsku, jednak przez niekorygowane latami i utrwalane błędy w wymowie niestety nie jest $w$ tym języku rozumiana. 


\section{Sytuacja 4}

Matka chłopca z IV klasy, którego nauka liczenia kończyła się niepowodzeniem, zgłosiła do wychowawcy klasy postulat zmiany. Miałaby ona polegać m.in. na możliwości używania kalkulatora do najprostszych obliczeń. Nauczyciel oraz pedagog uznali jednak, że tak znaczące obniżenie wymagań na wczesnym etapie edukacji utrudni dziecku dalsze realizowanie programu matematyki, ponieważ podstawowe sprawności rachunkowe są potrzebne na każdym kolejnym etapie uczenia się. Uczniowi zaproponowano natomiast dodatkową godzinę zajęć dydaktyczno-wyrównawczych, w których czasie będzie mógł ćwiczyć umiejętność mnożenia z wykorzystaniem lubianych przez niego ćwiczeń z komputerem. Matce przekazano także informacje o bezpłatnych portalach internetowych, na których można znaleźć atrakcyjne dla dziecka ćwiczenia matematyczne pozwalające na lepsze utrwalenie materiału nauczania.

\section{Ocena praktyczności danego rozwiązania, z uwzględnieniem nakładu pracy i czasu nauczycieli \\ oraz innych osób pracujących z uczniem}

Proces wspierania ucznia mającego specjalne potrzeby edukacyjne wymaga tworzenia koalicji i poszukiwania sojuszników. Tylko wzajemna współpraca wszystkich zainteresowanych stron daje szanse na wypracowanie kompromisu i najbardziej korzystnych dla dziecka racjonalnych dostosowań i modyfikacji. Konieczne jest zatem bardzo konkretne ustalenie, jakie działania mogą być podjęte, jak bardzo są czasochłonne i kto (oraz na jakich warunkach - umowy o pracę, umowy-zlecenia, wolontariatu) będzie je wykonywał. Nie jest zatem słuszne podejmowanie decyzji o dostosowaniach, które są niepraktyczne lub wymagają nieproporcjonalnie dużego wkładu pracy w stosunku do przewidywanych korzyści. Nadmierne obarczanie dodatkowymi obowiązkami nauczycieli czy rodziców nie jest racjonalnym dostosowaniem, rodzi frustrację i niechęć do uczniów mających specjalne potrzeby, obniża także motywację do podejmowania działań na ich rzecz w przyszłości.

\section{Sytuacja 5}

Rodzicom chłopca z silnymi objawami nadpobudliwości psychoruchowej zaproponowano spotkania terapeutyczne w godzinach pracy gabinetu pedagoga szkolnego (przed godz. 15). Rodzice, pracujący od godz. 7 
do 15, początkowo kilkakrotnie brali udział w spotkaniach, jednak na dłuższą metę okazało się to niemożliwe. Nie zaproponowano im innej godziny spotkań, uznano, że bezzasadnie przerwali uczestnictwo w spotkaniach i nie dołożyli starań, aby wystarczająco współpracować z pedagogiem szkolnym. Jest to przykład nieracjonalnego dostosowania, wymagającego od jednego z podmiotów edukacji zbyt trudnych dla niego zadań.

\section{Sytuacja 6}

Do klasy VI szkoły ogólnodostępnej przeniósł się uczeń z dysfunkcją wzroku (wymagał pracy na materiałach w powiększonym druku). Uzgodniono, że szkoła zapewni mu takie materiały. Okazało się jednak, że kopie przygotowywane na wysłużonej szkolnej kserokopiarce są słabo czytelne, a powiększanie fragmentów książek i materiałów własnych nauczycieli trwa bardzo długo. Prośby nauczycieli o wymianę sprzętu nie były uwzględniane przez kilka tygodni. Nie godząc się z taką sytuacją, zaczęli korzystać z usług profesjonalnego kopiowania, opłacając je z własnych funduszy. Takie rozwiązanie oznacza nałożenie na nauczycieli nieusprawiedliwionych dodatkowych obciążeń i nie jest racjonalnym dostosowaniem.

\section{Konieczność przestrzegania zasad BHP - dostosowanie nie może zagrażać życiu ani} bezpieczeństwu innych uczniów i pracowników szkoły

Każde dostosowanie musi być zgodne z obowiązującym prawem i nie może narażać nikogo na żadne niebezpieczeństwa. Pozwolenie rodziców ucznia z głęboką dysfunkcją wzroku na samodzielne przychodzenie do szkoły osobom postronnym może wydawać się niebezpieczne. Jednak taka decyzja zależy od oceny sytuacji przez rodziców i służy nabyciu przez ucznia jak największej samodzielności. Opisana sytuacja nie naraża na niebezpieczeństwo innych osób i jest podjęta zgodnie z prawem przez rodziców dziecka. Wszelkie jednak działania, w których uczestniczą inni uczniowie i pracownicy szkoły, muszą uwzględnić nie tylko potrzeby ucznia ze SPE, lecz także pełne bezpieczeństwo innych podmiotów edukacji. Dotyczy to zarówno tzw. otoczenia fizycznego (np. podjazdy dla wózków i rampy muszą być stabilne, nie mogą zagrażać bezpieczeństwu innych dzieci), jak i zachowania uczniów ze SPE (niekontrolowane wybuchy agresji wobec innych osób). 


\section{Sytuacja 7}

Chłopiec z padaczką jest uczniem szkoły ogólnodostępnej. Uczeń regularnie przyjmuje leki i nie ma ataków, jednak wszyscy nauczyciele zostali przeszkoleni, jak powinni się zachować, gdyby doszło do takiej sytuacji. Zorganizowano też spotkanie rodziców i wychowawcy. Ustalono, że szczególne sytuacje mogą pojawić się na zajęciach z wychowania fizycznego. Zgodnie z zaleceniami lekarzy uczeń może brać udział wraz z innymi dziećmi w zajęciach WF, ale niektóre ćwiczenia są dla niego niewskazane. Nauczyciel wie, że uczeń z padaczką w czasie zajęć gimnastycznych nie powinien wspinać się na drabinki (w czasie takich zadań może odgrywać rolę pomocnika sędziego-nauczyciela i oceniać poprawność wykonania zadania przez inne dzieci), nie może też asekurować innego dziecka, by bezpiecznie wykonało zadanie (np. skok przez kozła), bo mogłoby to zagrażać bezpieczeństwu tego drugiego ucznia.

\section{Sytuacja 8}

Matka chłopca z poważnymi zaburzeniami alergicznymi zgłosiła prośbę o podwyższenie w klasie temperatury powietrza, ponieważ wtedy jej dziecko lepiej się czuje, a zmiany alergiczne są mniej dokuczliwe. Po konsultacjach ze specjalistami oceniono jednak, że podwyższenie temperatury $w$ klasie byłoby niekorzystne dla innych uczniów, którym byłoby w tej sytuacji zbyt gorąco, a to zagrażałoby ich dobremu samopoczuciu. Oznaczałoby to nieracjonalne dostosowanie, które co prawda służyłoby jednemu dziecku, ale przeszkadzałoby innym. Po rozmowie z pielęgniarką szkolną matka zgodziła się cieplej ubierać swoje dziecko do szkoły, a dyrektor przystał na to, aby dziecko na obowiązujący w szkole mundurek nakładało potrzebny mu w niektóre dni ciepły polar.

\section{Standardy edukacyjne (przede wszystkim w zakresie realizacji podstawy programowej) nie mogą zostać znacząco zmienione}

Zastosowane dla konkretnego ucznia modyfikacje i dostosowania nie mogą naruszać dobra innych dzieci, jeśli chodzi o wysoką jakość edukacji. Dotychczasowe badania nie potwierdzają obniżenia się poziomu edukacji w klasach integracyjnych. Okazało się, że jest wręcz przeciwnie - w niektórych z nich poziom edukacji jest wyższy niż w innych klasach $w$ tej samej szkole. Może się to wiązać ze szczególnie starannie planowanym i prowadzonym procesem dydaktycznym (w którym często 
bierze udział dwóch nauczycieli), a także z mniejszą liczebnością klas oraz wyższym poziomem kompetencji społecznych dzieci, które uczą się w klasach integracyjnych. W niektórych szkołach rodzice jednak protestują przeciwko obecności dzieci mających specjalne potrzeby w klasach ich dzieci, uzasadniając to obniżeniem poziomu nauczania, nadmierną ilością czasu przeznaczanego przez nauczycieli dla uczniów ze SPE, zaniżaniem wymagań w procesie oceniania. Należy zatem podkreślić, że dostosowania i modyfikacje nauczania powinny być tak opracowane, by w żaden sposób nie obniżać standardów edukacji w danej placówce. Jak jednak wspomniano wcześniej, zazwyczaj staranność przygotowywania procesu nauczania dziecka ze SPE działa korzystnie na poziom edukacji w całej klasie. Uczniowie i rodzice mają także szanse doświadczenia poczucia bezpieczeństwa i wzajemnej solidarności, wiedząc, że jeśli ich dziecko będzie w którymś momencie edukacji potrzebowało pomocy, to zostanie mu ona udzielona.

\section{Sytuacja 9}

W klasie IV uczy się dziecko z zespołem Downa. Na spotkaniu klasowym rodzice zgłosili swoje obawy, że nie jest realizowany program zajęć z przyrody, a nauczyciel poświęca zbyt dużo czasu na tłumaczenie pojęć i instrukcji do zadań choremu uczniowi. Nauczyciel przyznał, że dziecko z zespołem Downa nie radzi sobie z materiałem, ale jako nauczyciel czuje się odpowiedzialny za zrealizowanie przez niego podstawy programowej. Po dyskusji w gronie pedagogicznym ustalono, że pomimo dobrego radzenia sobie ucznia z nauką na poziomie edukacji wczesnoszkolnej w klasie IV konieczne jest dokładniejsze skonstruowanie jego Indywidualnego Programu Edukacyjno-Terapeutycznego, uwzględniającego potrzebne modyfikacje w programie nauczania. Dyrektor skierował także do pracy w tej klasie studenta-praktykanta, który podjął się indywidualnej regularnej pracy z uczniem. Nauczyciel przyrody postanowił przepracować swój warsztat metodyczny, tak aby w pełni zrealizować program w klasie IV, jednocześnie zapewniając jego realizację w zakresie wyznaczonym dla ucznia ze SPE.

\section{Dostosowania i modyfikacje nie mogą naruszać dobra innych uczniów}

Dobra uczniów danej klasy nie obejmują tylko zapewnienia im poczucia bezpieczeństwa oraz pełnej realizacji programu nauczania. Wysokiej 
jakości edukacja obejmuje przecież wiele wydarzeń i działań, które co prawda nie są zawarte w oficjalnych dokumentach, ale sprawiają uczniom wiele radości, są lokalną tradycją i stanowią nowe okazje do podnoszenia różnego typu kompetencji. Dotyczy to wycieczek klasowych, udziału w lokalnych działaniach kulturalnych, lekcji prowadzonych poza budynkiem szkoły, kreatywnych i niestandardowych projektów edukacyjnych. Dostosowania i modyfikacje wprowadzane ze względu na dobro ucznia ze SPE nie mogą być przeszkodą w podejmowaniu takich działań przez innych uczniów. W każdym konkretnym przypadku wymaga to oczywiście rozmowy i zgodnych ustaleń. Uczniowie powinni mieć możliwość zdecydowania, czy np. Dzień Dziecka chcą świętować dyskoteką (w której nie będzie mógł wziąć udziału ich kolega z epilepsją, ponieważ nie może przebywać w pomieszczeniu, gdzie są światła stroboskopowe), czy wspólnym wyjściem do escape room, w którym będą mogli bawić się wszyscy uczniowie. Takie kwestie powinni ustalać nie tylko nauczyciele i rodzice, a odpowiednio moderowana dyskusja może być znakomitą praktyczną lekcją akceptacji i szukania kompromisu.

\section{Sytuacja 10}

W zwyczaju szkoły $X$ jest coroczny wyjazd $V$ klasy na trzydniową wycieczkę, w której czasie uczniowie poznają jeden z parków narodowych. W klasie uczy się chłopiec z poważną chorobą nerek, który często musi korzystać z toalety, stale przyjmuje leki i ma duże ograniczenia dietetyczne. Wychowawca klasy ma dylemat: czy w związku z tym klasa powinna pojechać na tę wycieczkę, czy raczej zorganizować wycieczkę jednodniową, bez nocowania poza domem. Uczniowie bardzo chcą pojechać na dłuższą wycieczkę. W gronie nauczycieli zdecydowano, że powinna się ona odbyć, ponieważ jej brak oznaczałby dla uczniów poważne ograniczenie w procesie ich edukacji, zarówno ze względów poznawczych, jak i ich rozwoju społecznego (dla wielu uczniów jest to pierwszy samodzielny kilkudniowy wyjazd). Zorganizowano także w tej sprawie spotkanie $z$ rodzicami chorego dziecka, którzy początkowo potwierdzili brak jego udziału w tej wyprawie. W czasie rozmowy okazało się jednak, że możliwe jest spełnienie kilku warunków, tak aby uczeń mógł pojechać razem z klasą. Zdecydowano, że: autokar w czasie kilkugodzinnej podróży będzie regularnie co godzina zatrzymywał się i uczniowie będą mieli możliwość skorzystania z toalety, w ośrodku chłopiec otrzyma miejsce w pokoju kilkuosobowym z łazienką (aby 
mógł spędzać czas z rówieśnikami, ale jednocześnie bez skrępowania korzystać w nocy z toalety), ośrodek zapewni właściwe posiłki dietetyczne, a nauczyciel przypomni dziecku o przyjęciu lekarstw. Takie dostosowanie przebiegu wycieczki zapewniło wszystkim uczniom skorzystanie z tego ważnego elementu edukacyjnego.

\section{Sytuacja 11}

Uczniowie rozwiązują test po zakończeniu realizacji pewnej części materiału. Test był zapowiedziany odpowiednio wcześniej, wszyscy uczniowie mieli materiały umożliwiające przygotowanie się do niego. Nauczyciel wie, że jeden z uczniów ma obniżoną koncentrację uwagi i łatwo się rozkojarza, rozpraszając przy tym także innych uczniów i przeszkadzając im w pracy. W porozumieniu z rodzicami ucznia i nim samym zapada decyzja, że chłopiec napisze sprawdzian w cichym pomieszczeniu - $\mathrm{w}$ gabinecie pedagoga. W czasie pisania testu będzie mógł wstawać i przechadzać się po pomieszczeniu, co zazwyczaj robi w sytuacjach napięcia. Zmiana miejsca uczenia się oznacza także racjonalne dostosowanie, konieczne dla ucznia i jego rówieśników.

\section{Konieczna jest ocena kosztów danych rozwiązań i realnych możliwości pozyskania funduszy \\ na wdrożenie danego rozwiązania}

W każdym kraju możliwości edukacyjne związane są z funduszami budżetowymi, a ich zazwyczaj jest zbyt mało, aby zaspokoić wszystkie zgłaszane potrzeby. Dotyczy to także uczniów mających specjalne potrzeby edukacyjne - zarówno model projektowania uniwersalnego, jak i niezbędne dostosowania oraz modyfikacje w sytuacjach szczególnych oznaczają konieczność ponoszenia dodatkowych kosztów związanych z zakupem produktów lub usług (pracy specjalistów i nauczycieli). $Z$ tego względu o pieniądzach należy rozmawiać w lenteksie (albo jest coś tak dziwnego jak "lenteks edukacji", albo to literówka i powinno być "kontekście" - wyjaśnię z autorem) edukacji uczniów ze SPE - aby jak najrozsądniej wydać każdą budżetową złotówkę.

\section{Sytuacja 12}

Nauczyciel korzysta na lekcji z opracowanej przez siebie karty pracy. W zależności od potrzeb uczniowie otrzymują je wydrukowane czcionką różnej wielkości, na papierze białym lub pastelowym. Mają też możliwość 
rozwiązywania tych samych zadań na tablecie. Różnorodność środków potwierdza zastosowanie zasad projektowania uniwersalnego. Jeden z uczniów ma znaczny niedowład ręki i nie może korzystać ze standardowego urządzenia. Potrzebna jest specjalna mysz komputerowa, która pomoże mu kontrolować ruchy i rozwiązywać zadania. Zakup takiej myszy (finansowany z pieniędzy publicznych) oznacza racjonalne dostosowanie.

\section{Sytuacja 13}

Uczeń słabosłyszący posługuje się mową, ma wszczepiony implant ślimakowy, co znacznie zwiększa jego możliwości odbierania mowy dźwiękowej. W sali szkolnej stworzono dobre warunki akustyczne - ściany wyciszone są korkiem, na posadzce jest wykładzina, a krzesła mają na nóżkach miękkie nakładki, żeby uniknąć hałasu związanego z szuraniem. Uczeń ma jednak trudności z jednoczesnym słuchaniem i robieniem notatek, szczególnie na zajęciach z języka polskiego. Rodzice zgłosili ten problem, ale szkoła nie ma funduszy na zatrudnienie profesjonalnego skryby. W tej sytuacji wychowawca zaproponował, żeby każdego dnia inny uczeń z klasy pełnił funkcję osoby robiącej szczegółową i czytelną notatkę, a następnie zamieszczał ją w zamkniętej grupie na portalu szkoły. Taka notatka jest znakomitym wsparciem dla ucznia słabosłyszącego, który może koncentrować się całkowicie na uczestniczeniu w lekcji, jednocześnie może być przydatna dla innych uczniów. Takie rozwiązanie jest przykładem racjonalnego dostosowania, stwarza także okazję do kształtowania w uczniach postawy odpowiedzialności i współpracy.

\section{Zakończenie}

Inkluzja społeczna osób z niepełnosprawnościami, obejmująca także nauczanie inkluzyjne (włączające), to współcześnie nie tylko marzenie, lecz także postulat wynikający z przepisów prawnych (np. Konwencja o prawach osób niepełnosprawnych) oraz rekomendacji autorytetów w zakresie edukacji i niepełnosprawności (por. Vanier, 2013, 2015; Kristeva, Vanier, 2012). W nauczaniu inkluzyjnym kluczową rolę odgrywa zastosowanie zasad projektowania uniwersalnego oraz niezbędnych dostosowań i modyfikacji, które powinny być postrzegane nie tyle przez pryzmat funduszy i nadzwyczajnych kompetencji nauczyciela, ile koniecznych zmian w zakresie mentalności i postaw wszystkich podmiotów edukacji - uczniów (i tych ze SPE, i tych, którzy nie zgłaszają specjalnych potrzeb), rodziców, nauczycieli i organów prowadzących szkoły. 


\section{Bibliografia}

$\rightarrow$ Domagała-Zyśk, E. (2017), Standardy i wskazówki przygotowywania oraz adaptacji narzędzi diagnostycznych i procesu diagnostycznego dla dzieci i młodzieży z lekkq niepełnosprawnościq intelektualnq oraz trudnościami w uczeniu się [w:] K. Krakowiak (red.), Diagnoza specjalnych potrzeb rozwojowych i edukacyjnych dzieci i młodzieży. Standardy, wytyczne oraz wskazówki do przygotowania i adaptacji narzędzi diagnostycznych dla dzieci i młodzieży z wybranymi specjalnymi potrzebami rozwojowymi i edukacyjnymi, Warszawa: ORE, s. 195-205.

$\rightarrow$ Domagała-Zyśk, E. (2015), Projektowanie uniwersalne w edukacji osób z wadq słuchu [w:] M. Nowak, E. Stoch, B. Borowska (red.), Z problematyki teatrologii i pedagogiki, Lublin: Wydawnictwo KUL, s. 553-568.

$\rightarrow$ Domagała-Zyśk, E. (2018), Dostosowanie lekcji języka angielskiego jako obcego do potrzeb uczniów z dysfunkcją słuchu w nauczaniu wczesnoszkolnym, "Szkoła Specjalna", nr 1, s. 12-20.

$\rightarrow$ Kristeva, J., Vanier, J. (2012), Bezsens słabości, Poznań: Wydawnictwo w Drodze.

$\rightarrow$ Vanier, J. (2015), Wielkie pytania życia, Kielce: Wydawnictwo Charaktery.

$\rightarrow$ Vanier, J. (2013), Znaki, Kraków: Wydawnictwo Esprit. 


\section{Edukacja międzykulturowa w szkołach i jej znaczenie. Wyzwania współczesnej edukacji \\ w ramach inicjatyw UE}

Magdalena Bartoszak

Szkoła, oprócz edukowania, w swoją misję ma wpisane także wspieranie wychowania. Rozumienie sposobu myślenia oraz zachowania drugiego człowieka stanowią klucz do osiągnięcia sukcesu w wymiarze zarówno indywidualnym, jak i społecznym. Zrównoważony rozwój, działania ONZ, prawa człowieka, edukacja globalna i międzykulturowa - warto zwrócić na nie szczególną uwagę w programach nauczania. Tak jak drzewo potrzebuje solidnych korzeni, by rosnąć, tak uczeń potrzebuje solidnych fundamentów wiedzy, bez których trudno wejść w życie i w pełni, z korzyścią dla siebie i innych, funkcjonować.

\section{Słowa kluczowe:}

\section{edukacja międzykulturowa}

pedagogika na rzecz równego traktowania

zrównoważony rozwój

kompetencje kluczowe

ONZ

\section{Edukacja 2030}




\section{Intercultural education in schools \\ and its importance. Challenges \\ of contemporary education \\ as part of IHU initiatives}

Magdalena Bartoszak

The world is setting new challenges for us, especially in education. Due to the constantly progressing process of globalization, it seems extremely important to focus the attention of the young generation on bringing knowledge about other cultural nations. Understanding the ways of people's thinking and behaviors are the key to achieve success both, in the individual and in the social dimension. Sustainable development, UN activities, human rights, global education and cross-cultural education - are worth paying particular attention to them in education programmes. Just as a tree needs solid roots, humans need a solid knowledge base to good functioning, for the benefit of himself and others.

\section{Keywords:}

cross-cultural education

pedagogy for equal treatment

sustainable development

key competences

UN

Education 2030 


\section{Wstęp}

Świat stawia przed nami coraz to nowe wyzwania. Z uwagi na stale postępującą globalizację $\mathrm{i}$ istniejący kryzys migracyjny niezwykle istotne wydaje się przybliżanie młodemu pokoleniu wiedzy o innych nacjach i kulturach. Szkoła, oprócz edukowania, w swoją misję ma wpisane także wspieranie wychowania. Rozumienie sposobu myślenia oraz zachowania drugiego człowieka, formułowanie i wyrażanie własnego zdania, kooperacja z innymi dla wspólnych korzyści, adaptacja w różnych kontekstach społecznych - wszystko to kształtuje kompetencje osobiste i społeczne oraz odpowiednie postawy moralne. Kompetencje społeczne zaliczane są do grupy ośmiu kluczowych umiejętności pozapoznawczych, które można określić jako zestaw umiejętności nabywanych w czasie ustawicznego treningu społecznego, determinujących efektywność jednostki w procesie radzenia sobie w różnorodnych sytuacjach społecznych wymagających współdziałania, dzielenia się i komunikacji z innymi, udzielania pomocy czy okazywania ogólnie pojmowanej życzliwości (Kwiatkowski, 2017).

Przemiany, jakie dokonują się w wielu krajach, sprawiają, że idea wielokulturowego wychowania nabiera szczególnego znaczenia (Żebrowski, 2003). Zjawisku integracji europejskiej nadaje się szczególną wartość, mając na uwadze procesy związane ze współpracą i współdziałaniem, prowadzeniem właściwego dialogu oraz potrzebą wspierania w zakresie zachowania ciągłości i tożsamości kulturowej społeczeństw. Wychowanie wielokulturowe to jeden z nurtów współczesnej pedagogiki. Jego zadaniem jest przygotowanie ludzi do życia w pluralizmie kulturowym i etnicznym. Wielokulturowością zajmuje się także psychologia międzykulturowa, która wyjaśnia mechanizmy rządzące ludzkim zachowaniem na styku kultur, także stawia wiele pytań o kulturowe uwarunkowania ludzkich myśli, uczuć i zachowań. Procesy globalizacji sprawiają, że coraz częściej mamy kontakty z przedstawicielami różnych środowisk i kultur, z ludźmi wyznającymi odmienne od naszych systemy wartości czy inaczej postrzegającymi otaczającą nas rzeczywistość. Dla wychowania międzykulturowego istotne jest poszanowanie prawa ludzi do odmienności kulturowej. Edukacja jest dziedziną życia społecznego, w której wiele celów i wartości można osiągnąć w działaniu zbiorowym. Przykładem może być funkcjonowanie szkolnictwa powszechnego. Jak wynika z przeprowadzonej analizy, możliwości „wychowania do wspólnoty" są dotychczas "słabo wykorzystane", mówi się wręcz 
o zaniedbanej w tym względzie funkcji edukacji (Czerwiński, 2016, za: Madalińska-Michalak, 2017).

Edukacja międzykulturowa powstała w krajach zróżnicowanych narodowościowo, etnicznie, religijnie i kulturowo. Stanowiła odpowiedź na nowe i złożone wyzwania edukacyjne XX w. W Polsce została zapoczątkowana w 1993 r. publikacjami Mirosława S. Szymańskiego, Jerzego Nikitorowicza, Tadeusza Lewowieckiego i Tadeusza Pilcha (Januszewska, Manista, 2017). Edukacja międzykulturowa ma na celu uwrażliwianie oraz kształtowanie otwartej postawy wobec odmienności kulturowej, popularyzowanie wiedzy o kulturach i społeczeństwach świata. Jej zadaniem jest propagowanie idei równości, tolerancji, poszanowania praw drugiego człowieka, przeciwdziałanie uprzedzeniom i dyskryminacji. Celem edukacji międzykulturowej jest także poszerzanie własnej tożsamości jednostkowej i społecznej przez kontakt z innymi kulturami; stanowi ona matrycę wzajemnego oswajania się i porozumiewania ludzi różnych kultur, pozwala łagodzić konflikty i nieporozumienia. Polega na uczeniu się o różnych grupach kulturowych, ceni różnice, ogranicza rasizm, uczy otwartości i nastawienia na współpracę, promuje dialog kulturowy. Wspomaga rozwój inteligencji emocjonalnej, ma swoje zastosowanie we wszystkich dziedzinach nauczania. W sytuacji styku dwóch kultur można wyodrębnić kilka faz. Zwykle na początku występują sytuacje konfliktowe (starcia dwóch kultur), a następnie procesy akomodacji (zewnętrzne przystosowanie), po czym następują próby poznawania kultury zastanej i poszukiwanie punktów stycznych z kulturą rodzimą. Dochodzi więc do adaptacji kulturowej wyrażającej się tolerancją dwóch kultur. Ważne jest tu otwarcie na różnorodność kulturową poprzez budowę kompetencji i motywacji do przezwyciężania dystansu wobec „inności” (Januszewska i in., 2017).

Istnieją podstawowe dokumenty narodowe, które określają obowiązujące standardy ochrony praw osób należących do mniejszości narodowych. Są to m.in.: Europejska konwencja o ochronie praw człowieka i podstawowych wolności, Pakt praw obywatelskich i politycznych, Europejska konwencja ramowa o ochronie mniejszości narodowych, Konwencja w sprawie likwidacji wszelkich form dyskryminacji rasowej, Raport Genewskiego Spotkania Ekspertów w sprawach mniejszości narodowych KBWE czy Konwencja ONZ o prawach dziecka. Edukacja wielokulturowa nie ma na celu zacierania różnic między kulturami, ale troskę o świadomość ich istnienia i pełną tego akceptację. Istotne jest 
przygotowanie ludzi do życia w ponowoczesnym świecie. Pedagogikę (edukację) międzykulturową postrzega się jako "pedagogikę spotkania się kultur" lub jako „pedagogikę konfliktu kultur” (Żebrowski, 2003). Wzajemne porozumienie jawi się jako jedyne słuszne rozwiązanie na drodze do podejmowania wspólnych działań i utrzymania dobrostanu zarówno jednostkowego, jak i na poziomie społeczeństw.

Rada Unii Europejskiej ustanowiła osiem kompetencji kluczowych w procesie uczenia się przez całe życie (Zalecenie Parlamentu Europejskiego i Rady z 18 grudnia 2006 r. w sprawie kompetencji kluczowych w procesie uczenia się przez całe życie, 2006/962/WE). W dokumencie wymieniono m.in. kompetencje osobowe i obywatelskie, których częścią jest edukacja międzykulturowa. Państwa są zobowiązane do rozwijania ducha tolerancji i dialogu kultur, ważna jest też współpraca wszystkich ludzi żyjących na ich terytorium, niezależnie od tożsamości etnicznej, kulturowej, językowej czy religijnej, zwłaszcza w dziedzinie edukacji. Edukacja międzykulturowa kształtuje i rozwija się w kontekście narastających problemów wielokulturowego świata, wielonarodowych i wielowyznaniowych państw, złożonego procesu krystalizowania się społeczeństw wielokulturowych. Osiągnięcie porozumienia i wzajemnego zrozumienia ludzi różnych kultur związane jest z realizacją paradygmatu dialogu i współistnienia. Nadrzędnym zadaniem edukacji międzykulturowej jest zatem pobudzanie do myślenia dywergencyjnego, czyli do dostrzegania i poszukiwania wielu możliwych dróg rozwiązania określonego problemu (Nikitorowicz, 2014). Powstawanie społeczeństw wielokulturowych to efekt wielu procesów cywilizacyjnych, takich jak wzmożony ruch migracyjny do wysoko rozwiniętych krajów przemysłowych, uznanie praw człowieka i mniejszości etnicznych do współkształtowania demokracji w tych krajach oraz globalizacja komunikacji w kontaktach międzyludzkich. Edukacja międzykulturowa ma motywować do aktywnego uczestnictwa w procesie poznawania odmiennych kultur i uwrażliwiania na nie. Aby móc osiągnąć ten cel, niezbędna jest świadomość własnych wartości, przekonań, wyznawanych zasad, postawa otwartości i chęci nawiązania dialogu z drugim człowiekiem. Brak obaw i wyzbycie się zarówno lęku przed utratą własnych wartości kulturowych, jak i poczucia zagrożenia ze strony innych umożliwia wzajemne poznawanie się ludzi i osiągnięcie założeń edukacji międzykulturowej. Działania na rzecz propagowania idei międzykulturowości powinny znaleźć swoje odzwierciedlenie w szkolnych programach nauczania. 
Rozwój kompetencji międzykulturowych umożliwia przygotowanie do skutecznego oraz konstruktywnego uczestnictwa w życiu społecznym i zawodowym, w tym m.in. zwiększa umiejętność radzenia sobie w sytuacji porażki czy generowania rozwiązań w sytuacjach konfliktowych. Rozumienie wielokulturowych oraz społeczno-ekonomicznych wymiarów społeczeństw europejskich, wzajemnej interakcji narodowej tożsamości kulturowej oraz tożsamości europejskiej pozwala w optymalny sposób funkcjonować w wymiarze zarówno indywidualnym, jak i społecznym.

Edukacja międzykulturowa w tzw. szerokiej perspektywie zwraca uwagę na:

1. potrzebę integracji treści wielokulturowych,

2. postrzeganie edukacji jako procesu współtworzenia wiedzy,

3. konieczność przeciwdziałania uprzedzeniom,

4. założenia pedagogiki na rzecz równego traktowania, która jest zasadniczym elementem edukacji wielokulturowej.

Edukacja międzykulturowa w ujęciu Banksa to „strategia nauczania i budowania atmosfery, która pomaga uczniom z różnych grup społecznych, zróżnicowanych pod względem rasowym, etnicznym i kulturowym, przyswoić wiedzę, umiejętności i postawy potrzebne do efektywnego funkcjonowania w sprawiedliwym, humanitarnym i demokratycznym społeczeństwie, a także do jego tworzenia i umacniania. Istotą tej koncepcji jest pomaganie uczniom w dojrzewaniu do przyjęcia postaw krytycznych i aktywnych obywateli demokratycznego społeczeństwa" (Banks, 1993 za: Grudzińska, Kubin, 2010).

Pedagogika ta rozumiana jest jako proces edukacyjny, nie tylko koncentruje się na identyfikacji i wykorzystywaniu efektywnych sposobów nauczania, lecz także przykłada dużą wagę do otoczenia. Zachęca nauczycieli do stosowania strategii nauczania wspomagających w procesie uczenia się (analiza punktów widzenia przyjętych przez autorytety, a następnie podejmowanie prób formułowania własnych interpretacji rzeczywistości). Celem nie jest znalezienie jedynej słusznej odpowiedzi, ale odkrywanie połączeń między poszczególnymi zagadnieniami oraz pomysłami. Pedagogika na rzecz równego traktowania zakłada także chęć nawiązania współpracy między nauczycielami z różnych kręgów kulturowych i wzajemną wymianę doświadczeń. Jakie płyną z niej korzyści? Lokuje ona ucznia w centrum procesu nauczania i opiera się 
na relatywizmie kulturowym, czyli opisywaniu czyjegoś zachowania bez użycia wartościowania i stosowania odniesień do standardów własnej kultury (vs. etnocentryzm kulturowy, czyli tendencja do traktowania i stosowania norm własnej grupy jako standardów w percepcji grup obcych). Wreszcie, pedagogika na rzecz równego traktowania rzuca wyzwanie strukturze głębokiej (planowanie oraz aranżacja przestrzeni sal szkolnych wymagają zmian). Czy 45-minutowe rozkłady zajęć umożliwiają uczniom refleksję nad wiedzą i jej jednoczesną internalizację? Czy układ ławek sprzyja integracji uczniów?

Wyróżnia się osiem sposobów pojmowania wielokulturowości:

1. współistnienie kultur,

2. odmienne wartości osobiste,

3. zbiór różnych grup kulturowych,

4. sprawiedliwość i równość społeczna,

5. proces nadawania znaczenia nauczaniu i uczeniu się,

6. ogólny klimat szkoły,

7. ogólnooświatowa współpraca na rzecz środowiska przyrodniczego,

8. uczenie się konkurowania w ogólnoświatowej gospodarce.

Tych osiem sposobów opisuje Martin J. Haberman, który zwraca także uwagę na potrzebę stopniowania celów edukacji wielokulturowej, a są to:

1. negacja podgrup dyskryminowanych,

2. tolerancja (wszyscy uczą się żyć i współpracować razem, niezależnie od różnic),

3. akceptacja różnorodności (każda odmienność jest wartością dla świata i ludzi),

4. obrona prawa do odmienności,

5. odpowiedzialność za zmianę (wszyscy są odpowiedzialni za działanie na rzecz przeciwdziałania dyskryminacji i uprzedzeniom) (Haberman, 2000, za: Żebrowski, 2003).

Zadaniem pedagogiki międzykulturowej jest wypracowanie wizji edukacyjnej przygotowującej wszystkich, niezależnie od pochodzenia i kultury, do życia w świecie opartym na wzajemnym szacunku i tolerancji oraz odrzuceniu uprzedzeń rasowych i ksenofobicznych. Fundamentem budowania podstaw integracji europejskiej są akceptacja oraz zrozumienie różnych stylów komunikacji, metod rozwiązywania 
problemów, podejmowania decyzji. Edukacja wielokulturowa powinna mieć na względzie zarówno pracę pedagogiczną z cudzoziemcami, jak i przygotowanie całego społeczeństwa do akceptacji różnic kulturowych, etnicznych i obyczajowych (Lalak, 1993, za: Żebrowski, 2003). Edukacja międzykulturowa ma kształtować wśród uczniów proaktywną postawę nastawioną na poszanowanie kultury zarówno własnej, jak i cudzej.

W raporcie Europejskiego Instytutu Porównawczych Badań Kulturowych Dzielqqc się różnorodnościq̨. Narodowe podejścia do dialogu międzykulturowego w Europie wyrażono przekonanie, że mając na uwadze prawidłowe i bezpieczne funkcjonowanie społeczeństwa europejskiego, edukacja międzykulturowa nie powinna się odnosić tylko do "zwykłej" tolerancji, lecz należy dążyć do osiągnięcia stanu „podzielanej wspólnie przestrzeni", czyli trzeba budować takie wymiary możliwego współprzebywania, które wszyscy będą uznawać za wspólną wartość (Wiesand, 2008, za: Rogalska-Marasińska, 2017). Aby dojść do projektowanej optymalnej relacji międzykulturowej, w raporcie przedstawiono konieczne fazy, przez które powinni przejść mieszkańcy Europy:

1. Mapping Roads (wyznaczanie dróg i połączeń) - obejmuje określanie praktyk wykluczania i dyskryminowania pewnych grup społecznych oraz planowanie poprawy warunków społeczno-ekonomicznych, koniecznych, aby dialog międzykulturowy miał szansę zaistnieć.

2. Breaking down Walls (burzenie murów) - dotyczy usuwania barier w dochodzeniu do równości międzyludzkiej, walki z uprzedzeniami, rasizmem, ze stereotypami, a także wspierania aktywności jednostek, które w sferze polityki, ekonomii i kultury proponują alternatywne rozwiązania, czyli odmienne od tych przyjętych jako główny nurt aktywności instytucji europejskich.

3. Building Bridges (budowanie mostów) - polega na rozwijaniu międzykulturowych umiejętności i kompetencji poprzez edukację, sztukę, programy w mediach, które dostarczają jednostce narzędzi umożliwiających swobodne uczestnictwo w dialogu międzykulturowym.

4. Sharing Spaces (dzielenie się przestrzenią) - zakłada tworzenie takich miejsc, gdzie mogłyby być prezentowane pomysły, poglądy, doświadczenia, przekonania i wierzenia. Przewidując pojawienie 
się sytuacji konfliktowych, uczestnicy wspólnot działaliby tak, by „W sposób zgodny nie zgadzać się ze sobą". Taka postawa umożliwiłaby głębsze zrozumienie różnych poglądów, punktów widzenia świata i praktyk życiowych, a nawet mogłaby doprowadzić do wypracowania nowych sposobów działań.

W modelu akulturacji Johna Berry'ego wyróżnia się cztery strategie: integrację, asymilację, separację oraz marginalizację. Integracja to optymalna strategia, pozwalająca na sprawne funkcjonowanie zarówno w nowej kulturze, jak i starej, umożliwiająca płynne przechodzenie z jednej do drugiej. Asymilacja to dostosowanie się do nowego środowiska i uznanie norm oraz wartości kraju goszczącego, przy jednoczesnym odrzuceniu korzeni kulturowych kraju pochodzenia. Separacja polega na alienowaniu się od wartości i zwyczajów nowego środowiska życia oraz kultywowaniu wartości/korzeni kraju wychowania. Ten brak otwartości może (choć nie musi) być skutkiem nieprzychylności ze strony społeczeństwa. Marginalizacja z kolei to alienowanie się zarówno od wartości/korzeni kraju wychowania, jak i nowego środowiska. Takie odrzucenie wpływa silnie destrukcyjnie na jednostkę, wzmaga u niej poczucie wyalienowania, rodzi zaburzenia tożsamościowe oraz inne zaburzenia psychiczne. Jedynie procesy integracji służą zdrowiu jednostki. Powinno się promować warunki pozwalające mniejszościom narodowym podtrzymywać i rozwijać swoją kulturę (...) ze szczególnym uwzględnieniem religii, języka, tradycji i kulturowego dziedzictwa. Odejście od etnocentryzmu, czyli wizji spostrzegania własnego kraju w sposób wyższościowy, będzie się przyczyniać do obalania stereotypów i uprzedzeń oraz sprzyjać otwartości na odmienność kulturową. Za szczególne zadania edukacyjne uznaje się: pogłębianie poczucia tożsamości narodowej, z jednoczesnym wytwarzaniem świadomości współodpowiedzialności za losy Europy i globu; (...) "przyciąganie" innych swoją kulturą, czynienie kultury własnej atrakcyjną dla innych, nieograniczanie się do postaw podejrzliwości i nieufności oraz zapewnienie dynamiki i kreatywności narodów w wyniku otwartości na wymianę (Nikitorowicz, 2014).

Wykreowana w krajach Europy Zachodniej idea relatywizmu kulturowego oraz poprawności politycznej w efekcie prowadziła ku wykluczaniu tożsamościowemu i marginalizacji nie tylko imigrantów, ale także obywateli kraju ich przyjmującego. Stało się tak za sprawą poszerzenia zakresu praw dla imigrantów na prawa grupowe, ale nie zrobiono nic, aby 
te grupy mogły utożsamiać się z państwem (tamże). Sprowadzano od lat 60. i 70. XX w. ludność z krajów, które wcześniej były koloniami, nie obejmując ich żadnymi programami adaptacyjnymi, nie określając ich praw ani form kultywowania własnej religii i zasad funkcjonowania w nowych warunkach. Błędy w polityce społecznej, odgradzanie się od „innych kulturowo", traktowanie ich jako ludzi drugiej kategorii oraz zaniedbania w oświacie spowodowały wykorzystywanie opiekuńczego charakteru państwa i wzrost roszczeń wobec władz i społeczeństwa (...) nie można mówić, czy coś się sprawdziło, czy nie, gdy nie prowadzono określonej polityki społecznej. Przyjmowano imigrantów i odgradzano się od nich. Nikt się nad tym nie zastanawiał dopóty, działały zabezpieczenia socjalne i nie występowały reakcje antypaństwowe. Tego, że powstawały getta etniczne, nie można określić polityką wielokulturowości. Można to określić skrajną i nieprzemyślaną ideą poprawności politycznej, niewtrącania się i realizowania obok (Nikitorowicz, 2014). „W zaimkach »my«i "oni « wyraża się przede wszystkim nie podział wszystkich ludzi na dwie odrębne grupy, lecz różnica dwóch zdecydowanie odmiennych postaw: uczuciowego związku i antypatii, zaufania i podejrzliwości, pewności siebie i trwogi, gotowości do współpracy i wrogości" (Bauman, 2002, za: Żebrowski, 2003). Celem edukacji międzykulturowej jest wzajemne rozumienie i akceptacja istniejących różnic między narodami, myślenie wspólnotowe. Współczesna edukacja międzykulturowa ma na celu odnoszenie się do aktualnych problemów społecznych, zwiększanie stopnia świadomości uczniów i wyposażanie w wiedzę. Edukacja międzykulturowa uczy empatii i zaufania do drugiego człowieka, odnosi się do etyczno-moralnej sfery uczuć. W procesie edukacji należy wyposażać człowieka w kompetencje oraz umiejętności potrzebne do świadomego i odpowiedzialnego tworzenia kultury i wspólnoty. Samoświadomość i empatia należą do składowych inteligencji emocjonalnej. Można śmiało powiedzieć, że edukacja międzykulturowa przyczynia się do jej rozwoju wśród uczniów.

Najważniejszą działalność na rzecz wspólnotowego myślenia narodów podjęły Organizacja Narodów Zjednoczonych i jej agenda - Organizacja Narodów Zjednoczonych do spraw Oświaty, Nauki i Kultury, której głównym celem jest „rozwijać ludzkość poprzez oświatę i naukę, budować międzynarodowe zrozumienie, współpracę, zaufanie i pomoc" (Rogalska-Marasińska, 2017). Warto wspomnieć także o raporcie dla UNESCO Międzynarodowej Komisji do spraw Edukacji dla 
XXI w., stanowiącym przesłanie dla narodów świata, w którym mocno zaakcentowano znaczenie edukacji dla świata wielokulturowego. W publikacji zatytułowanej Edukacja: Jest w niej ukryty skarb na pierwszy plan wysunięto ideały pokoju, wolności i sprawiedliwości społecznej: "Jedyną drogą zmiany świata jest ta, która się dokonuje z woli i wewnętrznej siły człowieka, jego oczekiwań i dążeń". Za cel nadrzędny edukacji postawiono kreatywny rozwój jednostki, odkrywanie oraz eksponowanie możliwości człowieka. Cel ten można osiągnąć, uwzględniając cztery podstawowe rodzaje uczenia się:

1. uczyć się, aby żyć wspólnie,

2. uczyć się, aby wiedzieć,

3. uczyć się, aby działać,

4. uczyć się, aby być.

W raporcie wskazuje się na wagę systematycznego przygotowania do życia „w warunkach mieszania się kultur, racji, systemów wartości, podziału dóbr i współzawodnictwa, a także współpracy i integracji, poszanowania standardów i norm międzynarodowych" (Rogalska-Marasińska, 2017).

\section{Globalny Program Działań na rzecz zrównoważonego rozwoju i wizja edukacji do roku 2030}

Projekt Edukacji 2030 wyrasta na następujących filarach: powszechny i bezpłatny dostęp do edukacji, edukacja równa i włączająca (sprzeciwiająca się wszelkim formom dyskryminacji, począwszy od dyskryminacji płci), edukacja przez całe życie oraz edukacja dobrej jakości. Dopiero w takich warunkach może odbywać się pełen proces kształcenia (przyswajanie wiedzy podstawowej, rozwijanie twórczego myślenia i uczenie się rozwiązywania problemów) oraz wychowania (rozwijanie umiejętności kognitywnego myślenia, kompetencji społecznych i emocjonalnych, kształtowanie postaw na rzecz przestrzegania powszechnych praw człowieka i szacunku dla kulturowej różnorodności) (tamże).

Podczas Światowej Konferencji na temat Edukacji na rzecz Zrównoważonego Rozwoju w 2014 r. zainicjowano nowy plan edukacyjny o nazwie Globalny Program Działań (GAP - Global Action Programme). Przyjęto, że społeczność międzynarodowa przejdzie od deklaracji i prób wdrażania założeń edukacji na rzecz zrównoważonego rozwoju do inicjowania własnych, osadzonych w lokalnych kontekstach i podejmo- 
wanych na szeroką skalę konkretnych praktyk. Oczekuje się nie tylko ściślejszej współpracy międzysektorowej i politycznego wsparcia, lecz także bliższych relacji uczelni ze szkołami niższych szczebli kształcenia na polu badawczym, w zakresie innowacji oświatowo-metodycznych oraz w procesie monitorowania i ewaluacji uzyskiwanych efektów zrównoważonej edukacji. Dążenia te wynikają z potrzeby rzetelnego i perspektywicznego przygotowania młodzieży do twórczego funkcjonowania w przyszłości. To właśnie nowe pokolenia młodych mają się stać "strażnikami przyszłości”. Dlatego należy im zapewnić edukację dobrej jakości, która będzie opierać się na odpowiednio przygotowanych do zawodu nauczycielach i na wzbogaconych o tematykę zrównoważenia programach nauczania. Dzięki takiemu wykształceniu na miarę XXI w. młodzież będzie mogła rozwiązywać problemy zgodnie z ideą harmonii, zrównoważenia i odpowiedzialności za wspólne dobro.

Bezpośrednio do zagadnienia zrównoważonego rozwoju w obrębie problematyki edukacyjnej odnosi się szczegółowy cel wizji edukacji do 2030 r. - zapewnić wszystkim uczącym się możliwość zdobywania wiedzy oraz umiejętności dotyczących: praw człowieka, równości płci, promowania kultury pokoju i przeciwstawiania się przemocy, działania na rzecz globalnego obywatelstwa oraz doceniania różnorodności kulturowej. Nauczyciele określani są w programie mentorami zmiany. Mentor to osoba, która jest wzorem dla wychowanków, kimś doświadczonym, godnym zaufania doradcą. Nauczyciele powinni być zatem zmotywowani i edukowani w zakresie zrównoważonego rozwoju, aby móc jak najlepiej wykorzystywać wiedzę i przekazywać ją na swoich zajęciach. Zapewne będzie to łatwiejsze i skuteczniejsze, gdy zarówno $w$ trakcie przygotowania do zawodu nauczyciela, jak i podczas różnych form dokształcania i doskonalenia zawodowego adepci oraz pracujący już nauczyciele zostaną wielowymiarowo przygotowani do tego zadania przez uczelnie wyższe oraz inne instytucje pedagogiczne. Edukacja na rzecz zrównoważonego rozwoju oraz wynikająca z niej edukacja na rzecz globalnego obywatelstwa (GCED - Global Citizenship Education) mają stanowić główną przestrzeń działań formujących i samokształtujących każdego człowieka. W związku z tym w Ramowym planie działań w projekcie Edukacji 2030 zaproponowano następujące strategie:

1. Zmiana polityki oświatowej i przekształcenie podstaw oraz programów nauczania, aby promować edukację na rzecz zrównoważonego rozwoju i edukację na rzecz globalnego obywatelstwa. 
Należy je włączyć w główny nurt edukacji formalnej, a także realizować w edukacji pozaformalnej i nieformalnej. Potrzebne będzie więc nowe kształcenie i dokształcanie nauczycieli, a także rozwinięcie instytucji wspomagających szeroko rozumiane działania wychowawcze. Takie postępowanie ściśle łączy się z realizacjq Globalnego Programu Działań, a w szczególności z podejmowaniem takich tematów jak prawa człowieka, równość płci, zdrowie czy odpowiedzialne obywatelstwo.

2. Zapewnienie wszystkim, niezależnie od płci i wieku, dostępu do edukacji poszerzajq̨cej wiedzę, rozwijającej umiejętności i kształtującej postawy, które sq niezbędne, by budować pokojowo nastawione, zdrowe i zrównoważone społeczeństwa.

3. Rozwijanie i promocja dobrych przykładów i praktyk edukacyjnych, które zwiększajq współpracę międzynarodowa oraz ułatwiajq wzajemne poznanie i zrozumienie.

4. Kierowanie programów z obszaru edukacji na rzecz zrównoważonego rozwoju i edukacji na rzecz globalnego obywatelstwa do osób/edukatorów, którzy następnie będq działać w swoich środowiskach lokalnych.

5. Budowanie przekonania, że edukacja zawdzięcza swą kluczowq i wychowawczą rolę $w$ dochodzeniu do zrównoważenia dzięki kulturze. Kultura bowiem umożliwia dostrzeganie lokalnych uwarunkowań społecznych i kulturowych, uwrażliwia na znaczenie dziedzictwa kulturowego i form ekspresji praktykowanych przez danq społeczność, uwydatnia korzyści płynq̨ce z różnorodności kulturowej i podkreśla wagę przestrzegania praw człowieka.

6. Wykorzystywanie i/lub tworzenie rzetelnych narzędzi umożliwiajq̨cych ewaluację edukacji na rzecz zrównoważonego rozwoju i edukacji na rzecz globalnego obywatelstwa szczególnie w obszarze kognitywnych, społeczno-emocjonalnych i wychowawczych efektów kształcenia, a także współpraca z Instytutem Statystyki UNESCO.

7. Promowanie kształcenia międzydyscyplinarnego, tak aby treści dotyczq̨ce zrównoważenia i globalnego obywatelstwa pojawiały się na wszystkich etapach edukacyjnych i we wszystkich formach kształcenia. Program kształcenia ma szerokie humanistyczne podstawy i dobrze wpisuje się w złożone, globalne realia oświatowe i społeczne (Rogalska-Marasińska, 2017). 
Edukacja globalna i na rzecz zrównoważonego rozwoju, w tym edukacja międzykulturowa, stanowią wyzwanie dla współczesnych szkół. Nikła wśród kadr pedagogicznych w szkołach znajomość psychologii międzykulturowej skutkuje trudnościami w pracy z uczniem z innych kręgów kulturowych. Brak wiedzy, jak zaspokajać specjalne potrzeby edukacyjne takich uczniów, uniemożliwia efektywne zaplanowanie pracy z nimi i miarodajne oddziaływanie. $Z$ kolei brak miarodajnego oddziaływania może skutkować niską samooceną ucznia czy osiąganiem przez niego nieadekwatnych wyników edukacyjnych. Wynikłe w ten sposób trudności z pewnością będą rzutować na inne obszary życia ucznia i mogą zagrażać jego dobrostanowi. Niezwykle istotne zatem wydaje się włączenie do programu nauczania pedagogicznego studiów obligatoryjnych ścieżek dotyczących pracy z uczniem o innym zapleczu kulturowym. Jedynie nauczyciel, który wyzbył się stereotypowego postrzegania i uprzedzeń, będzie zdolny pracować efektywnie z uczniem innego pochodzenia kulturowego. Zdobyta podczas studiów wiedza (wykłady, ćwiczenia, warsztaty) pozwoliłaby nauczycielowi zwiększyć świadomość jego oddziaływania na ucznia. Dziś w polskich szkołach problematyka wielokulturowości omawiana jest bardzo rzadko, a nawet wcale. Istnieje duże prawdopodobieństwo, że nauczyciel zorientowany na potrzebę kształtowania wśród uczniów postaw tolerancji i szacunku wobec odmienności kulturowej zadba o włączenie odpowiednich treści do zajęć szkolnych. Z kolei osobista niechęć nauczyciela, rodząca się z przekonań dyskredytujących inne nacje kulturowe, przeciwdziałać będzie krzewieniu wśród uczniów idei wielokulturowości. Dla przyszłych pedagogów kluczowa powinna stać się analiza własnych przekonań dotyczących funkcjonowania uczniów pochodzących z różnych grup etnicznych.

Czego nauczyciel może się nauczyć, stosując metodę uwzględniającą różnice kulturowe?

1. Może pomóc uczniowi z innego kręgu kulturowego stać się intelektualnym liderem klasy.

2. Może włączać uczniów "do wspólnoty uczących się".

3. Doświadczenia życiowe uczniów legitymizowane są jako część "oficjalnego programu nauczania".

4. Nauczyciele i uczniowie włączają się w walkę przeciwko status quo.

5. Nauczyciel ma potrzebę poszerzać swoją wiedzę międzykulturową i wychodzi z taką inicjatywą. 
Studia pedagogiczne nie przygotowują nauczycieli w wystarczającym stopniu do pracy z dzieckiem o odmiennej niż polska kulturze pochodzenia. Niezwykle istotna w procesie nauczania jest umiejętność budowania więzi. Nie tylko stereotypowe myślenie i uprzedzenia, lecz także poziom kompetencji interpersonalnych może wspomagać bądź hamować proces adaptacji ucznia-migranta w szkole. Nawiązanie z nim właściwego kontaktu będzie podstawą do prowadzenia miarodajnego oddziaływania oraz wspomagania procesu adaptacji ucznia. Warto wspomnieć, że takie dziecko, trafiając do polskiej szkoły, z pewnością przeżywa szok kulturowy, a zderzenie z nową rzeczywistością zazwyczaj jest dla niego bardzo trudne. Omówienie zagadnień związanych z pracą z uczniem migrantem w polskim systemie oświaty wymaga odrębnych rozważań, jednak zarys tej problematyki można streścić w następujących pytaniach: Co kadra pedagogiczna wie o kraju pochodzenia migranta? Czy znane są normy/wzorce interakcyjne kultury kraju pochodzenia tego dziecka? Czy nauczyciele znają zasady funkcjonowania systemu edukacyjnego, w jakim kształcił się uczeń? Czy znane są sposoby dyscyplinowania przyjęte w kulturze kraju wychowania i szkoły ucznia? W jaki sposób odkryć potencjał nowego ucznia? Co wiadomo o systemie oceniania w szkołach kraju, z którego przybył uczeń?

Osiąganie niskich wyników w nauce przez uczniów-migrantów jest bardzo poważnym problemem, który wymaga uwagi, wyciągnięcia wniosków i przygotowania rekomendacji do dalszych działań. Osoba z innego kręgu kulturowego zaliczana jest do grupy uczniów mających tzw. specjalne potrzeby edukacyjne. Należy zachować niezwykłą ostrożność i stwarzać warunki edukacyjne dla uczniów-cudzoziemców, dostosowując wymagania do możliwości, jednak nie obniżając standardów edukacyjnych, a także dostrzegać potencjał ucznia.

Chęć stałego rozwoju i pogłębiania wiedzy wśród nauczycieli stanowi wyznacznik sukcesu zarówno w osobistej karierze zawodowej, jak i w przełożeniu na pracę z uczniem. Warte uwagi są wizyty studyjne nauczycieli (realizowane w tych samych krajach co Erasmus/Erasmus+), które umożliwiają wymianę innowacyjnych idei oraz doświadczeń, nawiązanie kontaktów zawodowych w zakresie tematów stanowiących przedmiot wspólnego zainteresowania, na poziomie europejskim. Uczestnicy promują jakość i przejrzystość systemu edukacji oraz mają okazję wymienić się doświadczeniami zawodowymi, podnosząc tym samym poziom swoich kompetencji, zarówno merytorycznych, 
jak i kulturowych. Międzynarodowy projekt edukacyjny Future Youth School Forum (finansowany z grantu Erasmus + oraz Ministerstwa Nauki i Szkolnictwa Wyższego) pokazał, że szczególnie istotne w kształceniu nauczycieli jest rozwijanie umiejętności wychowawczych zorientowanych na wartości oraz świadomości zagrożeń globalnych. Ważne jest, by traktować różnorodność kulturową jako integralną część procesu edukacyjnego na każdym poziomie nauczania oraz adresować treści kulturowe do wszystkich uczniów. Edukować w taki sposób, aby różnorodność kulturową traktować jako cenny zasób, który wpływa pozytywnie na rozwój zarówno jednostki, jak i społeczeństwa (Lelek, 1999, za: Madalińska-Michalak, 2017).

\section{Zakończenie}

W dzisiejszym świecie, w którym mamy do czynienia ze stale postępującym procesem globalizacji oraz kryzysem migracyjnym, niezbędne jest wprowadzanie do edukacji aktualnej problematyki społecznej (np. uchodźczej) oraz zapraszanie uczniów do dyskusji, uwrażliwiając ich na potrzeby innych ludzi. Aby nauczyciel mógł jako mentor zmiany pracować i rozmawiać z uczniami o międzykulturowości, niezbędne jest jego osobiste zaangażowanie, poczucie sprawstwa i kompetencji w zarządzaniu wiedzą. Zrównoważony rozwój, działania ONZ, prawa człowieka, edukacja globalna i międzykulturowa - warto, aby zwrócić na nie szczególną uwagę w szkolnych treściach nauczania. Tak jak drzewo potrzebuje solidnych korzeni, by rosnąć, tak uczeń potrzebuje solidnych fundamentów wiedzy, bez których trudno wejść w życie i w pełni, z korzyścią dla siebie i innych, funkcjonować. 


\section{Bibliografia}

$\rightarrow$ Banks, J.A. (1993), Multicultural Education: Historical Development, Dimensions, and Practice [w:] Review of Research in Education, Vol. 19, s. 3-49.

$\rightarrow$ Bauman, Z. (2002), O odpowiedzialności za świat [w:] K. Janowska, P. Mucharski, Rozmowy na nowy wiek, t. II, Kraków: Wydawnictwo Znak, s. 217-229.

$\rightarrow$ Boski, P. (2009), Kulturowe ramy zachowań społecznych. Podręcznik psychologii międzykulturowej, Warszawa: Wydawnictwo Naukowe PWN.

$\rightarrow$ Dejneka, P., Mikołajko, A. (red.) (2017), Pogranicza kulturowe w perspektywie współczesności, Warszawa: Wydawnictwo Naukowe UKSW.

$\rightarrow$ Grudzińska, A., Kubin, K. (red.) (2010), Szkoła wielokulturowa-organizacja pracy i metody nauczania. Wybór tekstów, Warszawa: Forum na rzecz Różnorodności Społecznej.

$\rightarrow$ Januszewska, E., Markowska-Manista, U. (2017), Dziecko „inne" kulturowo w Polsce. Z badań nad edukacja szkolnq, Warszawa: Wydawnictwo Akademii Pedagogiki Specjalnej.

$\rightarrow$ Kwiatkowska, A., Grzymała-Moszczyńska, H. (2011), Psychologia międzykulturowa, [w:] J. Strelau, D. Doliński (red.), Psychologia akademicka. Podręcznik, t. II, Gdańsk: Gdańskie Wydawnictwo Psychologiczne, s. 449-496.

$\rightarrow$ Kwiatkowski, S.T. (2017), Kształcenie społeczno-emocjonalne nauczycieli szkół podstawowych - fakultatywność czy obligatoryjność? [w:] J. Madalińska-Michalak (red.) O nowa jakość edukacji nauczycieli, Warszawa: Wydawnictwo Uniwersytetu Warszawskiego, s. 327-349.

$\rightarrow$ Lalak, D. (1999), Obywatelstwa europejskie Polaków - zadania edukacji wielokulturowej [w:] Pedagogika społeczna w Polsce - między stagnacją a zaangażowaniem, t. Il, s. 267-269.

$\rightarrow$ Madalińska-Michalak, J. (red.) (2017), O nowq jakość edukacji nauczycieli, Warszawa: Wydawnictwo Uniwersytetu Warszawskiego. 
$\rightarrow$ Muszyńska, J., Danilewicz, W., Bajkowski, T. (red.) (2013), Kompetencje międzykulturowe jako kapitał społeczności wielokulturowych, Warszawa: Wydawnictwo Akademickie "Żak".

$\rightarrow$ Nikitorowicz, J. (2016), Wartość dialogu międzykulturowego w przezwyciężaniu konfliktów na pograniczach kulturowych, "Multicultural Studies”, t. I, nr 1, s. 53-63.

$\rightarrow$ Nikitorowicz, J. (2014), Zadania edukacji międzykulturowej w kontekście problemów wielokulturowego świata, „Studia Kulturowo-Edukacyjne”, t. IX, nr 1, s. 6-25.

$\rightarrow$ Nikitorowicz, J. (2009), Tożsamość i obywatelstwo. Ku edukacji w dialogu międzykulturowym w nowej Europie [w:] M. Szymański „Debata edukacyjna”, nr 2, 25-30.

$\rightarrow$ Nikitorowicz, J. (2012), Nowe wyzwania edukacji międzykulturowej w kontekście współczesnych dylematów wokół kreowania społeczeństwa wielokulturowego [w:] M. Biernacka, K. Krzysztofek, A. Sadowski, Społeczeństwo wielokulturowe-nowe wyzwania i zagrożenia, Białystok: Wydawnictwo Uniwersytetu w Białymstoku, s. 100-117.

$\rightarrow$ Nikitorowicz, J. (2007), Prognozy Nowej Europy w kontekście realizowania zadań edukacji międzykulturowej [w:] J. Nikitorowicz, D. Misiejuk, M. Sobecki (red.), Etniczność i obywatelskość w Nowej Europie. Konteksty edukacji międzykulturowej, Białystok: Trans Humana, s. 15-29.

$\rightarrow$ Nisbett, R.E. (2011), Geografia myślenia. Dlaczego ludzie Wschodu i Zachodu myślq inaczej, Sopot: Wydawnictwo Smak Słowa.

$\rightarrow$ Pasamonik, B., Markowska-Manista, U. (2017) (red.), Kryzys migracyjny. Perspektywa społeczno-kulturowa, t. I, Warszawa: Wydawnictwo Akademii Pedagogiki Specjalnej.

$\rightarrow$ Pasamonik, B., Markowska-Manista, U. (2017) (red.), Kryzys migracyjny. Perspektywa pedagogiczno-psychologiczna, t. II, Warszawa: Wydawnictwo Akademii Pedagogiki Specjalnej.

$\rightarrow$ Rogalska-Marasińska, A. (2017), Edukacja międzykulturowa na rzecz zrównoważonego rozwoju. Edukacja. Teorie kształcenia i wychowania, Łódź: Wydawnictwo Uniwersytetu Łódzkiego.

$\rightarrow$ Sielatycki M. (2008), Kompetencje nauczyciela w Unii Europejskiej [w:] K. Sujak-Lesz (red.), Kształcenie nauczycieli w szkole wyższej. Wybrane zagadnienia. Wrocław: Wrocławskie Wydawnictwo Oświatowe, Centrum Edukacji Nauczycielskiej.

$\rightarrow$ Schaffer, H.R. (2005), Psychologia dziecka, Warszawa: Wydawnictwo Naukowe PWN. 
$\rightarrow$ Witkowski, L. (2009), Wyzwania autorytetu w praktyce społecznej i kulturze symbolicznej, Kraków: Oficyna Wydawnicza "Impuls".

$\rightarrow$ Żebrowski, J. (2003), Edukacja wielokulturowa w integrujq̨cej się Europie [w:] Prace Naukowe. Akademia im. Jana Długosza w Częstochowie. Pedagogika, t. XII, s. 109-120. 



\section{Projekt eTwinning jako sposobność do rozwijania inteligencji \\ wielorakich uczniów}

Jolanta Okuniewska

W artykule zaprezentowano założenia teorii rozwoju inteligencji wielorakich Howarda Gardnera oraz omówiono siedem podstawowych rodzajów inteligencji. Zaproponowano formy pracy z uczniami mające wpływ na rozwój inteligencji wielorakich. Poprzez dokładne omówienie międzynarodowego projektu eTwinning pt. Open the Gates to the Universe wskazano działania, które sprzyjały rozwojowi inteligencji wielorakich uczestniczącym w nim uczniów.

\section{Słowa kluczowe:}

Howard Gardner

inteligencje wielorakie

rozwój inteligencji wielorakich

inteligencje wielorakie w szkole

projekt eTwinning

rozwój inteligencji wielorakich 


\section{eTwinning project as a way to develop Multiple Intelligences of students}

Jolanta Okuniewska

In the article, the assumptions of the Howard Gardner's multiple intelligences theory were presented. Also, seven basic types of intelligence were presented. The material proposes the forms of working with students, which influence the development of multiple intelligences. By carefully elaborating on the international eTwinning project, "Open the Gates to the Universe", the activities which supported the multiple intelligences development of the participant students were indicated.

\section{Keywords:}

Howard Gardner

multiple intelligences

development of the multiple intelligences

multiple intelligences at school

eTwinning project

the development of multiple intelligences 


\section{Wstęp}

Realizacja projektów eTwinning wzbogaca proces uczenia się oraz nauczania. Dzięki projektom nauka staje się atrakcyjna, a zajęcia bogatsze o nowe metody i formy pracy. Projekty eTwinning na stałe zagościły w polskich szkołach, nauczyciele mają świadomość, jak organizować pracę projektową, żeby osiągnąć cele edukacyjne i sprawić, aby nauka była przygodą. Podczas realizacji zadań projektowych uczniowie kształtują kompetencje miękkie, czyli umiejętności: pracy w grupach, planowania, uzgadniania stanowiska, analizy danych, eliminacji błędów, weryfikowania wiadomości, prezentowania wyników badań i wniosków z nich płynących, komunikowania się w językach obcych i języku ojczystym. Uczniowie biorą też odpowiedzialność za podjęte działania, czyli za swoje uczenie się. Trudno kształtować te kompetencje podczas zwykłych zajęć, gdy dominuje podawcza metoda pracy. Praca nad projektem eTwinning wymaga od nauczyciela właściwego planowania realizacji etapów poszczególnych działań. Jednak podczas tego planowania sam do pomocy ma partnerów w projekcie oraz uczniów. Aby projekt był wartościowy, zarówno nauczyciele, jak i uczniowie powinni mieć równorzędne role już na etapie planowania zadań. Gdy uczniowie czują, że mają wpływ na to, co robią, mogą zgłaszać swoje propozycje, a jeśli dodatkowo spotykają się one z życzliwym zainteresowaniem nauczyciela, to chętniej uczestniczą w wykonywaniu zadań. Właśnie realizacja projektów eTwinning jest doskonałym sposobem na aktywizowanie uczniów, a także indywidualizację wymagań, dostosowywanie ich do potrzeb i możliwości dzieci oraz młodzieży.

\section{Rozwijanie inteligencji}

Gdy przyjrzymy się rodzajom inteligencji, które wyróżnił Howard Gardner, i przeanalizujemy dowolny projekt eTwinning, przekonamy się, że można w trakcie jego realizacji świadomie planować aktywności i wpływać na rozwijanie wszystkich rodzajów inteligencji uczniów.

Howard Gardner jest amerykańskim psychologiem w Harvard Graduate School of Education i neurologiem w Boston University School of Medicine. U schyłku lat 70. i na początku 80. XX w. wyróżnił u człowieka siedem typów inteligencji (Gardner, 2002). Uznał, że człowiek rodzi się ze wszystkimi rodzajami inteligencji i są one jednakowo ważne. Gardner nazwał je profilem inteligencji właściwym dla danej jednostki. W procesie rozwoju i pod wpływem czynników zewnętrznych człowiek 
wykorzystuje określone rodzaje inteligencji i je doskonali. W tym miejscu należy podkreślić rolę nauczyciela, który - mając tę wiedzę - może projektować sytuacje edukacyjne w taki sposób, by wzmacniać mocne strony dziecka i usprawniać słabsze.

Gardner wyróżnił siedem rodzajów inteligencji: językową - lingwistyczną, matematyczno-logiczną, ruchową, muzyczną, wizualno-przestrzenną, przyrodniczą, interpersonalną oraz intrapersonalną.

$\rightarrow$ Inteligencja językowa przejawia się w zamiłowaniu do słowa mówionego i pisanego, wierszyków, zagadek, rymów i rytmów tworzonych ze słów. Dziecko z dobrze rozwiniętą inteligencją językową jest wrażliwe na dźwięki i melodię języka oraz modulację głosu, dobrze interpretuje teksty poetyckie i prozę. Nie ma trudności w nauce języków obcych. Charakteryzuje je bogate słownictwo, umiejętność argumentowania i prowadzenia dyskusji. Chętnie słucha opowiadań, ale też ma umiejętność tworzenia własnych, ma pamięć słuchową, zadaje mnóstwo pytań. Z łatwością zapamiętuje nawet trudne wyrazy, całe zwroty i oryginalne nazwy. Aby rozwijać ten rodzaj inteligencji, nauczyciel powinien wykorzystywać gry słowne, zgadywanki, czytanie wierszy i opowiadań, ciekawych tekstów popularnonaukowych, skłaniać dzieci do zadawania pytań i poszukiwania odpowiedzi. Ciekawą i kształcącą zabawą będzie kończenie zdań, opowiadań, zmiana zakończenia historii w książce czy opowiadaniu, a także przedstawianie i zapisywanie własnych twórczych historii, wymyślanie zagadek, tworzenie definicji. Należy stwarzać okazje do swobodnych wypowiedzi, dyskusji i argumentowania wyborów czy stanowiska w jakiejś sprawie. Bardzo dobrze sprawdzą się tutaj zabawy dramowe, przedstawienia i scenki.

$\rightarrow$ Inteligencja matematyczno-logiczna charakteryzuje się umiejętnością logicznego myślenia, podawania właściwej kolejności obrazków, dostrzegania prawidłowości, zależności, związków przyczynowo-skutkowych, właściwym klasyfikowaniem przedmiotów, nazw, symboli. Osoba z rozwiniętym tym typem inteligencji lubi porządek, ustaloną kolejność, czytelne instrukcje, jest precyzyjna i zorganizowana. Nauczyciel powinien stosować zagadki pobudzające myślenie, aranżować sytuacje prowadzące do analizowania zachowania bohaterów lektur, wyciągania wniosków, porządkowania wydarzeń, szeregowania obrazków 
i klasyfikowania ich według podanych cech. Sprawdzą się tutaj zabawy matematyczne związane z szacowaniem, przeliczaniem, matematyczne historyjki i gry planszowe. Gry planszowe mogą być przygotowane przez dzieci, mogą one też wymyślić zasady, instrukcje oraz grafikę.

$\rightarrow$ Inteligencja ruchowa przejawia się zwłaszcza w umiejętności pokazywania emocji własnym ciałem, aprobowaniu wszelkich zabaw ruchowych, ćwiczeń fizycznych, manualnych. Dziecko $z$ rozwiniętym tym typem inteligencji ma dobre wyczucie odległości oraz przestrzeni, szybko uczy się jazdy na rowerze, skacze sprawnie na skakance i z łatwością kozłuje piłką. Podczas zabaw muzycznych lub rozmowy często gestykuluje i używa mowy ciała. Rozwijanie inteligencji ruchowej to organizowanie zabaw ruchowych, zajęć artystycznych, zawodów, lekcji majsterkowania, gotowania, szycia, nauka tańców, udział w sztukach teatralnych, przygotowywanie spektakli, scenek z tańcem i przyborami do ćwiczeń oraz kalamburów z pokazywaniem.

$\rightarrow$ Inteligencja muzyczna to dobre poczucie rytmu, wrażliwość na dźwięki i melodie odzwierciedlana w ruchu ciała, bujaniu się do muzyki, podśpiewywaniu przy wykonywaniu innych czynności. Dziecko chętnie śpiewa piosenki, samodzielnie komponuje muzykę, mrucząc, wystukując rytm i wykorzystując do zabawy dostępne przedmioty. Lubi słuchać muzyki, ma swoje ulubione piosenki, czasem zmienia ich słowa, dodaje zwrotki oraz zmienia linię melodyczną. Aby rozwijać i wzmacniać ten rodzaj inteligencji, trzeba pozwolić dzieciom na eksperymenty muzyczne, wsłuchiwać się w dźwięki otoczenia, nagrywać dźwięki i zamieniać informacje w melodie. Dobrym sposobem jest organizowanie orkiestry, która gra na samodzielnie wykonanych instrumentach perkusyjnych, instrumentach melodycznych dostępnych w szkole i prezentowanie utworów szerszemu odbiorcy. Warto bawić się w rymowanie, wymyślanie piosenek oraz codziennie słuchać różnorodnych utworów.

$\rightarrow$ Inteligencja wizualno-przestrzenna przejawia się w zdolności do dostrzegania szczegółów w otaczającym świecie, wrażliwości na kształty, kolory, przestrzeń i linie. Osoby o wysokim poziomie tego rodzaju inteligencji myślą obrazami, opisują otoczenie, wymieniając szczegóły i kolory, lubią bawić się mapami, planami, 
tworzyć labirynty, rzeźbić, wycinać i kleić przestrzenne modele. Mają łatwość w poruszaniu się w nowym miejscu, zapamiętują charakterystyczne elementy i nimi się kierują. Szybko uczą się korzystania ze schematów, z tabel, planów, diagramów. Gdy rozłożą jakiś przedmiot na elementy, sprawnie złożą go z powrotem. Interesują się działaniem przedmiotów, sprzętów i rozumieją instrukcje. Chętnie posługują się obrazkami, tworzą mapy myśli. Wzmacnianie tego rodzaju inteligencji i wspieranie kompetencji związanych z myśleniem wizualno-przestrzennym to organizowanie zajęć technicznych, budowanie modeli z klocków, plasteliny, modeliny i z wykorzystaniem różnych materiałów dostępnych w klasie oraz materiałów przyrodniczych. Podczas zajęć edukacji plastycznej należy wykorzystywać różne techniki plastyczne i ciekawe materiały. Warto rysować mapy myśli i korzystać ze schematów, wykonywać notatki z symbolami, pozwalać na planowanie wypraw, przygotowywanie map do zabaw w poszukiwanie skarbów, zwiedzania najbliższej okolicy.

$\rightarrow$ Inteligencja przyrodnicza przejawia się w zainteresowaniu otoczeniem przyrodniczym, zwierzętami i roślinami oraz eksperymentowaniem i doświadczaniem przyrody. Osoby z rozwiniętą inteligencją przyrodniczą chętnie spędzają czas na świeżym powietrzu, rozumieją związki przyczynowo-skutkowe zachodzące w przyrodzie i interesują się ekologią. Potrafią rozpoznawać gatunki zwierząt, chętnie czytają przyrodnicze książki, kolekcjonują albumy i oglądają filmy przyrodnicze. Najczęściej hodują ciekawe okazy zwierząt, czasem dziwnych i niespotykanych, opiekują się roślinami, zakładają hodowle w doniczkach. Wzmacnianie tego rodzaju inteligencji polega na prowadzeniu hodowli, opisywaniu etapów i eksperymentowaniu. Należy stwarzać okazje do przebywania i doświadczania w różnych ekosystemach, prowadzenia obserwacji o każdej porze roku, dokumentowania procesów przyrodniczych, tworzenia albumów okazów oraz zdjęć, ponieważ to umożliwia wyciąganie wniosków, stawianie hipotez i weryfikowanie pomysłów. W klasie można zorganizować kącik hodowli roślin, założyć akwarium czy klasowy ogródek.

$\rightarrow$ Inteligencja interpersonalna to dobre relacje $w$ grupie, umiejętność pracy zespołowej, łatwość nawiązywania kontaktów, umiejętności komunikacyjne i silne cechy przywódcze. Osoby 
o takich cechach są lubiane przez rówieśników, ponieważ są empatyczne i nie powodują konfliktów. Potrafią prowadzić dialog i rozwiązywać problemy poprzez rozmowę i używanie mądrych argumentów. Są asertywne i potrafią określić własne potrzeby. Rozumieją mowę ciała, odbierają informacje niewerbalne i je analizują. Doskonalenie tej inteligencji polega na stwarzaniu okazji do pracy zespołowej nad projektami, tworzeniu scenek dramowych, analizowaniu postępowania bohaterów lektur, budowaniu dialogów i ich nagrywaniu, organizowaniu zabaw w odgadywanie nastrojów, kalamburów. Należy pozwalać uczniom na dokonywanie wyborów i uzasadnianie decyzji, podejmowanie samodzielnych akcji polegających na wcześniejszym planowaniu i prezentowaniu wyników.

$\rightarrow$ Inteligencja intrapersonalna to skupienie na sobie, wybór aktywności polegających na pracy samodzielnej. Osoby z rozwiniętą inteligencją intrapersonalną znają swoje mocne strony i mają zbudowaną motywację wewnętrzną, stawiają sobie cele i dążą do ich osiągnięcia. Bardzo lubią przebywać same i o sobie decydować. Wzmacnianie tego rodzaju inteligencji polega na moderowaniu czynności w taki sposób, by uczeń mógł wybrać zadanie, samodzielnie zaplanować etapy pracy, zająć się organizowaniem środowiska do aktywności i zaprezentować efekt końcowy. Należy podkreślać potrzeby innych, uwrażliwiać na emocje i zachęcać do pracy w parach lub zespole, pamiętając o indywidualnych predyspozycjach dziecka.

Przyjrzyjmy się aktywnościom przewidzianym dla uczniów w międzynarodowym projekcie Open the Gates to the Universe i przeanalizujmy je pod kątem rozwijania inteligencji wielorakich.

Projekt był realizowany przez rok szkolny w partnerstwie ze szkołami w Portugalii, Rumunii i na Cyprze. Uzyskał liczne nagrody i wyróżnienia w kraju oraz Europie.

Celem projektu było:

$\rightarrow$ pogłębienie wiedzy o Kosmosie, Układzie Słonecznym, planetach i gwiazdach, o Ziemi i jej miejscu we Wszechświecie,

$\rightarrow$ rozbudzenie zainteresowania astronomią i astronautyką,

$\rightarrow$ prowadzenie prostych obserwacji astronomicznych, korzystanie z aplikacji 3D, 
$\rightarrow$ poznanie zagadnień związanych z pogodą,

$\rightarrow$ przygotowywanie doświadczeń, prezentowanie ich i wyjaśnianie prostych zjawisk fizycznych,

$\rightarrow$ doskonalenie umiejętności prezentacji i autoprezentacji,

$\rightarrow$ doskonalenie umiejętności planowania własnych działań i pracy w zespołach,

$\rightarrow$ doskonalenie kompetencji językowych w języku ojczystym i obcym,

$\rightarrow$ pogłębienie wiadomości o krajach partnerskich,

$\rightarrow$ doskonalenie umiejętności świadomego korzystania z TIK.

W pierwszym etapie uczniowie ze szkół partnerskich mieli za zadanie się przedstawić. Wykorzystali do tego celu szablony kosmonautów wycięte z bloku technicznego i wkleili do nich swoje zdjęcia. Ta aktywność kształtowała inteligencję interpersonalną, intrapersonalną, lingwistyczną i wizualno-przestrzenną. Dzieci musiały zaplanować swoje działania, zapoznać się z instrukcją, wykonać zadanie według niej, a następnie zaprezentować się w klasie. Na początku wystąpili uczniowie, których inteligencja językowa i interpersonalna była dość dobrze rozwinięta. Dzięki temu swobodnie się zaprezentowali, a na ich przykładzie prezentowali się pozostali uczniowie. Nauka od innych i z innymi to najlepsza metoda pracy. Przy tym znany i atrakcyjny cel pozwalał na zaangażowanie wszystkich uczniów.

Podczas pracy nad modelem Układu Słonecznego dzieci kształtowały inteligencję wizualno-przestrzenną, matematyczno-logiczną, językową, interpersonalną i ruchową. Wykonały prace badawcze, czytały informacje w różnych źródłach, uzgadniały stanowiska, porównywały wiadomości, przygotowywały materiały, planowały etapy pracy, wycinały, kleiły poszczególne elementy Układu Słonecznego, mierzyły odległości i porównywały wielkości. Odpowiadały na pytania kolegów i koleżanek, wyjaśniając wątpliwości, które powstały w wyniku oglądania kilku modeli Układu Słonecznego.

Ciekawym zadaniem było przygotowanie ilustracji, które zostały wykorzystane do zobrazowania przygód kosmonauty na stacji kosmicznej. Najpierw został odczytany początek historyjki i wymyślany kolejny fragment. Do tego fragmentu należało wykonać obrazek, a następnie uczestnicy wybrali jeden, który najbardziej oddawał ich część opowiadania. Oprócz inteligencji wizualno-przestrzennej doskonalona była 
inteligencja interpersonalna i intrapersonalna. Uczestnicy wykorzystywali okazję do kształtowania inteligencji językowej. Dzieci uzasadniały wybór danej ilustracji tak, by twórca otrzymał właściwą informację zwrotną i nie czuł się źle. To trudna sztuka, bo wymaga wczucia się w emocje drugiej osoby. Dzięki takim aktywnościom podczas realizacji jednego zadania rozwijanych było kilka rodzajów inteligencji.

Uczniowie bardzo lubili zadania związane z przygotowaniem i przeprowadzeniem doświadczeń. Dokonywali wyboru doświadczenia, podejmowali samodzielne decyzje i planowali czas wykonania. Uczyli się obowiązkowości i odpowiedzialności za zadanie. Doskonalili inteligencję intrapersonalną. W klasie po zademonstrowaniu doświadczenia odpowiadali na pytania kolegów i koleżanek, musieli wykazać się wiedzą i w przystępny sposób udzielić odpowiedzi. Doskonalili inteligencję językową i interpersonalną. Nawet uczniowie, którzy zwykle niezbyt chętnie wypowiadali się na forum klasy, podczas tego rodzaju aktywności przełamywali lęk i pokonywali nieśmiałość. Mieli możliwość zaprezentowania swoich umiejętności i zdobytej wiedzy, podejmowali ryzyko, starali się sprostać wyzwaniu. Pracowali ze świadomością postawionego sobie samodzielnie celu.

Młodsi uczniowie bardzo lubią wszelkie prace plastyczne i techniczne. Dzięki temu staranniej piszą, są cierpliwe, uczą się postępować według zaplanowanych etapów, trenują kompetencje miękkie. Partnerka z Rumunii przysłała modele sondy kosmicznej Rosetty w postaci rzutu płaskiego i siatki do wycięcia oraz sklejenia. Należało odczytać schemat siatki i instrukcję postępowania, która była przedstawiona w postaci rysunków. Uczniowie samodzielnie przeanalizowali etapy pracy i pomagając sobie wzajemnie, przygotowali cztery modele Rosetty. Nie była to łatwa praca, ponieważ odczytanie schematu sprawiło niektórym trudność, a dzieci z dobrze rozwiniętą inteligencją wizualno-przestrzenną musiały udzielać pomocy pozostałym. Korzyści odniosły obie grupy uczniów. Jedni doskonalili inteligencję wizualno-przestrzenną, a drudzy nabywali te kompetencje, by następnie móc je doskonalić. Nie byłoby to możliwe bez zaplanowania pracy przez nauczyciela i stworzenia dogodnych sytuacji indywidualizujących wymagania. Dodatkowo dzieci kształtowały inteligencję interpersonalną, językową i intrapersonalną.

Wszelkie prace plastyczne, projektowanie logo projektu, ilustrowanie opowiadania, przygotowywanie projektu nowego narzędzia dla kosmonauty to znakomite okazje do kształtowania inteligencji matematycz- 
no-logicznej, ruchowej, wizualno-przestrzennej, językowej. Uczniowie, współpracując ze sobą, muszą się komunikować, uzgadniać stanowiska, dochodzić do porozumienia. Uczą się rozwiązywać konflikty i prowadzić dialog w taki sposób, by przekonać partnerów do swojej racji. Podczas tych dyskusji nabierają pewności siebie i uczą się szacunku dla kolegów o innych poglądach. Mają szansę poczuć smak porażki i nauczyć się, jak sobie z nią poradzić, a także jak wyciągnąć z niej naukę i zaakceptować to, że nie zawsze jest się zwycięzcą.

Kiedy tworzyły najprostszą muzykę ilustrującą dźwięki Kosmosu, bawiły się doskonale i nawet nie zdawały sobie sprawy, że kształtują inteligencję muzyczną. Mądry nauczyciel tak bowiem prowadzi zajęcia i projektuje aktywności, że aktywizuje każdą sferę poznawczą ucznia.

Podczas realizacji projektów eTwinning, dzięki wykorzystaniu nowoczesnych technologii, nauczyciel ma więcej możliwości by, doskonalić inteligencje wielorakie uczniów, rozbudzać je i wpływać na rozwój podopiecznych w optymalny sposób. Internet oferuje bogactwo narzędzi, które wykorzystywane w projektach eTwinning wpłyną na rozwój inteligencji wielorakich.

$\rightarrow$ Inteligencję językową możemy kształtować, wykorzystując narzędzia do nagrywania wypowiedzi, publikowania wypowiedzi ustnych i pisemnych, platformy do wspólnego pisania, tworzenia multimediów, mówiących awatarów czy podcastów.

$\rightarrow$ Inteligencję matematyczno-logiczną pomogą nam doskonalić narzędzia do tworzenia map myśli, schematów, krzyżówek, grafów, sudoku, puzzli, kalkulatory graficzne, arkusze kalkulacyjne online i offline.

$\rightarrow$ Inteligencję wizualno-przestrzenną możemy kształtować, korzystając z narzędzi do projektowania brył przestrzennych, druku 3D, planowania ogrodów, tworzenia obrazów, rysowania, programowania w wizualnym języku itp.

$\rightarrow$ Inteligencję muzyczną pozwolą nam doskonalić programy do obróbki plików dźwiękowych, nagrywania słuchowisk, do publikowania zilustrowanych historyjek wzbogaconych narracją nagraną przez uczniów, do słuchania nagrań muzycznych, bajek i opowiadań, programowania muzyki z obrazków, schematów itp.

$\rightarrow$ Inteligencję ruchową najlepiej kształtować w swobodnych zabawach dzieci, wymyślanych grach i według dziecięcych instrukcji. 
W sieci możemy znaleźć sporo narzędzi, które uatrakcyjnią takie zajęcia: gry komputerowe $w$ grupie $z$ interaktywnościami do wykonania gestami, ciałem, gry na ekranach dotykowych, programy do tworzenia animacji, odgrywania scenek.

$\rightarrow$ Inteligencję interpersonalną pozwolą kształtować narzędzia do współpracy: czaty, komunikatory, gry grupowe, poczta elektroniczna, programy do pracy zdalnej pozwalające na edycję tego samego dokumentu czy obrazka.

$\rightarrow$ Inteligencję intrapersonalną rozwiniemy, pracując z programami angażującymi dziecko i pozwalającymi na indywidualizację zarówno tempa pracy, jak i zagadnień, nad którymi dziecko pracuje. Będą to gry edukacyjne dla pojedynczego gracza, projektowanie tych gier, gry z instrukcjami, programy do burzy mózgów, edycji filmów lub zdjęć, edytory tekstów itp.

Teoria inteligencji wielorakich Howarda Gardnera daje nauczycielowi pewność, że planując zagadnienia, aktywności i zadania do realizacji w projekcie, wpływa on w pełny sposób na rozwój dziecka i stwarza mu warunki do najlepszego rozwoju. 


\section{Bibliografia}

$\rightarrow$ Gardner, H. (2002), Inteligencje wielorakie. Teoria w praktyce, Poznań: Media Rodzina. 


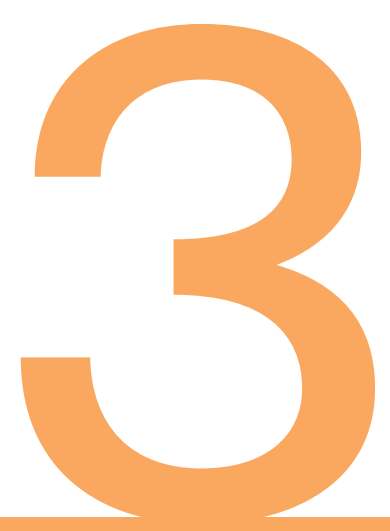




\section{Kompetencje cyfrowe}




\section{Język programowania jako kompetencja XXI w.}

Monika Mojsiejonek, Małgorzata Knap

Tekst poświęcony jest wprowadzaniu programowania do polskich szkół.

Opisano w nim liczne zalety nauczania dzieci kodowania. Na początku omówiono pojęcie kodowania oraz opisano poglądy prof. Macieja Sysły i wyniki badań Lindy Liukas na temat umiejętności kodowania u dzieci i młodzieży. Za główny cel wprowadzenia programowania do szkół postawiono potrzebę pokazania uczniom, w jaki sposób wykorzystać komputer do rozwiązania określonego problemu. Następnie opisano wyniki badań Marca Prensky'ego nad dziećmi i młodzieżą dorastającymi. Wyjaśnione zostały terminy cyfrowi tubylcy oraz cyfrowi imigranci oraz przedstawione zostały różnice pomiędzy tymi dwiema grupami. W dalszej części tekstu omówiono rekomendacje dotyczące uczenia się i nauczania programowania w polskich szkołach, opisanych przez Centrum Edukacji Obywatelskiej. Następnie zasygnalizowano najczęściej pojawiające się wśród praktykujących nauczycieli wątpliwości oraz podano kilka wskazówek, jak rozpocząć przygodę z programowaniem. Przedstawiono również pomysły na wprowadzenie kodowania w wersji online i offline. Opisana też została kampania "Programowanie z eTwinning", zorganizowana i przeprowadzona przez eTwinning Polska.

\section{__ Słowa kluczowe:}

przywództwo nauczycieli

zawód nauczyciela

warunki pracy 


\section{Programming language \\ as a competence of $\mathrm{X}$ KI century}

Monika Mojsiejonek, Małgorzata Knap

The following text concerns the issue of introducing programming to schools in Poland. It presents numerous advantages of teaching children how to code even at a very young age. The first part of the article is devoted to the term "coding". The views of Maciej Sysło and Linda Liukas on the ability of coding have been briefly described. What is more, teaching young learners how to use a computer in order to solve a certain problem has been presented as the main aim of introducing coding to schools. In the second part of the text, the view of Marc Prensky on children and teenagers of XXI century has been described. The terms "digital natives", "digtal immigants" and the differences between them have been explained. The third part of the article focuses on recommendations concerning learning and teaching programming at schools, described by Centrum Edukacji Obywatelskiej. The fourth part of the article comments on the most common doubts of teachers, who are at the beginning of their adventure with teaching coding. It is closely connected with the fifth part of the text, in which some guidelines on how to start coding with students have been given. The sixth and the seventh parts of the article cover multiple ideas on introducing programming on-line and off-line to the classroom. The last part is devoted to a campaign held by eTwinning Poland, named "Programowanie z eTwinning". 
Kiedy w grudniu 2015 r. Ministerstwo Cyfryzacji zapowiedziało wprowadzenie szybkiego Internetu we wszystkich polskich szkołach, a Ministerstwo Edukacji Narodowej przedstawiło projekt nowej podstawy programowej informatyki, uwzględniającej nauczanie programowania już od najmłodszych klas szkoły podstawowej, wielu rodziców i nauczycieli zareagowało dość sceptycznie. "Niech nauczą się najpierw czytać i pisać, a nie kodować!" - to zdanie pojawiało się w wielu dyskusjach jako główny kontrargument przeciwko wprowadzanym zmianom. Czy jednak programowanie, kodowanie może zaszkodzić dziecięcym umysłom, utrudnić im przyswajanie podstawowych umiejętności: pisania, czytania, liczenia? Według ekspertów oraz nauczycieli i rodziców dzieci, które przygodę z programowaniem już rozpoczęły - wręcz przeciwnie.

\section{Czym tak naprawdę jest kodowanie?}

Zacznijmy od uściślenia znaczenia terminu kodowanie. Profesor Maciej Sysło stwierdził, że kodowanie jest to skrót myślowy, a w języku informatycznym wręcz uproszczenie (innpoland.pl, 2016). Nie istnieje krótsze słowo, które określałoby samą czynność tworzenia kodu, czyli języka komunikacji z maszyną.

Celem podstawowej edukacji jest przekazanie nam wiedzy ogólnej, której częścią w XIX w. stało się również programowanie. Umiejętność kodowania można porównać do innych umiejętności nauczanych w szkołach od lat (Koodi, 2016). Warto jednak mieć świadomość, że nie każdy, kto uczy się biologii, zostanie biologiem, tak jak wielu ludzi uczących się programowania nigdy nie zostanie programistami. Każdy powinien mieć jednak prawo do zrozumienia, jak działa kodowanie i w jakich aspektach naszego codziennego życia jest przydatne.

W nowej podstawie programowej informatyki odchodzi się od określenia umiejętność obsługi komputera. Zamiast niej dzieci uczą się, jak posługiwać się komputerem i dostępnymi dzięki niemu narzędziami, aby rozwiązać konkretny problem. Brzmi poważnie, lecz dla młodszych uczniów programowanie ma być przede wszystkim zabawą. Pomocne w tym są takie programy jak Scratch, występujący również w wersji Junior. Dzieci tworzą w nim krótkie historie z interaktywną postacią, która wykonuje polecenia zapisane za pomocą kodu ukrytego w schematach blokowych. Im starszy uczeń, tym bardziej rozbudowane historie i skomplikowane działania scratchowego duszka. 
Jednocześnie należy podkreślić, że umiejętność kodowania przydatna jest nie tylko w pracy z komputerem, ponieważ każdy z nas wykorzystuje różnego rodzaju kody w swoim codziennym życiu. Kodem może być przepis na ciasto, instrukcja złożenia modelu samolotu, wskazanie komuś drogi. W jednym z popularnych na YouTube filmów z serii "Exact Instructions Challenge" ojciec prosi dzieci o podanie szczegółowych wytycznych, jak zrobić kanapkę. Zadanie wydaje się proste, jednak kilkulatki muszą się bardzo natrudzić, by podawane przez nie instrukcje - kody - dały efekt zgodny z zamierzonym.

Wpływ, jaki nauka programowania ma na młodych ludzi, został doceniony w wielu krajach na świecie. 14 krajów, w tym Polska, zdecydowało się włączyć programowanie do podstawy programowej nauczania informatyki już od najmłodszych klas szkoły podstawowej. W styczniu $2016 \mathrm{r}$. prezydent Barack Obama ogłosił program Computer Science for ALL i obiecał znaleźć na niego 4 mld dol. Również w styczniu 2016 r. rząd Wielkiej Brytanii wyposażył milion uczniów w micro:bit - programowalny mikrokomputer. Obserwując tak daleko idące zmiany, nie można udawać, że skupienie się na nauce programowania to tylko chwilowa moda, która na pewno przeminie.

\section{Dlaczego programowanie jest w szkołach potrzebne?}

Wprowadzenie programowania do szkół ma na celu przede wszystkim rozwijanie u uczniów umiejętności myślenia logicznego i komputacyjnego, kreatywności, a także współpracy z innymi ludźmi mającymi ten sam problem do rozwiązania. To jednak nie wszystko. Już w $2001 \mathrm{r}$. Marc Prensky twierdził, że współcześni uczniowie nie są tymi samymi ludźmi, dla których został stworzony obecnie obowiązujący system nauczania, ponieważ są oni pierwszym pokoleniem, które dorastało otoczone nowoczesną technologią (Prensky, 2001). Komputery, konsole do gier czy telefony komórkowe nie mają przed nimi tajemnic i są integralną częścią ich życia, co doprowadziło do całkowitej zmiany sposobu, w jaki ich umysły przetwarzają informacje. Prensky podkreśla, że mózgi naszych uczniów najprawdopodobniej różnią się od naszych pod względem fizycznym, co jest spowodowane właśnie podporządkowaniem ich życia nowoczesnej technologii, przez którą, a może raczej dzięki której zmianie uległy ich procesy myślowe (tamże). W przeciwieństwie do nas, cyfrowych imigrantów, którzy musieli nauczyć się posługiwania komputerem w codziennym życiu, uczniowie XXI w. to cyfrowi tubylcy, 
którzy traktują świat komputerów, smartfonów i Internetu jak swoje środowisko naturalne.

Tabela 1. Różnice między cyfrowymi imigrantami i cyfrowymi tubylcami

\begin{tabular}{l|l}
\multicolumn{1}{c|}{ cYFRowI IMIGRANcı } & \multicolumn{1}{c}{ cyFrowı TUBYLcr } \\
\hline $\begin{array}{l}\text { Wolą tekst drukowany od tekstu wyświe- } \\
\text { tlonego na ekranie }\end{array}$ & $\begin{array}{l}\text { Nie mają problemów z pracą z tekstem } \\
\text { wyświetlonym nawet na małym ekranie }\end{array}$ \\
\hline $\begin{array}{l}\text { Tekst jest dla nich ważniejszy od obrazu } \\
\text { i dźwięku }\end{array}$ & $\begin{array}{l}\text { Obraz i dźwięk jest dla nich ważniejszy } \\
\text { od tekstu }\end{array}$ \\
\hline $\begin{array}{l}\text { Informacji poszukują w encyklopediach, } \\
\text { w bibliotece }\end{array}$ & Informacji poszukują w Internecie \\
\hline Przetwarzają informacje szeregowo & Przetwarzają informacje równolegle \\
\hline $\begin{array}{l}\text { Są bardziej cierpliwi i wytrwali } \\
\text { Preferują systematyczne uczenie się }\end{array}$ & $\begin{array}{l}\text { Preferują uczenie się za pomocą ekspery- } \\
\text { mentów, edukację akcydentalną }\end{array}$ \\
\hline $\begin{array}{l}\text { Zawsze czytają instrukcję przed skorzy- } \\
\text { staniem z jakiegoś urządzenia }\end{array}$ & $\begin{array}{l}\text { Nie czytają instrukcji, wykorzystują metodę } \\
\text { prób i błędów }\end{array}$ \\
\hline $\begin{array}{l}\text { Korzystają z komputera, Internetu, } \\
\text { smartfona itd. w podstawowym zakresie } \\
\text { (tworzenie dokumentów tekstowych, } \\
\text { pisanie e-maili, wyszukiwanie prostych } \\
\text { informacji, wykonywanie połączeń tele- } \\
\text { fonicznych, pisanie SMS-ów) }\end{array}$ & $\begin{array}{l}\text { Korzystają ze wszystkich dostępnych } \\
\text { funkcji komputera, Internetu, smartfona itd. } \\
\text { w sposób kreatywny i twórczy; korzystają } \\
\text { z wielu funkcji jednocześnie (tzw. zjawisko } \\
\text { konwergencji mediów) }\end{array}$ \\
\hline $\begin{array}{l}\text { Nie przywiązują się do posiadanych urzą- } \\
\text { dzeń mobilnych }\end{array}$ & $\begin{array}{l}\text { Są bardzo przywiązani do posiadanych } \\
\text { urządzeń mobilnych, nie wyobrażają sobie } \\
\text { bez nich życia }\end{array}$ \\
\hline $\begin{array}{l}\text { Używają przestarzałego języka, niezrozu- } \\
\text { miałego dla cyfrowych tubylców }\end{array}$ & $\begin{array}{l}\text { Używają nowoczesnego języka, dzięki tech- } \\
\text { nologii komunikują się bez zobowiązań, na- } \\
\text { stawieni są na lekkie, mało istotne rozmowy }\end{array}$ \\
\hline
\end{tabular}

Źródło: L. Hojnacki, Pokolenie m-learningu - nowe wyzwanie dla szkoły [w:] „E-mentor", nr 1(13), 2006, s. 23-27 oraz M. Prensky, Digital Natives, Digital Immigrants [w:] „On the Horizon", 2001, Vol. 9, No. 5.

Jak wynika $\mathrm{z}$ tabeli $\mathrm{nr}$ 1, pokolenie XXI w. funkcjonuje w zupełnie odmienny sposób niż porównywana grupa. Jest to sprzeczne $z$ wciąż popularnym wśród nauczycieli przekonaniem, że uczniowie się nie zmieniają, a więc również stosowane w szkole metody nauczania mogą pozostać bez zmian. Co więcej, cyfrowi imigranci nie do końca wierzą w skuteczną naukę podczas jednoczesnego oglądania programu telewizyjnego czy słuchania muzyki, z czym współczesne dzieci i nastolatki 
nie mają najmniejszego problemu. Wprowadzenie do szkół programowania motywuje nauczycieli do zmiany takiego podejścia oraz do poszerzania swoich kompetencji dotyczących stosowania nowoczesnych technologii. Usprawnia również komunikację na linii nauczyciel-uczeń, pozwala lepiej zrozumieć świat cyfrowych tubylców i niejako oswaja nauczycieli próbujących dotąd uchodzić za nieomylnych, a często nawet wszechwiedzących w oczach uczniów.

\section{Rekomendacje dotyczące uczenia się i nauczania programowania w szkołach}

Centrum Edukacji Obywatelskiej opublikowało na swojej stronie internetowej Koduj z klasq rekomendacje w sprawie uczenia się programowania i rozwijania kompetencji cyfrowych uczniów. $Z$ dokumentu wynika, że zarówno programowanie, jak i myślenie komputacyjne są umiejętnościami coraz bardziej cenionymi na rynku pracy w Polsce i za granicą. Podkreślona została również bardzo duża rola myślenia komputacyjnego, mediów masowych i elektronicznych w naszym codziennym życiu. Dynamicznie rozwijające się społeczeństwo, życie zawodowe i społeczne oparte na zdolności rozumienia oraz przetwarzania informacji wymuszają na nas opanowanie w przynajmniej podstawowym stopniu umiejętności wykorzystywania technologii komunikacyjnych i poszerzania naszych kompetencji medialnych. W dalszej części rekomendacji podane są wytyczne do sprawnego i skutecznego wprowadzania programowania do szkół. Szczególny nacisk położony został m.in. na stosowanie zróżnicowanych metod nauczania kodowania, opartych jednocześnie na treściach leżących w centrum zainteresowania dzieci i młodzieży (roboty, mikrokomputery, postaci z popularnych gier ¡ kreskówek). Podkreślono również szczególną rolę współpracy między nauczycielami, dzięki której mogą powstać ciekawe projekty interdyscyplinarne, motywujące do pracy większą część społeczności szkolnej lub nawet ją całą. Praca uczniów powinna być twórcza, oparta na aktywnej współpracy. Zamiast opierać się na gotowych rozwiązaniach, należy zachęcać młodych adeptów programowania do kreatywności i otwartego podejścia do problemu. CEO uświadamia też czytelnikom, że edukacja cyfrowa nie powinna opierać się wyłącznie na programowaniu. Animacje, montaż filmów, tworzenie stron internetowych czy grafika komputerowa pomagają uniknąć sytuacji, w której uczniowie zrażają się do informatyki z powodu nadmiaru języków programowania 
do opanowania. Według CEO „idzie o to, by pokazać, że komputery i języki programowania to narzędzia pomagające rozwiązywać problemy z różnych dziedzin życia" (Rekomendacje..., s. 4).

Jeśli chodzi o nauczycieli, to CEO zaleca pozostawienie im dużej autonomii i zapewnienie możliwie jak najbardziej zróżnicowanych materiałów do prowadzenia zajęć. Należy także zachęcać nauczycieli niezwiązanych wcześniej z nauczaniem informatyki lub zajęciami komputerowymi, by wprowadzili przynajmniej elementy programowania do swoich zajęć. Zadaniem dyrektora szkoły jest zapewnienie gronu pedagogicznemu możliwości udziału w szkoleniach zakresu wykorzystywania nowoczesnych technologii na lekcjach różnych przedmiotów. Warto również przyjrzeć się uważniej kwestii nauczania programowania dzieci i młodzieży z różnego rodzaju niepełnosprawnościami, zgodnie z założeniami szkoły włączającej.

\section{Odkodujmy kodowanie}

Nauczyciele na początku poznawania umiejętności kodowania mają wiele wątpliwości co do jego nauczania. Najczęściej obawiają się wejść na tym etapie w rolę "koderów-specjalistów". Pojawiają się również głosy, że współcześni uczniowie są tak obeznani z technologią, że nauczyciel z pokolenia cyfrowych imigrantów może jedynie się ośmieszyć, podejmując z nimi temat kodowania. Warto sobie jednak uświadomić, że zdecydowana większość cyfrowych tubylców doskonale zna się na popularnych grach komputerowych i obsłudze mediów społecznościowych (jednocześnie mając nadal poważne problemy z przestrzeganiem netykiety oraz zachowaniem bezpiecznego dystansu do nowo poznanych w sieci osób), ale w bardzo słabym stopniu radzi sobie z podstawowymi narzędziami i programami, których wykorzystywania uczy się na lekcjach informatyki i zajęciach komputerowych. Obeznanie młodych ludzi z technologią jest zdecydowanie wybiórcze i ściśle powiązane z ich zainteresowaniami. Właśnie te luki w wiedzy uczniów może wypełnić nauczyciel, który wprowadzając do swoich klas kodowanie, połączy to, co młodzież interesuje, z tym, co sam bardzo często wykorzystuje w życiu codziennym. Na przykład wskazywanie drogi, określanie kierunków geograficznych oraz podążanie zgodnie z nimi po narysowanej wcześniej mapie, aby dojść do określonego punktu - wykonując to zadanie, uczeń szuka rozwiązania problemu "Jak osiągnąć wyznaczony cel?". Podobnie kiedy nauczyciel poprosi uczniów o napisanie krok po 
kroku instrukcji, jak ugotować jajko - celem może tu być otrzymanie jajka ugotowanego na miękko lub na twardo, w zależności od polecenia lub preferencji ucznia. I to również jest kodowanie.

Przykłady te są również dowodem na to, że wcale nie potrzebujemy profesjonalnego wyposażenia, aby wprowadzić kodowanie do szkół. Wystarczą kartki, długopisy, sznurki, koraliki, kostki do gry. Aby wprowadzić podstawy systemu binarnego już w pierwszej klasie szkoły podstawowej, wystarczy poprosić uczniów o przyniesienie sznurka lub żyłki i koralików w dwóch różnych kolorach. Na lekcji wyświetlamy tabeli ASCII lub wręczamy dzieciom kopie takiej tabeli i prosimy o zrobienie bransoletek lub naszyjników z zakodowaną w nich za pomocą koralików pierwszą literą imienia. Może to być doskonały prezent np. z okazji Dnia Matki. Wykonując to zadanie, dzieci ćwiczą sprawność manualną, myślenie komputacyjne (w jakiej kolejności nawlec koraliki na sznurek lub żyłkę, aby poprawnie zakodować literę) i przy okazji się bawią, zupełnie nieświadome zachodzącego jednocześnie procesu uczenia się¹.

Nauczanie kodowania można bez problemu połączyć z nauką każdego innego przedmiotu szkolnego. Na językach obcych wprowadzamy zakodowane słówka, które uczniowie muszą odkodować za pomocą wybranego szyfru. Na matematyce wykorzystujemy gry logiczne: Multiplication Squares, znane jako mnożenie kości, magiczne kwadraty, trzy w jednej linii itp. Poza tym możemy zachęcić uczniów do budowania figur geometrycznych o określonych wymiarach za pomocą kolorowych kartek - ćwiczymy dzięki temu umiejętność logicznego myślenia i planowania. Na języku polskim zakodowujemy plan wydarzeń z lektury, wykorzystując prostą tabelkę. Najmłodszych uczniów wprowadzamy w świat kodowania, prosząc ich o ułożenie zgodnie z instrukcją wieży z kolorowych kubeczków lub zachęcając dzieci do odwzorowania ułożonej wcześniej wieży za pomocą kolejnych kubeczków. Pomysły te można mnożyć w nieskończoność, wykorzystując własną wyobraźnię i kreatywność, ale także czerpiąc z pomysłów podsuwanych nam przez uczniów. 


\section{Jak zacząć?}

Każdą naszą aktywność poświęconą kodowaniu powinniśmy rozpocząć od wyznaczenia sobie i uczniom konkretnego celu. Pamiętajmy, że celem nadrzędnym jest $w$ tym przypadku rozwijanie kompetencji cyfrowych, a więc przede wszystkim zbudowanie podstaw, na których nasi uczniowie rozwiną umiejętność programowania, oraz nauczenie ich myślenia w sposób komputacyjny. Pod tym pojęciem kryje się wiele aktywności prowadzących do rozwiązania danego problemu w sposób bardziej efektywny, co mogą nam ułatwić m.in. komputery. Umiejętność myślenia komputacyjnego pomaga podczas wyjaśniania poważnych problemów. Przede wszystkim umożliwia nam dzielenie tych problemów na mniejsze, łatwiejsze do rozwiązania poprzez współpracę osób zaangażowanych $w$ to zadanie. Zmusza nas również do poszukiwania, dostrzegania i wykorzystywania podobieństw między już rozwiązanymi problemami a tymi, z którymi obecnie próbujemy się uporać. Zachęca do stosowania uproszczeń, korzystania z instrukcji, skupienia się nad możliwie najdokładniejszym opisem kroków i zasad, których należy przestrzegać, aby osiągnąć zamierzony cel. W końcu - motywuje do wyszukiwania i poprawiania błędów oraz uczenia się dzięki nim.

Jednak takie wytłumaczenie celu naszej pracy może być mało zrozumiałe dla uczniów, którzy przecież nie oczekują od nauczycieli nudnej teorii. Chcą doświadczać, eksperymentować, próbować. Aby zaangażować uczniów w działania poświęcone rozwijaniu myślenia komputacyjnego, warto spróbować zachęcić ich do rozejrzenia się wokół siebie. Może istnieje jakiś problem dotyczący szkoły lub samych uczniów, który już dawno powinien zostać rozwiązany? Rozpocznijmy pracę od burzy mózgów, zbierzmy pomysły, a następnie zdecydujmy, który z problemów jest najbardziej naglący i jak można go rozwiązać. Zastanówmy się, w czym może nam pomóc nowoczesna technologia. Na koniec pozostaje już tylko utworzyć uczniowskie zespoły problemowe, które podzielą się zadaniami.

W pracy nad problemem warto polegać na kreatywności cyfrowej, którą uczniowie, jako cyfrowi tubylcy, mają już w znacznym stopniu rozwiniętą. Wykorzystajmy ich zainteresowanie tworzeniem gier, budowaniem robotów, projektowaniem prostych programów czy aplikacji lub komponowaniem piosenek. Tych bardziej obeznanych z technologią nie bójmy się postawić w roli ekspertów czy liderów. I przede wszystkim pamiętajmy, że umiejętność współpracy przydaje się nie tylko w programowaniu. 


\section{Programowanie online}

Rozpoczynając włączanie programowania do lekcji, warto w pierwszej kolejności zapoznać się ze wspomnianym już wcześniej programem Scratch. Na podobnej zasadzie działają aplikacje dostępne na stronie Code.org, dodatkowo łącząc naukę programowania z popularnymi i lubianymi przez dzieci oraz młodzież postaciami z popularnych kreskówek, filmów i gier, np. Minecraft czy Kraina Lodu.

Początkującym poleca się narzędzie do tworzenia gier 3D poprzez naukę kodowania. Program nazywa się Kodu Game Lab i jest bardzo przyjazny użytkownikowi. Ma prosty interfejs oraz zawiera poradniki, w których proces tworzenia gry opisany jest krok po kroku. Nie wymaga od użytkownika wiedzy programistycznej ani zaawansowanych języków programowania, takich jak np. C++.

Dla użytkowników systemu Android stworzono LightBota - przyjaznego robota, który uczy użytkowników kodowania. Aplikacja dostępna jest w wielu językach i przeznaczona dla uczniów w wieku od czterech do ośmiu lat oraz dla młodych koderów w wieku od dziewięciu lat. Kolejną aplikacją na smartfon lub tablet jest Catrobat, dzięki któremu można zaprogramować aplikacje i gry, aby następnie w nie zagrać samodzielnie lub udostępnić je innym użytkownikom.

Z kolei młodzieży polecany jest MIT App Inventor - intuicyjne środowisko do nauki programowania. Służy do tworzenia w pełni funkcjonalnych aplikacji na tablet lub telefon, które można wykonać już w 30 minut. MIT App Inventor wspomaga kreatywność i samodzielność uczniów. Przykładem pracy z tą aplikacją może być pomysł sześciu uczennic jednej ze szkół średnich, które zaprojektowały program mający wspierać ich niewidomą koleżankę w poruszaniu się po szkole. W Mołdawii natomiast grupa młodych kobiet stworzyła za pomocą MIT App Inventor aplikację, dzięki której można namierzyć źródła wody pitnej.

Innymi polecanymi programami do wprowadzenia w szkole kodowania są m.in. Run Marco!, Kodable, The Foos. Aplikacje te wykorzystują naturalną ciekawość świata dziecka, jego zainteresowanie nowoczesnymi technologiami oraz motywują do poszerzania umiejętności kodowania poprzez stopniowe zwiększanie poziomu trudności i częste pozytywne komunikaty zwrotne.

Każdy z programów online służących do nauki kodowania warto najpierw samodzielnie przetestować, a następnie wybrać te aplikacje, które nam najbardziej odpowiadają i są najlepiej przystosowane do potrzeb 
naszych uczniów. Aby ułatwić sobie pracę, można za pomocą narzędzia Symbaloo stworzyć tzw. nauczycielską narzędziownię, w której znajdą się odnośniki do wszystkich przydatnych w nauce programowania stron, narzędzi, programów i aplikacji. Taką narzędziownię można również udostępnić uczniom, zachęcając ich tym samym do samodzielnego odkrywania i poszerzania wiedzy oraz rozwijania umiejętności kodowania.

\section{Kodowanie offline}

Pomimo znacznego postępu technologicznego oraz wielu programów, które wspierają szkoły w zdobywaniu funduszy na nowoczesny sprzęt, w wielu polskich placówkach nadal brakuje wyposażenia, które ułatwiłoby uczniom naukę programowania. Również organa prowadzące rzadko decydują się na doposażenie szkół w maty do kodowania, roboty edukacyjne czy specjalne zestawy klocków, uznając programowanie za kolejny trend, który przeminie. Nauczyciele XXI w. bez problemu radzą sobie jednak w takich sytuacjach. Przykładem są wspomniane już wyżej gry logiczne i kolorowe kubeczki.

Do przygotowania lekcji poświęconych nauce programowania nauczyciel może wykorzystać również stronę CS Unplugged, zawierającą dużą liczbę darmowych materiałów z rozmaitymi zadaniami, w których wykorzystuje się karty, sznurek czy kredki. Na portalu znaleźć można również przykłady gier ruchowych, w których ćwiczenie logicznego myślenia czy umiejętności współpracy jest nadrzędnym celem. Materiały zawarte na tej stronie są odpowiednie dla wszystkich grup wiekowych, a ich wykorzystanie zależy wyłącznie od inwencji twórczej nauczyciela.

Fani gier planszowych z przyjemnością odkryją Cody Roby - uczącą podstaw kodowania grę, którą tworzy się samodzielnie z przygotowanych materiałów. Mali koderzy dużo chętniej korzystają z narzędzia, które sami stworzyli, czują również znacznie większą odpowiedzialność za efekt końcowy pracy swojej i grupy.

W programowaniu offline znakomicie sprawdzają się również różnego rodzaju szyfry, za których pomocą kodujemy i odkodowujemy wiadomości. Kod binarny, szachownica Polibiusza, AtBash czy szyfr Cezara są nieskomplikowane, a zapisywanie za ich pomocą "tajnych" informacji sprawia wiele radości. Uczniowie udzielający się aktywnie w harcerstwie z pewnością chętnie wprowadzą swoich kolegów w świat szyfrów skautowskich, takich jak Gaderypoluki, Czekoladka czy szyfr ułamkowy. Warto również zachęcić młodzież do samodzielnego tworzenia szyfrów, 
które później zostaną wykorzystane na lekcji. Nauczyciele, którzy już rozpoczęli wprowadzanie kodowania do szkoły, często przyznają się do wręczania dzieciom zakodowanych celów lekcji (które powinny, zgodnie z zasadami oceniania kształtującego, być przekazywane uczniom na początku każdej lekcji). Odkodowywanie słów i wyrażeń określających to, czego się na danych zajęciach nauczą, pobudza ciekawość uczniów i pomaga im skupić się na temacie lekcji.

\section{Kampania „Programowanie z eTwinning”}

1 września 2016 r. Ministerstwo Edukacji Narodowej uruchomiło w szkołach Pilotaż Programowania. Jego realizacja została wsparta przez program eTwinning, który 1 października tego samego roku rozpoczął kampanię „Programowanie z eTwinning".

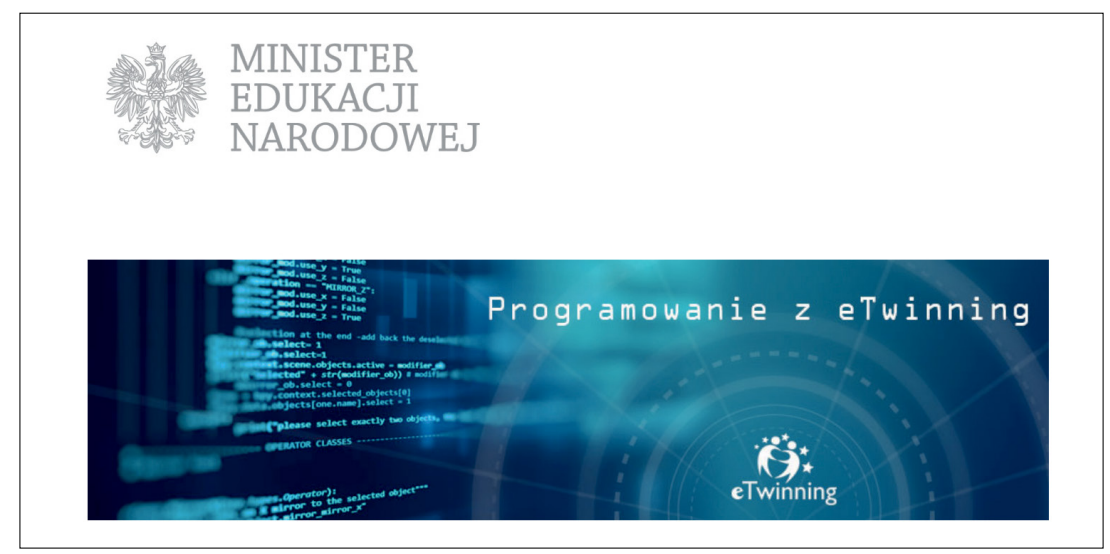

Źródło: www.etwinning.pl/programowanie-z-etwinning/.

W ramach kampanii w całej Polsce zorganizowano seminaria szkoleniowo-kontaktowe, wprowadzono również specjalną bezpłatną ofertę szkoleniową online, poświęconą narzędziom szczególnie przydatnym podczas pracy z uczniami z różnych grup wiekowych. Dodatkowo, w sekcji Inspiracje na portalu eTwinning Polska, znalazły się szczegółowe opisy przeprowadzonych projektów, w których wykorzystano programowanie oraz scenariusze lekcji, jakie zainteresowani nauczyciele mogą wykorzystywać na swoich zajęciach. Dla wszystkich, którzy zdecydowali się realizować projekt poświęcony programowaniu, przygotowano specjalną kategorię "Programowanie z eTwinning" 
w ogólnopolskim konkursie „Nasz projekt eTwinning 2017". Celem było nagrodzenie najbardziej kreatywnych, innowacyjnych projektów rozwijających umiejętności związane z kodowaniem. Honorowy patronat nad kampanią objął minister edukacji narodowej.

\section{Podsumowanie}

Programowanie, dotychczas zarezerwowane dla programistów i koderów, przestało być dziedziną niszową. Wzrost świadomości przydatnych w codziennym życiu umiejętności, jakie można dzięki niemu wyćwiczyć, sprawia, że nie powinno się go traktować wyłącznie jako chwilowego trendu. Zadaniem nauczycieli XXI w., postępowych pedagogów idących z duchem czasu, jest pogodzenie się z tym, że cyfrowi tubylcy (uczniowie) nie odwrócą się nagle od technologii ani nie wrócą do czasów książki, tablicy i kredy. Świat się zmienia, a zadaniem nauczycieli jest jak najlepiej przygotować dzieci i młodzież do dorosłego życia, w którym nowoczesne technologie będą odgrywać coraz większą rolę. 


\section{Bibliografia}

$\rightarrow$ Hojnacki, L. (2006), Pokolenie m-learningu - nowe wyzwanie dla szkoły [w:] "E-mentor", nr 1(13), s. 23-27.

$\rightarrow$ Prensky, M. (2001), Digital Natives, Digital Immigrants [w:] „On the Horizon”, Vol. 9, No. 5. 


\section{Netografia}

$\rightarrow$ Dzieci sq dobre... w programowaniu - wywiad z prof. Maciejem Sysło (2016), INNPoland.pl, innpoland.pl/124517,dzieci-sa-dobre-w-programowaniu-wywiad-z-prof-maciejem-syslo, dostęp 30.04.2018.

$\rightarrow$ Programowanie z eTwinning (2016), etwinning.pl, www.etwinning.pl/programowanie-z-etwinning, dostęp 30.04.2018.

$\rightarrow$ Rekomendacje w sprawie uczenia się programowania i rozwijania kompetencji cyfrowych uczniów, kodujzklasa.ceo.org.pl/sites/kodujzklasa.ceo.org.pl/files/ rekomendacje_w_sprawie_programowania.pdf, dostęp 20.06.2018. 



\section{Nowoczesne technologie \\ w nauczaniu przedmiotów ścisłych}

Sławomir Wronka

Na rynku możemy zaobserwować gwałtowny rozwój technologii, w szczególności urządzeń służących do komunikacji. Narzędzia te mogą stać się pomocne także dla nauczycieli przedmiotów ścisłych. Artykuł stanowi przegląd głównych rodzajów dostępnych technologii i urządzeń. Przedstawiono w nim również warunki ich stosowania w celu efektywnego wsparcia procesu edukacyjnego. 


\section{Modern technologies in teaching science}

Sławomir Wronka

On the market one can observe a rapid development of ICT technology, in particular different devices focused on communication. Such tools can be helpful for teachers even for the youngest students. The article reviews main types of available technologies and devices, as well as discusses the conditions for their effective use in order to effectively support the educational process.

\section{Keywords:}

new technologies in school 


\section{Wstęp}

Gwałtowny rozwój technologii stawia nowe wyzwanie przed nauczycielami: Jak efektywnie korzystać z dostępnych narzędzi, nie poprzestając na efektownej warstwie powierzchniowej - zachwycie nad grafiką, interakcją poprzez ekrany dotykowe itp. Uczniowie mają coraz lepsze smartfony, często wyposażone w szybkie procesory, duże wyświetlacze oraz nielimitowany dostęp do Internetu. Czy możliwe jest wykorzystanie sprzętu należącego do uczniów do nauczania przedmiotu? Jakie narzędzia zaproponować? Jak nad tym zapanować? Jak nauczyciel może do tego zachęcić, wiedząc, że konkuruje z grami, mediami społecznościowymi i innymi zasobami Internetu?

Niewątpliwie otwierają się duże możliwości dla zaangażowanych nauczycieli, którzy mogą przejmować inicjatywę, generować nowe pomysły, traktować nowoczesne technologie jako jeszcze jedną drogę dotarcia do uczniów czy nawiązania z nimi szczególnej relacji płynącej z osobistej pasji. Jednocześnie szybkie zmiany, jakie zachodzą na rynku nowych technologii, mogą wydawać się dużym zagrożeniem dla nauczycieli bardziej zachowawczych, którzy lubią być dobrze przygotowani do zajęć, nie lubią zaś improwizacji ani wkraczania w obszary, w których uczniowie są lub potencjalnie mogą być sprawniejsi. Nie należy także zapominać, że szybkie pisanie na małej klawiaturze, sprawniejsze obsługiwanie ekranu dotykowego i różnorodnych aplikacji niekoniecznie przekładają się na dobrą znajomość zjawisk fizycznych czy umiejętność przygotowania eksperymentu, korzystając z dostępnych narzędzi i przyrządów rzeczywistych lub wirtualnych. Nauczyciel w dalszym ciągu pozostaje mentorem, przewodnikiem, niezastąpionym wsparciem, dzięki któremu wiedza zostaje wyłożona w logiczny sposób i zrozumiana przez uczniów. Ważnym i trudnym zadaniem nauczyciela jest zaplanowanie wykorzystania nowoczesnych narzędzi, tak aby zapewnić ciągłość, logikę i spójność przekazu. Uczeń powinien być prowadzony za rękę zgodnie z zaplanowanym przebiegiem lekcji. Wygodnie jest, gdy zastosowanie indywidualnych komputerów może być kontrolowane przez nauczyciela np. poprzez zdalne uruchamianie i blokowanie dostępu do danej aplikacji, Internetu lub ogólnie komputera (notebooka, laptopa).

Właściwym rozpoczęciem używania nowoczesnych technologii na lekcji będzie nauka o zasadach korzystania z Internetu. Ten punkt jest ważny z powodu bezpieczeństwa sprzętu (możliwość zawirusowania, blokady, wykradzenia lub utraty danych), bezpieczeństwa osobistego 
uczniów (zagrożenie przygodnym kontaktem w sieci, który może mieć kontynuację w rzeczywistości) i szansy wyrobienia dobrych nawyków na przyszłość, takich jak nieudostępnianie haseł osobom postronnym, częsta zmiana hasła, stosowanie haseł trudnych do odgadnięcia i zasada bezpiecznej bankowości internetowej.

Kolejnym krokiem jest właściwe przygotowanie przed każdą lekcją jej konspektu lub scenariusza. Przede wszystkim technologia ma być pomocna w przekazaniu treści uczniom, nie jest zaś celem samym w sobie ani narzędziem mającym jedynie uatrakcyjnić zajęcia. Czasem te same treści można przekazać lepiej, stosując tradycyjną metodę podawczą, kontakt z rzeczywistym zjawiskiem lub obiektem, wykonanie eksperymentu.

Wiele wzorów dobrej praktyki przygotowania lekcji można znaleźć w Internecie. Przykładem może być pozycja Ostrowskiej i Sterny: „Najpierw zaplanuj dobrą lekcję, a potem zastanów się nad użyciem narzędzi TIK. Z naszych doświadczeń wynika, że nauczyciele czasami »zachłystują się « nowymi technologiami i do pomysłu TIK »dorabiają lekcję. W rozdziale poświęconym najczęstszym błędom w tworzeniu konspektów lekcji podamy kilka przykładów chybionych »zachłyśnięć«. Trudno się dziwić takim praktykom wobec wszechobecnego propagowania technologii informacyjno-komunikacyjnych w różnych dziedzinach naszego życia. Warto pamiętać, że celem nauczyciela/nauczycielki jest efektywne i skuteczne uczenie się uczniów, a nie pokazywanie nowinek" (Ostrowska, Sterna, 2015).

Nauczyciel musi rozważyć, czy zastosowanie komputerów lub innych urządzeń umożliwi korzystniejsze osiągnięcie zamierzonego celu edukacyjnego, czy będzie zbędnym rozproszeniem i lepiej jest skorzystać z tradycyjnych metod. „Trzeba wnikliwie przeanalizować, czy (TIK - dop. aut.) nie jest stosowana tylko dla wymogu »nowoczesności«, zastępując tradycyjne narzędzia, które mogłyby być skuteczniejsze. Po czym poznać, że użycie TIK na danej lekcji zwiększyło szanse osiągnięcia celów przez uczniów? Odpowiedzi na to pytanie można udzielić, gdy możliwe jest porównanie efektów uczenia się z wykorzystaniem TIK z efektami uczenia się bez użycia TIK. Proponujemy przyjąć następujące kryteria oceny:

Uczniowie:

$\rightarrow$ byli skoncentrowani na celach uczenia się, a nie na obsłudze narzędzi TIK, 
$\rightarrow$ szybciej osiągnęli cele uczenia się niż wtedy, gdy nie używali TIK,

$\rightarrow$ więcej się nauczyli (pod względem wiedzy, świadomości i umiejętności),

$\rightarrow$ byli mocniej zaangażowani w uczenie się oraz bardziej aktywni intelektualnie,

$\rightarrow$ potrzebowali mniej czasu na opanowanie tych samych umiejętności niż przy zastosowaniu tradycyjnych metod nauczania" (tamże).

Dopiero po właściwym przygotowaniu scenariusza lekcji i precyzyjnym określeniu celów, które nauczyciel pragnie osiągnąć, można przystąpić do właściwego przeprowadzenia zajęć. Istotne jest również właściwe rozplanowanie czasu i podsumowanie pracy, tak aby również ten ostatni punkt mógł odbyć się w skupieniu i porządku.

Warta polecenia jest również publikacja Efektywne wykorzystanie nowych technologii na lekcjach. Przedstawione są w niej kategorie strategii nauczania, które wspomagane są przez konkretne narzędzia TIK (takie jak edytory tekstu, aplikacje multimedialne, oprogramowanie do przeprowadzania burzy mózgów, media edukacyjne, oprogramowanie do komunikacji i współpracy). Wśród tych kategorii wyróżniamy:

$\rightarrow$ wyznaczanie celów i przekazywanie informacji zwrotnej,

$\rightarrow$ motywacja do podejmowania wysiłku i nagradzanie osiągnięć,

$\rightarrow$ uczenie się oparte na współpracy,

$\rightarrow$ wskazówki, pytania i informacje wstępne,

$\rightarrow$ przekazywanie informacji w formie pozawerbalnej,

$\rightarrow$ podsumowywanie materiału i sporządzanie notatek,

$\rightarrow$ zadania domowe i ćwiczenia,

$\rightarrow$ rozpoznawanie podobieństw i różnic,

$\rightarrow$ stawianie i sprawdzanie hipotez (Pitler, Hubbel i Kuhn, 2015).

\section{Technologie i urządzenia spotykane w szkole}

Obecność komputera w szkole jest dzisiaj już czymś oczywistym. Zamiast lub oprócz komputerów stacjonarnych coraz częściej pojawiają się laptopy i tablety, gdyż są mniejsze, lżejsze, a ekran dotykowy jest bardziej intuicyjny niż tradycyjna myszka.

W klasycznym modelu lekcji (głównie podawczym) dużą rolę odgrywa rzutnik, mobilny monitor lub odbiornik TV z opcją 3D o odpowiednio dużym ekranie. W młodszych klasach sprawdzi się rzutnik wyświetlający obraz na podłodze (tzw. magiczny dywan). Kiedy część lub całość pre- 
zentowanych treści pobierana jest bezpośrednio z Internetu, ważne jest szybkie i pewne łącze. W przeciwnym razie długie oczekiwanie na załadowanie filmu czy prezentacji może całkowicie zakłócić tok zajęć. Jeżeli to możliwe, materiały powinny być pobrane wcześniej i odtwarzane z lokalnego dysku. Oszczędzi to nauczycielowi niepotrzebnego stresu.

Komputery wspomagane są przez kamery, aparaty cyfrowe, czytniki podczerwien czy mikroskopy. Obok klasycznej drukarki coraz częściej można spotkać drukarki 3D, drukujące warstwowo obiekty zarówno z tworzyw sztucznych, jak i metali. Urządzenia te są atrakcyjne dla uczniów, choć ich zastosowanie dominuje na zajęciach pozalekcyjnych lub w szkołach ponadpodstawowych kształcących w kierunkach technicznych.

Kolejnym urządzeniem spotykanym w szkole są tablice interaktywne. Przykładowy ich model jest połączeniem tablicy magnetycznej, ekranu projekcyjnego, warstwy interaktywnej i systemu dźwięku. Możliwe jest zdalne przekazywanie informacji, np. poprzez podłączenie systemu wideokonferencyjnego czy rozesłanie wytworzonych materiałów pocztą elektroniczną. Tablice współpracują ze specjalnymi piórami-wskaźnikami lub można po nich pisać palcem (w zależności od rodzaju tablicy). Często wyposażone są w oprogramowanie do analizy gestów, co wspomaga np. przełączanie slajdów w prezentacji. W wyświetlanym filmie czy obrazie można dokonywać zmian, podkreśleń, dopisków bezpośrednio na ekranie, z zapisaniem do pliku osiągniętych rezultatów. Z tablicy może korzystać kilka osób jednocześnie. Współczesne oprogramowanie w standardzie zapewnia m.in. możliwość śledzenia i nagrywania wykonywanych czynności, funkcję rozpoznawania narysowanych odręcznie obiektów (np. figur geometrycznych na lekcji matematyki), rozpoznawanie pisma i zamianę odręcznego na tekst edytowalny. Na lekcjach matematyki i fizyki pomocne mogą być wirtualne narzędzia, takie jak kątomierz, cyrkiel, dopasowywanie funkcji do narysowanego przebiegu.

W szkołach coraz częściej można też korzystać ze specjalnych okularów przenoszących nas w świat rozszerzonej lub całkowicie wirtualnej rzeczywistości. Używają ich już nie tylko zapaleni miłośnicy gier komputerowych. Najczęściej w celach edukacyjnych używa się ich na lekcji historii, np. do zwiedzania wirtualnych budowli i zabytków, ale mogą też znaleźć zastosowanie na zajęciach z przyrody, biologii, matematyki czy fizyki. Umożliwiają bowiem zanurzenie się w trójwymiarowym świecie organizmów, figur i konstrukcji, których elementy można nie 
tylko opatrywać rozwijanymi etykietami opisowymi, lecz także odsuwać, by zajrzeć pod spód, czy zmierzyć. $Z$ uwagi na silne oddziaływanie na zmysły okulary te mogą niezwykle uatrakcyjnić zajęcia, co zwiększa szanse nauczyciela na zainteresowanie przedmiotem. Jednocześnie rośnie ilość zapamiętanych informacji poprzez oddziaływanie multisensoryczne. Należy jednak pamiętać w przypadku tego urządzenia, że ma być ono przydatne w przekazywaniu treści, a nie być tylko atrakcyjne dla użytkowników.

Naturalnym rozwinięciem obecności użytkownika w wirtualnym świecie są specjalne rękawice imitujące dotyk. Obserwacja obiektów w trójwymiarowym otoczeniu zachęca np. do ich podniesienia. Wyzwaniem dla inżynierów jest stworzenie urządzeń, dzięki którym poczujemy ciężar, strukturę powierzchni dotykanych materiałów, a także ich temperaturę. Istniejące prototypy umożliwiają np. wirtualną grę na fortepianie, a obserwowane trendy pozwalają przewidywać intensywny rozwój kolejnych generacji takich rękawic, a nawet całych kombinezonów oddziałujących na zmysł dotyku.

Warto zauważyć również intensywny rozwój mikroprojektorów oraz projektorów trójwymiarowych/holograficznych. Zapowiadane na rok szkolny 2018/2019 premiery nowych urządzeń obejmują m.in. miniaturowe projektory umieszczone w zegarku, które umożliwiają wyświetlanie ekranu telefonu bezpośrednio na przegubie ręki i obsługę aplikacji ruchem palca. Z kolei projektory trójwymiarowe przeniosą nas do rzeczywistości znanej dotychczas wyłącznie z filmów science fiction. $W$ trakcie rozmowy generowany będzie trójwymiarowy obraz naszego rozmówcy tuż przez nami - w powietrzu. Podobnie będzie z oglądanym filmem czy aplikacją. Obserwacja obrazu 3D nie będzie wymagać przy tym żadnego dodatkowego wyposażenia, np. okularów.

Urządzeniami obecnymi w szkole są również prywatne tablety i smartfony uczniów. W wielu szkołach ich używanie w czasie lekcji jest zabronione. Jednak powszechność nowoczesnych telefonów może skłaniać do zmiany podejścia nauczycieli w kierunku wykorzystania tych urządzeń w celach edukacyjnych. Dzięki zastosowaniu ciekawych aplikacji może się okazać, że uczeń niejako zabierze szkołę również do domu, prowadząc np. obserwacje, pomiary, eksperymenty. W ten sposób możemy nauczyć uczniów naukowego podejścia do pracy, pokazać im elementy analizy błędów i statystyki, kształtując w nich systematyczność i wytrwałość. 


\section{Specyfika nauczania przedmiotów ścisłych}

Nowoczesne narzędzia mogą być wykorzystywane w najróżniejszy sposób. Dzięki temu tłumione czasami przez podstawę programową inwencja i kreatywność nauczycieli mogą być wykorzystane. W przedmiotach ścisłych, takich jak matematyka i fizyka, większe zastosowanie będą miały narzędzia obliczeniowe i symulacyjne, w biologii i chemii - wizualizacyjne i demonstracyjne, choć nie zawsze. Przykładowo w realizacji tematu o bryłach na matematyce może pomóc wejście do wirtualnego trójwymiarowego świata, dzięki któremu uczniowie mogą łatwiej zrozumieć takie pojęcia jak "podstawa" i „wysokość", a także poznać sposoby rysowania brył w rzutach. I odwrotnie - algorytmy genetyczne i sieci neuronowe mogą pojawić się na lekcji biologii.

Typowe zastosowania urządzeń elektronicznych w procesie dydaktycznym obejmują:

$\rightarrow$ uatrakcyjnienie metody podawczej poprzez wykorzystanie przez nauczyciela prezentacji multimedialnych, filmów, animacji, zdjęć itp.,

$\rightarrow$ samodzielne wyszukiwanie informacji przez uczniów, np. w naukowej bazie danych,

$\rightarrow$ quizy i ćwiczenia utrwalające zdobytą wiedzę,

$\rightarrow$ wykorzystanie narzędzi komunikacyjnych do wykonywania wspólnych ćwiczeń i zadań z inną szkołą, np. w programach eTwinning,

$\rightarrow$ wykonanie wirtualnego eksperymentu (fizyka lub chemia), który w normalnych warunkach szkolnych nie jest możliwy do przeprowadzenia lub byłby zbyt czasochłonny,

$\rightarrow$ pracę wspólną grupową, podczas której każdy wykonuje fragment całego zadania (np. zwiększenie ilości dostępnych danych poprzez zrównoleglenie obliczeń, co skutkuje przykładowo zmniejszeniem błędu wyznaczanej liczby $\pi$ itd.),

$\rightarrow$ poznawanie otaczającego świata, np. podróż w specjalnych okularach przez Układ Słoneczny, wnętrze organizmu, obserwacja powstawania związków chemicznych,

$\rightarrow$ samodzielne tworzenie programów ukierunkowanych tematycznie (po uprzednich zajęciach z programowania),

$\rightarrow$ przyspieszenie dojścia do konkluzji w danym temacie dzięki zastosowaniu tablicy interaktywnej, 
$\rightarrow$ samodzielne przygotowywanie pokazów, eksperymentów, prezentacji przez uczniów.

Powyższa lista nie wyczerpuje tematu, ponieważ - jak już podkreślono - szeroka gama urządzeń otwiera duże możliwości, a baza programów i dostępnych aplikacji nieustannie się rozwija.

\section{Technologia - szansa i zagrożenie}

Pomimo dobrego przygotowania się i zaplanowania zajęć wykorzystanie urządzeń elektronicznych zawsze wiąże się z pewnym ryzykiem. Każdy sprzęt może się zepsuć, dlatego warto mieć scenariusz awaryjny. A nawet jeśli wszystko działa poprawnie od strony technicznej, to jest kilka pułapek, o których warto pamiętać:

$\rightarrow$ Uczniowie ukradkiem uruchamiają inne programy lub przeglądają Internet.

Od strony merytorycznej pomóc tu może precyzyjne przygotowanie poleceń, ich odpowiednia liczba i unikanie zadań ogólnych typu teraz poćwiczcie. Pomocny może się także okazać podział zadań między poszczególnych uczniów z określeniem konkretnego czasu na wykonanie polecenia. Natomiast od strony technicznej warto zadbać o takie przygotowanie sali/pracowni, aby nauczyciel mógł w każdej chwili zdalnie przejąć kontrolę nad komputerem danego ucznia, wyłączyć dostęp do Internetu czy konkretnych programów lub aplikacji. Takie rozwiązanie będzie trudniejsze w przypadku korzystania z tabletów lub smartfonów należących do uczniów.

$\rightarrow$ Różne poziomy zaawansowania grupy.

W przypadku korzystania z urządzeń komputerowych jako pomocy na lekcjach innych niż informatyka problem ten może zostać zminimalizowany dzięki precyzyjnemu przygotowaniu poleceń dla uczniów. Celem pracy nie jest sprawna obsługa sprzętu, ale wykonanie ćwiczenia przede wszystkim od strony treści. Pomocne będzie rozbicie zadań na proste polecenia i przygotowanie gotowych odnośników do kliknięcia zamiast wpisywania adresu internetowego.

$\rightarrow$ Uczeń lub grupka uczniów gubią się i rozpraszają całą klasę.

W przypadku korzystania z Internetu pomocne może być przygotowanie na lekcję zestawu odnośników, tak aby uczniowie nie musieli 
przepisywać adresów stron WWW. Można również zdefiniować bardziej precyzyjne kroki, a unikać poleceń ogólnych, a także korzystać z bardziej intuicyjnych programów.

$\rightarrow$ Zawieszanie się połączenia internetowego.

Rozwiązaniem jest albo pobranie wszystkich materiałów wcześniej i odtwarzanie ich z dysku lokalnego, albo scenariusz alternatywny lekcji.

$\rightarrow$ Niektórzy uczniowie sprawniej od nauczycieli obsługują urządzenia TIK, więc nauczyciele obawiają się, że mogą się ośmieszyć.

Należy przede wszystkim pamiętać, że taka sytuacja nie jest ujmą dla nauczyciela, podważającą jego wiedzę i doświadczenie. Pewna doza dystansu i rozwiązanie problemu humorem pomogą z pewnością wybrnąć z trudnej sytuacji. Nauczyciel nie musi być mistrzem szybkiego klikania, może nawet prosić uczniów o pomoc techniczną. Autorytet budowany jest dzięki odczuwalnym korzyściom, jakie przynosi korzystanie z nowoczesnych technologii na danej lekcji. Sprawność techniczno-manualna będzie zachętą dla uczniów, by częściej wykorzystywać swoje umiejętności na lekcji lub w domu.

\section{Przykładowe źródła}

W zasobach internetowych znajduje się dużo zarówno płatnych, jak i darmowych narzędzi do wykorzystania na lekcjach. Poniżej kilka przykładowych odnośników:

$\rightarrow$ www.krainanauki.pl

$\rightarrow$ www.e-doswiadczenia.mif.pg.gda.pl

$\rightarrow$ www.chemia.pk.edu.pl

$\rightarrow$ www.profesor-why.pl

$\rightarrow$ www.laboratoria.wsl.com.pl

$\rightarrow$ www.edukator.pl

$\rightarrow$ www.ilf.fizyka.pw.edu.pl

$\rightarrow$ www.dla-dzieci.com.pl

$\rightarrow$ www.scholaris.pl/cms

$\rightarrow$ www.profesor.pl/index.php

\section{Podsumowanie}

Nowoczesne technologie wkraczają do naszego życia, przekształcając bezpowrotnie obraz świata. Czas od wynalezienia danej technologii 
czy urządzeń do ich wprowadzenia nieustannie się skraca, powodując coraz szybsze zmiany w otoczeniu. Upowszechnienie elektryczności zajęło kilkadziesiąt lat, komputerów osobistych - około 10, a telefonii komórkowej - tylko kilka. Zmiany te są wyzwaniem, ale także szansą dla nauczycieli, którzy z powodzeniem mogą stosować pojawiające się urządzenia $i$ technologie $w$ procesie edukacji. Chociaż wymaga to nieustannego dostosowywania się, nauki nowych narzędzi, zmiany ustalonych już scenariuszy sposobu przekazywania treści, mogą one stać się drogą do efektywniejszej pracy, pełnej satysfakcji z osiągniętych wyników.

Żadne urządzenie ani żadna aplikacja nie zastąpią jednak doświadczonego pedagoga, który musi zaplanować, jak poprowadzić ucznia przez meandry nowego tematu, tak aby uzyskać efekt pełnego zrozumienia treści. 


\section{Netografia}

$\rightarrow$ Ostrowska, M., Sterna, D. (2015), Technologie informacyjno-komunikacyjne na lekcjach. Przykładowe konspekty i polecane praktyki, Warszawa: Centrum Edukacji Obywatelskiej, <glowna.ceo.org.pl/sites/default/files/tik_na_lekcjach_2015_06_02.pdf>, dostęp 22.06.2018.

$\rightarrow$ Pitler, H., Hubbel, E.R., Kuhn M., Efektywne wykorzystanie nowych technologii na lekcjach, Warszawa: Ośrodek Rozwoju Edukacji w Warszawie, Centrum Edukacji Obywatelskiej, <glowna.ceo.org.pl/sites/default/files/pitler-hubbel-kuhn_ efektywne-wykorzystanie-nowych-technologii_0.pdf >, dostęp 22.06.2018. 


\section{Jak zetrzeć kurz nieaktualności $\mathrm{z}$ dawnych tekstów kultury? \\ Dziedzictwo kulturowe w dobie nowoczesnych mediów na przykładzie Mendla Gdańskiego Marii Konopnickiej}

Rafał Mazur

Określenie dziedzictwo kulturowe często kojarzy się z czymś starym, archaicznym, a jednak stanowiącym wielką wartość. Jak sprawić, aby taki tekst kultury ciągle oddziaływał na odbiorców, mimo że wydaje się już nieaktualny? Artykuł na przykładzie dzieła Marii Konopnickiej Mendel Gdański przedstawia wiele pomysłów umiejętnego wykorzystania nowoczesnych mediów i technologii, tak aby forma nie przysłoniła treści, lecz podkreśliła jej uniwersalizm i ponadczasowość.

\section{_ Słowa kluczowe: \\ dziedzictwo kulturowe \\ tekst kultury \\ Żydzi \\ subkultury \\ dyskusja \\ słowo \\ nowoczesne media \\ nowe technologie}




\section{How to wipe off the obsolete dust from ancient cultural texts? Cultural heritage in the era of modern media, based on the example of Mendel Gdaniski by Maria Konopnicka}

Rafał Mazur

The term: cultural heritage is often associated with something old and archaic but of great value for a given group. What can be done to keep a cultural text from the past still able to influence the recipients, even though it seems to be outdated? The article, based on the example of Maria Konopnicka's work Mendel Gdański, presents a number of ideas of skillful usage of modern media and technology, so that the form does not obscure the content, but emphasizes its universalism and timelessness.

\section{Keywords:}

cultural heritage

cultural text

Jews

subcultures

discussion

word

modern media

new technologies 


\section{Wprowadzenie}

Pojęcie dziedzictwo kulturowe w ostatnich czasach coraz częściej kojarzy się z czymś, co zostało przez kogoś uznane za ważne i z tego powodu jest znane oraz szanowane. Może być to zabytek, który wpisano na listę UNESCO, dzieło malarskie, które osiąga zawrotne ceny na aukcjach, lub na stałe zapisany w historii utwór muzyczny. I choć lista przykładów dziedzictwa kulturowego jest coraz dłuższa, one same wydają się coraz bardziej oddalone od ludzi. Dziedzictwo kulturowe jest bowiem obce i niedostępne dla zwykłego człowieka, niebędącego specjalistą w danej dziedzinie. Oczywiście nie mam tutaj na myśli niedostępności fizycznej, gdyż każdy może w dowolnym momencie zobaczyć zabytek czy poznać książkę. Mam na myśli raczej dostępność emocjonalną. Wydaje się bowiem, że przykłady dziedzictwa kulturowego są za szybą pozwalającą zobaczyć obiekt, ale jednocześnie oddzielającą od prawdziwego poznania. Przypominają lektury szkolne omawiane często nie dlatego, że same w sobie stanowią wielką wartość, ale przede wszystkim z powodu umiejscowienia ich na liście pozycji, których znajomość jest niezbędna podczas egzaminu. Obecnie dochodzi nawet do paradoksu, który polega na tym, że lepiej dla książki, by nie znalazła się w wykazie lektur, ponieważ wtedy od razu zaczyna kojarzyć się z kartkówkami, ze sprawdzianami, z egzaminami, czyli wszystkim tym, co z przyjemnością ma niewiele wspólnego.

Teksty dziedzictwa kulturowego wydają się przykryte warstwą kurzu, który należy natychmiast zmieść, aby mogły na nowo zacząć oddziaływać na odbiorców, wpływać na nich i prowokować do myślenia. Cóż bowiem po pięknych zabytkach, wybitnych utworach literackich, zapierających dech w piersiach malowidłach, jeśli są one oddalone od odbiorców i zamiast autentycznie poruszać, mają jedynie przyklejoną naklejkę z napisem dzieło wybitne, zachwycajqce?

Nowe media i nowe techniki nauczania muszą być zatem świeżym powiewem powietrza, który delikatnie zdmuchnie kurz przeszłości, nie niszcząc przy tym unikalności ani oryginalności dzieła. Cyfryzacja i digitalizacja niosą za sobą, oprócz oczywiście szerokiego spektrum możliwości uwspółcześnienia danego tekstu kultury, również ryzyko zdawkowego i powierzchownego potraktowania samego dzieła. Korzystając z nowych technologii, można często, kosztem treści, za bardzo skupić się na treści wizualnej. Oczywiście nie można zanegować tego, że dzięki procesowi technologicznemu dostęp do kultury stał 
się bardziej egalitarny. Czy dzięki temu pojawiła się jednak możliwość głębszego przeżywania dzieła? Czy posiadanie kubka lub zakładki do książki z wizerunkiem obrazu Pocałunek Gustava Klimta uczyniło obraz bardziej czytelnym?

Jak więc sprawić, by przykłady dziedzictwa kulturowego wyszły z muzeum, izb pamięci oraz gablot i na nowo zaczęły oddziaływać na odbiorców? Co zrobić, by dzieła o ważkiej treści stały się na powrót aktualne i atrakcyjne, a jednocześnie nie zagubiły ducha epoki, w której powstały. I wreszcie, jak umiejętnie wykorzystać nowe media i technologie, by pozwolić tekstom kultury na nowo zaistnieć w świadomości odbiorcy?

Aby odpowiedzieć na powyższe pytania, warto najpierw się zastanowić, czym jest dziedzictwo kulturowe. Jan Pruszyński w książce Dziedzictwo kulturowe. Jego straty i ochrona prawna określa je następująco: "Dziedzictwo kulturowe to zasób rzeczy nieruchomych i ruchomych wraz ze związanymi z nim wartościami duchowymi, zjawiskami historycznymi i obyczajowymi uznawanymi za podstawę ochrony prawnej dla dobra konkretnego społeczeństwa i jego rozwoju oraz dla przekazania ich następnym pokoleniom, $z$ uwagi na zrozumiałe i akceptowane wartości historyczne, patriotyczne, religijne, naukowe i artystyczne, mające znaczenie dla tożsamości i ciągłości rozwoju politycznego, społecznego i kulturalnego, dowodzenia prawd i upamiętniania wydarzeń historycznych, kultywowania poczucia piękna i wspólnoty cywilizacyjnej" (Pruszyński, 2001, s. 49-50).

W powyższej definicji nie tyle zwrócono uwagę na samo istnienie danego elementu, ile podkreślono relację, jaka powinna zaistnieć między tekstem kultury a jego odbiorcą. Bardzo ważne jest, aby każde dzieło niosło za sobą pewien przekaz wartości będących ciągle aktualnymi mimo upływu lat czy nawet wieków. Dziedzictwo kulturowe to bowiem nie jednorazowo wytworzony produkt, który po spełnieniu swojej misji może być umieszczony w izbie pamięci. Takie dzieło ma nieustannie wpływać na odbiorców, ciągle zmuszać do myślenia, inspirować do poszukiwań nowych dróg i rozwiązań (Pruszyński, 2001).

Pruszyński w swojej książce wymienia różne typy dziedzictwa kulturowego. Pierwszy z nich to dziedzictwo materialne, które może być zarówno ruchome, jak i nieruchome. „Podział zabytków na ruchome i nieruchome wynika $z$ terminologii cywilnoprawnej (mobilia, immobilia). Nieruchomości - zabytki nieruchome, to obiekty trwale związane 
z miejscem (situm). Zabytki ruchome - dzieła sztuki, zbiory biblioteczne, meble, wyposażenie wnętrza zabytku ruchomego" (Pruszyński, 2001, s. 80). Kolejnym rodzajem jest niematerialne dziedzictwo kulturowe, które obejmuje wszystkie nienamacalne elementy składowe danej kultury, tzn. tradycje, zwyczaje, obrzędy, przekonania, wierzenia, a nawet zachowania, podkreślające poczucie wspólnoty danej grupy, spajające ją w całość i pozwalające na trwanie. Ostatnią grupę tworzą wytwory naturalne, czyli elementy przestrzeni, które ze względu na swoją wyjątkowość stanowią nieocenioną wartość dla danej społeczności. Przykładami mogą być góry, morza, jeziora, wodospady i inne obiekty przyrodnicze. Niektórzy zaliczają tutaj również wsie, osady, a nawet miasta, uważając, że wytwór rąk ludzkich w pewnym momencie zespala się z obiektem naturalnym i razem tworzy nowe zjawisko (tamże).

Spośród trzech wymienionych rodzajów najłatwiejsze do poznania - i to w dodatku bez konieczności używania nowoczesnych technologii i mediów - wydają się przykłady naturalnego dziedzictwa narodowego. Żaden cyfrowy przekaźnik nie może bowiem zastąpić krajoznawczej wycieczki, choć oczywiście dzięki dronom czy mikrokamerom można zobaczyć cuda natury, nie ruszając się z domu. Przed dużo większym problemem stają ci, którzy chcą przybliżyć przykłady dziedzictwa kulturowego należące do dwóch pozostałych rodzajów. Użycie nowych mediów i technologii w tym przypadku musi być bardzo przemyślane.

Mendel Gdański Marii Konopnickiej to dzieło, które młodzież traktuje przez pryzmat nowelistyki tendencyjnej, a zatem zgodnie $z$ ich rozumowaniem jako nieciekawe, smutne i subiektywne. Lekturze nie sprzyja również to, że utwór powstał w pozytywizmie, kojarzącym się albo $z$ obecną na prawie każdym egzaminie maturalnym Lalkq Bolesława Prusa, albo z historycznymi dziełami Henryka Sienkiewicza, czyli monumentalizmem formy. Nie pomaga również sama autorka, którą najczęściej utożsamia się z patetyczną Rotą lub baśnią O krasnoludkach i sierotce Marysi. Nowela Konopnickiej po wielu zmianach programowych nie znajduje się obecnie na liście obowiązkowych lektur szkolnych, co - jak wiadomo - ma swoje plusy i minusy, gdyż z jednej strony nie wszyscy uczniowie mają okazję się zapoznać z jej treścią, z drugiej nie ma przyklejonej etykietki obowiązkowości, co uwalnia ją od wszystkich negatywnych skojarzeń.

Mendel Gdański to krótki utwór opowiadający historię warszawskiego Żyda, który staje się ofiarą nietolerancji i prześladowań ze stro- 
ny Polaków. Choć sama historia wydaje się prosta i bardzo czytelna, nowela zawiera w sobie wiele sensów, mogących stać się przyczyną rozważań i przemyśleń. Tematów godnych poruszenia jest aż nazbyt wiele: motyw dziecka, motyw pracy, problem inności, problem nietolerancji, ambiwalentny obraz Polaków, obraz XIX-wiecznej Warszawy itd. Dzieło Marii Konopnickiej jest wielką wartością także dlatego, że łączy w sobie różne rodzaje dziedzictwa kulturalnego - jako książka przedstawia wartość materialną, ale opisuje także zwyczaje, tradycje i zachowania, zatem ma wartość niematerialną, gdyby zaś potratować miasto jako naturalne środowisko funkcjonowania Żydów, można pokusić się o znalezienie elementów dziedzictwa naturalnego. Z kolei z racji tego, że dzieło opowiada o XIX w. i porusza problem kwestii żydowskiej, a dodatkowo stanowi wartość kulturową, warto użyć nowoczesnych mediów i technologii, aby przybliżyć je odbiorcy.

Omawianie wszystkich tematów przy jednym dziele wydaje się bezcelowe i prowadzi do powierzchownego poznania całości. Sensownym wydaje się wybranie jednego z tematów i oparcie na nim dalszego przebiegu zajęć. Przed przystąpieniem do pracy warto także zadać sobie pytanie, jaki powinien być efekt finalny.

\section{Najważniejszy jest początek}

Wisława Szymborska podczas odczytu noblowskiego w 1996 r. powiedziała, że w przemówieniu najtrudniejsze jest zawsze pierwsze słowo, i miała rację. To właśnie początek, czyli wprowadzenie w tematykę zajęć, pozwala skupić uwagę odbiorców, zainteresować ich omawianym problemem i zbudować odpowiednią relację. Dzięki nowoczesnym mediom i technologiom nie tylko można w atrakcyjny sposób rozpocząć spotkanie, lecz także, za sprawą różnorodności środków, wprowadzić odbiorców w odpowiedni nastrój, wzbudzić chęć rywalizacji czy wyciszyć ich i uspokoić. Kluczowy staje się jednak dobór środków, aby formą nie przesłonić treści.

Nieocenioną pomocą podczas prowadzenia zajęć są smartfony oraz możliwość wykorzystywania łatwego dostępu do Internetu. Telefony w dzisiejszych czasach stały się niezbędnym środkiem komunikacji i najszybszym sposobem dostępu do informacji, dlatego zamiast zabraniać korzystania z nich, warto włączyć je do procesu edukacyjnego. Zyskują na tym zarówno same zajęcia, jak i uczniowie, którym telefon kojarzy się z relaksem i czasem wolnym, a nie obowiązkiem nauki. Do- 
stęp do Internetu pozwala wykorzystać różnego rodzaju aplikacje, które pełnią funkcję dydaktyczną.

Jedną z takich pomocy jest program Kahoot!. Aplikacja ta została stworzona w celu współzawodnictwa i zabawy. Pozwala ona na wzięcie udziału w quizie, do którego pytania układa moderator zabawy. Najprostsza wersja zakłada przygotowanie 10 pytań i czterech odpowiedzi (trzech błędnych i jednej poprawnej) do każdego z nich. Chcąc uatrakcyjnić zabawę, w tle każdego pytania można wstawić zdjęcia ilustrujące zagadnienie. Czas na udzielenie odpowiedzi jest regulowany i zależy od nauczyciela. Udział w zabawie może mieć dwie formy: indywidualną lub drużynową. Po zainstalowaniu aplikacji na dowolnym urządzeniu (laptop, smartfon, tablet) należy wpisać odpowiedni kod, który generuje moderator zabawy po zalogowaniu na swoje konto. Następnie należy wybrać nick i przystą̧ić do rywalizacji. Każde pytanie, a także cztery odpowiedzi są wyświetlone na ekranie moderatora zabawy. Uczestnicy natomiast muszą przy każdym pytaniu w swoim urządzeniu wybrać odpowiedni kształt przyporządkowany odpowiedzi. Po udzieleniu odpowiedzi lub upłynięciu czasu wyświetlone są wyniki wraz ze statystyką, dzięki czemu na bieżąco można śledzić swoje poczynania na tle grupy. Po zakończeniu zabawy wyświetlone jest także zestawienie całości. Wielką zaletą tej aplikacji jest możliwość używania przez odbiorców własnych telefonów, a także sprawdzanie wiedzy w odmienny sposób. Minus stanowi charakter zabawy, która rozpręża odbiorców i po której zakończeniu często należy sprawić, by uczniowie skupili się na nowo. Dlatego bardzo ważną rolę odgrywa moderator, który w odpowiednim momencie musi dokonać podsumowania z wyjaśnieniem zasadności użycia tej aplikacji.

Chcąc poruszyć problem nietolerancji, inności, wielokulturowości, przy omawianiu Mendla Gdańskiego można przygotować quiz dotyczący wyrazów zapożyczonych funkcjonujących w języku polskim. Po zakończeniu interakcji łatwo zauważyć, jak wiele wyrazów obcego pochodzenia istnieje w polszczyźnie, a ich nierodzimość jest często niemożliwa do rozpoznania. Zabawa ta pokazuje, że często inność zaczyna być widoczna dopiero wtedy, gdy jest nazwana albo przez kogoś podkreślona. Nie istnieje również takie zjawisko jak kultura jednonarodowościowa. Nie ma bowiem ani jednego społeczeństwa, które funkcjonuje w izolacji ani nie korzysta $z$ dorobku światowego.

Inną formą wprowadzenia w temat inności i tolerancji może być też wyświetlenie i omówienie filmu Duże zwierzę w reżyserii Jerzego Stuhra, 
a następnie dyskusja, w której tekstem prowokującym do rozmowy można uczynić również piosenkę napisaną na potrzeby tego dzieła, czyli Polowanie na wielbłąda zespołu Myslovitz.

Bardzo ważne jest, by liczba elementów wprowadzających nie zdominowała samego tekstu, który odbiorcy powinni poznać. Współczesne media mają skupić uwagę słuchaczy i w atrakcyjny sposób wprowadzić temat rozważań, nigdy jednak nie powinny zdominować samego dzieła. Wszyscy ludzie bowiem, niezależnie od wieku, lubią wypowiadać się na różnorakie tematy i chcą, by ich zdanie było słyszalne i zauważone.

Po interaktywnym wstępie, pokazującym aktualność omawianego tematu, należy skupić się na tekście i pozwolić odbiorcom na zbadanie jego wyjątkowości. Zadaniem osoby prowadzącej zajęcia jest poprowadzenie odbiorców przez świat dzieła, bez narzucania opinii i myśli. Jednakże z racji doświadczenia i wiedzy musi ona wskazywać fragmenty, przy których warto się zatrzymać i których sens należałoby głębiej przemyśleć. Dopiero wtedy, gdy w odbiorcach pojawią się uczucia związane z tekstem, można mówić o tym, że kurz pamięci został starty, a dzieło na powrót stało się żywe.

Przy odczytywaniu sensów noweli Konopnickiej warto zwrócić szczególną uwagę na dwa fragmenty. Pierwszy z nich związany jest $z$ akceptacją samego siebie oraz poczuciem odrębności:

"- Nu, co to jest żyd? Nu, jaki ty żyd? - mówił już łagodniejszym głosem. - Ty się w to miasto urodził, toś ty nie obcy, toś swój, tutejszy, to ty prawo masz kochać to miasto, póki ty uczciwie żyjesz. Ty się wstydzić nie masz, żeś żyd. Jak ty się wstydzisz, żeś ty żyd, jak ty się sam za podłego masz, dlatego, żeś żyd, nu, to jak ty możesz jakie dobro zrobić dla to miasto, gdzie ty się urodził, jak ty jego kochać możesz?... Nu?..." (Konopnicka, 1962, s. 384-385).

Drugi zaś stanowi bardzo ciekawy wywód argumentacyjny, w którym tytułowy bohater wskazuje na absurdalność całej sytuacji oraz poczucie nierozrumienienia nagłej wrogości wobec Żydów:

„Pan dobrodziej powiada, co by żyd nie był obcy? Nu, i ja tak samo powiadam. Czemu nie? Niech un nie będzie obcy. Na co un obcy ma być, na co ma obcym się robić, kiedy un i tak swój? Pan dobrodziej myśli, co jak tu deszcz pada, to un żyda nie moczy, bo żyd obcy? Albo może pan dobrodziej myśli, co jak tu wiatr wieje, to un piaskiem nie sypie w oczy temu żydowi, bo żyd obcy? Albo może pan dobrodziej myśli, że jak 
ta cegła $z$ dachu leci, to una żyda ominie, bo un obcy? $\mathrm{Nu}$, to ja panu dobrodziejowi powiem, że una jego nie ominie. I wiatr jego nie ominie, i deszcz jego nie ominie! Patrz pan dobrodziej na moje włosy, na moje brode... Uny siwe są, uny białe są... Co to znaczy? To znaczy, co uny dużo rzeczy widziały i dużo rzeczy pamiętają. To ja panu dobrodziejowi powiem, co une widziały wielgie ognie i wielgi pożar, i wielgie pioruny na to miasto bić, a tego, co by od te ognie i od ten pożar, i od te pioruny żydy były uwolnione, to uny tego nie widziały! $\mathrm{Nu}$, a jak noc jest na miasto, to una i na żydów jest, to i na żydów wtedy nie ma słońce!" (Konopnicka, 1962, s. 389).

Oba fragmenty są znakomitą platformą do dalszych dyskusji. Pierwszy dotyczy przede wszystkim kultury żydowskiej i wynikających z niej zwyczajów oraz tradycji. Wykorzystanie nowych technologii i mediów przy tej tematyce wydaje się nie tylko zasadne, lecz także konieczne. Oczywiście żadna nowinka technologiczna nie zastąpi możliwości osobistego obcowania z dziełami kultury. Nieocenioną pomocą przy poznawaniu historii Żydów jest wizyta w Muzeum Historii Żydów Polskich Polin, jednakże nie zawsze jest ona możliwa. Na szczęście, dzięki powszechnemu dostępowi do Internetu, można odbyć taką wędrówkę wirtualnie i zapoznać się z wieloma aspektami tej społeczności. Z racji tego, że polskie i żydowskie tradycje przenikały się od dawna, warto zainteresować się kulturalnymi ofertami regionu, gdyż bardzo często okazuje się, że repertuar teatralny czy wystawa korelują z omawianymi treściami.

Nowoczesne media i technologie zapewniają również szeroki i łatwy dostęp do innych dzieł, pomocnych przy omawianiu kwestii żydowskiej. Takie elementy odrębności jak strój, zwyczaje, tradycje, jedzenie i muzyka można przybliżyć za pomocą różnorakich źródeł. Przykładem mogą być chociażby:

$\rightarrow$ strony internetowe: sztetl.org.pl, www.polin.pl/pl,

$\rightarrow$ muzyka: Kroke, Rzeszów Klezmer Band, Justyna Steczkowska,

$\rightarrow$ sztuki teatralne: Dybuk, Teatr Przedmieście w Rzeszowie,

$\rightarrow$ filmy: Fanatyk, reż. Henry Bean, Pianista, reż. Roman Polański,

$\rightarrow$ malarstwo: obrazy Chagalla, Brunona Schulza.

Przy doborze tekstów kultury warto kierować się wiekiem i zainteresowaniami grupy. Choć odwołań i nawiązań jest niezwykle dużo, przy budowaniu kontekstu należy zachować umiar. Przeładowanie przekazu 
innymi treściami powoduje bowiem potraktowanie tekstu podstawowego jako jednej z ilustracji, nie zaś jako głównego źródła. Najlepszym sposobem wydaje się ograniczenie do jednej dodatkowej inspiracji lub dwóch, chociażby połączenia muzyki z prezentacją obrazów.

Jeżeli tekstem ilustrującym jest muzyka, to warto pozwolić odbiorcom korzystać z telefonu, aby mogli śledzić tekst lub nawet nucić razem z wokalistą. Oczywiście zależy to od tematu zajęć i specyfiki grupy. Jednakże pozwalanie na korzystanie z nowoczesnych technologii za każdym razem uwspółcześnia omawiany temat, a także angażuje odbiorców.

Po omówieniu tekstu kultury zawsze warto przeprowadzić dyskusję, gdyż w ten sposób można sprawić, by omawiane dzieło wywołało w odbiorcach trwałe emocje. W przypadku Mendla Gdańskiego można chociażby porozmawiać o zasadności wyróżniania się poprzez ubiór, muzykę czy jedzenie.

Drugi tekst przedstawia argumentację Mendla Gdańskiego, który próbuje wytłumaczyć zegarmistrzowi absurdalność całej sytuacji. Powyższy fragment jest wypowiedzią głównego bohatera, jednakże na uwagę zasługuje cała rozmowa wyżej wymienionych postaci. Znakomicie obrazuje ona bowiem jałowość dyskursu, gdzie z jednej strony w sposób lakoniczny i zdawkowy wypowiada się niemający żadnych rzetelnych argumentów na poparcie własnego stanowiska zegarmistrz, a $z$ drugiej strony na absurdalne zarzuty w merytoryczny i spokojny sposób odpowiada Żyd. Cała konwersacja przypomina coraz bardziej popularny hejting, gdzie krytykujący internauci publikują pod wpływem emocji pełne wulgaryzmów wypowiedzi, które nijak nie przypominają logicznego wywodu argumentacyjnego.

Taka analogia pozwala odbiorcom zauważyć, że problem hejtingu nie jest zjawiskiem nowym, lecz właściwie istnieje od zawsze. Dodatkowo dyskurs dwóch bohaterów pokazuje, jak karykaturalnie wygląda rozmowa, w której jedna strona zamiast argumentów używa emocji. Po odkryciu analogii zasadnym wydaje się pokazanie przykładów hejtingu w Internecie i obnażenie bezpodstawnie krytykujących. Oczywiście jest to dość odważne posunięcie z racji tego, że często takie fora pełne są wulgaryzmów i obscenicznych porównań. Łagodniejszą formą może być chociażby wyświetlenie krótkich filmów, na których znane postacie czytają negatywne komentarze związane z ich osobą. Zwalczanie nienawiści w sieci propagują chociażby projekt HejTy, będący polskim 
odpowiednikiem zagranicznego Celebrities Read Mean Tweets, czy kampania reklamująca nowy sezon serialu Opowieści podręcznej zatytułowana Na poczq̨tku było słowo. Pokazanie przykładów hejtingu wraz z komentarzem obnażającym absurdalność wypowiedzi obrazuje bezcelowość dyskusji z kimś, kto kieruje się tylko nienawiścią i nie posiada żadnej wiedzy na temat, na który się wypowiada.

Żeby odbiorca zapamiętał, a także docenił tekst, musi go najpierw poczuć i zrozumieć. Sama lektura często nie pozostawia w czytelniku trwałego śladu, dlatego należy sprawić, aby odbiorca zacząć traktować omawiany problem personalnie. Nowoczesne media i technologie niosą $w$ tym przypadku wielką pomoc. Kluczowymi jednak elementami doboru mediów i technik są umiar w ich stosowaniu oraz specyfika grupy odbiorców.

Tekstem bezpośrednio korespondującym z nowelą Marii Konopnickiej jest wiersz Adama Asnyka Do Młodych. Utwór pokazuje, jak grupy różnie spoglądające na rzeczywistość powinny koegzystować.

W kontekście omawianego problemu szczególnie ważne wydają się następujące słowa:

"Szukajcie prawdy jasnego płomienia!

Szukajcie nowych, nieodkrytych dróg... [...]

Ale nie depczcie przeszłości ołtarzy,

Choć macie sami doskonalsze wznieść;

Na nich się jeszcze święty ogień żarzy,

I miłość ludzka stoi tam na straży,

I wy winniście im cześć!" (Asnyk, 1973, s. 195).

Fragment ten pokazuje, jak ważne są nieustanny rozwój i poszukiwanie tego, co inne. Każde pokolenie, każda grupa ma prawo walczyć o swoją przestrzeń. Jednakże, co podkreśla poeta, należy znaleźć ją nie kosztem innych, ale z ich pomocą. Omawiając powyższy tekst kultury, który również jest przykładem dziedzictwa kulturowego, warto zrezygnować z nowych technologii, by pozwolić zabrzmieć słowom. Utwór nie stwarza większych problemów w odczytaniu i precyzyjnie przekazuje swoje ukryte znaczenie, dlatego posiłkowanie się dodatkowymi pomocami nie wydaje się konieczne. $Z$ racji tego, że wiersz Asnyka namawia do buntu i walki, zasadnym staje się przeprowadzenie dyskusji o przekornej naturze człowieka i sprzeciwie wobec zastałej rzeczywistości. 
Jak zakończyć powyższe rozważania, aby w pamięci słuchaczy zostały teksty literackie, które powstały w XIX w.? Podobnie jak początek, tak i zakończenie jest momentem, który odgrywa bardzo ważną rolę, gdyż kondensuje i utrwala zdobytą wiedzę.

I tu po raz kolejny w sukurs mogą przyjść nowe techniki i media, ponieważ pozwalają raz jeszcze zainteresować słuchaczy i skupić ich uwagę na problemie. Jednym ze sposobów podsumowania jest technika dramy, polegająca na odegraniu scenek aktorskich, które pokazują, jak teksty kultury zostały zrozumiane przez odbiorców. Nowe technologie pozwalają na unowocześnienie wymienionej techniki, np. nagranie krótkiego filmu.

Podczas omawiania wiersza Asnyka warto zauważyć, że przykładem grup, które szukają swego odrębnego miejsca, są subkultury. Jednym ze sposobów poznania ich może być nakręcenie krótkiego filmu związanego z buntem. Uczestnicy takiego projektu mają za zadanie wybrać jedną w wielu subkultur i dokładnie ją zbadać, a następnie przedstawić przed resztą odbiorców. Prezentacja powinna zawierać elementy przemówienia, wykładu oraz recenzji. Każdy z uczestników (mogą być to również małe grupki) musi ubrać się i wystylizować tak jak przedstawiciele opisywanej przez siebie subkultury, a następnie przedstawić ich historię i zasady. Bardzo ważne jest, aby każda grupa przedstawiona była rzetelnie, bez ironii, z poszanowaniem poglądów innych. Konieczne jest również omówienie elementów stroju i muzyki jako wyrazów odmienności. Prelegenci muszą także opisać, z czym i w jaki sposób walczy dana subkultura, a następnie dokonać subiektywnej oceny.

Przykład takiej prezentacji znajduje się na stronie internetowej Zespołu Szkół Muzycznych nr 1 w Rzeszowie ${ }^{1}$. Powyższy film został przygotowany przez uczniów klasy V OSM II st. ${ }^{2}$, a opracowaniem i montażem zajęła się jedna z uczennic - Wiktoria Bialic. Całość została zarejestrowana za pomocą smartfonów i aparatu fotograficznego. Powyższa metoda pracy, wykorzystująca nowoczesne media i technologie, pozwala słuchaczom od początku do końca brać udział w procesie twórczym, czuć się za niego odpowiedzialnym i z pewnością taka prezentacja na dłużej zostaje w ich pamięci.

1. www.youtube.com/watch?v=fpKZE2Rz-9M\&list=PLXrPqWa-Y9zgZfG5ng5I_E-Ulu0JnEs7 \&index=2.

2. Klasa V OSM programowo odpowiada klasie II liceum. 
Nowe media i nowe technologie to dla kreatywnego nauczyciela nieoceniona pomoc i platforma dająca szerokie spektrum możliwości. Wielką zaletą cyfryzacji i digitalizacji jest możliwość wsparcia procesu edukacyjnego i przywrócenia dawnym dziełom ich blasku i splendoru. Choć $w$ wielu przypadkach mogą one zastąpić wiele z dotychczas stosowanych metod, nigdy nie wolno pozwolić, by zajęły miejsce żywej interakcji z odbiorcą. Najważniejszym sposobem na przeżycie tekstu kultury było i jest słowo - możliwość oceny, badania, rozumienia i refleksji. I choć współczesne media mogą okazać się bardzo przydatne w procesie edukacji, nigdy nie zastąpią dyskusji ani innej formy rozmowy. Zadaniem nowych technologii i mediów jest zatem przeniesienie dawnych tekstów kultury do teraźniejszości oraz nadanie im współczesnego charakteru. Dzięki temu dzieła powstałe w przeszłości mogą okazać się uniwersalne, ponadczasowe i nadal skłaniać do przemyśleń. Jednak aby tak się stało, bardzo ważne jest, by każde spotkanie z dziedzictwem kultury zostawiło trwały ślad w postaci emocji i przeżycia. 


\section{Bibliografia}

$\rightarrow$ Asnyk, A. (1973), Do Młodych [w:] A. Asnyk, Wiersze wybrane, Warszawa: Państwowy Instytut Wydawniczy.

$\rightarrow$ Czerwińska, K., Marcol, K., Rusek, H. (red.) (2012), Studia etnologiczne i natropologiczne. Dziedzictwo kulturowe "nadbagażem" codzienności?, t. 12, Katowice: Wydawnictwo Uniwersytetu Śląskiego.

$\rightarrow$ Jedynak, B. (2004), Dziedzictwo obyczaju narodowego Polaków. Pamięć i zapomnienie, Lublin: Wydawnictwo UMCS.

$\rightarrow$ Konopnicka, M. (1962), Mendel Gdański, Obrazek [w:] M. Konopnicka, Nowele, Warszawa: Czytelnik.

$\rightarrow$ Ks. Michał Czajkowski, K.M. (2004), Żydzi i chrześcijanie - wspólne dziedzictwo wiary, Toruń: Wydawnictwo Uniwersytetu Mikołaja Kopernika.

$\rightarrow$ Mateusz Hübner, K.Z. (red.) (2016), Dziedzictwo kulturowe w śwadomości współczesnego człowieka, Toruń: Wydawnictwo edukacyjne AKAPIT.

$\rightarrow$ Monika, A., Murzyn, J.P. (red.) (2007), Dziedzictwo kulturowe w XXI w. Szanse i wyzwania, Kraków: Międzynarodowe Centrum Kultury.

$\rightarrow$ Pruszyński, J. (2001), Dziedzictwo kultury Polski. Jego straty i ochrona prawna, t. 1, Poznań: Kantor Wydawniczy: Zakamycze. 


\title{
Cyberbezpieczeństwo w szkołach: skuteczne strategie dzialania
}

\author{
Aneta Wilk, Adam Stępiński
}

Wraz z postępującym rozwojem technologii cyberbezpieczeństwo ma kluczowe znaczenie dla uczniów, nauczycieli i szkół. Edukacja w zakresie e-bezpieczeństwa jest istotnym czynnikiem skutecznego wdrażania bezpieczeństwa informatycznego w szkołach. Żadne środki ostrożności nie będą jednak skuteczne, jeśli użytkownicy nie będą mieli świadomości, jak bezpiecznie korzystać z Internetu. Wszystkie podmioty, których dotyczy ta kwestia, powinny być świadome zagrożeń, jakie mogą napotkać w sieci. Im więcej działań edukacyjnych w zakresie zapewnienia e-bezpieczeństwa zostanie podjętych, tym większa pewność, że uczniowie poczują się bezpieczni w cyfrowym świecie. Poza tradycyjnymi działaniami prowadzonymi w trakcie zajęć informatycznych szkoły powinny próbować ustanowić kompleksową politykę obejmującą starannie opracowane działania i szczegółowe wytyczne zarówno dla uczniów, jak i rodziców. Wskazane jest podjęcie działań zapobiegawczych, opracowanie zestawu zasad, jak zachowywać się w określonych sytuacjach, monitorowanie aktywności online uczniów i szybkie działanie w przypadku jakichkolwiek niepokojących incydentów. Nauczyciele powinni motywować uczniów do odpowiedzialnego zachowania w Internecie i rozwijać ich świadomość właściwego zarządzania swoimi danymi, dbałość o reputację w sieci, respektowanie praw autorskich.

\section{Słowa kluczowe: \\ cyberbezpieczeństwo \\ zagrożenia online \\ tożsamość internetowa \\ eTwinning, prawa autorskie}




\section{Cyber-security in schools: effective strategies}

Aneta Wilk, Adam Stępiński

With progressive and continuous change to technology, cyber security is crucial to students, teachers and schools. User education is considered the most important factor for successful implementation of IT security in schools. All precautions will become ineffective if user awareness is not aroused. All students, teachers and parents should comprehend their responsibilities, obligations and threats they may encounter while being online. Thus the more e-safety measures and educational steps are taken, the more confident we can be that students are secure as far as cybersafety is concerned. Apart from traditional activities carried out during IT classes schools should try to establish a complex policy covering carefully designed activities, projects, school events and detailed guidance for students, teachers and parents. It seems to be advisable to take preventive actions, elaborate a set of rules how to behave in certain situations, monitor students' online behaviour carefully and act promptly in case of any worrying incidents. What is more, educators need to motivate young Internet users to act online responsibly like managing data knowingly, taking care of their online reputation and identity, respecting copyrights etc. There are more and more organisations and national and international initiatives and undertakings which support teachers in their efforts to introduce their students to the responsible and safe use of the Internet potential. 


\section{Wstęp}

We współczesnym świecie media elektroniczne są w coraz większym stopniu miejscem gromadzenia i wymiany informacji, a także kanałem komunikacji. Dzieci i młodzież są w największym stopniu narażone na wszelkie zagrożenia wynikające z niewłaściwego użytkowania mediów elektronicznych. Składa się na to kilka czynników:

$\rightarrow$ osoby młode są mniej świadome niebezpieczeństw, jakie mogą napotkać w wirtualnym świecie,

$\rightarrow$ ich kompetencje cyfrowe dopiero się kształtują,

$\rightarrow$ korzystanie z mediów elektronicznych stanowi dla nich część codziennego życia', konsekwencją tego może zaś być zwiększone ryzyko ekspozycji na niebezpieczne treści.

Biorąc pod uwagę to, że media cyfrowe, a w szczególności Internet, są nieodłączną częścią życia społecznego nastolatków, ich codziennej aktywności i rozrywki (Wrzesień-Gandolfo, 2014), coraz większe znaczenie zyskuje edukacja cyfrowa młodych ludzi, za którą odpowiedzialność w głównej mierze ponoszą nauczyciele oraz rodzice.

Wychodząc naprzeciw wyzwaniom, jakie wiążą się z korzystaniem z nowoczesnych technologii przez młodych ludzi, szkoły coraz częściej wdrażają strategię e-bezpieczeństwa do szkolnego planu nauczania. Istotną kwestią, o której edukatorzy powinni pamiętać podczas opracowywania takiej strategii, jest oparcie jej na praktycznych metodach pracy, których wdrożenie pozwoli uczniom rozwijać kompetencje cyfrowe oraz pomoże zrozumieć podstawowe zasady e-bezpieczeństwa.

\section{Jak motywować dzieci i młodzież do odpowiedzialnego korzystania z mediów elektronicznych?}

Aktywność w świecie cyfrowym, podobnie jak w tym realnym, opiera się na pewnych standardach związanych z kulturą osobistą, ze sposobem zachowania się wobec innych ludzi, z wyrażaniem emocji, przetwarzaniem informacji o sobie oraz swoim najbliższym otoczeniu. Młodzi ludzie powinni być nie tylko tego świadomi, lecz także posiadać umiejętności, które pozwolą im bezpiecznie funkcjonować w cyberprzestrzeni.

1. Według badań w Polsce dzieci po raz pierwszy najczęściej logują się w Internecie w wieku dziewięciu lat. 93 proc. młodych internautów w Europie deklaruje, że loguje się do sieci przynajmniej raz w tygodniu, a 60 proc. codziennie lub prawie każdego dnia. Zob. Kirwil, 2011, s. 9. 
Najbardziej podstawowa umiejętność, jaką młodzi ludzie powinni posiadać, to właściwe zarządzanie swoimi danymi w sieci oraz dbałość o reputację online. Regulaminy większości serwisów internetowych zezwalają na korzystanie ze swoich usług osobom powyżej 13. roku życia. Jednak badania wskazują, że dzieci i młodzież znacznie wcześniej zaczynają swoją aktywność na portalach internetowych, szczególnie w mediach społecznościowych. Według danych podanych w raporcie EU Kids Online 38 proc. dzieci w przedziale wiekowym 9-12 lat ma profil na portalu społecznościowym (Livingstone, Haddon, Görzig, Ólafsson i in., 2011). Zważywszy na powyższe dane, edukacja dzieci i młodzieży w kontekście dbania o własną reputację i wizerunek w sieci jest szczególnie ważna, ponieważ wraz z aktywnością młodych ludzi w Internecie powstaje baza danych, która buduje ich wizerunek online i może w przyszłości wpływać na postrzeganie ich przez inne osoby (Wrzesień-Gandolfo, 2014). Kształtując nawyki bezpiecznego korzystania z mediów elektronicznych przez uczniów, warto zapoznać ich z pojęciem danych osobowych oraz uwrażliwić na konieczność ich ochrony. Rozpoczynając swoją aktywność w cyfrowym świecie, powinni oni znać i umieć praktycznie stosować kilka podstawowych zasad. Po pierwsze, powinni być świadomi, że im mniej anonimowi pozostają w sieci, tym bardziej rośnie potencjalne ryzyko zagrożeń związanych z korzystaniem przez nich z mediów elektronicznych. Rejestracja na wielu portalach zwykle wymaga podania szczegółowych danych osobowych, m.in. imienia, nazwiska, daty urodzin. Korzystanie z portalów społecznościowych często zachęca młodych ludzi do umieszczania na swoim profilu innych szczegółowych informacji, np. adresu e-mail, adresu zamieszkania czy adresu szkoły. Podawanie tak wielu informacji wiąże się z potencjalnymi niebezpieczeństwami - dziecko np. może stać się ofiarą phishingu (kradzieży danych osobowych w sieci), jego profil mogą zobaczyć osoby spoza kręgu znajomych i wykorzystać umieszczone w nim informacje w nieuprawniony sposób, np. poprzez publikowanie w sieci danych o dziecku bez jego wiedzy, jego profil może stać się również obiektem zainteresowania osób o skłonnościach pedofilskich. W środowisku online dzieci i młodzież mogą odczuwać mniejsze niż w świecie realnym ograniczenia. Wynikiem tego może być skłonność do nadmiernego ujawniania innym informacji o sobie (Pyżalski, 2012). Tymczasem raz umieszczone $w$ Internecie informacje czy zdjęcia mogą być trudne do usunięcia. Istnieje prawdopodobieństwo, że pojawią się 
one ponownie wiele lat później, mogąc zaszkodzić przyszłej karierze czy relacjom prywatnym danej osoby (Amann-Hechenberger, Buchegger, Schwarz, 2014). Mając konto na portalu społecznościowym, młodzi ludzie często bezrefleksyjnie dzielą się również swoją codzienną aktywnością z innymi użytkownikami, niejednokrotnie nadają publiczny status swoim internetowym wpisom. W konsekwencji raz opublikowaną informację trudno jest zatrzymać. Może być ona przetwarzana przez inne osoby, komentowana i wykorzystywana ze szkodą dla jej właściciela (Dbaj o fejs. Przewodnik dla młodzieży, 2013). Rolą edukatorów jest uwrażliwienie nastolatków na potencjalne ryzyko związane z publikowaniem takich informacji oraz zapewnienie edukacji w zakresie nabycia przez nich umiejętności zarządzania swoim profilem w mediach społecznościowych. Po drugie, korzystając z wszelkiego rodzaju usług internetowych, młodzi ludzie są zobowiązani do zapoznania się $z$ ich regulaminem. Niechęć do czytania informacji w regulaminie może skutkować nieświadomą akceptacją różnych niepożądanych działań przez dany serwis, np. pobierania dodatkowych opłat za korzystanie z określonych usług czy przetwarzania danych osobowych użytkownika przez inne podmioty. Po trzecie, młodzi internauci powinni wiedzieć, na jakie niebezpieczeństwa są narażeni w Internecie i gdzie zwracać się o pomoc. Oprócz podjęcia rozmowy z zaufanymi osobami - rodzicami czy nauczycielami - mogą oni również skorzystać z pomocy telefonicznej oferowanej przez fundację Dajemy Dzieciom Siłę². Po czwarte, dzieci i młodzież korzystający z serwisów internetowych oraz poczty e-mail powinni być świadomi, jak stworzyć bezpieczne hasło do konta w serwisie internetowym oraz chronić je przed ewentualną kradzieżą.

Prowadząc projekty online z uczniami, nauczyciele powinni zwrócić szczególną uwagę na zagadnienie netykiety, czyli zasad właściwego zachowania w Internecie. Używanie kulturalnego języka, publikowanie odpowiednich treści, szacunek dla partnerów projektowych, unikanie ostrego krytycyzmu, odpowiadanie na wiadomości, aktywny udział w dyskusjach, niespamowanie innych oraz przestrzeganie ustalonych terminów to tylko kilka przykładów zasad zachowania, które warto promować. Dobrym pomysłem jest wypracowanie przez międzynarodową grupę projektową wspólnego zestawu zasad netykiety (syn-

2. Informację o pomocy telefonicznej można uzyskać pod adresem: fdds.pl/oferta/pomoctelefoniczna/, dostęp 18.04.2018. 
chroniczne i asynchroniczne dyskusje, burze mózgów i w rezultacie wspólny wybór np. 10 najważniejszych zasad jako swoistego kodeksu zachowania podczas pracy projektowej). Bardzo pomocne mogą tutaj okazać się narzędzia online typu: wideokonferencje, fora, blogi, kreatory do zbierania pomysłów czy narzędzia do przeprowadzania głosowania.

Problemem ściśle związanym z netykietą jest zagadnienie podwójnej tożsamości. Uczniowie powinni być świadomi tego, że tak jak przez swoje codzienne zachowanie w szkole, domu czy na dodatkowych zajęciach tworzą swój określony obraz dla innych, tak poprzez działania w Internecie mogą zostawiać trwałe ślady, będące źródłem informacji o nich nie tylko dla najbliższego otoczenia, lecz także każdej osoby mającej dostęp do zasobów online. Jak już zostało wspomniane wcześniej, może to mieć ogromne znaczenie w przyszłych kontaktach społecznych i towarzyskich oraz w sferze zawodowej. Dziś coraz częściej stosowaną przez pracodawców praktyką jest wynajmowanie firm specjalizujących się w analizie i interpretacji aktywności online osób, które starają się o zatrudnienie.

Podczas zajęć ze swoimi uczniami nauczyciele bardzo chętnie sięgają do zasobów Internetu, który oferuje gotowe pomysły na lekcje, scenariusze zajęć, programy eventów edukacyjnych, filmy czy quizy. Jednym z bardziej popularnych portali jest sieciaki.pl. Promuje on bezpieczne sposoby korzystania z zasobów, przedstawia efektywne metody edukowania dzieci i młodzieży w zakresie bezpieczeństwa w Internecie oraz oferuje szeroką bazę filmów i gier interaktywnych. Podobny profil ma strona programu Komisji Europejskiej Safer Internet www.saferinternet.pl. Dział materiałów edukacyjnych tego portalu zawiera dodatkowo liczne kursy e-learningowe dla uczniów, nauczycieli, rodziców oraz bardzo szeroką bazę multimedialną obejmującą popularne kreskówki, takie jak Owce w sieci, 3... 2... 1... Internet, Krasnoludki 2.0 czy Mój przyjaciel Necio, a także filmy edukacyjne - Zostań znajomym swojego dziecka, Dodaj znajomego oraz W sieci. Niektóre z tych materiałów dostępne są w różnych wersjach językowych, dlatego coraz chętniej sięgają do nich również nauczyciele języków obcych, wykorzystując je jako materiał stymulujący do dyskusji pisania esejów.

$\mathrm{Na}$ oddzielną uwagę zasługuje publikacja The Web We Want (www.webwewant.eu), która rozwijana była na przestrzeni ostatnich kilku lat przez uczniów, nauczycieli i specjalistów z zakresu e-bezpieczeństwa pod patronatem European Schoolnet. Nastolatkowie z kilkunastu 
europejskich krajów opracowali podręcznik dla swoich kolegów w innych krajach, a nauczyciele i specjaliści - przewodnik metodyczny, zbiór scenariuszy zajęć zawierających pomysły na ciekawe zadania, które można przeprowadzić z uczniami zarówno podczas lekcji, jak i pracując nad projektem edukacyjnym. Prowadzenie portalu The Web We Want w kilkunastu językach daje szanse wykorzystania tych materiałów w przedsięwzięciach międzynarodowych online oraz w projektach uwzględniających wizyty uczniów w szkołach partnerskich.

Z ciekawych pomysłów na zapewnienie e-bezpieczeństwa na uwagę zasługują: wypracowanie w szkole procedur postępowania dla uczniów i nauczycieli, tworzenie banku zasobów dydaktycznych z zakresu wspomnianej tematyki oraz udział placówek w akcjach ogólnie dostępnych. Do tych ostatnich należy projekt Cyfrowo Bezpieczni (www. cyfrowobezpieczni.pl). Objął on swoim zasięgiem już ponad 2,2 tys. szkół i prawie 170 tys. uczniów. Oprócz wspomnianych już form wsparcia to przedsięwzięcie umożliwia uzyskanie przez nauczyciela umiejętności szkolnego mentora cyberbezpieczeństwa, wzięcie udziału w konkursie "Jesteśmy cyfrowo bezpieczni" czy skontaktowanie się ze specjalistą w ramach punktu konsultacyjnego dla dyrektorów, nauczycieli i rodziców. Innym przykładem inicjatyw wspierających nauczycieli w ich działaniach ukierunkowanych na bezpieczeństwo online jest projekt fundacji Nowoczesna Polska i Collegium Civitas "Cybernauci - kompleksowy projekt kształtowania bezpiecznych zachowań w sieci" (www.cybernauci.edu.pl). Są to warsztaty dla uczniów, nauczycieli i rodziców, które oparte są na wymianie informacji między tymi grupami.

Oprócz działań skoncentrowanych na uświadamianiu adolescentom, jak bezpiecznie poruszać się w cyfrowym świecie, zadaniem edukatorów jest również pokazanie uczniom, jak mogą oni wykorzystywać nowoczesną technologię w procesie uczenia się. Coraz częściej dzieci i młodzież nie rozstają się ze swoimi urządzeniami mobilnymi - telefonami, tabletami, odtwarzaczami MP3/MP4. Według badań GUS z $2016 \mathrm{r}$. obejmujących gospodarstwa domowe aż 90 proc. dzieci w wieku 5-15 lat korzystało z komputera, 25 proc. - z konsoli do gier, a 44 proc. ze smartfona (Wójcik, 2017). Korzystanie z urządzeń mobilnych w szkole, szczególnie z telefonów komórkowych, jest często ograniczone regulaminami obowiązującymi w instytucjach oświatowych. Warto jednak podkreślić, że włączanie ich jako narzędzi do realizacji zajęć dydaktycznych może mieć sporo zalet. Przy użyciu telefonu komórkowego 
uczniowie mogą na przykład stworzyć interaktywny quiz czy podcast, nagrać krótki film, zdobywać wiedzę za pomocą przydatnych aplikacji. Korzystając ze swoich urządzeń mobilnych w czasie zajęć lekcyjnych, uczniowie mogą się również dowiedzieć, jak efektywnie wykorzystywać funkcje różnych urządzeń, tak by były one przydatne w nauce i przyswajaniu informacji z różnych dziedzin ${ }^{3}$.

\section{Program eTwinning jako bezpieczne środowisko współpracy szkół}

\section{za pośrednictwem mediów elektronicznych}

Program eTwinning można zdefiniować jako społeczność szkolną gromadzącą szkoły i przedszkola z całej Europy (choć nie tylko), współpracującą poprzez media elektroniczne ${ }^{4}$. Udział w programie oraz realizacja projektów za jego pośrednictwem w pełni odpowiadają wymogom współczesnej edukacji cyfrowej, pozwalając rozwijać umiejętności i kompetencje uczniów jako cyfrowych obywateli (Cassels, Gilleran, Morvan, Scimeca, 2016). Można wymienić wiele powodów, które wpływają na to, że program jest bezpiecznym i atrakcyjnym miejscem współpracy zarówno dla nauczycieli, jak i uczniów:

$\rightarrow$ w programie zarejestrowani są wyłącznie nauczyciele, których profile weryfikują Krajowe Biura Kontaktowe eTwinning,

$\rightarrow$ dane uczniów zaangażowanych w realizację projektów eTwinning oraz informacje zamieszczane przez nich w karcie projektu nie są powszechnie upubliczniane (uczniowie mogą bezpiecznie komunikować się ze sobą za pomocą narzędzi przestrzeni TwinSpace, tj. wewnętrznej poczty elektronicznej, forum i czatu),

$\rightarrow$ nauczyciele uczestniczący w projekcie oraz jego administratorzy decydują, które materiały wypracowane $w$ trakcie trwania projektu (np. prezentacje, filmy, zdjęcia) będą mieć status publiczny.

Poprzez aktywne uczestnictwo w realizacji projektów eTwinning uczniowie uczą się nie tylko tego, jak być odbiorcami treści cyfrowych, lecz także tego, jak je tworzyć (Cassels, Gilleran, Morvan, Scimeca, 2016). Rozwijanie tych umiejętności jest możliwe dzięki narzędziom do

3. Zob. Amann-Hechenberger, Buchegger, Schwarz, 2014, s. 55-66.

4. Źródło: www.etwinning.pl/czym-jest-etwinning/, dostęp 18.04.2018. 
współpracy, komunikacji oraz publikacji materiałów, z jakich uczniowie zarejestrowani w projekcie mogą korzystać. Należy podkreślić, że są to narzędzia, których uczniowie mogą bezpiecznie używać, ponieważ informacje wymieniane za ich pośrednictwem (forum, czat, system wideokonferencji, TwinMail, czyli skrzynka mailowa dostępna w karcie projektu) są niewidoczne publicznie. Karta projektu jest zatem bezpieczną przestrzenią nie tylko nauki, lecz także spotkań i wymiany informacji między młodymi ludźmi z różnych krajów partnerskich. Dzięki temu mogą oni pod nadzorem nauczycieli koordynujących projekt kształtować swoje kompetencje cyfrowe oraz właściwe zasady zachowania się w przestrzeni online.

To jednak nie wszystkie zalety programu eTwinning. Dzięki uczestnictwu w nim nauczyciele otrzymują wsparcie w rozwoju wiedzy i umiejętności związanych z bezpiecznym korzystaniem z mediów elektronicznych. Polscy nauczyciele mają możliwość wzięcia udziału w tygodniowym kursie prowadzonym na platformie Moodle - „Tydzień z e-safety" (www.etwinning.pl/kursy-internetowe) oraz dołączenia do międzynarodowej grupy Bringing eSafety into eTwinning projects (www.groups.etwinning.net/7617), w której ramach nauczyciele z całej Europy wymieniają się sprawdzonymi pomysłami na zapewnianie cyberbezpieczeństwa wśród dzieci i młodzieży.

\section{Jak legalnie korzystać z twórczości innych osób?}

Realizując projekt, wykonując zadanie domowe czy przygotowując się do przedstawienia, uczniowie często korzystają z materiałów opracowanych przez inne osoby (zdjęcia, pliki muzyczne, książki, artykuły). W świetle polskiego prawa autorskiego (Dz.U. 1994 nr 2, poz. 83) mamy prawo korzystać z wcześniej rozpowszechnionych utworów, które są już podmiotami prawa autorskiego, oraz dzielić się nimi w ramach tzw. dozwolonego użytku osobistego (Wrzesień-Gandolfo, 2014). Należy jednak pamiętać, że nie można tych dzieł rozpowszechniać bez zezwolenia właściciela autorskich praw majątkowych (Wrzesień-Gandolfo, 2014).

Nauczyciele, uczniowie oraz biblioteki mogą korzystać w celach edukacyjnych z rozpowszechnionych publicznie zasobów (z wyłączeniem oprogramowania i baz danych) pod pewnymi warunkami:

$\rightarrow$ utwory wykorzystywane są wyłącznie w ramach lekcji i zajęć szkolnych, 
$\rightarrow$ rozpowszechnianie utworów nie może wykraczać poza grupę uczniów, której prezentowany jest dany materiał,

$\rightarrow$ wykorzystywanie danego utworu w ramach działalności instytucji oświatowej, np. podczas imprez szkolnych, ale tylko pod warunkiem, że nie łączy się to pośrednio lub bezpośrednio z osiąganiem korzyści majątkowych i artyści wykonawcy oraz osoby odtwarzające utwory nie otrzymują wynagrodzenia (art. 31 ust. 2 ustawy o prawie autorskim) (Fidler 2015, Dozwolony użytek w edukacji - infografika).

W przypadku gdy nauczyciel lub uczniowie chcą podzielić się publicznie wytworami pracy własnej, w których wykorzystana została twórczość innych osób, należy bezwzględnie pamiętać o konieczności przestrzegania praw autorskich. Wplatając fragmenty utworu innej osoby do swojej pracy, należy go zacytować, czyli wskazać imię i nazwisko autora, a także źródło pochodzenia (Fidler, 2015).

Innym sposobem włączenia twórczości innych osób do swojej pracy może być skorzystanie $z$ utworów dostępnych do przetwarzania, kopiowania i rozpowszechniania na zasadzie tzw. otwartych licencji. Do najbardziej popularnych licencji tego typu, które regulują kwestie między ochroną praw autorskich a dzieleniem się twórczością, należą licencje Creative Commons. Opierają się na zasadzie, że twórca zawsze zachowuje prawa autorskie do utworu, jednocześnie umożliwiając innym kopiowanie i rozpowszechnianie. W zależności od typu licencji, jaka jest przyznana przez autora danemu utworowi, jego wykorzystywanie może odbywać się na różnych zasadach, np. wyłącznie w warunkach niekomercyjnych lub z ograniczeniem tworzenia utworów zależnych5.

W pracy edukacyjnej kwestii praw autorskich należy poświęcić szczególną uwagę. Warto przeprowadzić z uczniami osobną lekcję z tej tematyki, by zaznajomić ich z obowiązującymi przepisami, wyposażyć w umiejętność poszukiwania materiałów oraz ich legalnego wykorzystywania. W czasie lekcji dotyczącej tej tematyki warto również zapoznać uczniów z warunkami licencji Creative Commons, nauczyć ich wyszukiwania materiałów objętych wspomnianymi licencjami (np. poprzez wyszukiwarkę dostępną pod linkiem search.creativecommons.org/?lan$\mathrm{g}=\mathrm{en}$ ) oraz odpowiednio cytować wykorzystywany przez nich materiał. 


\section{Podsumowanie}

Zapewnienie uczniom warunków bezpiecznego korzystania z zasobów online jest ważnym elementem organizacji każdej placówki oświatowej. Cyberbezpieczeństwo jest zagadnieniem złożonym i dlatego konieczne jest przygotowanie oraz stosowanie rozwiązań uwzględniających potrzeby i realia szkolne. Aby nasze starania były skuteczne, należy przede wszystkim prowadzić efektywne działania profilaktyczne uświadamiające całej społeczności szkolnej zasady korzystania z technologii informacyjno-komunikacyjnych i zagrożenia płynące z ich użytkowania. Co więcej, szkoły powinny mieć procedury reagowania w konkretnych sytuacjach, a w przypadku ujawnienia lub podejrzenia na przykład cyberprzemocy - natychmiast interweniować.

Podejmując próbę odpowiedzi na pytanie, jak motywować dzieci i młodzież do odpowiedzialnego korzystania z mediów elektronicznych, można wysunąć tezę, że im więcej działań w tematyce e-bezpieczeństwa jest podejmowanych przez nauczycieli, rodziców i inne osoby zaangażowane w edukację, tym lepiej dla bezpieczeństwa uczniów online. Oprócz tradycyjnych form pracy $w$ tym zakresie na lekcjach informatyki i godzinach wychowawczych coraz częściej w działania z zakresu wspomnianej tematyki angażują się nauczyciele innych przedmiotów wykorzystujących na zajęciach nowoczesne technologie. Znaczącą rolę odgrywają tutaj nauczyciele języków obcych, którzy poza zadaniami i dyskusjami tematycznymi na zajęciach coraz chętniej biorą udział w międzynarodowych projektach online, w których zagadnienia e-bezpieczeństwa mają swoje ważne miejsce. Coraz częściej polskie szkoły organizują własne eventy edukacyjne lub angażują się w ogólnopolskie i międzynarodowe (np. jedno- lub kilkudniowe typu Dzień Bezpiecznego Internetu czy "Tydzień z e-safety"). Dodając do tego coraz liczniejsze oferty warsztatów dla uczniów, nauczycieli i rodziców z odpowiedzialnego korzystania z mediów elektronicznych, tworzony jest wielotorowy model oddziaływania na młode pokolenie, który wydaje się optymalnym rozwiązaniem w poruszanej tematyce. 


\section{Bibliografia}

$\rightarrow$ Amann-Hechenberger, B., Buchegger, B., Schwarz, S. (2014), Korzystanie z telefonu komórkowego w szkole. Zarzq̨dzanie szansami i zagrożeniami, Warszawa: Fundacja Rozwoju Systemu Edukacji.

$\rightarrow$ Kirwil, L. (2011), Polskie dzieci w Internecie. Zagrożenia i bezpieczeństwo-część 2. Częściowy raport z badań EU Kids Online II przeprowadzonych wśród dzieci w wieku 9-16 lat i ich rodziców, Warszawa: Szkoła Wyższa Psychologii Społecznej-EU Kids Online-PL.

$\rightarrow$ Livingstone, S., Haddon, L., Görzig, A., Ólafsson K. (2011), EU Kids Online, London: The London School of Economics and Political Science.

$\rightarrow$ Pyżalski, J. (2012), Agresja elektroniczna i cyberbullying jako nowe ryzykowne zachowania młodzieży, Kraków: Oficyna Wydawnicza "Impuls".

$\rightarrow$ Wójcik, Sz. (2017), Zagrożenia dzieci i młodzieży w Internecie [w:] M. Sajkowska (red.), Dzieci się liczq̨ 2017. Raport o zagrożeniach bezpieczeństwa i rozwoju dzieci w Polsce, Warszawa: Fundacja Dajemy Dzieciom Siłę, s. 270-287.

$\rightarrow$ Wrzesień-Gandolfo, A. (red.) (2014), Bezpieczeństwo dzieci online. Kompendium dla rodziców, nauczycieli i profesjonalistów, Warszawa: Polskie Centrum Programu Safer Internet. 


\section{Netografia}

$\rightarrow$ Cassels, D., Gilleran, A., Morvan, C., Scimeca, S. (2016), Rozwijanie świadomości cyfrowej obywatela. Aktywny rozwój postawy obywatelskiej poprzez eTwinning 2016, www.etwinning.net/eun-files/book2016/PL_eTwinningBook.pdf, dostęp 19.04.2018.

$\rightarrow$ Dbaj o fejs. Przewodnik dla młodzieży, www.dbajofejs.pl/files/dbajofejsfdn.pdf, dostęp 17.04.2018.

$\rightarrow$ Dozwolony użytek w edukacji-infografika, otwartawiedza.centrumcyfrowe.pl/ zasoby/dozwolony-uzytek-w-edukacji-infografika, dostęp 16.04.2018.

$\rightarrow$ Fidler, M. (2015), Zmiany w prawie autorskim - wyjaśnienia MEN dotyczące szkół i przedszkoli, www.portaloswiatowy.pl/komunikaty-men-i-cke/zmiany-w -prawie-autorskim-wyjasnienia-men-dotyczace-szkol-i-przedszkoli-12085. html, dostęp 16.04.2018. 



\section{Wyzwania i zagrożenia \\ przestrzeni cyfrowej dla edukacji \\ i aktywności zawodowej}

Anna Andrzejewska

Najnowsze rozwiązania technologiczne na niespotykaną dotąd skalę wzbogacają przestrzeń edukacyjną, a także aktywność zawodową człowieka. W sposób globalny wpływają na przemiany w edukacji, specjalistyczne badania i innowacyjne działania nauczyciela oraz ucznia. Mają ogromny wpływ na wykonywanie różnorodnych zawodów, a zatem zmianę paradygmatu wykonywanej pracy.

W artykule skoncentrowano się na wyzwaniach, a także zagrożeniach przestrzeni cyfrowej w tych obszarach. Poruszono w nim zagadnienia dotyczące:

1. Roli najnowszych technologii w edukacji.

2. Kompetencji cyfrowych w edukacji i aktywności zawodowej.

3. Zagrożeń przestrzeni cyfrowej jako wyzwania pedagogicznego.

\section{_ Słowa kluczowe:}

\section{edukacja}

kompetencje cyfrowe

aktywność zawodowa

wyzwania przestrzeni cyfrowej

zagrożenia przestrzeni cyfrowej 


\title{
Challenges and threats of the digital space for the education and the professional activity
}

\author{
Anna Andrzejewska
}

The latest technological solutions enrich on an unprecedented scale the educational space as well as the professional activity of a human being. In a global way they influence changes in the education, specialist research and innovative activities of the teacher and the student. They have a huge impact on the performance of various professions, and therefore change the paradigm of the work performed by humans. The article focuses on the challenges, but also on the threats of digital space in above mentioned areas. Especially the article is devoted to the problems of:

1. The role of the latest technologies in education.

2. Humans' digital competence in education and professional activity.

3. The threats of the digital space as a pedagogical challenge.

\section{_ Keywords: \\ education \\ digital competences \\ professional activity \\ challenges of the digital space \\ threats of the digital space}




\section{Wprowadzenie}

Powstające coraz doskonalsze komputery i inne urządzenia cyfrowe, tworzące świat nowych technologii informacyjno-komunikacyjnych, globalnie wpływają na przemiany w edukacji, specjalistyczne badania oraz innowacyjne działania nauczyciela i ucznia. Ma to ogromny wpływ na różnorodne zawody, a zatem zmianę paradygmatu wykonywanej pracy.

„Pod koniec XX wieku zaszły dwa procesy: konwergencja mediów cyfrowych oraz połączenie komputerów w sieci. Sprawiły one, że powstały równolegle do świata naturalnego cyberprzestrzeń i rzeczywistość wirtualna" (Tanaś, 2015, s. 7). Te światy tworzone przez urządzenia cyfrowe zapewniają nie tylko multimedialną i komunikacyjną łączność, lecz także jej globalny zasięg połączony z interakcyjnością i mobilnością. Powszechne staje się zastosowanie najnowszych rozwiązań cyfrowych w szkolnictwie ogólnym, zwłaszcza zawodowym. Te nowe cechy i jednocześnie wartości przemian stają się nowymi wyzwaniami dla rynku pracy. Nie bez znaczenia te przemiany ilościowe i jakościowe są dla pedagogiki pracy i mających z nią ścisły związek edukacji ustawicznej, edukacji dorosłych i potrzeb doskonalenia nowych kompetencji cyfrowych. Słuszny zatem jest postulat Bogusława Śliwerskiego: „Internet zmienił świat, a świat zmienia Internet. Edukacja nie może być spóźnionym włóczęgą w sieci" (Śliwerski, 2016, s. 38).

W dzisiejszym zmediatyzowanym i cyfrowym świecie ważne staje się zastanowienie nad dorobkiem społecznym i pedagogicznym, a także metodologicznym w zakresie celowego i odpowiedzialnego korzystania z najnowszych mediów oraz technologii cyfrowych. Uwaga ta jest istotna ze względu na rosnącą aktywność coraz większej rzeszy użytkowników w przestrzeni cyfrowej, zwłaszcza w odniesieniu do młodych osób, które z niezwykłą umiejętnością i sprawnością posługują się narzędziami nowych technologii. Znaczenia nabiera również refleksja nad rozwojem kompetencji cyfrowych nie tylko nauczycieli, lecz także osób zatrudnionych w różnych gałęziach gospodarki. „Współczesna, ale przede wszystkim przyszła praca zawodowa jest i będzie w coraz większym stopniu uzależniona od zdobyczy techniki i będących ich pochodną rozwiązań technologicznych. Tempo zmian w tym zakresie powoduje konieczność ciągłego uczenia się. Nie wystarczają już kompetencje zdobyte w szkole, na uczelni (edukacja formalna), należy je w umiejętny sposób uzupełnić i doskonalić na różnego rodzaju studiach 
podyplomowych, kursach specjalistycznych, szkoleniach praktycznych i warsztatach - w drodze pozaformalnej" (Kwiatkowski, 2016, s. 81).

W związku z tak dynamicznymi przemianami w obszarze mediów cyfrowych nie można pomijać konieczności zapewnienia bezpieczeństwa w przestrzeni cyfrowej zwłaszcza najmłodszemu pokoleniu. To nowe zadanie spoczywa na nauczycielach, którzy powinni nauczyć swoich wychowanków mądrego, krytycznego i selektywnego poruszania się w tym świecie. „Człowiek uwikłany w cyberprzestrzeni, rzeczywistości rozszerzonej i świecie wirtualnym, a nawet coraz bardziej od nich zależny, potrzebuje wiedzy na temat funkcji mediów cyfrowych, ich języka i kultury. Wydaje się, że współczesne media cyfrowe można sprowadzić do następujących funkcji edukacyjnych:

$\rightarrow$ narzędzi komunikacji społecznej,

$\rightarrow$ narzędzi nauczyciela i ucznia w procesach kształcenia i samokształcenia, a także ich nowej organizacji kształcenia, zwanej kształceniem zdalnym,

$\rightarrow$ organizatora czasu wolnego człowieka,

$\rightarrow$ przestrzeni jego aktywności poznawczej, twórczej, ludycznej i społecznej,

$\rightarrow$ narzędzia pracy i jej pola.

Każda z nich wymaga oglądu pedagogicznego. Pozorne podobieństwo mediów cyfrowych do tradycyjnych rodzi bowiem obawę o brak umiejętności posługiwania się nimi, nierespektowanie istotnych różnic kulturowych i społecznych, a także o niepożądane dydaktyczne i osobowe skutki. Wykorzystanie mediów cyfrowych w procesie kształcenia stwarza potrzebę nowej metodyki, wynikającej ze szczególnych cech narzędzia" (Tanaś, 2015, s. 14).

Biorąc pod uwagę wspomniany ogląd pedagogiczny, przedmiotem analiz w publikacji uczyniono następujące zagadnienia:

1. Rola najnowszych technologii w edukacji.

2. Kompetencje cyfrowe w edukacji i aktywności zawodowej.

3. Zagrożenia przestrzeni cyfrowej jako wyzwanie pedagogiczne.

\section{Rola najnowszych technologii w edukacji}

Postęp i rozwój w każdej dziedzinie nauki jest w większości efektem rozwoju technologii komputerowych i informatycznych. W znaczny 
sposób usprawniają one pracę człowieka. Pierwsze zastosowania komputerów w edukacji polegały tylko na jej wspomaganiu, obecnie stają się nieodłącznymi elementami każdej dziedziny nauczania. Rozwijająca się technologia umożliwia indywidualizację drogi kształcenia, a także personalizację podejścia do uczących się (zob. Siemieniecki, 2004, s. 52).

Rozporządzenie Ministra Edukacji Narodowej z 27 sierpnia 2012 r. w sprawie podstawy programowej wychowania przedszkolnego oraz kształcenia ogólnego w poszczególnych typach zawiera m.in. takie zadania: „Ważnym zadaniem szkoły podstawowej jest przygotowanie uczniów do życia w społeczeństwie informacyjnym. Nauczyciele powinni stwarzać uczniom warunki do nabywania umiejętności wyszukiwania, porządkowania i wykorzystywania informacji z różnych źródeł, z zastosowaniem technologii informacyjno-komunikacyjnych, na zajęciach z różnych przedmiotów" (Dz.U. z dn. 30.08.2012 r., poz. 977). Technologie informacyjno-komunikacyjne w bardzo dużym stopniu uatrakcyjniają proces uczenia się. Pozwalają osiągać lepsze wyniki w nauce i bardziej angażują samych uczniów w proces edukacyjny. llość informacji oraz ich ogromne zasoby pozwalają na swobodne dzielenie się nimi. Powszechny dostęp do multimediów sprzyja zwiększaniu kompetencji nauczycieli, a także uczniów.

„Świat mediów elektronicznych rozwija swe cyfrowe postacie, integruje i czyni atrakcyjniejszymi wizualnie, dźwiękowo i estetycznie swe komunikaty oraz urządzenia służące komunikacji i przetwarzaniu, zyskuje potężnych sprzymierzeńców w osobach i instytucjach promujących rzeczy materialne i niematerialne" (Tanaś, 2007, s. 11). Narzędzia technologiczne stale są zmieniane i udoskonalane, aby umożliwiać jak najlepsze użytkowanie. W procesie edukacyjnym natomiast poprzez ciekawą formę wpływają na uczenie się oraz zaspokajają potrzeby edukacyjne poprzez spełnianie swoich funkcji.

Dynamiczny rozwój multimediów spowodował, że tradycyjna szkoła odeszła do lamusa. Kształcenie z wykorzystaniem środków multimedialnych stwarza o wiele większe możliwości. Świadczy o tym chociażby oddziaływanie na różne zmysły, którym informacje przekazywane są wielotorowo. Najczęściej odbywa się to dzięki: modelom, materiałom audio, materiałom słownym i graficznym. W wyniku uruchomienia tylu bodźców uczeń aktywizuje się w sposób manualny, emocjonalny oraz intelektualny. Interpretując powyższe, nasuwa się pojęcie koncepcji nauczania wielostronnego. Skoncentrowane jest ono na kształceniu 
efektywnym, charakteryzującym się aktywnością ucznia (zob. Okoń, 2009 , s. 146). Potrzebę kształcenia z wykorzystaniem multimedialnych rozwiązań zauważa Józef Bednarek, stwierdzając, że jest ono "przedmiotem bardzo licznych prac naukowo-badawczych i publikacji [...]. Badania prowadzone w szkolnictwie wskazują, że media mogą nie tylko skutecznie wspomagać każde kształcenie, ale również samodzielnie organizować proces dydaktyczno-wychowawczy" (Bednarek, 2006, s. 90).

W tym kontekście ważny stał się aspekt cyfryzacji szkoły. Cyfrowa szkoła ma służyć pełnemu wykorzystaniu technologii informatycznych nie tylko na zajęciach komputerowych. Nowoczesna szkoła wykorzystująca w pełni nowe technologie i rozwijająca się tym samym z duchem czasu jest przede wszystkim dostępna dla każdego, bez względu na miejsce zamieszkania, pochodzenie czy status ekonomiczny.

Wśród korzyści, jakie niesie ze sobą cyfryzacja szkół, można wyróżnić możliwość wielokrotnego wykorzystania pewnych zasobów informacji, szybkiego dostosowania tematu zajęć do możliwości konkretnej klasy, przekazywanie informacji w postaci atrakcyjnych gier czy prezentacji oraz oszczędność czasu samego nauczyciela, ponieważ komputer automatycznie sprawdza wykonane zadania. Kolejnymi korzyściami są elastyczny czas uczenia się oraz możliwość wykonywania tej czynności w wybranym momencie.

Na mobilną technologię w obszarze edukacji składają się następujące elementy:

1. Urządzenia mobilne, czyli przenośne, które mają funkcje komputera $z$ bezprzewodowym dostępem do Internetu.

2. Bezprzewodowy dostęp do Internetu.

3. Wirtualne środowisko kształcenia (ang. Virtual Learning Environment -VLE), które służy do organizacji procesu kształcenia oraz przechowywania indywidualnych zasobów uczniów i nauczycieli, dostępne w każdej chwili i z dowolnego miejsca, w którym jest dostęp do Internetu. Szczególnym miejscem środowiska internetowego jest platforma edukacyjna, która może być również spersonalizowanym środowiskiem uczenia się. Pojęć tych używa się często wymiennie.

4. Dostosowanie organizacyjne - wykorzystanie wymienionych elementów do celów edukacyjnych w szkole oraz w domach uczniów. 
Najważniejszym elementem edukacji mobilnej jest wirtualne środowisko kształcenia, zapewniające internetowy dostęp do wielu elementów takich jak: aplikacje internetowe, zorganizowane grupy uczących się, np. klasy, zasoby edukacyjne gromadzone przez różne instytucje oraz do indywidualnych zasobów uczniów i nauczycieli. Zasoby te obejmują: materiały edukacyjne, zadania domowe, testy i oceny. Taka formacja umożliwia pracę zarówno zsynchronizowaną (grupa ma możliwość pracy w jednym czasie), jak i asynchroniczną (każdy może pracować sam, oddzielnie). To środowisko jest tworzone przez uczących się, ale i nauczających. Ponadto ma charakter społeczny dzięki takim narzędziom jak: spotkania, blogi, grupy dyskusyjne, czaty. Wirtualne środowiska kształcenia odgrywa ogromną rolę w kształceniu na odległość.

Do wskaźników charakteryzujących rolę cyfrowej szkoły w społeczeństwie informacyjnym (wiedzy) należy zaliczyć wiele nowych swoistych cech. Są nimi m.in.:

$\rightarrow$ czas wolny dzieci, bawiących się gadżetami elektronicznymi i grami komputerowymi,

$\rightarrow$ kształcenie, w którym obok tradycyjnego nauczyciela wykorzystuje się edukację na odległość, aplikacje multimedialne,

$\rightarrow$ praca realizowana w cyberprzestrzeni, e-biznes, e-administracja, e-usługi, pozwalające na niestandardowe i elastyczne formy zatrudnienia oraz aktywności zawodowej, do czego wykorzystuje się tworzenie informacji, jej przetwarzanie i wykorzystanie,

$\rightarrow$ produkcja, a w niej: rozwój sektora ICT, wzrost jego znaczenia w funkcjonowaniu pozostałych branż, w tym także wzrost wydatków inwestycyjnych na najnowsze technologie, cyfryzację gospodarki i usług teleinformatycznych,

$\rightarrow$ kultura i sztuka globalna, multimedialna i wirtualna o charakterze globalnym,

$\rightarrow$ sieciowość, dla której charakterystyczne są: sieć jako model współczesnego społeczeństwa i powstanie społeczności wirtualnych.

Do tych obszarów aktywności zawodowej należy się przygotować poprzez edukację dzieci i młodzieży w cyfrowej szkole. Jednocześnie należy prowadzić badania naukowe, by wzbogacić teorię i praktyki edukacyjne, szczególnie te dotyczące kształcenia na wszystkich jego poziomach, oraz modyfikację dotychczasowych tradycyjnych rozwiązań 
oświatowych, w których w coraz większym stopniu stosuje się wdrażane technologie informacyjne 1 . Wiele wyników badań nad cyfrową szkołą zostało przedstawionych w raportach Ministerstwa Edukacji Narodowej, Instytutu Badań Edukacyjnych, Ministerstwa Administracji i Cyfryzacji, Głównego Urzędu Statystycznego, PISA, Pearson, UNESCO oraz innych instytucji naukowych i edukacyjnych?2.

Należy bardzo mocno zaakcentować, że najważniejszymi elementami wirtualnego procesu kształcenia są uczeń oraz nauczyciel, który swoim zaangażowaniem, wiedzą teoretyczną i praktyczną decyduje o powodzeniu kształcenia mobilnego. Innowacyjny pedagog powinien rozbudzić pasję do nauki w wychowanku, kształtować w nim umiejętność analizy problemów, stawiania im czoła oraz szukania rozwiązań.

Warto również zwrócić uwagę, że „pomimo założeń programowych dotyczących przedmiotu technologie informacyjne, gdzie tematyka świadomego i umiejętnego korzystania z zasobów internetowych została już dawno ujęta [...]", młode pokolenie "nadal wykazuje braki w umiejętnościach odnajdywania, selekcjonowania i hierarchizowania informacji" (Olczak, 2008, s. 188). Potwierdza to założenie, że edukacyjna cyberprzestrzeń wciąż wymaga rozwoju, a program nauczania informatyki w szkołach musi być udoskonalony. Szczególnie że w dzisiejszych czasach zmieniają się role społeczne, co oznacza, że to młode pokolenie przybliża starszym zastosowania możliwości wirtualnego świata oraz naucza korzystania z nich.

\section{Kompetencje cyfrowe w edukacji i aktywności zawodowej}

Najnowsze technologie mają wpływ na szybkie zmiany rynku pracy. Nowe funkcje i zadania komputerów oraz technologii telekomunikacyjnych rzutują na zmiany struktury rynku i relacje społeczne. Typową

1. Badanie społeczne SA pt. Komponent badawczy rządowego programu Cyfrowa Szkoła prowadzone na zlecenie MAiC przez Millward Brown zostało przeprowadzone wśród uczniów klas IV roku szkolnego 2012/2013, Warszawa 2013.

2. Raporty i sprawozdania: Ministerstwo Edukacji Narodowej i Ministerstwo Administracji i Cyfryzacji, Sprawozdanie z realizacji „Rzq̨dowego programu rozwijania kompetencji uczniów i nauczycieli w zakresie stosowania technologii informacyjno-komunikacyjnych Cyfrowa Szkoła, Warszawa, 2013; Ministerstwo Administracji i Cyfryzacji (MAiC), Komponent badawczy Cyfrowa Szkoła", Warszawa 2013; Główny Urząd Statystyczny - dane statystyczne dotyczące m.in. wyników Narodowego Spisu Powszechnego z 2011 r., GUS - dane z 2012 r. dotyczące komputeryzacji szkół; inne raporty: m.in. firmy Pearson, $\mathrm{np}$. The Learning Curve. Education and skills for life, 2012. 
pracę fizyczną w wielu przypadkach zastępują technologie informacyjno-komunikacyjne, wykonują ją także roboty, w tym także humanoidalne. Pojawiają się nowe zawody, które nie były znane jeszcze kilka lat temu. W każdej dziedzinie gospodarki i niemal w większości zawodów kluczowego znaczenia nabierają kompetencje cyfrowe. Bardzo wiele zadań zawodowych wymusza na pracownikach umiejętność wyszukiwania, selekcji i przetwarzania informacji. Od poziomu tych kompetencji zależy innowacyjność firm, ich konkurencyjność, a także efektywność. Dlatego wielu pracodawców poszukuje pracowników, którzy w pełni rozumieją potrzebę funkcjonowania w technicznym świecie oraz sprawnie posługują się narzędziami nowych technologii. Za sprawą Internetu pokonywane są bariery w tworzeniu nowych firm, powstaje wiele zawodów, które można wykonywać zdalnie. Ewolucji ulega wiele branż, m.in. marketingowa czy usług medycznych.

W obliczu powyższych rozważań kluczowego znaczenia nabierają kompetencje cyfrowe. „Rozwój kompetencji cyfrowych jest istotny nie tylko w perspektywie ciągłego rozwoju nowych technologii, ale możliwości ich stosowania w rozmaitych obszarach życia, by efektywniej radzić sobie z różnego rodzaju wyzwaniami. Technologie cyfrowe przenikają bowiem - czy raczej należy powiedzieć: mogą przenikać - każdy aspekt naszego życia, pozwalając często na szybsze, wygodniejsze i tańsze radzenie sobie z codziennymi zadaniami: od zakupów, poprzez umawianie się na spotkanie towarzyskie, pracę zawodową, po naukę i płacenie rachunków" (Jasiewicz, Filiciak, Mierzecka, Śliwowski, Klimczuk, Kisilowska, Tarkowski, Zadrożny, 2018).

Znaczenie umiejętności korzystania z technologii jest coraz ważniejsze także dlatego, że czynnik ten staje się obecnie nowym wymiarem wykluczenia cyfrowego. Wraz z upowszechnieniem technologii informacyjno-komunikacyjnych sama dostępność sprzętu i korzystanie z nich przestają być czynnikiem różnicującym. Znacznie większe różnice ujawniają się między użytkownikami, którzy mają odpowiednie kompetencje i potrafią użyć technologii tak, by przynosiły korzyści i poprawiały ich sytuację życiową, a tymi, którzy ich nie posiadają, dla których komputery i Internet to przede wszystkim źródło rozrywki (Batorski, 2012).

Obszar umiejętności cyfrowych zawierają w sobie:

$\rightarrow$ łatwość korzystania z ogółu istniejących mediów, począwszy od gazet, a skończywszy na społecznościach wirtualnych, 
$\rightarrow$ aktywne użytkowanie mediów w wyniku stosowania interaktywnej telewizji, wyszukiwarek internetowych bądź przez udział w społecznościach wirtualnych oraz coraz lepsze wykorzystywanie potencjału mediów $\mathrm{w}$ dziedzinie rozrywki i dostępu do kultury, a także międzykulturowego dialogu, uczenia się oraz codziennych zastosowań,

$\rightarrow$ krytyczny stosunek do mediów, odnoszenie się do ich jakości oraz treści,

$\rightarrow$ kreatywne stosowanie mediów dzięki temu, że ewolucja technologii medialnej oraz Internetu umożliwia stale zwiększającej się liczbie użytkowników tworzenie oraz rozpowszechnianie komunikatów

$\rightarrow$ pojmowanie ekonomii mediów, a także rozumienie zależności między pluralizmem a własnością mediów,

$\rightarrow$ świadomość zagadnień wiążących się ściśle z prawami autorskimi, które są konieczne dla realizacji „kultury legalności”, zwłaszcza wśród młodszej generacji, która występuje zarówno jako konsumenci, jak i producenci treści (Bednarek, 2012).

Umiejętności korzystania z technologii odgrywają szczególnie istotną rolę dlatego, że to od nich zależy, w jaki sposób technologie informacyjno-komunikacyjne są wykorzystywane i jakie są tego efekty dla ich użytkowników. Innymi słowy, to, co dana osoba robi w Internecie, jak sprawnie porusza się w sieci, co potrafi w niej zrobić, przekłada się na to, jak radzi sobie w różnych sferach życia. Umiejętność dobrego wykorzystania Internetu jest istotna zarówno w edukacji, jak i dla pozycji na rynku pracy, uczestnictwa $w$ życiu społecznym i kulturze, a także dla podtrzymywania relacji społecznych i wielu innych obszarów (Batorski, 2012).

Za zagadnieniem kompetencji cyfrowych kryje się więc rozległy zbiór umiejętności, które zapewniają sprawne oraz świadome czerpanie z nowych technologii, a także aktywne uczestniczenie w życiu społeczeństwa informacyjnego (wiedzy).

Znaczenie kompetencji cyfrowych akcentowane jest w dokumencie Komisji Europejskiej Agenda cyfrowa dla Europy 2010-2020. Jest to dokument podkreślający rozwijanie wiedzy i umiejętności w zakresie medialnym oraz istnienie dysproporcji między tymi, którzy mają dostęp do technologii, a tymi, którzy takich możliwości nie mają. Zwraca się 
w nim uwagę, że należy podjąć działania mające na celu zmniejszenie podziałów i wykluczenia cyfrowego. W tym obszarze ogromna rola przypada szkołom, a więc także nauczycielom ${ }^{3}$.

Nowa rola i nowe miejsce edukacji cyfrowej wyrażają się w potrzebie przygotowania uczniów i dorosłych do natychmiastowego dostępu, za pośrednictwem mediów cyfrowych i technologii informacyjno-komunikacyjnych, do wiedzy ogólnej i specjalistycznej stającej się coraz silniejszym wyznacznikiem postępu, rozwoju społeczno-ekonomicznego i statusu każdego człowieka. W wielu zaleceniach Unii Europejskiej podkreśla się to, że kompetencje cyfrowe $w$ coraz większym stopniu stają się umiejętnością niezbędną w życiu indywidualnym i społecznym, a brak dostępu do technologii informacyjno-komunikacyjnych lub niezdolność czy nieumiejętność korzystania z nich stanowią poważne utrudnienie procesu pełnej integracji społecznej (i e-integracji), a także istotną barierę w rozwoju osobistym (Ogonowska, 2016).

$Z$ biegiem lat coraz więcej będzie technologii w naszym życiu, a kompetencje cyfrowe staną się motorem innowacyjnej gospodarki. Globalny trend związany ze stałym dostępem do informacji i ciągłych integracji społecznych wpisuje się w potrzeby i priorytety wchodzącego na rynek pracy pokolenia Z, dla którego Internet, a zwłaszcza media społecznościowe i inne technologiczne nowości są oczywistością i które nie ma barier w posługiwaniu się nimi. $Z$ racji tego, że pokolenie $Z$ dopiero wchodzi w dorosłe życie i niewielka liczba jego przedstawicieli rozpoczęła budowanie kariery, badania na temat ich oczekiwań wobec życia i pracy są dopiero w początkowej fazie. Jednak już mówi się o tym pokoleniu, że będzie miało duży wpływ na otaczający świat, zrewolucjonizuje i unowocześni rzeczywistość, w której żyjemy, a nawet może ją zmienić na niespotykaną skalę.

Dlatego ważne staje się w obliczu rozwoju nowych technologii przygotowanie przyszłych absolwentów studiów do wykonywania nowych zawodów w obszarze cyberprzestrzeni, co jest szczególnie istotne dla procesu kształcenia w ramach specjalności edukacja medialna prowadzonej przez Zakład Edukacji Medialnej Akademii Pedagogiki Specjalnej im. Marii Grzegorzewskiej. Ich charakterystyki zostały opracowane

3. Por. Komunikat Komisji do Parlamentu Europejskiego, Rady, Europejskiego Komitetu Ekonomiczno-Społecznego i Komitetu Regionów. Europejska agenda cyfrowa, eur-lex.europa. eu, dostęp 23.08.2016. 
przez Józefa Bednarka i Annę Andrzejewską oraz wprowadzone 1 lipca 2010 r. do Klasyfikacji zawodów i specjalności. Są to:

$\rightarrow$ metodyk multimedialny (2351044),

$\rightarrow$ pedagog medialny (235107),

$\rightarrow$ metodyk edukacji na odległość (235103),

$\rightarrow$ specjalista ds. uzależnień od mediów cyfrowych (263305).

Zawody te stanowią podstawę do opracowania nowych specjalności studiów pedagogicznych, a także studiów podyplomowych - doskonalących i kwalifikacyjnych.

\section{Zagrożenia przestrzeni cyfrowej jako wyzwanie pedagogiczne}

Epoka cyfrowa ma ogromny wpływ na współczesnych młodych jej użytkowników. Powszechność technologii postawiła przed nimi duże wyzwania. Nie jest łatwo przyjąć nadmiar informacji, które napływają ze wszystkich stron. Trudno jest także zachować równowagę między dwiema rzeczywistościami: realną i wirtualną. Zadziwia to, że młodzi ludzie doskonale sobie z tym radzą. „Wydaje się, że nowinki techniczne nigdy im się nie przejedzą, a ich talent do wszystkiego, co cyfrowe, jest zadziwiający" (Tapscott, 2010, s. 51). Młodzi ludzie nie doświadczają już rzeczywistości bezpośrednio. Wszystko dociera do nich poprzez media. "Realne jest to, co się dzieje na ekranie telewizora lub komputera" (Bendyk, 2004, s. 94). „Dla niektórych osób życie wirtualne jest tak pociągające, iż staje się ono życiem podstawowym. W cyberprzestrzeni tworzą swój własny, zamknięty świat - ograniczony do najbliższej przestrzeni życiowej, składającej się z kuchni, łóżka i komputera. Kiedy są z dala od niej, czują się źle, a czas spędzony w inny sposób uznają za stracony" (Andrzejewska, 2009, s. 176).

„Problematyka wyzwań cywilizacyjnych, społeczno-kulturowych, edukacyjno-wychowawczych i wielu innych nigdy dotąd nie była tak ważna jak obecnie. Ich znaczenie i miejsce wynika z wyjątkowej dynamiki różnorodnych przemian, zwłaszcza informacyjno-technologicznych. $Z$ tego powodu podejmowane zagadnienia są przedmiotem zainteresowania przedstawicieli wszystkich dyscyplin naukowych, poszczególnych

4. W nawiasach podano numer zawodu i specjalności. 
środowisk akademickich, nauczycieli i pedagogów i wielu innych specjalistów związanych z profilaktyką, diagnozą i terapią oraz legislacją. Są one także podstawą doskonalenia różnorodnych teorii, koncepcji, głoszonych idei, przyjmowanych strategii, raportów, dyrektyw, a także założeń kształcenia w postaci planów i programów oraz działalności naukowo-badawczej środowisk akademickich. Stanowią bogaty obszar refleksji teoretycznej i powstających koncepcji oraz jednocześnie działań praktycznych, realizowanych przez nauczycieli. Wynikają one z nowych wyzwań multimedialnego kształcenia ustawicznego" (Bednarek, 2010, s. 9).

W kontekście tych analiz niezwykle istotnego znaczenia nabiera problematyka zagrożeń powodowanych przez cyfrowy świat. Komputer i Internet coraz częściej towarzyszą młodym ludziom w poszukiwaniu odpowiedzi na nurtujące ich pytania. W przestrzeni wirtualnej oprócz uzyskania na nie odpowiedzi młody człowiek napotyka także wiele pułapek i niebezpieczeństw, których niejednokrotnie nie jest świadom. Zagrożenia te mają wielowymiarowy charakter. Chodzi tu nie tylko o dostęp do nieodpowiednich treści, lecz także niebezpieczeństwo chorób wzroku, układu mięśniowo-szkieletowego, chorób psychicznych. Szczególnie niepokojące są uzależnienia, a także coraz bardziej nasilające się specyficzne zachowania związane z realizowaniem różnorodnych form przemocy i agresji w świecie zarówno wirtualnym, jak i rzeczywistym, zmiany o charakterze społecznym oraz zagrożenia z zakresu etyki, zanik samodzielnego myślenia i pogłębionej refleksji. Problem ten nie dotyczy już pojedynczych osób, ale jest zjawiskiem mającym charakter masowy, jest niezwykle dynamiczny i występuje powszechnie. Od kilku lat jego siła i zasięg się nasilają.

Zagrożenia generowane przez to nowe środowisko dotyczą wszystkich, jednak nie wszyscy $w$ takim samym stopniu je rozumieją i przeżywają. Ich skutki mają ogromny wpływ na teraźniejsze i przyszłe życie dzieci oraz młodzieży. Wzrost nadużyć internetowych jest bardzo niepokojący i z roku na rok staje się coraz większym problemem. Większości udaje się uniknąć toksycznych relacji i traumatycznych wydarzeń, jednak istnieje bardzo duża grupa młodych użytkowników, którzy ulegają magii świata wirtualnego i często podejmują różne ryzykowne zachowania w świecie nie tylko wirtualnym, lecz także realnym.

Problemy związane z zagrożeniami cyberprzestrzeni są nowym zjawiskiem, jeszcze niewystarczająco rozpoznanym na gruncie nauk 
społecznych i humanistycznych. W Polsce do tej pory nie przeprowadzono kompleksowych ani interdyscyplinarnych badań w tym zakresie, uwzględniających negatywne skutki dla jednostki dotkniętej zagrożeniem ze strony wirtualnego świata. Dlatego u progu trzeciego tysiąclecia te nowe zjawiska stają się coraz większym wyzwaniem dla wielu środowisk zajmujących się wychowaniem.

„Współczesny świat i jego rozwój, a także funkcjonowanie w nim człowieka (zwłaszcza najmłodszego pokolenia) zmienił się na niespotykaną skalę. Dynamika tych przeobrażeń, w każdej dziedzinie, będzie jeszcze większa, powszechna, ale też nie w pełni przewidywalna za sprawą technologii informacyjno-komunikacyjnych i mediów cyfrowych. To one, w jeszcze większym stopniu niż w poprzednich wiekach, powodują chaos aksjologiczny, zjawisko globalizacji i niepewności, szybkie przenikanie różnych informacji, trudności w adaptowaniu się ludzi do nowych wyzwań, rodzenie się nowych zagrożeń, jakże odmiennych od dotychczasowych, z którymi w przeszłości też sobie człowiek nie radził" (Bednarek, Andrzejewska, 2017, s. 25).

Nowe obszary badań naukowych związane z niebezpieczeństwami komputera, Internetu i telefonii komórkowej wobec dzieci, młodzieży, dorosłych i osób starszych obejmują grupy konkretnych zagrożeń. Warto zatem przedstawić obecnie tworzoną i uzupełnianą klasyfikację tych zagrożeń mających bezpośredni czy pośredni wpływ na powstawanie patologii związanych z siecią (ze światem wirtualnym). Są one szerzej omawiane w publikacjach, w których zaliczono do nich zagrożenia:

$\rightarrow$ zdrowia psychicznego i fizycznego: dolegliwości wzroku, wady słuchu, dolegliwości układu kostno-mięśniowego, dolegliwości cieśni nadgarstka, dolegliwości kciuka, schorzenia innych narządów, autodestrukcja, samookaleczenie, samobójstwa w cyberprzestrzeni, zaburzenia rozwoju psychofizycznego człowieka.

$\rightarrow$ społeczno-wychowawcze: cyberbullying, przemoc i agresja w sieci, hazard w sieci, second life, sekty w świecie wirtualnym, handel żywym towarem i organami, zaburzenie kontaktów interpersonalnych, funkcjonowanie człowieka w świecie robotów humanoidalnych, człowiek w społeczeństwie nadzorowanym.

$\rightarrow$ Poznawczo-intelektualne: korzystanie z gadżetów elektronicznych i innych, związane z brakiem przeżywania, nieumiejętnością rozwiązywania problemów i działania w zakresie poznawania i opanowania wiedzy. 
$\rightarrow$ substancjami chemicznymi: bigoreksja, narkotyki, lekarstwa, napoje energetyzujące, dopalacze, suplementy diety $i$ inne.

$\rightarrow$ moralne: cyberpornografia, prostytucja w sieci, cyberpedofilia, cyberseks, seksting, gadżety erotyczne, nadzorowanie i kontrola człowieka, subkultury młodzieżowe.

$\rightarrow$ infoholizm i zagrożenia, które niosą gry komputerowe. Obejmują przyczyny, przebieg i skutki zagrożeń oraz uzależnień.

$\rightarrow$ związane z przestępczością teleinformatyczną: przestępstwa przeciwko ochronie informacji, hacking komputerowy, podsłuch komputerowy, bezprawne niszczenie informacji, sabotaż komputerowy, łamanie praw autorskich, przestępstwa przeciwko wiarygodności dokumentów, cracking, wirusy komputerowe, przechowywanie i zajęcie danych komputerowych oraz wirtualne przestępstwa finansowe (zob. Andrzejewska, 2014; Andrzejewska, Bednarek 2015; Bednarek 2014).

\section{Podsumowanie}

Problematyka współczesnych wyzwań i zagrożeń, jakie niesie przestrzeń cyfrowa w obszarze edukacji i aktywności zawodowej, staje się globalnym i jednocześnie uniwersalnym problemem dla globalnej społeczności świata realnego i wirtualnego. Szczególne znaczenie tej problematyki podkreślane jest w najnowszych raportach światowych, Unii Europejskiej i Polski. Są to bowiem najważniejsze i jednocześnie perspektywiczne obszary oraz kierunki działalności decydujące o przyszłości świata w kontekście priorytetów, jakimi będzie się kierować ludzkość u progu trzeciego tysiąclecia.

Rozwój i zastosowanie najnowszych technologii i mediów cyfrowych w edukacji nie tylko istotnie zmienia, lecz także burzy kanony wielowiekowych osiągnięć edukacji związanych z ponadczasowymi wartościami dla najmłodszego pokolenia. W przeszłości dzieci i młodzież w toku edukacji oraz kształcenia przygotowywani byli przez rodziców, nauczycieli i wychowawców do bezpiecznego oraz odpowiedzialnego funkcjonowania w świecie realnym. Gwałtownie i dynamicznie pojawiające się najnowsze rozwiązania technologiczne powiązane ze sztuczną inteligencją diametralnie zmieniają nie tylko organizację i przebieg pracy zawodowej, lecz także ważniejsze podstawowe funkcje i zadania szkoły związane z przygotowaniem uczących się do nowych wyzwań edukacyjnych, przed jakimi staje szkoła bez względu na poziom i specyfikę kształcenia. 
W tym kontekście istnieje zatem potrzeba kształtowania i doskonalenia nowych kompetencji cyfrowych zarówno uczniów, bez względu na ich wiek, jak i nauczycieli każdego poziomu oraz kierunku kształcenia. Są one ściśle powiązane z szeroko rozumianymi kompetencjami społecznymi, pedagogicznymi, emocjonalnymi i metodycznymi. Poziom ich wykształcenia w szkole decyduje o przyszłym awansie, sukcesie i mobilności zawodowej w nowych uwarunkowaniach e-pracy, niestandardowych i elastycznych formach zatrudnienia związanych z e-zawodami.

Zupełnie nowym wyzwaniem społecznym, pedagogicznym stają się zagrożenia związane z przestrzenią cyfrową. O ile powszechne przez całe stulecia było kształcenie i wychowanie do celowego i świadomego korzystania z możliwości realnego świata, o tyle obecnie pojawia się swoisty paradoks polegający na braku edukacji dla bezpiecznego funkcjonowania najmłodszego pokolenia w cyfrowym świecie. Swoisty dysonans między potrzebami w tym zakresie a możliwościami aktywności najmłodszego pokolenia w tym środowisku będzie się powiększał. Także nowe wyzwania cywilizacyjne z powszechnie znaną lukq ludzkq̨ nabierać będą nowego wymiaru. Z tego też powodu działalność naukowo-badawcza, edukacyjna, dydaktyczna, informacyjno-promocyjna i medialna związana z sygnalizowaniem nowych wyzwań nabiera nowego znaczenia. 


\section{Bibliografia}

$\rightarrow$ Andrzejewska, A., Bednarek, J. (red.) (2014), Zagrożenia cyberprzestrzeni i świata wirtualnego, Warszawa: Wydawnictwo Difin.

$\rightarrow$ Andrzejewska, A. (2014), Dzieci i młodzież w sieci zagrożeń realnych i wirtualnych. Aspekty teoretyczne i empiryczne, Warszawa: Wydawnictwo Difin.

$\rightarrow$ Andrzejewska, A. (2009), Świat wirtualny kreatorem rzeczywistości dziecka [w:] J. Bednarek, A. Andrzejewska (red.), Cyberświat-możliwości i zagrożenia, Warszawa: Wydawnictwo Akademickie "Żak".

$\rightarrow$ Badanie społeczne prowadzone na zlecenie MAiC przez Millward Brown SA pt. Komponent badawczy rządowego programu Cyfrowa Szkoła, Warszawa 2013.

$\rightarrow$ Bednarek, J. (red.) (2014), Człowiek w obliczu szans cyberprzestrzeni i świata wirtualnego, Warszawa: Wydawnictwo Difin.

$\rightarrow$ Bednarek, J., Andrzejewska, A. (red.) (2015), Cyberprzestrzeń. Człowiek. Edukacja. Dylematy społeczności cyfrowej, Kraków: Wydawnictwo Akademii Pedagogiki Specjalnej, NASK, Oficyna Wydawnicza "Impuls".

$\rightarrow$ Bednarek, J., Andrzejewska, A. (2017), Społeczno-edukacyjne konteksty przemian informacyjno-cywilizacyjnych, „Zeszyty Naukowe Uczelni Warszawskiej im. Marii Skłodowskiej-Curie", nr 1(55).

$\rightarrow$ Bednarek, J. (2006), Multimedia w kształceniu, Warszawa: Wydawnictwo Naukowe PWN.

$\rightarrow$ Bednarek, J. (2010), Multimedialne kształcenie ustawiczne nauczycieli. Teoria, badania, praktyka, Warszawa: Wydawnictwo Wyższej Szkoły Pedagogicznej TWP.

$\rightarrow$ Bednarek, J. (2012), Nowe kompetencje medialne społeczeństwa wiedzy [w:] W. Skrzydlewski, S. Dylak (red.), W stronę edukacji medialnej, Poznań-Rzeszów: Wydawnictwo Polskiego Towarzystwa Technologii i Mediów Edukacyjnych.

$\rightarrow$ Bendyk, E. (2004), Antymatrix. Człowiek w labiryncie sieci, Warszawa: Wydawnictwo W.A.B. 
$\rightarrow$ Główny Urząd Statystyczny - dane statystyczne dotyczące m.in. wyników Narodowego Spisu Powszechnego z 2011 r.

$\rightarrow$ GUS - dane z 2012 r. dotyczące komputeryzacji szkół.

$\rightarrow$ Komponent badawczy Cyfrowa Szkoła (2013), Warszawa: Ministerstwo Administracji i Cyfryzacji (MAiC).

$\rightarrow$ Kwiatkowski, S.M., Kolejny etap współpracy pedagogów z Polski i Ukrainy , "Edukacja Zawodowa i Ustawiczna, Polsko-Ukraiński Rocznik Naukowy", nr 1/2016.

$\rightarrow$ Ogonowska, A., Kompetencje cyfrowe we współczesnej cywilizacji medialnej, „Annales Universitatis Paedagogicae Cracoviensis Studia de Cultura”, VIII(2)/2016.

$\rightarrow$ Okoń, W. (2009), Elementy dydaktyki szkoły wyższej, Warszawa: PWN.

$\rightarrow$ Olczak, R. (2008), Internet - wiarygodne czy niewiarygodne źródło informacji [w:] T. Lewowicki, B. Siemieniecki (red.), Media w edukacji-szanse i zagrożenia, Toruń: Wydawnictwo Adam Marszałek.

$\rightarrow$ Rozporządzenie Ministra Edukacji Narodowej z dn. 27.08.2012 r. w sprawie podstawy programowej wychowania przedszkolnego oraz kształcenia ogólnego w poszczególnych typach szkół, Dz.U. z dn. 30.08.2012 r., poz. 977.

$\rightarrow$ Sprawozdanie z realizacji Rządowego programu rozwijania kompetencji uczniów i nauczycieli w zakresie stosowania technologii informacyjno-komunikacyjnych Cyfrowa Szkoła, Ministerstwo Edukacji Narodowej oraz Ministerstwo Administracji i Cyfryzacji.

$\rightarrow$ Śliwerski, B., Czy sieć zastąpi szkołę i rodziców w edukacji i wychowaniu? - nowe wyzwania dla rodziców i systemu edukacji [w:] M. Tanaś (red.) (2016), Nastolatki wobec Internetu, Warszawa: Wydawnictwo NASK.

$\rightarrow$ Tanaś, M., Prolegomena do pedagogiki medialnej, M. Tanaś, S. Galanciak (red.) (2015), Cyberprzestrzeń. Człowiek. Edukacja. Cyfrowa przestrzeń kształcenia, Kraków: APS, NASK, Oficyna Wydawnicza "Impuls".

$\rightarrow$ Tanaś, M. (2007), O potrzebie pedagogicznej refleksji nad kulturą i językiem mediów [w:] M. Tanaś (red.), Kultura i język mediów, Kraków: Oficyna Wydawnicza "Impuls".

$\rightarrow$ Tapscott, D. (2010), Cyfrowa dorosłość. Jak pokolenie sieci zmienia nasz świat, tłum. P. Cypryański, Warszawa: Wydawnictwa Akademickie i Profesjonalne.

$\rightarrow$ Raport, The Learning Curve. Education and skills for life, Pearson, 2012. 


\section{Netografia}

$\rightarrow$ Batorski, D., Stan kompetencji z zakresu edukacji medialnej i informacyjnej w Polsce [w:] J. Lipszyc (red.) (2012), Cyfrowa przyszłość. Edukacja medialna i informacyjna w Polsce - raport otwarcia, Warszawa: Wydawnictwo Fundacja Nowoczesna Polska, nowoczesnapolska.org.pl/wp-content/uploads/2012/01/Raport-Cyfrowa-Przysz\% C5\% 820\% C5\% 9B\% C4\% 87-.pdf, dostęp 22.05.2018.

$\rightarrow$ Jasiewicz, J., Filiciak, M., Mierzecka, A., Śliwowski, K., Klimczuk, A., Kisilowska, M., Tarkowski, A., Zadrożny, J., Ramowy Katalog Kompetencji Cyfrowych, cppc. gov.pl/wp-content/uploads/zal.-13-Ramowy_katalog_kompetencji_cyfrowych. pdf, dostęp 18.05.2018.

$\rightarrow$ Komunikat Komisji do Parlamentu Europejskiego, Rady, Europejskiego Komitetu Ekonomiczno-Społecznego i Komitetu Regionów. Europejska agenda cyfrowa, http://eur-lex.europa.eu, dostęp 23.08.2016. 



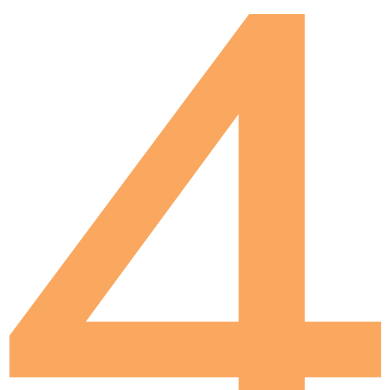




\section{Kompetencje społeczne nauczycieli}




\section{Od psychologii do edukacji: zasady podnoszenia \\ skuteczności nauczania \\ i wychowania}

Przemysław Bąbel

Metody nauczania i wychowania powinny wywodzić się z praw odkrytych w badaniach podstawowych, a ich skuteczność powinna zostać zweryfikowana w badaniach naukowych. Źródłem skutecznych metod nauczania są wyniki badań nad pamięcią, a skutecznych metod wychowawczych - wyniki badań z zakresu analizy zachowania. Wyniki badań pamięci są proponowane jako podstawa skutecznych praktyk w nauczaniu, a wyniki badań przeprowadzonych w ramach analizy behawioralnej są proponowane jako podstawa skutecznych praktyk wychowania.

\section{Słowa kluczowe:}

\section{analiza zachowania}

praktyki oparte na dowodach

w pedagogice i nauczaniu

pamięć 


\section{From psychology to education: principles of increasing \\ the effectiveness of teaching \\ and upbringing}

Przemysław Bąbel

There are two equally important key aims of education: instruction and upbringing. It is argued that that both aims should be achieved by evidence-based practices in pedagogy and teaching. Practices in instruction and upbringing should be based on the rules derived from the results of the basic science studies. Moreover, the effectiveness of those practices should be empirically verified. The results of the studies on memory are proposed as a basis for effective practices in instruction; and the results of the studies conducted within behavior analysis are proposed as a basis for effective practices in upbringing.

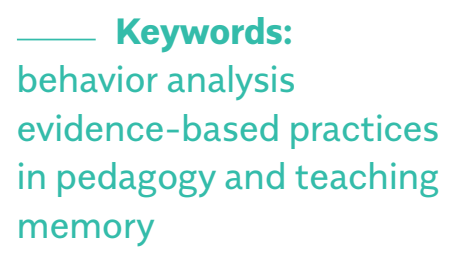




\section{Wprowadzenie}

Prawo oświatowe już w preambule wyróżnia dwie funkcje oświaty: nauczanie i wychowanie. „Nauczanie i wychowanie [...] za podstawę przyjmuje uniwersalne zasady etyki. Kształcenie i wychowanie służy rozwijaniu u młodzieży poczucia odpowiedzialności, miłości Ojczyzny oraz poszanowania dla polskiego dziedzictwa kulturowego, przy jednoczesnym otwarciu się na wartości kultur Europy i świata" (ustawa z dn. 14.12.2016 r. Prawo oświatowe). Artykuł pierwszy tejże ustawy także wyraźnie wskazuje na te dwie funkcje systemu oświaty, który „zapewnia w szczególności:

1) realizację prawa każdego obywatela Rzeczypospolitej Polskiej do kształcenia się oraz prawa dzieci i młodzieży do wychowania i opieki, odpowiednich do wieku i osiągniętego rozwoju;

2) wspomaganie przez szkołę wychowawczej roli rodziny;

3) wychowanie rozumiane jako wspieranie dziecka w rozwoju ku pełnej dojrzałości w sferze fizycznej, emocjonalnej, intelektualnej, duchowej i społecznej, wzmacniane i uzupełniane przez działania z zakresu profilaktyki problemów dzieci i młodzieży [...] (ustawa z dn. 14.12.2016 r. Prawo oświatowe).

Warto zwrócić uwagę, że ustawa nie daje prymatu żadnej z tych funkcji, a zatem szkoła powinna w równej mierze zapewnić nauczanie i wychowanie. Rodzi się pytanie, jakie to nauczanie i to wychowanie powinny być? Prawo oświatowe daje w tym zakresie pewne wskazówki. Artykuł 44 ust. 3 mówi: „Minister właściwy do spraw oświaty i wychowania określi, w drodze rozporządzenia, w odniesieniu do różnych typów szkół i rodzajów placówek, wymagania wobec szkół i placówek, dotyczące prawidłowości i skuteczności działań, o których mowa w ust. 1, w zakresie: 1) przebiegu procesów kształcenia, wychowania i opieki; [...] 6) uzyskiwanych efektów kształcenia i wychowania" (ustawa z dn. 14.12.2016 r. Prawo oświatowe).

Z kolei zgodnie z art. 55 ust. 3: „Nauczyciele, o których mowa w art. 60 ust. 8, wykonujący czynności z zakresu nadzoru pedagogicznego, mają prawo: [...] 6) przeprowadzania badań służących ocenie efektywności działalności dydaktycznej, wychowawczej oraz opiekuńczej szkół i placówek" (ustawa z dn. 14.12.2016 r. Prawo oświatowe). Podobnie art. 60 ust. 9 głosi, że „Kurator oświaty oraz organy, o których mowa w ust. 1 i 4 oraz $w$ art. 53 i art. 54, mogą zlecać wyspecjalizowanym instytucjom lub osobom posiadającym odpowiednie kwalifikacje pro- 
wadzenia badań i opracowywania ekspertyz służących ocenie efektywności działalności dydaktycznej, wychowawczej oraz opiekuńczej szkół i placówek" (ustawa z dn. 14.12.2016 r. Prawo oświatowe).

Ze wskazanych przepisów dość jednoznacznie wynika, że nauczanie i wychowanie mają być skuteczne. Co to jednak znaczy?

\section{Oparte na dowodach metody nauczania i wychowania}

Wybierając metody oddziaływania, nie tylko edukacyjne, mamy tendencję do opierania się na własnym lub cudzym doświadczeniu. Zasadniczo jest to strategia przystosowawcza: jeśli z mojego doświadczenia albo z doświadczenia koleżanki wynika, że jakaś metoda okazała się skuteczna w przeszłości w podobnej sytuacji, to powinna zadziałać i tym razem. Dlatego na przykład tak popularna jest homeopatia - jeśli odczuwamy pozytywne skutki po przyjęciu środka homeopatycznego albo ktoś z naszych znajomych je odczuwa, to mamy tendencję do przyjmowania środków homeopatycznych w przypadku podobnych schorzeń w przyszłości. Czy jednak to, że po zażyciu środków homeopatycznych ludzie czują się lepiej, znaczy, że właśnie homeopatia doprowadziła do tego efektu? Ani na podstawie własnego doświadczenia, nawet wielokrotnego, ani na podstawie anegdotycznych historii innych, chociażby najbardziej zaufanych osób nie możemy odpowiedzieć na to pytanie z co najmniej dwóch powodów. Po pierwsze, brakuje nam porównania, co działoby się, gdybyśmy nie przyjęli środków homeopatycznych? Może wyzdrowielibyśmy tak samo szybko? A może nawet szybciej? Przyczyny tego, że zdrowiejemy po zażyciu środków homeopatycznych, mogą leżeć gdzie indziej. Na przykład w spontanicznej remisji - ludzie wychodzą z chorób często bez żadnego leczenia. Zazwyczaj też stosujemy kilka różnych metod leczniczych jednocześnie, na przykład przyjmowaniu środków homeopatycznych może towarzyszyć przyjmowanie innych leków, więc przyczyną zdrowienia może być równie dobrze homeopatia, jak i inne leki albo i jedno, i drugie. Po drugie, gdybyśmy nawet stosowali środki homeopatyczne przy co drugim zachorowaniu (albo tylko u jednego dziecka, a u drugiego nie), żeby porównać ich efekty ze skutkami nieprzyjmowania środków homeopatycznych, to nadal nie moglibyśmy odpowiedzieć na pytanie, czy homeopatia działa, ponieważ choroby mogą się różnić zarówno u tego samego dziecka, jak i u dwojga dzieci. Reasumując, na podstawie własnego doświadczenia ani doświadczenia innych nie możemy 
odpowiedzieć na pytanie, czy jakaś metoda leczenia lub jakaś interwencja, np. metoda nauczania, są skuteczne.

Żeby móc określić skuteczność jakiegoś oddziaływania, musimy wylosować odpowiednio dużą grupę osób, które cierpią na jakąś dolegliwość, np. ból przewlekły, albo mają jakąś potrzebę, np. zwiększenia skuteczności zapamiętywania. Następny krok to wylosowanie spośród tych osób dwóch podgrup - jednej, która zostanie poddana temu oddziaływaniu, i drugiej, która nie zostanie mu poddana, ale zostanie poddana oddziaływaniu pozorowanemu (placebo, np. otrzyma tabletkę niezawierającą aktywnej substancji), względnie zostanie poddana innemu oddziaływaniu, którego skuteczność została dowiedziona we wcześniejszych badaniach. Po zakończeniu interwencji porównujemy obie grupy. Jeśli grupa, w której zastosowaliśmy nowe, badane oddziaływanie (np. lek przeciwbólowy albo trening pamięci), będzie funkcjonowała istotnie lepiej niż druga grupa, czyli ta w której tego oddziaływania nie zastosowaliśmy albo zastosowaliśmy pozorowane działanie (placebo), lub co najmniej tak samo dobrze jak grupa, w której zastosowaliśmy inne oddziaływanie o dowiedzionej skuteczności, to będziemy mogli powiedzieć, że ta nowa interwencja jest skuteczna, czyli jej działanie jest oparte na dowodach. Tego typu badania nazywamy randomizowanymi kontrolowanymi badaniami (ang. randomized controlled trials).

Dlaczego tak ważny jest aspekt losowania? Ponieważ zapewnia on, że badana próba będzie podobnie zróżnicowana jak populacja (np. znajdą się w niej osoby o różnych, istotnych z perspektywy choroby lub potrzeb uwarunkowaniach), a w każdej z badanych grup te różnice rozłożą się podobnie (np. osoby o podobnych uwarunkowaniach znajdą się w każdej z grup). To jest coś, czego nie może nam zapewnić własne doświadczenie.

Zanim jednak będziemy mogli powiedzieć, że dane oddziaływanie jest skuteczne, takie badanie musi zostać wielokrotnie powtórzone (zreplikowane). Dopiero jeśli wyniki serii badań, prowadzonych przez różne zespoły badawcze, często przy użyciu różnych metodologii, będą zgodne, wówczas będziemy mogli mówić o oddziaływaniach o dowiedzionej naukowo skuteczności. Co ważne, nie wystarczy, że ekspert czy osoba uchodząca za eksperta rekomenduje jakieś oddziaływanie jako skuteczne - kluczowe, żeby dostępne były wyniki z opisanych wyżej badań, przemawiające za skutecznością danej metody. 
Jak to się ma do skuteczności metod nauczania i wychowania? Wprawdzie Prawo oświatowe nie definiuje skuteczności nauczania i wychowania, ale odwołując się do medycyny opartej na dowodach (ang. evidence-based medicine) czy empirycznie potwierdzonych terapii w psychoterapii (ang. empirically supported treatments), można przyjąć, że skuteczne metody nauczania i wychowania to takie, których skuteczność została potwierdzona w trafnych - zarówno wewnętrznie, jak i zewnętrznie - badaniach naukowych. Trafność wewnętrzna oznacza, że metoda i procedura badawcza zostały właściwie dobrane do badanego problemu (np. do metody nauczania, której skuteczność ma być badana). $Z$ kolei trafność zewnętrzna zakłada, że uzyskane wyniki można uogólniać i odnosić do populacji, której badanie dotyczy (np. uczniów na określonym poziomie edukacyjnym). By zapewnić trafność zewnętrzną, metoda badań musi spełniać kryteria metodologiczne procedury naukowej, wyniki badań powinny zostać opublikowane w uznanym, recenzowanym czasopiśmie naukowym, surowe dane powinny być udostępnione innym zainteresowanym badaczom, badania powinny zostać zreplikowane (powtórzone) przez niezależnych badaczy, a metoda badawcza, wyniki i ich interpretacje powinny zostać poddane naukowej dyskusji (Brzeziński, 2000). Innymi słowy, możemy przyjąć, że kryteria skuteczności metod nauczania i wychowania powinny być zbliżone do kryteriów skuteczności interwencji w medycynie i psychoterapii. Tym samym będziemy mogli mówić o opartej na dowodach praktyce w pedagogice i nauczaniu (ang. evidence-based practices in pedagogy and teaching) (Garstka, 2016).

Niestety, w praktyce edukacyjnej stosowanych jest bardzo wiele metod, których skuteczność nie została dowiedziona w trafnych wewnętrznie i zewnętrznie badaniach naukowych. Należą do nich bardzo popularne metody, takie jak kinezjologia edukacyjna, neurolingwistyczne programowanie (NLP), integracja sensoryczna (SI) oraz neurodydaktyka ${ }^{1}$. Popularność tych metod oparta jest na doświadczeniu własnym jej autorów i ich zwolenników, a nie na wynikach badań naukowych, które potwierdzałyby ich skuteczność. Warto zwrócić uwagę, że autorzy ci często uchodzą za ekspertów, choć nimi nie są. Najlepszy przykład stanowi dr Marzena Żylińska, popularyzatorka neurodydaktyki, 
o której książce wypowiedział się w oficjalnym stanowisku Komitet Neurobiologii Polskiej Akademii Nauk, stwierdzając m.in.: „Lektura tej książki nasuwa przygnębiającą refleksję, że choć dr Żylińskiej brakuje podstawowej wiedzy z zakresu neurobiologii, o czym świadczą rażące błędy merytoryczne, Autorka stara się wytworzyć w czytelniku przekonanie, że aktualna wiedza $w$ tej dziedzinie osiągnęła już taki poziom, że w oparciu o nią można skutecznie kształtować procesy edukacji" (Komitet Neurobiologii Polskiej Akademii Nauk, 2015).

Na negatywnym przykładzie neurodydaktyki (nie tylko skuteczność jej metod nie została potwierdzona, lecz także zostały one sformułowane na postawie błędnych danych) można wskazać, jak powinna wyglądać droga od badań naukowych o charakterze podstawowym do stosowania opartych na nich metod w nauczaniu i wychowaniu. Wyniki badań podstawowych, a zatem takich, które są podejmowane w celu zdobycia nowej wiedzy o podstawach zjawisk i obserwowalnych faktów (np. pamięci czy zachowania), a nie w celu bezpośredniego zastosowania ich w praktyce, powinny stać się punktem wyjścia do sformułowania zasad nauczania i wychowania. Na podstawie tych zasad zaproponowane mogą zostać metody nauczania i wychowania, ale przed ich upowszechnieniem należy zbadać ich skuteczność w trafnych badaniach naukowych (por. rysunek nr 1). Innymi słowy, wychodząc od badań naukowych, dochodzimy do badań naukowych.

Rysunek 1. Droga od badań podstawowych do skutecznych metod nauczania i wychowania
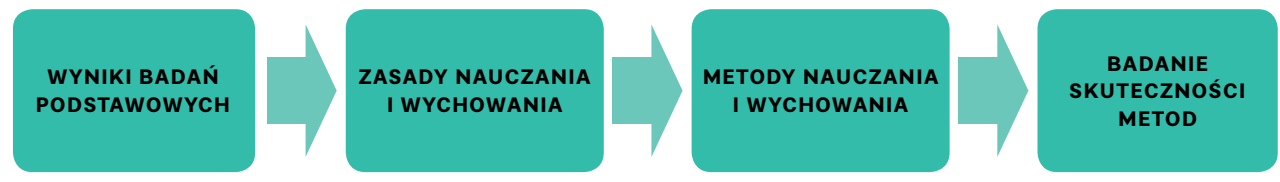

Źródło: Opracowanie własne.

Celem tego artykułu jest wskazanie dwóch obszarów badawczych, w których wyniki badań podstawowych stanowią filar formułowania zasad nauczania i wychowania, będących źródłem metod nauczania i wychowania, których skuteczność została dowiedziona w badaniach naukowych. 


\section{Skuteczne nauczanie a wyniki badań nad pamięcią}

Skuteczne nauczanie doprowadza do zapamiętania nowych informacji i ułatwia ich późniejsze przypominanie (Bąbel, Wiśniak, 2008, 2015). Źródeł skutecznych metod nauczania należy zatem szukać w wynikach badań nad pamięcią ${ }^{2}$. W tym miejscu przytoczone zostaną tylko najważniejsze informacje o współczesnym, opartym na najnowszych wynikach badań rozumieniu pamięci oraz wynikających z niego zasadach skutecznego nauczania.

Współcześnie pamięć najczęściej rozumie się jako proces kodowania, przechowywania i wydobywania informacji. W takim ujęciu pamięć ma charakter dynamiczny - przebiega w trzech fazach: kodowania, przechowywania i wydobywania (rysunek nr 2). Kodowanie, zwane także zapamiętywaniem, to proces prowadzący do utworzenia reprezentacji informacji w pamięci, czyli tzw. śladu pamięciowego. Z kolei przechowywanie informacji, nazywane także magazynowaniem, jest procesem utrzymywania przez jakiś czas w pamięci zakodowanych uprzednio informacji. Wydobywanie, zwane także odpamiętywaniem czy przypominaniem, to proces lokalizowania i uzyskiwania dostępu do przechowywanych w pamięci reprezentacji informacji. W każdej z tych faz informacje ulegają zmianom, a o skuteczności pamięci mówimy wtedy, gdy uda nam się zakodować informację, przechować ją przez odpowiedni czas, a w końcu wydobyć w jak najmniej zmienionej postaci.

Rysunek 2. Trzy fazy pamięci
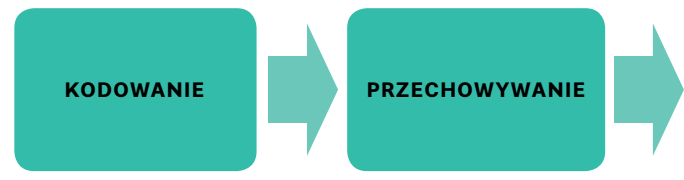

WYDOBYWANIE

Źródło: Opracowanie własne.

Nie tylko pamięć składa się z faz, lecz także wyróżnia się kilka rodzajów pamięci, w których fazy te zachodzą. Zasadniczo wymienia

2. Zainteresowany czytelnik znajdzie ich szczegółowe omówienie w wielu opracowaniach, z których najbardziej kompleksowa jest książka Jagodzińskiej (2008). 
się trzy magazyny pamięci: pamięć sensoryczną, pamięć krótkotrwałą oraz pamięć długotrwałą. Pamięć sensoryczna jest wstępnym magazynem pamięci, przechowującym bardzo krótko (maks. 2 sekundy) dużą liczbę danych dostarczanych przez zmysły. Ze względu na krótki czas przechowywania informacji w pamięci sensorycznej magazyn ten bywa także nazywany pamięcią ultrakrótką. Po wyjściu z pamięci sensorycznej informacje trafiają do pamięci krótkotrwałej, czyli magazynu przechowującego przez krótki, choć znacznie dłuższy niż pamięć sensoryczna, czas (do 30 sekund) niewielką liczbę danych (od 5 do 9 elementów). Pamięć krótkotrwała zwana jest też pamięcią operacyjną lub roboczą, gdyż trafiają do niej nie tylko informacje z pamięci sensorycznej, lecz także te wydobyte z pamięci długotrwałej, a wykorzystywane $w$ danej chwili. Z pamięci krótkotrwałej informacje trafiają następnie do pamięci długotrwałej, czyli magazynu przechowującego ogromne ilości informacji przez długi czas (od kilku godzin do wielu lat). Tym samym aby informacja została trwale zapamiętana, musi wejść do magazynu pamięci sensorycznej, następnie do magazynu pamięci krótkotrwałej, a wreszcie do magazynu pamięci długotrwałej. Drogę informacji przez poszczególne magazyny pamięci ilustruje rysunek 3. Na każdym etapie tej drogi dochodzi do utraty informacji - nie wszystkie informacje przejdą z pamięci sensorycznej do krótkotrwałej oraz z pamięci krótkotrwałej do długotrwałej. Należy przy tym podkreślić, że fazy pamięci nie są tożsame $z$ trzema podstawowymi rodzajami pamięci, lecz $w$ każdym z trzech magazynów pamięci zachodzą trzy fazy pamięci.

Rysunek 3. Droga informacji przez magazyny pamięci

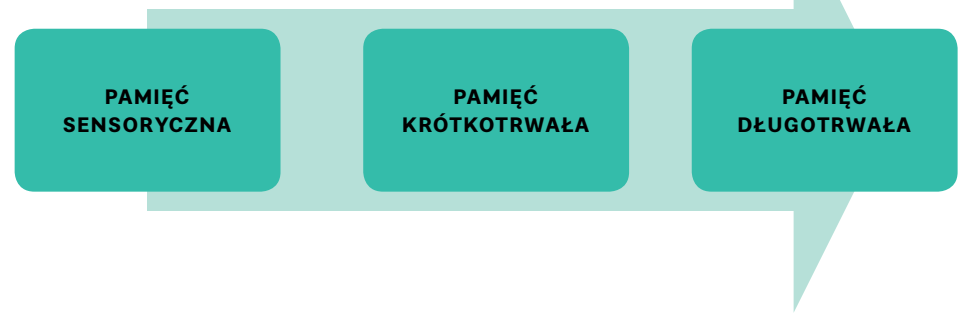

Źródło: Opracowanie własne. 
Pamięć długotrwała przechowuje nie tylko ogromną ilość informacji, lecz także dane bardzo zróżnicowane. Dlatego wyróżnia się kilka jej rodzajów, co ilustruje rysunek nr 4. Zasadniczy podział pamięci długotrwałej opiera się na kryterium możliwości wyrażenia słowami przechowywanych danych. Pamięć deklaratywna to ta część pamięci długotrwałej, której zawartość można zakomunikować słownie, natomiast pamięć proceduralna przechowuje umiejętności, nawyki i procedury działania (np. pływanie czy jazda na rowerze) i przejawia się w praktyce i niezwykle trudno wyrazić słowami jej zawartość (np. choć potrafimy pływać, to trudno byłoby nam opisać, na czym to działanie polega). Dlatego zawartość pamięci deklaratywnej określa się jako wiedzę, że, a treść pamięci proceduralnej zwana jest wiedzq, jak.

Rysunek 4. Wybrane rodzaje pamięci długotrwałej

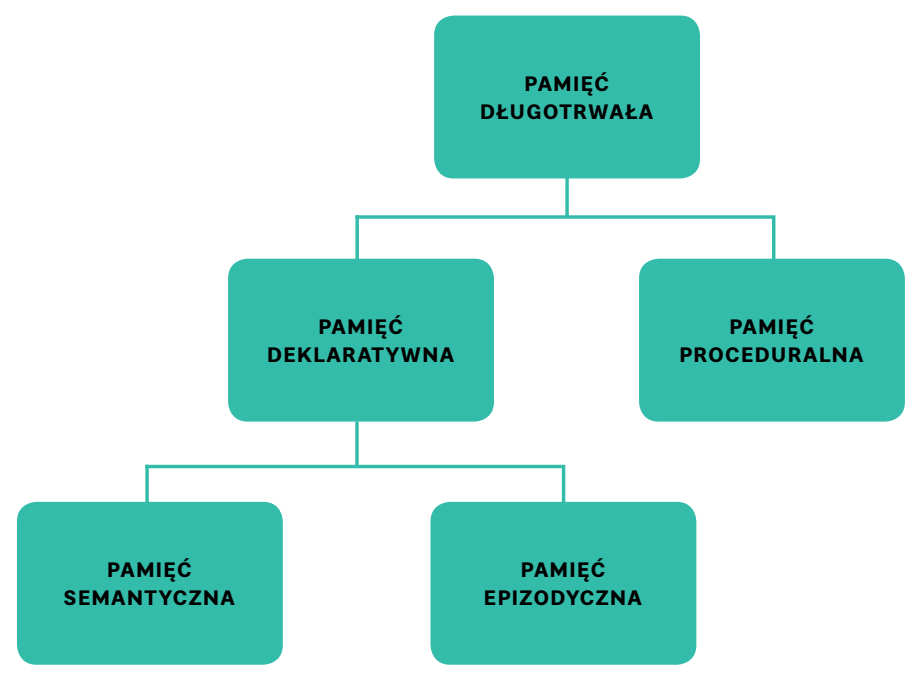

Źródło: Opracowanie własne.

Pamięć deklaratywna nie jest jednorodna i rozróżnia się dwa jej rodzaje: pamięć semantyczną i epizodyczną. Pamięć semantyczna przechowuje znaczenia słów, koncepcje i teorie oraz ogólne wiadomości o otaczającym świecie. Dlatego pamięć semantyczna zwana jest też 
pamięcią faktów. Pamięć epizodyczna przechowuje z kolei wspomnienia zdarzeń wraz z kontekstem, w jakim się wydarzyły, na który składają się: czas, miejsce, okoliczności itp. Ten rodzaj pamięci zwany jest więc także pamięcią zdarzeń.

Bąbel i Wiśniak $(2008,2015)$ na podstawie wyników badań nad pamięcią (i uczeniem się) sformułowali 12 zasad skutecznej edukacji (nauczania). Pierwsza zasada skutecznej edukacji głosi, że nauczyciel musi kierować uwagą uczniów tak, by zwrócili uwagę na to, co ma być zapamiętane, gdyż tylko wtedy możliwe będzie przejście informacji z pamięci sensorycznej do krótkotrwałej. Ponieważ pojemność pamięci krótkotrwałej jest ograniczona, druga zasada głosi, że nauczyciel musi zachęcać uczniów do grupowania analizowanych informacji. Drugim, nie mniej istotnym ograniczeniem funkcjonowania pamięci krótkotrwałej jest czas przechowywania w niej informacji. Żeby go wydłużyć, należy je powtarzać, o czym mówi trzecia zasada skutecznej edukacji. Czwarta zasada zaś głosi, że tylko powtarzanie opracowujące, czyli nadawanie znaczenia nowym informacjom, odnoszenie ich do już posiadanej wiedzy lub powiązanie $z$ nią pozwala na przeniesienie ich do pamięci długotrwałej. Ponieważ uczniowie zwykle lepiej zapamiętują te informacje, które dotarły do nich na początku oraz na końcu lekcji, bądź znajdowały się na początku lub na końcu materiałów dydaktycznych, piąta zasada skutecznej edukacji wskazuje, jak sprawić, by równie dobrze pamiętane były informacje ze środka lekcji lub $z$ analizowanych materiałów dydaktycznych. Zgodnie z szóstą zasadą skutecznej edukacji lepiej zapamiętujemy obrazy niż słowa, dlatego nauczyciel powinien pobudzać wyobraźnię uczniów, żeby zamieniali informacje werbalne $w$ wizualne. Ponieważ łatwiej zapamiętujemy informacje, które dotyczą nas samych, siódma zasada głosi, że kluczem do skutecznej edukacji jest odnoszenie wiedzy do osoby ucznia. Zasada ósma zachęca z kolei do uczenia przez doświadczenie, które należy do najskuteczniejszych metod nauczania. Zgodnie z dziewiątą zasadą należy wzbudzać emocje u uczniów, ponieważ umiarkowane pobudzenie emocjonalne sprzyja zapamiętywaniu informacji. $Z$ kolei z 10. zasady wynika, jak bardzo istotne skutki dla uczenia się mają przerwy. Ponieważ mimo zapamiętania informacji uczniowie mogą mieć kłopot $z$ ich przypomnieniem sobie, 11. zasada skutecznej edukacji podpowiada, jak wykorzystywać wskazówki, żeby ułatwić przypominanie. Zgodnie z ostatnią, czyli 12. zasadą, należy odpowiednio 
motywować uczniów, wzmacniając ich wysiłki w stosowaniu się do wcześniej omówionych zasad³.

\section{Skuteczne wychowanie a analiza zachowania}

Analiza zachowania jest nauką o zachowaniu oraz o czynnikach środowiskowych, które na nie wpływają (Bąbel, Ostaszewski 2008a, 2008b; Bąbel, Suchowierska, Ostaszewski, 2010, 2016). Na analizę zachowania składają się trzy działy. Eksperymentalna analiza zachowania zajmuje się badaniami podstawowymi, w których odkrywane są prawa rządzące zachowaniem. Celem stosowanej analizy zachowania jest tworzenie - na podstawie praw zachowania wypracowanych przez eksperymentalną analizę zachowania - procedur służących do kształtowania i modyfikowania istotnych społecznie zachowań oraz eksperymentalne weryfikowanie ich skuteczności. Ogół technik terapeutycznych wykorzystujących podstawowe procesy uczenia się do zmiany zachowania zwany jest terapią behawioralną, która w Polsce traktowana jest jako synonim stosowanej analizy zachowania. $Z$ kolei teoretyczna analiza zachowania zajmuje się historią dziedziny, analizami filozoficznymi, teoretycznymi i metodologicznymi. U podłoża wszystkich działów analizy zachowania leży filozofia nauki stworzona przez Burrhusa Frederica Skinnera, zwana radykalnym behawioryzmem (Bąbel i in. 2010, 2016; Bąbel, Ostaszewski 2008a, 2013; Skinner, 1974/2013).

Z perspektywy analizy zachowania przyczyny większości zachowań (z wyjątkiem tych zdeterminowanych genetycznie) leżą w środowisku. Warunkowanie sprawcze (zwane także instrumentalnym) jest paradygmatem badawczym eksperymentalnej analizy zachowania, a także podstawą większości metod kształtowania i modyfikacji zachowania wypracowanych przez stosowaną analizę zachowania. Z perspektywy warunkowania sprawczego przyczyną zachowań (określanych skrótem B, od ang. behavior) są ich konse-

3. Zainteresowany czytelnik znajdzie szczegółowe omówienie wymienionych zasad wraz z przykładami opartych na nich metod nauczania w publikacjach Bąbla i Wiśniak $(2008,2015)$. Metody, techniki i ćwiczenia doskonalące pamięć, stworzone na podstawie tych samych zasad, szczegółowo omawiają Bąbel i Baran (2011). Z kolei Czerniawska i Ledzińska (2007) prezentują praktyczne, oparte na wiedzy o pamięci, wskazówki dla uczniów i studentów, jak się skutecznie uczyć. Bardziej akademickie ujęcie problematyki nauczania opartego na wynikach badań nad pamięcią i procesami poznawczymi znaleźć można u Ledzińskiej i Czerniawskiej (2011). 
kwencje środowiskowe (oznaczane zazwyczaj skrótem C, od ang. consequence), które dzieli się na wzmocnienia i kary. Wzmocnienia to takie konsekwencje zachowania, które prowadzą do wzrostu prawdopodobieństwa jego wystąpienia w przyszłości, podczas gdy kary prowadzą do spadku częstotliwości zachowania w przyszłości. Wzmocnienia mogą być pozytywne, gdy zachowanie skutkuje pojawieniem się $\mathrm{w}$ środowisku bodźca pożądanego (np. ocena bardzo dobra, pochwała), lub negatywne, gdy zachowanie powoduje ustanie działania bodźca awersyjnego, czyli kary, lub zapobiega jego pojawieniu się (np. uniknięcie nagany, możliwość nieuczestniczenia w niechcianych zajęciach). Podobnie kary dzielimy na pozytywne, jeśli zachowanie skutkuje pojawieniem się bodźca awersyjnego (np. nagana, dezaprobata), oraz negatywne, jeśli w rezultacie zachowania ustaje działanie bodźca pożądanego, czyli wzmocnienia, lub bodziec pożądany nie pojawia się wcale (np. skreślenie z listy uczestników wycieczki, brak możliwości uczestniczenia w zajęciach, w których ma się ochotę wziąć udział).

Zachowanie i jego konsekwencje występują zawsze w określonych warunkach środowiskowych, które określa się mianem bodźców kontrolujących lub poprzedzających (a oznacza się zazwyczaj skrótem $A$, od ang. antecedent). Bodźce te nie są wprawdzie przyczyną zachowań, jak błędnie się niekiedy twierdzi, ale zmieniają prawdopodobieństwo pojawienia się zachowania. Bodźce kontrolujące dzielimy na różnicujące, w których obecności zachowanie jest wzmacniane (np. zajęcia z ulubionego przedmiotu, lubiany nauczyciel), oraz wygaszeniowe, które zapowiadają, że wzmocnienie nie wystąpi (np. zajęcia z przedmiotu, z którego nauką uczeń słabiej sobie radzi, nielubiany nauczyciel). Bodźce poprzedzające (A), zachowanie (B) oraz jego konsekwencje (C) stanowią trójelementową zależność, jaka powstaje w toku warunkowania sprawczego, zwaną w skrócie ABC (rysunek nr 5). Trójelementową zależność można opisać, odwołując się do prawa efektu, które głosi, że zachowanie (B), które w danej sytuacji (A) wywołuje zadowolenie (C), zostaje $z$ tą sytuacją (A) skojarzone i jeśli w przyszłości sytuacja (A) ta się powtórzy, to rośnie prawdopodobieństwo, że również to zachowanie (B) zostanie powtórzone. Jeśli natomiast $w$ danej sytuacji (A) zachowanie prowadzi do odczucia dyskomfortu (C), to zmniejsza się prawdopodobieństwo powtórzenia tego zachowania (B) w podobnej sytuacji (A) w przyszłości. 
Rysunek 5. Trójelementowa zależność powstająca w wyniku warunkowania sprawczego
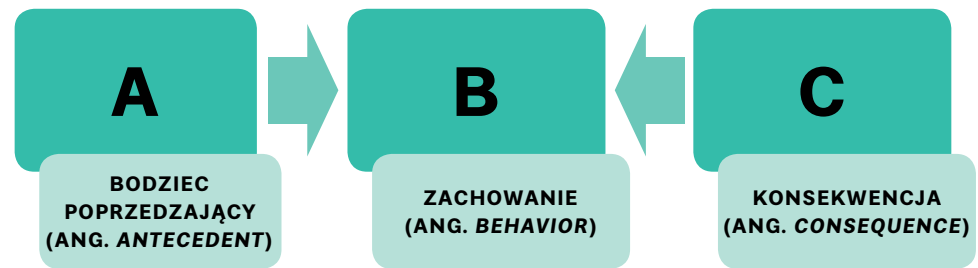

Źródło: Opracowanie własne.

Reasumując, z perspektywy analizy zachowania przyczyną zachowań są ich konsekwencje środowiskowe, a bodźce poprzedzające zachowanie zmieniają jedynie prawdopodobieństwo jego pojawienia się. Konsekwencją takiego, a nie innego umiejscowienia przyczyn zachowania, które dokonało się - podkreślmy to - w toku setek, jeśli nie tysięcy badań eksperymentalnych prowadzonych przez przeszło sto lat, stało się wypracowanie metod kształtowania i modyfikacji zachowania, które opierają się na manipulacji tymi przyczynami. Stanowią one domenę stosowanej analizy zachowania.

Stosowana analiza zachowania ma trzy zasadnicze cele. Po pierwsze, rozwijanie zachowań pożądanych poprzez zwiększanie częstotliwości zachowań pożądanych, które uczeń wykazuje; kształtowanie nowych zachowań pożądanych, których uczeń nie ma w repertuarze swoich zachowań; wyzwalanie zachowań pożądanych, które znajdują się w repertuarze zachowań ucznia, ale ich nie przejawia. Po drugie, redukowanie zachowań trudnych (niepożądanych) poprzez zmniejszanie ich częstotliwości, a najlepiej całkowite eliminowanie. Po trzecie, celem stosowanej analizy zachowania są utrzymanie i generalizacja efektów interwencji, tak żeby skutki podjętych oddziaływań trwały po ich zakończeniu nie tylko w środowisku, w którym przeprowadzana była interwencja, lecz także poza nim.

Cele te realizowane są przez dwa typy oddziaływań. Po pierwsze, manipulowanie bodźcami poprzedzającymi, które może mieć na celu niedopuszczenie do wystąpienia zachowań trudnych lub wyzwalanie zachowań pożądanych. Po drugie, manipulowanie konsekwencjami w celu kształtowania zachowań pożądanych poprzez dostarczenie 
pożądanych konsekwencji (wzmocnień pozytywnych i negatywnych), zmniejszanie częstotliwości/eliminowanie zachowań trudnych poprzez utratę pożądanych konsekwencji (kary negatywne) lub zmniejszanie częstotliwości/eliminowanie zachowań trudnych poprzez negatywne konsekwencje (kary pozytywne) ${ }^{4}$.

\section{Wnioski}

Misją szkoły jest zarówno nauczanie, jak i wychowanie. Metody nauczania i wychowania powinny opierać się na dowodach naukowych, tzn. powinny wywodzić się z praw odkrytych w badaniach podstawowych, a ich skuteczność powinna zostać zweryfikowana w badaniach naukowych. Wyniki badań nad pamięcią dostarczają zasad skutecznego nauczania i opartych na nich metod podnoszenia skuteczności nauczania. Z kolei wyniki badań z zakresu analizy zachowania dostarczają praw zachowania i opartych na nich metod wychowawczych o dowiedzionej naukowo skuteczności.

4. Omówienie konkretnych metod zainteresowany czytelnik znajdzie u Bąbla, Suchowierskiej i Ostaszewskiego $(2010,2016)$. Szczegółowe praktyczne informacje o wykorzystaniu tych metod w pracy z dziećmi nietypowo rozwijającymi się, w kontekście edukacji specjalnej, prezentują Bąbel (2011) i Suchowierska, Ostaszewski i Bąbel (2012), natomiast zastosowania metod stosowanej analizy zachowania w pracy z dziećmi typowo rozwijającymi się, w kontekście edukacji masowej, znaleźć można u Bąbla (2009). 


\section{Bibliografia}

$\rightarrow$ Bąbel, P. (2011), Terapia behawioralna zaburzeń rozwoju z perspektywy analizy zachowania [w:] „Psychologia Rozwojowa”, nr 3, s. 27-38.

$\rightarrow$ Bąbel, P. (2009), Punktowe systemy oceniania w praktyce edukacyjne, [w:] N. Grzegorczyk-Dłuciak (red.), Czas na dialog! Materiały z I Ogólnopolskiej Konferencji Nauczycieli Szkolnictwa Specjalnego, Kraków: Oficyna Wydawnicza "Impuls", s. 35-52.

$\rightarrow$ Bąbel, P., Baran, A. (2011), Trening pamięci. Projektowanie, realizacja, techniki i ćwiczenia, Warszawa: Difin.

$\rightarrow$ Bąbel, P., Ostaszewski, P. (2013), O Skinnerze i behawioryzmie [w:] B.F. Skinner, Behawioryzm, Sopot: Gdańskie Wydawnictwo Psychologiczne, s. 9-20.

$\rightarrow$ Bąbel, P., Ostaszewski, P. (2008a), Wprowadzenie do psychologii behawioralnej [w:] P. Bąbel, P. Ostaszewski (red.), Współczesna psychologia behawioralna. Wybrane zagadnienia, Kraków: Wydawnictwo Uniwersytetu Jagiellońskiego, s. 7-21.

$\rightarrow$ Bąbel, P., Ostaszewski, P. (red.) (2008b), Współczesna psychologia behawioralna. Wybrane zagadnienia, Kraków: Wydawnictwo Uniwersytetu Jagiellońskiego.

$\rightarrow$ Bąbel, P., Suchowierska, M., Ostaszewski, P. (2016), Analiza zachowania. Vademecum, Sopot: Gdańskie Wydawnictwo Psychologiczne.

$\rightarrow$ Bąbel, P., Suchowierska, M., Ostaszewski, P. (2010), Analiza zachowania od A do Z, Gdańsk: Gdańskie Wydawnictwo Psychologiczne.

$\rightarrow$ Bąbel, P., Wiśniak, M. (2015), 12 zasad skutecznej edukacji. Czyli jak uczyć, żeby nauczyć?, Sopot: Gdańskie Wydawnictwo Psychologiczne.

$\rightarrow$ Bąbel, P., Wiśniak, M. (2008), Jak uczyć, żeby nauczyć, Warszawa: Wydawnictwa Szkolne i Pedagogiczne.

$\rightarrow$ Brzeziński, J. (2000), Badania eksperymentalne w psychologii i pedagogice, Warszawa: Scholar.

$\rightarrow$ Czerniawska, E., Ledzińska, M. (2007), Jak się uczyć?, Bielsko-Biała: Wydawnictwo Park. 
$\rightarrow$ Garstka, T. (2016), Psychopedagogiczne mity. Jak zachować naukowy sceptycyzm w edukacji i wychowaniu, Warszawa: Wolters Kluwer.

$\rightarrow$ Jagodzińska, M. (2008), Psychologia pamięci. Badania, teorie, zastosowania, Gliwice: Wydawnictwo Helion.

$\rightarrow$ Kołakowski, A., Pisula, A. (2011), Sposób na trudne dziecko. Przyjazna terapia behawioralna, Sopot: Gdańskie Wydawnictwo Psychologiczne.

$\rightarrow$ Ledzińska, M., Czerniawska, E. (2011), Psychologia nauczania. Ujęcie poznawcze, Warszawa: Wydawnictwo Naukowe PWN.

$\rightarrow$ Minahan, J., Rappaport, N. (2014), Kod zachowania. Jak rozszyfrować i zmienić najtrudniejsze zachowania, Warszawa: Wydawnictwo Fraszka Edukacyjna.

$\rightarrow$ Minahan, J. (2016), Kod zachowania. Przewodnik, Warszawa: Wydawnictwo Fraszka Edukacyjna.

$\rightarrow$ Skinner, B.F. (1974/2013), Behawioryzm, Sopot: Gdańskie Wydawnictwo Psychologiczne.

$\rightarrow$ Suchowierska, M., Ostaszewski, P., Bąbel, P. (2012), Terapia behawioralna dzieci z autyzmem. Teoria, badania i praktyka stosowanej analizy zachowania, Sopot: Gdańskie Wydawnictwo Psychologiczne.

$\rightarrow$ Ustawa z dnia 14 grudnia 2016 r. Prawo oświatowe (Dz.U. 2018, poz. 996).

$\rightarrow$ Zielińska, M. (2012), Jak reagować na agresję uczniów? Skuteczne techniki radzenia sobie z problemem, Gdańsk: Harmonia Universalis. 


\section{Netografia}

$\rightarrow$ Komitet Neurobiologii Polskiej Akademii Nauk (2015), Opinia o ksiq̨żce dr Marzeny Żylińskiej „Neurodydaktyka. Nauczanie i uczenie się przyjazne mózgowi”, Wydawnictwo Naukowe UMK, 2013, www.kneurobiologii.pan.pl/images/stories/ List\%20do\%20Minister\%20Edukacji\%20z\%20opinia\%200\%20ksiazce\%20 Neuroedukacja.pdf, dostęp 30.06.2018. 


\section{Znaczenie inteligencji emocjonalnej $w$ funkcjonowaniu ucznia i nauczyciela}

Katarzyna A. Knopp

W pierwszej części artykułu omówiono takie zagadnienia jak sposób definiowania inteligencji emocjonalnej oraz jej znaczenie funkcjonalne. W dalszej części opisano wpływ inteligencji emocjonalnej na funkcjonowanie szkolne uczniów i funkcjonowanie zawodowe nauczycieli, a także możliwości jej rozwijania poprzez celowe oddziaływania wychowawcze. Przybliżono również najbardziej znane na świecie programy ukierunkowane na kształtowanie zdolności emocjonalnych.

\section{Słowa kluczowe:}

inteligencja emocjonalna

\section{dzieci i młodzież}

nauczyciele

rozwój 


\section{The importance of emotional intelligence in the functioning of the student and teacher}

Katarzyna A. Knopp

The first part of the article discusses such issues as the way of defining emotional intelligence and its functional meaning. In the following, there is described the influence of emotional intelligence on pupils' school functioning and the professional functioning of teachers, as well as the possibilities of developing it through targeted educational activities. The most known programs focused on shaping emotional abilities were also presented.

\section{Keywords:}

emotional intelligence

children and adolescents

teachers

development 


\section{Wprowadzenie}

Inteligencja emocjonalna to pojęcie, które pojawiło się w publikacjach naukowych stosunkowo niedawno, a jednak w bardzo szybkim tempie zdobyło popularność zarówno w środowisku naukowym, jak i w praktyce pedagogicznej oraz psychologicznej. Rozważania na temat inteligencji emocjonalnej podzieliły się na dwa nurty - modeli mieszanych i modeli zdolnościowych. Przedstawicielami pierwszego podejścia są m.in. Bar-On (1997) oraz Goleman (1997), którzy definiują inteligencję emocjonalną jako zbiór zdolności, kompetencji, cech osobowości, a nawet charakterystyk motywacyjnych, które przyczyniają się do właściwego funkcjonowania człowieka. Ponieważ w tym ujęciu inteligencja emocjonalna definiowana jest nie tylko w kategoriach zdolności, lecz także innych właściwości, ich modele nazywane są mieszanymi (ang. mixed models) i krytykowane za nieuprawnione wychodzenie poza tradycyjne rozumienie inteligencji. W drugim nurcie rozważań skoncentrowano się na modelu zdolnościowym Mayera i Saloveya (1999), w którym inteligencję emocjonalną rozumie się jako zbiór zdolności przetwarzania informacji emocjonalnych, wśród których wymienia się: zdolność spostrzegania i wyrażania emocji, zdolność wykorzystywania emocji w procesach myślenia, zdolność rozumienia i nazywania emocji oraz zdolność regulacji emocji.

Niezależnie od różnic w sposobie definiowania inteligencji emocjonalnej badacze są zgodni, że jest ona tą właściwością, która w znaczącym stopniu przyczynia się do efektywnego funkcjonowania człowieka. Obecnie dysponujemy już licznymi badaniami poświęconymi znaczeniu inteligencji emocjonalnej. W literaturze przedmiotu podkreśla się związki między inteligencją emocjonalną a dobrostanem psychicznym i zdrowiem fizycznym. Badacze wskazują, że deficyty w zakresie inteligencji emocjonalnej (głównie niski poziom zdolności regulacji emocji i radzenia sobie $z$ emocjami negatywnymi) istotnie zwiększają prawdopodobieństwo chorób somatycznychoraz zaburzeń psychicznych, np. chorób układu krążenia, zaburzeń odżywiania, nerwic czy depresji (zob. np. Goleman, 1997; Knopp, 2016; Salovey, 2001). Osoby o niskiej inteligencji emocjonalnej są również bardziej podatne na uzależnienia od narkotyków, tytoniu i alkoholu (Goleman, 1997; Mayer, Cobb, 2000; Trinidad, Johnson, 2000). Z kolei wysoka inteligencja emocjonalna sprzyja zachowaniu dobrostanu psychicznego, zdrowia i dobrej kondycji oraz chroni przed uzależnieniami. Badacze dowodzą również, 
że istnieje pozytywny związek inteligencji emocjonalnej z poczuciem szczęścia, spełnienia i satysfakcji życiowej (Mayer i in., 2000; Matczak, Knopp, 2013).

Inteligencję emocjonalną najsilniej łączy się jednak z funkcjonowaniem człowieka $w$ relacjach interpersonalnych. Okazuje się, że osoby o wyższym jej poziomie tworzą silniejsze i bardziej trwałe więzi z innymi, mają bardziej udane relacje przyjacielskie i rodzinne, są bardziej popularne i lubiane, częściej stają się przywódcami grup nieformalnych, a nawet lepiej sprawdzają się w roli rodziców (zob. np. Goleman, 1997; Knopp, 2014; Lopes i in., 2003; Van der Zee i in., 2002). Ciekawa jest również konsekwentnie stwierdzana $w$ badaniach dodatnia korelacja między inteligencją emocjonalną a tendencją do zachowań altruistycznych i empatii (Carlo i in., 1991; Charbonneau; Nicol, 2002), przy czym zależność ta zaznacza się zarówno u dzieci, jak i u dorosłych. Jednakże osoby inteligentne emocjonalnie w sytuacjach kryzysowych same chętniej proszą o pomoc i lepiej wykorzystują udzielane im wsparcie (Ciarrochi i in., 2002). Jak więc widać, inteligencja emocjonalna przyczynia się do efektywności funkcjonowania człowieka na różnych płaszczyznach życia.

\section{Wpływ inteligencji emocjonalnej}

\section{na funkcjonowanie nauczyciela i ucznia}

Inteligencja emocjonalna może spełniać też bardzo ważną funkcję w środowisku szkolnym, przy czym jej rolę należy rozpatrywać z perspektywy zarówno nauczycieli, jak i uczniów.

Szkoła jest miejscem, gdzie nauczyciele przekazują uczniom wiedzę, ci drudzy zaś ją przyswajają. Jednakże w szkole zachodzą również bardzo liczne i intensywne interakcje z innymi ludźmi. Biorąc to pod uwagę, w funkcjonowaniu szkoły można wyróżnić dwa aspekty - poznawczy i społeczny. Można przypuszczać, że zarówno uczniowie, jak i nauczyciele o wyższej inteligencji emocjonalnej będą lepiej funkcjonować poznawczo w szkole - sprawne przetwarzanie informacji emocjonalnych i ich wykorzystywanie będzie bowiem sprzyjać nabywaniu nowych umiejętności, przyswajaniu wiedzy i rozwiązywaniu różnorakich problemów poznawczych. Zdaniem niektórych badaczy włączanie emocji w procesy myślenia wspomaga generowanie pomysłów i kreatywność, a rozumienie emocji umożliwia przyjmowanie różnych punktów widzenia oraz ogląd i analizę problemu z odmiennych perspektyw (por. Caruso, 
Wolfe, 2001; Matczak, Knopp, 2013), co jest ważne z punktu widzenia ucznia i nauczyciela. Jednakże roli inteligencji emocjonalnej w szkole nie można sprowadzić jedynie do wspomagania procesów uczenia się i nauczania. Przede wszystkim bowiem inteligencja emocjonalna sprzyja funkcjonowaniu społecznemu w środowisku szkolnym. Osoba obdarzona nią w wysokim stopniu jest otwarta na emocje własne i innych ludzi, lepiej je kontroluje oraz reguluje i w konstruktywny sposób wykorzystuje uzyskiwane na tej drodze informacje. Ponadto sprawne identyfikowanie emocji pozwala prawidłowo zrozumieć emocje innych ludzi (np. współpracowników i uczniów), a co za tym idzie - zauważać, że ktoś potrzebuje pomocy, i udzielić jej w sposób adekwatny do sytuacji (zob. np. Caruso, Wolfe, 2001; Matczak, Knopp, 2013).

Nauczanie jest profesją wymagającą i związaną z wieloma obciążeniami emocjonalnymi. Wiele badań dowodzi, że wysoka inteligencja emocjonalna pozwala nauczycielom lepiej radzić sobie z wymaganiami i problemami zawodowymi, a jednocześnie efektywniej wykonywać obowiązki. Podwyższanie inteligencji emocjonalnej pedagogów jest więc korzystne zarówno z punktu widzenia ich własnego funkcjonowania, jak i funkcjonowania ich uczniów i całej społeczności szkolnej. W badaniach wykazano m.in. dodatnie związki między inteligencją emocjonalną nauczycieli a ich zadowoleniem z pracy i zaangażowaniem w nią, a także adaptacyjnymi strategiami radzenia sobie ze stresem zawodowym (Mérida-López, Extremera, 2017; Sun i in., 2017; Yin i in., 2013). Są również empiryczne dowody na to, że wysoka inteligencja emocjonalna jest swego rodzaju czynnikiem chroniącym nauczycieli przed wypaleniem zawodowym, a także zwiększającym ich ogólny dobrostan emocjonalny i zdrowie (Landa i in., 2006; Wróbel, 2013).

Badania potwierdzają, że inteligencja emocjonalna ma duże znaczenie również $w$ funkcjonowaniu uczniów. Koreluje ona dodatnio z szeroko rozumianym powodzeniem szkolnym i akademickim (Barchard, 2003; Bar-On, 1997; Gil-Olarte i in., 2006; Gumora, Arsenio, 2002; Halberstad, Hall, 1980; Mestre i in., 2006; Newsome i in., 2000; Parker i in., 2004). Dane empiryczne dowodzą, że uczniowie o wysokiej inteligencji emocjonalnej lepiej sobie radzą z adaptacją w nowej szkole, rzadziej chodzą na wagary oraz rzadziej są wydalani z placówek edukacyjnych (Petrides i in., 2004), cechuje ich większa motywacja do nauki, mają też lepsze oceny, nauczyciele zaś żywią mniej obaw o ich postępy w nauce, prace domowe i zachowanie (Marczak, 2008; Qualter i in., 2007). Jako 
ciekawostkę można przytoczyć to, że poziom inteligencji emocjonalnej zbadany już u małych dzieci może być trafnym prognostykiem ich późniejszego funkcjonowania w szkole. Na przykład w badaniach Izarda i współpracowników (2001, za: Elfeinbein i in., 2002) wykazano, że wysoka zdolność interpretowania emocji wyrażanych na twarzy przez pięcioletnie dzieci jest dodatnim predyktorem ich radzenia sobie w szkole cztery lata później. Co ciekawe, w innych studiach ta sama zdolność była silnie powiązana z osiągnięciami akademickimi, głównie z ocenami, które uczniowie otrzymywali od nauczycieli, a tylko słabo związana ze zdolnościami poznawczymi (Halberstadt, Hall, 1980; Parker i in., 2004).

Dysponujemy także danymi o zależności między zdolnościami emocjonalnymi uczniów a ich funkcjonowaniem społecznym w szkole i popularnością wśród kolegów. Okazuje się, że dzieci o wysokiej inteligencji emocjonalnej są bardziej lubiane przez rówieśników, mają z nimi lepsze relacje, mają więcej przyjaciół i częściej są liderami grup nieformalnych (zob. np. Saarni, 1999). W badaniach Jaworowskiej i Matczak (2001) wykazano ponadto, że uczniowie o wyższej inteligencji emocjonalnej oceniane są przez kolegów jako najlepiej rozumiejące innych, najbardziej pomocne, asertywne i popularne.

Podsumowując tę część rozważań, należy zwrócić uwagę na dwie kwestie. Po pierwsze, huraoptymistyczne zapewnienia niektórych autorów publikacji popularnonaukowych o tym, że inteligencja emocjonalna jest najważniejszym predyktorem szczęścia i sukcesów (np. osiągnięć szkolnych i zawodowych) w świetle danych naukowych nie są do końca prawdziwe. Owszem, może ona przyczyniać się do lepszego funkcjonowania człowieka w różnych sferach życia, w tym sprawniejszego odgrywania roli ucznia lub nauczyciela, ale należy pamiętać, że nie jest ona remedium na wszelkiego rodzaju problemy współczesnej szkoły. Każdy pojedynczy konstrukt wyjaśnia bowiem tylko niewielką część powodzeń lub porażek życiowych. Jedynie uwzględnienie inteligencji emocjonalnej obok innych zdolności i cech może zwiększyć trafność prognozowania powodzenia szkolnego i zawodowego (zob. Matczak, Knopp, 2013). Po drugie, należy wziąć pod uwagę, że związek między inteligencją emocjonalną a poznawczym i społecznym funkcjonowaniem w roli nauczyciela lub ucznia nie jest jedno-, lecz dwukierunkowy (zob. Matczak, Knopp, 2013). Nie tylko inteligencja emocjonalna może sprzyjać efektywności funkcjonowania w szkole lub pracy, lecz także samo środowisko szkolne może wspierać rozwój inteligencji 
emocjonalnej u danej osoby. Może się to dziać w sposób naturalny lub poprzez celowe zabiegi stymulujące rozwój zdolności emocjonalnych, o czym będzie mowa w dalszej części artykułu.

\section{Stymulowanie rozwoju inteligencji emocjonalnej}

Inteligencja emocjonalna nie jest dyspozycją wrodzoną. Badacze są zgodni, że kształtuje się ona przez całe życie w wyniku nabywania doświadczeń emocjonalnych i społecznych. Jak już wspomniano wcześniej, dzieje się to w sposób naturalny - mając do czynienia z różnego rodzaju sytuacjami życiowymi, interakcjami z innymi ludźmi, problemami, stopniowo uczymy się dostrzegać i wyrażać emocje, rozumieć je, wykorzystywać i kontrolować (zob. Knopp, 2010). Ten naturalny trening zachodzi także w środowisku szkolnym. Przed uczniem lub pracownikiem stawia się wiele zadań natury poznawczej i społecznej, z którymi musi on sobie poradzić. Oprócz sprawnego wykonywania pracy lub nabywania wiedzy oczekuje się od niego również na przykład dostosowywania się do norm społecznych, sprawnej współpracy z kolegami oraz wrażliwości na potrzeby innych. Środowisko szkolne dostarcza również określonych wzorców zachowań i kreuje określone wymagania i warunki działania. W wyniku tego każdy członek społeczności szkolnej przechodzi swoisty trening zdolności emocjonalnych. Im lepiej funkcjonuje szkoła, tym lepiej stymuluje rozwój emocjonalny.

Jednakże oprócz tego naturalnego treningu wynikającego z odgrywania roli ucznia lub nauczyciela możliwe jest podjęcie celowych zabiegów mających na celu podwyższenie poziomu inteligencji emocjonalnej. Badacze podkreślają bowiem, że jest ona plastyczna i poddaje się ona kształtowaniu poprzez oddziaływania psychostymulujące lub psychokorekcyjne (por. Elias i in., 1997; Knopp, 2010; Grabowska i in., 2015). W krajach o wysokim poziomie rozwoju cywilizacyjnego popularny stał się w ostatnich czasach emotional literacy movement, czyli ruch kształcenia emocjonalnego (zob. np. Elias i in., 1997). Jest to „brakujące ogniwo" w systemie edukacji, które należy uzupełnić (Elias, 1997). Jako przykłady szeroko zakrojonych programów stymulujących rozwój kompetencji społeczno-emocjonalnych wymienić można chociażby programy PATHS, RCC, SDC i Self Science, które funkcjonują już od długiego czasu, a ich skuteczność została pozytywnie zweryfikowana.

Program PATHS przeznaczony jest dla uczniów szkół podstawowych. Jego głównym celem jest uczenie rozpoznawania i wyrażania emocji 
oraz zarządzania nimi, rozszerzanie języka związanego z emocjami i relacjami społecznymi, rozwijanie zdolności rozwiązywania problemów i samokontroli (Elias i in., 1997). Z kolei Program Twórczego Rozwiązywania Konfliktów (Resolving Conflicts Creatively Program, RCCP) jest jednym z największych i najdłużej prowadzonych programów. Połączono w nim nauczanie umiejętności emocjonalnych i społecznych z problematyką relacji różnych grup społecznych oraz konstruktywnym rozwiązywaniem konfliktów (Elias i in.,1997; Lantieri i Patti, 1996; Mayer, Salovey, 1999). Z kolei istotą realizowanego w niektórych szkołach publicznych stanu Connecticut Programu Rozwoju Społecznego (Social Development Curriculum, SDC) jest kształtowanie zdolności społecznych i emocjonalnych w kontekście różnych oddziaływań profilaktycznych (np. zapobiegania uzależnieniom lub podejmowania nieprzemyślanych decyzji o aktywności seksualnej). Program jest bardzo intensywny. Obejmuje on dzieci od przedszkola do XII klasy, a w każdym roku szkolnym na jego realizację przewidziane jest od 25 do 50 lekcji, podczas których uczniowie trenują między innymi uświadamianie sobie emocji i uczuć, umiejętność wczuwania się w przeżycia innych ludzi, radzenie sobie z emocjami negatywnymi oraz rozumienie komunikatów niewerbalnych. Efektywność programu sprawdzana jest co dwa lata poprzez szeroko zakrojone badania kwestionariuszowe uczestników. Na ich podstawie dowiedziono skuteczności programu w zakresie zmniejszania przemocy szkolnej oraz doświadczanego przez dzieci i młodzież poczucia beznadziejności (Shriver i in., 1999). Także w programie Nauka o Sobie (Self Science) sporo uwagi poświęcono komponentom inteligencji emocjonalnej. Program realizowany jest w wybranych szkołach w Kalifornii w wymiarze 54 lekcji i obejmuje uczniów od I do VIII klasy. Opiera się on na trzech założeniach:

1. nie ma myślenia bez emocji ani odczuwania bez myślenia,

2. integralną częścią uczenia się jest samowiedza,

3. rozwijanie świadomości własnych przeżyć zwiększa możliwość uczenia się.

Jego celem jest trenowanie takich umiejętności jak:

$\rightarrow$ definiowanie i nazywanie uczuć,

$\rightarrow$ odczytywanie mowy ciała,

$\rightarrow$ rozumienie symboliki emocji,

$\rightarrow$ wzbudzanie emocji, źródła emocji oraz odpowiedzialność za emocje. 
Program ma również na celu naukę mówienia o uczuciach i potrzebach, słuchania, dzielenia się, pocieszania innych, rozwiązywania konfliktów i przełamywania wrogości, ustalania priorytetów i celów życiowych, uwzględniania w swym postępowaniu innych osób, podejmowania świadomych decyzji, a także angażowania swojego czasu i energii na potrzeby społeczności (Stone-McCown i in., 1998).

Wszystkie wspomniane programy mają kilka wspólnych cech. Po pierwsze, są szeroko zakrojone - obejmują tysiące dzieci w różnym wieku. Po drugie, są włączane w system edukacji - zajęcia odbywają się na terenie szkoły, w ramach lekcji lub jako zajęcia pozalekcyjne. Wreszcie, po trzecie, oddziaływania, jakim poddawani są uczestnicy, mają charakter długofalowy i intensywny. Należy również zaznaczyć, że cele programów nie ograniczają się jedynie do rozwijania określonych zdolności, ale dotyczą motywowania uczestników do wykorzystywania nabytych umiejętności w codziennym funkcjonowaniu oraz zmiany ich sposobu postrzegania samych siebie.

Idea kształcenia społeczno-emocjonalnego stopniowo popularyzowana jest również w Polsce (zob. np. Grabowska i in., 2015; Knopp, 2010). W polskich szkołach podejmowane są coraz liczniejsze próby realizacji zajęć rozwijających kompetencje społeczno-emocjonalne uczniów. Nie są one jednak tak szeroko zakrojone ani intensywne jak te wspomniane wcześniej.

W świetle obecnej wiedzy o inteligencji emocjonalnej wprowadzanie do instytucji oświatowych celowych programów, które mogłyby wspierać nabywanie zdolności emocjonalnych i kompetencji społecznych zarówno przez uczniów, jak i nauczycieli, wydaje się w pełni uzasadnione. Jednakże, jak wskazują badacze, należy zachować w tej kwestii rozsądek i ostrożność (zob. np. Elias i in., 1997; Knopp, 2010; Liff, 2003). Konieczne są bowiem: bardzo rzetelne opracowanie takich programów na podstawie solidnych danych naukowych, praktyczna realizacja ich przez dobrze przygotowanych specjalistów, wiarygodna ewaluacja oraz monitorowanie długofalowych efektów. Przy spełnieniu wymienionych warunków zajęcia tego typu mogą być użytecznym narzędziem w poprawie funkcjonowania szkolnego oraz pozaszkolnego dzieci i młodzieży, a także podnoszeniu efektywności zawodowej nauczycieli i radzeniu sobie przez nich z obciążeniami związanymi z ich profesją. 


\section{Bibliografia}

$\rightarrow$ Bar-On, R. (1997), EQ-i. Bar-On Emotional Quotient Inventory. A measure of emotional intelligence. User's manual, Toronto: Multi-Health Systems.

$\rightarrow$ Barchard, K.A. (2003), Does emotional intelligence assist in the prediction of academic success? [w:] "Educational and Psychological Measurement", nr 63, s. 840-858.

$\rightarrow$ Carlo, G., Knight, G.P., Eisenberg, N., Rotenberg, K.J. (1991), Cognitive processes and prosocial behaviors among children: the role of affective attributions and reconciliations [w:] "Developmental Psychology", nr 27, s. 456-461.

$\rightarrow$ Caruso, D.R., Wolfe, Ch.J. (2001), Emotional intelligence in the workplace [w:] J. Ciarrochi, J.P. Forgas, J.D. Mayer (red.), Emotional intelligence in everyday life: a scientific inquiry, Philadelphia: Psychology Press, Taylor \& Francis Group, s. 150-167.

$\rightarrow$ Charbonneau, D., Nicol, A.A.M. (2002), Emotional intelligence and prosocial behaviours in adolescents [w:] "Psychological Reports", nr 90, s. 361-370.

$\rightarrow$ Ciarrochi, J., Deane, F., Wilson, C.J., Rickwood, D. (2002), Adolescents who need help the most are the least likely to seek it: the relationship between low emotional competence and low intention to seek help [w:] "British Journal of Guidance \& Counselling", nr 30(2), s. 173-188.

$\rightarrow$ Eisenberg, N., Fabes, R.A., Losoya, S. (1999), Reakcje emocjonalne: ich regulacja, korelaty społeczne i socjalizacja [w:] P. Salovey i D.J. Sluyter (red.), Rozwój emocjonalny a inteligencja emocjonalna: problemy edukacyjne, Poznań: Dom Wydawniczy Rebis, s. 223-280.

$\rightarrow$ Elfenbein, H.A., Marsh, A.A., Ambady, N. (2002), Emotional intelligence and the recognition of emotion from facial expressions [w:] L. Feldman Barrett, P. Salovey (red.), The wisdom in feeling, New York, London: The Guilford Press, s. 37-59.

$\rightarrow$ Elias, M.J. (1997), The missing piece: making the case for greather attention to social and emotional learning in the schools [w:] "Education Week", nr 17(5), s. 36-38. 
$\rightarrow$ Elias, M.J., Zins, J.E., Weissberg, R.P., Frey, K.S., Greenberg, M.T., Haynes, N.M., Kessler, R., Schwab-Stone, M.E., Shriver, T.P. (1997), Promoting social and emotional learning. Alexandria, VA: Association for Supervision and Curriculum Development.

$\rightarrow$ Gil-Olarte Marqeuz, P., Palomera Martin, R., Brackett, M.A. (2006), Relating emotional intelligence to social competences and academic achievement among high school students [w:] "Psicothema", nr 18, s. 118-123.

$\rightarrow$ Goleman, D. (1997), Inteligencja emocjonalna, Poznań: Media Rodzina of Poznań.

$\rightarrow$ Grabowska, A., Knopp, K.A., Paź, M. (2015), Integracja-empatia-komunikacja. Program treningu kompetencji społecznych dla dzieci [w:] „Kwartalnik Naukowy Fides et Ratio", nr 1(21), s. 94-116.

$\rightarrow$ Gumora, G., Arsenio, W.F. (2002), Emotionality, emotion regulation and school performance in middle school children [w:] "Journal of School Psychology", nr 40, s. 395-413.

$\rightarrow$ Halberstadt, A.G., Hall J.A. (1980), Who's getting the message? Children's nonverbal skill and their evaluation by teachers [w:] "Developmental Psychology", nr 16, s. 564-573.

$\rightarrow$ Jaworowska, A., Matczak, A. (2001), Kwestionariusz Inteligencji Emocjonalnej INTE. Podręcznik, Warszawa: Pracownia Testów Psychologicznych PTP.

$\rightarrow$ Knopp, K.A. (2010), Inteligencja emocjonalna oraz możliwości jej rozwijania u dzieci i młodzieży, Warszawa: Wydawnictwo UKSW.

$\rightarrow$ Knopp, K. (2014), Czy rodzicom potrzebna jest inteligencja emocjonalna? [w:] "Kwartalnik Naukowy Fides et Ratio", nr 4(18), s. 20-35.

$\rightarrow$ Knopp, K.A. (2016), Exploring the relationship of emotional intelligence with mental health status in polish unemployed persons - differences between men and women [w:] "Polish Psychological Bulletin", nr 47(4), s. 436-444.

$\rightarrow$ Landa, J.M.A., López-Zafra, E., De Antoñana, R.M., Pulido, M. (2006), Perceived emotional intelligence and life satisfaction among university teachers [w:] "Psicothema", nr 18, s. 152-157.

$\rightarrow$ Lantieri, L., Patti, J. (1996), Waging peace in our schools, Boston: Beacon.

$\rightarrow$ Liff, S.B. (2003), Social and emotional intelligence: applications for developmental education [w:] "Journal of Developmental Education", nr 26(3), s. 28-34.

$\rightarrow$ Lopes, P.N., Salovey, P., Straus, R. (2003), Emotional intelligence, personality and the perceived quality of social relationship [w:] "Personality and Individual Differences", nr 35, s. 641-658.

$\rightarrow$ Marczak, K. (2008), Inteligencja emocjonalna a funkcjonowanie szkolne młodzieży gimnazjalnej, nieopublikowana praca magisterska, Warszawa: WSFiZ. 
$\rightarrow$ Matczak A., Knopp, K.A. (2013), Znaczenie inteligencji emocjonalnej w funkcjonowaniu człowieka, Warszawa: Liberi Libri.

$\rightarrow$ Mayer, J.D., Cobb, C.D. (2000), Educational policy on emotional intelligence: does it make sense? [w:] "Educational Psychology Review", nr 12, s. 163-183.

$\rightarrow$ Mayer, J.D., Salovey, P. (1999), Czym jest inteligencja emocjonalna? [w:] P. Salovey i D.J. Sluyter (red.), Rozwój emocjonalny a inteligencja emocjonalna: problemy edukacyjne, Poznań: Dom Wydawniczy Rebis, s. 21-69.

$\rightarrow$ Mayer, J.D., Salovey, P., Caruso, D. (2000), Models of emotional intelligence [w:] R. Sternberg (red.), Handbook of intelligence, Cambridge: Cambridge University Press.

$\rightarrow$ Mérida-López, S., Extremera, N. (2017), Emotional intelligence and teacher burnout: a systematic review [w:] "International Journal of Educational Researche", nr 85, s. 121-130.

$\rightarrow$ Mestre, J.M., Guil, R., Lopes, P.N., Salovey, P., Gil-Olarte, P. (2006), Emotional intelligence and social and academic adaptation to school [w:] "Psicothema", nr 18, s. 112-117.

$\rightarrow$ Parker, J.D.A., Summerfeldt, L.J., Hogan, M.J., Majeski, S.A. (2004), Emotional intelligence and academic success: examining the transition from high school to university [w:] "Personality and Individual Differences", nr 36, s. 163-172.

$\rightarrow$ Qualter, P., Whiteley, H.E., Hutchinson, J.M., Pope, D.J. (2007), Supporting the development of emotional intelligence competencies to ease the transition from primary to high school [w:] "Educational Psychology in Practice", nr 23, s. 79-95.

$\rightarrow$ Saarni, C. (1999), Kompetencja emocjonalna i samoregulacja $w$ dzieciństwie [w:] P. Salovey i D.J. Sluyter (red.), Rozwój emocjonalny a inteligencja emocjonalna: problemy edukacyjne, Poznań: Dom Wydawniczy Rebis, s. 75-125.

$\rightarrow$ Salovey, P. (2001), Applied emotional intelligence: regulating emotions to become healthy, wealthy and wise [w:] J. Ciarrochi, J.P. Forgas, J.D. Mayer (red.), Emotional intelligence in everyday life: a scientific inquiry, Philadelphia: Psychology Press, Taylor \& Francis Group, s. 168-184.

$\rightarrow$ Shriver, T.P., Schwab-Stone, M., Defalco, K. (1999), Why SEL is the better way: the New Haven Social Development Program [w:] J. Cohen (red.), Educating minds and harts: social emotional learning and the passage into adolescence, New York: Teachers College Press, s. 43-60.

$\rightarrow$ Stone-McCown, K., Freedman, J.M., Jensen, A., Rideout, M.C. (1998), Self Science: the emotional intelligence curriculum, San Mateo: Six Seconds. 
$\rightarrow$ Sun, P., Chen, J.J., Jiang, H. (2017), Coping humor as a mediator between emotional intelligence and job satisfaction [w:] "Journal of Personality Psychology", nr 16, s. 155-159.

$\rightarrow$ Trinidad, D.R., Johnson, C.A. (2002), The association between emotional intelligence and early adolescent tobacco and alcohol use [w:] "Personality and Individual Differences", nr 32, s. 95-105.

$\rightarrow$ Van der Zee, K., Thijs, M., Schakel, L. (2002), The relationship of emotional intelligence with academic intelligence and the Big Five [w:] "European Journal of Personality", nr 16, s. 103-125.

$\rightarrow$ Wróbel, M. (2013), Praca emocjonalna a wypalenie zawodowe u nauczycieli: moderujqca rola inteligencji emocjonalnej [w:] „Psychologia Społeczna”, $\mathrm{nr}$ 81(24), s. 53-66.

$\rightarrow$ Yin, H., Lee, J.C.K., Zhang, Z., Jin, Y. (2013), Exploring the relationship among teachers' emotional intelligence, emotional labor strategies and teaching satisfaction [w:] "Teach. Educ", nr 35, s. 137-145. 



\section{Coaching w edukacji. \\ Innowacje na rzecz rozwoju}

Lilianna Kupaj

Niniejszy artykuł wyjaśnia, czym jest coaching, w szczególności coaching edukacyjny. W tekście dokonano przeglądu definicji coachingu oraz roli coacha $w$ edukacji. Zawiera również przegląd badań nad coachingiem, z uwzględnieniem badań w coachingu edukacyjnym. Przedstawia również model uczenia się i zmiany Roberta Diltsa oraz role, które wynikają z niego $w$ pracy nauczyciela.

\section{Słowa kluczowe:}

\section{coaching}

coaching w edukacji

innowacje 


\section{Coaching in education. \\ Innovation for development}

Lilianna Kupaj

This article is devoted to explain what coaching is in general, in particular educational coaching. The article reviews the definition of coaching and the role of the coach. It also contains a review of research on coaching, including research in educational coaching. It presents Robert Dilts' learning and change model and the roles that result from it in the teacher's work.

Keywords:

coaching

educational coaching

innovation 


\section{Wstęp}

Coaching w Polsce jest stosunkowo młodą dziedziną rozwijania potencjału ludzkiego, a w edukacji ma zaledwie kilkuletnią historię. $\mathrm{Na}$ świecie coaching pojawił się w latach 70 . XX w. w sporcie, skąd został zaimplementowany do biznesu. Do Polski trafił jako wsparcie dla menedżerów na najwyższych stanowiskach i dopiero później pojawił się jako pomoc $w$ życiu i edukacji. Jedna z definicji podaje, że jest to krótka interwencja, która ma na celu poprawę wyników i/lub rozwój kompetencji zawodowych (Clutterbuck, 2003). Z kolei rozszerzona definicja coachingu mówi: „Jest to proces pomagania ludziom i zespołom w realizacji szczytowych osiągnięć. Polega na aktywizowaniu mocnych stron ludzi (tzw. wewnętrznych zasobów), pomocy w przekraczaniu osobistych barier i ograniczeń pojawiających się na drodze do optimum swojego funkcjonowania oraz ułatwianiu im bardziej efektywnego współdziałania w zespole. Skuteczny coaching uwzględnia zatem zwiększanie efektywności jednostki w obszarze zarówno zadaniowym, jak i relacyjnym. Coaching dąży do osiągnięcia konstruktywnej zmiany, skupiając się na definiowaniu i osiąganiu konkretnych celów. Metody stosowane w coachingu są zorientowane bardziej na cel niż na problem. Skupiają się przede wszystkim na rozwiązaniu, promując rozwój nowych strategii myślenia i działania" (Dilts, 2006, s. XXIII).

Definicja, którą podaje Dilts, zakłada istnienie wewnętrznych zasobów klienta: umiejętności, talentów, które każdy posiada i które można wydobyć, stosując odpowiednie techniki, narzędzia, modele i kompetencje. Powyższe założenia mają swoje źródło w pracy genialnego psychoterapeuty Miltona Ericksona (Haley, 1993).

Zadaniem coachingu jest tworzenie zmiany $w$ dotychczasowym życiu klienta. Jest to niedyrektywny proces cechujący się partnerską relacją. Zadanie coacha polega na:

$\rightarrow$ pomocy jednostkom i organizacjom $w$ tym, by rozwijały się szybciej i osiągały lepsze rezultaty,

$\rightarrow$ koncentrowaniu się na celach, które wybierają klienci,

$\rightarrow$ wyłanianiu rozwiązań i strategii z informacji pochodzących od klienta,

$\rightarrow$ zapewnieniu nowej perspektywy oraz pomocy klientom $w$ budowaniu ich naturalnej siły,

$\rightarrow$ budowaniu relacji z klientem. 
Tego, że coaching jest wysoce efektywną metodą rozwijania potencjału ludzkiego, dowodzi wiele międzynarodowych badań. International Coach Federation ${ }^{1}$ (Międzynarodowe Stowarzyszenie Coachów) zleciło przeprowadzenie w $2008 \mathrm{r}$. dużego badania. Dowodzi ono skuteczności coachingu w następujących obszarach:

$\rightarrow$ pewności siebie (80 proc.),

$\rightarrow$ budowania relacji w związkach (73 proc.),

$\rightarrow$ kompetencji komunikacyjnych (72 proc.),

$\rightarrow$ kompetencji interpersonalnych (71 proc.),

$\rightarrow$ wydajności w pracy (70 proc.),

$\rightarrow$ uzyskania równowagi w życiu zawodowym i osobistym (67 proc.),

$\rightarrow$ zdrowia, dobrego samopoczucia (63 proc.),

$\rightarrow$ rozwoju życia zawodowego i nowych możliwości zawodowych (62 proc.),

$\rightarrow$ organizacji życia osobistego (61 proc.),

$\rightarrow$ zarządzania firmą (61 proc.),

$\rightarrow$ zarządzania czasem (57 proc.),

$\rightarrow$ efektywności zespołów (51 proc.).

W badaniu wzięło udział 2165 osób z 64 krajów.

Kolejne badania firmy A Better Perspective ${ }^{\mathrm{TM}} \mathrm{M}_{2}$, zrealizowane w $2009 \mathrm{r}$. na reprezentatywnej grupie składającej się 339 osób, wskazały korzyści $\mathrm{z}$ coachingu tym razem dla całej organizacji. Dotyczyły one:

$\rightarrow$ pełnego wykorzystania indywidualnego potencjału pracownika (79 proc.),

$\rightarrow$ wzmocnienia osobistego i zaangażowania we własny rozwój (69 proc.),

$\rightarrow$ wzrostu wydajności całej organizacji (69 proc.),

$\rightarrow$ podniesienia kreatywności i zdolności uczenia się (63 proc.),

$\rightarrow$ wzrostu rzeczywistej motywacji pracowników (57 proc.),

$\rightarrow$ ułatwienia przyswojenia nowych stylów zarządzania i kultury organizacji (39 proc.),

$\rightarrow$ wzmocnienia stosunków między ludźmi i/lub oddziałami firmy (35 proc.).

1. Badanie PricewaterhouseCoopers wykonane na zlecenie International Coach Federation, ICF Global Coaching Client Study Executive Summary, 2009.

2. www.abetterperspective.com/Benefits_of_Coaching.htm. 
Dodatkowym dowodem skuteczności metody coachingu w biznesie jest tzw. zwrot z inwestycji, czyli ROI ${ }^{3}$ (Return of Investment). Na podstawie rankingu 100 spółek magazynu "Fortune 100" "The Economic Times" przedstawił raport o tym, że dzięki wdrożeniu metody coachingu w firmach zwrot $z$ inwestycji jest prawie sześć razy większy niż koszty wprowadzenia programu szkoleniowego. Dotyczy to następujących obszarów: poprawy relacji pracowników, efektywności pracy zespołowej oraz satysfakcji z wykonywanej pracy. Rekordowe wskaźniki rentowności pokazują wzrosty nawet do 529 proc. według badania przeprowadzonego na 500 spółkach branży telekomunikacyjnej z listy rankingowej „Fortune 500" 4

Jeśli tak wiele badań dowodzi skuteczności coachingu w biznesie, to rodzi się pytanie, co się zmieni, rozwinie, wzrośnie, jeśli metodę coachingu wprowadzi się do edukacji, do polskich szkół? Chociaż coaching w edukacji jest relatywnie młodą dziedziną, to liczba dowodów, która wspiera to pole naukowe, wciąż rośnie. Oto wyniki badań z Wielkiej Brytanii i ze Stanów Zjednoczonych, z których wynika, że coaching edukacyjny może na wiele różnych sposobów pozytywnie oddziaływać na doświadczenia związane z nauką zarówno nauczycieli, jak i uczniów.

Jak dotąd dowiedziono, że:

1. Coaching ma pozytywny wpływ na stosowanie metod dydaktycznych w klasach (Brown, Reumann-Moore, Hugh, Christman, Riffer, 2008). Ross i Shidler pokazali również wyraźny związek między coachingiem nauczycieli a osiągnięciami ich uczniów (Ross, 1992; Shidler, 2009).

2. Coaching w odniesieniu do nauczycieli jest w stanie zwiększyć stopień zaangażowania ucznia (Brown, Reumann-Moore, Hugh, Christman, Riffer, 2008).

3. Coaching odgrywa ważną rolę we wspieraniu nauczycieli w ich refleksji nad własnym rozwojem zawodowym i w rozwoju profesjonalnych relacji nauczycieli z innymi nauczycielami (Brown, Reumann-Moore, Hugh, Christman, Riffer, 2008).

3. www.nbportal.pl/slownik/pozycje-slownika/roi.

4. Metrix Global ROI Study. USA: Metrix Global, LLC. CIPD (2004). 
4. Evers, Brouwers i Tomic (2006) wykazali, że executive coaching może prowadzić do wzrostu oczekiwań dotyczących wyników i własnej skuteczności nauczyciela.

5. Coaching indywidualny dla uczniów prowadzi do „znacznego wzrostu poziomu odporności psychicznej" (Green, Grant, Rynsaardt, 2007).

6. Coaching profesjonalny zwiększa zaangażowanie uczniów w osiąganie celów oraz sam proces osiągania celów (tamże).

7. W badaniach regionalnych $w$ Wielkiej Brytanii Passmore i Brown (2009) odkryli, że wyniki egzaminów polepszyły się w przypadku 16-letnich uczniów w szkołach o niskim poziomie edukacyjnym.

8. Badania w Wielkiej Brytanii wykazały, że zajęcia uczniów szkół średnich z kompetencji coachingowych mają pozytywny wpływ na postawę do uczenia się (Passmore, Brown, 2009; Withmore, 2002).

9. Madden, Green i Grant (2011) odkryli, że użycie rozwiązań opartych na coachingu wspiera uczniów szkół podstawowych w odnajdywaniu i identyfikowaniu ich własnych sił oraz zasobów.

$\rightarrow$ Kupaj (2017) w wyniku przeprowadzonych badań twierdzi, że uczniowie mają bardzo dobry kontakt z rówieśnikami, potrafią tworzyć z nimi dobre relacje i współpracować w grupie. Uczniowie potrafią również porozumiewać się z osobami dorosłymi, lepiej z rodzicami niż z nauczycielami. Mają umiejętność budowania zdrowych relacji z dorosłymi osobami, znaczącymi w ich życiu. Uczniowie zwiększyli swój wpływ na własne życie. Uważają też, że mają wpływ na to, czego się uczą, i na swoje zdrowie.

$\rightarrow$ Kupaj i Krysa (2017) stwierdziły w wyniku przeprowadzonych badań, że motywacja w znaczącym stopniu może zależeć od oczekiwań uczniów: najwyższe wskazania dotyczyły relacji/bliskości ucznia z nauczycielem.

\section{Kogo dotyczy coaching w szkolnym systemie edukacji?}

Szkoła to system, do którego należą: dyrektor szkoły, nauczyciele, dzieci i młodzież oraz ich rodzice. To również kultura organizacyjna tworzona przez całe społeczeństwo szkoły. Dyrektor może używać narzędzi i kompetencji coachingowych, pracując z nauczycielami, nauczyciele mogą używać narzędzi i kompetencji coachingowych, pracując 
z uczniami i ich rodzicami. Ostatecznym odbiorcą coachingu w szkole jest jednak uczeń.

Rysunek 1. Obszary zastosowania kompetencji coachingowych w szkole

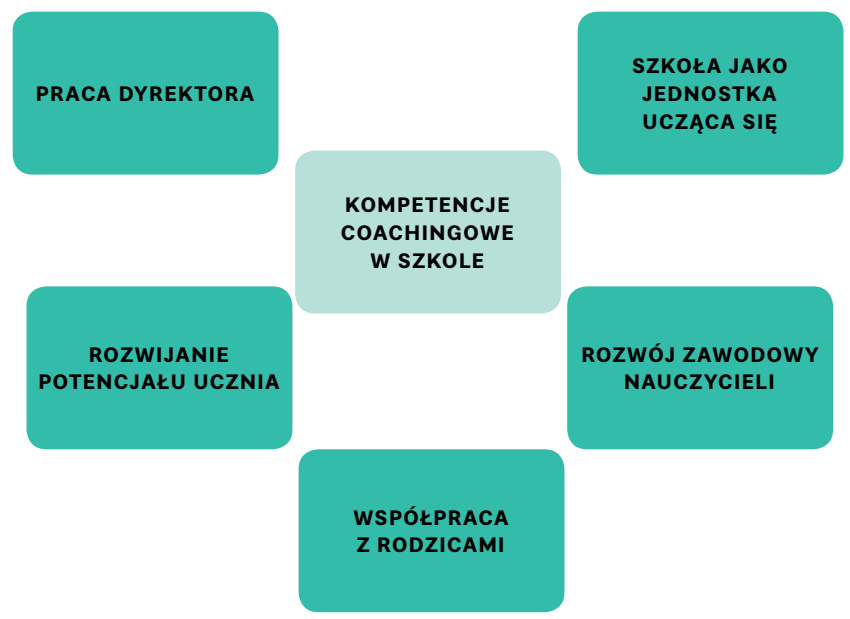

Źródło: Opracowanie własne.

\section{Inspiracje}

Inspiracje do wdrożenia coachingu w edukacji zostały zaczerpnięte z doświadczeń coachów edukacyjnych, literatury oraz badań naukowych. Jedną z bardziej inspirujących historii jest sesja, którą przeprowadził Robert Dilts z 11-letnim chłopcem. Opisuje on rozmowę coachingową, której celem była pomoc w zniwelowaniu dysfunkcji polegającej na braku umiejętności przeliterowania poprawnie wyrazów (tej umiejętności w Stanach Zjednoczonych dzieci uczą się w szóstym roku życia). W trakcie rozmowy Dilts zapytał chłopca o ulubiony film oraz ulubioną postać z tego filmu. Okazało się, że był to wielki miś Wookiee z Gwiezdnych wojen. Następnie zapytał dziecko, czy może wyobrazić sobie Wookieego. Chłopiec natychmiast skierował wzrok w górę i powiedział, że właśnie go widzi. Następnie miał wyobrazić sobie, że Wookiee podnosi łapy, lewą i prawą, kierując ramiona na bok (Dilts pokazał, jak to ma wyglądać). Pod prawą łapą Robert Dilts prosił dziecko o wieszanie po kolei następujących liter: P, H, E. Między 
kolejnymi literami Dilts robił stosowne przerwy, po czym upewniał się, czy chłopiec już je tam zawiesił. Następnie zapytał go, czy może zrobić tak, aby Wookiee otworzył paszczę i kiedy otrzymał odpowiedź twierdzącą, kazał mu zobaczyć, jak z tej otwartej paszczy wychodzą kolejne litery: N, O, M, E. Za każdym razem Dilts upewniał się, czy chłopiec robi to, co on mówi. Na koniec poprosił go jeszcze o zawieszenie paru liter pod lewą łapą Wookieego. Były to: N, O, N. Wówczas poprosił chłopca, aby powiedział, jakie litery wiszą pod prawym ramieniem stworka (tu pokazał mu, o które ramię chodzi). 11-latek bez wahania podał litery: P, H, E. Następnie Dilts powiedział mu, że Wookiee właśnie otwiera paszczę, i zadał mu pytanie, jakie litery z niej wychodzą. Chłopiec szybko odpowiedział: N, O, M, E. Wreszcie Dilts kazał mu podać litery, które zawiesił pod lewym ramieniem Wookieego. Dziecko natychmiast odpowiedziało: N, O, N. W ten sposób, szybko i bez zastanowienia, chłopiec przeliterował słowo: phenomenon. Całość sesji nie przekraczała 45 minut.

To, co zrobił Robert Dilts z 11-letnim chłopcem, jest dowodem na to, że jeśli zastosujemy specjalne metody, to możemy pomóc uczniom rozwijać ich naturalne zasoby. Dilts wykorzystał zmysł wzroku, czyli wyobraźnię chłopca, uruchomił czucie i ruch rąk - zmysł odczuwania oraz na końcu poprosił chłopca o przeliterowanie wyrazu, uruchamiając jego zmysł słuchu.

Z kolei Sugata Mitra, profesor Uniwersytetu w Newcastle, w swoich eksperymentach "Dziura w ścianie" i "Szkoła w chmurze" udowadnia, że dzieci potrafią się samodzielnie uczyć, w dodatku bez ingerencji dorosłych, wiedzione ciekawością i chęcią eksplorowania. Jego podejście wykracza poza obecną epokę, poza dyrektywne podejście do nauczania w szkołach (TED 2013) ${ }^{5}$. Inny profesor - John Hattie z Auckland University - wyszedł z założenia, że najlepsze efekty w nauczaniu osiągniemy, gdy spojrzymy na uczenie się oczami uczniów. Prowadzone przez niego metaanalizy trwały 15 lat. Hattie dokonał ponad 900 analiz na podstawie 52 tys. badań wykonanych na grupie 240 mln uczniów. Efektem jego pracy było m.in. wyodrębnienie 30 czynników wpływających na osiągnięcia uczniów: największego, średniego oraz niewielkiego wpływu. Do czynników znacznie wpływających na osiągnięcia uczniów należą: 
$\rightarrow$ oczekiwania uczniów,

$\rightarrow$ wiarygodność nauczyciela,

$\rightarrow$ informacja zwrotna ucznia,

$\rightarrow$ ewaluacja kształtująca nauczycieli,

$\rightarrow$ wzajemne nauczanie,

$\rightarrow$ relacje nauczyciel-uczeń,

$\rightarrow$ programy wykorzystujące strategie metapoznawcze,

$\rightarrow$ przyspieszenie (np. przeskoczenie jednego roku nauki),

$\rightarrow$ programy rozwijające umiejętność rozumienia tekstu,

$\rightarrow$ programy wzbogacające słownictwo,

$\rightarrow$ tworzenie map myśli.

Część czynników ma bezpośrednią korelację z kompetencjami coachingowymi, takimi jak oczekiwania uczniów, relacje nauczyciel-uczeń, informacja zwrotna oraz postawa coacha charakteryzująca się wiarygodnością.

Z przedstawionych przykładów wynika, że uczniowie, podobnie jak dorośli, posiadają zdolności, umiejętności, system wartości i przekonań, które umożliwiają im naturalny proces uczenia się. Jeśli dać im odpowiednią dawkę wolności, pozbawioną przymusu, to proces nauczania może zdecydowanie przyspieszyć i sprawiać uczniom przyjemność.

\section{Na czym polega coaching edukacyjny?}

"Coaching edukacyjny jest to rozmowa jeden na jeden koncentrująca się na wzmocnieniu uczenia się i rozwoju poprzez zwiększenie samoświadomości i poczucia osobistej odpowiedzialności" (Nieuwerburgh, 2012). Z kolei Kupaj i Krysa definiują coaching edukacyjny w odniesieniu do pracy nauczyciela: „Jest on procesem mającym na celu rozwijanie kompetencji pedagogów i przez to osiąganie przez nich lepszych efektów nauczania. Wspomniany proces zachodzi poprzez zrozumienie tożsamości, przekonań, wartości, umiejętności i zachowań własnych oraz uczniów, umiejętną pracę z nimi oraz przez to skuteczną motywację do nauki" (Kupaj, Krysa, 2013). Swoją definicję oparły na modelu uczenia się i zmiany Roberta Diltsa, nazywanym czasem poziomami logicznymi (Dilts, 1990, 1993, 2000). Model ten określa życie człowieka bez znaczenia, w jakim systemie funkcjonuje (osobistym czy zawodowym). Może być rozumiany na wielu różnych poziomach: środowiska, zachowań, umiejętności, wartości i przekonań, tożsamości oraz celu. 
Środowisko określa konteksty, w których osoba działa, pracuje i żyje. Środowiskiem są: miejsce pracy, nauki, ludzie wokół nas, rodzina, przyjaciele. Poziom zachowania jest tym, co dana osoba mówi i robi. Jest tym, co jest postrzegane przez otoczenie jako działania i słowa. Poziom umiejętności określa zasoby i zdolności dostępne w postaci cech, takich jak wrażliwość, elastyczność, myślenie zorientowane na cel, umiejętność komunikowania się i wiele innych. Poziom wartości i przekonań dotyczy opinii i poglądów ludzi uważanych za prawdziwe, ale nie oparte na faktach. Na tym poziomie pojawiają się przyzwolenie i motywacja, które wspierają lub wstrzymują określone umiejętności oraz zachowania. Poziom tożsamości opisuje to, co osoba myśli o sobie, co zakodowała na swój temat, i ma kluczowe znaczenie dla tego, kim jest. Poziom celu dotyczy postrzegania przez ludzi w większych systemach, do których należą i w których uczestniczą. Odnosi się do sensu życia i działania.

Odnosząc ten model do systemu edukacji, można zobaczyć, jaką rolę może odgrywać nauczyciel na wszystkich poziomach logicznych. Nauczyciel może więc pełnić funkcję:

$\rightarrow$ przewodnika dla ucznia, pokazując mu środowisko szkolne,

$\rightarrow$ coacha przez małe "c", rozwijając zachowania ucznia,

$\rightarrow$ nauczyciela uczącego umiejętności uczenia się,

$\rightarrow$ mentora, wspierając system wartości i przekonań ucznia, budując odpowiednią postawę do nauki,

$\rightarrow$ sponsora rozwijającego bezwarunkowe poczucie wartości ucznia,

$\rightarrow$ inspiratora wyzwalającego głębsze zrozumienie sensu, np. uczenia się (rysunek nr 2).

Praca na poszczególnych poziomach zawsze wyzwala zmianę u osoby poddanej coachingowi. I tak zmiana powierzchowna pojawia się, jeśli dotyczy poziomu środowiska, zachowań i umiejętności, a przechodząc na wyższe poziomy wartości i przekonań oraz tożsamości, wyzwala zmianę głęboką i trwałą. Na najwyższym poziomie celu pojawia się duża zmiana życiowa (Bennewicz, 2011). 
Rysunek 2. Model uczenia się i zmiany Roberta Diltsa

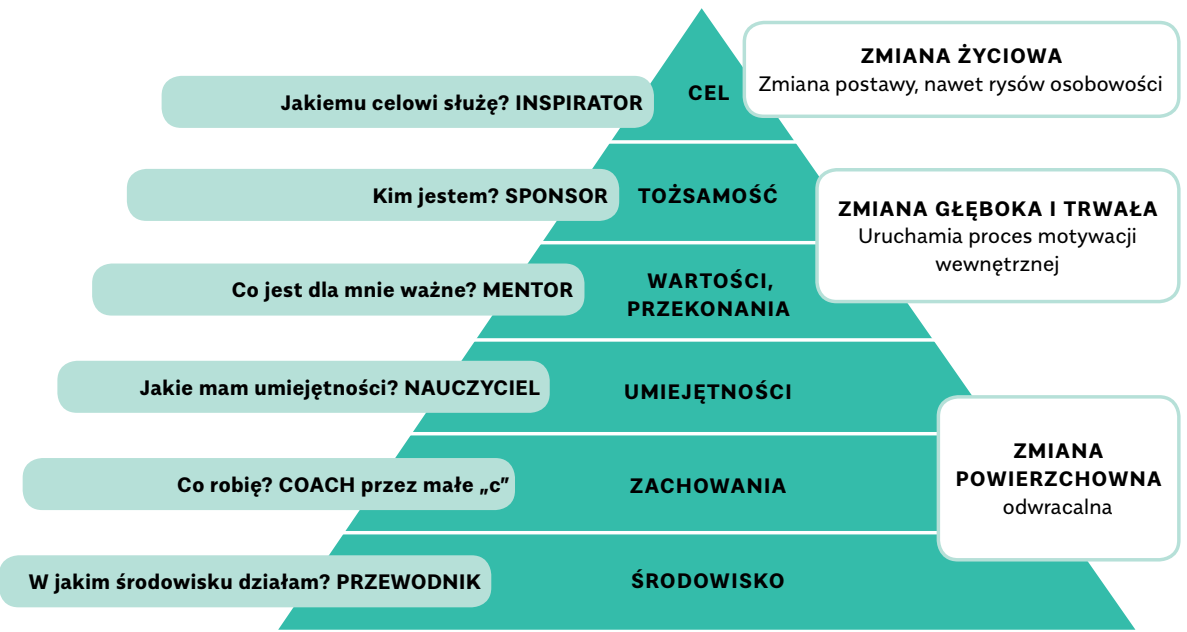

Źródło: Opracowanie własne.

W lepszym zrozumieniu modelu Diltsa i jego zastosowania w nauczaniu pomoże poniższe studium przypadku (źródła własne autorki).

\section{Studium przypadku, uczeń I klasy gimnazjum:}

Do mojego gabinetu przyprowadzono ucznia z powodu zagrożenia jedynkami z 90 proc. przedmiotów. Palił papierosy i zdarzało się, że zażywał narkotyki. Nauczyciele mieli o nim bardzo złe zdanie. Był niekomunikatywny, mówił jedno zdanie, dwa na godzinę. Był zamknięty i skryty. Z wywiadu z wychowawcą dowiedziałam się, że nauczyciele mieli z nim utrudniony kontakt. Nie uczył się, nie widział w tym żadnego celu. Mówił: „Po co się uczyć?” (poziom celu). Pod koniec roku z większości przedmiotów miał proponowane jedynki, był zagrożony (poziom zachowań). Przeprowadziłam z nim dwie sesje coachingowe poświęcone skutecznej nauce, czego rezultatem miało być przejście do kolejnej klasy. Mama ucznia opisywała, że nie potrafi w żaden sposób mu pomóc i wpłynąć na niego. Chłopiec podczas pierwszego spotkania stwierdził, że nie potrafi się uczyć (poziom umiejętności). Jedna z zasad coachingu mówi, że ludzie mają wystarczające zasoby, aby osiągnąć 
sukces, więc postanowiłam udowodnić chłopcu, że potrafi się uczyć, że posiada umiejętności. Ważne było też to, że chłopiec chodził do szkoły na zajęcia i nie opuszczał lekcji (poziom zachowań). Poprosiłam, aby przyniósł na sesję podręczniki przedmiotów, których mu się najtrudniej uczy. Wybrałam za zgodą ucznia fizykę i podczas sesji przerobiliśmy jedną lekcję. Chłopiec rozwiązał dwa zadania: jedno łatwe, drugie trudniejsze z gwiazdką. Powiedziałam do niego: „Widzisz, potrafisz się uczyć, zrobiłeś nawet trudne zadanie". A chłopiec na to: „Nauczyciele i tak mi nie uwierzą, że potrafię. Pomyślą, że to przypadek" (poziom wartości i przekonań - wartość: wiara i przekonanie, że nauczyciele mu nie uwierzą). Praca podczas sesji coachingowej poszła w kierunku budowania wiary we własne umiejętności oraz podważenia nieużytecznego przekonania związanego z opinią nauczycieli na jego temat, nieopartego na faktach. Jednak na kolejnej sesji, gdy już chłopiec miał dużo większą wiarę w siebie, znowu zakwestionował swój sukces, mówiąc: "Wie pani, ja to nie jestem w ogóle wartościowy". I tu już weszliśmy na poziom tożsamości. Na tym poziomie zaczęła się głęboka praca nad jego myśleniem o sobie samym, o swoim poczuciu wartości. Rozmowy coachingowe zakończyły się sukcesem, chłopiec przeszedł do kolejnej klasy (warunkowo z jednego przedmiotu). Po kilku latach po spotkaniu z wychowawcą ucznia dowiedziałam się, że w domu chłopca była bardzo toksyczna atmosfera między rodzicami i ukrywany alkoholizm jednego z rodziców (poziom środowiska). To najprawdopodobniej była przyczyna trudności ucznia w nauce.

Nauczyciele stosujący metodę coachingu w pracy mają do dyspozycji cały wachlarz kompetencji, metod, modeli i narzędzi. Kompetencje coachingowe zostały zebrane i najdokładniej opisane przez stowarzyszenie International Coach Federation ${ }^{6}$ (icf.org.pl). Należą do nich:

1. Działanie zgodne z etyką i ze standardami. Zawiera zrozumienie zasad etycznych i standardów coachingu oraz umiejętność zastosowania ich we wszystkich sytuacjach coachingowych.

2. Zawarcie umowy coachingowej. Oznacza, że coach rozumie i w sposób efektywny omawia $z$ klientem reguły i konkretne parametry relacji coachingowej (m.in. kwestie organizacyjne, opłaty, terminy, włączenie dodatkowych osób, jeżeli zajdzie taka potrzeba). 
3. Zbudowanie zaufania i poczucia bezpieczeństwa klienta.

4. Obecność coachingowa "tu i teraz". Jest to zdolność bycia w pełni świadomym oraz tworzenia spontanicznej relacji z klientem, stosowanie stylu, który zarówno jest otwarty, elastyczny, jak i daje poczucie pewności.

5. Aktywne słuchanie. To umiejętność całkowitego skupienia się na tym, co mówi, a czego nie mówi klient w celu zrozumienia znaczenia słów klienta w kontekście jego pragnień oraz w celu wspomagania klienta w autoekspresji.

6. Trafne pytania. Są umiejętnością zadawania pytań, które odkrywają informacje potrzebne do uzyskania maksymalnego efektu dla klienta i dla relacji coachingowej.

7. Bezpośrednia komunikacja. Jest umiejętnością efektywnej komunikacji podczas sesji coachingowej oraz stosowania języka, który ma najsilniejszy pozytywny wpływ na klienta.

8. Budowanie świadomości. To umiejętność integracji i właściwej oceny wielu różnych źródeł informacji oraz przedstawiania interpretacji, które pomagają klientowi poszerzać świadomość, a tym samym osiągnąć uzgodnione rezultaty.

9. Wspieranie projektowania działań. To umiejętność tworzenia z klientem możliwości ciągłego uczenia się podczas coachingu oraz sytuacji w życiu/pracy, a także do podejmowania nowych działań, które w najbardziej efektywny sposób prowadzą do uzgodnionych rezultatów coachingu.

10. Wspieranie planowania i ustalania celów. To umiejętność tworzenia i utrzymywania razem z klientem efektywnego planu coachingu.

11. Zarządzanie procesem i odpowiedzialnością. Jest umiejętnością utrzymania uwagi klienta na tym, co ważne, przy jednoczesnym pozostawieniu klientowi odpowiedzialności za podejmowanie działań.

W książce Coaching in education Nieuwerburgh (2012) pisze, że organizacje oświatowe zainteresowane podejściem coachingowym będą musiały rozważyć wdrożenie w swoich placówkach takich umiejętności jak: aktywne słuchanie, zadawanie pełnych mocy pytań, rozwijanie inteligencji emocjonalnej, dawanie i otrzymywanie informacji zwrotnej oraz stawianie wyzwań. 
Stosowanie wybranych kompetencji coachingowych szczególnie ważnych w procesie nauczania może prowadzić do rezultatów przedstawionych w tabeli nr 1.

Tabela 1. Najważniejsze właściwości, które rozwija coaching

\begin{tabular}{|c|c|}
\hline NAZWA KOMPETENCJI & ROZWIJANE UMIEJĘTNOŚCI I POSTAWY \\
\hline $\begin{array}{l}\text { Planowanie i wytycza- } \\
\text { nie celów, projektowa- } \\
\text { nie działań }\end{array}$ & $\begin{array}{l}\rightarrow \text { potrafi formułować własne cele, potrzeby i oczekiwania, } \\
\rightarrow \text { potrafi wizualizować cele, } \\
\rightarrow \text { potrafi tworzyć plan, którego rezultaty są osiągalne, mierzalne, } \\
\text { konkretne i ma określone docelowe daty. } \\
\text { Prowadzi to do postawy: proaktywnej, przedsiębiorczej } \\
\text { oraz wywierania wpływu na własne życie. }\end{array}$ \\
\hline Budowanie relacji & $\begin{array}{l}\rightarrow \text { posiądzie umiejętność budowania relacji opartej na poczuciu zaufa- } \\
\text { nia i bezpieczeństwa. } \\
\text { Prowadzi do tworzenia satysfakcjonujących kontaktów/związków, } \\
\text { rozwija współpracę. }\end{array}$ \\
\hline Obecność coachingowa & $\begin{array}{l}\rightarrow \text { potrafi korzystać z własnej intuicji i ufa wewnętrznej mądrości, } \\
\rightarrow \text { potrafi uczyć się za pomocą metafor, } \\
\rightarrow \text { rozwija inteligencję emocjonalną. } \\
\text { Prowadzi do budowania odwagi, siły emocjonalnej, zaufania do siebie. }\end{array}$ \\
\hline Aktywne słuchanie & $\begin{array}{l}\rightarrow \text { potrafi słuchać treści i emocji w rozmowie z drugą osobą, } \\
\rightarrow \text { potrafi słuchać na dwóch poziomach (słuchanie powierzchowne } \\
\text { i głębokie). } \\
\text { Prowadzi do klarownej, zrozumiałej komunikacji. }\end{array}$ \\
\hline Pytania pełne mocy & $\begin{array}{l}\rightarrow \text { potrafi formułować i zadawać otwarte pytania. } \\
\text { Prowadzi do budowania ciekawości i kreatywności. }\end{array}$ \\
\hline $\begin{array}{l}\text { Budowanie } \\
\text { świadomości }\end{array}$ & $\begin{array}{l}\rightarrow \text { widzi inne, szersze perspektywy, inne punkty widzenia, } \\
\rightarrow \text { potrafi identyfikować swoje silne strony, } \\
\rightarrow \text { potrafi nazwać i odkryć swoje wartości oraz niektóre przekonania } \\
\quad \text { (wspierające uczenie się i niewspierające). } \\
\text { Buduje świadomość siebie, swoich kompetencji, uczenia się, } \\
\text { systemu wartości, przekonań. }\end{array}$ \\
\hline
\end{tabular}

\section{Podsumowanie}

Oblicze coachingu w Polsce wciąż się zmienia. Osoby pracujące w zawodzie coacha stają się coraz większymi profesjonalistami. Pojawiło się wiele książek, podręczników, badań. Dwa lata temu powstała specjalizacja 
coachingowa skierowana do nauczycieli: edu coach, podlegająca akredytacji międzynarodowej.

Wprowadzenie na szeroką skalę coachingu edukacyjnego do szkół, czyli kompetencji coachingowych, modeli, narzędzi i metod, może pomóc nauczycielom w rozwoju osobistym i zawodowym, aktywnie motywować uczniów do samodzielnego odkrywania siebie, budowania siły wewnętrznej i odważnego stawiania celów. Metoda coachingu edukacyjnego bezpośrednio pomoże uczniom w odnalezieniu własnego miejsca w nieprzewidywalnej i trudnej rzeczywistości społecznej, by mogli poczuć się spełnionymi i przeżywać radość życia. 


\section{Bibliografia}

$\rightarrow$ Bennewicz, M. (2011), Coaching i mentoring w praktyce, Warszawa: Difin.

$\rightarrow$ Brown, D., Reumann-More, R., Hugh, R., Christman, J.B., Riffer, M. (2008), Links to Learning and Sustainability: Year Three Report of the Pennsylvania. High School Coaching Initiative, Philadelphia: Research for Action.

$\rightarrow$ Clutterbuck, D. (2003), Creating a coaching climate, London: Clutterbuck Associates.

$\rightarrow$ Dilts, R. (2006), Od przewodnika do inspiratora, Warszawa: PINLP.

$\rightarrow$ Dilts, R., DeLozier, J. (2000), The Encyclopedia of Systemic Neuro-Linguistic Programming and NLP New Coding, Santa Cruz: NLP University Press.

$\rightarrow$ Dilts, R., Bonissone, G. (1993), Skills for the Future. Managing Creativity and Innovation, Capitola: Meta Publications.

$\rightarrow$ Dilts, R. (1990), Changing Belief Systems with NLP, Capitola: Meta Publications.

$\rightarrow$ Evers, W.J., Brouwers, A., Tomic, W. (2006), A quasi-experimental study on management coaching effectiveness [w:] "Consulting Psychology Journal: Practice and Research", 58(3), s. 174-182.

$\rightarrow$ Green, S., Grant, A.M., Rynsaardt, J. (2007), Evidence-based life coaching for senior high school students: Building hardiness and hope [w:] "International Coaching Psychology Review", Vol. 2, No. 2007.

$\rightarrow$ Haley, J. (1993), Niezwykła terapia: Techniki terapeutyczne Miltona H. Ericksona: Strategiczna terapia krótkoterminowa, Gdańsk: GWP.

$\rightarrow$ Hattie, J. (2015), Widoczne uczenie się dla nauczycieli. Jak maksymalizować siłę oddziaływania na uczenie się, Warszawa: Biblioteka Szkoły Uczącej Się.

$\rightarrow$ Kupaj, L., Krysa, W. (2014), Kompetencje coachingowe nauczycieli, Warszawa: Wolters Kluwer.

$\rightarrow$ Kupaj, L., Krysa, W. (2017), Preferencje motywacyjne uczniów na różnych poziomach edukacyjnych, Sosnowiec: Oficyna Wydawnicza Humanitas. 
$\rightarrow$ Madden, W., Green, S., Grant, A.M. (2011), A Pilot Study Evaluating Strengths-Based Coaching for Primary School Students: Enhancing Engagement and Hope [w:] "International Coaching Psychology Review", 6, s. 71-83.

$\rightarrow$ Nieuwerburgh, C. (2012), Coaching in education. Getting better Results for Students, Educators, and Parents, London: KARNAC.

$\rightarrow$ Passmore, J., Brown, A. (2009), Coaching non-adult students for enhanced examination performance: a longitudinal study, "Coaching: An International Journal of Theory, practice and research" 2(1), s. 54-56.

$\rightarrow$ Withmore, J. (2002), Coaching for Performance: Growing People, Performance and Purpose, London: Nicholas Brealey. 


\section{Netografia}

$\rightarrow$ Kupaj, L. (2017), Komunikat z badań CLW 2017. Coachingowe lekcje wychowawcze w tarnowskich szkołach ponadgimnazjalnych, coachingedukacyjny. edu.pl/2018/04/25/coachingowe-lekcje-wychowawcze-wyniki-badan/, dostęp 28.06.2018.

$\rightarrow$ Ross, J.A. (1992), Teacher efficacy and the effect of coaching on student achievement [w:] "Canadian Journal of Education", www.researchgate.net/publication/226587752_The_Impact_of_Time_Spent_Coaching_for_Teacher_Efficacy_on_Student_Achievement, dostęp 28.06.2018.

$\rightarrow$ Schidler, L. (2009), The impact of time spent coaching for teacher efficacy on student achievement [w:] "Early Childhood Education Journal", 36(5), s. 453-460, link.springer.com/article/10.1007\%2Fs10643-008-0298-4, dostęp 28.06.2018. 


\title{
Prestiż zawodu \\ a kompetencje nauczycieli
}

\author{
Dominika Walczak
}

Ogólnopolska Konferencja Naukowa

SZKOŁA W ŚWIECIE ZMIAN

I NOWYCH TECHNOLOGII

W artykule poruszono dwa kluczowe pojęcia mające wpływ na jakość pracy nauczyciela - prestiż i kompetencje, a przede wszystkim ich wzajemne powiązania. Autor analizuje propozycję zestawu kompetencji nauczycieli, który został wypracowany w toku dyskusji zespołu ds. opisu kompetencji nauczycieli ${ }^{1}$, powołanego w 2017 r. przy Ministerstwie Edukacji Narodowej, otwierając tym samym dyskusję na temat profilu kompetencyjnego nauczycieli. Tak pomyślany artykuł w żadnym stopniu nie wyczerpuje żadnego z podejmowanych w nim wątków, jest jedynie jednym z wielu głosów w sprawie.

\section{Słowa kluczowe:}

nauczyciele

prestiż

kompetencje

1. W pracach zespołu udział wzięli: dr Paweł Poszytek (Fundacja Rozwoju Systemu Edukacji) - przewodniczący zespołu, dr Beata Jancarz-Łanczkowska (Ośrodek Rozwoju Edukacji), dr Piotr Minkiewicz (Instytut Badań Edukacyjnych) oraz eksperci współpracujący - Liliana Budkowska (FRSE), Marta Choroszczyńska (Mazowieckie Samorządowe Centrum Doskonalenia Nauczycieli), prof. dr hab. Joanna Madalińska-Michalak (Uniwersytet Warszawski), Alicja Pietrzak (FRSE), Anna Ryś (Łódzkie Centrum Doskonalenia Nauczycieli i Kształcenia Praktycznego), Ewa Sprawka (ŁCDNiKP), dr Dominika Walczak (IBE, Akademia Pedagogiki Specjalnej). 


\section{Prestige of the teaching profession and teacher's competences}

Dominika Walczak

In the hierarchies of occupations and professions, teachers invariably occupy a high position. However, teachers themselves do not feel that their profession was socially respected. The discrepancy of qualitative results between the hierarchy of professions and perception of prestige by teachers themselves are the starting point to pose the question of what determines the prestige of the teaching profession. In this article the author identifying components of the prestige of the teaching profession, identifying the conditions for awarding prestige to the teaching profession by different actors of school life. The author believes that learning about the factors responsible for raising the prestige of the teaching profession and teachers seems also important from the point of view of defining the set of teachers' competences necessary in everyday work.

\section{Keywords: \\ teachers \\ prestige \\ competences \\ teachers' prestige \\ teacher's competences}




\section{Wprowadzenie}

Dobrze funkcjonująca szkoła może zasadniczo zmienić osiągnięcia uczniów, a wśród czynników, które wywierają największy wpływ na ucznia, są - obok uporządkowanego rozkładu materiału i poczucia bezpieczeństwa - poszczególni nauczyciele (Marzano, 2012). Na plan pierwszy w procesie uczenia się i nauczania wysuwa się kontekst społeczny, a mianowicie sposób przekazywania wiedzy, umiejętności i postaw.

Z uwagi na ogromną rolę nauczycieli w procesie dydaktycznym i wychowawczym uczniów inwestycja w nauczycieli ma decydujące znaczenie. Dziś priorytetem polityki europejskiej jest podnoszenie atrakcyjności i prestiżu zawodu nauczyciela. W praktyce oznacza to konieczność starannego doboru i zatrudniania nauczycieli, zapewniania nauczycielom skutecznego kształcenia i doskonalenia, zapobieganie porzucaniu zawodu, wspieranie młodych nauczycieli oraz zapewnianie im stałego zgłębiania wiedzy, podnoszenia umiejętności i kompetencji społecznych (Komisja Europejska/EACEA/Eurydice, 2015).

Rekonstrukcja mechanizmów kształtowania się pozycji społecznej nauczyciela, a zatem poznanie wyobrażeń samych nauczycieli o sobie i swojej pracy oraz społecznych oczekiwań wobec nauczycieli w dobie spadku atrakcyjności zawodu nauczyciela w Polsce i w Europie, wydaje się nabierać szczególnego znaczenia w kontekście roli nauczycieli. Poznanie czynników podnoszących prestiż tego zawodu wydaje się także istotne z punktu widzenia określenia zestawu kompetencji nauczycieli niezbędnego $\mathrm{w}$ codziennej praktyce pracy.

\section{Prestiż i kompetencje - znaczenie pojęć}

Prestiż, często nazywany zamiennie szacunkiem, poważaniem, uznaniem czy autorytetem, traktować można jako "układ kryteriów integrujących sposób działania jednostek i kategorii społecznych w terminach wyższości i niższości społecznej" (Domański, Sawiński, 1991, s. 224). To z jednej strony stosunek wyższości/niższości między grupami społecznymi, z drugiej indywidualne poczucie niższości/wyższości między jednostkami.

Prestiż jest wynikiem percepcji i ocen. Kształtowany jest przez to, kim się jest $w$ rozmaitych przejawach odgrywanych ról i zajmowanych pozycji. Jest wartością, którą z jednej strony daje się innym, a z drugiej otrzymuje się od innych (Domański, 2012). To pozytywne lub negatyw- 
ne uprzywilejowanie „w domenie szacunku społecznego" (Weber, 2002), którego podstawowymi wyznacznikami są takie cechy jak bogactwo, władza i wiedza, wykazujące stałą tendencję do wzajemnego przyciągania się i kumulowania (Wesołowski, Domański, 2000).

Współczesne reguły przyznawania prestiżu są w dużej mierze indywidualistyczne - odnoszą się przede wszystkim do osobistych osiągnięć. Prestiż jednostki jest dziś szczególnie zależny od poziomu kwalifikacji, wiedzy, umiejętności, kompetencji społecznych czy wynagrodzenia (Wesołowski, Domański, 2000). Warunkiem wysokiego prestiżu danej pozycji jest jej ważność i wymóg długiego, kosztownego oraz uciążliwego procesu przygotowania niezbędnego do jej zajmowania. Prestiż i idące za nim korzyści materialne są wyłącznie związane z pozycjami ważnymi i wymagającymi przygotowania. Można zatem prestiż z jednej strony traktować jako nagrodę za poniesione nakłady, z drugiej jako mechanizm motywacji, skłaniający do podjęcia wysiłku (Wesołowski, 1962). „Należy jednak podkreślić, że pozycja nie dlatego daje władzę i prestiż, że płyną z niej wysokie dochody. Wysokie dochody płyną z niej raczej dlatego, że jest ona funkcjonalnie ważna, a będąca w dyspozycji kadra z tego lub innego powodu nieliczna" (Davies, Moore, 2005, s. 442). Wykształcenie i władza to zatem środki do osiągnięcia korzyści materialnych i prestiżu.

Z punktu widzenia jednostki prestiż jest psychologiczną nagrodą - ludziom zależy, aby ich darzono szacunkiem. Prestiż ułatwia także radzenie sobie z przeciwnościami losu. Szacunek okazuje się innym, aby zakomunikować, że ich praca jest doceniana, a także by zmotywować ich do lepszej pracy (Domański, 2012).

Możemy mówić o czterech typach prestiżu: osobistym, pozycyjnym, sytuacyjnym i zinstytucjonalizowanym. Najczęściej obecny w myśleniu ludzi jest prestiż osobisty, czyli wartość przypisywana w związku z osobistymi przymiotami. Źródłem tego prestiżu są cechy osób. Prestiż osobisty uzewnętrznia się w bezpośrednich kontaktach między przyjaciółmi, sąsiadami, w gronie rodzinnym, w pracy. Drugim typem prestiżu jest prestiż pozycyjny, wynikający z atrybutów zajmowanych pozycji - zawodu, stanowiska czy odgrywanych ról społecznych. Trzeci typ to prestiż sytuacyjny, który charakteryzują krótkotrwałość i zależność od konkretnych okoliczności. Prestiż zinstytucjonalizowany manifestuje się przede wszystkim w specyfice formy, a wyznacznikiem tego prestiżu jest sposób, w jaki szacunek okazuje się innym (Domański, 2012). 
Definicje prestiżu można odnieść także do prestiżu zawodów - „z jednej strony zależny jest od pewnych społecznych cech, jakimi charakteryzuje się każdy wykonawca danego zawodu, takich jak np. wykształcenie, stopień posiadanej władzy lub stopień zamożności. $Z$ drugiej strony jest on zależny od przyjmowanego systemu wartości, związanego zazwyczaj z jakąś ideologią społeczną. Od systemu wartości zależy, jakie to cechy zawodu brane są pod uwagę w prestiżowej ocenie i jaki jest kierunek tych ocen" (Wesołowski, Sarapata, 1961, s. 99). W badaniach empirycznych prestiż zawodów operacjonalizuje się w postaci hierarchii zawodów - badani, odwołując się do własnych ocen, dokonują hierarchizacji zawodów według kryterium prestiżu (poważania społecznego).

Odnosząc pojęcie prestiżu do nauczycieli, rodzą się pytania: Czy polscy nauczyciele cieszą się prestiżem? Jakie czynniki wzmacniają, a jakie obniżają prestiż nauczycieli? Który rodzaj prestiżu jest szczególnie ważny w pracy nauczyciela?

Istnieje wiele definicji kompetencji. Szczególnie dużo miejsca poświęcono temu pojęciu w psychologii, zarządzaniu, pedagogice i socjologii.

Dla psychologów kompetencje oznaczają zdolność do wykonania jakiegoś zadania lub dokonania czegoś (Reber, Reber, 2005). Są zatem definiowane w kategorii sprawczości, dzięki której jednostka może oddziaływać na innych (Wojciszke, 2016). W zarządzaniu kompetencje to taka dyspozycja danej osoby, która prowadzi do zachowań zgodnych z wymogami stanowiska pracy, określonymi przez parametry środowiska organizacyjnego, co z kolei przynosi pożądane wyniki (Boyatzis, 2008). To zestaw wiedzy, umiejętności i odpowiedzialności, który ma wpływ na przebieg pracy i pozostaje $w$ korelacji z osiąganiem wyników w pracy (Parry, Proctor-Thomson, 2003). Pedagodzy podkreślają, że kompetencje są wynikiem procesu kształcenia, który pozwala na wykonywanie określonych czynności zawodowych na oczekiwanym poziomie, który wynika z integracji wiedzy, umiejętności czy sprawności (Kwiatkowska, 2008). Kompetencje wyrażają się w demonstrowaniu na wyznaczonym przez społeczne standardy poziomie umiejętności adekwatnego zachowania się, w świadomości potrzeby $i$ konsekwencji takiego właśnie zachowania oraz w przyjmowaniu na siebie odpowiedzialności za nie (Czerepaniak-Walczak, 1999). A zatem, co podkreślają socjolodzy, kompetencje dotyczą zintegrowanego wykorzystania 
w obszarze życia osobistego i zawodowego zdolności, cech osobowości, a także nabytej wiedzy i umiejętności (Levy-Leboyer, 1997). Kompetencje indywidualne to także uświadamianie sobie przez jednostkę posiadanych zdolności, wiedzy i umiejętności. Stanowią zarówno kapitał przypisany, jak i osiągnięty w procesie socjalizacji pierwotnej oraz socjalizacji wtórnej, w tym socjalizacji do pracy, a także doświadczenia nabytego w czasie pracy (Spencer, Spencer, 1993). Obok kompetencji indywidualnych występują także kompetencje instytucjonalne - związane ze specyfiką danej instytucji i zatrudnionej w niej kadry. Odnoszą się do charakterystyk wszystkich pracowników, także ich identyfikacji z instytucją, do jej działalności i branży. Budują solidarność zawodową i wspólnotę instytucjonalną. Łączą pracowników o tożsamych kompetencjach, tworząc $w$ ten sposób wspólnoty branżowe, m.in. lekarzy, prawników czy nauczycieli (Putnam, 1994). Kompetencje ukierunkowane na pracę powiązane $z$ dziedzinami pracy, w których jednostka jest kompetentna, stanowią profil kompetencyjny roli zawodowej lub stanowiska pracy w myśl stwierdzenia: właściwy człowiek na właściwym miejscu (Woodruffe, 1991).

W perspektywie rozwoju osobistego oraz kariery zawodowej ogromne znaczenie mają kompetencje kluczowe. Ich znaczenie dla odnoszenia sukcesów w życiu podkreślone zostało tak dobitnie po raz pierwszy w zaleceniu Parlamentu Europejskiego i Rady z 18 grudnia 2006 r. w sprawie kompetencji kluczowych w procesie uczenia się przez całe życie. Kompetencje kluczowe to te, których wszyscy potrzebują do samorealizacji i rozwoju osobistego, zatrudnienia, włączenia społecznego, zrównoważonego stylu życia, udanego życia w pokojowych społeczeństwach, kierowania życiem w sposób prozdrowotny i aktywnego obywatelstwa (Komisja Europejska, 2018). Do kompetencji kluczowych, rozwijanych w perspektywie uczenia się przez całe życie i we wszystkich kontekstach społecznych, należą:

1. kompetencje w zakresie rozumienia i tworzenia informacji,

2. kompetencje w zakresie wielojęzyczności,

3. kompetencje matematyczne oraz kompetencje w zakresie nauk przyrodniczych, technologii i inżynierii,

4. kompetencje cyfrowe,

5. kompetencje osobiste, społeczne i w zakresie umiejętności uczenia się,

6. kompetencje obywatelskie, 
7. kompetencje w zakresie przedsiębiorczości,

8. kompetencje w zakresie świadomości i ekspresji kulturalnej (Komisja Europejska, 2018).

Podsumowując, niezależnie od definicji można zauważyć, że kompetencje są kategorią wieloaspektową, łączoną z profesjonalizmem. Oznaczają zdolność skutecznej realizacji określonych zadań związanych z pracą lub osiągania pożądanych, wymiernych rezultatów oraz zdolność realizacji konkretnych wzorcowych zachowań. Co więcej, kompetencje nie są stałe - $w$ drodze rozwoju i treningu można na nie wpływać i je udoskonalać. W najbardziej ogólnym ujęciu kompetencje można określić jako szeroko rozumianą zdolność do podejmowania określonych działań. Tę zdolność do działania warunkują w znacznym stopniu wiedza, umiejętności i kompetencje społeczne nabyte w procesie uczenia się (czyli określone efekty uczenia się). Odwołując się do Ustawy o zintegrowanym systemie kwalifikacji, wiedzę będziemy rozumieć jako zbiór opisów obiektów i faktów, zasad, teorii oraz praktyk odnoszących się do działalności zawodowej nauczyciela; umiejętności jako zdolność do wykonywania zadań i rozwiązywania problemów właściwych dla działalności zawodowej nauczyciela, a kompetencje społeczne (postawy) jako zdolność do kształtowania własnego rozwoju oraz autonomicznego i odpowiedzialnego uczestniczenia w życiu zawodowym i społecznym, z uwzględnieniem etycznego kontekstu własnego postępowania. Istotne, że wiedza, umiejętności i kompetencje społeczne nie mogą być traktowane całkowicie rozłącznie:

$\rightarrow$ wiedza zawsze obejmuje pewien komponent umiejętności,

$\rightarrow$ umiejętności zawsze zawierają pewne elementy wiedzy,

$\rightarrow$ składnikiem kompetencji społecznych zawsze są jakieś umiejętności i pewna wiedza.

Uwaga, kompetencje są jednak czymś więcej niż zbiorem efektów uczenia się, bo na kompetencje człowieka składają się również zdobyte już doświadczenie oraz predyspozycje i uzdolnienia („Mała encyklopedia ZSK", 2017).

W kontekście nauczycieli pytanie brzmi: Jakiej wiedzy, umiejętności i postaw potrzebuje nauczyciel, by cieszyć się wysokim prestiżem i skutecznie wykonywać swoje obowiązki zawodowe, między innymi wesprzeć ucznia w nabywaniu kompetencji kluczowych? 


\section{Prestiż zawodu nauczyciela i nauczycieli}

\section{- społeczne postrzeganie i oczekiwania}

Spróbujmy odpowiedzieć na postawione wyżej pytania o prestiż zawodu nauczyciela, a także osób wykonujących ów zawód, czyli nauczycieli.

Nauczyciele przez Polaków postrzegani są jako ludzie o wysokich kwalifikacjach, czerpiący satysfakcję z tego, co robią, a ich praca jawi się jako stresująca, odpowiedzialna i ciężka. Jednocześnie częste są też opinie, że nauczyciele pracują za mało i mają zbyt długie urlopy. Co więcej, ponad połowa Polaków nie ceni tego zawodu na tyle, by chcieć, aby ich dzieci w przyszłości go wykonywały (CBOS, 2012).

$Z$ badań prestiżu zawodów wynika, że nauczyciele na tle innych profesji cieszą się w Polsce wysokim i stabilnym poważaniem, choć faktem jest, że obecna pozycja nauczyciela jest nieco niższa, niż była pod koniec okresu PRL. W sierpniu 2013 r. nauczyciele znaleźli się w siódemce najbardziej szanowanych przez Polaków zawodów, wyprzedzając zawód lekarza (CBOS, 2013).

Nikt $z$ biorących udział $w$ badaniu dotyczącym pozycji społeczno -zawodowej nauczycieli i ich szans na szkolnym oraz pozaszkolnym rynku pracy (Smak, Walczak, 2015) nie miał wątpliwości, że zawód nauczyciela wiąże się z ogromną odpowiedzialnością, przede wszystkim za ucznia - jego edukację i wychowanie. Owa odpowiedzialność jest także postrzegana jako podstawowa trudność w pracy nauczyciela (Walczak, 2017).

Polacy nie tylko postrzegają zawód nauczyciela jako trudny, lecz także ufają nauczycielom. W 2016 r. Polacy zdecydowanie najlepiej ocenili nauczycieli z powodu ich uczciwości i rzetelności zawodowejtylko trzy zawody wypadły w tej ocenie lepiej: naukowcy, pielęgniarki i informatycy (CBOS, 2016).

Wydaje się, że wysoka lokata zawodu nauczyciela na drabinie hierarchii prestiżu zawodów wynika w Polsce od lat $z$ :

$\rightarrow$ przypisywanej wysokiej użyteczności społecznej zawodu,

$\rightarrow$ poczucia niezbędności i ważność funkcji, jaką pełnią nauczyciele,

$\rightarrow$ uciążliwości pracy,

$\rightarrow$ odpowiedzialności,

$\rightarrow$ poświęcenia,

$\rightarrow$ powołania do wykonywania zawodu,

$\rightarrow$ tego, że jest to praca niedoceniona w wymiarze finansowym, czyli niskopłatna (Reszke, 1982). 
Społeczne postrzeganie zawodu nauczyciela nie tylko wyznacza jego wysokie miejsce na drabinie hierarchii zawodów, lecz także rzutuje na postrzeganie ludzi w zawodzie. Zanim postaram się odpowiedzieć na pytanie, jacy nauczyciele cieszą się wysokim prestiżem, chciałam zwrócić uwagę na postrzeganie zawodu przez samych nauczycieli. Z międzynarodowego badania nauczania i uczenia się TALIS 2013 wynika, że polscy nauczyciele wyżej oceniają swoją satysfakcję z miejsca pracy niż z wykonywanego zawodu, a ze stwierdzeniem, że zawód nauczyciela jest ceniony w społeczeństwie, zgodziło się jedynie 20 proc. $z$ nich. Jednocześnie najbardziej problemowymi obszarami w wykonywaniu zawodu nauczyciela są, obok niskiego prestiżu zawodu, wysokość wynagrodzenia, brak pewności zatrudnienia oraz przeciążenie pracą [Hernik (red.), 2015].

Dostrzegalne rozbieżności między społecznym postrzeganiem zawodu a percepcją prestiżu zawodu nauczycieli pozwalają postawić hipotezę o spadku prestiżu pozycyjnego nauczycieli - wynikającego z atrybutów zajmowanych pozycji, czyli wykonywanego zawodu, przy jednoczesnym wzroście znaczenia prestiżu osobistego. Jednocześnie prestiż zinstytucjonalizowany nauczycieli - który manifestuje się przede wszystkim w specyfice formy, a jego wyznacznikiem jest sposób, w jaki okazuje się go innym - będzie pochodną prestiżu osobistego. W praktyce oznacza to, że nie wszyscy nauczyciele będą szanowani, ale ci, którzy legitymują się dużą wiedzą merytoryczną i umiejętnościami metodycznymi, angażują się i wkładają dużo wysiłku w swoją pracę, a także stawiają na ciągły rozwój i umiejętności interpersonalne, które przekładają się na relacje z uczniami, rodzicami uczniów i innymi nauczycielami oraz dyrektorem szkoły.

W świetle istniejących badań możemy twierdzić, że obecnie w pracy nauczyciela szczególnego znaczenia nabiera jednostkowy kapitał społeczny - pozycja i relacje w grupach społecznych - oraz kapitał kulturowy rozumiany jako umiejętności, zwyczaje, nawyki, style językowe, rodzaje ukończonych szkół, gust i styl życia. W ocenie przyznawanej nauczycielom przez uczniów oraz rodziców uczniów kluczowe znaczenie mają bowiem zasoby nauczycieli o charakterze społecznym i kulturowym, choć sami nauczyciele życzyliby sobie posiadać przede wszystkim zasoby materialne - wysoki kapitał ekonomiczny (pieniądze i przedmioty materialne) - oraz symboliczne, a więc kapitał symboliczny, który instytucjonalizowałby nadrzędną pozycję nauczycieli wobec innych osób biorących udział w życiu szkoły. 


\section{Kompetencje nauczycieli w świetle wybranych badań}

Podkreślić należy raz jeszcze, że wśród czynników wzmacniających prestiż nauczyciela kluczowe znaczenie mają dziś jego cechy osobiste - posiadana przez niego wiedza, umiejętności, kompetencje społeczne, a także styl pracy z uczniem, wpływ na funkcjonowanie szkoły oraz wymiary klimatu szkoły, wśród których kluczowe są relacje różnych aktorów życia szkoły.

Dobry nauczyciel, zdaniem osób funkcjonujących w szkole, łączy w sobie cechy dobrego dydaktyka, metodyka i psychologa. Nieustannie pogłębia wiedzę z nauczanego przedmiotu, potrafi przekazać ją uczniom oraz doskonalić umiejętności w sposób równie przystępny, jak i ciekawy, a jednocześnie indywidualizuje pracę z uczniem. Cechuje go także sprawiedliwość zarówno w traktowaniu uczniów, w tym ich ocenianiu, jak i egzekwowaniu zasad obowiązujących w szkole i na lekcji, co sprzyja zaufaniu, jakim darzą go uczniowie oraz ich rodzice. W końcu charakteryzuje go pasja, z jaką wykonuje swój zawód. Dzięki niej nie tylko z większym zaangażowaniem wykonuje swój zawód, lecz także jest bardziej wiarygodny dla ucznia, stając się dla niego autorytetem $w$ danej dziedzinie. Dodatkowo legitymuje się wysokimi kompetencjami społecznymi, w tym zwłaszcza interpersonalnymi. W swojej codziennej pracy nastawiony jest na ucznia i jego rodziców. Ucznia traktuje podmiotowo i z szacunkiem, słucha, co ma do powiedzenia, nie są także mu obojętne jego problemy osobiste ani rodzinne.

Pytanie, czy wszyscy polscy nauczyciele są w stanie sprostać tak formułowanym oczekiwaniom? Czy nauczyciele posiadają niezbędny zestaw kompetencji, by móc profesjonalnie wykonywać swoją pracę? Próbując jedynie zasygnalizować odpowiedź na te pytania, odwołam się do wybranych badań, których wyniki rzucają światło na kwestie kształcenia nauczycieli, ich rozwój zawodowy, relacje w gronie pedagogicznym i styl pracy z uczniami, jakże kluczowe z punktu widzenia prestiżu zawodu nauczyciela.

\section{Ksztalcenie nauczycieli}

Identyfikując czynniki określające wysokie miejsce nauczyciela w hierarchii zawodów, a także szacunek dla konkretnych nauczycieli, nie sposób nie zauważyć, że szczególnie ważne są oczekiwane i dostrzegane przez różnych aktorów życia szkoły kompetencje nauczycieli, kształtowane między innymi w procesie rozwoju zawodowego na poziomie 
kształcenia wyższego, doskonalenia zawodowego oraz codziennej pracy w szkole.

Ocena systemu kształcenia nauczycieli daje odpowiedź na pytanie o posiadane i brakujące kompetencje kandydatów do pracy w zawodzie nauczyciela. Liczne badania wskazują, że nauczyciele nabywają kompetencji zawodowych przede wszystkim dzięki doświadczeniom praktycznym w szkole. Zaskakująco małe znaczenie w zdobywaniu umiejętności pedagogicznych nauczyciele przypisują wykształceniu kierunkowemu na uczelni i praktyce zawodowej podczas studiów (Wiłkomirska, 2004, 2005, 2010; Walczak, 2012).

Początkujący nauczyciele jako swój atut wymieniają wiedzę merytoryczną z zakresu prowadzonego przedmiotu i metodyki prowadzenia zajęć, a także aktywną postawę objawiającą się gotowością i potrzebą ciągłego doskonalenia zawodowego, poszukiwania coraz to ciekawszych form prowadzenia zajęć, nawiązywania lepszego kontaktu z uczniem i motywowania go do nauki. Wśród swoich słabości wskazują przede wszystkim problemy z utrzymaniem dyscypliny w klasie, trudności w relacjach z uczniami, w tym z jednej strony dużą nieufność wobec uczniów, a z drugiej zbytnią pobłażliwość, brak cierpliwości, dystansu, opanowania, a także kierowanie się wiedzą stereotypową w ocenie uczniów. Ponadto początkujący nauczyciele przyznawali się do bezradności w zetknięciu z problemami uczniów - między innymi problemami rodzinnymi, osobistymi, $w$ tym $w$ relacjach $z$ rówieśnikami. Brakowało im też kompetencji wspierających kontakt z rodzicami uczniów - badani zgodnie twierdzili, że ten aspekt pracy był absolutnie pomijany w procesie kształcenia nauczycieli. Co więcej, kłopotliwe okazały się także czynności administracyjno-sprawozdawcze - brak precyzji i systematyczności początkujących nauczycieli w prowadzeniu dokumentacji. Poważnym ograniczeniem była także nieznajomość obowiązującego prawa oświatowego. Wymieniano także trudności z zarządzaniem procesem kształcenia uczniów oraz własnym czasem. Co - sądząc po wypowiedziach respondentów - oznacza, po pierwsze, powstawanie sporych zaległości w postaci narastających partii niezrealizowanego materiału, a w związku z tym konieczność jego nadrabiania i ryzyko niezrealizowania, a po drugie, niezwykłą czasochłonność procesu przygotowywania się do lekcji, która niekoniecznie przekłada się na jakość zajęć (Walczak, 2012).

Niedostatki w edukacji nauczycieli powodują, że pracującym nauczycielom brakuje wielu umiejętności. Nawet jeśli większość z nich ma 
wystarczająco szeroką wiedzę w zakresie przedmiotu, którego nauczają, to brakuje im przede wszystkim niezbędnych do wykonywania zadań zawodowych umiejętności rozwiązywania problemów wychowawczych, nowoczesnych kompetencji dydaktycznych, woli i umiejętności doprowadzenia każdego ucznia do sukcesu dydaktycznego, umiejętności społecznych organizowania życia w klasie i szkole, organizowania relacji szkoły z otoczeniem.

\section{Rozwój zawodowy nauczycieli}

Na starcie zawodowym większość nauczycieli dokształcała się w pierwszych miesiącach pracy. Zdarza się jednak - o czym świadczą wypowiedzi zarówno początkujących nauczycieli, jak i dyrektorów szkół-że oferta rozwoju zawodowego jest nieadekwatna do potrzeb nauczycieli rozpoczynających pracę w zawodzie. Z wypowiedzi początkujących nauczycieli wynika również, że badani nie znają ani nie rozumieją kryteriów korzystania z oferty form doskonalenia finansowanego przez szkołę (Walczak, 2012).

Wyniki badania TALIS 2013 wskazują, że niemal wszyscy polscy nauczyciele uczestniczą w różnych formach rozwoju zawodowego. Najwięcej nauczycieli deklarowało swój udział w krótkotrwałych formach rozwoju - kursach/warsztatach oraz w konferencjach lub seminariach. Do rzadkości należały wizyty obserwacyjne w firmach, instytucjach publicznych czy organizacjach pozarządowych. Podejmowane przez nauczycieli działania z zakresu doskonalenia zawodowego dotyczyły przede wszystkim zagadnień związanych z wiedzą i ze zrozumieniem nauczanego przedmiotu, z pracą z uczniami mającymi specjalne potrzeby edukacyjne oraz kompetencjami pedagogicznymi w zakresie nauczanego przedmiotu. Jednocześnie w tych trzech dziedzinach potrzeby doskonalenia się polskich nauczycieli okazały się dość niskie. Niezależnie od potrzeb doskonalenia w danym obszarze nauczyciele na ogół dość wysoko ocenili przydatność poszczególnych zagadnień. Największy pozytywny wpływ na nauczanie miały formy doskonalenia podejmujące zagadnienia dotyczące wiedzy i zrozumienia nauczanego przedmiotu oraz znajomości programu nauczania. Okazuje się, że wśród polskich nauczycieli większe potrzeby w zakresie rozwoju zawodowego mają nauczyciele młodsi: z wiekiem, ale także wraz z długością stażu potrzeby te maleją. Wyjątkiem jest wykorzystywanie technik komputerowych w nauczaniu, na które największe zapotrzebowanie jest wśród 
nauczycieli najstarszych, co może wskazywać na różnice pokoleniowe, świadczące o lepszej znajomości tych technik przez młodsze roczniki (Piwowarski, 2015).

\section{Relacje w gronie pedagogicznym}

Jak wynika z badania TALIS 2013, nauczyciele, którzy brali udział w sieci współpracy oraz w indywidualnych i wspólnych badaniach w trakcie zajęć doskonalących zawodowo, znacznie częściej wskazywali, że byli zaangażowani we wspólne działania edukacyjne. Tymczasem prawie jedna czwarta polskich nauczycieli stwierdziła, że na żadnych zajęciach w ramach doskonalenia zawodowego nie było wspólnych działań ani wspólnych badań (Piwowarski, 2015).

Jeśli chodzi o prestiż nauczycieli, to szczególnego znaczenia nabierają dziś relacje w gronie pedagogicznym, stanowiące jeden z wielu składników klimatu szkoły i klasy, rozumianego jako jakość relacji społecznych, cech środowiska kształcenia i wychowania, bezpieczeństwa fizycznego i emocjonalnego oraz charakterystyki środowiska fizycznego (Ostaszewski, 2012).

Z badań TALIS 2013 wynika, że najczęstszą formą współdziałania polskich nauczycieli jest uczestnictwo w dyskusjach na temat przebiegu nauki konkretnych uczniów - aż trzy czwarte nauczycieli prowadzi takie rozmowy z innymi nauczycielami przynajmniej raz w miesiącu. Zdecydowanie częściej takie rozmowy prowadzą kobiety niż mężczyźni, najczęściej nauczyciele matematyki i języka polskiego. Również inne formy współdziałania i wzajemnego wsparcia, takie jak współpraca z innymi nauczycielami w celu zapewnienia wspólnych standardów oceny postępów uczniów w nauce czy wymiana materiałów dydaktycznych z innymi nauczycielami, wybierają najczęściej nauczyciele języka polskiego i matematyki. Ponad 40 proc. nauczycieli gimnazjów przynajmniej raz $w$ tygodniu wymienia się z innymi nauczycielami materiałami dydaktycznymi, przy czym w największym stopniu dotyczy to nauczycieli matematyki, języka polskiego oraz innych języków. Co więcej, polscy nauczyciele dość rzadko obserwują nawzajem swoje lekcje i dzielą się uwagami na ich temat (Przewłocka, 2015a).

Zdecydowana większość nauczycieli - biorąca udział w badaniu dotyczącym bezpieczeństwa w szkole, klimatu szkoły i klasy - pozytywnie ocenia atmosferę w gronie pedagogicznym. Ponad trzy czwarte deklaruje, że w pokoju nauczycielskim panuje miła atmosfera. Jeszcze 
więcej potwierdza, że nauczyciele często pomagają sobie w rozwiązywaniu trudności wychowawczych. Jednocześnie co czwarty zaznacza, że nauczyciele niechętnie przyznają się przed innymi nauczycielami, że mają problemy związane z pracą. Stosunkowo wysoką ocenę poziomu wzajemnego wsparcia potwierdzają też odpowiedzi dotyczące pomocy kolegom w sytuacji konieczności wykonania większej pracy. Gorzej niż wsparcie oceniany jest poziom zaufania: niewiele ponad połowa potwierdza, że nauczyciele ufają sobie wzajemnie. Istotne, że wysoko przez nauczycieli oceniane są nie tylko relacje z innymi nauczycielami, lecz także z dyrektorem szkoły. Zdecydowana większość nauczycieli bardzo wysoko ocenia dyrektora i jego relacje z gronem pedagogicznym. Około czterech piątych uważa, że traktuje on nauczycieli z szacunkiem, pomaga im $w$ trudnych sytuacjach $i$ jest otwarty na ich propozycje. Podobny odsetek jest zdania, że dyrektor pozostawia nauczycielom decyzje dotyczące pracy z uczniami. Nieco mniejszy odsetek nauczycieli (ale wciąż znacząca większość) potwierdza, że dyrektor docenia pracę nauczycieli, traktuje ich sprawiedliwie i im ufa. Jednocześnie blisko jedna czwarta wskazuje na problem niechętnego przyznawania się przed dyrekcją do problemów dydaktycznych i wychowawczych (Przewłocka, 2015b). Brak zaufania, a przez to gotowości do przyznawania się do problemów wydaje się, że osłabia relacje w gronie pedagogicznym. Badania TALIS 2013 wskazują, że w Polsce rzadziej niż w innych krajach nauczyciele otwarcie rozmawiają o trudnościach (Przewłocka, 2015a).

Współpraca z innymi nauczycielami rozumiana jako udzielanie sobie nawzajem wsparcia czy pożyczanie materiałów może, ale nie musi oznaczać pracy zespołowej. W spotkaniach zespołów, na co wskazują wyniki badania TALIS 2013, biorą udział praktycznie wszyscy nauczyciele (99 proc.), najczęściej jeden-trzy razy w miesiącu (Przewłocka 2015a). Wydaje się, że w wielu polskich szkołach praca zespołowa jest raczej wyzwaniem niż przyjętym stylem pracy grona pedagogicznego. Wyniki badania TALIS 2013 wskazują, że regularnie w każdym tygodniu uczestniczy w nich tylko 5 proc. nauczycieli, podczas gdy średnio w krajach TALIS odsetek ten wyniósł 20 proc. (Przewłocka, 2015a). Analiza danych zebranych podczas ewaluacji zewnętrznych prowadzonych od 2010 do 2013 r. w ramach Systemu Ewaluacji Oświaty - nadzór pedagogiczny, pokazuje, poza wieloma bardzo pozytywnymi aspektami pracy zespołowej nauczycieli, pewną niepokojącą tendencję do sprowadzania funkcjonowania zespołów do pisemnego podsumowania ich działal- 
ności - wtedy celem staje się samo raportowanie. Tworzenie zespołów zadaniowych, głównie w celu realizacji zapisów prawa oświatowego, wydaje się ograniczać możliwe korzyści wynikające z pracy zespołowej.

\section{Styl pracy z uczniami}

Polscy nauczyciele są dobrze przygotowani do pracy, jeśli chodzi o kompetencje merytoryczne (wysoki poziom wiedzy przedmiotowej) oraz dydaktyczno-metodyczne. Świadczą o tym zarówno wypowiedzi samych nauczycieli (znajdujące także odzwierciedlenie w badaniu TALIS 2013), jak i dobre wyniki polskich uczniów w badaniach międzynarodowych (np. PISA - Programme for International Student Assessment, Program Międzynarodowej Oceny Umiejętności Uczniów). Problemy pojawiają się w sferze umiejętności wychowawczych i psychologicznych, w tym w kwestiach związanych z relacjami z uczniami i rodzicami, radzenia sobie $z$ ich problemami. Wyniki badania TALIS 2013 pokazują, że choć relacje społeczne w szkole są przez polskich nauczycieli oceniane raczej pozytywnie, to na tle innych krajów mamy w tym zakresie wyraźne problemy: w Polsce mniejsze są zainteresowanie i troska nauczycieli o uczniów. Różnice widać zwłaszcza w przypadku dbania o dobre samopoczucie uczniów. Mniejsza jest też otwartość na opinie uczniów (Przewłocka, 2015a). Problemy w tym zakresie dobitnie pokazały także wyniki badania PISA 2012: w rankingu stworzonym na podstawie odpowiedzi 15-latków z krajów OECD Polska zajęła ostatnie miejsce, jeśli chodzi o relacje nauczycieli z uczniami. W Polsce aż 26 proc. uczniów nie zgadza się ze stwierdzeniem, że "uczniowie mają dobre relacje z większością nauczycieli", podczas gdy w innych krajach takie negatywne opinie są dużo rzadsze - np. w Portugalii podziela je zaledwie 9 proc. uczniów, średnia dla krajów biorących udział w badaniu wynosi zaś 18 proc. Podobnie negatywnie polscy uczniowie ocenili inne aspekty relacji z nauczycielami. Polscy nauczyciele wprawdzie dostrzegają problem, jednak porównanie konkretnych wartości procentowych ujawnia ogromne różnice między nauczycielami a uczniami w postrzeganiu klimatu społecznego szkoły i niedocenianie skali problemów przez nauczycieli.

Dominujące $w$ dalszym ciągu w praktyce szkolnej kształcenie nastawione na przekazywanie i utrwalanie wiedzy generuje stosunkowo bierną rolę ucznia, a tym samym nie sprzyja niezależności poznawczej oraz utrudnia rozwijanie samodzielnego myślenia i bardziej złożonych umie- 
jętności wśród uczniów. Badania wskazują, że nauczyciele wszystkich przedmiotów stosują w dużej mierze nieskuteczne metody podawcze, unikają pracy w grupach i parach, nie premiują samodzielności uczniów [Federowicz, Choińska-Mika, Walczak (red.), 2014]. Wielu nauczycieli zbyt dużo uwagi poświęca kształceniu zdolności odtwórczych uczniów, mniej się zaś skupiają na umiejętnościach. W naukach przyrodniczych zbyt rzadko wykorzystują metody dydaktyczne bezpośrednio związane z metodą naukową, nie cenią samodzielnego wnioskowania na zajęciach z przedmiotów przyrodniczych, historii czy z matematyki, interpretację literacką traktują jako gotową i daną do przyjęcia przez uczniów, a w kształceniu językowym (dotyczy to zarówno języka polskiego, jak i języków obcych) stawiają na wiedzę oraz odtwarzanie wzorców, nie na komunikację. Nie są powszechne prace w grupach ani parach.

\section{Zamiast zakończenia - kluczowe kompetencje nauczyciela}

Do tej pory w tym artykule starano się wykazać, że tym, co może pomóc nauczycielom poczuć się docenionymi i spełnionymi w pracy, niezależnie od uwarunkowań formalnych, jest prestiż osobisty. Szacunek i autorytet budowane na podstawie wysokiej jakości wiedzy, umiejętności i kompetencji społecznych, a także oparte na zaufaniu i współpracy relacje z uczniami, rodzicami uczniów i innymi nauczycielami, w tym także dyrektorem szkoły.

Wskazówki te jednak nie wystarczą, by odpowiedzieć na pytanie: Jakich kompetencji potrzebuje współczesny nauczyciel, by z jednej strony mógł sprawnie wykonywać wszystkie czynności zawodowe, a z drugiej sprostać oczekiwaniom społecznym? Konieczne wydaje się zatem stworzenie zestawu kluczowych kompetencji nauczycieli, uwzględniających specyfikę zawodu, w tym ciągły rozwój zawodowy. Taki zestaw kompetencji z jednej strony wyznaczałby kierunki kształcenia i rozwoju zawodowego nauczycieli, z drugiej mógłby odegrać doniosłą rolę w podnoszeniu atrakcyjności i prestiżu zawodu nauczyciela - podkreślając niezwykłą złożoność pracy nauczyciela, mógłby stanowić istotną wskazówkę dla kandydatów do zawodu, a także pomóc w przełamaniu negatywnego stereotypu pracy nauczycieli, wedle którego wykonują pracę lekką, łatwą i przyjemną.

Zestaw kluczowych kompetencji nauczycieli powinien uwzględniać z jednej strony wpływające na pracę szkół i nauczycieli powszechne zjawiska, takie jak wzrost znaczenia kompetencji w życiu zawodowym 
i społecznym jednostek, demokratyzacja dostępu do wiedzy, wzrost informatyzacji, inflacja wyższego wykształcenia, a także proces indywidualizacji, partycypacji obywatelskiej oraz potrzeby w zakresie wyrażania własnej podmiotowości, z drugiej zaś mnogość czynności zawodowych nauczycieli. Wśród czynności zawodowych nauczycieli znajdują się zarówno czynności dydaktyczne, w tym prowadzenie lekcji, jak i wychowanie oraz opieka, a także inne zadania statutowe szkoły, czynności administracyjne i tworzenie dokumentacji oraz rozwój zawodowy.

Zachęcamy do pogłębionej dyskusji na temat kompetencji nauczycieli. Za punkt wyjścia autor artykułu proponuje przyjąć listę 17 kluczowych kompetencji zaproponowanych przez zespół ds. kompetencji nauczycieli (patrz tab. 1).

Tab. 1. Zestaw kluczowych kompetencji nauczycieli

\begin{tabular}{|c|c|c|}
\hline WIEDZA ZAWODOWA & PRAKTYKA NAUCZYCIELSKA & $\begin{array}{c}\text { ZAANGAŻOWANIE ZAWODOWE/ } \\
\text { TOŻSAMOŚĆ ZAWODOWA }\end{array}$ \\
\hline \multicolumn{3}{|c|}{ KOMPETENCJE: } \\
\hline przedmiotowe & dydaktyczne & dot. etyki zawodowej \\
\hline psychologiczno-pedagogiczne & $\begin{array}{l}\text { wychowawcze/Opiekuńcze/ } \\
\text { Profilaktyczne }\end{array}$ & dot. rozwoju \\
\hline diagnostyczno-badawcze & poznawcze & emocjonalno-społeczne \\
\hline prawne & komunikacyjne (językowe) & kulturowe I wielokulturowe \\
\hline $\begin{array}{l}\text { dot. znajomości instytucji } \\
\text { wspierających }\end{array}$ & badawcze & \\
\hline \multirow[t]{2}{*}{ dot. zasad bezpieczeństwa (BHP) } & cyfrowe & \\
\hline & przywódcze & \\
\hline
\end{tabular}

Przyglądając się czynnościom zawodowym nauczycieli, możemy uznać, że głównymi filarami pracy nauczyciela są: wiedza zawodowa, praktyka nauczycielska i tożsamość zawodowa. Kluczowe kompetencje nauczycieli można zatem pogrupować według trzech filarów pracy nauczyciela odpowiadające wiedzy, umiejętnościom i postawom, mając świadomość, że nie mogą być traktowane całkowicie rozłącznie. 


\section{Bibliografia}

$\rightarrow$ Boyatzis, R.E. (2008), Competencies in the 2 st century, "Journal of Management Development", No. 1.

$\rightarrow$ Centrum Badania Opinii Publicznej (2012), Wizerunek nauczycieli (Komunikat z badań BS/173/2012), Warszawa: Centrum Badania Opinii Publicznej.

$\rightarrow$ Centrum Badania Opinii Publicznej (2013), Prestiż zawodów (Komunikat z badań BS/164/2013), Warszawa: Centrum Badania Opinii Publicznej.

$\rightarrow$ Centrum Badania Opinii Publicznej (2016), Społeczne oceny uczciwości i rzetelności zawodowej (Komunikat z badań nr 34/2016), Warszawa: Centrum Badania Opinii Publicznej.

$\rightarrow$ Czerepaniak-Walczak, M. (1999), Kompetencja: słowo kluczowe czy "wytrych" w edukacji, „Neodidagmata” 1999, nr XXIV.

$\rightarrow$ Davis, K., Moore, W. (1945), Some Principles of Stratification, "The American Sociological Review", No. 2, za: Wesołowski, W. (1962), Funkcjonalna teoria stratyfikacji Davisa i Moore'a, „Studia Socjologiczne”, 1962, nr 4, s. 95-116.

$\rightarrow$ Davis, K., Moore, W. (2005), O niektórych zasadach uwarstwienia [w:] P. Sztompka, M. Kucia (red.), "Socjologia. Lektury", Kraków: Wydawnictwo Znak, s. 437-445.

$\rightarrow$ Domański, H. (2012), Prestiż, Toruń: Wydawnictwo Naukowe Uniwersytetu Mikołaja Kopernika.

$\rightarrow$ Domański, H., Sawiński, Z. (1991), Wzory prestiżu a struktura społeczna, Wrocław-Warszawa-Kraków: Ossolineum.

$\rightarrow$ Domański, H., Wesołowski, W. (2000), Prestiż - formy historyczne [w:] Encyklopedia socjologii, t. III, Warszawa: Oficyna Naukowa, s. 195-201.

$\rightarrow$ Federowicz, M., Choińska-Mika, J., Walczak, D. (red.) (2014), Liczq się nauczyciele. Raport o stanie edukacji 2013, Warszawa: Instytut Badań Edukacyjnych. 
$\rightarrow$ Hernik, K. (red.) (2015), Polscy nauczyciele i dyrektorzy w Międzynarodowym Badaniu Nauczania i Uczenia się TALIS 2013, Warszawa: Instytut Badań Edukacyjnych.

$\rightarrow$ Komisja Europejska/EACEA/Eurydice (2015), The Teaching Profession in Europe: Practices, Perceptions, and Policies (Zawód nauczyciela w Europie: polityka, praktyka i odbiór społeczny), Raport Eurydice, Luksemburg: Urząd Publikacji Unii Europejskiej.

$\rightarrow$ Komisja Europejska (2018), Zalecenie Rady w sprawie kompetencji kluczowych w procesie uczenia się przez całe życie, COM (2018) 24, Bruksela, 17.01.2018.

$\rightarrow$ Komisja Europejska/EACEA/Eurydice (2015), The Teaching Profession in Europe: Practices, Perceptions, and Policies (Zawód nauczyciela w Europie: polityka, praktyka i odbiór społeczny), Raport Eurydice, Luksemburg: Urząd Publikacji Unii Europejskiej.

$\rightarrow$ Kwiatkowska, H. (2008), Pedeutologia, Warszawa: Wydawnictwa Akademickie i Profesjonalne.

$\rightarrow$ Levy-Leboyer, C. (1997), Kierowanie kompetencjami. Bilanse doświadczeń zawodowych, Warszawa: Poltext.

$\rightarrow$ Mała encyklopedia ZSK (2017), Warszawa: Instytut Badań Edukacyjnych.

$\rightarrow$ Marzano, R.J. (2012), Sztuka i teoria skutecznego nauczania, Warszawa: Wydawnictwo Civitas.

$\rightarrow$ Ostaszewski, K. (2012), Pojęcie klimatu szkoły w badaniach zachowań ryzykownych młodzieży, „Edukacja”, 2012, 4(120), s. 22-38.

$\rightarrow$ Parry, K.W., Proctor-Thomson, S.B. (2003), Leadership, culture and performance: The case of the New Zealand public sector, "Journal of Change Management", Vol. 3(4).

$\rightarrow$ Piwowarski, R. (2015), Rozwój zawodowy nauczycieli [w:] Hernik, K. (red.) (2015), Polscy nauczyciele i dyrektorzy w Międzynarodowym Badaniu Nauczania i Uczenia się TALIS 2013, Warszawa: Instytut Badań Edukacyjnych.

$\rightarrow$ Przewłocka, J. (2015a), Praktyki, przekonania i postawy nauczycieli [w:] Hernik, K. (red.) (2015), Polscy nauczyciele i dyrektorzy w Międzynarodowym Badaniu Nauczania i Uczenia się TALIS 2013, Warszawa: Instytut Badań Edukacyjnych.

$\rightarrow$ Przewłocka, J. (2015b), Bezpieczeństwo uczniów i klimat społeczny w polskich szkołach (Raport z badania), Warszawa: Instytut Badań Edukacyjnych.

$\rightarrow$ Putnam, R.D. (1994), Demokracja w działaniu. Tradycje obywatelskie we współczesnych Włoszech, Kraków: Znak.

$\rightarrow$ Reber, A.S., Reber, E.S. (2005), Słownik psychologii, Warszawa: Wydawnictwo Naukowe Scholar. 
$\rightarrow$ Reszke, I. (1982), Kryteria prestiżu zawodów , "Studia Socjologiczne”, nr 3-4, s. 173-194.

$\rightarrow$ Smak, M., Walczak, D. (2015), Pozycja społeczno-zawodowa nauczycieli, Warszawa: Instytut Badań Edukacyjnych.

$\rightarrow$ Spencer, L.M., Spencer, S.M. (1993), Competence at Work. Models for Superior Performance, New York: Wiley Sons.

$\rightarrow$ Walczak, D. (2012), Poczq̨tkujący nauczyciele (Raport z badania), Warszawa: Instytut Badań Edukacyjnych.

$\rightarrow$ Walczak, D. (2017), Prestiż zawodu nauczyciela i nauczycieli a kompetencje zawodowe i społeczne [w:] Madalińska-Michalak J. (red.), O nowq jakość edukacji nauczycieli, Warszawa: Wydawnictwo Uniwersytetu Warszawskiego, s. 204-224.

$\rightarrow$ Weber, M. (2002), Gospodarka i społeczeństwo. Zarys socjologii rozumiejq̨cej, Warszawa: Wydawnictwo Naukowe PWN.

$\rightarrow$ Wesołowski, W. (1962), Funkcjonalna teoria stratyfikacji Davisa i Moore'a, „Studia Socjologiczne", 1962, nr 4, s. 95-116.

$\rightarrow$ Wesołowski, W., Sarapata, A. (1961), Hierarchie zawodów i stanowisk, "Studia Socjologiczne", 1961, nr 2, s. 91-124.

$\rightarrow$ Wiłkomirska, A. (2004), Kształcenie nauczycieli w Polsce - stare i nowe dylematy, Referat wygłoszony na konferencji Rzecznika Praw Obywatelskich: Misja-Pasja-Kompetencja. Status nauczyciela i jego przygotowanie do zawodu, Kraków, 25.10.2004.

$\rightarrow$ Wiłkomirska, A. (2005), Ocena kształcenia nauczycieli w Polsce, Warszawa: Instytut Spraw Publicznych.

$\rightarrow$ Wiłkomirska, A. (2010), Reforma kształcenia nauczycieli a zmiany w strukturze kompetencji, „Kwartalnik Pedagogiczny”, t. I, 2010, str. 129-150.

$\rightarrow$ Wojciszke, B. (2016), Psychologia społeczna, Warszawa: Wydawnictwo Naukowe Scholar.

$\rightarrow$ Woodruffe, Ch. (1991), Competent by any Rother Name, "Personnel Management", vol. 23. 


\title{
Kompetentny nauczyciel \\ - przyszłość czy rzeczywistość
}

\author{
Liliana Budkowska, Paweł Poszytek
}

Artykuł przedstawia problematykę kompetencji nauczycieli, strukturę pojęcia oraz odniesienie do przepisów prawa oświatowego w Polsce i Europie, a także propozycję zespołu roboczego ujęcia kompetencji nauczycielskich w trzech filarach, które dotyczą profesjonalnej wiedzy zawodowej, profesjonalnej praktyki oraz tożsamości zawodowej i zaangażowania nauczycieli.

\section{Słowa kluczowe:}

kształcenie nauczycieli

kompetencje

kompetencje nauczycieli 


\section{The competent teacher \\ - future or reality}

Liliana Budkowska, Paweł Poszytek

The article presents the issues of teachers' competences, the structure of them and a reference to educational law in Poland and Europe, as well as a work's group proposal on the recognition of teaching competences in three pillars that relate to professional knowledge, professional practice and professional identity and teacher involvement.

\section{- Keywords: \\ teacher education \\ competences \\ teacher competencess}




\section{Wprowadzenie}

Mówiąc o kompetencjach nauczyciela, należy opisać je jako złożone połączenie wiedzy, umiejętności, zrozumienia, wartości, postaw i dążeń, które leżą u podstaw skutecznego działania nauczyciela w szkole i poza nią. Kompetencje różnią się od umiejętności, które definiuje się jako zdolność do wykonywania złożonych czynności z łatwością, precyzją i umiejętnościami adaptacyjnymi (Madalińska-Michalak, 2016, 2017).

W rozważaniach nad kompetencjami nauczyciela trzeba zwrócić uwagę na wiele aspektów analizowanego tutaj pojęcia. I tak w badaniu kompetencji jako pojęcia pedagogicznego warto wziąć pod uwagę:

$\rightarrow$ „podmiotowy charakter - kompetencje są własnością podmiotu indywidualnego (jednostki) lub podmiotu zbiorowego (np. społeczeństwo, grupa osób, organizacja),

$\rightarrow$ złożoną strukturę - kompetencje mają różną strukturę w zależności od ich rodzaju, o budowie kompetencji decydują takie ich wyznaczniki jak chociażby: wiedza, umiejętności, cechy osobowościowe, systemy wartości, doświadczenie, motywacja do pracy,

$\rightarrow$ stopniowalność - podmiot osiąga kompetencje na różnym poziomie, co rzutuje na przykład na sprawność i zdolność do wykonania określonego zadania, przy czym określony poziom kompetencji podmiotu jest wyznaczony przez stopień rozwoju poszczególnych elementów tworzących daną kompetencję (np. poziom wiedzy czy umiejętności w danym zakresie),

$\rightarrow$ dynamikę - wyraża się w zmianie kondycji poszczególnych korelatów kompetencji, a w rezultacie może prowadzić do zmiany całej kompetencji, co z kolei mówi o możliwości jej rozwijania,

$\rightarrow$ możliwość rozwoju - kompetencje traktujemy jako rezultat procesu uczenia się podmiotu w toku nabywania i wytwarzania znaczących dla podmiotu doświadczeń edukacyjnych w czasie jego życia,

$\rightarrow$ ujawnianie się kompetencji w określonym kontekście sytuacyjnym (sytuacyjność kompetencji) - kompetencje uwidaczniają się, gdy podmiot podejmuje się wykonania zadań w określonych warunkach,

$\rightarrow$ interaktywność kompetencji wobec warunków, w jakich funkcjonuje dany podmiot - ustawiczne aktualizowanie kompetencji stosownie do kontekstu (nowe doświadczenia rzutują na rozwija- 
nie wiedzy, doskonalenie umiejętności i postaw podmiotu, które to postawy uwidaczniają się w działaniu),

$\rightarrow$ możliwość przeniesienia posiadanych kompetencji na inne sytuacje, inne układy odniesienia - prowadzi to do poszerzania pola wolności i odpowiedzialności, a wraz z tym zdolności do wykonywania nowych zadań" (Madalińska-Michalak, 2016, s. 12).

W innym spojrzeniu na kompetencje można je podzielić na trzy grupy:

$\rightarrow$ kompetencje bazowe, pozwalające nauczycielowi na porozumienie się z uczniami i współpracownikami,

$\rightarrow$ kompetencje konieczne, bez których nauczyciel nie mógłby pracować konstruktywnie - należą do nich kompetencje interpretacyjne, autokreacyjne oraz realizacyjne,

$\rightarrow$ kompetencje pożądane, które mogą, lecz nie muszą znajdować się w profilu zawodowym danego nauczyciela - należą do nich zainteresowania i umiejętności związane ze sportem, sztuką itp. (Dylak, 1995).

\section{Kompetencje nauczycieli w świetle obowiązujących przepisów prawa}

Dynamicznie zmieniająca się rzeczywistość, a co za tym idzie - nowe wymagania, jakie postawiono przed szkołą, spowodowały zmianę myślenia o kształceniu nauczyciela, czego efektem było stworzenie podstaw prawnych w zakresie kształcenia przygotowującego do wykonywania zawodu nauczyciela i określenia standardów tego kształcenia w wielu krajach europejskich. Istotny wkład w tę kwestię miał zespół ekspertów pracujących w programie ET 2010 poprzez ustanowienie Common European Principles for Teacher Competiences and Qualification - wspólnych europejskich zasad dotyczących kompetencji i kwalifikacji nauczycieli (Komisja Europejska, 2005).

Zasady europejskie opisują wizję nauczyciela w Europie następująco:

a) zawód nauczyciela to zawód wymagający wysokich kwalifikacji,

b) kompetencje nauczyciela powinny być rozpatrywane w kontekście uczenia się przez całe życie,

c) rozwój zawodowy powinien być powiązany z mobilnością nauczyciela,

d) w rozwoju nauczyciela ważną rolę odgrywa współpraca między nauczycielami i instytucjami. 
Oprócz tych wspólnych zasad UE proponuje trzy środowiska, w których nauczyciele z państw członkowskich powinni móc działać:

a) praca $z$ innymi,

b) praca z wiedzą, technologią i informacjami,

c) praca ze społeczeństwem i w społeczeństwie.

Inne dokumenty ukazują założenia dotyczące opracowania profilu nauczyciela i dobre praktyki w zakresie rozwoju kompetencji nauczycieli. Są wśród nich: Rethinking education Investing in skills for better socioeconomic outcomes (Komisja Europejska, 2012a), Teaching Professions for Better Learning Outcomes (Komisja Europejska, 2012b), Policy approaches to defining and describing teacher competences (Komisja Europejska, 2011) i Supporting teacher competence development for better learning outcomes (Komisja Europejska, 2013a).

Należy pamiętać, że w ramach programu Edukacja i Szkolenia 2010 zespół ekspertów Unii Europejskiej opracował europejskie ramy odniesienia dotyczące kluczowych kompetencji w uczeniu się przez całe życie. Ramy te określiły, po raz pierwszy na poziomie europejskim, podstawowe kompetencje potrzebne obywatelom dla ich dobrostanu. W ich obrębie sformułowano osiem kluczowych kompetencji, które miały istotne znaczenie dla ich włączenia do podstaw programowych, także w naszym kraju.

W 2006 r. Parlament Europejski i Rada Unii Europejskiej przyjęły zalecenie w sprawie kompetencji kluczowych w procesie uczenia się przez całe życie. W przedmiotowym zaleceniu zwrócono się do państw członkowskich o "rozwijanie oferty kompetencji kluczowych dla wszystkich w ramach ich strategii uczenia się przez całe życie, w tym strategii osiągnięcia powszechnej alfabetyzacji, a także wykorzystanie dokumentu »Kompetencje kluczowe w uczeniu się przez całe życie - europejskie ramy odniesienia «". Od czasu przyjęcia zalecenia stanowiło ono jeden z kluczowych dokumentów referencyjnych dla rozwoju kształcenia, szkolenia i uczenia się ukierunkowanych na kompetencje. Obecnie wymagania dotyczące kompetencji zmieniły się w związku z rosnącą liczbą miejsc pracy poddanych automatyzacji, coraz istotniejszą rolą technologii we wszystkich dziedzinach pracy i życia oraz zwiększającym się znaczeniem kompetencji społecznych, obywatelskich i w zakresie przedsiębiorczości, które pozwalają wykształcić odporność na zmiany i zdolność dostosowania się do nich. Obowiązujące zalecenie Rady 
z 22 maja 2018 r. w sprawie kompetencji kluczowych w procesie uczenia się przez całe życie wśród kompetencji kluczowych wyróżnia:

$\rightarrow$ Kompetencje $w$ zakresie rozumienia i tworzenia informacji, rozumiane jako zdolność identyfikowania, rozumienia, wyrażania, tworzenia i interpretowania pojęć, uczuć, faktów i opinii w mowie oraz piśmie, przy wykorzystaniu obrazów, dźwięków i materiałów cyfrowych we wszystkich dziedzinach i kontekstach. Zakładają one zdolność skutecznego komunikowania się i porozumiewania się z innymi osobami, we właściwy i kreatywny sposób.

$\rightarrow$ Kompetencje w zakresie wielojęzyczności, określające zdolność do prawidłowego i skutecznego korzystania z różnych języków w celu porozumiewania się. Jeśli chodzi o zakres umiejętności, to pokrywa się on zasadniczo z umiejętnością rozumienia i tworzenia informacji: opiera się na zdolności rozumienia, wyrażania i interpretowania pojęć, myśli, uczuć, faktów i opinii w mowie oraz piśmie (rozumienie ze słuchu, mówienie, czytanie i pisanie) w odpowiednim zakresie kontekstów społecznych i kulturowych, w zależności od potrzeb lub pragnień danej osoby.

$\rightarrow$ Kompetencje matematyczne oraz kompetencje w zakresie nauk przyrodniczych, technologii i inżynierii; kompetencje matematyczne to zdolność rozwijania i wykorzystywania myślenia oraz postrzegania matematycznego do rozwiązywania problemów w codziennych sytuacjach. Istotne są zarówno proces i działanie, jak i wiedza, przy czym podstawę stanowi należyte opanowanie umiejętności rozumowania matematycznego. Kompetencje matematyczne obejmują - w różnym stopniu - zdolność i chęć wykorzystywania matematycznych sposobów myślenia oraz prezentacji (wzory, modele, konstrukty, wykresy, tabele). Kompetencje w zakresie nauk przyrodniczych dotyczą zdolności i chęci wyjaśniania świata przyrody z wykorzystaniem istniejącego zasobu wiedzy i stosowanych metod, w tym obserwacji i eksperymentów, w celu formułowania pytań i wyciągania wniosków opartych na dowodach. Kompetencje techniczne i inżynierskie to stosowanie tej wiedzy i metod w odpowiedzi na postrzegane ludzkie potrzeby lub wymagania. Kompetencje w zakresie nauk przyrodniczych, technologii i inżynierii obejmują rozumienie zmian spowodowanych działalnością człowieka oraz rozumienie swojej odpowiedzialności jako obywatela. 
$\rightarrow$ Kompetencje cyfrowe, obejmujące pewne, krytyczne i odpowiedzialne korzystanie $z$ technologii cyfrowych $\mathrm{i}$ interesowanie się nimi w celu uczenia się, pracy i udziału w społeczeństwie. Obejmują one umiejętność korzystania z informacji i danych, komunikowanie się i współpracę, umiejętność korzystania z mediów, tworzenie treści cyfrowych (w tym programowanie), bezpieczeństwo ( $w$ tym komfort cyfrowy i kompetencje związane z cyberbezpieczeństwem), kwestie dotyczące własności intelektualnej, rozwiązywanie problemów i krytyczne myślenie.

$\rightarrow$ Kompetencje osobiste, społeczne i w zakresie umiejętności uczenia się to zdolność do autorefleksji, skutecznego zarządzania czasem i informacjami, konstruktywnej pracy z innymi osobami, zachowania odporności oraz zarządzania własnym uczeniem się i karierą zawodową. Obejmują one zdolność radzenia sobie z niepewnością i ze złożonością, umiejętność uczenia się, wspierania swojego dobrostanu fizycznego i emocjonalnego, utrzymania zdrowia fizycznego i psychicznego oraz zdolność do prowadzenia prozdrowotnego i zorientowanego na przyszłość trybu życia, odczuwania empatii i zarządzania konfliktami we włączającym i wspierającym kontekście.

$\rightarrow$ Kompetencje obywatelskie to zdolność działania jako odpowiedzialni obywatele oraz pełnego uczestnictwa w życiu obywatelskim i społecznym, na podstawie rozumienia pojęć i struktur społecznych, gospodarczych, prawnych i politycznych, a także wydarzeń globalnych i zrównoważonego rozwoju.

$\rightarrow$ Kompetencje $w$ zakresie przedsiębiorczości to między innymi zdolność wykorzystywania szans i pomysłów oraz przekształcania ich w wartość dla innych osób. Przedsiębiorczość opiera się na kreatywności, krytycznym myśleniu i rozwiązywaniu problemów, podejmowaniu inicjatywy, wytrwałości oraz na zdolności do wspólnego działania służącego planowaniu projektów mających wartość kulturalną, społeczną lub finansową i zarządzaniu nimi.

$\rightarrow$ Kompetencje w zakresie świadomości i ekspresji kulturalnej obejmują rozumienie sposobów kreatywnego wyrażania oraz komunikowania pomysłów i znaczeń w różnych kulturach, za pomocą różnych rodzajów sztuki i innych form kulturalnych, oraz poszanowanie tego procesu. Obejmują one angażowanie się w rozumienie, rozwijanie i wyrażanie własnych pomysłów 
oraz odczuwanie swojego miejsca lub roli w społeczeństwie na wiele różnych sposobów i w wielu kontekstach.

O tworzeniu i modyfikowaniu podstaw prawnych w zakresie kształcenia przygotowującego do wykonywania zawodu nauczyciela i określenia standardów tego kształcenia w Polsce świadczą następujące dokumenty: Rozporządzenie Ministra Nauki i Szkolnictwa Wyższego z dn. 17 stycznia 2012 r. w sprawie standardów kształcenia przygotowującego do wykonywania zawodu nauczyciela (Dz.U. 2012, poz. 131), które było poprzedzone rozporządzeniem Ministra Edukacji Narodowej i Sportu z dn. 7 września 2004 r. w sprawie standardów kształcenia nauczycieli (Dz.U. 2017, poz. 2110)'

Obowiązujące w prawie oświatowym standardy kształcenia określają zarówno ogólne efekty kształcenia, jak i szczegółowe, w podziale na wiedzę, umiejętności i kompetencje społeczne. Zgodnie z rozporządzeniem po zakończeniu kształcenia przygotowującego do wykonywania zawodu nauczyciela absolwent:

$\rightarrow$ posiada wiedzę psychologiczną i pedagogiczną pozwalającą na rozumienie procesów rozwoju, socjalizacji, wychowania i nauczania-uczenia się,

$\rightarrow$ posiada wiedzę z zakresu dydaktyki i szczegółowej metodyki działalności pedagogicznej, popartą doświadczeniem w jej praktycznym wykorzystywaniu,

$\rightarrow$ posiada umiejętności i kompetencje niezbędne do kompleksowej realizacji dydaktycznych, wychowawczych i opiekuńczych zadań szkoły, w tym do samodzielnego przygotowania i dostosowania programu nauczania do potrzeb i możliwości uczniów,

$\rightarrow$ wykazuje umiejętność uczenia się i doskonalenia własnego warsztatu pedagogicznego z wykorzystaniem nowoczesnych środków i metod pozyskiwania, organizowania i przetwarzania informacji oraz materiałów,

1. Rozporządzenie Ministra Edukacji Narodowej i Sportu z dn. 7 września 2004 r. w sprawie standardów kształcenia nauczycieli (Dz.U. nr 2017, poz. 2110) utraciło moc z dniem 1 października 2011 r. w związku z wejściem w życie ustawy z dn. 18 marca 2011 r. o zmianie ustawy - Prawo o szkolnictwie wyższym, ustawy o stopniach naukowych i tytule naukowym oraz o stopniach i tytule w zakresie sztuki oraz o zmianie niektórych innych ustaw (Dz.U. nr 84, poz. 455 , i nr 112, poz. 654). 
$\rightarrow$ umiejętnie komunikuje się przy użyciu różnych technik zarówno z osobami będącymi podmiotami działalności pedagogicznej, jak i z innymi osobami współdziałającymi w procesie dydaktyczno-wychowawczym oraz specjalistami wspierającymi ten proces,

$\rightarrow$ charakteryzuje się wrażliwością etyczną, empatią, otwartością, refleksyjnością oraz postawami prospołecznymi i poczuciem odpowiedzialności,

$\rightarrow$ jest praktycznie przygotowany do realizowania zadań zawodowych (dydaktycznych, wychowawczych i opiekuńczych) wynikających z roli nauczyciela (Dz.U., 2012) ${ }^{2}$.

Określenie zakresu i poziomu kompetencji niezbędnych nauczycielowi do podjęcia pracy edukacyjnej pozwala na rozpoczęcie współpracy między szkołami wyższymi a placówkami systemu doskonalenia zawodowego nauczycieli w procesie dochodzenia do biegłości zawodowej.

\section{Kompetencje a filary pracy nauczyciela}

Analizując zapisy obowiązującego prawa oświatowego oraz codzienną praktykę nauczycielską, można założyć, że praca nauczyciela i wymagane od niego kompetencje oparte są na trzech filarach, które dotyczą profesjonalnej wiedzy zawodowej, profesjonalnej praktyki oraz tożsamości zawodowej i zaangażowania nauczycieli (Madalińska-Michalak, 2017). Graficzne ujęcie tego założenia zostało przedstawione na rysunku nr 1.

2. Rozporządzenie Ministra Nauki i Szkolnictwa Wyższego z dn. 17 stycznia 2012 r. w sprawie standardów kształcenia przygotowującego do wykonywania zawodu nauczyciela (Dz.U. 2012, poz. 131). 
Rysunek 1. Filary pracy nauczyciela

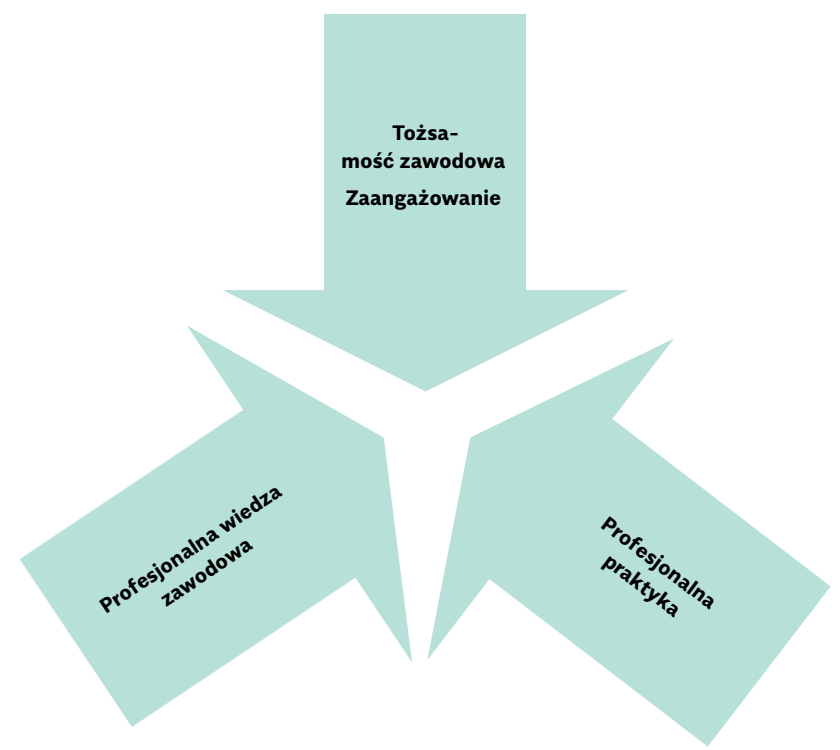

Źródło: Madalińska-Michalak, J. (2017), Filary pracy a kompetencje nauczyciela [w:] Edukacja i praca nauczyciela: ciągłość - zmiana - konteksty, J. Madalińska-Michalak, N. Pikuła, K. Białożyt (red.), Kraków: Wydawnictwo Scriptum, s. 29-55.

Madalińska-Michalak J., Budkowska L., Kompetencje nauczycieli, materiały robocze powstałe w ramach grupy tematycznej „Opis kompetencji nauczycieli”, Warszawa 2017.

Filary te można opisać następująco (zob. Madalińska-Michalak, 2017):

Wiedza zawodowa mówi o tym, że nauczyciel:

$\rightarrow$ zna ucznia i wie, jak on się uczy,

$\rightarrow$ zna przedmiot, którego uczy, i wie, jak nauczać tego przedmiotu.

Nauczyciele, którzy dobrze znają swoich uczniów, są wrażliwi na zróżnicowanie uczniów ze względu na język, kulturę, religię. Mają świadomość tego, jak warunki rozwojowe uczniów i dotychczasowe doświadczenia życiowe wpływają na ich uczenie się. Wiedzą, jak zorganizować swoje lekcje, by indywidualizować nauczanie i uczenie się uczniów, jak sprzyjać rozwojowi fizycznemu, społecznemu, intelektualnemu, emocjonalnemu, duchowemu oraz rozwojowi cech osobistych uczniów. Nauczyciele znają podstawę programową i potrafią odnieść się do niej krytycznie. Mają również wiedzę merytoryczną i metodyczną z zakresu nauczanego przedmiotu 
- nauczyciele nie tylko znają swój przedmiot, lecz także wiedzą, jak prowadzić zajęcia edukacyjne, jak rozbudzać zainteresowania poznawcze oraz wspierać rozwój intelektualny uczniów przez umiejętny dobór metod aktywizujących, technik nauczania i środków dydaktycznych, a także badać i oceniać osiągnięcia uczniów również na podstawie własnej praktyki nauczycielskiej. Nauczyciele mają wiedzę z zakresu technologii informacyjno-komunikacyjnych, potrafią ją wykorzystać w odpowiednich warunkach, tak aby poszerzyć możliwości uczenia się uczniów.

Praktyka zawodowa - w przypadku tego filaru można założyć, że nauczyciel wykazuje kompetencje niezbędne do realizacji zadań dydaktycznych, wychowawczych i opiekuńczych, w tym do samodzielnego przygotowania i dostosowania programu nauczania do potrzeb i możliwości uczniów. Nauczyciel jest zatem praktycznie przygotowany do realizowania zadań zawodowych, czyli dydaktycznych, wychowawczych i opiekuńczych wynikających z jego roli. Potrafi on:

$\rightarrow$ tworzyć i podtrzymywać wspierające oraz bezpieczne warunki uczenia się uczniów,

$\rightarrow$ oceniać, dostarczać informacji zwrotnych i przygotowywać sprawozdania dotyczące uczenia się jego podopiecznych,

$\rightarrow$ planować nauczanie i uczenie się oraz efektywnie nauczać i uczyć się z uczniami.

Nauczyciele mają wiedzę o skutecznych strategiach nauczania i uczenia się. Wykorzystują je do wdrażania dobrze zaplanowanych programów nauczania i zajęć dydaktycznych. Regularnie oceniają różne aspekty swojej praktyki zawodowej (realizację przypisanych im zadań w zakresie nauczania, wychowania, opieki), aby upewnić się, że zaspokajają potrzeby edukacyjne swoich uczniów. Interpretują i wykorzystują dane z oceny uczniów w celu rozpoznania barier w uczeniu się i wyzwań dla uczniów, aby poprawić ich wyniki nauczania. Działają skutecznie na wszystkich etapach cyklu nauczania i uczenia się, w tym planowania uczenia się i oceniania, opracowywania programów nauczania, procesu nauczania, dostarczania informacji zwrotnych o uczeniu się uczniów i raportowania wyników osiągnięć ich rodzicom/opiekunom.

Zaangażowanie zawodowe/tożsamość nauczycieli - nauczyciele modelują efektywne uczenie się i rozwój: pokazują, jak można się uczyć i rozwijać, podejmują działania upowszechniające wzory dobrej prak- 
tyki pedagogicznej. Potrafią kierować własnym rozwojem osobowym i zawodowym poprzez rozpoznawanie swoich potrzeb edukacyjnych, ich analizowanie, ewaluowanie, poszerzanie własnego uczenia się, mierzenie się $z$ wyzwaniami zarówno $w$ grupie, jak i indywidualnie $w$ trakcie całej swojej kariery zawodowej. Nauczyciel jest zatem zaangażowany w uczenie się i rozwój zawodowy oraz współpracuje z kolegami z pracy, rodzicami, opiekunami uczniów, ze środowiskiem pozaszkolnym buduje konieczne partnerstwa. Nauczyciele wykazują profesjonalizm w interakcjach z uczniami, kolegami, rodzicami/opiekunami uczniów i ze społecznością. Przejawiają umiejętność współpracy z innymi, są wrażliwi na potrzeby uczniów, rodziców/opiekunów. Skutecznie komunikują się z nimi na temat rozwoju i osiągnięć edukacyjnych ich dzieci. Nauczycieli cechują: wrażliwość etyczna, empatia, otwartość, refleksyjność, postawa prospołeczna, troska o dobro ucznia, budowanie relacji opartych na zaufaniu, wzajemnym szacunku, akceptacji i odpowiedzialności. Nauczyciele cenią sobie szanse zaangażowania się we wspólnoty praktyków w szkole i poza nią, aby wzbogacić swoje doświadczenia, rozwijać się, a tym samym stwarzać uczniom coraz lepsze warunki edukacyjne. Rozumieją powiązania między szkołą, domem i społecznością w rozwoju społecznym i intelektualnym swoich uczniów. Działają na rzecz własnej profesji, przejawiają autonomię, sprawczość, otwartość, optymizm, krytyczne myślenie, wytrwałość, odporność. Są pozytywnie nastawieni do innych i świadomi siebie.

Tak zarysowane filary pracy nauczyciela pozwalają na wyszczególnienie kompetencji, które są powiązane z każdym z wyróżnionych filarów.

1. Profesjonalna wiedza zawodowa, a w niej:

$\rightarrow$ kompetencje przedmiotowe (merytoryczne), prawno-organizacyjne, z zakresu bezpieczeństwa (BHP), z zakresu wiedzy psychologiczno-pedagogicznej, wiedzy diagnostyczno-badawczej, znajomości instytucji wspierających i działających na rzecz systemu edukacji, źródeł wiedzy (merytorycznej/przedmiotowej).

2. Profesjonalna praktyka, a w niej:

$\rightarrow$ kompetencje dydaktyczne, wychowawcze/opiekuńcze/profilaktyczne, badawcze, cyfrowe, komunikacyjne (językoznawcze), poznawcze (kognitywne), przywódcze, adaptacyjne.

3. Tożsamość zawodowa i zaangażowanie, a w niej: 
$\rightarrow$ kompetencje z zakresu etyki zawodowej, doskonalenia i własnego rozwoju, emocjonalno-społeczne oraz kulturowe i wielokulturowe.

Podczas pracy nad rekomendacją zespół określił ponadto możliwości rozwijania kompetencji w procesie rozwoju zawodowego nauczyciela, wyróżniając trzy poziomy w nabywaniu biegłości zawodowej i kompetencji - nauczyciel na starcie, nauczyciel specjalista oraz nauczyciel ekspert. Taki podział pozwala na opracowanie indywidualnego portfolio, które po autoanalizie może być punktem wyjścia do opracowania ścieżki rozwoju zawodowego, połączonego z systemem awansu, opartego na państwowych egzaminach przy warsztacie pracy, czasem z udziałem doradców metodycznych.

\section{Doskonalenie kompetencji nauczycieli}

W związku z tym, że zawód nauczyciela jest zawodem zaufania publicznego, powinien być on otoczony szczególną troską ze strony państwa. Dbałość o odpowiednio wysoki poziom kształcenia oraz stałe podnoszenie kwalifikacji nauczycieli należą do najważniejszych wyzwań, przed jakimi stoi środowisko nauczycielskie. Równie istotnym zagadnieniem jak kształcenie kadry pedagogicznej jest jej rozwój zawodowy.

Nauczyciele, zarówno stawiający pierwsze kroki w zawodzie, jak i ci bardziej doświadczeni, często odczuwają potrzebę nieustannego doskonalenia własnego warsztatu pracy, poszukiwania nowych inspiracji do prowadzenia ciekawych zajęć, nabywania kolejnych kompetencji i kwalifikacji. Cechuje ich otwartość na zmiany i ciekawość świata, co potwierdza opinia przedstawiona przez Christophera Daya: „Poznawcza otwartość jest niezbędna, aby zachować i rozwijać swój profesjonalizm, który z kolei jest jednym z fundamentów dobrego nauczania. O pasję należy więc dbać, kontynuując swoją naukę" (Day, 2008, s. 133).

Często potrzeba samodoskonalenia jest wynikiem poszukiwania rozwiązań indywidualnych trudności, takich jak niska samoocena, brak możliwości dzielenia się z innymi swoimi problemami czy doświadczeniami, wypalenie zawodowe i związany z tym brak motywacji do aktywnego działania w procesie edukacyjnym.

\section{Podsumowanie}

Wychowanie powinno być takie, „żeby tworzyło nie tylko ludzi dobrze wychowanych, co zdolnych do życia na własny rachunek" (Konarzewski, 
1994, s. 284). Zdolnych do przyjmowania odpowiedzialności za własny rozwój umysłowy i fizyczny, za sprawność i zdrowie, ludzi posiadających odpowiednie kompetencje. Aby wypełnić to zadanie, potrzebni są nauczyciele o wszechstronnych kompetencjach, otwarci i nieustannie poszukujący, ponieważ tylko tacy mogą wyposażyć swoich uczniów w odpowiednie kompetencje do życia w niezwykle szybko zmieniającym się świecie. Oznacza to, że nauczyciel to zawód, w którym oprócz wiedzy i kompetencji znaczenie mają osobowość, postawa i powołanie. Stefan M. Kwiatkowski, mówiąc o różnicach między zawodem nauczyciela a innymi zawodami, wskazuje na postawy, które rozpatrywane są jako element cech psychofizycznych. „Pełny układ cech tworzą: sprawności sensomotoryczne, zdolności (do czegoś) i cechy osobowości. I właśnie te ostatnie wyróżniają nauczycieli spośród innych grup zawodowych. Obok bowiem preferowanych przez ogół pracodawców takich cech jak na przykład gotowość do ciągłego uczenia się, dla nauczycieli istotne są właściwości, które pozwalają mówić o tym zawodzie również w kategoriach powołania i posłannictwa (misji) oraz ponadprzeciętnego zamiłowania (pasji). Właśnie cechy osobowości są podstawowym wyróżnikiem nauczyciela; oczywiście, cechy pożądane z punktu widzenia realizacji zadań zawodowych" (Kwiatkowski, 2008, s. 28). 


\section{Bibliografia}

$\rightarrow$ Czerepaniak-Walczak, M. (1999), Kompetencja: słowo kluczowe czy "wytrych" w edukacji [w:] „Neodidagmata”, nr XXIV.

$\rightarrow$ Czerepaniak-Walczak, M. (2006), Kompetencje emancypacyjne, Gdańsk: Gdańskie Wydawnictwo Psychologiczne.

$\rightarrow$ Day, C. (2008), Nauczyciel z pasją. Jak zachować entuzjazm i zaangażowanie w pracy, Gdańsk: Gdańskie Wydawnictwo Psychologiczne.

$\rightarrow$ Day, C. (2004), Rozwój zawodowy nauczyciela. Gdańsk: Gdańskie Wydawnictwo Psychologiczne.

$\rightarrow$ Gaś, Z.B. (2001), Doskonalq̨cy się nauczyciel, Lublin: Wydawnictwo Uniwersytetu Marii Curie-Skłodowskiej.

$\rightarrow$ Head, K., Taylor, P. (1997), Readings in Teacher Development, Oxford: Heinemann ELT.

$\rightarrow$ Konarzewski, K. (1994), O wychowaniu w szkole [w:] K. Kruszewski (red.), Sztuka nauczania. Czynności nauczyciela, Warszawa.

$\rightarrow$ Kwiatkowski, S.M. (2008), Oczekiwania społeczne wobec nauczycieli - w kierunku szlachetnej utopii [w:] B. Muchacka, M. Szymański (red.), Nauczyciel w świecie współczesnym, Kraków.

$\rightarrow$ Madalińska-Michalak, J. (2015), Dyrektor szkoły liderem - inspiracje i perspektywy, Warszawa: Wolters Kluwer.

$\rightarrow$ Madalińska-Michalak, J. (2016), Kompetencje przywódcze dyrektora szkoły - wyzwania wobec teorii i praktyki [w:] „Kwartalnik Pedagogiczny”, t. LXI, z. 4, s. 9-28.

$\rightarrow$ Madalińska-Michalak, J. (2017), Filary pracy a kompetencje nauczyciela [w:] Edukacja i praca nauczyciela: ciągłość - zmiana - konteksty, J. Madalińska-Michalak, N. Pikuła, K. Białożyt (red.), Kraków: Wydawnictwo Scriptum, s. 29-55.

$\rightarrow$ Madalińska-Michalak, J., Góralska, R. (2017), Wspieranie rozwoju dziecka a kompetencje emocjonalne nauczyciela [w:] M. Nawrot-Borowska, D. Zając (red.), 
Dziecko i dzieciństwo. Wybrane konteksty badań, Bydgoszcz: Uniwersytet Kazimierza Wielkiego, s. 117-135.

$\rightarrow$ Schaefer, K. (2005), Jak przeżyć szkołę. Gdańsk: Gdańskie Wydawnictwo Psychologiczne.

$\rightarrow$ Woodward, T. (1991), Models and Metaphors in Language Teacher Training. Cambridge: Cambridge University Press.

$\rightarrow$ Woodward, T. (1992), Ways of Training, Harlow: Longman.

$\rightarrow$ Fazlagić, J.A. (2007), Zarzq̨dzanie wiedzq w szkole, Warszawa: Wydawnictwo CODN.

$\rightarrow$ Szempruch, J. (2012), Nauczyciel w warunkach zmiany społecznej i edukacyjnej, Kraków: Impuls.

$\rightarrow$ Taraszkiewicz, M. (2001), Jak uczyć jeszcze lepiej! Szkoła pełna ludzi, Poznań: Arka.

$\rightarrow$ Traktat o Unii Europejskiej i Traktat ustanawiający Wspólnotę Europejską (2006), Dz.Urz. C 321E 2006.

1. Edukacja w Europie: różne systemy kształcenia i szkolenia-wspólne cele do roku 2010. Program prac dotyczqcy przyszłych celów systemów edukacji, Luksemburg: Biuro Urzędowych Publikacji Wspólnot Europejskich 2002, FRSE, Warszawa 2003.

2. Zalecenie Rady z dn. 22 maja 2018 r. w sprawie kompetencji kluczowych w procesie uczenia się przez całe życie, Dz.Urz. C 189 Unii Europejskiej, 2018/C 189/01. 
Stefan M. Kwiatkowski

Akademia Pedagogiki Specjalnej

im. Marii Grzegorzewskiej w Warszawie

\section{Krystyna Chałas}

Katolicki Uniwersytet Lubelski

Jana Pawła II

\section{Monika Borowiec-Gabryś,}

Wioletta Kilar, Tomasz Rachwal

Uniwersytet Pedagogiczny w Krakowie

Magdalena Górowska-Fells, Beata Płatos, Agnieszka Rybińska

Fundacja Rozwoju Systemu Edukacji

Joanna Dąbrowska-Resiak,

Mateusz Jeżowski, Michał Pachocki

Fundacja Rozwoju Systemu Edukacji

Edward Torończak

Fundacja Rozwoju Systemu Edukacji

\section{Anna Krzyżanowska}

Regionalny Ośrodek Doskonalenia

Nauczycieli i Informacji Pedagogicznej

„WOM" w Rybniku

\section{Krzysztof J. Szmidt}

Uniwersytet Łódzki

\section{Jan Fazlagić}

Uniwersytet Ekonomiczny w Poznaniu

\section{Ewa Domagala-Zyśk}

Katolicki Uniwersytet Lubelski

Jana Pawła II

\section{Magdalena Bartoszak}

Akademia Pedagogiki Specjalnej

im. Marii Grzegorzewskiej w Warszawie

\section{Jolanta Okuniewska}

Szkoła Podstawowa nr 13

w Olsztynie 


\section{Monika Mojsiejonek}

Szkoła Podstawowa im. Jana Pawła II w Zaborze

\section{Małgorzata Knap}

Fundacja Rozwoju Systemu Edukacji

\section{Sławomir Wronka}

Narodowe Centrum Badań Jądrowych

\section{Rafal Mazur}

Wyższa Szkoła Informatyki

i Zarządzania w Rzeszowie

\section{Aneta Wilk,}

Szkoła Podstawowa

im. ks. mjr. Franciszka Łuszczki

w Lubeni

\section{Adam Stępiński}

Liceum Ogólnokształcące

im. Mikołaja Kopernika w Tarnobrzegu

\section{Anna Andrzejewska}

Akademia Pedagogiki Specjalnej

im. Marii Grzegorzewskiej

w Warszawie

\section{Przemysław Bąbel}

Uniwersytet Jagielloński

\section{Katarzyna A. Knopp}

Uniwersytet Kardynała Stefana

Wyszyńskiego w Warszawie

\section{Lilianna Kupaj}

Szkoła Coachingu Lilianna Kupaj

\section{Dominika Walczak}

Akademia Pedagogiki Specjalnej im.

Marii Grzegorzewskiej

Instytut Badań Edukacyjnych

\section{Liliana Budkowska, Paweł Poszytek}

Fundacja Rozwoju Systemu Edukacji 

Publikacja zawiera teksty opracowane przez gości specjalnych Kongresu Rozwoju Systemu Edukacji, zorganizowanego przez FRSE 10 września 2018 r. w Warszawie oraz materiały z Ogólnopolskiej Konferencji Naukowej Szkoła w świecie zmian i nowych technologii, która odbyła się w dn. 21-22 maja 2018 r. w Zakopanem.

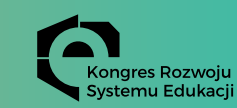

Ogólnopolska Konferencja Naukowa SZKOŁA W ŚWIECIE ZMIAN I NOWYCH TECHNOLOGII

Fundacja Rozwoju Systemu Edukacji (FRSE) funkcjonuje od 1993 r. Jest jedyną w Polsce instytucją z tak dużym doświadczeniem w zarządzaniu kilkunastoma edukacyjnymi programami europejskimi. W latach 2007-2013 koordynowała w Polsce programy "Uczenie się przez całe życie" (Erasmus, Leonardo da Vinci, Comenius i Grundtvig) oraz "Młodzież w działaniu". Obecnie pełni funkcję Narodowej Agencji Programu Erasmus+ na lata 2014-2020. Równolegle Fundacja realizuje europejskie inicjatywy informacyjno-edukacyjne, tj. eTwinning, Eurodesk Polska, Eurydice, Europass, ECVET i EPALE. Wspiera również współpracę z krajami Wschodu, poprzez Polsko-Litewski Fundusz Wymiany Młodzieży, Polsko-Ukraińską Radę Wymiany Młodzieży oraz Centrum Współpracy SALTO z Krajami Europy Wschodniej i Kaukazu. Od 2014 r. FRSE uczestniczy we wdrażaniu Programu Operacyjnego Wiedza Edukacja Rozwój.

Fundacja jest organizatorem wielu wydarzeń edukacyjnych, w tym konkursów, których celem jest promowanie rezultatów projektów (EDUinspiracje i EDUinspirator, European Language Label, SElfie+). Koordynuje obchody Europejskiego Tygodnia Młodzieży oraz współorganizuje wydarzenia odbywające się w ramach Europejskiego Dnia Języków. Prowadzi działalność analityczno-badawczą oraz wydawniczą (wydaje m.in. kwartalniki o tematyce edukacyjnej: Języki Obce w Szkole oraz Europa dla Aktywnych). 